UC-NRLF

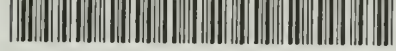

B 4 b2] 042 

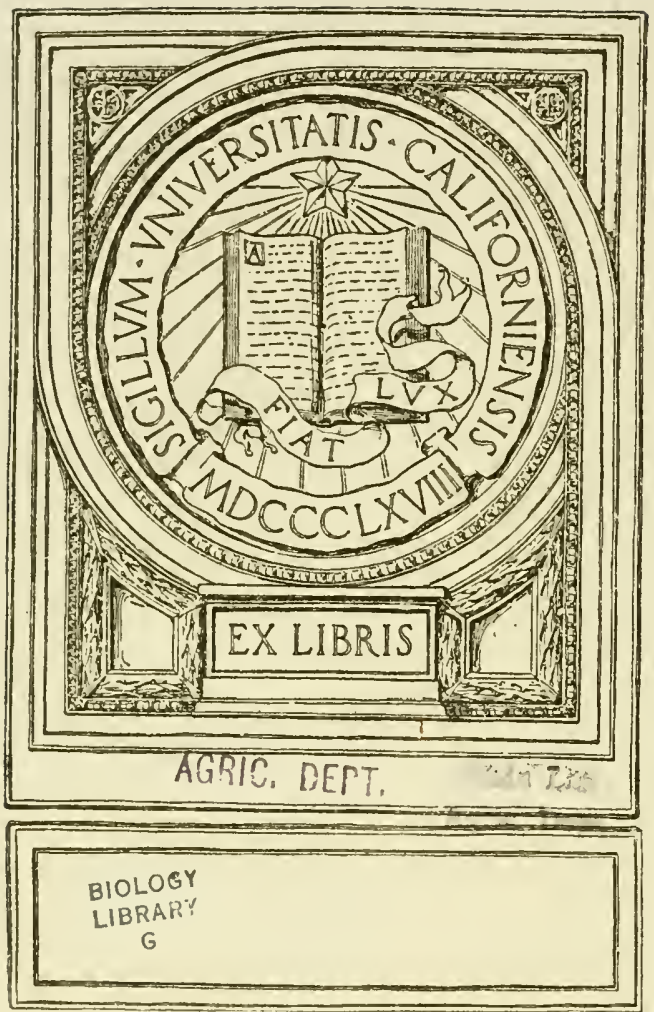




DEPARTMENT OF AGRICULTURE.

\title{
CON'TAGIOUS DISEASES
}

DOMESTICA'TED ANIMALS.

\author{
INVESTIGATIONS
}

BY

\section{DEPARTMENT OF AGRICULTURE,}

1883-1884.

WA STIT NGTON :

GOVERNMENT PLINING OFFICE.

1 ss 4 . 



\section{DEPARTMENT OF AGRICULTURE.}

\section{CON'TAGIOUS DISEASES}

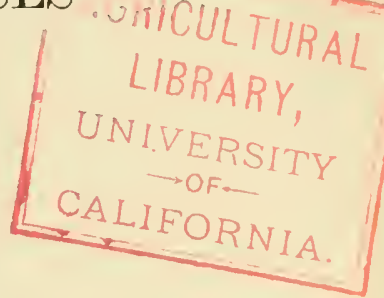

\section{DOMESTICA'TED ANIMALS.}

INVESTIGATIONS

BY

DEPARTMENT OF AGRICULTURE,

$1883-1884$.

TIASHINGTON:

GOVERNMENT PRINTING OFFICE.

1854 .

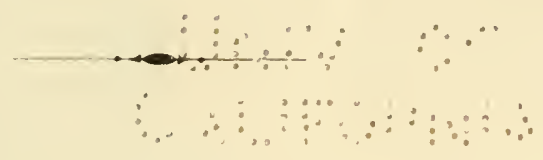




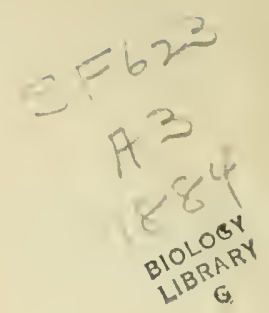

Maia Lib.

Agric. Dent

$$
\begin{aligned}
& \because \because \vdots \quad \vdots \vdots \vdots \vdots \vdots \\
& \therefore: \because: \because \because \because \because \vdots \vdots \vdots \quad \vdots
\end{aligned}
$$




$$
\text { कर }
$$

$\frac{1}{40.25}$ 


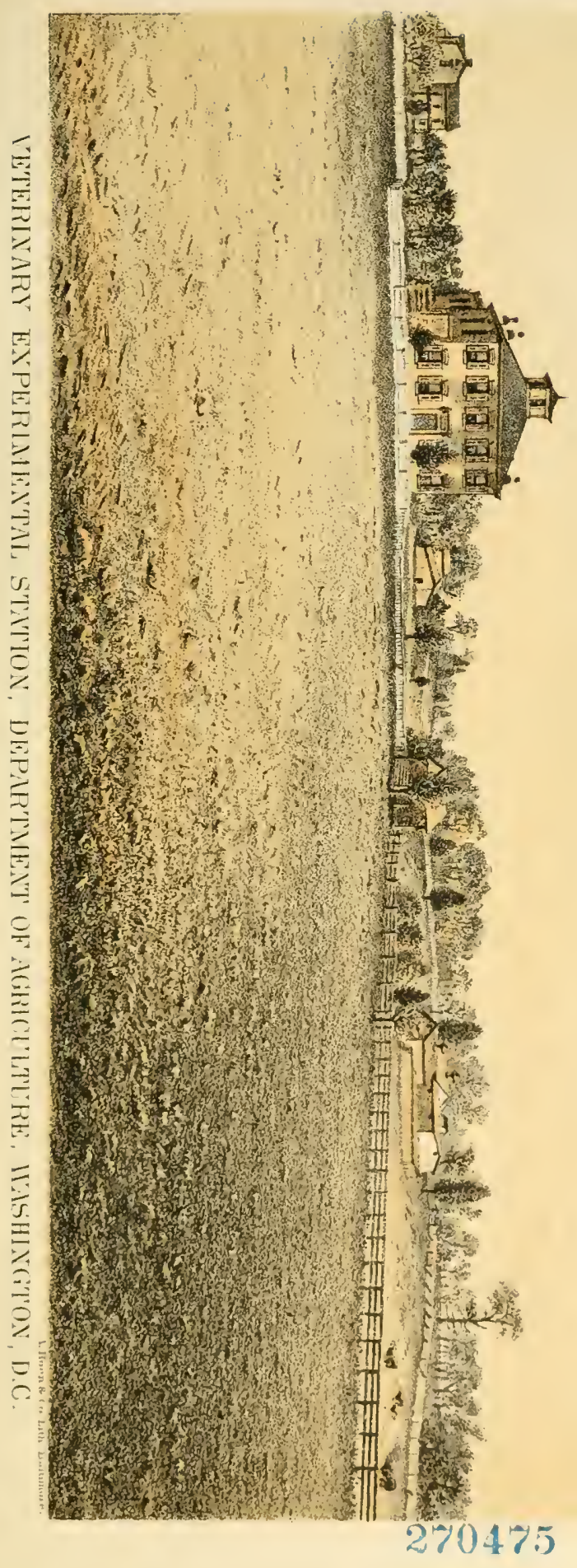





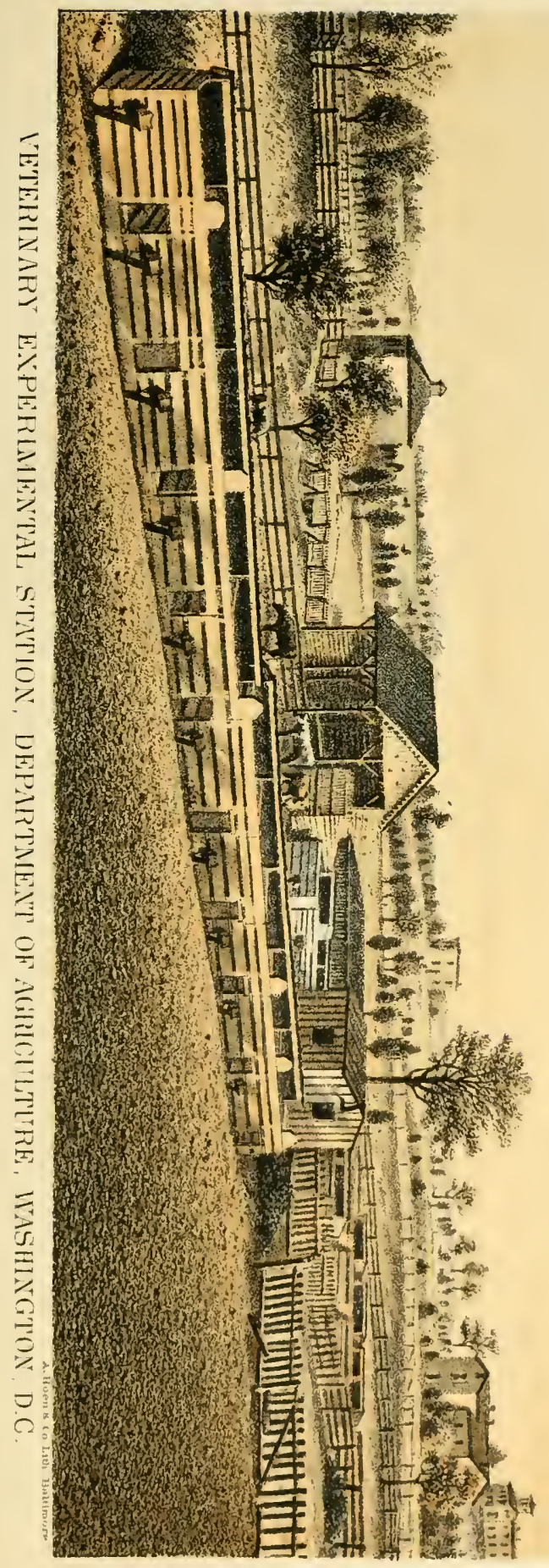





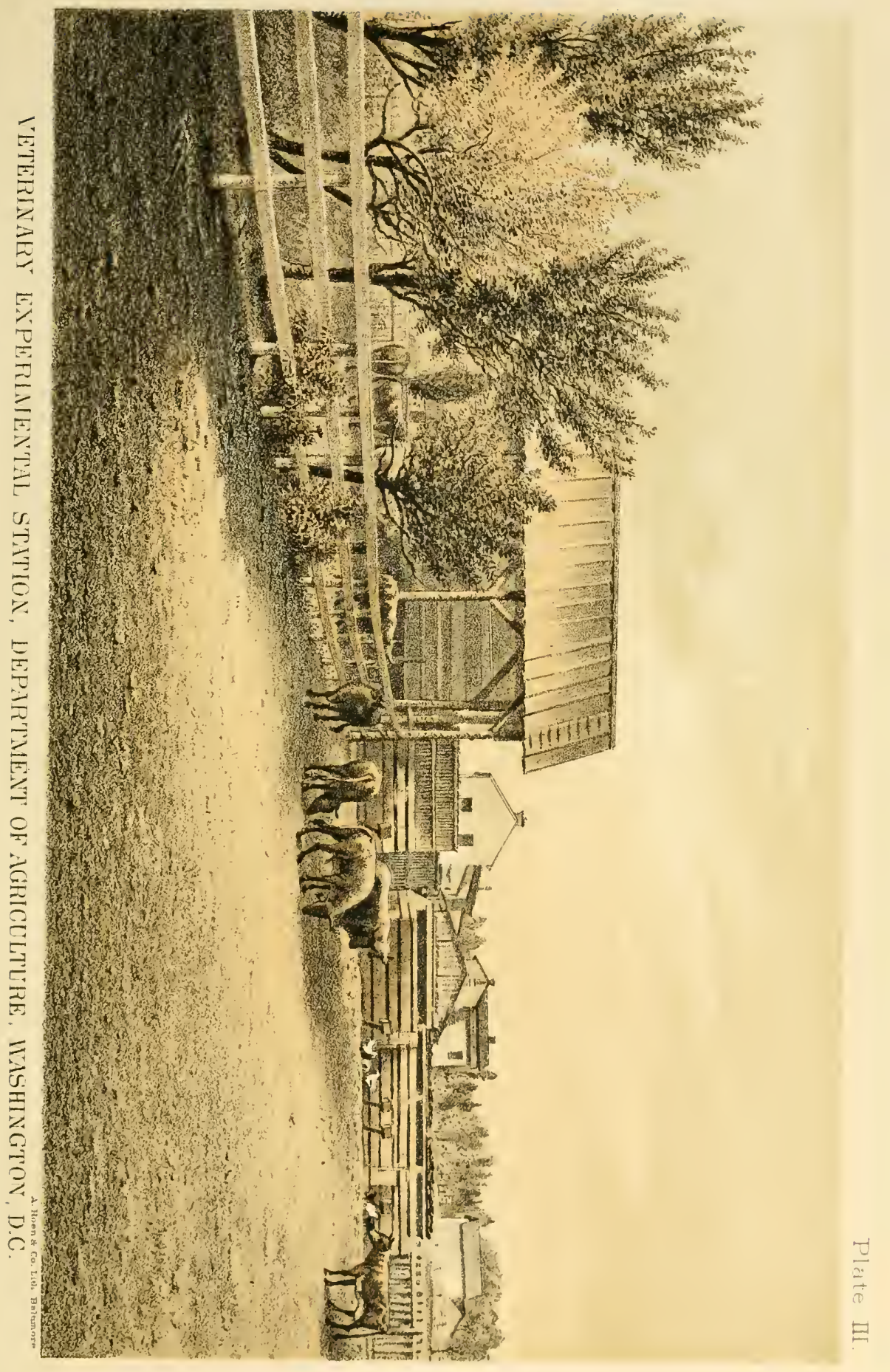





\section{LETTER OF TRANSMITTAL.}

Hon. GEO. B. LoRING,

Commissioner of Agriculture :

Sin: I have the honor to herewith transmit a report of the results of the experiments and investigations of the Veterinary Division for the year 1853-84. The first Annual Report of the Burean of Animal In. dustry, which will contain a detailed statement of the investigations made and all the work accomplished since the organization of the Burean, in conformity with the act passed at the last session of Congress, will be submited for your approval at the close of the year.

My work at the Veterinary Experimental Station has been greatly retarled rluring the past three or four months, made neeessary in the investigation of an outbreak of ergotism among eattle in the West, and later in the supervision of the work necessary for the organization of the Burean of Aumal Industry. In addition to this I spent the months of August and September in tracing the cattle infected with contagions pleuro-pnenmonia in some of the Westeru States, a detailed aecount of which will be furnished you in the First Anumal Report of the Bureau of Animal Industry.

My report proper coutains the results of experiments and investigations of Plenro-pnenmonia, Ergotism, Sonthern Cattle Ferer, and Swine Plague.

In addition to the above this volume will contain interesting and valnable papers on the following subjects: Ergotism anong eattle in Kansas, by M. R. Trumbower, V.S.; syngamus tracheulis, or Gape Disease of Fowls, translated from the French by Dr. Theobald Smith; Proceedings of the International Veterinary Congress, as roporterl by Dr. James Law; Hamburg International Exhibition, reported by Mr. J. H. Sanders and Dr. Rush Shippen Huidekoper; a detailed report of the losses sustained by an extensive ontbreak of Southern cattle terer amoug cattle in Kansas, by Dr. M. R. Trumbower; Investigations as to the Cause of Sonthern Cattle Fever, by Dr. J. H. Detmers; Contagious Animal Discases, and their Relation to the Public Health, by Dr. Ezra M. Hunt; results as to the prevalence of trichina as shown by the report of the recent commission appointerl by the President; salt nsed in packing; extrats from letter's of correspondents, and statistical returus as to losses and general emolition of fam animals as reported by the regular correspondents of the Department.

Very respectiully, Sce,

1). E. SALMON,

Chief of Bureau of A nimal Industry.

WasHINGTON, D. C., Octuber 노, 1854. 



\section{RESULTS OF INVESTIGATIONS MADE DURING THE YEAR 188:- -84 .}

How. Geo. B. Loring,

Commissioner of Agriculture:

SIR: In my last report brief mention was made of the Veterinary Ex. perimental Station established by your direction near this city. Since then many additions have been made to this Station, and it is now thonght a more letailed deseription will prove of interest to those engaged in investigations as to the canse, transmission, and prevention of infectious and contagions diseases incident to domestic animals both in this and in other countries.

The Station is loeated on the Benning's Bridge road, ahont one-fonrth of a mile east of the northeastern bomblary of the city. The plat of gronmd on which it is located eonsists of 7 aeres of rolling land, which is subdirided by new fencing into three pasture fields. The largest inclosure contains 4 acres, the second 2 acres, and the third 1 acre. There are seven outbuildings for the accommodation of cattle and the protection of the necessary implements for keeping the place in proper condition. Two wooden and two brick structures are used for the accommodation of cattle alone. The interior of the stables are fitted up with box stalls located on each side of a 4-toot passa ge-way extending the entire length of the buildings. The average measurement of each stall is 8 lig 10 feet. One stable contains eight stalls, a second five, and a third four. When necessary, two steers or cows can oceupy each stall with eomfort. Ample feed-rooms are attacherl to each stable.

The fourth building is a woolen strueture 25 feet wide by 31 feet in length, with interior free of compartments. This bnilling is used for the protection from inclement weather of the cattle, which are allowed to graze on the largest pasture field, and has been left open on the sonth side.

Fonr rows of pig-pens are located at different points on the premises. One of these pens is 60 feet in length by 10 feet in wilth, and is subdirided into ten compartments. Two others are 30 feet in length, and contain five pens each. The fourth is clivided into fonr pens. Ten or twelve pigs can he accommodated with eomfort in each pen. They are smpplied with cast-iron water-tronghs, and the floors of each, as well as those of the stables, are lidid in eoncrete, which prevents the absorption of water and facilitates disinfection. 
In addition to the pens and stables a large chicken-honse, 25 feet in length by 12 feet in width, has been provided for experiments with contagions rliseases incident to fowls. A small building, mirlway between the peus and stables, has been fitted up for post-mortem examinations, and is supplied with all the necessary instruments for making autopsies.

A brick dwelling house, about 40 feet square and two stories in height, is located near the northern extremity of the grounds, and is occupied by W. H. Rose, V.S., superintendent of the Station. The water for the Station is supplied by two excellent wells conveniently located. Plates I, II, and III, accompanying this report, give accurate views of the buildings and gromuls from different points.

\section{INVESTIGATIONS OF PLEURO-PNEUMONIA.}

\section{DISTRICT OF COLUMBIA.}

No șstematic inspection of cattle has yet been made in the District of Columbia, but we have secured a number of sick cows which have been slanghtered and examined in order to determine the nature of the disease from which they were suffering. Other cases have been bronght to our attention by Dr. Townshend, the able health officer of the District, in regard to which we hare made all the investigations that were possible. During the year we have in this way found the disease in ten stables in which more than one cow was kept, and in three others in which the diseased animal was the only one owned. In one stable two have died; in a second, one had died and two were sick; in a third, five had died and six were more or less affected; in a fourth, two had been lost; in a fifth, six har? been lost; in a sixth, five had died; in a serenth, three had died; and in the remaining three stables the loss, so far as we are aware, has been one animal each.

The total number of animals referred to above is twentr-seven which have died, and eight which were sick at inspection. In these cases the symptoms and post-mortem appearances of the animals examined were those of contagions plenro-pnenmonia, and the history, when it conld be obtained, also pointed in this direction. The following instance is an illustration of this :

A cow belonging to Mrs. Flanigan, of Benning's road, was discovered sick, May 22, 1853. The symptoms were a severe, dry congh emaciation, arched back, extenled hearl, and turning ont of the elbows. Percussion and anscultation showed that there was dullness and loss of respiratory murmur over the right lnng.

This animal was preserved until August 27, and then slanghtered. The anterior portion of the right lung was found to contain a large encyster mass of hepatizerl lung tissue, finly 5 inches in diameter, which was begimning to disintegrate and break down into pus. The 
left lung was affeeted with ehronic bronehitis, and many of the bronchi were fillerl with a thick, white, tenaeious pus.

The disease was bronght to this stable in the latter part of December, 1882, by a cow dealer who lives near the nary-yard. She presented symptoms of disease in abont two weeks after purchase and lingered for six weeks with symptoms of aente lung disease. Three weeks after the death of this first cow a seeond beeame siek, with similar symptoms, and died after four weeks' illness.

Two others were successively affected in a similar manner and died; and, finally, the fifth eame down with the disease about the 1st of May, 1883.

On May 29, 1S53, we received at the Veterinary Experiment Station a cow from the stable of Catharine Bresnahan, of Lincoln avenne. This animal was somewhat tympanitie and stood with arehed back, elbows turned out, and extended head. With each expiration there was a lond moan. Examination over the lungs revealed dullness, tenderness, and loss of respiration on the right side.

This animal died luring the night of June 3, and was examined the following day. The right lung was found to be firmly attaled to the ribs and diaphragm over nearly the whole surface of contact. This lung was almost completely hepatized; the posterior part was gangrenous; the merlian portion showed old hepatization, in which there was little difference in color between the lobular and the interlobular tissue, while the anterior portion was freshly hepatized and presented the distinctly marbled appearance seen in acnte plemo-pnemmonia, and thought by some to be characteristie of that disease. The eondition of this lung showed beyoud question that the inflammation was a progressive one, and, beginning in the posterior portion of the organ, hat successively invalled the median and anterior portions.

The existence of inflammation of different ages, showing the progressive character of the disease, is now regarded by the learling anthorities of Europe as the most satisfactory means of distinguishing between contagions plenro-pnemmonia and the sporadic intlammations of the respiratory organs. 'The plenral eavity contained about a quart of effision, and the mueous membrane of the bronchial tubes was of a deep red color.

This animal presented, eonsequently, all the symptoms and post-mortem appearances rleseribed as peculiar to plenro-pnenmonia. The only history that conld be obtained was that a number of cows had previously been affeeted in this stable with similar symptoms.

September 18, 1883, I examined a cow on Nineteenth street, which had rapid and diffienlt hreathing, with extended head and elbows turned out as in eases of plenro-puemonia. There was dullness over the lower half of both lungs, with resonance above, but no respiratory murmur conld be detected over the left side from the shoulder backward. This animal died on the morning of September 21, and on examination the left 
lung was found solidly attached to the ribs and diaphragm. There was. an abundant effusion of liquid into the pleural eavity ; the perieardium was greatly distended and attached to the eostal pleura. On seetion the lung was found free from inepatization, but the pericardium was greatly thickened and transformed into a fibrous eyst inelosing the heart. The surface of the heart showed that this organ had been intensely influned; it was roughened aud eovered with granulations, mostly gray in color, but over parts of the surface mottled with deep red. The heart tissue, to a depth of half an inch from the surface, had mulergone fibrous degeneration, was colorless, and resisted the hnife. A painting was made of this organ and is reproduced in this report as Plate $1 \mathrm{~V}$; it shows very plainly the thickenerl pericardium, the mottled apjearance of the surface of the heart, whieh organ was cut across to reveal the depth of the fibrous degeneration.

There may be a question as to the exact nature of this cliseasewhether it was induced by the virus of lung plague or whether by other eanses. No diseased animals har been introduced on the place, but there had been opportunity of exposure to animals running at large. The absence of hepatization is not conchusive eridence that it was not lung plague. This disease quite often confines itself to the serous membranes without appreeiably affeeting the lung tissue, and pericarditis and epicarditis are manifestations which have been described as oceurring in the infected stables of Emrope. I am inclined to think, therefore, that this affection was the result of exposure to the lung-plague rirus.

January 12, 1884, three cows were slaughtered at the Veterinary Experiment Station in presence of ILon. James Wilson, of Iowa, member of the House Committee on Agricultnre, and of delegates from the Chica go convention of stockmen and of clistinguished veterinarians, in order to demonstrate the character of the disease from which the cattle in this vicinity were suffering. The first one was a young eow that I found January 1, 1884, at the stable of the owner near Washiugton. At that time her breathing was rapid and labored, a distinet grunt or moan being emitted at each expiration. On perenssion orer the region occupied by the lungs the right side was found perfeetly dull and without resonance, while the left sicle was resonant over the upper half, but very dnll below. Ausenltation showed complete loss of respiratory murmur over the whole of the right and over the lower part of the left sicle. There was no cough.

This eow had been purchased about a month previously, from a dealer who had brought her from the Shenandoal, Valley, in Virginia, and had kejt her for a number of days (the exact time not known) at his stable in Washington. She was noticed to isolate herself from the remainder of the herd while at pasture, and to be disinelined to move, almost as soon as she was placed with the herd. She commenced moaning at each expintion more than two weeks before I saw her, and was then separated from the other animals. January 2 she was removed to the Experiment Station, her temperature at that time being about $103^{\circ} \mathrm{F}$. 


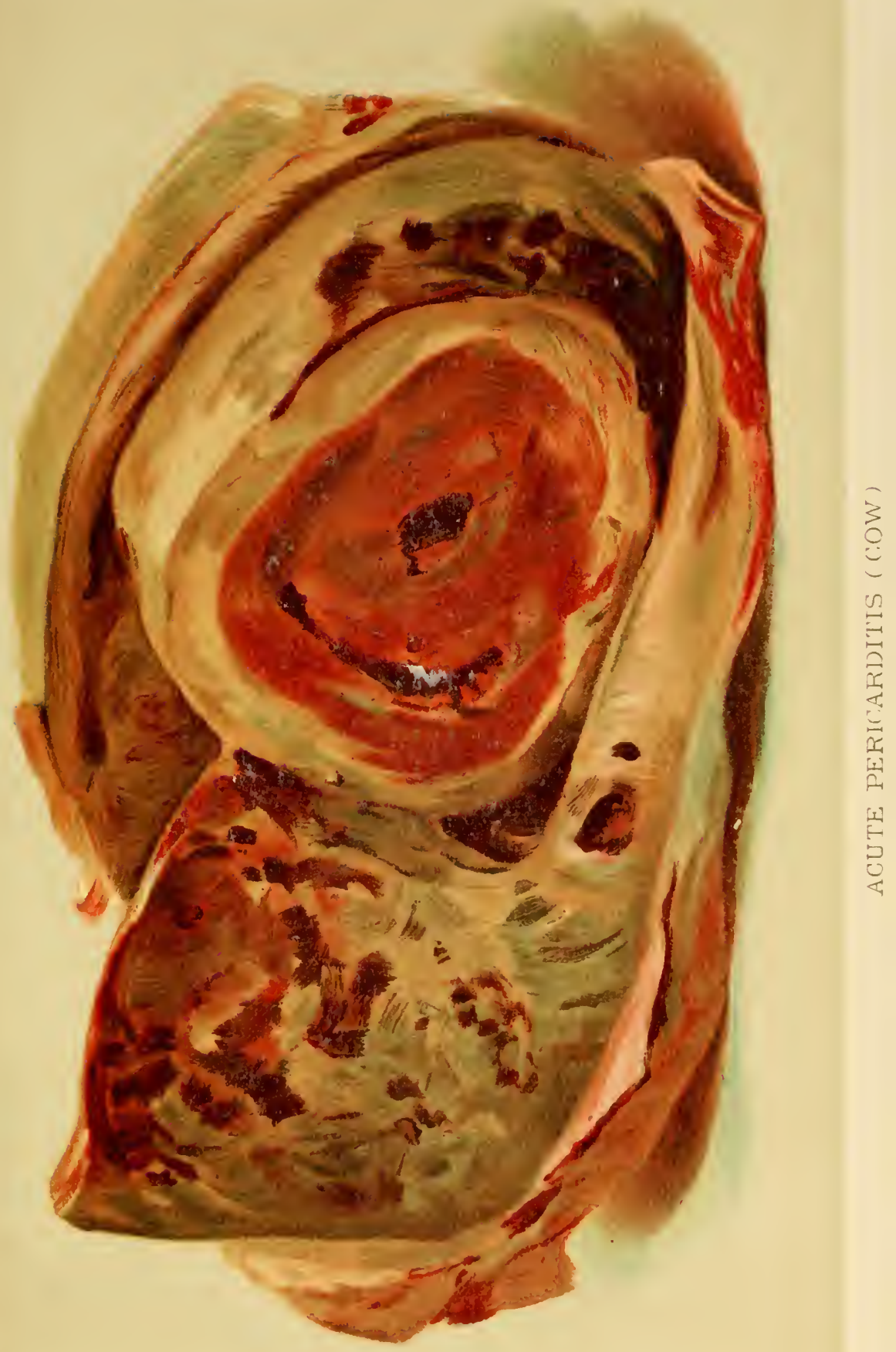



This cow died during the night of Janmary 11, and was examined about 11 o'clock the following day. On opening the thorax abont 2 gallons of amber-colored liquid escaped. The right lmug was solialy attached to the costal pleura and diaphiagm by thick false membranes of recent formation. On the left side the attachments were not so extensive, and the membranes were of still more recent growth. On each side there were thick masses of coagulated lympl, weighing from 2 to 3 pounds, and of a whitislı color and firm consistency, which indieated their formation a number of days before the death of the animal. The lung tissue presented no sigus of hepatization.

The second cow examined was bromght to the Station over two months before, and at the time of this examination was somenhat emaciated. She was conghing when firsi seen, had little appetite, and an examination of the lumes showed dulluess and loss of respiratory murmur over the lower part of the right lung.

Three animals had previously been lost in the stable firm which she eame, and before doath they presented symptoms of lum dis ease.

This cow was slanghtered, and on opening the cavity of the thorax the left long was foumd adherent to the diaphragm and the right lung to the costal plenra. The right lung contained fom or fire masses, varying from two to four inches in diameter, smromcled by a thin cyst wall and composed of hepatized lung tissue in a disintegrating condi. tioll.

The third animal, which was also somewhat emaciated, was obtained January 10, from a stable where two eows had been lost in the preceding summer. She had been purchased for \$.5n two ol three months before she sickened, and was at that time in good health. When bronght to the station her temperatme was $1040 \mathrm{~F}$, and there was complete dulluess and loss of respination over the left lung. Her eondition was substantially the same ou the day of examination, Jannary 12. When, after slanghter, the ribs of the left side were remored, a cousid. erable quantity of amber-colored liquid escaped. 'This lung was completely hepatized and solidly attached to both the rils and diapluagm. A section of the $\operatorname{lng} g$ disclosed the interlobular tissue distemled with lymph, thomgh not to the degree sometimes serm. There was, however, a very distinct narbled appearance, and a difierence of coloration between the npler and lower parts of the long that probably resulted from a difference in the age of the hepatization in these two portions. The right lung of this animal was in a nomal conclition.

A fourth cow was obtained fom a Washington stable the same day that the above examinations were mate. Sle died during the night of Jamary 12. Her appearance before death and the combition of her lungs when examined were very similar to that of the thind cow mentioned above.

May 1, 1854, a sick cow was reported at Miss Finninis, on M street, 
in this eity. She was examined the same day and found to be moaning with each expiration; her breathing was labored; there was salivation, extended heal, and elbows turned out. The bronchial breathing was londest on the right sile; the left side was very dnll on perenssion up to and somewhat abore the median line. The right side had a dull area at lower portion of thorax and another above the median line.

May 5 , this animal, now sinking rapidly and already tympanitic, was slanghterel. The antopsy revealed the left lung completely solidified with the exception of a very small part of the anterior lobe. Varions stages of inflammation were to be seen in the different purts of the lung. There were thick filse membranes and solid adhesions to the diaphragm and costal pleura. The right lung was extremely emphysematons, and parts of it allherent to the costal pleura, but there was no hepatization of its tissines.

\section{CONNECTICUT.}

In the latter part of August, 1853, I investigated an outbreak of disease at Salem, Conn., which had affected cattle on the farms of H. E. Williams and Captain Seaman, of that place. The history of this outbreak may be summarizer as follows: Hon. E. H. Hyde, of the State Commission on Diseases of Domestie Animals, first visiter the farm of Mr. Williams on Angust 8 , and at that time found a young bull in the lot partially recovered from an attack of disease, and a cow and an ox were both rery sick with what he consillered to be the typieal symptoms of plenro pnemmonia. At Captain Seaman's a cow was very sick and presented the same symptoms as were seen with the affected cattle belonging to Willians.

The next morning Dr. Rice, of Hartford, was ealleıl, and on arrival, Williams' cow was found to have died during the night.

A post-mortem examination was male and the lung found attached to the walls of the chest; when cut across it was seen to be solidly hepatized, of a marbled appearance, and presented all the characters of eontagions plenro-pneumonia. The Commission advised slanghter, which was objected to, but the same day after the departure of the State officer's. the sick ox belonging to Williams and the cow belonging to Seaman were slanghtered. These animals were not examined professionally, but the descriptions which I receiven from those who were present were sufficient to satisfy me that the lungs were solidified and attached to the ribs.

Angust 29, I visited Mr. Willians' farm and learned from him the particulars of the outbreak. The first symptoms of disease were seen in one of the cows June 20 , and a second cow wats attacked on June 23 ; both of these died firom the effects of the disease July 3 . At the time of my visit, Angust 29, there were six animals on the place: one ox, quite sick with left lung soliditied; one Jersey cow, had been quito sick but was now better; one young Jersey bull, with left lung solidi- 
fied, and three Jersey cows, in which I found no evidence of disease. Only one animal bad been brought on the place within a year precenling the outbreak, and that was a Jersey cow named Mollie Lathrop 3rd, No. 7627. She was obtained by exelıange with Charles Decline, of New Durham, X. J., on April 10, 1833. This cow aborted the last of May, but has shown no other signs of sickness. At the time of eximination she was in fine conclition, fat, glosiy, with no cough and no signs of lung disease, revenled by either auscultation or percussion.

I visited Charles Decline at New Durham, N. J., on August 30. He stated to me that he exchanged cows with Williams about April 16. His cow went to New London on the same boat that the other returner by. According to the statement of Williams' farmer, the two cows were together abont a quarter of an hour at New London. The cow Decline received from Williams sickened about the last of May. Abont a week later, she and another Jersey eow which stood besicle her, and which was also sick, were kitled and examined by his son, who is a veterinary surgeon. Both were affected with lung disease which he pronounced to be plenro-puemonia. The lungs were hepatized, marbled in color, and attached to the walls of the chest.

Decline purchased Mollie 3al of Mr. Whitenack, of Dnuellen, N. J., December 13, 1881. He says that he never hal any disease anong his cattle until after the cow arriver from Connecticnt, and attributes the infection to lier.

It was evident that some of the facts connected with the history of the disease in these two herds had been concealed, but it was rery certain that the disease had existed in both herds, and it was rery probable that one of the herds han been infected as the result of the exchange referred to above. Considering that there had been no disease in Connecticnt until nine weeks after the exchange, and that it was admitted to have existed in !eclines' herd four weeks earlier than it appeared among Willians's cattle; and consilering, further, that the vicinity of New Durham has long been infected with plenrospenmonia while none had previously existed in the neighborhood of Salem, and the probability is that the disease was earried from New Jersey to Comnecticut. There is one other possibility, however, viz., that both cows were infected on the boat or between the boat landing and Decline's place.

This theory is not probable, for the reason that a second cow was sick at Decline's by the last of May, and this would reguire the assmmption that two full periods of incubation had elapsed between $A$ pril 16 and May 30; that is, within six weeks. Now, it is very seldom that the period of incubation of plenro-pnenmonia is less than four weeks, and it is generally longer than this; consequently, it is rerg mulikely that in two successive cases on the same farm it would be reduced to three weeks. 'The almitted faet that both sickened at about the same time is an indication that both were infeeted at the same time, and from a 
common souree, rather than that one contracted the disease from the other.

A second risit was made to the farm September 7 , in company with Hon. E. Н. Hyde and T. S. Gold, of the State Commission on Diseases. of Animals, and Doctors Thayer, Rice, and Parkinson. At this time the bull and ox still presented symptoms of plemro-pnemmonia. The eow, Mollie 3rd, was again carefully examined and showed a rather large area of dullness over the region of the heart and another low down on the right side. My own opinion was that this dullness did not indieate any disease of the lnugs, though some of the others thought differently. It was admitted by all, howerer, that there were no positive sigus of diseased lungs in her case.

A third risit was made, in company with the same gentlemen, with the exception of Dr. Thayer, September 12, when the ox mentioned above was slanghtered and examiner. This animal was now believed by the owner to have recovered. The autopsy revealed the left lumg solidly attached ovel a large surface to the thoracic wall and diaphragm. One-third of the organ was encysted and beginning to disintegrate, another thind shomed more recent hepatization and was not yet encyster. A section showed the eharacteristic marbled appearance, and the difference in the age of the inflammatory process in varions parts of the lung.

Members of the State Commission liare since informed me that the bull continued to fail and was destroyed by the owner on the 27 th of October. Before this, however, the Commission was called September IS to see a new case of the disease, which had developed on the farm of Amos Williams, the second neighbor south from the originally infected premises. This was a cow, which presented the typical symptoms and post mortem appearances of plemo-pnemmonia, having been condemned and killed by the Commission.

To recapitulate: H. E. Williams had seven auimals affected out of his herd of nine by the introduetion of the cow from New Jersey, which animal was so slightly diseased as never to attract attention. Of the seren sick ones three died of the disease. Two of those slanghtered probably could not have recovered; one of the slanghtered oxen was. impoving, while the remaining eow was very sick when 1 last saw her. The aljoining farm on the north and the second one on the sonth each lost one animal from the disease. There were, eonsequently, nine animals affected in this ontbreak.

\section{PENNSYLYANIA.}

October 3 and 4 I visited Chester County, Pennsylvania, in company with Mr. T. .J. Elge, speeial agent of the governor, and Dr. Bridge, State Veterinarian. On the farm of W. P. Thomas I witnessed the slanghter of : cows, and on the farm of J. H. Garret I saw 5 others lilled, these having been condemned br the State anthorities as affected with 
contagious pleuro-pneumonia. The autopsies revealed the existence of a rery similar condition in each of the animals. In most eases a whole lung was hepatized and firmly attached to the diaphragm and ribs. In several of the animals both lungs were affected. 'The pleural eavity contained large quantities of straw-colored effusion, and the connective tissue of the lungs was excessively distended with exndation of a similar liquicl. The inflammation was very plainly of a progressive character, and the marbling of the lung was as distinct as in any eases I hare ever seen.

The disease was introduced into this section by a ear-load of 14 cows brought by John Noble from Baltimore. Where these cows were originally infected is a contested point between the authorities of Pennsylvania and those of Maryland; but there is no reason to doubt that the outbreak near West Chester was caused by this lot of animals.

These cows were sold as follows: July 19, to W. H. Shepherd, 1; July 26 , to W. P. Thomas, 3 ; July 26, to H. Enehes, 4 ; July 27, to J. H. Garret, 2; August 1, to J. Kelly, 2; not traced at time of report, 2.

Mr. Shepherl's cow was found siek with symptoms of pleuro-pneu. monia September 8, and slanghtered by the State anthorities. The autopsy revealed the characteristic lesions of lung plagne. September 13 a cow was found affected with the same disease and slanghtered on Mr. Garret's farm. September 29 it was neeessary to slaughter one of Mr. Thomas' cows. October 1 it was found that two cows had already died on Mr. Enches' farm, and that six others were sick.

According to information received from Dr. Bridge, October 23,1884 , the number of eattle exposed and slaughtered on aeconnt of sickness was as follows:

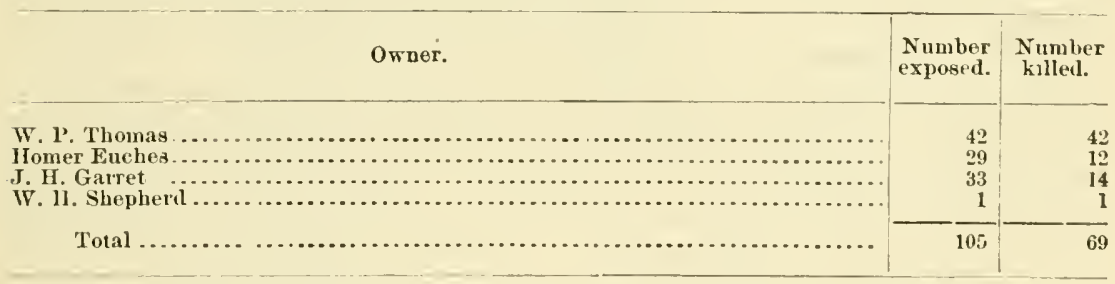

Eight adjoining herds were infected by the above, as follows:

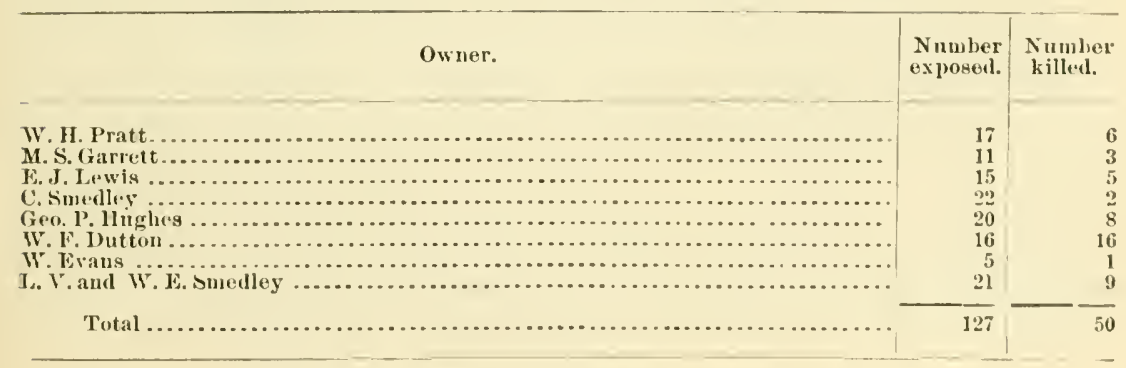


The affected cows which I saw were native animals in good eondition. They had excellent pastures to run on, and there was no local canse whatever which could be suspeeted of producing this or any other disease. Besides, the time of year was not one in which acute lung diseases are seen among eattle. Nearly every one of the afterted lungs which I saw when in this State showed the typical lesions of pleuropueumonia so plainly that, according to the best anthorities in the reterinary profession the world over, any one of them would have been sufticient to afford a safe basis for diagnosing the disease.

Besides the herds infeeted by the contagion introduced with the lot of eattle from Baltimore, six herds have been infeeted from other sourees since September, 1853. The following table shows the number exposed in each of these and the number destroyed after showing symptoms of the disease:

\begin{tabular}{|c|c|c|}
\hline Owner. & $\begin{array}{l}\text { Number } \\
\text { exposed. }\end{array}$ & $\begin{array}{l}\text { Number } \\
\text { killed. }\end{array}$ \\
\hline 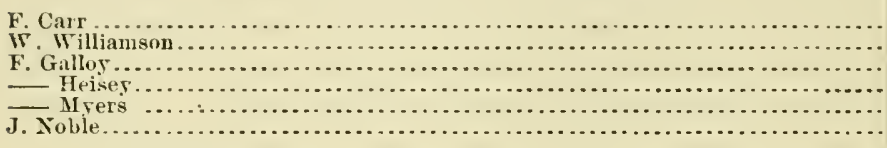 & $\begin{array}{r}3 \\
5 \\
20 \\
9 \\
17 \\
10\end{array}$ & $\begin{array}{r}1 \\
2 \\
14 \\
5 \\
\frac{2}{0}\end{array}$ \\
\hline 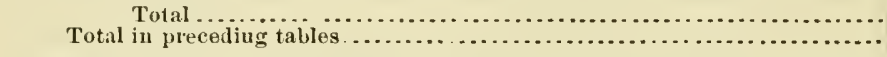 & $\begin{array}{r}64 \\
232\end{array}$ & $\begin{array}{r}24 \\
119\end{array}$ \\
\hline Total for State of Pennsslvania . . . . . . . . . . . . . . . . . . . . . . . . . . . . . . & 296 & 143 \\
\hline
\end{tabular}

NEW JERSEY.

Dr. Rowland, an Inspeetor of this Department, stationed at Jersey City, N.J., diseorered during the summer of 1853 that animals affected with pleuro-pneumonia were being shipped to New York from Hunterdon County, New Jersey. An investigation was ordered by Dr. L. M. Hunt, secretary of the New Jersey State board of bealth, and a number of herds ivere found in Hunterdon Couity which had been for some time affected with this disease. Owing to the fact that the owner of the affected herds was a large eattle dealer who gathered up cheap animals from varions parts of New Jersey and Pennsylvania, and to the additional fact that the disease had been upon his premises for an indefinice time, the origin of the trouble could not be satisfaetorily traced.

The owners of the infeeted herds had resorted to inoenlation to arrest the progress of the disease, and it was said that all fresh animals whieh arrived were speedily inoculated. In spite of this, however, the losses were very heary, though their full extent conhl not be ascertained. Dr. Miller, who investigated the condition of these animals, November 1, informed me that ont of one herd, containing 60 head, w2. had been lost; from another containing (ii) hearl, 8 were known to have died, and 1 was lilled to obtain virus for inoculation; from another, containing 46 head, $S$ hath died; from a fourth, containing 70 hearl, 10 had died; and from 
a fiftl, 6 had died. There had, consequently, been at least 55 deaths; in addition, a certain number had partially recovered, and some diseased animals had been sold.

According to the best information we could obtain the total number of cases of pleuro-pmeumouia which had oceurred in this comnty was not less thau 100. These herds were quarantined and the State authorities are doing everything possible with their limited appropriation to stamp out the disease; but where so many animals have been exposed, and where the contagion has been sown broadeast over the pastures of half a dozen farms, experience shows that it is next to impossible to remove all danger except by lilling all animals exposed and quarantining the farms for a long time.

\section{MARYLAND.}

Owing to the variety of reports in regard to the existence of pleuro. pneumonia in Maryland, Dr. Rose was directed to proceed to Balti. more during the last week of October, 18s3, and examine a sufficient number of stables to form a basis for eonciusions in regard to the dis. tribution of the disease in that section. The cases of sickness mentioned are only those in which the symptoms indicated plenro puenmonia. The following is a list of stables in the order in which they were examined, with a eondensed summary of the information obtained :

Stable No. 1: Contaius thirty-five cows. One chronic case, two recent deatlis.

Stable No, 2: Thirteen cows. No disease.

Stable No. 3: Sixteen cows. One chronic case, two recent deaths.

Stable No. 4: Seven cows. No information.

Stable No. 5: Nineteen cows. Adurit that cows are exchanged as soon as they show signs of disease.

Stable No, 6: Nine cows. Three recent deaths.

Stable No. 7: Two cows. Adnits recent deatlus from lung disease.

Stable No. 8: Thirteen cows. T'wo recent deaths from acnte lung discase.

Stable No. 9: Seventeen rows. Ilave lost many in the past. All alle now well.

Stal,le No. 10: Eiglateen cows. Have lost two during the summer.

stable No. 11 : Nineteen cows. Wubll neithes allow an examination uor give informations.

Stable No. 12: Seven eons. None sick. No information.

Stable No. 13: Eleven eows. None sick.

Stable No. 14: Fifty-six cows. One acute and four chronic cases of pleuro-pnenmonia. Have lost heavily in past years.

Stable No. 15: Eighteen cows. Five sick with acute lung disease witluin two months, of which three diel.

Stable No. 16: Forty-two cows. Acknowlelge a loss of over 200 cows fiom lum iiscabe within three years. Screral now conghing.

Stable No. 17: Fifty animals. No disease.

Stable No. 18: Thirty-six animals. No disease.

Stable No. 19: Original leerd 32 animals. Thre di deluring September and October. Calf died in Octoher which State Veterinarian cxamined and pronounced aflected with pleuro-pneumonia. 'Three still sick with same disealse. First cow to sicken eame from another stable in Baltimore within at tew weelis. 
The herds in the nineteen stables referred to above contained 395 animals, of which 12 were found to be sick or only partially recovered at the time of inspection; 3 cows had reently been exchanged while sick, and 18 recent rleaths had oceurred. The total number of animals which had recently siekened with symptoms of pleuro-pneumonia in the above stables was, consequently, 33 , or 8.3 per cent.

This inspeetion, while it camnot be taken as a very aceurate indication of the proportion of the Baltimore dairy eattle which are constantly affected with plenro-pneumonia, is nevertheless sufficient to show that a very large proportion of the stables are infected, and that many uases of the disease oecur.

A considerable number of inoculation and cohabitation experiments have been made and are still in progress, and wiil be given in rletail in the First Annual Report of the Burean of Animal Industry.

The following statement was prepared for the use of the House Committee on Agriculture in Jannary, 18st:

\section{EXTENT OF PLEURO-PNEUMONIA AND THE IMPORTANCE OF NATIONAL ACTION IN REGARD TO THE CONTAGIOUS DISEASES OF ANIMALS.}

The pxtent of territory infected with contagions pleuro-pnenmonia of cattle and the number of animals actnally sufferiug from this disease, are insigniticant in eomparison with the anmual direct aud indirect losses traceable to it, and the danger to which our immense live-stock industry is continually suljeeted.

In Connectient two herds were mfeeted dnring the past snumer, in whieh 12 animals were exposed and 7 contracted the disease. In one of these herds the affectur animal was destroyed, and at last accounts no others had eontraeted the disease; in the other herd 4 animals had died, or had been killed, and 2 with very extensively diseased lungs remained in quarantine. Both of these were Jerseys, and the owner refused to bave them destroyed. What has been done with them, or what will be, I am mable to say, as the State anthorities scem powerless to proceed beyond quarantine, and this seems to have been by no means secure.

In the State of New York, althongh the disease is almost entirely eonfined to the western emd of Long Island, to Staten Island, and New York City, these loealities are quite extensively infeeted, and as there are more than two thonsand stables, some of which contain several humberl eows, and many of whieh contain from 50 to 100 , it is the most dangerons district in the eomtry at this time. Recent reports are to the efteet that the disease is extending through the river eonnties, and exists in herds located firom 50 to 60 miles north of New York City. How many eattle are affected in these comnties I an unible to say, but the existence of the disease here is really of much greater importanee to the eountry at large than the number of diseased animals would lead one to suppose, beeanse it is a distriet where many thoroughbred eattie are raised and from which they are shipped to all parts of the United States.

Now Jersey was recontly supposed to be nearly free fom pleuro-pmenmonia, but the fict that a number of eases oecurred withont the knowledge of the State authorities, that a still barger number of herds were lately known to be infected in Union and Essex Comnties, and that a veryextensive outbreak in Hunterion County was reeently traced by moms of sick cattle shipperl to the New York market, and diseovered by the iuspector employed by the United States Department of A grieulture who is stalioned at Jersey Cily, leads to tho suspicion that a thorongh inspection of the State might bring to light still other cases. The llunterilon Comnty outbreak was one of the most extensive lhat has recently oceured. It was smpposed to late originated from a car-load of cows hronght from lennsylvania; hut where these were in- 
fecterl is not known. Seven herls, at last acconnts, were in cuarantine; and as all were largo herls, containing from 40 to 70 eattle, a large number of animals were exposed.

Inoeulation was extensirely practiced to elheek the fatality; but, in spite of this, reliable anthority places the loss at wrer 50 head.

In Penusylvania there has recently beeu another very extensive ontbreak, which was the result of taking a ear-load of 14 eows from the Calvert stock-yards in Baltimore to Chester Comnty. Most of these cows were taken into large dairy herds, which they thoromgly infected. In each of these eases the Baltimore cows were the first to sicken, aud a large proportion of the nativecattl were soon affected with the same disease. These herbs were visited the 3rl of October by the Veterinarian of the Department of Agriculture, in company with the State anthorities, who killed 8 of the animals in lis presence in order to satisfy hin as to the nature of the disease. The cases were typlical cases of pleuro-puenumonia, and all those appearances were present which were recently accepted by the International Veterinary Congress held at Brussels as characteristic of contagions pleno-pmenuonia. In most cases a whole lung was hepatized; the inflummation was of different ages, showing the progressive character of tho disease; the interlobular tissue was greatle distended with the exudation, aud the plenrisy was intense. Aceording to au oficial report, dated Oetoluer 30 , the $n$ mbler of animals known to have been exposed was 104, and the number of sick ones that had been killed or had died was 46 . A semi-official report of the present montl places the nmmber destroyed at 70 . It is now believed that the distase lias been euticly overeome, and that the State of Pennsylvania is free from it.

In Marylaud and the District of Columbia there are many infected herels in which a eomplaratively large number of aniuals aumally coutract the disease. by direetiou of the Commissioner of Agriculture a reliable Inspector was sent to Baltimore late, in Oetober, to learn the condition of the stables there as regards this disease.

Nineteen stables, containing $39 s$ animals, were examined. In twelve of these the infection was admitted; oue had lost more than 200 animals withiu three years; others had lost heavily for years; 12 sick animals were found, 18 reeent deaths were admitted, and 3 sick cows had just been sold or exchanged. This number of stables comprises but a small part of those in the vicinity of baltimore, but it is believed that the number is sufficient to demonstrate the presence aud dangerous eharacter of the disease. Wo have no information of plemro-pneumonia in the comtry disfriets of Maryland at any great distanco frou the cities.

One or more hercls near the District of Columbia have recently lost a number of cows, aud it latest accomnts had some sick. Withiu the Distriet, without making auy regular iuspection, three infected herds have been found where from 3 to 6 animals are arluitted to have been lost within the year. In Virginia there are stables from which animals lave reently been lost with symptoms of this disease; but none of these could be securel for exanination, and therefore we can not bo positive in regard to the uature of the disiase.

\section{REASONS FOR BELIFVING IT CONTAGIOUS}

The first great reason for believing this to be eontagions plenro-puemmonia is the fact that nowlue in the comutry outsile of the comparatively small strip of territory strotehing from Conncetient to Virginia, and east of the Alloglnany . Iomntains, have any rases bean fonud which har any cluse resemblanes to the disease muler consideration. If this disease were the result of climatic canses, or if it were prodnerel loy juproper ford and care, then we should cortainly lind it distributed over the whole comery, or at least in all of thoso parts of it where similar comditions exist. It ean-

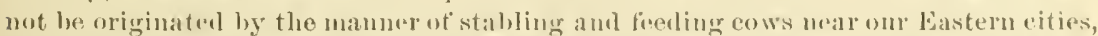
fir substantially thesame eomelitions rxist at Rochester, l3uflalo, Cleveland, l)etroit, Chicago, Saint Lonis, Cincinnati, and other Western cities, and no veterinarian has

5751 D $1-$ 
been able to find any similar cases of disease there, although special inspection has been male hy competent persons.

The disease is not contined to stable cows, however, nor to those seasons of the year when acnte lumg tiseases ean be acconntert for by the inclemency of the weather. The onthreak referred to in Comnectient occurred in the summer, in a conntry distriet, and where the cattle were running upon nice pasture fielils. The extensive onthreaks in New Jersey and Pennsylvania also happened in summer, and were in the best farming districts of these States.

In this connection attention is called to the fact that in the State of Pennsylvania about ninety herds have heen infected since March, 1879, and that notwithstanding the appointment of special agents in every part of the State, and the investigation of all cattle diseases whererer found, there was no disease resembling plenro-pnenmonia discovered exeept in eight of the sixty-seven counties of that State. The remaining fifty-nine comties have been free from any suspicion of this plague. What is even more significant is the fact that these connties are not distributed over varions parts of the state, but that they join each other, and are all in the sonthenstern corner of the State, where there is the greatest danger of infection by cattle brought from Philadelphia aud Baltimore. With seventeen of these herds the infeetion was traced to cattle from Baltimore or other points in Maryland; with twenty-one it was traced to Philarelphia; with ten it was traced to cattle from herds in Pennsylvania known to be diseased.

The most favorable conditions of life were not sufficieut to protect the cattle where this disease was introduced. I have already mentioned that a number of the outbreaks referred to occurred during the summer, and that the animals were running npon irreproachable pasture fields. Mang of the affected cows were somng and in fine condition. In Connecticnt a Jersey bnll, less than two years old, and two steers fit for beef, were anong the victims. Again, the disease as we see it here does not ocenr in isolatel herds a single case at a time, as does nou-infectious lung disease, but when it enters a herd a majority of the cattle are affected sooner or later. Solue of the herds in Brooklyn and Baltimore have been losing cows from this plague for years, and one near the latter city, where but ahont fifts eows were kept at a time, has lost between 200 and 300 cows within three years.

These instances, all recut, are refered to, not as all the evidence bearing on this point, but simply as examples of what has been ocenring for years past; aud it is believed that they cannot be explained on any other hypothesis than the contariousness of the disease.

DANGER GREATER THAN EXTENT OF INFECTED TERRITORY AND NUMBER OF DISEASED ANIMALS WOULD INDICATE.

Glancing over the teritory which I have stated to be infected, it must be confessel that it is not extensive-a siugle farm with perhaps five animals in Connecticut, about fonr connties in New York, as many in New Jersey, two or three countics in Maryland, and possibly a few stahles in Delaware ambl Virginia.

In most of the infected herils there are bnt one or two sick animals at a time, and frennently there are none; for where the disease has existerl for at certain time thes susceptible animals die oft and only those which possess a certain immunity from it rentain.

As about 20 per cent, of all the animals exposen are able to resist the contagion indefinitely, a hed of emmaratively insuserptible eattle is in time acouired, and the time necessary for this is shortened lootl in Baltimowe and brooklyn by the practien of inoculation.

But these staliles and grounds remain infected, and a large portion of the new cows bought into them eontract the disease muless they are previonsly protected by inoculation. The practioes of inoculation does not destroy the infection; on the of her latmel it kecps it mp, hut it elables dairymen to keep their eows in infected stables 
without great loss, when without it more than half of the new cows bromglit into them wonkl surely die.

Another fact of great importance brought out by the experiments of the fremch plenro-pnemmonia commission is that about:30 per cent. of the aninals exposed to this disease show no symptoms of it heyoml a slight romgh. Snehamimals are probals] as dangerous to others as those which have it in a more severe form, and yef they can be transpurted to various parts of the combry without exciting the least suspicion.

The animal which is supposed to have cansed the ontbreak in Commectirut was probahly in this condition, as a careful examination of ber lụngs did not puable the vetrorinarians to defect any evilences of the disease; and yet plenro-pnenmonia existed in the stable from which she eame, amb her armission into the new herl was followed by the seren cases that have been mentioned. Similar instances are refered to again and anain by the vetoriuariaus of every country where the disease exists.

These intected districts, though small, are then a real danger to the wholecomntry, because all the way from Connecticnt to Virginia there is a large and increasing unmber of herls of thoronghbrel cattle, which are frequeutly shipped to the West and some of which have from time to time been infected with this disease. Fortunately, the owners of thoronghbred cattle have generally had too mueh regard for their reputation to ship cattle when there was any lisease in their herds, and the common cattle have not been sent to a sufficient distance to do much harm.

But with the increased wice of eattle a large number aro being shippen from the East toward the West, and the dangerot carying the disease is consequently increasing. If the car-loarl of cattle shipued from Baltimore to Chester Connty, Pennsylvania, hal gone to the ranges of the West, they might liave done irreparable liarm. Again, the thoroughbred Jelsey cow which went from an infected stable in New Jersay might as rearlily have been shipped to the West; and I have been informed that if the Commecticnt onthreak harl occurren a few months later one or more of theleris would have been sent, according to contwact, to a Western State. Now, while it is true that plenro-pnemmonia has existed in the East for forty vears without having been carrind to the Wrst, it must be almittel, from what has occurrel somany times in Pennşrania aud Comecticut, that there has been danger of this, and that this dauger is inereasing with the larger mumber of cattle uow being shipped in that direstion. No dombt this danger has been exaggerated, but the fact that there is danger, and that the rlisease ance carried to the Western herding groumb would proluably be beyoml our control, if we can judge from the experience of Australia and South Africa, is sufficient to show the importanee of grappling with it while it can lue so easily handled. The rapidity with which a distase spreads on these ranges, when once introchurel, is illustrated hy an ocouruene of last smmuer in Sonthwestern 'Texas. A drove of eattl. bronght a communicahlo dist ase to that section, which the army surgeons helirval to heroutagious pleuro-puenuonia; hut heforeany careful examination

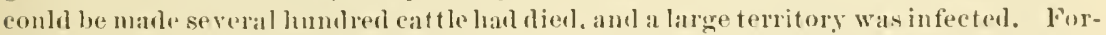
tunately, investigation showed that this was not plenro-pnemmonia, bnt a disease which does not ont last a single season of the goar. If it harl poved to be plenro-pmemonia, wombl it not have heren a watimal calamity? With a larue torritory alroaly infecterl, with no unney and no jower to control the disease, and vecurring in smmmer months, before the State and national Jerislative bolies would convene, it is diticult to see

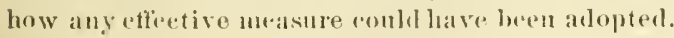

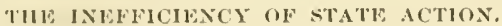

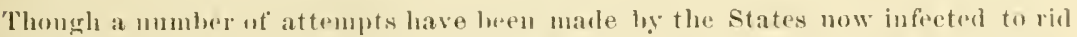
themselves of plemo-pmenmonia these have gemerally ur always failed, hecause for various reasous tho work was unt thoromghly dome. Wo saw the State anthoritios of ('ommecticut muable to rexterminate the disease a fow montlis ano, when but a sin-

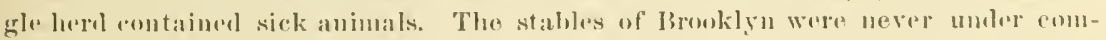

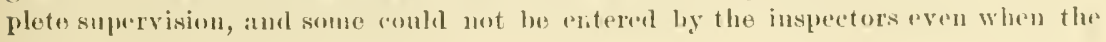


State of New York was most active in the endeavors at extirpation; and though the authorities of New Jersey have been engaged at the same task for live years, the State has probalily never during that time heen intirely free from pleuro-pneumonia. In Maryland the assertion has been made again and again that there were no cases of this dhsease in the State, and yet dnring any part of this time a thorongh inspection conld not have failed to reveal a considerable number. At best the attempts of the States bave heen spasmodic; and while one State was earnestly striving to accomplish something a mejghboring one would allow the shipment of diseased eattle, and connteract the influence of the former. As a rule, thersfore, State action has never been thoromgh, and the lack of mity of action between the States has prevented any lasting benefit aven when much has been acemplished.

ADVANTAGES OF TIE WORK BEING DIRECTED BY TIE UNITED STATES GOVERN$M \mathrm{ENT}$.

A rational direction of the work for the extermination of pplenro-pnemmonia would overeone at ouce the disconraging features which have done so much to prerent the efforts of the individual States from heing effective. With inspections in every infected state the shipment of diseased cattle wonld soon cease; new outbreaks would thus be prevented, and the danger which has so long menaced the great 'attle interests of the conntry wonld be removerl. The work would be more thorongh and energetic, becanse those engaged in it wond not be direetly or indirectly depeuclent npon the good-will of the interested cattle owners for their positious, and the plea of inability to pay for the diseased eattle which ought to be slaughtered would also be overcome. These have been the principal obstacles to the sncess of State action, and practically they are so great as to make it next to impossille for the states alone to free themselves from this plagrie.

TIE PRESLACE OF PLEURO-PNEUMONIA COSTS ANNUALLY MORE TIIAN WOULD BE NECESSARY FOR ITS IESTRUCTION.

Owing to the presence of plenro-pnemmonia in the United States, every stem shipped to Great Britain mnst be slanghtered within a certain time on the wharf where he is landed. This restriction upon the export cattle trade is said by competent anthori. ties to make the price of our steers average $\$ 10$ less than similar animals shipped from Canala. With over 100,000 beeves going abroad every year, this makes a loss of $\$ 1,000,000$ ammally, or enough to elear our comntry of the diseatse. Besides this, there are the continnal lowses which are going on in the infected districts, and the distmrbed condition of trafle from the many false alarms in regard to the spread of this disease, the entire anmal losses being estimated by goorl anthorities as high as $\$ 3,000,000$.

\section{IMPORTANCE OF INVESTIGATING OTHER DISEASIS.}

The proposition of cstahlishing a permanent burean for investigating the communicable diseases of animals is a matter of the greatest importance. While we have no more disease than ofluer conntries in poportion to the mumber of our animals, the chormons development of onr live-stock industry has made the question of contagious diseases one of pentiar interest to ns. The canse of these planges, which has been an impenetrahle mystery dnring all the past ages of the worlel, is boing revealed by the science of to-day, and the infinitely small organisms which are able to produce such terrible havoe in onr tlocks and herts are at last being hronght muller subjection themselves, ant their stmly has revealed much of the greatest value to $\mathrm{ns}$ in $0 \mathrm{~m}$ warfare against them. $\Lambda$ comntry with so mueh at stake, with millioms of dollarsanmually swejt away hy this class of maladies, eamot atford to be idle. Other nations which lave much less eajuital invested in animals than we have, see the neeessity for this work and are malking provisions for it; and it is to the credit of onr comntry that we weie one of the first to anter this fiold, and that results latre been aceomplishen which will hear eomparison with the investigations of any other conntry. 
But while much has been done, while millions of dollars have alrearly been saverl to our farmers by the facts thus fiar discovered, we have only made a leeginuing in the great work that is before us. Some of the most important rliseases affeeting onr animals are still mysteries to ns, and thongli they are distributed over latre territories and decimate the live stock, we are imnorant of their eanse; we do not know how they are kept np from year to year; we have nomeans of combating them, and the illea of freping ourselves from their ravages has scarcely dawnerl upon us. A striking example of the vecessity of snch work is secn in the recent investigations of Texils cittle fever. This divease has been alvaneing and intecting new teritory for a "rntury, and until the last year or two we knew nothing about it, and onr best infumed reterinarians and stockmen did not suppose that it was fondel in one-fifth of the territory which it has actually overmu. These wore points whieh it was necessilly to nuderstand before either legislative bodies or individuals could adopt intelligent meatsures for preventing the annual losses which have been most discomaging to the eattle industry in large sections of the conntry. And with every disease there are echullly important points still to be investigated.

The laboratory and experiment station which have been fitted up duriug the past summer under the direetion of the Commissioner of Agricnlture, for investigating contagrions liseases, make it possible to attempt the solution of questions which were formerly beyond our reach. The libboratory contains the most improverl apparistus for sueb investigations, mueh of whieh was constructed according to new designs, especially for this work, and it is safe to say that the facilities here are now equal to those possesser by investigators of similar diseases in any eountry, and in some rospects ther greatly surpass them.

In conclusion, I wonld say there is not a departwent of original research or of agrienltural investigation in regirm to which there is moro pressing need for development than this, and none which promises to effeet a greater saving. Our losses are now heary, but they must inerease as our animal population increases, as vew diseases are introduced, and fresh areas are infected. But it is not alone a question of dollars: the investigation of animal contagia must throw new light on those human plingres whith $i_{\mathrm{u}}$ our eountry alone sweep a cuarter of a million of human lives out of existence each fear. Some of these animal diseases are commnuicable to man, and have a greater inthence over our health and lives than is generally supposed, and any means of controlling them camnot fail to have an important influence on human health as well.

\section{ENZOOTICS OF ERGOTISM.}

Garly in March, 1SSt, a disease amoug the cattle of Cofley County, Kansas, which was supposed by certain veterinarians to be foot-andmouth disease in a most virnlent form, was bronght to the attention of the ofticers of that State; and such exaggerated aceounts were sent to the press fiom day to day as to canse a freling of insecmity amd alarm among all engaged in the live-stock industry of the West. The 3al of Mald, Dr. Wilhite risited the farm of Mr. Daniel Keith, located in Coffey Comnty, 1 miles norlawest of Neosho Falls, and promonnced the tromble among his cattle to be foot and-mouth disease. The same day Governor Gilick telegrapherl as follows:

Hon. (iko. 13. Lonisti,

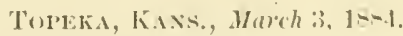

Commissioner of Agricullure.

A very malignant distase lats broken ont ameng the cattle in Neosho comuty, this State. It is supposed to be lle liont-and-month discase. The feet become sore and 
soon rot off. The disease sometimes extemds to the kues. Over a hundred animals have been attacked in a few lays. Great consternation among the cattle owners. Can your Departuent send here a competent veterinary surgeon? No oue here cau advise what to do.

G. Wr. GLICK, Gorernor of Kansas.

Two days later the following dispatch was received:

Hoh. (iEo. 13. Lorixi,

Tирека, Kaxs., Warch 5, 1884.

Commissioner of Agriculture:

Veterinary surgeon reports disease of which I advised you to be font-and-month dis. ease.

G. W. GLICK, Gorernor of hiansas.

On the receipt of this dispatch, and similar representations by the Senators from Kansas, Dr. M. R. Trumbower, a veterinarian whose previous reports of various diseases haul le! us to put great confirlence in his knowledge and julgment, was directed to proceed at once to Neosho Falls, and make an early report in regard to the natme of the disease among cattle which was said to exist at that place. He started on the 6th, but could not reach the affecterf farms mil the 9th of March.

In the mean time, at thr request of the governor, General Angur detailed Dr. Holeombe, of the ar uy veterinary service, to make an immediate investig tion. In company with the governor, the secretary of thr. State Board of Agrimitmre, and a delegation of citizens from Emporia, I)r. Holeombe reached Neosho Falls March 6, and after a hurried examination of the Keith, Goodrich, and Bearl herds he reported that the disease was the genuine epizoütic aphtha of Europe. The following dispateh was received at the Department of Agriculture the same daly :

Hon, Geo. B. Lonisg,

Neosio Falls, Kaxs, Warch 6.

Commissioner of Agricallure:

Veeterinary surgeons A. A. Holcomb and A. II. Wilhite have to-day made an examiwation of the infeeted cattle, and pronounce it foot-and-month disonse. Over 100 hearl are affected, but the disease is confined to stock cattle on a half dozen farms. (7. W. GLICK, Grorernor of liansas.

When 1)r. Trumbower reach d Neosho Falls, he fomd an excited throng of people who urged upon him the neesssity of making an immediate diagnosis, and relying lather mon the represent itions of others, which in many important respects prover to be incorrect, than mpon what lie was actually able to sece, and a earefiul judgment has d mpon this alone, loe was lenl to comenr in the opinion of the pofessional gen-

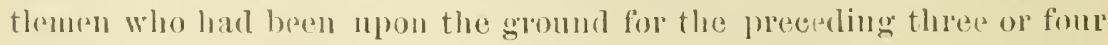
dais.

On Mareh 10, Dr. Holeombe mate his formal report to the governor, in which ocemeres the following sentence:

Tlant it is foot-and-month disease cannot be doulded when the symptoms are eonsicleres ; for to recapitulate, the varions eases show vesicles amd ulecrs of the month ;

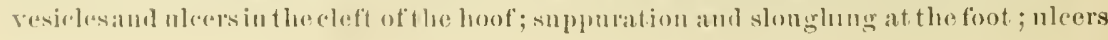


of the rectmm; vesicles and uleers of the udder; diarhea; a temperature varying from 101 to 104.4 degrees Fahr., and the most remarkable emaciation even in eases where the appetite is goor.

The excitement now became so great that by your direction I left Washington, March 13, to investigate the natme of the discase and to see what action, if any, was necessary to hold it in check. At Chicago I learned of what was supjosed to be a similar outbreak at Effingham, Ill., and was requested by Di'. Rumch, secretary of the State Board of Health, and by otler's largely interested in the eattle industries of the State, to make an immediate investigation. The condition of alfairs in Kansis, however, was so nrgent that I concluded to mess on as rapidly as possible.

I reached Topeka March 15, and inmediately had an interview with the governor and with the secretary of the State Board of Agrienlture. I was informed by botl that the malady was moloubtedly foot-andmonth disease, but that it was so quarantined that there was little danger of its immediate extension; and at the request of the gorernor I poceded the following day to Pawnee County, to investigate a sup)posed outbreak of plenro-pnemmonia. I found the cattle there to be suffering fiom ehronic indigestion, the result of feeding too exclusively for a long time on dried sorghum with a probably insufficient water supply.

I at once returner, reaching Neosho Falls March 19, and after a careful investigation was able to telegraph you on the 21 st that the affection was not foot-and-month discase, but that it had been prodnced by local causes and that there was no danger of its spreading:

Returning through Topelia, I reported my conclnsion to the governor and was informed that experiments would be made with susteptible animals to decide the nature of the disease. I was invited to assist in these experiments, and at first decided to do so, but I soon leamed that the investigation necessary to satisfy l)r. Inolembe, who had just been appointed State veterinarian, was such as fo require much moro time than 1 conld give to it. I accordingly visited Kirksville, Mo., ly gom direction, where I foumd an outhera of the same disease as existed at Neosho Falls, and from there returned to Washington.

In Kansas I met Professor Stalker, of Iowa, Plofessor Faville, of Colorado, Colonel Groom, of 'lexas, and Dr. IIopkins, of Wyoming. Who harl been tommissioned by their respective States to report on the natme of the disease and the necessity of quarantining all cattle, sheep), and pigs from Kansas. I was also requested by the secoletaly of the Illimois state board of health to inform him if there was any neressity for his State to adopt similar measmes. Fortumately, aach of these

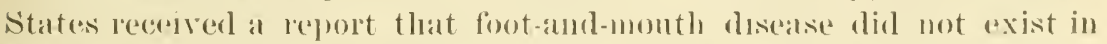
Kansas, and what threatened to be an almost romplete suspemsion of the live-stock husiness of the West was averted. There is no donbt, howerer, that the cattle industry suffered a considerable loss from tho 
exeitement. 'The market became unstraty, the price of cattle declined, and buyers becane excechingly cautions.

April 9 I receiver information that Dr. MeEachran, principal of the Montreal veterinary sehool and live-stock inspector for Canada, had visited Neosho Falls, Kans., aml Effingham, Ill., as the representative of the Canadian Govermment, and positively asserted that the malady at both places was the real foot-and-mouth disease of Europe. April 10, a telegram from the State agent for Kansas of the United States Department of Anriculture convesed the information that the State reterinarian har just reprted to the governor that six healthy tattle colabited with the sick animals had all contracted the clisease, and that further experiments by inoculation wonld at once be made. A letter from the governor of the saime date, received two lays later, contained similar statements. A few days laterstill an item appeared in the press dispatches from Washington, stating that "a private dispateh was received here to day from the governor of Kansas, saying that cases of sickness among cattle which had been most carefully examined had turned out to be true foot-and-month disease. He was afiaid that some cases had got in the herls. There was an attempt made at first to keep the matter quiet, but the information was deemed such as should go to the public."

It now seemed that a repetition of the former exeitement and panic was abont to occur, and by your clirection I visited Kansas a second time with instructions to make such experiments as might be necessary to demonstrate the non-contagious nature of the disease beyond question. I reached Emporia April 20, and was there met hy a telecram from Ne. osho Falls asling me to join the State reterinarian and Professor Law at the goreruor's office on the moruing of the 22d. Not intending to turn backwark until the difference of opinion was conclusively settled, I telegraphed in reply requesting these gentlemen to meet me at Emporia on their way to Topeka. This they did on Mareh 21, and I had a couference with them, at which the State veterinarian anduited that all attempits to conver the discase by inoculation upon cattle, rabbits, and sheep had failed; that the second experimental lot of cattle which hat colnabited with the first lot when they were supposed to br suffering with foot-and-mouth disease had not heen in the least affected; that the foot symptoms of the first lot hat only been noticed with two aninals, were rery slight and of exceedingly short duration; and that, finally, whatever the discase might be, it was not the continental footand-month disease.

After receiving this information I returned to 'opeka, attended the meting of the livestock commission in the governor's oflice, when the State verterinarian leported that the malady at Neosho Falls was mot the foot-and-mouth disease, anel the governor sent out a dispateh to the same effect.

On my way to Washington I visited the herds in the vicinity of Etfing- 
ham, Ill., examined the cattle and the food and assured myself that the disease there was identical with that in Kansas and Missomi, and that it was in every case traceable to the ergot which existed in great abundance in the liay.

SITUATION OF TIIE AFFECTED IIERDS AND BRIEF HISTORY OF TIIE DISEASE.

The eattle disease in Kansas which recently attracted so much attention from its smpposerl irlentity with the contagions foot-and-month alisease of Enrope, was first notieed in the herel of Daniel Keith abont the 23 il or 24th of December, 1883. Mr. Keith's farm is located 4 miles northwest of Neosho Falls. The first to sicken were some yearlings, which were noticed in the morning standing "humped "1)," with drooping heads and jerking the hind fret in a peculiar manner. These would walk but little and wonld soon lie down. Within two or three days they were inclined to lie continnally. The feet were examined and foumd frec from mnd the interdigital space was described as red, swollen, and sensitive, the toes spread apart. The feet began to swell at the coronet, or as high as the fetlock; a line of separation was established, and pus appeared within two or three days from the first symptoms. The mouths were not examined, but the animals were supposerl to be eating all right.

On or abont December 10, Mr. Keith had purchased 63 head of yearlings of Mr. Davis, all of which had been gathered within a radius of 10 miles. Two cows and 6 yearlings were bouglit of Alexander Linn, 1 nile down the river from Neosho Falls. This lot of yearlings were sair to have sickened within a few daps after their arrival on the Keith farm; it is believed that some were siek within three days and that all were suffering within a week, and dmring this time they has been ferl on shelled corn and mowerl oats. There ajpears to be some doubt as to how severely they were affected, whether they were all attacked on the same diy, and the exact nmmber of days they were on the farm before showing any symptoms. While it was asserted that they ate mo hay it was anduitterl that there was probably some hay in the racks. Eight other animals were pmohased abont the same time of neighbors living within 'os' 3 miles.

By Jammiry 1 he hat between 20 and 30 heal sick, a mmber of

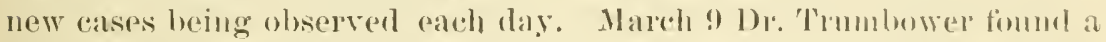
red gearling steer with a very lont month, mucus memblanes murh resldenerl, a vesicle the size of a dime on the soft palirte, and two smaller ones on the tomgue. There was also a small ulcer on the muroms mem.

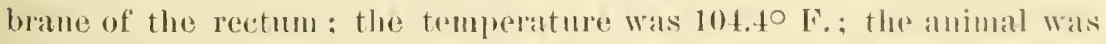
lying down, and when foreed to rise it moverl very stifly, but there was no swelling of the feet. The following day the vesieles were formel

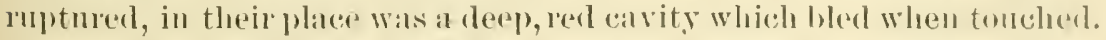
Temperature still 104.40. Mareh 20 this animal appeatred well. 
The cattle on this furm were dividerl in to two lots, which were in adjoining inclosures, and were separated only by rail fences. The second lot contained 40 two-year-old steers, purehased abont November 1, and was free from disease nntil February 2S, thongh some of these had broken throngh the fence at times and mingled with the diseased part of the herd. Nareh 10 about 10 or 12 animals in the second lot were sick. Three dass later Dr. Trumbower found 2 that wonld lose all four feet. At this time there were 118 head of cattle on the farm, of which 74 were more or less affected. Nine animals had one foot off, 4 had two feet off, 1 four-year-old cow lost both hind feet and a toe from one fore foot, 3 others were affected in but one foot, 6 in two feet, and 1 in three feet. In nearly all that showed lameness there were more or less inonth symptoms.

Across the roal, and nearly opposite to 11 r. Keith, lives Ed ward Hindman. It was here that the cattle belonging to A. C. Goodrich were loented. The 10th of March this herd numbered 96 head. The first animal affected was a mileh eow, noticed to be lame Jamuary 10. No other cases ocenred until February 14 or 15 , when one was seen to be lame in the morning after a heary ice storm. The following morning 16 were lame. Alter that he discovered new cases almost daily, and on March 14, when they were separated from the well ones, 65 head were affected. March 19 the most severe cases were as follows: 18 animals lad lost both hind feet, 5 had lost one hind foot, 1 had lost both hind feet and one fore foot, aud 1 had lost all of its feet. Seren of the others were lame in the hind fert, and the remainder of the 65 head affected were more or less lame.

In each of the above-mentioned herds the sick animals at the time of my visits, Mareh 19 and 22, had small erosions of the mucons membrane of the month, and 2 or 3 had hard rellowish ernsts in the same situa tion an inch or more in extent. In no ease were these snfficient to in. terfere with mastication. This lesion was more noticeable in the old ehronic rases than in the recent ones.

The third herd which contained diseased animals was located about 22 miles from those already mentioned. It belonged to J. W. Beard. This herd contained 70 head of animals, and 3 cows and 2 steers are all that have heen affected. All had been rmnning together until the discase was noticed, when the sick were separated from the well The first symptoms were observed on the 17 th of February, when a cow was seen to be latme. The second one to go lame was a eow hought of $\mathrm{Mr}$. Keith and bromght to the farm February 18 -she became lame about

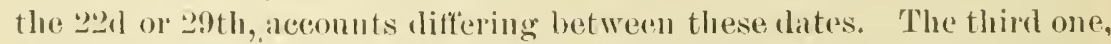
a steer, hecame affected Mareh 1. The fourth was a cow observed to be sick March 1 or:. It in reported that she slavered rery profusely. Mr. Beard states that he examined her mouth and fomd it rery red and the tongne coveresl with little pimples. At teu o'clock next moming she dierl. This animal had not been lame. The fitth one was taken abont 
the same time. It was lame in one foot, became better, was affected in a secoud foot, and was entirely recovered trom lameness by Marm 11. At this time Dr. Trumbower fonnd several small sores and discolored spots in the month, and the temperature was 102.5 degrees, or very nearly the arerage of eattle in health. The highest temperature foum by Dr. Trumbower was that of the cow jurchased of Mr. Kieith, which reached 102.5 degrees-a point too low to indicate ferer with any certainty.

The fourth and only remaining herd in the neighborhood of Neosho Falls was that of Christian Pribbernow, whose farm is located on Owl Creek, 10 miles sontheast of the town. There were on this farm is 3 head of cattle, aud but 16 have shown any signs of the disease. This herd was made up as follows: 54 gearliugs, 24 two year old steces, 13 two-year-old heifers with ealf, 15 three-year-old steers, and 75 cows and heifers. The gearlings had been put in a separate pen and ferl on oats and com-fodder-none of these were affected. 'Three apparenty well animals were lassoed and examined; their montlis contained small erosions and discolorations of the mucons membranes. The temperature of one, thought to be slightly lame, was 101 degrees; that of another, apparently in perfect health, was 103 degrees. Six of the affected ones have either lost their feet or have them in such eondition that they will surely separate from the legs, and "2 others have lost digital bones. None of these animals lave shown salivation or loss of appetite: but the months contained erosions and discolorations similar to those seen in otluer herols.

At Hall's Summit, a distance of 20 or 20, miles north from Neosho Falls, George R. Smith owned 2 cows. Abont February 1 one became lame; there was noticeable slavering and loss of appetite for screral days. This eow ealved Folnuary 2, and 1)r. Trumbower saw her Mareh 17, when the calf appeared well but small. The row was recheced to a skeleton. Her right hind leg had broken off half way between the fetlock and hock joints, earying with it the lower half of the metatarsal bone. The left hind leç was separating at abont the same point. One toe of the left fole foot was eoming ofl at the first joint.

Neal IIatford, some 20 miles northwest of Yrosho Falls and 15 miles west of Hall's Summit, was the farm of Mr. ()'Toole, where anothele ont-

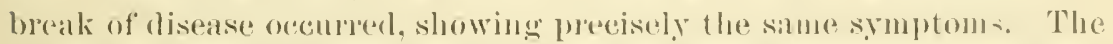
animals at this plate were leporterl to have been killed before my risit, and eonsequently I disl not see the herd. Wr. Wilhite, as I Was in-

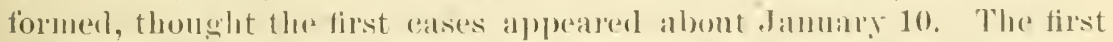

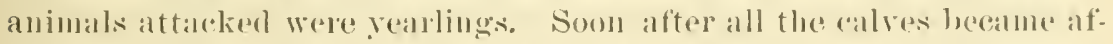
fected in the salue way. Then the larresteres in the feedisg pen were att alekel.

About the millale of Mareh the governor of Kansis seut a reterimatian to investigate a disease whieh was reported to exist in Gshorne. Comeg. Aceording to resbal information which I received fiom the 
State ofticers while at Topeka, this disease was substantially the same as that which exister at Neosho Falls. The tistance between these two points must be at least 175 miles in a clirect line.

After investigating the disease in the neighborhoor of Neosho Falls, I proceeded as directed to Kirlisville, Arlair Comty, Missouri, to visit herds at that place reported to be affected with foot-and-month disease. On Mareh 27 I was at the farm of William Bragg, who lived 5 miles south of Kirksville. The disease in this section was first noticed here, but later 6 other herds, within a radins of 4 miles. have had affected animals. The only new animal introduced on the Bragg farm was a steer bought in the neighborhood about December 20. This was one of the first to sicken, but there was no disease on the farm from which it eame. A cow that had been purchased a month earlier sickened alont the same time. This was in the latter part of Jannary. The weather had been extremely eold early in Jannary, and reached $10^{\circ}$ or 120 below zero at other times cluring the month.

At the time of my first visit there were 4 animals lying in the stable. One eow harl lost a hind leg from about half way between the hock and fetlock joints; the bones had separated at the latter joint and the metatarsal bone protruded half its length beyond the flesh. The other hind leg was dividing at the fetlock joint. Six inches at the end of the tail was gangrenons, and was being separated from the remainder of the organ. There were a number of abrasions and small discolored spots in the month. A seeond cow had a healthy month; both hind feet were lost at the coronet, and the tip of the tail was gangrenons. A steer, probably two years old, had lost both hind feet at the fetlock, abont an inch of the tail was lifeless, and the month contained a number of sores and discolorations. A second steer was in almost precisely the same condition. A thind steer was walking anound the yald, very lame, and had a large slough of the tissues on the posterior surface of the fetlock joint. A fomrth steer in the pasture had both limbs as high as and in. clucling the fetlock joint stiff and cold. Still another animal was lame in the lind limb. Seven herds within a rarlius of 4 miles had suffered. Six abortions were reported.

April 24 and 25 I visited a number of the diseased herds in Eftingham and adjoining counties in Illinois. The farm of Lemuel Fannce is situated 10 mites northeast of lifingham and one and one-half miles from Montrose. The first eases appeared in the latter part of December, and began with diarthea and other signs of digestive distulbance. There were $z$ l hear of eattle on the farm and no new ones had been purehased at the time of or immediately preceding the ontbreak. Two eows, cach of which hąl both hind legs alfected, han been killed before my visit; 1 steer has a himel limb off" at the fetlock; another has a elear line of demareation formed at the fotlock, the part below being wangrenons; a bull has lost both toes from one foot and one toe from the other; 2other animals were very stift: One steer had two attacks and another had 
three attacks of lameness, and the latter entirely recovered. The animal that was first to suffer still had sores, $i . e$, erosions of the mucous membrane on the upper lip and gums exactly like those which I saw when examining the affected cattle at Neosho Falls and at Kirksville, though four months hat elapsed since the appearance of the disease. Some of the sick ones had slarered and smacked the lips, showing that the month was quite severely affeeted.

The horses on this farm luad also been troubled with an eruption in the months which had eaused salivation and lond smaeking of the tongne and lips. These were now entirely recovered, though slight evidences of the sores on the lips were still visible. The horses were seen to have lost appetite in Jannary or early in February. The last of February sores were observed in the montlis, and it was six weeks before these healen. Only one hog was kept, thongh many of the neighbor's hogs liad been continually ruming around the pastures. None of these hat been affected.

Three miles north and 1 mile west of Mr. Faunee's firm, Mr. Dubroe had yearlings in a high, drs lot, in which was an out-liouse for shelter, parly filled with hay. All of these were affected and all recovered. There were here 160 head of eattle, only $S$ or 10 of which, all told, were lame. Ten or 12 goats were running with the cattle, hut remained well; the two places mentioned above were so situated on different roads that there was little if any passing from one to the other, and the ontbreaks were therefore independent of each other.

Other cases of the disease occurred on the farm of Mr. John Mason, who lives near Whecler in Jasper County. This gentleman owned 120 hearl of cattle, of which 17 had been affeeted. Six animals were so bad that they had been killed; 2 others remained, one of which had lost a foot, and the sceond oue would lose both of the posterior feet at or above the fetlock; a part of the tail of this one was also gangrenous. Nine other's had been more or less lame but liad lost no limbs. On this farm and in close proxinity to the cattle were 25 horses and mules, 100 hogs and 40 shee'p, all of which had been free from disease.

In the town of Wheeler, a single family cow was found with the lower parts of the posterior limbs separatiug as a result of dry gangrene. This seemed to be the only sick animal in the town.

Mr. Keating, who lives for 8 miles from Elfingham, had also suffered from the same discase. His herd eonsisted of tĩ young cattle and 6 cows. None of the cows were aftected, and it is wortly of remark here

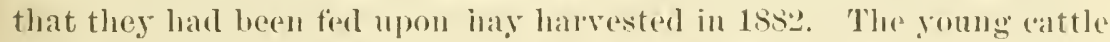
were fed upon the erop of 1883 , and of these 8 , which wele in a very had eondition firom the loss of their limbs, had been killed ; two others were still alive with the feet oft at the fertock. Alome half of the 4.5 young eattle were more or less affected. There were 60 shloej and a mumber of hogs on this farm, mone of which hat shown any signs of discase. The cattle here were attocked about the sth of January. 
These farms are mentioned as examples of what had ocenred at seventeen or eighteen different places that I learned of within a raslins of 15 miles from Effingham. As a matter of great interest comeeted with this snljocet, I was informed by a mumber of people that there had been a greater number of ahortions among mares, and more cases of difficult parturition cluring the past winter and spring than was ever known before.

Other herals were reported on goor anthority to be affected in the same manner at different points in Missouri, Illinois, Iowa, and Colorato.

\section{CLASS, CONDITTON, SURROUNDINGS, AND CARE OF THE ANIMALS.}

All the diseased animals on the farms visited by me were stock cattle in medium to thin condition. Those worst affected, in which one or more limbs were separating as a eonsequenee of dry gangrene, had evidently lost much flesh duriug the progress of the disease. There were no fat cattle on any of these farms. At Mrr. O'Toole's it was said by those who visited the place the fattening cattle were attacked as well as the stock cattle and calves.

On most of the farms there were cattle of all ages-calves, yearlings, two-year-olds, three-year-olds, and cows. The calves and yearlings seemed to eseape in a greater legree than the older cattle. In the Goodrich herd were 20 calves which occupied a lot through which the other animals were frequently driven to water and into which some of the lane ones were placed. This lot was separated by an open fence from that in which were kept the worst diseased animals of the herd, and jet not one of the calves suffered in the least. At Pribbernow's were $5 t$ yearlings ruming with the other eattle, and from which the worst aftected ones were only separated by a rail fence, and all of these escaped. At Keith's were y young ealres sucking diseased mothers, but themselves in good health. Here also were hogs and a litter of young pigs running in the same lot with the sick cattle, but free from any signs of disease. At Kirksville sheep had been running with the cattle and were also healthy. In Illinois, sheep, swine, and goats mingled with the affected herds with perfect safety.

The winter has undoubtedly been a severe one upon the stoek of the Westeru States, and the eattle were consequently somewhat bolow the average condition at this season of the year. The appearance of the disease cannot the explained by this fact, however, since thomsands of healthy herds were in worse condition than those on the farms in question. Some of these herds, and notienably that of Goodriels, were in much better than average condition; they had evidently been well fed and cared for.

There was nothing in the surromdings of the affected animals which wonld explain the development of the disease. The feeding lots in most cases were musually dry and the disease had apjeared at a time 
when all mud was frozen solid. The soil did not contenin enongh alkali, even at Neosho Falls, to make it at all probable that this comld have been the exciting canse of the disease. As is usmal in the managenent of eattle at the West, the herds were without shelter. At Keith's the eattle lots were in a ravine protected by timber; on some of the farms there was little protection of any kiml. Snch a comlition, howeren, is so common that it cond not be regarded as having much influence in the production of this trouble. All of the affected herds seem to have receired ordinarily good care. Keith had fed some of his cattle shelled corn and mowed oats in addition to hay. Pribbernow had fed his yearlings on millet, oats, and corn-forder, and eonsequently they had eaten less hay. Beard had fed shocked corn. In Illinois, Keating had fed liberally on corn. On most of the farms the water was very good, but probably deficient during the cold weather. Keith had pumperl water from his well; Goodrich's cattle drank from a poud; Beard's from the river, and P'ribbernow's from a creek. It was necessary to cut holes throngh the ice and these wonld soon freeze over; consequently, it may be admitted that in most cases there might have heen a deficieney of water.

When the animals first beeame lame it was supposed that mud had collected between the toes, and. becoming hard, was prodneing irrita. tion. The animals were eanght and their feet eleaned, but this had no effect on the development of the disease. It is evilent that the animals were earerl for as well as is ordinarily the case in this section of the country, and that the slight deficiency of water and the exposure to cold were accessory rather than the exciting canse of the disease.

SYMPTOMS AND CHARACTERS OF THE DISEASE.

The first symptoms of disease in the Illinois epizootic were diarliea, lameness, stiffiness of the lower joints of the affected limb, and coldness and insensibility of the same parts. In Kansas this derangenent of the digestive apparatus was not noticed. At all the places risited, however, the lesions of the feet were of a common character and were produced by a common process. In the more severe cases a constricted band formed around the lumb at the point separating the gangrenous from the living flesh. So marked was this constriction that some of the owners looked npon it as the initial lesion of the disease and cut across it with a knife in the hopes of re establishing the circulation. It is needless to say that this hope was delusive, since the part below the constriction was entirely lifeless before this was formed. The constriction was the first step in the effort of mature to rid the body of parts that were of no further use to it.

The next step in the process of separation was a crack in the slin at the mppere edge of the band of eomstrotion, which gradually extended towarl the center of the lumb, the softer parts dividing tirst and the tendons and ligaments resisting much longer. Generally this separa- 
tion was in the vicinity of a joint, and in this case, as the lower mem. bers of the limb were lost a comparatively eren surface was left which healed readily. Some animals lost only a toe, the dividing line passing through the joint between the os pedis and os corone ; other's lost both the os pedis and os coronce ; still others lost the three lower bones, and the line of separation passed throngh the fetlock joint, while in the most severe cases the line of constrietion formed at the npper third of the metatarsal bons and the fleshy parts sloughed off, leaving the mncovered bone protruding for more than half its length. Plates $\mathrm{V}$ and VI are drawings made from limbs whieh I seeured in Kansas.

It was reported by some of the reterinarians that small vesicles were formed in the interdigital space and abont the coronet, aud this was donbtless true, as such vesicles are not uncommon in gangrene; but their appearance was far from being the rule, as I did not sneceed in finding a single one in all the animals that I examined. In nearly all of the cases, whether the foot was affected with dry gangrene or whether there had been simply lameness without death of the part, the skin of the interdigital space and abont the coronet was perfeetly preserved. There was loss of neither epidermis nor hair, as there certanly wonld have been had the disease eommenced by a superficial inflammation in this region and extended to deeper parts of the foot or to higher parts of the limb. Indeed there were no abscesses, no burrowing of pus, no ulceration about the feet, which could lead one for a moment to sup. pose that the canse of the disease had commenced its action externally and extended gradually to the interior of the limb. On the other hand, the fact that the skin was intact in the great majority of cases, that the part was cold and insensible almost from the first, and that the line of separation passed entirely through the limb, removing one or more phalanges as completely as it conld lave been done with a knife, was suffieient evidence that the disease had an internal origin.

'The gangrene was not confined to the feet, however, for in Kansas, Missonri, and Illinois there were individual animals which were losing from 2 to 6 inches of the lower part of the tail by exactly the same process. The portion below the dividing line was very dry and hard, while the line itself was sharply defined, as thongh it had been a linifecut. With the greater part of the animals affected in the feet a careful examination of the end of the tail revealed a slongh of greater or less extent; sometimes it was simply the skin at the tip that was affected, but oftener one-half ineh, 1 inch or '2 inches would be found discolored, lifeless, and dry. In a very few ealses a part of the ear was tound in the sinne conlition.

One of the most interesting features of the enzootic, beeanse it had not been heretofore described, wats the implication of the mucons membrane of the month. With some animals this was limited to a more or less diffise red discoloration, without loss of substance. Míre freynently there were circumseribed dark red spots or patches, from a 

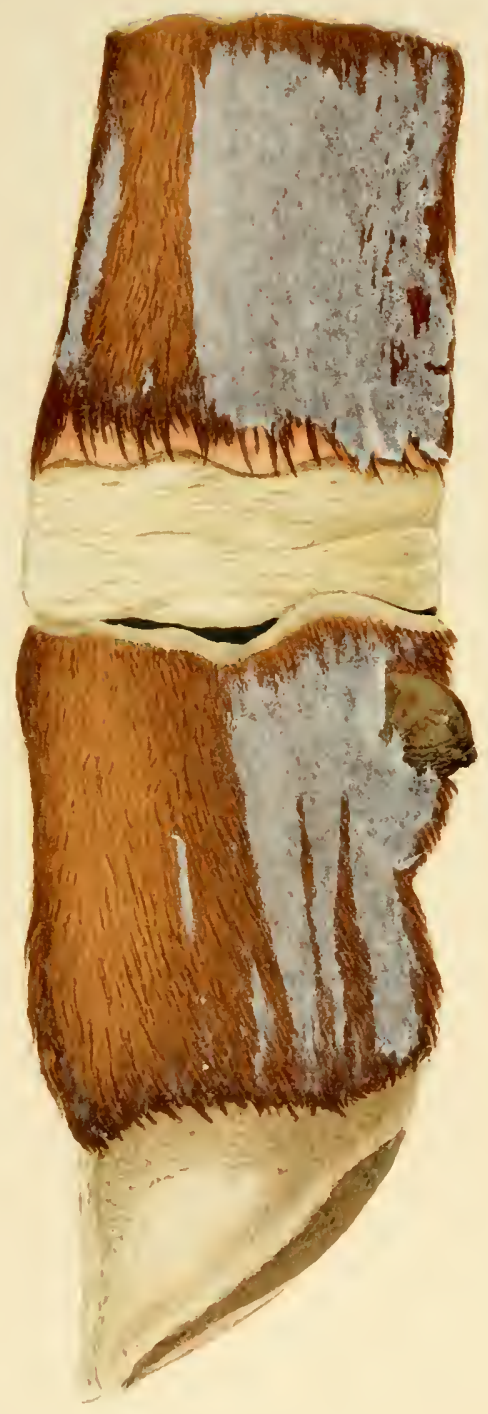

FROOJISM ( HANSAS) 



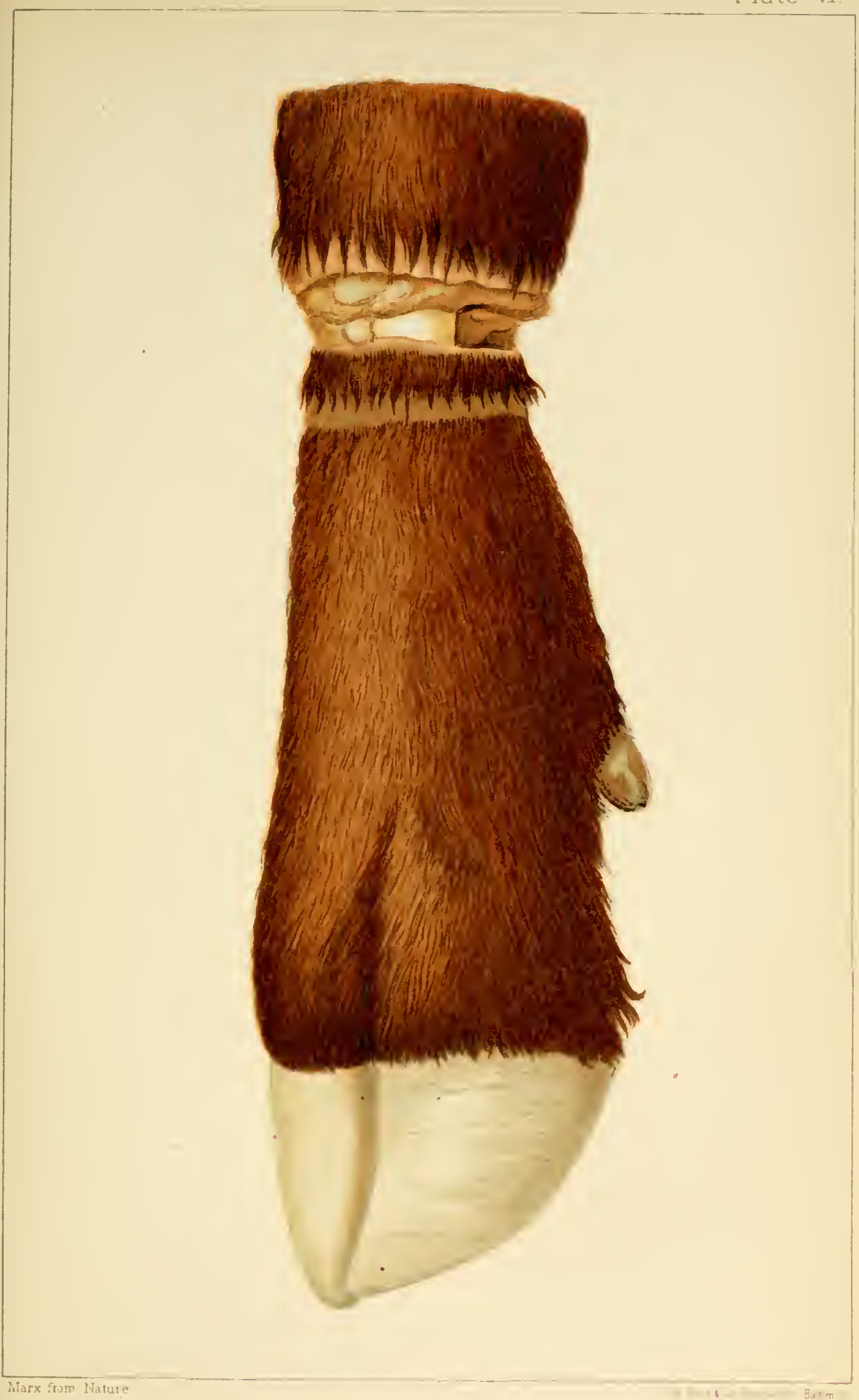

ERGOTISM ( KANSAS) 

fonrtl of an inch to an inch in diameter. Vers often there was loss of substance-erosions from a thirl to a half inch in diameter. Some of the reterinarians reported that they had discovered blisters in the mouths, anl it is not unlikely that these erosions in their first stages were more or less vesicnlar in character, bnt I was not fortunate enongh to see them in this stage at any of the places risited. In some animals the part of the membrane that was heing lost was still attached by shreds, in others it was entirely removed, but in no case did I see anything of the nature of a resicle. None of the erosions presenterl the appearance of ulcers, or showed any considerable inflammation. They were dirls-colored, the borders were not elevated, and the surromding blood-vessels were neither prominent nor injected. It appeared to be ouly the superficial layer of the nembrane that was interested.

In a very few animals a lesion of a different character was observed in the month. In these cases an irregnlar patch of mueous membrane from 1 to 2 inches in diameter was elevated, corrugated npon its surface, hard, insensible, and of a light color, tinged with pink and yellow. It seemed to be a cireminscribed gangrene of the mucons nembranc, the dead parts being partially deeolorized by soaking in the fluids of the mouth.

There was also an evident irritation of the mucons membrane of the posterior parts of the alimentary canal and organs of generation. That covering the rectmm and ragina was generally red, covered with mucus, and presented spots denuded of the eprithelinm. In Missomi six cases of abortion in cows were reported, and in Illinois there were many cases of abortion and dificult parturition with mares.

The constitutional symptoms were not very marker. The temperature of the animals which I examined was about normal, with the exception of a few from which one or more limbs were sloughing and with which there was suspicion of septic poisoning. Jrs. Holcombe and Trumbower olsserved high temperatures (104 to 104.8 degrees) in some eases in the early stages of the affection.

In those animals which recovered after showing laneness there was no loss of substance or iuflammation of the skin as would have resulted from freezing to a suffieient depth to canse lameness. In these animals the lameness and stifiness of the lower joints were the only symptoms of the disease in the feet, thongh the same animals frequently showed erosions in the months.

EVIDENCE IOINTING TO FIRGO'T AS THE CAUSE.

In each of the herds which I visited, with the single exception of Beard's, there were typical cuses of dry gamgrene of the extremities, with an evident preference for the posterior limbs. In the most severe cases there was complete death of the leg as high as the middle portion of the metatarsal bone. This dead part was sharply defined, first by a constriction and later by a crack from the living flesh above.

$5751 \mathrm{D} A--3$ 
It was not a death of the superficial structures alone, but the skin, tendons, and bone were all involved, and everg part of the leg below the line of separation just referred to was completely lifeless. A study of these legs showed very elearly that the disease had not begun at the hoof or in the interligital space and progressed upward, for these parts had not heeu changed by disease of any kind previous to the death of the whole affected part, which had evidently occurred rery suddenly. To my mind this condition male it rery plan that the tronble was not the result of any disease which had hegmu in the interligital space, or in the skin around the coronet. There conld be no mistaking the fact that the worst affected animals presented typical cases of dre gangrene, and the problem to be solved was to determine which of the conditions that these animals were subjected to would satistactorily acconnt for the enzoötic. When we turn to veterinary literature for information in regard to the aceepted eauses of dry gangrene, we learn that there are very few agencies which are liable to affect a number of animals at a time and are eapable of producing this effect. Compression, burning, canstics, plugging of bloor-vessels, and ergot abont completes the list of those that wonld be at all likely to produce dry gangrene in yomng animals, and of these the last is the only one that conld have possibly been instrumental in developing the ontbreaks in the West.

The peculiarities of the disease led me to examine the fcerl to learn if any unnsual quantity of ergot conld be tomnd. The result of this examination was to show that at every one of the farms where the diseased cattle were located, hay had been ferl which contained one or more grasses ergotized to an extreme degree. At Keith's, Beard's, and Pribbernow's, in Kansas, there was a large proportion of wild rye (Ely. mus virginicus, variety submuticus) which contained an extraordinary quantity of ergot. In many heads half the grains and in other heals every grain had been replaced by the fungus. Careful weighings of heads bronght to Washington, and from which some of the ergot had been lost in transit, gave in one case 12 per eent., and in another case 10 per cent, as the proportion of ergot. Now, if the lieal represented one-half the weight of the entire plant, from 5 to 6 per cent. of the weight of the rye must have been ergot; and if one-fith of the weight of the hay was marle up of wild rye, then a 20 -poumd ration of hay would eontain abont 4 onnces of ergot.

As is always the case where an attempt is male to aceonnt tor resnlts when the conditions affecting these have not been intelligently ouserved and carefully recorderl at the time, we found some appinent diserepancies in the ergot theory. The greater part of these have been explained in a remarkably satisfactory minner, and if we conlì know erery circomstance connected with the feeding and eare of the animals for thirty or forty days preceding their illness, clombtless the most eritical could be satisfied as to the cause of the disease in every subject. As we are compelled, however, to rely mon the more or less defective memories 


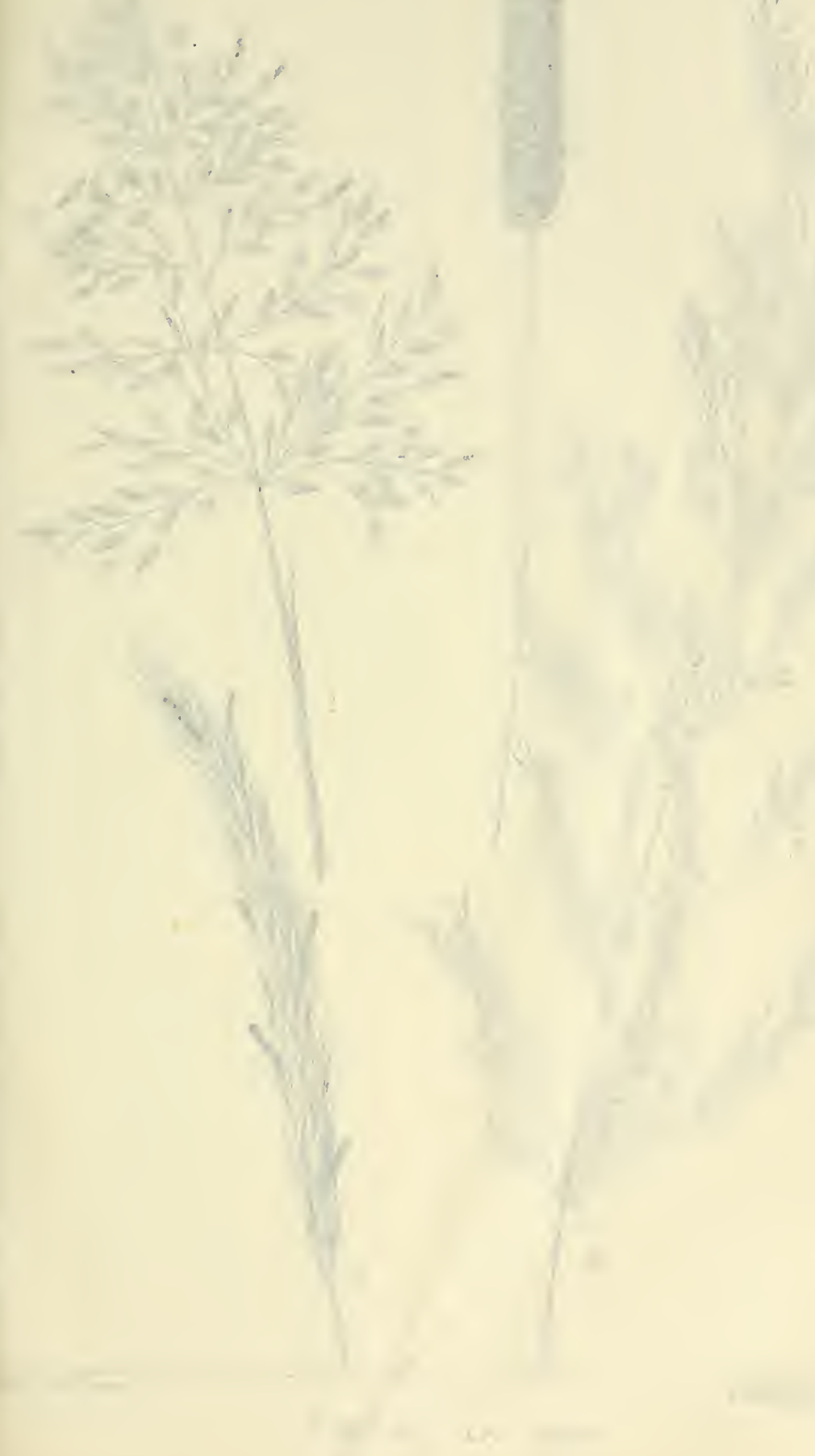




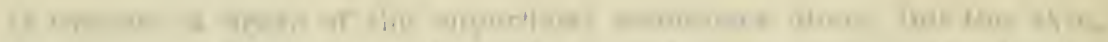

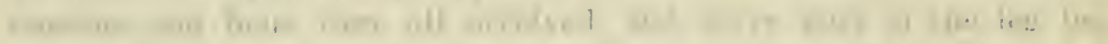

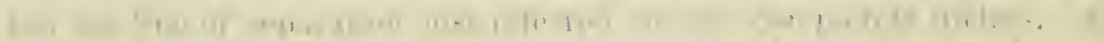

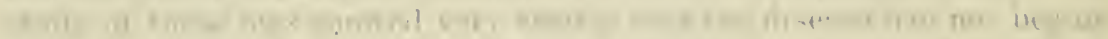

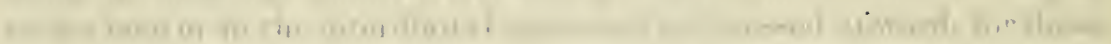

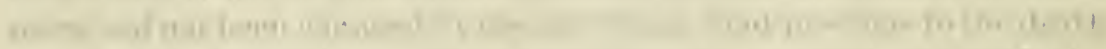

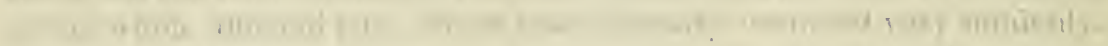

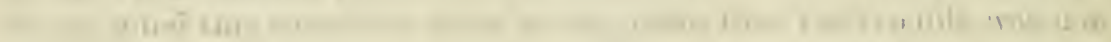

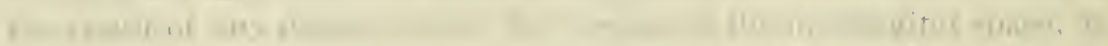

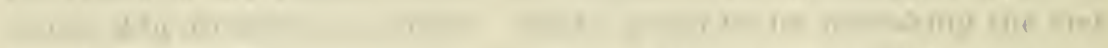

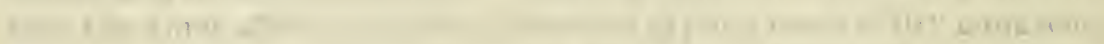

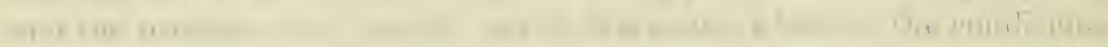

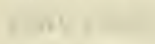

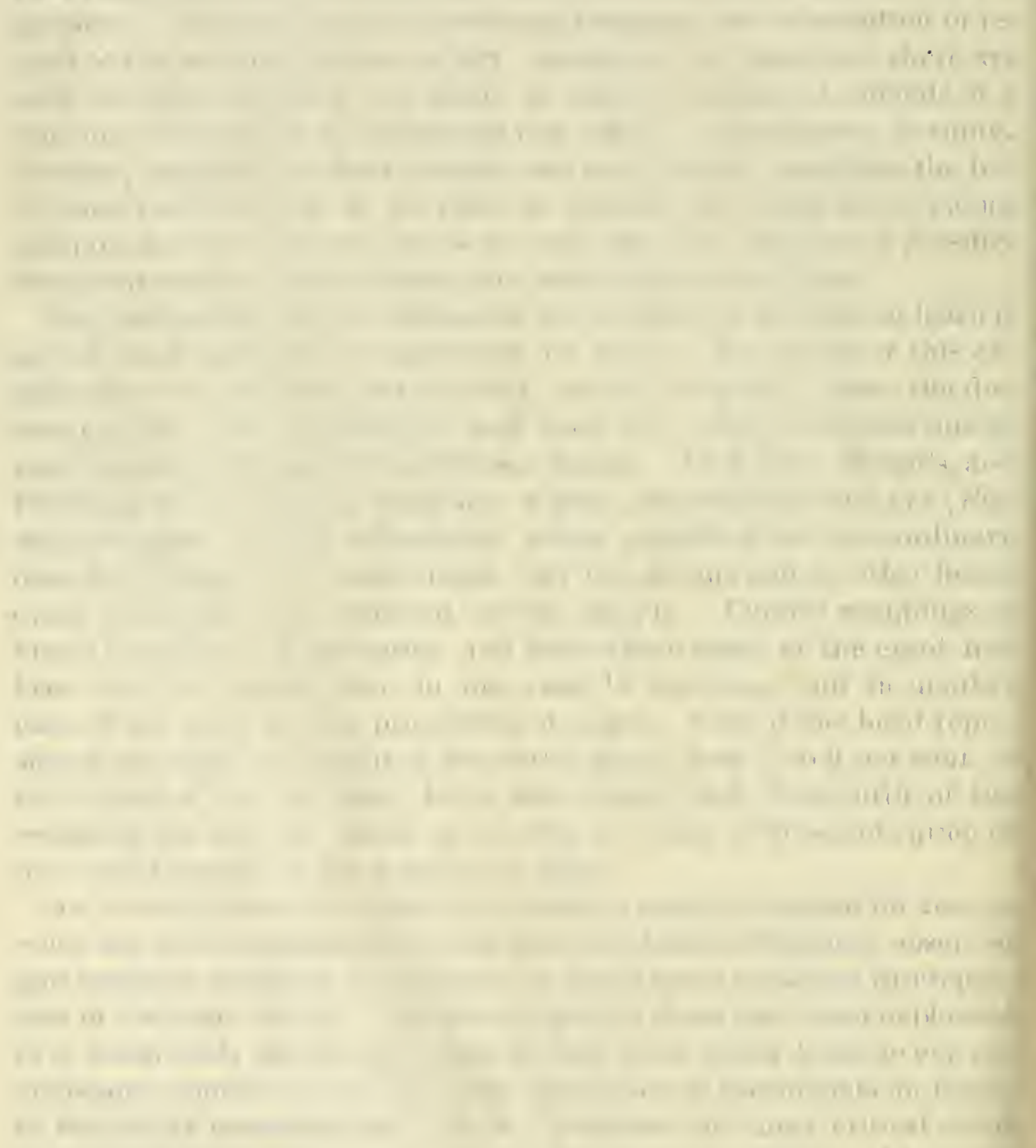



of the owners of the cattle, who, of course, dirl not make their observations in the light of subsequent developments, we must accept the sitnation as we find it and consider onrselves fortunate if a connection can be traced between canse and effect in the greater part of the cases. An exact estimate conld not be made of the quantity of ergot in a given quantity of the hay in Kansas, but the weight of ergot in the heals of wild rye indicated this rery elosely. The head shown in Plate VII, Figure 3 , is a good representation of this plant as it existerl in the har.

In Missouri the hay was made up mostly of red top (Algrostis evilyuris), but also contained some blue grass and timothy. The red top and bine grass contained a very large proportion of ergoted grains, and an occasional head of timothy was also affecterl. Figures 1,2 , and 4, Plate VIl, are drawings from specimens of these grasses taken from the layraclis at which the diseased cattle were eating.

In Illinois the hay was almost entirely composed of red top, and this containerl a relatively large amount of ergot. Careful weighings of slecimens of this bay and the ergot which it contaiued, from two of the worst affected farms, demonstrate that every 75 poumds of hay contains 1 pound of ergot : or. in other words, an animal eating 20 pounds daily of this lay consumed t.2 omnces of ergot. Joubtless this quantity might be taken claily for a considerable tine without prodncing apprecialule effects unler some combitions, but when the circulation in the extrenities is diminished by extremely cold weather, and when in and dition to this the water smpply is limited then ergot in this dose, coutinned day after dis, becomes very dangerous.

In Kinsas I examined the hạ on adjoining farms where no disease had appeared, and I found a rery much smaller proportion of ergot. At the Dibble farm, which joins Keith's, one might examine a dozen heads of rye withont finding a grain of ergot, and the same was tı of hay found in the town of Yeosho Fills. In Illinois, at two farms, I saw laty of the crop of 1582 and also that of 1853 , and while the former containerl some ergot the latter contained a greatly inereased proportion. It had beers noticed by the people here that the red-top laty of the crop of 1853 , for some mexplained reasom, was greatly inferiol' that animals neither relished it nor thrived when fed npon it, and it sold for $\$ 3$ a ton when other hay wonld bring s10. At keating's the animals ferl on the hay of 1852 eseared the disease entirely, while those fed npon the hay harvested in 1883 alone suffered.

Evidently the year 1883 was a firrorable one for the prouluetion of ergot over a very large area of the Western States, but the local conditions of soil and sitnation and the time of eutting the hay"had a very great influeres on its derelopment. All of the ergoted laty of the afterterl fanus in Kansas was cont from bottom lands, and in .Missonri and Illinow it was grown on rery level prairies the drainage of which was rery imperfect. I gain, the early cut hay was comparatively free, when that alluwed to ripen was bally affected. 
In brief, then, our reasons for considering the disease to be ergotism were, first, the character of the lesions, which were such as have always been ascribed to ergotism in the past, and as conld scarcely be produced in so many animals fiom any other known canse; and, secondly, the extraoldinary proportion of ergot found in the food of the animals on every affected farm.

It is very probable that the cold weather had a considerable influence in developing the effects of the ergot, and the greater part of the eases were first noticel duriug or soon after such weather. Many cases oc. curred soon after a severe iee storm or sleet. A gain, with the appearance of milder weather new cases ceased to appear, although the same hay was still being fecl. The two or three new eases in Missomi were the onlir exceptions to this statement.

I have no doubt, therefore, that the eases which I investigated, and the similar cases which ocenred about the same time in other localities, were cases of ergotism. Professor Law, of Cornell University, l'rofessol Stalker, of the Towa Agricultural College, and Plofessor Faville, of the Colorarlo Agricultmal College, have seen similar cases in their respective States, and concm in the opinion that they are flue to poisoning from ergot.

CIIAACTERS WHICH DISTINGUISIT THIS DISEASE FROM EPIZOOTIC APHTHA, OR FOOT-AND-MOU'II DISEASE.

II istory.-The foot-and-month disease of Europe is a specific ferer which only arises ly contagion from other aftected animals. In the whole history of America there have been no spontaneons ontbreaks of this discase, and in Eure the convietion is growing stronger every year that it has no other cause than contagion. We may accept it, therefore, as a fact that foot-amd-month disease cammot ocemr in the United States except by the introduction of virus from abroarl.

When a disease having some resemblance in its symptoms to foot-andmontli disease is fomnd in the interior of our country, more than a thousand miles from the ports where the contagion must necessarily be introducer, it becomes a matter worthy of the most eas chil consirleration to determine if there was any mans by which this contagion conlil have bren transported to the affected herd. When a contagions risease is spread broadcast over a comntry it may be difticult or improssible to trace inany ontbreaks; not so, howerer, with a single ontbreak produced by so virulent a contagion as that of the disease muler consideration. In sueh a case it would be remarkable if it could not be traced.

In the present instance the animals of the affected herds had been purchased ol raised in the neighborhood; no foreign animals or people had been mpon the farm where the first attacks oceurred. Foreign cattle harl for a long time been quarantined at the sea-boarl a suffieient time to make it impossible that this disease cond have been carried by 
them to the West. It was absolntely impossible to find any satisfactory manner by which a foreign contagion could have been introrluced.

This important iudication seems to have been greatly neglected in decioing nyon the nature of the disease in Kansas. It was said if this is foot-and-mouth disease we must ackiowled ge that we have it, whether we can trace its introduction or not. Plansible as this reasoning may seem we must admit that it is not always an easy matter to diagnose a disealse oft-Land firom its superficial characters. And in the diannosis, of contagious diseases we must renember that the strmptoms are lont the expression of the effects of the virns, and that these symptoms may be simulated more or less elosely by other agencies acting upon the animal eeonomy.

The history of the origin of any disease believerl to be contagions is, then, a most important part of the evidence to be taken into consideration before a diagmosis is reachet. We may take contagions plemropueumonia for example. Many cases of this disease resemble so closely spontaneous inflammations of the respiratory organs in cattle that it is absolutely necessary before a diagnosis can be reached to inquire if the contagions plenro-pnemmonia has been introfnced or if the malady occurred spontaneonsly. 'The same principle lohlds good to a greater or less extent with other diseases, and it mas be safely asserted that when the history does not receive proper consideration many mistakes will be matle that otherwise might be aroided.

Contagionsness.-The virus of foot-and-month disease is one of the most active contagions known. The period which elapses between exposnre and the appearance of the first symptoms of the elisease is, as a rule, but two or three days; a very large proportion of exposed animals become discased, and the plagne spreads rapidly from farm to farm. As a result of these characters, within a week after the introduction of foot and-month disease into a herel nearly every animal in that herd shows mumistakable evidences of having contracted it. A rery small proportion of the animals may resist the contagion, but this proportion is much less than with most other contagions diseases, and is so small that it does not affect the rule just mentioned.

The disease at Neosho Falls showed very different waracters from this. Goodrich's leerd suffered in the largest proportion, 6.5 ont of 96 , or bis per eent., being more or less aftereterl. The first ase here ocemred January 10, and no others mutil Felormary 15, or more than a month later. After this new cases continned to develop for two or three weeks. But in a lot adjoining that in which the sick wattle were placed there were 20 calles, which remaines entirels free from disease. The isolation of these calves was not sulficient to hold footand-month disease in chects for a single diny it was peren said that the siek cattle had heen driven throngh the calf lot to water, and that some of the smaller ones, when attacked, were placed with the calves.

At Keitl's it out of a total of 118 , or 63 per cent., were aftected. 
At the end of the first week but 20 or 30 head had been attacked, and from this time new cases continued to appear until Mareh, or during a perion of two months. Here also it is to be remembered that in a lot of animals separated from the sick ones by a simple rail fence there was no applaramee of disease until two months after it had attacked the first lot. Hogs were running in the lot with the worst cattle; thes eren ate the blood of the slaughtered ones and nibbled at the affected feet, but they din not suffer in the least. A sow had bronght forth a li: ter of pigs in a shed which forms a part of the inelosure, and these were doing well. Two calves were sncking mothers under the inflnence of the fisease but were themselves in good health.

At Pribhernow's only 8 per cent. of the animals lad been attacked, and anong a lot of 54 yearlings running with the other cattle there was not one case of clisease.

At Bearl's, in a herd of 75 , the first animal was lame a week before the second was affected; and then another week passed before the others showed any symptoms. Here only 6 per cent. of the cattle on the farm were attacked, and one died within twenty hours from the appearance of the first symptoms.

At Kirksville the proportion of animals that suffered was not definitely ascertained, but there was no evidence of eontagion, and sheep ruming with the affected cattle remained healthy.

In Illinois, on the Fannce farm, the horses suffered from an eruption in the month. The exact natnre of this disease it was impossible to ascertain at the time of my visit. It may be remarlied, however, that doorses seldom suffer from foot-and-month disease; and that this is the only case which ame nuder my notice on any of the affected firms where any other animals than cattle showed stmptoms that were even suspected to be in any way connected with the disease among the cattle. In this instance the eruption in the horses' months could not have resembled foot-and-month disease very elosely, for it remained at least six weeks, or three times the period of the latter disease. Here the geeighbors' hogs which were rumning around the farm falled to contract any disease or to earry it to other farms.

At Mr. Mason's there was still more striking evidence to show that the disease was very different from epizootic aphtha. One hundred hogs ams to sheep had been exposed, and not one suffered. Only 17 borine aximals out of 120 , or abont 15 per eent., showed any signs of the diseased. At Keating's, 60 sheep and a number of hogs were exposed but all remained well. At Dubroc's, goats were exposed without suftering.

The disease, therefore, did not resemble foot-and-mouth disease either in the proportion of the animals attacked or its rate of extension, or in attacking other species of animals than cattle.

Ocurrene at the seme time on videly separuted forms. - If foot-andmonth disease had been introduced into the heart of the conntry in any of the extratdinary was which were offered to explain its appeananee, 
mouth symptoms were much less severe than this, but two or three animals were reported to have had any salivation or any diffienlty in eating lay. Some of the mouths presenter erosions, which were mostly small, very superficial, and without any appearance of ulceration. I dicl not see a single blister, but a few of these were reported by those who. visiterl the herds at an earlier date. The lesions which I saw in the months scemed to be due rather to a softening of the mucous membrane than to resication; and I was assured that the appearances did not differ materially at the time of my visit from what they were when the veterinarians first saw them. In one or two aninals there were large patches of thickened mucous membrane of a yellowish color, hard and. diffieult to detach. Healthy herds in the vicinity were visited, and in the mouths of these cattle were found discolorations and erosions very similar to, though less extensive than, those seen in the sick ones. In Missouri some of the eattle had the mouths involved to a greater degree than any I saw in Kansas, but other's witl equally bad feet had perfectly sound mouths. Here I saw pieces of mucous membrane becoming detached, but no blisters. Figmes 1 and 2, Plate $\mathbf{X}$, show the highly inflamed condition of the ulcers in the real foot-and-montl dis. ease.

The eattle in Illinois still had erosions in their months as late as April 24, which were illentical in appearance with those I saw in Kansas. The steer which first came down with the disease on the Faunce farm, and which had consequently been affected abont four months, showed these about as plaiuly as any animals I saw in Kansas. In foot-anr-mouth disease the eruption disappears in from two to three weeks, and the animal is convalescent. Before proceeding to Kansas and Illinois the second time, I visited the herds at Portland, Me., which Iad been affected with foot-and-month disease. The contrast was very striking. Althongh the cattle in Mane har not showed the disease nutil the second week in February, they were on the 16th of April in apparently good health. 'There were no longer any soles in the months or on the feet. A week later than this 1 fomnd eattle in lllinois that sickened in December and still had as marked mouth symptoms as could be fomnd in any of the Western heris.

The feet symptoms.-The interdigital spaces and the coronet are the seat of the eruption in foot-and-month alisease. Not only is there redness, heat, and swelling in these parts, but there is formation of blisters, loss of epithelium, and a secretion from the whole affected suface of the skin. The appualance of the feet with sheep and eattle having this lisease is shown in ligs. 1, 2, and 3, Plate 1X. Sometimes abscesses form beneath the horn, from which the pus may burow and eause the Ioss of the hoofs, or even aflect the ligaments and joints. But severe eomplications in the region of the foot do not oecur except fiom this eause. With the cattle which I visited, the feet plesented a rerg different appearance. Some of the limbs were separiting, as a conse- 
quence of dry gangrene, half way between the fetlock and hock joints, with the skin of the foot still in perfeet condition, though deanl. In others the separation occurrerl at the fellock, and in many others at the joints below, but not as a conserquence of the burrowing of pus. Incleed, very little pus was to beseen in any of the feet. It is not rare to see the horn of one or both toes lost in foot-and-month disease, but it wonld be remarkable for the whole toe, inchuding the bone, to slongh offi, as oecurred so frequently here. I dicl not see a case where the hoof was lost withont a loss of the bone at the same time. The complete death of the foot to the fetlock, or eren higher, as occurred in all the worst eases in the West, is altogether unlieard of in foot-and-month disease. While there was redness, heat, and swelling above the line of separation, I saw no appealance of blisters between the toes or aromnd the coronet. A large proportion of the affected animals were simply lame, and had neither blisters nor sores about the feet. Finally, the disease was generally contined to the hind feet, or, if it attacked a forefoot, it was only after both hind ones were affected. Foot-andmonth disease has no such decided preference for the posterior extremities.

The eruption on the udder.-In only one case that I have heard of in the West was there any appearance of an eruption on the udler of the affected cow. This was a cow belonging to Mr. Keith, the goung ealf of which died, as was supposed from the effects of the disease contraeted from its mother. I am unable to atconnt for the sores which eviclently existed on the ndder of this cow, not having seen her mutil they were nearly healed. There is also considerable dombt as to the wanse of the calf's death. Certain it is that an ermption of bister's on the udder is an extremely common vecurrence in foot-and month disease (Fig. 3, Plate X). In the West, however, a considerable number of cows were affected, and but one had any symptoms of this kind.

lieviewing these symptoms, we can see that the disease which I inrestigated had few it any characters in common with foot-and-month disease. Anong the whole number there was not a single animal which presented the trpical charateres of this plague. There dir not apprar to be a single animal which presented even the typieal mouth symptoms, or the typical feet symptoms of that disease. The history, the chandeters, the symptoms, everything connected with the disease, led us to conclude, therefore, that it could not be the contagions foot-and-mouth disease.

CILARACTERS WHICH DISTINTEISH TIIS DISEASE FROAL FOTL-IN-TIIE. FOO'T.

The discase known as foul-iu-the foot, and often called foot-jot, has its origin in the skin of the interligital space. It begins as a superficial inflammation, which is followerl by sloughing, ulceration, suppurat. tion, the burrowing of pus, and the formation of simuses. By this pro- 
cess the disease may gradually extend heneath the horn of the toes and toward the deeper parts of the foot, mntil the tendons, bones, ligaments, anl articulations are involver. In extreme cases it may eren extend to or above the fetlock joint. Steel, in his new work on the "Diseases of the Ox," sums up this characteristic of the disease as follows:

Thus the pathological conditions of this clisease are, at first, the existence of inflammation in the interligital substanee, which may be partially removed by sloughing, then the presence of pus beneath the hoof-hom, boring and forming simple simses, which extend ontwals and burst on the surface. The patient is very lame, and the digits are separaled from one another in a remarkable manner.

That is, foul begins between the toes, forms sores there, and these slowly extend by ulceration and the burrowing of pus. Neither in Kansas, Missomi, nor Illinois were any such pathological characters as these seen. There was sudlen and conplete death of a toe or of a foot, or in some cases of a leg as high as the hock joint; the risease showed no tendency to extend, but was limited by a groove aromn the limb, which soon became a crack, and the affected portion was slonghed off. There was no burrowing of pus, no ulceration, and when the liteless portion of the limb had separaterl, the stump healed as readily as could be expecter. The disease was dry gangrene beyond question, and dry gangrene is not prodnced by foul-in-the-foot.

Again, those who so confidently promounced the disease to be foul, orerlooker the gangrene of the tails, which was present in a large number of eases, and was most marked in those animals in which the feet wore most severely affecterl.

Finally, the digestive disturbance and the lesions in the mouths were too evidently connected with the disease in the feet to be left entirely out of consideration.

It is surprising that two diseases having such different symptoms could be confonnded, and the mistake of such a number of competent veterinarians ean only be explained on the supposition that the examination was hurried and superficial, and that ergotism among animals has received but little attention in English-sjeaking comntries.

OB.JHCTIONS WIICH HAYE BEEN URGED AGAINST TIIE THEORY OF ERGOTISII IN KANSAS.

When we first diagrosed the disease at Neosho Falis to be ergotisn, we were met loy the objection that ergotism could not occur without ergot in the food, and that this condition did not exist on the affected farms. It repuired but a lew minutes inspection of the haly lacks, howerel, to satisfy the must skeptical that the hay at Keith's, bearel's, and Pribhernow's contained a larege quantity of ergot in the wild rye which matle my a consibleable proportion of the forage. And subsequent examination has powerl its existence nearly everywhere that this disease orciurerl. 
The second objection was that ergot did not probluce dry gangrene in animals; and this statement has been repeated again aud again by professional men who certainly onght to have known better. Tlue quotations from standarl anthorities as to the effects of ergot and the historical compilation contained in ofler sections of this report will be sufficient, I believe, to satisfactorily dispose of these assertions.

Again, it was said that it required enommous quantities of ergot to produce appreciable effects on eattle, and even if it conld in that case cause dry gangrene, the quantity found in the Kansas hay was tutally insufficient to aceount for these results. To this I reply that ergot in different seasons is known to differ widty in its poisonous qualities; that certain conditions, such as extremely rold weather and deficiency of drinking water, muloubtedly increase its effects in a very important degree, and that, finally, we do not know how much is actually necessary to cause dry gangrene. Careful estimates of the quantity of ergot in the hay in Mlinois, Missouri, and Kansas show that these cattle must have taken with their food from 3 to 4 onnces of this poison each day. The dose of ergot recommenderl by standarel vetermary anthorities as safe for medical purposes is abont ore ounce for grown animals, but it is not expected that this would he nsed for more than one or two days together. The diseaserl cattle, therefore, had taken from three to four full closes of ergot a day, and continued this for days and wedks. Cousidering that the action of ergot is to climinish the caliber of the bloor ressels, that the gangrene of the extremities is directly traceable to deficient blood supply, and that atmospherie cohl also has a marked tendency in this direction; that, in addition to all this, the drinking places were frozen orer, and the holes that were cont thromgly the ice were only kept open a slont time each day, it would aplueal that the conditions were rery faromble for the development of ergot poisoning.

Then it was reported that the outhreak in Osborne Comnty was certainly the same disease, and that the eattle had been pasturing on green rye and eomsequently eonlel not get ergot. A few inguiries hronght ant the firet, however, that the rye pasture had only been in mise for there weelis, while the disease had appeared at least six weelis previously. There was no reliable information as to what these cattle had been eating before the appealance of the disease, and the forage was not examined lyy any eompetent person.

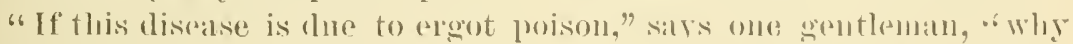
then is this the first ontbreali, since the Finnsas falmers latre lial this Same kind of lay to their cattle firom the first settloment of thra State?"

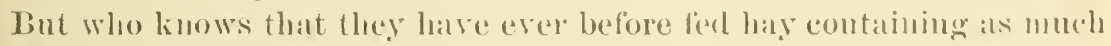
eregot? In Emope tho emzorities of ergotism have at times berm a cen-

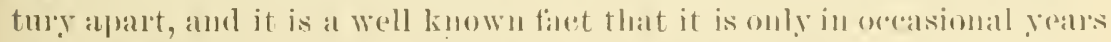

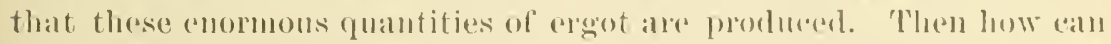
it be known that this is the first ontherak of tho disuase in kansiss? Cattle have frequently sullered with the same symptoms in New Iork, 
Pennsylvania, Iowa, and Missouri, and why not also in Kansas? Who outside of the immerliate vicinity of the snffering herds wonld have heard of the outbreak under consideration had it not been for the mistaken diagnosis that led the conntry to fear the presence of a dangerons. eontagions disease?

Again, would not this reasoning apply to any supposed cause of the disease as well as to ergot? No matter what prorlncerl the disease, if such an ontbreak has never occured hefore it might be said with just as much force, "Why, then, is this the first ontbreak?"

"A gain," the same gentleman goes on to say, "on Mr. Goodrich's farn, where the disease prevails, the lands are improved by cultivation, and there is no ergotized rye in his hay. Yet out of 96 cattle, 40 head of young stock are reported affected with the disease." This fact ras. the most tronblesome of all I had to contend with in making my diagnosis, and I appreciated its importanee perhaps as mneh as my eritics. could have appreciated it. The gentleman's statement is not absolntely eorrect, howerer, as there was a small quantity of ergoted rye in the hay; bnt still there was so much less than was seen at the other farms: as to make it impossible to explain why the cattle here should be affeeted. even to a greater degree than elsewhere. In my preliminary report I explained this by saying that wild rye was known to grow in patehes, and that, conserquently, hay that was being fed at one time could not be considered as exactly the same as that fed three months before. The apparent discrepancy in this ease has since been explained, however, in a much more satisfactory manner. Some time last fall $\mathrm{Mr}$. Goodrich bought two stacks of hay of $\mathrm{Mr}$. Keith, and it was this has that he hat been feeding to his cattle up to the time of the outbreak of the disease. When this fact was learned the whole matter became perfeetly clear, and what at first appeared the greatest objection to the ergot theory turned ont to be one of its strongest supports.

Then Mr. Beard is mentioned as having fed 55 head of cattle all winter on hay full of ergot, and escaped with but 5 discased animals. Mr. Beard, however, had fed his eattle twice a day on corn-fodder, that is, on corn which had been shocked but not husked, and as a natmal consequence his cattle ate very much less of the hay.

"Stranger still for" the ergot theory, Mr. Pribbernow fed 195 cattle on millet hay and eorn-fodder, and be has 14 of his yomng stock affected." Here, again, the zeal of the gentleman to make out a case against the ergot theory has led him to make statements which are not correet. Mr. Pribbernow hal some rery badly ergoted hay, which he showed to me, and told me that he had been feeding it to his cattle ; and, indeed, there was plenty of evirlence that this was the case from the condition of the feeding yards and racks. It is a fact, however, that 54 yearlings were ferl on millet hay, oats, and corn-forder in addition to the hay, and that not one of these was affected. The older cattle had been fed more 
exelusively on the hay, and it was among them alone that the effeet of the ergot was seen. These facts I noted down as they were related to me on the spot by Mr. Pribbernow.

"Another puzzle is presented by Mr. Keith buying 63 head of young stock from Mr. Daris on the 15th of December, and on the $23 d$ nearly all were down with the disease. Keith's hay eontains ergotized rye. Davis has had no sickness in his herd." This statement is also very ineorrect, and yet it contains a reference to the one unsolved difticulty connected with the Kansas outbreaks. The 63 head of eattle were purchased December 10, and as the first cases of sickness on this farm did not oecur mutil the 230 or 24 th, and as at the 1 st of January there were still less than thirty cases all told on the farm, it is plain that these animals had suffieient time to contract the clisease after their purchase.

The clifticnlty in regard to the ergot theory at Keith's was in conneetion with another lot of eattle bought about the 15th or 20th of December. This lot consisted of 6 yearlings and 2 cows, some of which Mr. Keith asserts were sick within three days and all within eight days, and that they were not fed upon hay during that time, but upon mowed oats and corn-fodder. He admitted, however, that there was probably hay in the racks to which they had access. There was much doubt as to the days on which these cattle were first seen to be lame, and as to how sererely they were affected. It is also impossible to say, at this time, on what they had been fed previons to their purchase. This difficulty, howerer, does not compare with that felt at first in regarl to the Goodrieh herd, and as the latter was satisfactorily explained at the last mimute, it is not at all improbable that there are some minown facts in regard to the 8 cattle in question that would explain this case just as satisfactorily.

I have reviewed above the chief objections that have been advanced to show that the disease in Kansas conld not be ergotism. It is unnecessary to add that they are mostly of the nature of captious critieism. The malady had been pronounced foot-and-mouth disease by some and foot-rot or fonl by others, and these gentlemen found it desirable to make out at least an apprarent case against ergotism. In other sections of this report I have given abundant evidence to show that it conld be nothing but ergotism, and the plates herewith presented, which were carefully prepared by a competent artist, are sufticient to prove this beyond donbt to any one who miderstands the pathology of these different diseases.

TIE NATURE, CHEMICAL COMPOSITION, AND ACTION OF ERGOT.

The substanee known as ergot is one of the stages in the life history of a fingus which has been named Claviceps purpurea. The term ergot was applied to it by the French from its fancied resemblance to the spur of a cock. The place which this fungus oecupies in the plan of nature 
mar be understood from the following table, which is taken prineipally from the classification proposed by Sachs:

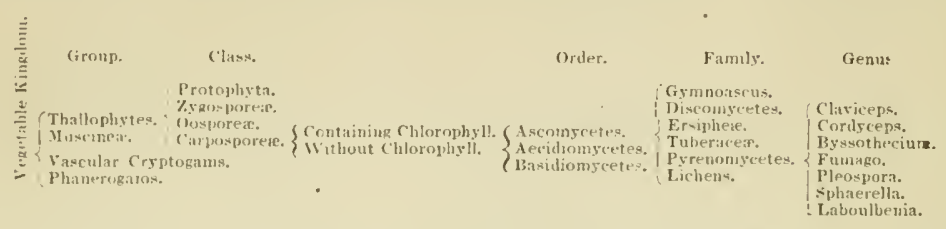

The growth of the claviceps brgins by the germination of eonidia or spores of this fungus, which have been carried by enrents of air or other means to the flowers of the grasses favorable for its development. These conillia or spores, as the case may be, germinate in contact with the exterual surfice of the ovary while this is still in an early stage of its growth, and form a mycelinm which penetrites the walls of the ovary, and, as a rnle, respeets only the summit. It thus by degrees substitutes itself in place of the tissue of the ovary, and, consequently, preserves to a considerable extent the form of this organ. It bears on its summit the stigma, while its external enat is traversed by deep groores and irregular earities. (In Plate VIII, Fig. 1, is seen the normal orary of the rye plant; Fig. 2 shows the same invaded by the elaviceps.)

In this stage of its existence it has been called the sphracelia. As it derelops it takes entire possession of the orary, obliterating its earity, and preventing the development of the orule. The ovule may be either entirely ahsent or it may be present in an inperfect form, but does not develop into a seed. The myeelium prodnces at the surface of the ovary a large number of oral corpuscles, which are called conislia, and which falling npon other flowers may germinate and again produce the mycelium or sphacelia form of the fungus. (Pl. VIII, Fig. 3, which is a eross-section of the orary, now called sphacelia, shows these coniclia at its borders.)

Thesphacelia, however, is not the ergot form of the fungus. At the base of this is produced a hard substance with a black or dark violet surfice, and white or grayish within, which is the true ergot or selerotium stage of the claviceps fungus. In the earliest period of the revelopment of the sclerotinm this is entirely covered by the sphacelia, hut it gradually increases in size and pushes the sphacelia before it until the latter is raised entirely beyond the floral ghlumes, and is supported on its summit (PI. VIII, Figs. 4, 5, 6). 'The selerotium, or ergot, contiunes to increase in size and length, and the deformed ovary or spluacelia adheres to it for a long time, and may eren be fonnd in a considerable proportion of the specinens as seen in hay or mature grain after enring. In these the form of the stigna can be realily made out in most eases by the use of a low power lens.

Lirgot is not therefore a diseased seed; on the contrary, it develops entirely below the orary and prevents the formation of the seed. It is entirely a fungus growth, and is the resting stage of the organism. It 

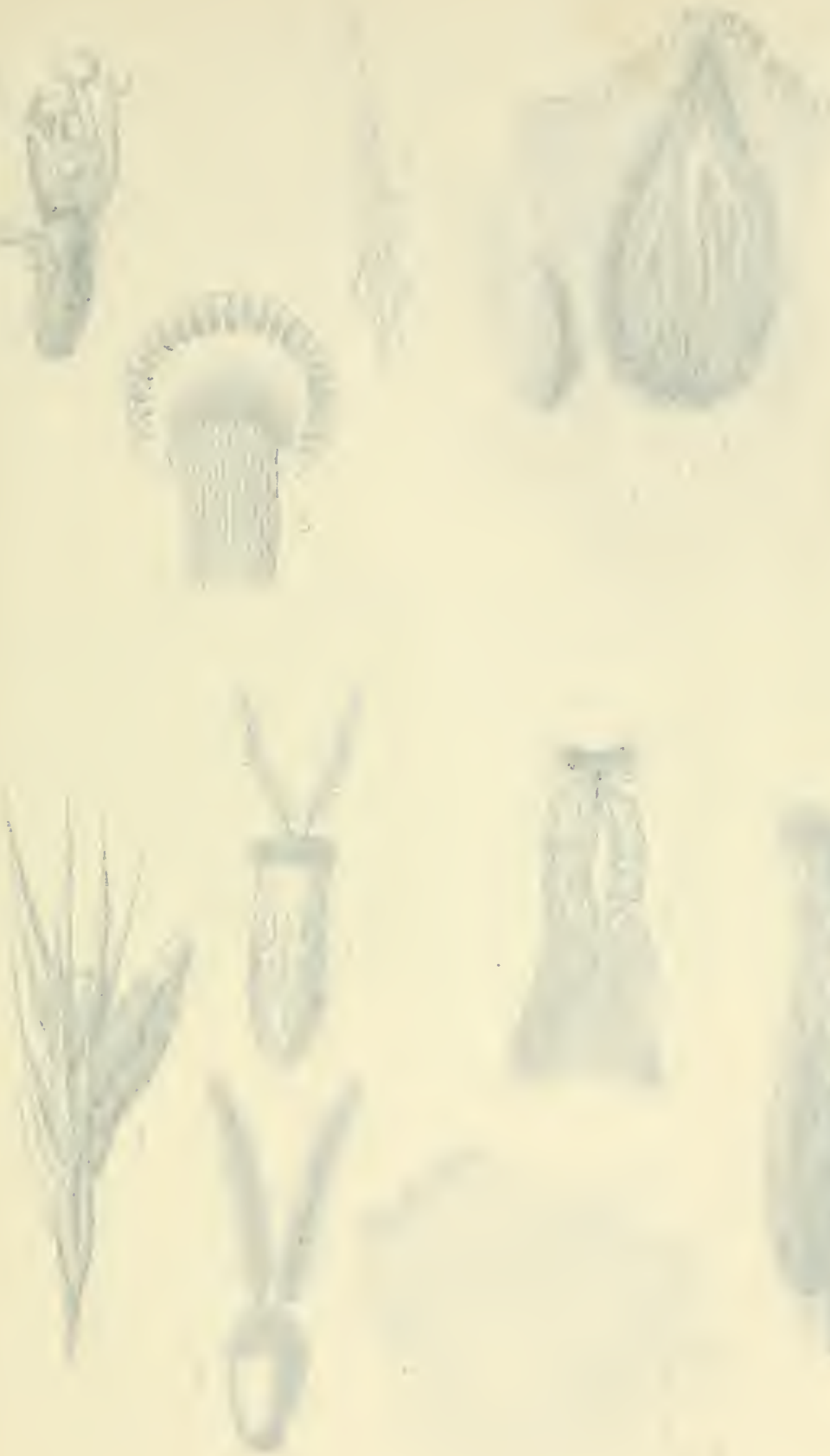


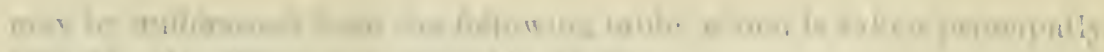

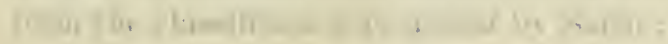

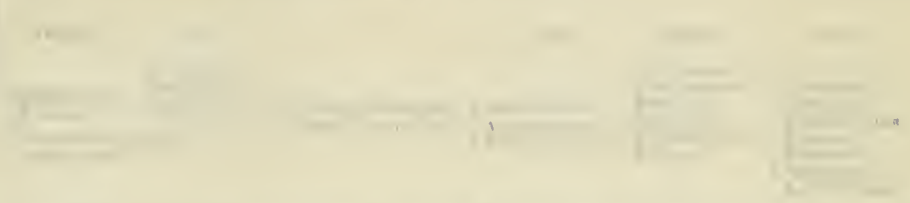

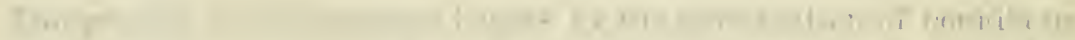

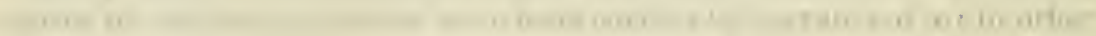

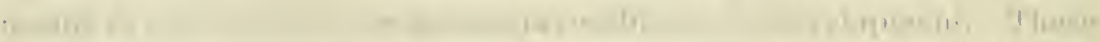
1. 1.

\section{and 11}

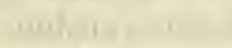

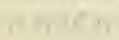

now

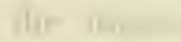

$+1 \ln \left(\frac{1}{2}\right.$

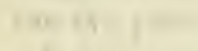

$1,1+1=0$

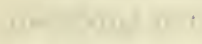

Anit in

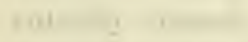

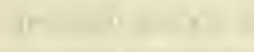

$\cdot+n$

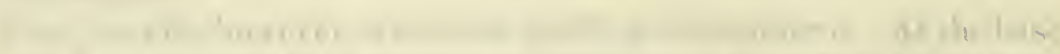

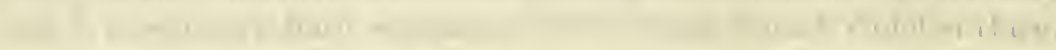

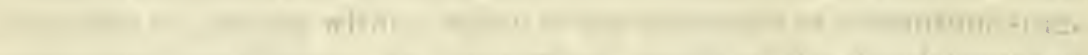
1.

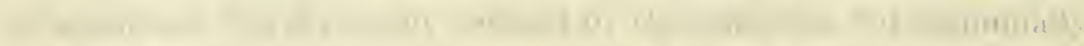

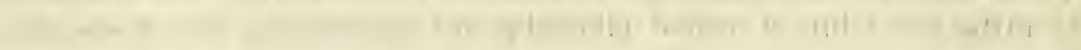

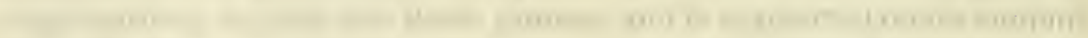

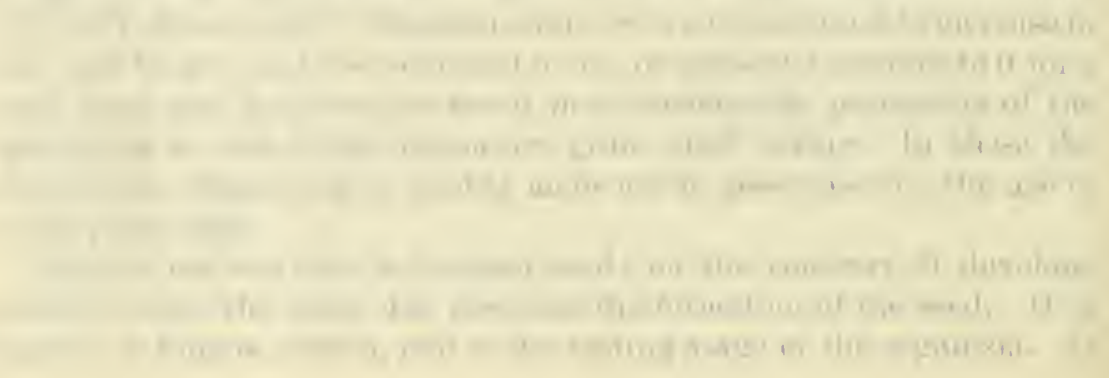



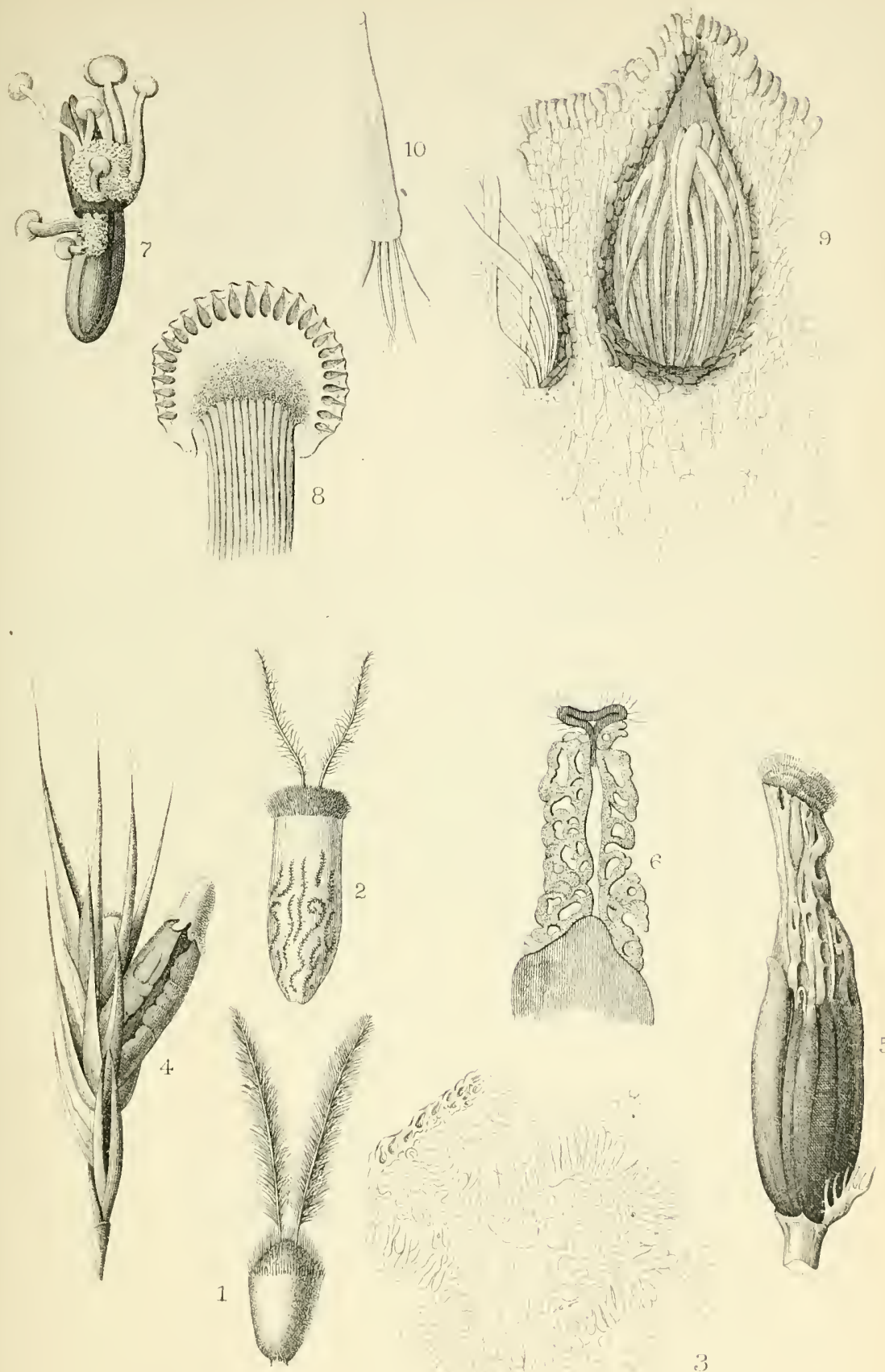

Marx fiom Nature

DEVELOPMENT OF FRGOT. 


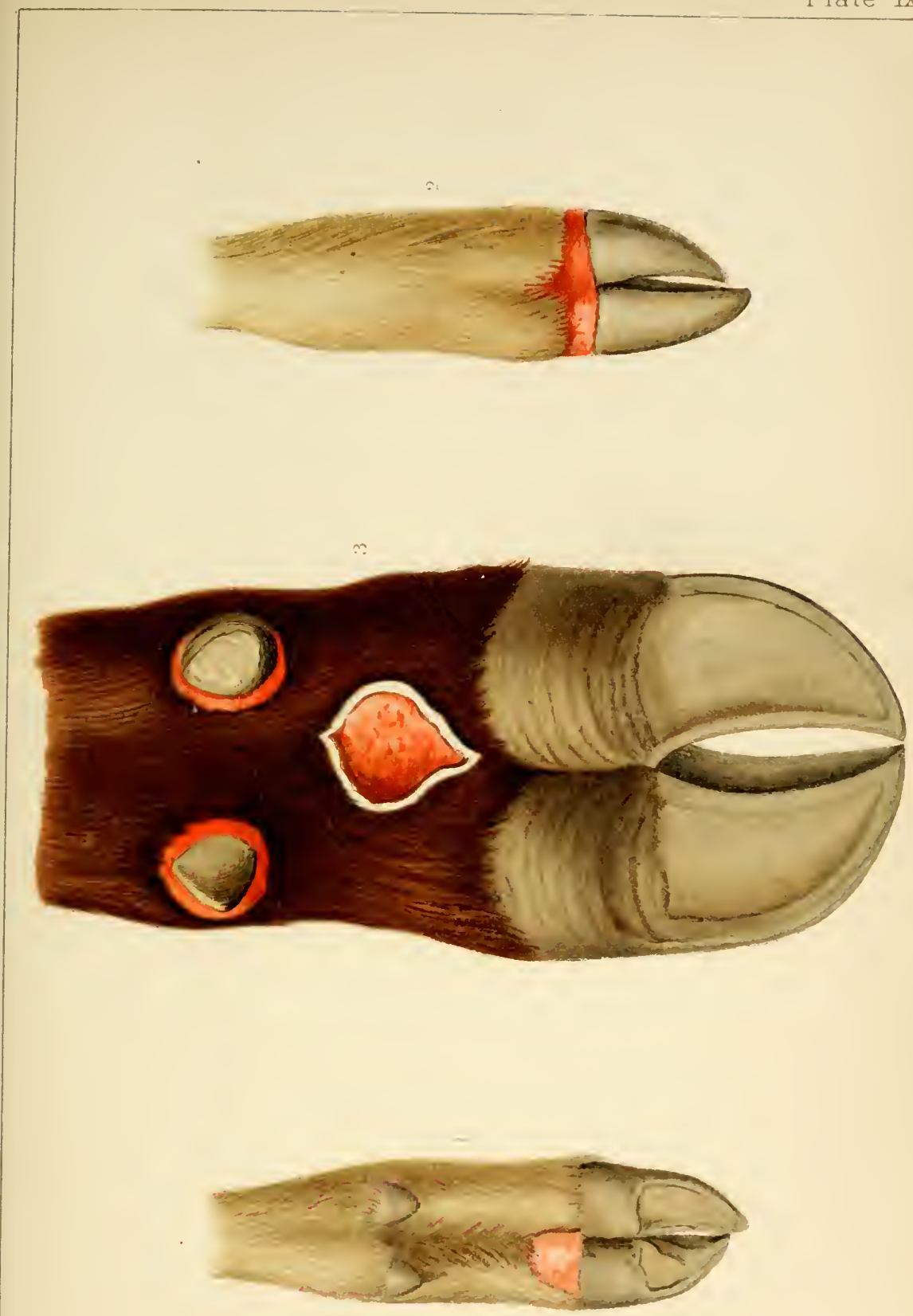

4

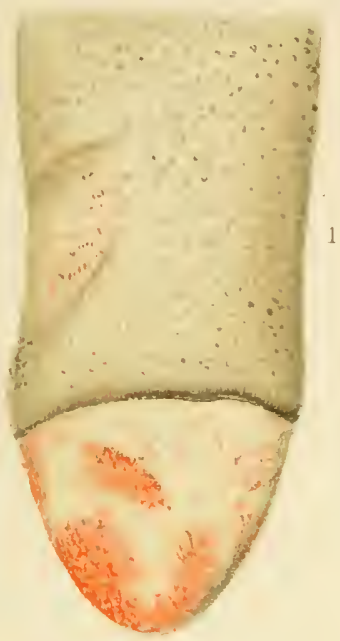

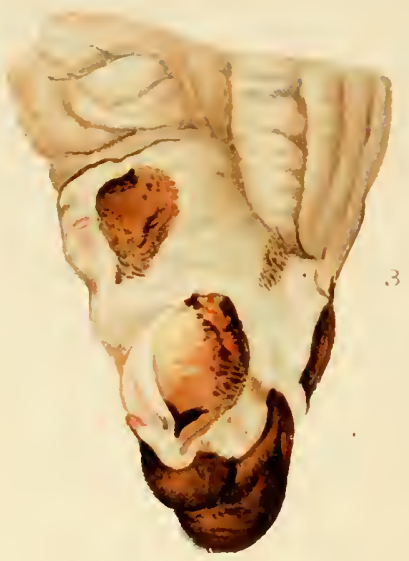

$?$
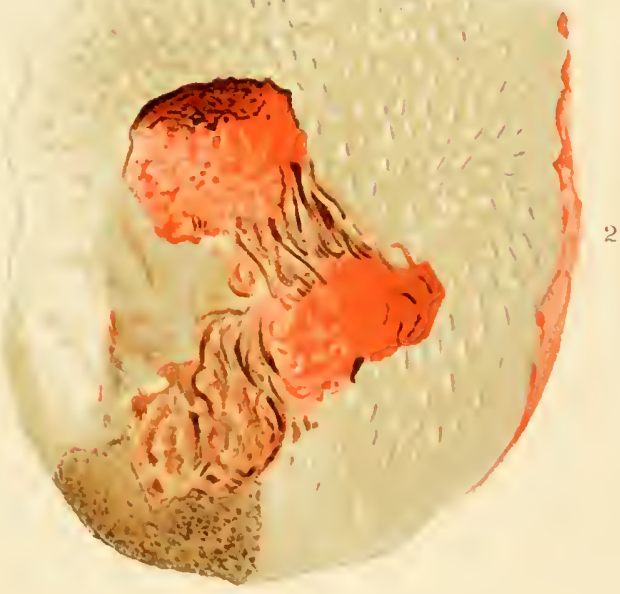

FOOT-AND-MOUTH DISEASE ( WALLEY) 

eontains little or no starch, and its microscopical strueture is that of the sclerotie myeelia. The sclerotim is looked upon as a hard compart, mass of imperfectly dereloped mycelia. It appears to be ahout a month from the time the fungus invades the ovary until the ergot is fully formerl.

The ergot is the dormant form of the fungus, and remains in this condition until antumn, or usmally until the next spring. If at this time it is in contact with the damp gromul it germinates and stromata grow from its surface (PI. VIII, Fig. 7). These eomsist of a long stalk and a grobular head, and become perfect froting fungi. In tha head a large nmmber of thask-shaped perithosia are formed (see I'l. VIII, Fig. s), which are filled from the bottom with a mumber of asci (Pl. VIII, Fig. 9), each of which contains sereral slender filiform spores (P'l. VIII, Fic.. 10).

When the spores reach the yomng flowers of rye, red top or other mearly allied masses, they germinate and form a myechim which invales the wall of the ovary and again prodnees a sphacelia. With this the eycle of derelopment of the fungus is completed and we probably have its entire life history. The metendogical conditions most farorable for the production of ergot are not well known. It has been asserter that it only appears in large quantities in laing seasons, but others believe that moistmre has little or 110 influence on its development. It is also uncertain whether more than one species of rarieeps is eoncerned in the produetion of regot in the different varieties of grasses. The ergot of the red-top hay in Missouri and Illinois produced idlentical effects with that in the wild rye of liansas, and it would therefore appear that the physiological effocts are substantially the same even thongh the species growing upon these two phats may be different.

The grains of ergot of rye are from half an inch to over an incls in length, and from one-fifteenth to one-sixth of an inch in dianeter: they are nearly eylindrical, sometimes slightly ribbed and furlowed, and often have irregular fissures; they are eurvel, and tapel towarl the ends. The color of the surface varies from lark violet to blue black or black; the interior is white, often tinted with violest. The ergot of wils rye, bhe grass, and red top has the same general appearance, lunt the grains are smaller. In red top many of the graius are so small that they are only recognized with difficulty ly the matided eye. Sometimes the taste is promomuced and disagreeable; lut the ergot in the wild rye of Kansas, where the ontbreaks of lisease ocemred, was"almost or entirely without taste, and certainly was in no sense disagrecable when masticaterl.

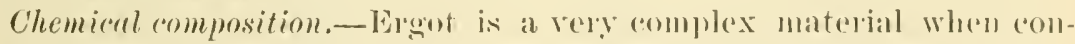
sirlered chemieally, and althongh it has beron studied by many competent ehemists, there is yet much louht as to the natmre of a mumber of

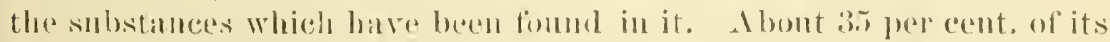
weight consists of a thick, fhubl, fixed oil, which is now holieved to bo 
ithont medical properties. Two non-crystallizable alkaloids hare been described and called, respectively, erbolina and ergotina; and one erystallizalble which has bren designated as ergotinine.

Sclerotir, ergotic, and fuscosclerotinic acids have been isolated. There is also a question of a peculiar aminoniacal base rarionsly stated to be methylamine, trimethylamine, and propylamia. A mneilaginous substance called sclevomucin and several other products of dombtful nature havebeen recognized. It has not yet been demonstrated which of these bodies eonstitutes the active prineiple of the drug, or whether the physiological effect mily not be due to a number acting together.

The one point on which most of those who have studied ergot have agreed is that water extracts the medical properties, and this seems to be abont the extent of our reliable information in regard to this department of the subject.

The action of ergot on the animal borly. - The action of this poison in large doses is very cleally given in the following extract from Dr. H. C. Wood's Treatise on Therapenties, Materia Medica and Toxicology :

According to Diez [quoted by Stille], the principal effects of poisonoms doses of ergot are in the lower animals profuse salivation, romiting, dilatatiou of the pupils, lumried breathing, frecpent pulsc, cries, trembling, staggering, paraplegia, sometimes diarrhea, sometines constipation, postration, urgent thirst, convulsions, * and death. Mr. Samued A. Wright, in a series of experiments (Edinburgh Med. and Surg. Journ., Oet., 18:39, vol. lii), noted, when the medicine was given by the month, symptoms similar to those just spoken of ; the paralysis was much more marked than the spasms. Late in the poisoning, the luart's action becane irregnlar and juteruittent, aud the ponlsations. which had been rapid, grew slow and feeble. In some cases the special senses seemed to be destroyed, and coldness of the surface was a very prominent symptom. Nr. Wright also injecterl a strong infusion of the drug direct] y into the torrent of the cirenlation. Death was in some cases prodnced in nine minntes, the spmptoms being immediate dilatation of the pupils, great increase in the rate of the cardiac pulsations, paralysis, and convolsions. When the fatal result was not bronght about in so short a space, great aucesthesia of the surface was noter a considerable tine before death; coldness of the surface and paralysis of the special senses were also present in some cases. In Dr. Kersch's experiments (Betz's Yfemor., vol. xviii), the concentrated infusion was injected into the jugnlar vein; the coldness of the surface was esprecially noted, and also great muscular rigidity. Ujon rabits, acerding to the researches of Wright, ergot acts very fecbly. In birds, as represented by chickens, turkeys, and pigeons, it canses symptoms analogons to those prodnced in mammals, as is testified by Tessier and ly Gross, hoth quoted by Stille, and by lbomjean (Traité de l'Ergot de seigle, Paris, 1815.)

The alove smmuary of the general symptoms cansed by poisonous doses of ergot show that the phenemena are mainly paralytic in their natme; but, although an eformons amonut has lwen written ahont the drug, we have very little knowledge as to the immoliate canses of the paralysis. Since hoth Wright (loc. cit., 111. 3:0, 321) and Koblure have fomd that the voluntary muscles are not attected by ergot, it womld seem that the norvons system must bar the brunt of the poison. Engene Inandelin is said to hawe shown that the peripheral nerves are not affected, and the experiments of Kïller have confirmal this so far as concerns the motor nerves and the watery extract of ergot. He fouml, howerer, that those portions of the drug not soluble in

"Poreira states that convulsione were not present in the experiments of Diez. 
water appeared to increase the excitability of the peripheral efterent nerves, and that upon the peripheral sensory nerves both portions of the ergot acted as a feeble depressint. On the whole, it is probable that the chief action of the drag is mpon the nerve centers.

The following experiments of Tessier also indicate the active nature of the ergot poison (Memoire sur les effets du seigle ergoté. Hist. Soc. Roy. de Med., 1777, 1775, Paris 1780, vol. ii, pp. 587-615):

These experiments were instituted with hygienic precautions upon a number of animals. Of two dneks fed mpon ergot, one, the female, died in nine or ten days. It had consmmed one onnce and three dlachms of ergot. There was a large riolet spot on the beak, the covering epillermis was raised "np by a collection of dark, fetid blool. The male died in fourteen days with the beak similarly affected; there was also drooping of one wing which showed two regions of inflammation, one in the fold and the other on the first phatinx. It had consmmed 2 onnces and 6 drachms of ergot. A turker was fed 8 ounces $+\frac{1}{2}$ drachms of ergot within twenty-two days. The antopsy revealed inflammation abont the beak, but none of the feet and wings. A pig six weeks old died at the end of twenty-three days after receiving 1 pound and 12 ounces of ergot. The antopsy revealed swelling of the four feet especially at articulations, which were a redilish violet color. The ears were livid, there was gangrene of one side of the head and varions internal inflammatory lesions. The articulations of the feet with the legs being nncovered there was seen, particularly with the posterior limbs, a thick, black, and fetid liquid. The animal previons to death had been able to support itselt better on its fore than on its hind limbs. A six-months' old pig died after being fed during sixty-nine days mpon a total of 22 pounds and 6 omnees of ergot. The autopsy revealed varions internal inflammatory lesions, several violet spots on front and hind legs, the end of the tail dark violet, and ears livid. The two first phalanges of the right anterior foot were gangrenons and dry, especially near the articulations. The bones themselves were tinted brown. The same parts of the left foot were gangrenons but not so far alvanced, as the bones were not altered. Upon each calcanemin there was a livid spot, larger on one than on the other. Dnring life there was on the twenticth day a purnlent discharge from two cavities in the articnlation of the right foot; these were soon covered with a erust. The limb remained cold. On the forty-second day the corresponding joint of the left anterior leg developerl a tmmor which by the tifty-eighth day became an open sore. Both legs were cold and swollen, dry, insensible, and portions of the muscles became detached. The animal was no longer able to walk.

Salerne, cited by Real, gave to a small male pig barley mixed with half its weight of ergot. At the end of tifteen days the legs beeame reil, secreted a yellowish and fetid humor, the skin of the back and beneath the abdomen became black in color. This food was continned for fifteen 
days and then replaced by some free from ergot. The animal died four days later; there was no gangrene of the feet. Read fed a pig three months old for tifteen days with ergoted wheat mixed with bran. Gangrene seized the left ear on the seventeenth day and it dropped off." The pig died two days later with convulsions. A gangrenous spot was found on the liver. (A. Tardy. De l'Ergotism, Paris, 1558.)

Flening, in his Mannal of Veterinary Sanitary Seience and Police, (Vol. I, 1. 65), says: "The ergot on rye, wheat, \&e., lias also given rise to extensive disease in man and animals, inchding birls, marked by eonvulsions, paralysis, dry gangrene of the limbs, loss of hair and horn, and other strange phenomena."

M. Tabourin, in his Nourean Traité de Matière Médicale de Thérapeutique et de Pharmacie T'étérinaires, Paris, $\mathbf{1 8 6 6}$, gives the following deseription of the action of ergot (pp. 448 to 450$)$ :

The effeets of ergot of rye shonld be divided into medicinal and toxie.

Medicinal effects. -The aetion that ergot of rye excreises on the natural surfaces and on the denndod tissnes has been very little stndied with animals, but alpears to be slightly irritating; with man it has been noticed that the aqueous extraet arrests capillary hemorrhages with considerable rapidity, and that it has a manifestly astringent aetion on dended tissues. In the digestive tube the effeets are but little marked when the medieine is given in suall doses; it is only when the quantities ingested are considerable that vouniting ocenrs with carnivora and a serions irritation of the intestines with all animals. In regard to the dynamie or general effects proAnced hy the ergot of rye in medieinal doses, when its active prineiples have been absolbed, they are almost nmoticeable with healthy animals and have been only very imperfeetly stndied up to this time. It follows, however, from the trials undertaken by various anthors on the greater part of the domestic animals, that this medieine produers with them as with man two effects somewhat opposed to each other: a very prononnced sedative action on the eirenlatory center, and an energetie stimnlation of the nervons eenters and partienlarly of the posterior portion of the spinal cord. We will return to these two euluminating effects of ergot of rye in eonnection with the toxic action that it has on the organism which we are now about to stndy.

Toxic effects - The poisoning of animals by ergot of rye is called ergotism. It may oceur at the ent of a longer or shorter time, according to varions circumstances and particularly aceording as the ergot is given alone or mixed with the fool. In the former ease, it ocenrs after a few days with birds, and after weeks or even months with manimals, accorling to the size of the doses and the time between them. In the second case it is much slower still, and when its existence is manifested by apparent phenomena the destruction of tho organism is alrealy consmmated and there is no means of providing a remedy for it. This is a remarkable example of ehronic or slow poisoning.

The chararteristie signs of ergotism are of two varieties. One of these is due to the nareotico-acid and exciting action that the ergot expreises on the nerve centers; the other is due to the seditive action that it prodnees on the heart. When the former prodominates, als has been olsserved with certain epidenies with the hmman speries, the ergotism is ealled convulsive; when, mu the eontrary, the seeond is more pronomnced the crootism is called gangrenons. It is difficult to establish this distinction with animals where the signs of the two varicties are mixed in nearly equal proportion as we shall demonstrate.

1. Solipeds. - Of all the dmestic animals, the solipeds are the least exposed to poison-

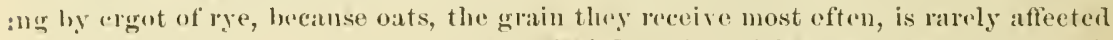
with this alteration. Only two anthors, MII: Itertwign and Parola, have made experi- 
ments on solipeds with eryot of rye. The former anduinistered three :mal onc--1nilf kil-

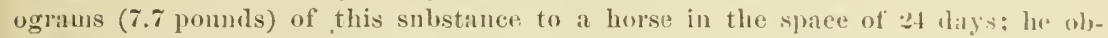
served some nervons phenowena and a great depression of the cirenlation, lnt 110 al 1pearance of gaugrene. The latter gare ergot of rye to a mule, aftictul with chronie coryza, for six days in the dose of one fotwo onnces a lay. There was slowing of the cirenlation, decreased temperature of the body, difficulty of respiration, lows of appetite and strength, general depression, muscular trembling, slight swelliug wi the kners toward the end, de. The suljeet was destroyed. The disehige from the nose hat disappeared.

2. Large mminants.-Poisoniug of large ruminants by ergot is more common than that of solipeds heeanse these animals receive chite often, as a supplenentary ration, the rejected grains eouning from the thrasher or from screening, which always contain more or less ergot of rye and of other graius. With the large runintunts the convulsive phenomena are not seen or are not very apparent; but the depressive effects on the eirenlatory system are, on the contrary, very maked. Besides, the health is maintained without serions disturbance during weeks and even months if the ergot is taken with the food. Only the extremities lose little by little their natnral warmth, as is noticed with the ears, the tail, the lower part of the limbs, \&e. The digital region, and sometimes even the metacarpal aud met:ftarsal regions, as MI. Decoste has observed, are smitten with dry gangrene. In this case, the parts lose their warnth, their seusibility, become harleued and mummified, and soon sejarate withont pain from the parts which have still remained living.

3. Small ruminunts.-It is kuown that the sheep may, like other auimals, feel the noxions inthence of ergot; but science is wanting in precise docmments concerning this rumiuant and the goat.

4. I'igs. - It follows from some experiments made on these animals by Tessier, that ergot of rye poisons them after a greater or less time aceording to their force of resistance. There is seen in the tirst place vertigo, unstealiness in standing, a tottering walk, moaning, swelling of the eyes, ve.; then the ears, the tail, the lower part of the limbs, lose their warmth and vitality; soon appear livid spots, which afterwarl becme black and gangrenons, and are the beginning point for the separation of the mortitied from the living parts.

5. Dogs, - M. Dien has given ergot of rye to tlogs in the dose of 15 grams (halt an onne(e) a day. The animals were soon taken with nansea, blooly diarrheal, a nasal discharge also colored with blool, depression, weakness, alml soon drop iufo a frightful marasmus. The experiments not having been pressed to the end, the phenomenat of dry gangrene could not he observed.

6. Forly. - These little animals are most exposed to the poisoning muler cousideration, beeause they often receive tor nompishment the residue from eleaning gran which always contains more or less ergot. The tirst signs of this poisoning are loss of liveliness, indifierence tu surromulings, and great dullness : then there is rertigo, drooping of the wings, $\mathbb{E} x$; finally appear more charateristic signs-al bloody dis-

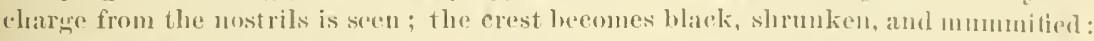
the leak dries and is detached : the same conrse is soon followed ly thes tongue; the feathers lose their luster and fall ont. Death rasults seron alter these symptoms are seent.

To recapitulate, the most orkinary signs of orgolisun with thre varions animials are as follows: Inluess, fixed expression, vertigo, dilated pupils, intoxication, ('ontal :

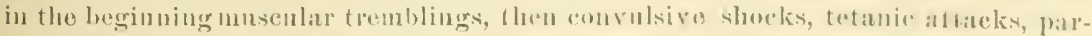
ticularly in the posturior members which afterwall hearome weak and paralyzed, anstealy posilion while standing, slow and dificult walk, de. : general weakmess, pre-

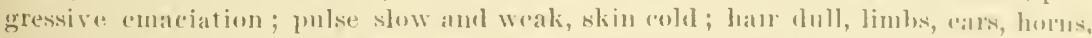

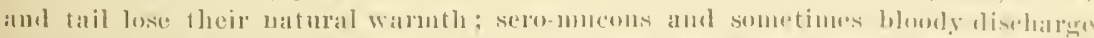

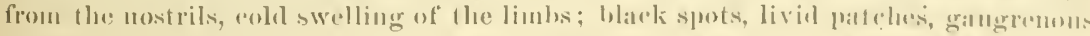

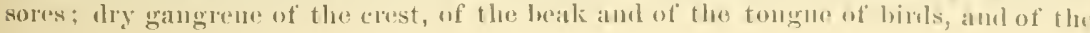


ears, the tail, the phalanges, the limbs, which become detached little ly little and piece by piece from the trunk withont intlammation or pain, de.

Lesions. - The digestive tub is nore or less iutenso] irritaterl, tho viscera are flabby and softened, the muscles semi-gelatinoms; the hlood thuid, violet colored, the interior of the ressels red as in putrid cliseases of e.

M. Verheyen, in his article on ergotism in the Nonrean Dictionnuive $p^{2}$ atique de Wélicine, de Chirurgie et d'Hygiène Vétérinaires, gives the following account of the effects of this poison:

Symptomatology.-In spite of the mumerous experimental studies of which the ergot of rye has been the oljoct, its effects on the organism are far from heing sufficiently molerstood to enable ns to write in a complete and connected manner tho part of the medieal history of ergotism relating to the symptomatology and pathological anatomy. The mode of action of ergot on the economy is only presented so far in a fragmentary state; the acquired knowlerge loes not permit the tracing of a physiological chart of all the phenomena produced hy this agent. A large number of experimenters, particularly among the modern ones, have only produced an acnte intoxication, of rapid progress, which lenves in ohscurity the evolution, the gradnation, and the snecession of the morbia phenomena; in a worl the progress of natural ergotism resultiug from the introdnetion into the economy of small but long contimed doses of the toxic substance. History mentions destructive epidenics, and others which have been relatively mild; this difference can only be due to predisposition and to the abundance of ergot. Rye is rieh in it in the ealawitous years; the high price of cereals, aud of all kinels of provisions, prevents the poorer classes from procuring sufficiently untritions foul. There, eonsequently, follows a constitntional debility and anemia, which siugularly favors galigrenous and convulsive disorlers. The observation, so precise, of $M$. Decoste, as regards the hygienic dict to which the cow, which was the sulject of it, lad been submitted, the conditions umer which the epizuïtic of the State of New York appented, proves that misery constitntes a preslisposing canse not less energetic for animals than for man. The experinenters have not taken into accomt these constitutioual molifications which inerease the suseeptibility to the poisonous agent, and give to ergotisu a new symptomatic expression. Here, it appears to us, is found the key to the mumerons cond radictions that are noticed when the experiments are compared with each ofher. To cite only a single example concerving the hoviue species, we see that Riemann dirl not smeeced at the end of cight days in provoking the least almormal pluenomenom, and that Wahlin protuced no other noticable symptom than eonstipation The anthors who have olserved cases of ergotism with animals during the comrse of an eppdenic may be correct when they mention the fact very smmm.rily, and limit themselves to a statement that the phenomena were absolntely similar to those presented by man. This identity justifies, to a certain extent, their laconisur, and the epilduic conditions explain the differences olutained by experimenting dnring the "pidenic perionds and ont of these periods. During the epilemies the rule relative to the gangremons form in the sonth

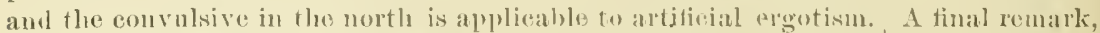
perfectly justitiol, and which has loon little if at all cousidered by the experimenters: Tessier, who bronglat a high urelar of intelligenee to the elneilation of the history of ergotism, asscrts that all animils show a very great mepugnauce to take ergot voluntarily; this is so insurmomutable for some indiviluals that they will die of lameger

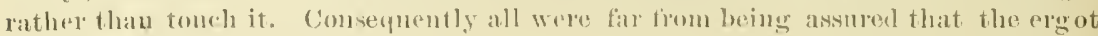
ofliered was really comsmmerl.

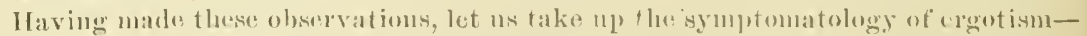
they will axelse the incomplete sketels that we trace.

These morlobl phencmena are very inconstant during the perion of invasion. Some-

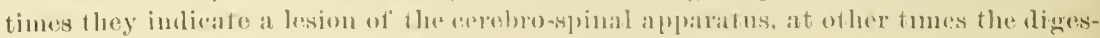

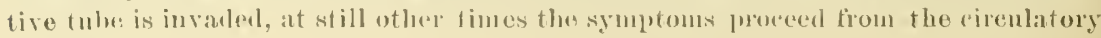


system. This variability is common with fowls, with ples, und with rarnivora. The predominance of the cerebro-spinal aticetion manifests itself in varions degrees of intensity: it may be arrested after development when the exciting canse, the alimentary use of ergot of rye, has ceased. In the first place, there is vertigo; the animals stumble as if they were intoxicated; they lose their equilibrim, fall on the side, and remain in a state of drowsiness, whel is not dissipated even when they arise. The lrair and feathers lose their lnster; the temperature of the skin is loweren; there is anasthesia, the insensibility following a condition of hyperasthesia; this alternation affects also the sight and the hearing (Wriglut). It is munistakable in the canine species; the pupils are constantly dilated. The symptous of nareotism that we havo just enumerated persist or are intermpted hy eonvulsive phenomena, smatimes of the limbs only, and sometimes of the whole body. The general couvilsions are characterized by tetanie epileptic attacks nsually followed by temporary paralysis of the posterior parts. The suffering is sometimes so intense that it is manifested by plaintivo cries and contortions. The nerrons attack wer, the animal falls again iuto a coudition of apathy or drowsiness. If the spasm is limited to the limbs, there reminins after the attack a cuntraction which persists for a certain length of time.

These phenomena which characterize spasmodic ergotism have au incletuite duration. Death may ocemr after a few hours or a few days as a result of a paroxysm, or the disease may be more prolonged and take a cluonic form. The nutrition suffers; the animals become thin in spite of the appetite, which, however, is irregular, and finally a convulsion at last destroys them in an advanced condition of marasmus. The circulation is abnormal, the pulse is slow, accelerated but afterwards retarderl; the arterial and cardiac contractions are spasmodic.

The participation of the digrestive tube, which may be either the principal or the accessory cause of the cerebro-spinal affection, is announced by nansea, pharyugial spasms, vomiting, diarrhea, sometimes followed by an insatiable hunger. If this is satisfied the food does not alleviate the hunger, for it eanses convulsions. In tho soutl all these symptoms may be preceded by gangreuous accidents; the latter may also precede when the circulatory lesion is the first to ocenr. With the gallinaceans the crest becomes coll, takes a violet or black color, shrivels, and dries; these phonomena are also quite constant in the north, but the dessication of the beak, sonetimes of the feet, constitutes an alteration exchsive to the south; gangrenous patches also cover the abdominal walls (Nillet). In gangrenons ergotism of the palmiperls, besides the beak, there is sometimes seen mortification of the point of the tongne ('Tessier), and of the interdigital membrane which is discolored and becomes dry and brittlo; then the digits are lost (Decoste). With mammals the gangrene at tacks tho lower part of one or several limbs, the ears or the tail; these parts become red as if they were the seat of an erysipelatons inflammation; the color changes to violet, to blue, or to black; they become mmmitied and detached when the convulsive paroxysm has not destroyed life before the completion of the work of elinination. While this is oecurring the loss of thesh progresses and marasmus comes on, then, tinally, a convulsive movemont which destroys the patient. The mummification also attacks isolated unscles and in very exceptional cases the dry form of gangrene is associated with the humid form (Tessier). The pulse remains small, feeble, slow, or indeed it becones accelerated, febrile, and precipitates marasmus.

Sheep which are subject to convulsive ergotism, are probsbly also subjeet to thes grangrebous form. We have alostaned trom considering it in the symptomatulogy because we have not met with documents which authorize us to generalizo the symptoms and to extend them to the ovine sprecies.

The gangrenous form is the only one which has beren observed with the bovine species; it remains locesl and is not complieated with the greater part of the greneral symptoms which may precede it with the other species of the domestie animals that have just been referred to. The appetite is preserved, the muzzle rmains moist, nd the expression of the eye is mot changed. These sigus of health often remain 
nutil the fatal termination of the disease. The cirenlatory lesion seems then to be alone in play; it is localized in the digital region of the posterior limbs (Randall), or extends to the metacarpal and metatarsal regions of the limbs of one side (Decoste). A slight swelling of these parts annonnees the beginning. The hair becomes dull, the skin is dried, hardened, and nummified as well as the parts immediately beneath it. The appetite is preserver, but the animals hecome thin; a fow indivilwals take flesh after the loss' of the gangrenous limbs and may be prepared for the butcher. Death in a condition of marasmus is the most common result. When the affection takes a relatively beuign form the gangrene does not destroy the part; the digital region loses its elasticits, the points of the toes are elevated, grow to an unusual length, and the weight is supported on the back of the fetlock. In this situation the animals pass a miserable existence until the owner, from pity, sends them to the buteher (Randall). The more benign form seems to us to have a resemblance to convulsive ergotism; the position of the posterior limbs has perhaps for its origu a contraction of the extensors.

In the records of epidemics of ergotism there are found but few references to the disease in the horse, and these are of no use in tracing the symptomatology. We are then rednced to a recapitulation of experinents to the number of $\lrcorner$ wo, one made by Hertwig and the other by Parola.

Hertwig administered to a horse within twenty-four days 3,552 grams [about 7 pouncls] of ergot of rye. The phenomena observed were slight eolics, loss of appetite, which disappeared within a few hours, drowsiness, which also soou passed away, dilation of the pupils, slight spasmodic contractions of the museles of the skin and diminished temperature of the surface of the body The pulsations of the arteries were retarded from 40 to 28 to the minute. The lay following the administration of the last dose all almormal phenomena had disappeared.

Parola experimented ou a vigorous aud lively mule affected with a nasal discharge. During six days he gave it, in adlition to its ordinary ration, ergot of rye in progressive doses of from 20 to 64 grams [ $\frac{2}{3}$ to 2 ounces] a das. The first day, the pulse was from 56 to 58 , with lowering of the external temperature. The second day, pulse 58 , respiration difhicnlt, tearful eyes, loss of appetite, dullness, beating of heart insensible. The third day, coldness of the skin, geveral tremors, difticult respiration, spasmodic trouble of the cardiac and arterial pulsations, absence of appetite, apathy, dullness, suppression of the nasal discharge, which returued after the nse of irritating injections. From the fourth to the seventh day, development of these symptoms, unsteady and difficult walk, trembling, inclined to lie, painfinl swelling of the kuees, the nasal discharge definitely arrested. After baving taken in all 284 grams $[0.6$ ponnds] of ergot, the mule, which hat continually lost in flesh and liveliness, became insensible and was destroyed.

It may be concludel from these facts that the horse escapes the pern ieious effects of ergot no more than other animals, and that, placed under favorable eonditions, one of the two forms of the disease may be clearly manifested, as the result of long and continned nse. Ergot is also a poison for insects; in Poland they kill flies by giving as a hait powder of ergot mixed with honey. Leeches, plunged into an infusion of ergot, perish instantly (Lorinser).

Anatomical characters. - Studied for centuries, ergotism presents, iv regard to its pat hological anatomy, lamentable deficiencies as well with mankiud as with animals. Considering the variation of symptoms it is useless to insist that the anatomical lesions cannot in all eases be the same. Those which we are abont to enumerate all belong to either artificial or experinental ergotism.

The rigor mortis is never excessive; the flabby nuscles are softened, the bones engorged with blood, particularly near the articnlations. The venons system is distended by a black, pitchy, semi-1luid blood; the arteries, sometimes empty, contain in other ciremustanees a red fluid blood. In the thoracic eavity the lnngs are found hepatized in the posterior portion; the heart thabby, small or voluminous, con tains 
fibrons eoagnla and a black, viseid, semi-fluid blood; in the left side of the heart, which is often empty, there is nothing found but fibrinous concretions. The uncons membrane of the small iutestine is pale, yellowish, infiltrated, and softened, souretimes covired with red stria or black points. These black points are componnds of fat and pigment (T. O. Hensinger). The mucous membrane of the large intestine shows hyperemia, which is far from being constant. The proventriculus of the gallinaceans has a gray or a wine-red appearance; its mneons membrane is nleerated or covered with granulations; the gizzarl is black.(Millet). Do not the granulations depend upon the ulceration of the pepsine glands? The cerebral envelopes, principally at the base, are congested, engorged with a black blood resembling that found in the veins; a section of the braiu shows sometimes a very apparent punctation; in other cases, nuch more common, it is anemie. Analagons ehanges are met with in the spinal cord.

The local disorders of gangrenons ergotism are those of $1 \mathrm{ry}$ gangrene (see Gangrene).

Physiological action.- The symptoms of gangrenons or convulsive ergotism, as a whole, indieate incontestably that the nervons system fills the principal rôle. The phenomena observed by Hoppe when be placed ergotine in contact with the isolated organs of the frog or the rabbit would remove all doubt if any conld exist. Ergotine canses a marked stimulation of the heart, followed by a weakening and a retardation of its movements; the intestine contracts, lout the contraction is not renewerl after a second application; the blood vessels dilate; soon follows a eontraction with congestion of the rasa vasorm which swell ambl canse the walls of the veins and arteries to become rigid; the sensitive nerves are partially paralyzed; later their sensibility is increased; a general intoxieation congests the brain and spinal corl. This last effect is not constant; the antopsies show that though the envelopes of the cerebro-spinal axis are always congested, wholly or in part, the nervons centers themselves are yuite often animic.

It follows from these results which are eonformable to what is observed in ergotism that the primitive phenomena depend npon a sedation of the sensory nerrous system, and this anisthesia is snceeeled by a hyperesthesia and a retardation of the cireulation. The exaltation of the sensibility has not always the same seat; this cirenmstance explains the variations of the symptoms and the predominant lesions of a functional apparatns. In all cases the hyperixthesia excites reflex actron, sonetimes in the intestinal tube (colic, vomiting, and cliarrhea); at other times in the voluntary muscles (contraetions and convulions); at still other times in the involuntary muscles of the vessels (gangrene). These reflex actions may be successive, simultaneous, or they are developed separately and remain separated during the whold course of the disease. With man, who can give an acconnt of his sulijeetive sensations, intense pain preceles the contraction; then follows, according to the intensity of the disease, convulsions varying from trembling to epileptic attacks. The over stimulation leads to exhanstion, which brifgs a ealm in the sensitivesystem. Intolerable pains, whieh are more localized, also preecele the dry gangrene; the patient feels in the part which beeomes the seat of it a cold sensation; later, this is recognized by the thermometer and to the patient it seems glacial; the sensation is los when the gangrenous efleet is aceomplishel. The lilatition of the vessels, followed by a narrowing of their ehannels are phenomena which are connected with primitive anasthesia, a seconlary hyperathesia, and with retlex action, which aflect the vaso-motor neves. The rigidity and congestion of the vaseular tubes, the weakening of the eontraction of the heart, retaril the eireulation in the extremities, favor the staguation of the bloorl, and consequently necrosis, even if the retlex phenomena are not suficiently intense to obliterate the ehannel of the aflerent vessel and probluce mortitication by anamia. What is produeed in an intense manner at one or several extremities is repented at all the periphery in gangrenons and convulsive ergotism; the lowering of the temperature has no other cause "than the retarlation of the circulation and the reflex muscular 
spasm. The cerebral phenomena are probably only seconiary and are due to the congestion of the brain and its envelopes; the and mil of this organ would also aceount for them. It is a law that local congestions go sidle by side with local aniemia; when ergotism beeomes chronie, the anomia is generalized, a common result in all diseases which are of loug duration. The absence of exulations removes all illea of inflammation, and if hepatization of the posterior lobes of the lnngs has becu fonm, partienlarly with the gallinaceans, this lesion is neither constant nor general.

The medium dose of this agent for medicinal purposes is given by Tabourin (Noureau Traité de Nat. Med., etc., II, p. 447) as follows: Cattle and horses, one-half to one ounce (16 to 32 grams); goats, sheep, aud pigs, oue to two drachus ( 4 to 8 grams); logs and cats, one-half to oue drachm (" 4 to 4 gams). Finley Dun says: As a parturient or styptic, for the mare or cow, one-half to one onnce; for sheep, swine, and bitches, abont one drachm (Tet. Medicine, 1. 212).

\section{HISTORY OF ERGOTISM.}

Wood states that epidemies of ergotism or chronie ergotic poisoning have been recorded from time to time since the dass of Galen [130 to 200, A. D. ] and of Cirsar [B. C., 100 to 44]. (Therap. Mat. Med, and Tox., 4th ed., p. 565.) There is much reason for doubt, however, in regard to the diagnosis of cases oceurring before the teuth century.

Verheyen says that, "From the ninth to the thirteenth eenturies several grave epidemies appeared in France. The first chroniclers who made mention of them, faithful to their traditional labit, confonnded them uuder the generic denomination of plague ( $p(s / e)$. In the tenth eentury these epidemies received a speeial name; they were called ignis sacer, arsura, claudes sen pestis igniaria. In the twelfth century the nomenclature was increased with the terms ignis sancti Antonii, saneti Martialis, Beatu Tirginis, ignis invisibilis, seu infermalis. All these expressions were used to designate one and the same affection, which was no other than ergotism.

The learned historian of the epidemies of feu sacré of the Niddle Ages, Professor Fuchs (Das heilige Fener im Mittelatter, Berhin, 1834), fixes the first invasion in the year 85\%. This explicit passagre of the ehroniele leares no doubt in this regard. Plaga magna resicurum turgentium grassatur in populo et detestabili eos putrealine consumsit, ita ut membra dissolutu ante mortem deciderunt. (Pertz, 11, 230.) The epidenie of 590 (Greg. Tur., X, 30) that some anthors refer to the feu sucré, does not appear to us to have presented the charaeters of this. Its course was extraordinarily rapid; it began with a slight hearlache, a forerunner of death (itu ut molico quisquis c'grotus rapitis dolore, pulsatus, animam funderet). These morbid charaeters ean no more be considered ergotism than the very vagne statement that near Limoges several were consumed by the feu releste with whieh some were burned in Tourraine (nomulli ab hoc igne sunt adusti). At the same time a very tatal epizootic ocenrred which dicl not spare the deer. A great drought had destroyed the herbage; it followed rains and inumdations, conlitions fivorable to the erolution of charbonous diseases. A fact supporting this riew, as well as the opinion of Fuchs, is that rye, which is an Asiatic plant, was only introluced into cnltivation dnring the Middle Ages (Link). Admitting, what is supposed, that Europe is inclebted for it to the invasion of the Huns, it is still very necessary to take into accomt the conclition of this part of the world before conchuling that at the end of the sixth century the new eereal had become generalized and had entered into the regnlar auricultural rotation of Ganl.

All the cpitlemies of fru suce correspond to years which were characterized by a rigrorous winter followed by a very raing summer, causing a deficieney in the hariests, ant bringing scarcity and fanine. The epilenics bagan alout the month of September or Ootoler and terminater in the spring, muless the atmospherie condition of the 
following year continued to be fatal to the products of the earth. Nomention is made of great epidemics of $f c u$ sacri during years which were charaeterized by probuctiveness, but local epidemies are met with whioh were circunseribud within the limits where the center of ergotism still exists in onr days, and which comprises la Sulognc, le Danphiné, le Lyonnaise, la Lorraine, and l'drtois.

If we take into aceomnt the conditions which conenr in the evolntion of feu sucre, it may he established, a priori, that the sanitary state of the domestic animals was not more favorahle than that of the hmman species, and that epizootics shomld have been more fresuent than they are mentioned by the ehroniclers. Are indications fomm in their amals which authorize ns to attribute these epizooties to the same soller, that is, to the fon sam?' This question camnot be solved; more than that, the accomints themselves torbid an hypothesis relative to the form and nature of simultaneous diseases. It is sufficient to cite this passage from the chroucle of St. Bavou, referring to the year 1127: Plaga divina Francium efligit, ignis scilicet corpora crucians. I'estilentia maxima furta est unimalium. What was this plague uf animals? Formulated in this manner it is impossible to conjecture. If in the presence of such profomulobseurities we are permitted to hazard an opjuion, we would say that in all probalibity the food of the animals did not consist of rye in these calanitous years when searcity aud famine were general, and when the eauso of fiu suche was muknown. Removed from the toxic factor, they rid not escape its powerful accessories, and the diseases which deeinated the herds must have been other than ergotism." Perliaps.the tirst epirlemic of feu sacré which ravaged Portugal in 1189 was an exeeption, ant it may be necessary to attribnte the concomitant epizootic to ergotism. It is thus described: Hujus etinm tempore morbi nunquam, ante, risi ingrubumt, forentissimis intra riscerl ardoribus, quibus homines quasi quadam rabie exngitabautur. Exortu eliam fumes, frugibus tum ri tempestatis, quam rerminibus corruptis, wt lues non minus nocens pecori quam hominibus et multorum relicte recur possessionibus (C. F. Heusinger, Fuehs).

The nurertinty relative to the form and nature of the epizootics is one of the most common facts in the records of the Midrle Age. 'Thus the beginning of the famous black plague in 1347 was preceded in several countries by epizootirs no less fital. In primis ha'c acerbu pestis in brutis animalibus incohavit; scubies ot lepra toluliter apprimebant "quos, bores, pecudes, et cupres ; itu ut pili de äorsi ipsorum depilubantur et cadebant et efficiebuntur macri et debiles, et post, puncos dics moriebantur. Deinde incipit hac rabiosu pestis per nniversnm mundum discurendo in miserabiles homines lathuliter sutire (Cutteis). This passage evidently refers to a gangrenous affection, which has nothing in common with fen sucre, for with the exfeption of the eprolenic of liritans, which occurred at the beginning of the hlack plague, no traces of ergotism are found until 1:37:, when it appeared anew in France (Tessier).

During the whole period of the Midulle Age hut rare epidemics of feu sacm are mentioned in tise north of Europe. Hensinger belirves that those of the fifteenth and sixteenth centuries, designated by the name of scorbutns, belonged to ergotism. This opinion appears to us to have fonndation; in faet the eelebrated botanist, bodonams, describer the epidemic of scorbutus, which oreurred in lielgimu in 155t, and wis characterized by gangrene of varions parts of the body. Ilo attributal it to the spoiled grain which was importol from Prussia, and says in another work (IIislurid frumentorum, Anto., 1569), that breas marle from spoiled ryo (seigle ulfire) causes tho disease called by the Germans scorbutus. 'The gangrenoms form of this aflection, which did not conform exactly to that observed in France and spalin, was replaced in the course of the sixteentle eentury by the eonvalsive form. When the "pidemies of ergotiom of the South and those of the North of Europe are couplired in very remarkable fact presents itself; in the sonth the gangrenoms form is the rule; a few of

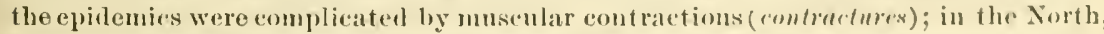

* The author appors to have overlooked the finct that such a disease might haro been produced by ergotized grasses.-I). E. S. 
on the contrary, dry gangrene was a rather rare afieetion. This phenomenon is applicable to animals with whieh ergotism has been observed during the contiunance of an epidemic as well as with those experimented npon. Fowls are the only exeeption, and with these gangrene of the comb is an almost constant result. Do the properties of ergot of rye differ in the north aud in the south? Chemical analyses unay, perhaps, inform us; in waiting for these we may admit that the phenomena are not dependent upon the dose. In 1340 , after threshing, ergot made up half the harvest of Fiuland. The epidemic showed itself as aente febrile, convnlsive ergotism. Death very often oecurred within forty-eight hours (Haartman).

Datiug from the seventeenth eentury observers were more attentive to the phenomena presented by animals during the epidemies of ergotism, but they notice the faet with a briefness which eaunot satisfy the seience of pathology, becanse the proper elements are not fiurnished for retracing the medieal history. Brumer, the reeorder of the epidemic of 1694, in le Harz, limits himself to this phrase: Novi pecora, armenta, sues, equos, anseres quoque non fuisse a contrgione immuniu. In spite of the contagion whieh he admits, Brunuer leaves nothing equivocal in regard to the eanse, for he says: $D$ egeneravit quoque secale et loco granorum alimentariorum protrusit cornicula nigra. The quoque relates to oats whieh had equally undergone degeneratiou, the characters of which are not indicated; its meal prodneed vertigo in the persons who eonsumed it. It would have been interesting to indieate the efteet produced in horses, but the author maintains an alsolute silence in regard to this. Thongh distingnished botanists affirm that the oat is subject to ergot, we must athit that our researehes to discover a fact where the injurions properties of ergoted oats have been noticed with auinais have remained withont sueeess.

In the description of the epidemie in Silesia in 172.2, we read that the King of Prussia crlered an exchange for somd rye of that affeeted with ergot, which, as nsual, cansed sickness of the horses and logs (Hecker). Convulsive ergotism reappeared in Silesia and Bohemia in 1736. Antoine Soring, the historian, makes the remark that it is known and demonstrated by experiment that ergoted rye produces disease with fowls and mammals, and that when animals suffer during the epidemies of ergotism it is conclnsive of the quantity and violent aetion of the ergot in the rye.

From 1765 to 1769 ergot was very abundant in Sweden in the rye and barley. The epidemics which followed were attributed by Linneus to the grain of the Raphanus raphanistrum, from whieh is derived the n:ime Raphania, which in Scandanavia is still given to eonvulsive ergotism. Wahlin, after having experimentally demonstrated the

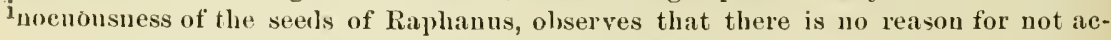
cusing ergot when, in the eourse of an epidemie, domestie animals sueh as fowls and hogs present similar symptoms to what are seen in man. This passage tends to prove not only that the domestie animals entract conrulsive ergotism, but also that the - ergot of barley is as dangerous as that of rye. This is, besides, eonfirmed by Retzins when he asserts that beer brewed with ergoter barley becomes a eause of convulsive ergotism for those who consume it. In Hesse, it has been often observad, notably in 1770, that the heals of balley eontained as many, if wot more, long, black grains as the rge. In onr times $(1856)$ this same remark has been male by T. O. Hensinger.

'Trabe, who left a much esteemed deseription of the epidemic of $17 \% 0$, whieh was very extensive in Hanover, says that so far as he was ahle to observe the fatets for himself, he saw in the cirele which he traversed a single pig attacked with convulsive ergotism. Iorses eating the ergoted breal were not incommoled ; bovine animals consumed the flomr with repugnanee, but also without ineonvenience. Dogs ant sheep were not atheeter, with the exception of the little village of Lohe, where I sheep suceumber aftur presenting the phenomena of the convulsive lisease. These animals had pastured on the rye fields after the harvest, whieh was nade in a very dry time, when an ahundanee was lost hy shelling. Tranbe did not discover a single case of aloortion which Soring and others thonght they observed with hogs. One fact impressed him: traveling through the villages which still contained the suffer- 
ers, the following spring, he heard general eomplaints in regard to the small number of the young fowls. But few egrgs were produced, and the hens dis not sit. Nothing of the kinl oecnred in the villages which had heen exempt from ergotism. Two fowls were sent him which presented the spasmodie symptoms; these hirls, placed upon their feet, fell to one side, allowed the head to hang, and agitated the limbs. When they arose of themselves the phalanges were eontracted spasmodically; they lived four weeks; no antopsy was made (Geschichte de' Friebelkrankheit, 1782, pl]. 13 and 15$)$.

It is seen that in these epidemies the eonvulsive form prerlominates; while in France the gangrenoms form is almost exelusive. The last extensive epiclenie from whieh this eomntry suffered oceurred in 1750 , aud the ravages at this time recalled those of the Mirllle Age. It commenced in Sologne, its traditional center, and extented throngh Landes, Flanders, and Artois. The ergot formed a third of the threshed rye; animals which were fed upon it contraeted the same gangrenons accidents as man (Salerne).

Towarl the last third of the eighteenth eentnry the epidemics of ergotism were no longer so frequent; the perfection of aurieulture may elaim a part in this happy result, but the greater part is ineontestably clue to the generalization of the eulture of the potato in the North and of maize in the Sonth. In spite of these alimentary guarautees ergotism was nct extingnished. In the present eentury it was mentioned by Ccurbant and Boldot, in 1855; Barrier ubserved the gangrenons form in the departments of Isère, Loire, Hante-Loire, Ardèche, anıl Rhone. Ergotism has reappeared in Rnssia, Fiuland, Sireden, and some cantons of Germans. In the epidemic deseribed by Wagner (18:31) the hogs which ate orgoted rye presented the same symp. toms of the disease as the hmman species, and Helm saw in Pomerania 12 hogs which, a few honrs after having consumed a ration of rye mixed with orgot, were tiken with vertigo and convulsions. They moaned and uttered anxions eries; the posterior parts were paralyzed, and the animals manifested their sufferings by singular eontortions The last epidemie oceurred in 1855; it appeared in Hesse, and eonenrred with that mentioned in France by Barrier.

A peculiarity worthy of remark was connected with the Hessian epillemie; the yonnger Hensinger, who recorded it, says that his father, professor at the University of Narbourg, who was charged by the Government to examine the harvests of the vear, aceomplished his mission before the threshing. In the sheares of the cereal he found a large quantity of Bromus secalinus [common ehess or cheat] rich in ergnt, thongh the heals of the rye were exempt from it ; and as this ergot presents all the physieal characters belonging to that of rye, it bezomes certain that this cereal is not always to be blamed as mueh as has been generally believed. Rye harvested on lands bally cultivated was infested with B:omus; when properly cultivated but little was prodneed. This fact demonstrates the great intluence of agrienltural progress on the extension of ergotisu and its cause. In eonntries where agrienlture is in an alvancer condition, as in Belginm, ergotism, either in the gangrenons or eonvolsivo form, is nnknown. The observation of Hensinger is not the only one; in two eommunes of the principality of Waldeek the ergot of "hess also cansed an epiclemie (Rorig).

This fact is not withont interest for the veterinarian, sinee straw makes up part of the fool of the domesticated herbivora, and the plants mixed in thesheaves, with the vature of their prodnetions, merits more attention than is generally bestowed upon it. During the eontinuance of the epidemic in Hesse, "T. O. Hensinger eollecterl information in regard to the diseases which atlected domestic animals. He liarned that in the commune of Roda, where the most peoples sulfererl, and where eonvulsive ergotism was most violent, the sheep presenterl symptoms which eonlal he raferreul to poisoning by ergot with the more reason as these animals were ferd with rye straw and reeeived the sereenings of the grain. The inhabitants complained of the great mortality anong the shepp; the shepherds reported that several haw , fumper the inclosures of the pastnres, that they were then taken with eourulsions aud turning in 
a circle liad dropped dead as if thuuderstricken. Abortions were frequent, as also early parturitious; the greater part of the lambs died.

Doctor Ramdall reports that in the State of New York a disease appears each winter among the cattle, which begins by a slight swelling of the lower parts of the posterior limbs, with stiftness of the joints. This affection, which has the appearance of being very mild, invariably teminates by dry gangrene of the parts first involved, which freaze after the mortification. In the severe clinate of New York the animals winter in the fields, and the farmers attribute the disease to freezing. Randall observes that if this were the real cause a circular line of demarkation would not divide the deal and living parts as regularly as happeus in this disease, and, finally, that the external appendages, less protected against the cold than the limbs when lying: shonld freeze sooner. He adds, and it is the opinion of sereral other plysicians, that the aftection is no other than gangrenons ergotism. Indeed the Poa pratensis is rich in ergot, and as it does not produce each year an equal quantity, Randill thinks that the cases more or less frequent correspond to the abundance of ergot. (Veterinarian, 1843.)

If, in presence of the facts enumerated, we camnot fail to recognize the existence of gangrenous and convulsive ergotism with animals, we must also adnit that these facts are neither so precise nor have the rigorous correlation of cause and effect which is desirable in pathology ; they do not even give the elements for a symptomatic table. Randall furnishes in this connection some important information; it agrees with that contained in the interesting observation of Decoste. (Rec., 1848.) These materials joined to the phenonena studied with animals in experiments permit us to trace the srmptoms of gangrenous and couvulsive ergotism.

Mr. Fleming, in his work entitled Animal Plagues, has compiled a considerable number of referenees to epidemies and epizooties of ergotism, which, while they contain a large part of the early records relating to this interesting subject, also illustrate the difficulty in deciding at the present time in regard to the real nature of some of the diseases to which allusions are made.

In A. D. 992 there was a long and severe winter and an extremely dry summer, followed by fimine. The wheat crops were affected with bliglt or ergot, and the forage was generally of a bad quality. Soon after there was a widespread and deadly epidemie of ergotism ( feu sacré) in France.

Ergotism was again prevalent in France in 994. (An. Pl., I, p. 58.)

In 1041 there was most umpropitious weather, accompanied by (arth. quakes, tempests, and inundations. It snowed heavily during harrest time. In many parts of Europe there were heary rains thronghout the year. Flanders was inundated by the sea, and there were great storms. The conseqnences of t!rese disturbanees were fimine and disease in England, Germany, and France. Cattle and men appear to have suffered eqnally. "The plagne of Divine Fire (ignis divina, ergotism, or erysipelas) aftlieted many, who were saved only through the merits of the Blessed Virgin. And in all that year it was rery sad in many and various things, both in tempests and in eartl's finits. Aud so much cattle perished in this year as no man before remembered, both through varions diseases and throngh bad weather." (An. Pl., I, pl. 60, 61.)

For 10S5 Mr. Fleming makes the following reeord: Epidemie erysipelas (ergotism?) in France, with inmmations and famine. "In the year" 
1055 there was disease in plants, and also in animals, throughont the world." (An. Pl., I, p. 63.)

In 1089-91, on the Continent, "in these years many men were killed by the ignis sacer (ergotism or gangrenous erysipelas), which destroyed their ritals, putrified their flesh, and blackened their limbs like to cliarcoal. Even if their lives were preserved their extremities were so affected that they were only reserved for a most pitiable existence." This epidemy is mentioned by several ancient chroniclers. Animals suffered as well as the human species. (An. Pl., I, p. 64.)

In 1099 gangrenous erysipelas (ergotism?) in France in the human speeies. From the sererity of the epidems, we may infer that animals also suffered. There were great inmudations in England by the sea and by the rivers, whereby people, cattle, and whole towns were drowned. (Au. Pl., I, p. 65.)

In 1127 the "divine plague" (ergotism?) appeared in mankind in France. Prayers to the Virgin Mary healed the afflieted, it is recorded. Great pestilence among animals.

In 1213 gangrenous erysipelas (feu sucré) in mankind in France and Spain.

Neither was the searcity limited to the finits of the earth, nor disease to the luman species, for birls, cattle, and sheep herame sterile, aud bronght forth no poungr, aud many rithing aud other horsts perished for lack of straw and barley. (Au. I'l., 1, p. :1.)

In 1598, after inmudations and heary fogs, there was a general epizoöty among eattle in Germany. In the same year there appeared ergotism in the human species. (An. Pl., I, p. 138.)

In 1694 an eruption of Mount Vesurius. A supposed epilemy and epizoïty of ergotism. Brumner writes:

By what unfortunate combination of circumstances, for so many years, the whole of nature seemed to labor under an unliealthy atmosphere remains a secret. Miny men, and those most learned, have writen on the state of the air, and I lave bern a spectator of most grievous calamities; for not only diul unwonted fevers attack aud kill the human race, and would submit to no remedies, but also the beasts were hatrassed hy deally discases. I know that sheep, eattle, pigs, horses, and geese were not free from the contagion. There was also a lack of corm, uot only on accomnt of the inorilinate consumption of it by the soldiers, but also from the character of the gromnel. Some of the corn was so plainly diseased that it was dangerons for man to eat of it. I know also that pease, which formed a great part of the fool of the army, were infested aml diseased by a small inseet, which made a minnte hole in them. I never remember sering such an abundant erop of darued (tares) mixed with tho oats, and which prevented the making of gromel oat moal, our chiof foou, for it was ueedless to aftempt tolabor on it, it was so bat. All grain disappeared, and in its place suall, black, horm-shapen masses hecame apparent, whieh were highly injurions to mankind. These were named "St. Martin's coln." A woman was shown to me hy a surgem $x$ lo suffered from convulsions every eleventh day, solely from rating this corrupt grain, and the same surgeou told me he hate amputated a leg mortified firom the same carse. (An. 1'l., I, lil. 166-167.)

In 1721 the winter was mild, but the spring time cold and damp, and the remainder of the year wet. Locnsts in France and the whole of 
Italy. Epidemic ergotism in Silesia during this and the next year, and searlatiua in man at St. Petersburg, Courlaud, and Lithnania. So notorious was it that diseased grain produced formirlable diseases in the lower animals, that while the epidemic eontinned in Silesia the King of Prussia issued an ediet forbidding the use of rye tainted by the ergot, because it seriously affected horses and pigs. (An. Pl., I, p. 234.)

Another strange phenomenon was the generally laborious parturitions of the domestic animals at this period:

The sheep in many places lambed with great diffieulty, so that the shepherds were obliged to nse foree to deliver them. Among the eattle one hears of nothing partieular berond the fact that the breeding cows and ewes brought forth their young with great diffienlty so that foree was obliged to be nserl to assist them. At Strelitz three fue young eows died from this laborious parturition. They trained so violently that all their interual organs were protruded. (An. Pl. I, p. 235.)

In this connection Mr. Fleming gives the following quotation from Hecker:

The uncertainty pertaining to the nature of epizootics of the Middle Ages, leaves us in doubt as to whether some of them might not belong to that elass which have a common origin with many of the epidemics of mankind. The ignis sacer, arsura, clandes sen pestis igniaria, ignis sancti Antomii, sancti Martialis, Beate Virginis, ignis incisibilis, sen infernalis, \&.e., wonld all seem to be employed to denote the same affeetion, and which we have reason to believe was ergotism. It is only by ehance, as it were, that wirle-spread and fatal diseases among the lower animals are mentioned as oeenring coinieidently with these obsenrely named epidemies, and when we real that the eauses of their ontbreak were unfiuvorable weather, which bronght about a diseased condition of the crops aud pastures we are only partially eulightened as to the nature of the affection.

The seorbntus of the fifteenth and sixteenth centuries has bcen supposed, with much reason, I think, to have been ergotism, and up to this period it appears to have developed in a gangrenous form. At this time, however, it ehanged to the convulsive type, which it has chiefly maintained to the present. A eurions feature in this disease is shown as it appears in the Sonth and North of Europe. In the Sonth, the grangrenons form is the rule; in the North the convulsive form is particularly marked, and very rarely the dry gangrene; while a few of the epilemies present both eharacters. The same pecnliarity is observable in the phenomena of ergotism in the lower animals during the existence of an epidemy, and it has also been shown to exist by experimentation; the only exception wonld appear to be in the ease of gallinaceous birds, in which gangrene of the crest or eomb is the most eonstant phenomenon. It is not until the seventeenth or eighteenth eenturies that we ean with eertainty find anthors describing ergotism in the epizootic form in animals and from that time till now observers have been numerons. (Page :34.)

Convnlsive ergotism appeared in mankind in Silesia and Bohenia (1736), and Antoine Soring, the historian of the epidens, notices that it had been remarked, and the subject had been demonstrated by experiment, that spured rye produces disease in fowls and mammiferons animals, and that when we know positively that animals are affected in this way during epidemies of ergotism, we maty conclude that the rye is very rich in ergot, and its action very violent. (An. P. I, p. 26(i.) 
In 1754 a very extensive epidemy of ergotism presailed in France, nearly approaching in its ravages those of the Middle Ages. It began at Sologne, its traditional birthplaee, and spread throngh the Llandes, Flanders, and Artois. The ergot was so abundant that it formed onethird of the rye. The auimals fed on it contracted the same gangrenous diseases as afflicted the human species. (An. Pl. I, 1. 354.)

The next ontbreak refersed to is described as follows :

An cpidemy of ergotism was also reported as occurring in many uortlern countries, cansed by the wheat, rye, and eorn having been diseased. It lasted during this and the next year, and animals seem to have suffered. Wagner described it as it appeared in the marshy districts of Saxony, the circle of Schlieben, and ou the binks of the Elster: "A light frost destrosed the blossom on the vine and the rye in 18:31. Each partially withered blossou of the rye erop, insteal of a bealthy seed, luronght forth a spur of ergot abont three-fourths of an ineh long. . * * * In some houses, where the disease raged most violently, grain was fouml eonsisting of two parts of diseased and one of bitter rye, retch and a variety of other sects. * * * Pigs ate ergotized rye (Mutterkom), and snffered from its effeets. Dogs, however, instinctively, aroisled it; but when compelled by hunger to eat it, they exhibited symptoms of madness (Tollueth). I believe that such fool was partaken of here and there by dogs, and that it assisted in produeing maduess, as dogs and cats were so affected that no man ever remembers seeing so miny mal as chring the existence of the ergotism ( Kriebellrankheit) amour the penple. This unhealthy grain may have harl something to do with the sickness among the lower animals which prevailed at this time, and whieh was ascribed to the choleraic inthence, thongh its share must have been small." (An. Pl. II, p. 17.)

\section{Raphrania in pig's was witnessed by Dr. Helm :}

Twelve pigs of varions ages were fed with rye which contained much ergot. A few homrs afterwarls convulsions set in, with foaming at the month; the animals grunted and groaned most piteonsly; became paralyzed in the hinder extremities, and expressed their agony in the strangest contortions. At first I presumed the dis. ease arose from the bite of a marl dog, but on opening the first animal that died I discovered the nature of the malaty hy finding in the stomaeh unch ergoted rye. The jaws were so tightly elosed that with great difficults a purge of white helleboro was introduced, and that was followed by a dose of vinegar and buttermilk and repeated clonches of very cold water. By these means seren of tbe aninals were sared. The other five died in the course of a few days. (An. Pl. II, p. 197.)

In our own country we have no eompilation of the references to aninal diseases which may have been male from time to time, and hence it is impossible for me to give a history of ergotism in this country. My attention, however, has been called to the following article in the Finners" Cabinet, Vol. III (1S33-39), 1). 161, which shows not only that the disease has occurred heretofore, but that its cause was recognized:

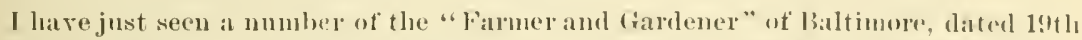
June last, which contains an article on the "Ifouf-ail" ot caltle, and copred fiom the femese former, upon which I will malke a few reusurks.

The writur of the alticle, John b. lbwers, dates from Ledyard, and ascribes tles loss of the hoofs in three cows to their having heen ferl for eight or nine blays on

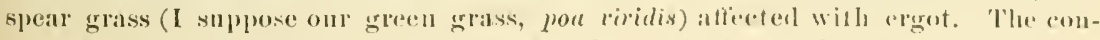
jecture is well founded, as you maly be assiured by leforring to the liftl volume of the 
Memoirs of the "Philadnphia Society for Promoting Agriculture," p. 196, where you will sec a paper of mine on the subject, which I think will leave no room to doubt as to the eanse of the disease. It is a enrious fact that the ergot of rye, if ground into meal with somd rye, when made into breal and eaten prodnces mortification of the Jower extremities in France. (See Memoirs of the same socirt 5 , volume 3, appendix, 1. 5.)

JAMES MEASE.

Chestnut Street, October 6, 1838.

1)r. James Mease, the writer of the above, gives the following arlditional information on the same subject:

In the year 1803, the late Joseph Cooper, of New Jerses, informed me that he had observed the hay made of the natural green grass, or spear-grass (poa rividis), growing on his fine meadows, on. Petty's Island, made ly banking ont the Delaware, to be occasionally affected with a black spear, abont one-fourth or half an inch in length, somewhat resembling the ergot in rye, and that cattle eating snch hay beeame affected with a disease in their hoofs, cansing them sometimes to drop off. He ascribed the morbid production in the grass to neglect in snpplying it with water from the river, by means of sluiees, iluring the dry season. Ulon my mentioning the faets soon afier to the late William Rush, of Philadelphia, an extensive grazier, he confirmed them from his own observations at Blooming Grove, near Gray's Conrt, in the State of New Tork, in the winter succeeding the very dry summer of the year 1793. The hay was the prodnce of a bog mealow; it is presumed, therefore, that it was made from the same natural grass that grew in the meadows of Joseph Cooper.

Some years after, Mr. W. T. Woodman, of Tredyftrin Township, Chester Connty, Pennsylyania, communicated to me an account, in the following letter, of a similar disease, and from a like cause, among his father's catıle:

"Having observed the remark in the Port Folio for May, I815, in the review of the third volume of the Memoirs of the Philadelphia Agrienltural Sueiety, that, "as yet, in America we have never hearl of auy human person falling a victim to the ergot, nor indeed is it satisfactorily ascertained that it has ever been injurious to onr animals, I think proper to conmunicate to you an account of a disease whieh in 1802 or 1203 prevailed in this neighborhood among milk cows particnlarly, but which also affecterl other eattle aul horses. You will pereeive that it was analogous to the one supposed to be occasioned hy ergot.

"For my part I am entirely ignorant of the canse, but still I am nnwilling to ascribe it to ergot (with which rye in this neig!horbool is more or less affected overy year), for this reason, that milk cows, which are never fed with rye by onr farmers or butter-makers, exhibited more violent symptoms than oxen or horses.

"The farmers attributed the disease to a peculiar mildew, which sometimes affects the grass on the bottom meadows of a small stream, the basin of which is very extensive, and rery luxiriant, and entirely appropriated to moadow land, and suffered to lye moler nat ural grass. No timothy or other grass seeds have ever been sown on it, to my knowledge.

"The cattle affected diul not appear to lose their appetite, and while they ate heartily of hay and other food becane daly more and more lean, manifesting great nueasiness, oceasionel most probably by violent itehing. Their hair in many places fell off, or was rublued off by the animal in striving to serateh itself. After these symptoms had continued for some tme, one or loth hind feet became sore aud the hoofs loose, at which period the animals began to grow better. Others lost their hoofs and part of their legs. 'Three of my fither's eows lost both of their hind feet, and some others in the neighborhood were equally as had. The legs began by drying and growing smaller from the hoof to half way between the fetlock and the hock, at which 
point it appeared as if a string of twine were tied very tight round the leg. Alove this part the flesh was to all appearance in perfect health; the lower part was hard, black, and offensire. When the lower part beeame quite dry, and little else than hone, it separated and fell off, after which the animals lived and ate heartily; hobbling along on the remaining stumps. They even luegan to grow fitt. Their health seemed perfect. They would, no dombt, have lived long in this state, and were killed only from motires of eompassion.

"One cow belonging to my father, whieh had lost onlș one of her hiud feet, and that at the first joint above the foot, bore a very strong, vigorons ealf, which lived and did well. The cow also afforded as much milk after as hefore her misfortume, and was pastured on the same grass to which her disease was attributed when in a state of hay.

"I think the disease was never kuown but one seasou. The firot symptom of it was observable in February, aud it reached its crisis about the middle of May, Shoula this communieation leat to ans further observations on the nature and canse of the disease I shall he much pleased, aud they may be of great service to the anriculturist. Should the disease erer again make its appearance I shall be nore particular in my observations.

"I remain, very respectfully,

"WM. T. WOODMAN.

"P. S.-It should be olsserved, that though we have evers rear more or less of the ergot, the cluntity of it is never considerable. I think there is seldom more than one pint to a hundred bushels of rye.

"Different remedies were tried, but none of them afforded any relief."

"Being desirious to acertain whether the disease of the grass to which Mr. W. referred had grown in meadows that had been deprived of their usnal suplyly of water, I aldressed a letter to him in referenee to this point, and received the following answer, muler date of June 10, 1815:

"Your favor of the 30 th ultimo came to hand the 4 th instant. Since the reeeipt of it I lare made numerous inquiries, for the purpose of obtaining additional information resjecting the disease (of which I communieated an aceomnt), and on the season precediug its prevaleuce, fe ; but I regret to inform you that farmers in general are so deficient in observation, and so entirely out of practice of recording facts, that $I$ have nnt been able satisfactorily to ascertain whether the season in whieh the "injurious hay was made" was a dry one or not.

"However, my father informs me that, as nearly as he ean reeolleet, about that period the ditch which eouveyed water to his meadow beeame so filled with mud and aecmmulations of mud and other matter as to reuder the supuly very imperfeet. As a lefieieucy of water appears to be the canse of the unwholesone pualities of the hay, it is highly prohable that the injurious has was ulade during the season that water was wanting. But shortly after this time the death of my grandfather in a great measure excluded my father from the benefit of the water. The original plantation beiug divided into two farms, and that of my father lying farther down the strean, the water of the artiticial conrse is exhansted before it reaches his laml. It shonld, howerer, be remated that sinee that period he mows his grass while it is very young, and before the seeds are tonched by the "snntty affeetion." Indeed, the farmers generally iu this neighborhood, sinee their eattle were affected with the disease, are earefnl to mow much earlier than they dis formerly:

"I an strongly indnced to believe that Mr. Conper ascribes the disease to the proper" eause, for I have been correctly informed that a loal of the injurious has was sold to - Rogers, who at that time kept the Buck Tavern, in seomel stret, whose cow, in consequence of feeding on it, was affecter with a disease of a similar nature.

lom friend, ac.,

5751 
The disease prevailed to a great extent in Orange County, New York in the rear 1820, and is very well and minutely described by Dr. Aruell, corresponding secretary of the agricultural socjety of that county. The facts detailed by him leave no doulst of the deaths of numerous cattle in his vicinits being caused by their eating hay made from some grass that was affected with the species of elgot obserred in the produce of the mearlows before mentioned. for he expressly mentions that the spear grass grew in the meadows in the towns of Wallkill and Blooming. Grove, where the disease prevailed, and in a bog meadow soil. Dr. A. remarks that, "the hay was cut in June or beginning of "July, immediately before harrest; that only cattle in good condition sufferen from eating the diseased hay, the poor and meager escaping." "The means of prevention pointed out by Dr. Arnell are similar to that judieally recommended by Mr. Woodman, viz., to cut the grass early, before the ergot forms; or, if it be found in the grass, to defer cutting it until late, when experience prores that it mas be safely userl; for Dr. A. remarks that "the ergot then becomes dry and shriveled, with. out any of the flom or vegeto-animal matter which it usually contains." But the hay made from such late-marle grass must be of little ralue, because Dr. A. says truly that "this spear grass is so early that if left to stand till the usual time of mowing meadows it loses all its succulent and nutritions properties." This agrees with our experience with respect to the spear grass of P'ennsylvania, where it ripens nest in order to the early Anthoxanthum odorutum, or sweet-scented mearlow grass. Still, however, it may be useful by answering one purpose of foor in all animals: to stimulate by distention, and to add to the stock of barn-yard manure. The various remedies tried to eure the disease in New York are enumerated by Dr. Arnell. Those that succeeded wele:

1. Poultices of soap, rye-meal, and salt, to the legs and feet.

$\because$ A wash of beef-brine, composed of saltpetre, aud common salt, applied several times a day, and after washing and rubbing the feet with the bitter-sweet ointment. Of the animals thus treater, one only lost its hoof.

In the treatment of the disease, the first object to be attended to is to remove the canse producing it. This is to be effected by drenches of castor-oil, or sweet-oil aml molasses and water warmed, to which may be alled, if found necessary, after the failure to operate of the first dose, half a pound of glauber salts, dissolved in warm water. During the operation of the drench corn meal, rye, or oatmeal, mixed with a large pro. poition of warm water, and a handful of common salt to every bucket of it, slonld be freely giren. The nse of hay free from ergot is as ob. riously indispensable. A handful of salt should be given every day to promote digrstion and give tone to the system. The local applications must be of a stimmlating natme to rouse the activity of the circulation and of the absorbents, and to enable the part laboring under a defi- 
ciency of vital energy to resume its healthy functions, or to throw oft the disease. Fish, or heef-hrine will answer as well as anj, but they should be well rubberl on the feet and legs. for friction greatly tenrls to assist in restoring the health of the parts. To prerent the appearance of ergot in the grass, care should be taken, when practicable, to supply the mealows with water in lry seasons.

In the Genesee Farmer, 15.57, 1. j0. was published the following letter, clearly referring to this disease :

Perhaps you are aware there is a complaint among cattie nccavionally, in this part of the workd, aud it mas be in many others. I have heart of it in Canala. I do uot know the correct name. It is not the hoof-ail, althongh it attacks the himet feet of cattle, and, if not arrested, the limb will rot off, np to the second joint of the lear, aud the animal must he killed, or it will die; after it has proceeder so far as to be incuraliele, the ouls way is to knock it in the heid.

I write this to inform sour numerous realers of a cure te have here, althongh perhaps the remedy is generally known. It is to cut oft the toes of the hind foot (in which ouly it appears), about an ịch horizontal, so as to open the foot -nticiently there for the blood to come nnt; then prit the foot in a stocking with plenty of tar at the toe. If taken in time this will effect a cure. It must be done early, however, when the animal first shows srmptoms of the complaint, by a freqnent and slight kicking ont of the hind foot, as if pricked with somethiug.

I have heard the canse attributerl to poisonous hay, such as sunt. Do ron or ans of rour correspoudents know augthing about it? If so, let us have, pour. or their, exjerience.

Morristowx, saint Lacrence County, I. F.

CHILTON FORD.

Again, in the same periodical, $1857, \mathrm{p} .245$, Tr tim the following repolt of this trouble in Portage Connty, Ohio:

In consernence of the appearance of a serere and fatal thisease among cattle in some parts of Fortage Comnty (Ohio) the past wiuter, the Farmer's Asopciation of Edluburn appointed the undersigned a committee to investigate the subject, and ancertain if possible the nature, cause, and cure of this malads. The report of this committee we herewith forwarl for publication in the Geneses Finmer, togatlur with a rewlution adopted by the association at the elose of an instructive discussion upon the arloption of the repurt.

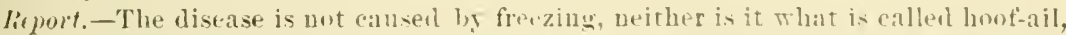
foot-rot, or forls. Its stmptoms seem to be a dealness of the pull of the tail, axteuding upwarl till in some cases the tlesh separates from the hone and falls oft. About the same time there is a pmple appearance just at the elge of the hair, almes the loof. It then commences swelling, becomes foterinh, pxtemling mparl to the ankle, and in some instances cansing a separation of the cottin-hous from the pastern joint. The lanseness is contined entirely to the hind feet. The blond is pale and thin, and in mot cases the animal retains a good appetite till wear the last. The cande llo alpprehend to be foeding on hag onntaining ergot (a prasitic fumgus growing within

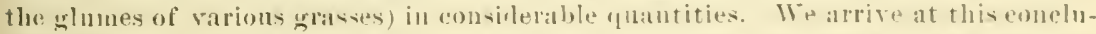
sion from the fact that the hay ferl hey one indivirlual who hat lont al laran mumber of

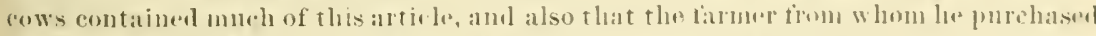

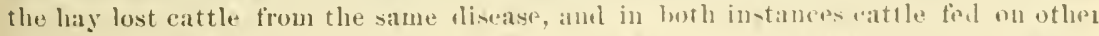
hay were not affected. In every well marked ease of this distane it has been atcer. taned that the hay on which the animals were fiol contained the argot. The hay in which the ergot was foumt the most, was the kind eal'ed the June, or sprearerriss, growing in old meadows where the soil is riclu and the growth rank. 
The serere frost on the 31st of Mar 1856, is supposed by some to hare been the canse of this disease in the grass by destroying the vitality of the seed before it arrived at perfection; while bs others it is attributed to the extreme warm growing weather in June cansing an overtlow of sap.

Although we consider the whole sulject in rolved in much obscurity and uncertaints, aud requiring further investigation, set we are satistied the best manner of treating the disease is imuediate resort to restoratives and a change of diet, whereby an increise of aumul heat and ritality is obtained, aud at the same time making an application of suitable remedies to the affected parts, by cutting off the toes until they bleed, and blue vittiol moderatels applied to the foot has in several instances been fonud beneficial. A free use of charcoal and salt in varions wars is molonbtedly a good preventive: and a careful examiuation of the has or grass on which stock is fed is iudispensable; if ergot is found in has it may be removed by threshing or tramping.

Of the specific nature and properties of the ergot in has, or whether they are identical with that of rye, we are not well informed. The immediate effects of the latter in large doses is well known, lunt it has no aftinity to the ordinary known effects of vegetable poisons. What effect would be produced by its gradual and continnil use we are not in possession of snfficient information to warrant us in speaking positively; but we do suppose, after a carefnl examination, that it operates on the blood of the animal, and nnless immediate remedies are applied it proves fatal.

P. BARRON, M. D.,

R. M. HART, Esq.,

J. Y. PEARSON, JONAS BOND,

Committee.

\section{The following resolution was unanimousls adopted:}

Resolved (inasmuch as the evilence atduced is conclusive), that ergot in has is the cause of this disease. The association caunot decide that it is the real canse of a poison being iutrodnced into the system, owing to our inability to analrze this substance; therefore we desire to ask the editors of our agricultural papers for more information, and to obtain a chemical analysis of ergot.

In the Chicato Tribune, March 14, 1884, appeared a letter signed J. Hosmer, containing the following paragraph, which, while it refers the disease to a different cause, evidently describes the same aftection :

In 173-74, in Chariton County. Missouri, the winter was vers serere, the mercury groing to more than $20^{\circ}$ below zero. The people on the open prairie, mostly Germans who had recently moved there, seeing that the native Missourians prorided no shelter for their stock provided none themselves. In the spring from one to three in a flock of eight to ten had the "black leg." It commenced to separate just where the skin joins the hoof. The animal being in great pain, lappred the infected part, and the poison was thus transferred to the month. It was nothing more or less than gangrene, as the leg rotted and became putrid.

In the month of February, 1Sst, a letter written to the editor of the Breeder's Gazette by Cushman Brothers, of North East, Pa., in regard to a strange disease of dairy cattle there was referred to me. This letter, written February 19, aud a second one from the same gentlemen, dated March $s$, in reply to some inquiries of mine, contained the followlowing information:

The dairy in question contained 18 cows, and the disease appeared abont Jannary 1, 18st. The first indication was " cocked "ankles behind, 
the leg's beginning to swell in a fer hours, and in two days were "as large as the skin could hold." This swelling only extencled as high as the hoek joint. In about a week the hoofs began to eome off'; the parts beneath were red, but there was no formation of pus. The feet were apparently healthy between the claws, the appetite good, the eses bright, and the end regularly masticated. The animals had been kept in a warm stable all winter. At the latter date mentioned four harl been killed, their appetite having finally failed, two more were very lad. "a scab having formed from top of hoof to several inches above ankle and leg rotting off;" the foot of one animal had come oft at first joint ahore the honf, the fore feet of none had been affected but with two the forelegs were then swelling abore the knees. One that had been affeeted without losing hoofs and had apparently recovered, was taken down a second time. Many people said their feet were frozen, but the owner says they have now ehanged their minds. He had looked carefully iu their mouths for sores but had found none.

This was undonbtedly ergotism, and was so diagnosed by Dr. Germer, the health ofticer of Erie, Pa., after the Kansas disease had been attributed to this eause.

In recent years several epizooties of ergotism hare also been obserred in New York br Professor Law, in Iowa bs Professor Stalker, and in Colorado by Professor Farille; and it seems probable that when our reterinarians learu to recognize this disease and to refer it to its proper origin, we shall find that it is not an uneommon affection of cattle.

\section{TREATIENT AND PREVENTION OF ERGOTISI}

When the first signs of this disorder appear the most important point to be attended to is to make a complete change of food, and to see that this is of good quality, mutritions, and free from ergot. It would also be proper to give a dose of physic (from one to two pounds of Epsom salts), in order to remore as mueh as possible of the poison still contained in the digestire organs, and to follow this with soft food, as mashes and roots. In the most serere cases. those in which a part of the limb is alrearly lifeless, treatment will arail but little. The greater number of cases, however, have not adranced to this stage when lameness is first uoticen, and these will be greatly benefited by remoring the canse. and placing the animal under conditions favorable for resisting the poison. A rery important condition is warmth. Even when animals are fed large quantities of ergot they seldom sufler exeept in cold weather: and consequently in attempting to check the adrance of the disease, adrantage shonld be taken of this fact hy placing the eattle in wirm sherls.

Another condition believed by some to have much influence on the derelopment of ergotism is the water supply. With plenty of water always at hand it is believed that larger quantities of ergot may be taken for a longer time than when the water supply is rleficient. In the coh winters which ocenr over much of our eattle-raising country, it is dithicult 
to incluce the animals to take a sufficient amount of water. Holes cut throngh the ice soon fireze orer, and the weather is frequently so serere that the cattle will arink only a few swallows of water before they will leavetoseck a shelter from the cuttins wincis, and when, latel in the day, thes try to obtain more watel, the drinking holes are frozen ovar. Where ergotism prevails the Tatering should receive close attention.

Ergotism can probably le entirely prevented by cutting the hay hefore the seeds liave formed. Both in Missomi and Illinois I saw the clearest examples of this. Hay comprosed of the same kinrls of grass, cut mon the same land, was free from ergot or lalgely infested with it, according as it had been eut green or rupe. This matter is worthy of careful consideration. Hay eut green is more digestible and in erery way more valuable than that which is allowed to become ripe aud wools; and the latter is much more liable to prodnce severe disease, such as indigestion, impaction, and ergotism.

This fatal disorder may, therefore, he merented in the future ly proper and careful management: the chief points in this being to ent the hay before the seeds have formed, to see that the animals have a sutificient quantity of drinking water, to lieel them in good condition by the liberal use of mutritions foorl, and to protect them as much as possible from the inclement weather. When it is fom necessary to feed has which contains a considerable quantity of ergot it is of comse noubly important to look after the water supply and the sheltur.

\section{GEOGRAPHICAL DISTRIBUTIUN OF SOUTHERN CATTLE FEVER.}

An approximately correct outline of the distriet permanently infected with sonthern fever is a matter of supueme importance, not only to the people who live within and near this district, but to those interested in live-stock in every lat of the country. The losses which occur every summer, and which in some years have been really disastrous to the stock owners of certain sections, have been largely the result of ignorance of the distriets from which it is dangerons to bring cattle in smmmer, aud to which alnlt cattle cammot be taken with safety at any season of the rear, unless they are to be slanghtered for beef within a short time after their arriral.

An attempt to make efficient laws to guard against this malady log regulating the movement of eattle from infected localities has generally failed to give relief, because these districts erould not be aceurately designated. States, therefore, as well as individuals, have heen mable to protect themselves, and the losses hare gone on rear after sear in spite of indivilual precautions and State laws. The cheap cattle of Georgia, Alabama, Mississippi, Arkansas, Southeastern Virginia, and other infected sertions are at times carried to the most remote sections of the conntry, and when this is doue in spring or summer extensive 
and fatal ontbreaks of sonthern feror among the susceptible animals which cross their trail or mix with them npon their pastures is the general result.

Last year such ontbrealis of disease are known to have occurred in New York, New Jersey, Pennsyl pania, Marylanr, Virginja, West Virginia, Ohio, Illinois, Missouri, Kausas, and even in Dakota. Colorado and Tyoming seem to have escaper, notwithstanding the introduction of Sonthern cattle, and this mas probahls dne to the peomliar climatic conditions, the excessire dlyness of the atmosphere preventing the multiplication of germs and soon destroving them.

It is evident, however, that this disease may be carried to most parts of the comntry and that hefore aurthing can be accomplished toward preverting the very important losses which are now ammally camsed by it, we must hare more accurate knowledgo of the section fom which cattle are liable to carry the infection. To obtain the information necessary to map ont the inferterl ristrict special agents have been emplored, who have carefully traversed every county along the horlerline of this district, aurl have iurestigaterl the eattle diseases with sufio. cient detail to lucate the limuts of the inferted district in inst cunnties with rery great accuracy. In some comnties a shar line cannot be llawn, leecanse it does not exist, bnt in such eases the line has been drawn suficiently toward the mninfected district to embrace, as is be lierell, all the territory that was really infecterl at the time of examination. As this district is being continually enlarged by a gradual thongh rery slow adrance of the infection, it is not safe to buy cattle near this line for slipment to the North in summer, unless a careful personal inrestigation is male hy the purchaser at the time.

The infected part of the South is clealy shown on the accompanying majs. To establish the boumdars-line of this district bejond controrersy our special agents have carefully reported the individual experi ence of thonsands of farmers, and others who have moved cattle either northward or sonthward in the vicinity of this line. These reports are far too numerous and roluminous to publish in detail, and, conseruentls, a simple resume of the farts as they are known to exist is all that we have attempted to give in this report. The location of the bolder-line of the inferted district is as follows:

\section{VIRGINIA.}

The northeastern extremity of the line is in Accomack Connty on the Atlantic seaboarl. The permanent existence of the disease on this jeniusula has not heretofore been suspected by the comntry at large A few facts had come to our notice within the past year ol two which seened to indicate that certain onthreaksot sonthem forer in Maryland had followerl the introluetion of eattle from Sorthampton County, which corers the extreme sonthern part of the peninsula. At the time it 
seemed impossible that this disease could have secured a permanent lodgement so far north, and the reports were scarcely credited.

A careful examination of the peninsula, howerer, has demonstrated the existence of the infection of southern cattle ferer throughout Northampton County, and extending for 2 or 3 miles across the boundary into the southern part of Accomack County. The infection seems to have been in Northampton County so long that no one remembers a tme when it was absent. It is said that there are local laws prohibiting the morement of eattle from Northampton to decomack at any season of the year, but that recently they have not beeu strictly enforcerl. In 1880 a considerable number of eattle that had been running upon commons in A ceomack Connty, 2 or 3 miles from the sonthern boundars, died with symptoms of sonthern fever. It was found by iurestigation that more or less cattle had died from pasturing on these commons every summer for the past ten year's.

In April, IS81, a drove of about 50 heald of cattle ras collected in Northampton County and driven to marliet across Accomack. At Pungoteague a stop of several hours ras made, and here at least six head of cattle contracted the disease during the following summer aud died. Two miles farther north another halt was made for dinner, and in this vicinity nine of the native animals died. Twenty miles north of this the herd seems to hare stopped again, and here a large number of native cattle died.

There seems to be no reason to doubt, then, that Northampton County has long been infected, and that the cattle from that section when driven among susceptible animals produce the same fatal results as has loug been recognized to follow a similar movement of Texas and Gulfcoast cattle. The infected part of Accomack Connty is rery narrow, perhaps not more than 5 miles wide, and it is said that the lisease is more malignant toward the seacoast than it is in the parts which border on the bay. This is in harmony with the fact that sonthern ferer is known to have existed along the seacoast in North Carolina and Virginia for many years before it invaded the interior.

A careful investigation of the comties north of the Rappahannock liver failed to reveal any trace of the disease. Not only were all the cattle apparently in good health, but imported cattle had remained free from disease after their introduction. Several instauces were related of bulls being brought from North or West and continuing to thrive in their new home. According to all the information attainable, then, there is no permanent infection north of the Rappahannock River.

Coming south of this river, we find that eattle brought from Gloucester and Matthews Comities to seetions of the State farther morth and west infect pastmres and thus destroy native animals. The facts ol). tained indicate that Middlesex Connty has become entirely infected, but we were unable to obtain evilence of any permanent infection in Essex County. In King and Queen County the infection has reached 
the pastures in the ricinity of King and Queen Court House within the last four or fire years, and it now survires there throngh the winter. Ten miles north of this cattle are susceptible to the disease and suffer when on the same pastures with others from south or east of that locality. While therefore the southeastern palt of this county is certaiuly infected the greater part is still fire. The same phenomena in regard to the extension of the disease that has been noticen in other' parts of the South were also apparent here. The effects of the divease had been apparent for twenty rears south and east of the courthouse, but the pastures here had not become infecterl until about five years ago, and since then cattle have been frepuently lost. In Caroline County there was an outbreak of disease in 1851 caused by cattle from Gloncester County.

In King William County we find the infection permanently locater on the Pamunliey River 3 or 10 miles ahore the New Kent County line, where it seems to have been for the past twenty rear's.

In Hanorer Comnty the permanent infection las been at Hanorer Court House and Ashland for a considerable number of rears. It is well known to the inbabitants that cattle brought from north or west of these places are nearly certain to die either the first or second summer after their arrival. The infection has extended but little besond these two points.

Henrico appears to be entirely overrun with the infection. All the cattle sold from this and the surrounding counties go to Richmond either to be killed for beef or to be shipped by boat to other markets, and con sequently there is little opportunity to collect instances of discase camsed by cattle carried from here to uninfected localities. On the other hand it is admitted pretty generally hy those who handle cattle that it is rery dangerons if not absolutely fatal to bring these from the elerated sectious of the State to any part of this county.

In Goochland county there have been very few cases of disease for a long time, but the southeastern extremity of the county is recognized to be dangerons to northern cattle. Farms on the James Rirer three or four miles above Goochland Court Honse lose a few anjmals from year to year with southern fever. There is, however, little opportunity for the disease to ocem, since the traftic in cattle in not extensice. Animals are not bronght from north or west because of their liability to become affected, and they are not brought from the South because this is believed to be dangerons to the natives.

Powhatan Comnty is undoubtedly infecterl, and has been in this condition for many years. It is reported by all the farmers along the James Rirer to be absolutely fatal to cattle to be brought from north of the river to the south side. They suffer to the same "xtent when simply carried from the north to the south hank as when the distanee is greater. Cattle from this comnty hare long bes consislered clangeroms to the native stock with which they came in contact whon being driven to lo. 
calities farther nortlı. The introluction of this disease is not remem bered by the oldest inhahitants, but so far back as the memory of man goes the present conditions have prevailer.

Cumberland County does not aplyear unnite so thoronghly infecterl. At Trenton Mills and McReit st there is no doubt of the permanent infection, but the sonthem extremity of the county still seems to be free from it. In the connties along the river it is rery plain that the sections inumediately adjacent to the river hare been longer infected and tha the disease here is more generally diffused and more rimlent than in the same comnties at a greater distauce from the water. And accord ingly as we attempt to investigate the coudition of other sections we encounter the difficnlty of fimbing a smaller number of cases and a greater mncertainty in the mimls of the inlsabitants as to whether the native pastmes really holu the infection from rear to rear, or whether each ont. loreak is the result of a fresh importation.

In Buckingham Comnty our reports confirn the statements that were made last rear. The infection extends up the sonth bank of the James River to a point slightly beroud the conflnence of the James and Slate Rivers. From here the boundary line of the infected district passes up along the west lyank of the Slate to Diana Mills; then the direction is a sontheastern one to the ricinity of Gravel Hill, and to McRea's, in Cumberland Comnty.

In Amelia and Sottowar Counties it has been impossible to trace ans line or even to demonstrate the complete infection of the territory. It is generally admitted that twenty years ago and longer there was a complete infection of this district, but of litte rears there lias been much less disease and it has become possible to loring in cattle from north and west with safetr. In these comnties there are no fences, and each man must necessarily keep his cattle upon his own pastures; as a conse. quence there is none of the indiscriminate mixing of cattle which used to occur, ant the chances of contagion are greatly lessened.

While there have been considerable losses in Prince En ward County there is little evilence of permaneut infection, except, perhaps, in the extreme eastern part. Most of the cases seem to have been the result of pasturing on commons that hall been frequented by animals from Lmenturg Conuts.

In Lumenburg there is no doubt of permanent infection. It is dangerons to bring cattle from west or north into this comnty, and, on the other land, cattle from this county have frequently spread disease wheu driren toward the west or north.

In Charlotte Connty the boundary of infection becomes plainer and follows very ne trly the line of the Richmond and Danrille Railroad in its whole eomse across the county.

From the point where this railroad crosses the Stannton River to the North Cinolna boundary, the line of infection was definitely locited in my last year's report. The ancompunving man delineates the portion 
of Virginia permanently infected with sonthern cattle ferer as correctly as this cond possibly be done. Parts of the line hare been retrand three and four times in order to hare it satisfactorily located.

\section{NORTII CAROLINA.}

The Bhe Rirlge Mountains of North Carolina are now looked npon by the people of this State as the practical bonudary line of the district permanentis infected with sontheru ferer. At some points, as in Wilkes Counts, the infection has not quite reachen the momntains, and at one other point it has crossed the ridge and invaded Henderson Connty. The la ws of the State, howerer, make the Blue Ridge the line, and prohibit the morement of eattle from the eastern comties at all seasons of the rear.

\section{SULTTH CAROLINA AND GEORGIA.}

The whole territory of South Carolina seems to have been overrun with this infection. The Bhe Ridge Mountains, which form a part of the northwestern boundary of the Stite, have here been erossed by this contagion and are no longer to $\mathrm{b}$ - considered as the line. The infected district beyond these momtains is, howerer, at present of small extent, and the arlvance is so slow as to be scarcely appreciable.

The small portion of Georgia which has heretofore been considered free from this infection is being rajully orerrm ; and it is now donlotful if any of even the northern tier of comnties can be considered entirely free. The monntain sec jons are no: so thoronghly infected, and it is probable that Towns, Inion, and Fannin Counties are practically free from the permanent infection.

Whitfield and Muray Connties have been quite thoroughly inspecter and the commons of both found to be infected in all parts. Many of the farms are also infected, but some still remain free, especially near the northern boundars. Cattle taken from these counties to the momntain ranges of Gilmer for pa sture have not so far as has been ascertainer? cansed any ontbreaks of disease. This is probably due to the fact that Giluer County is also prettr thoronghly werrm.

Here, as in mans other localities, there are evidences of a different intensity of the contagion in rarious parts of the counties, but more partieularly in different sections of the State. Thus, cattle which have pastured on the ordinary infected ranges of Whitfeh County withont harm, have become diseased as a conseruence of feeding along the trails and on the commons where cattle from Sonthern Georgia had lately grazed. The movement of bovine animals from one farm to another or from one county to another is also considered dangerons. The fatigue indnced by driving is without donbt one of the factors in producing the disease in such cases. Even eattle from the extreme south often sncenmb whe : exhausted by long journers. Similar facts have long been noticed with other diseases, and particularly with anthras. eattle 
which hare resisted the contagion on the infected farms beeoming victims to the rirus already within their bodies, when their rital resistance is lowered by great fatigue.

At Dalton there is a probability that permanent infection existed before the war, but not to the same extent as at present. The cattle driven from South Georgia to prorision the armies, and later those brought by the refugees returning to their homes, are believed to have been the means of distributing and intensifying the contagion throughout Northwest Georgia.

\section{TENNESSEE.}

The line of the infeeted district crosses the boundary line betreen Georgia and Temessee near the western slope of the momntains, aud follow's a north westerly direction to Parkville and Benton, in Polk County; then its direction is nearly directly west to Clerelaud, Bradley County, and to Snow Hill and Harrison, in James County. From this point the river becomes the line across Hamilton Comnty, Chattmooga and the Chiekamauga Yalley having been infected for a long time. The southwestern part of Polk and the southern parts of Bradley, James, and Hamilton Counties are, therefore, permanently infected. The district infected is here, as we have fonnd to be the case elsewhere, extending slowly towarl the north; and though this extension is slow it is ap. parently continuous, and the territory once overrum is seldom redeemed from the scourge. The points which we have mentioned as existing on the border line of the district hare only been infecterl within a few sears, and, as elsewhere in newly infected sections, it is the commons rather than the farms that are dangerous, and eren the commons are not uniformly affected.

In Marion Comuty the line of infection passes in a northwesterly direction up the east side of the Sequatchie Valley and within one or two miles of the Sequatchie County line, and then erosses the valles and down the west side for five or ten miles, passing aroum the mountain range and taking a southwesterly direetion to the vicinity of Jasper; from here the direction is again northwesterly to Decherd, in Frankliu Comity, the greater part of this county being apparently permanently infected. From Decherd the direction of the line is slightly sonth of west to Fayetterille, in Lincolu County, and trom this point along the Elk River to the Alabama State line in the vicinity of Teto Station. The sonthern part of Lincoln County is what is called the barren region, aud has been infected for many gears. In the rieinity of IIarbut's the line again erosses into Tennessee, taking a northwestern direction, and at the comity line between Giles aud Lawrence Counties is about five miles north of the Alabama State line. On the bonndary between Law. rence and Wayne Comnties this line is 10 miles north of Alabama. At this point there is a sudden bend toward the north, the line erossing to the northwestem corner of Wayne County, taking in about one-fith of 


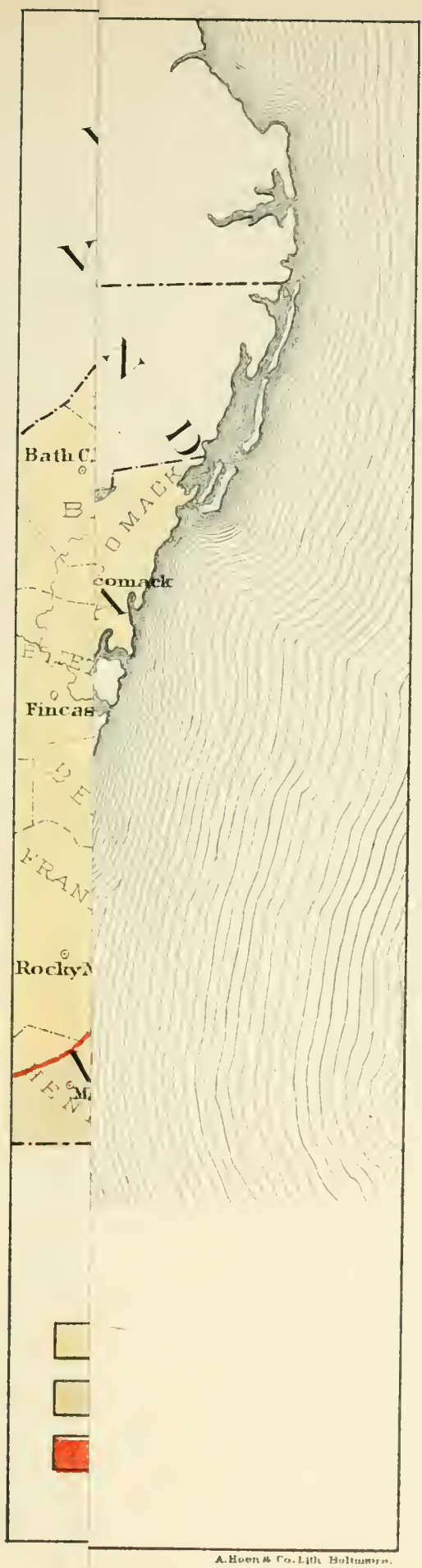




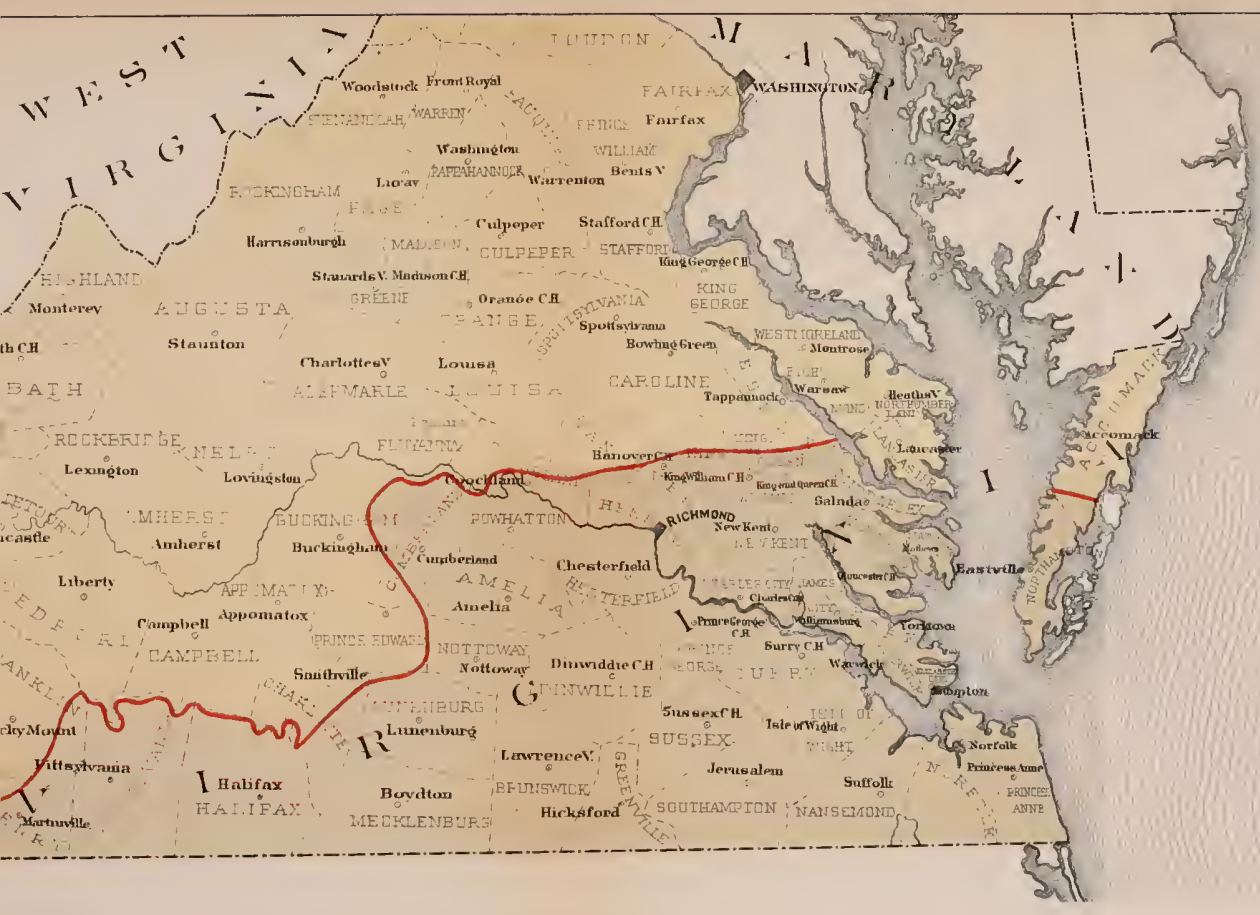

SOUTHERN CATTLE FEVER

Free from permanent infection

in Virǵinia

Permanently infected

By D.E.Salmon, D.V.M.

Border line definitely establıshed 


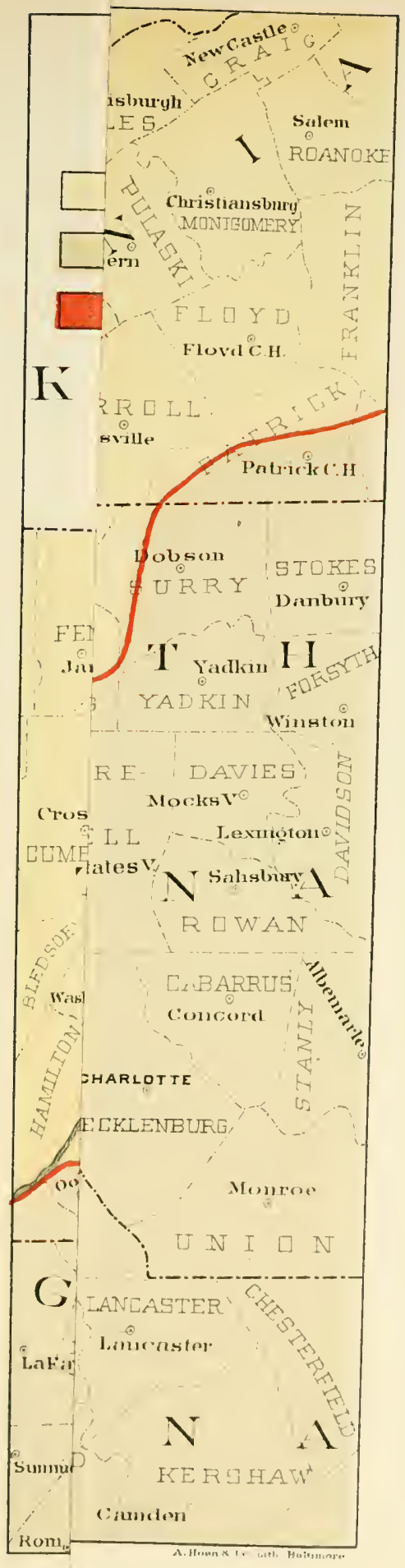





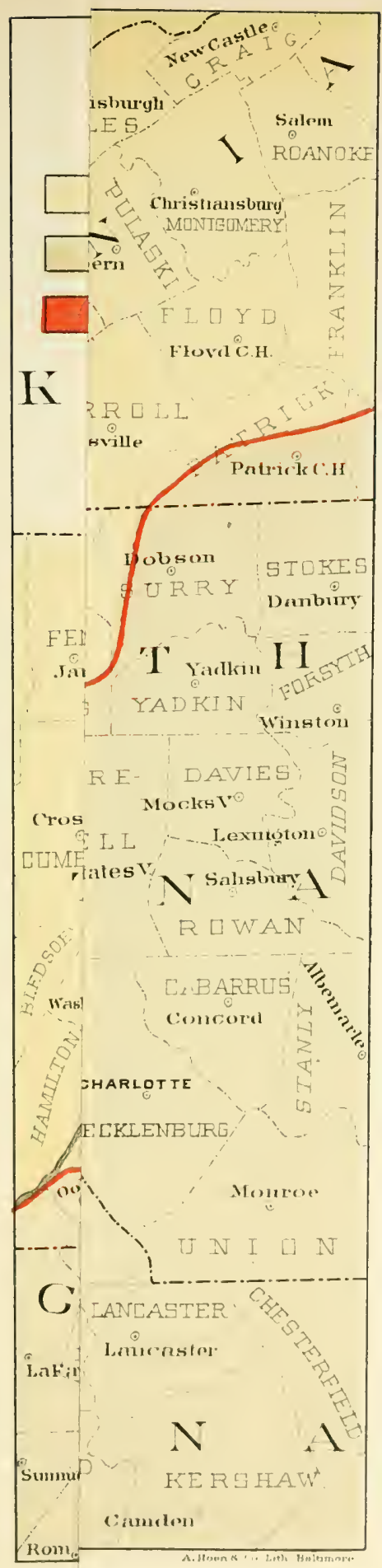




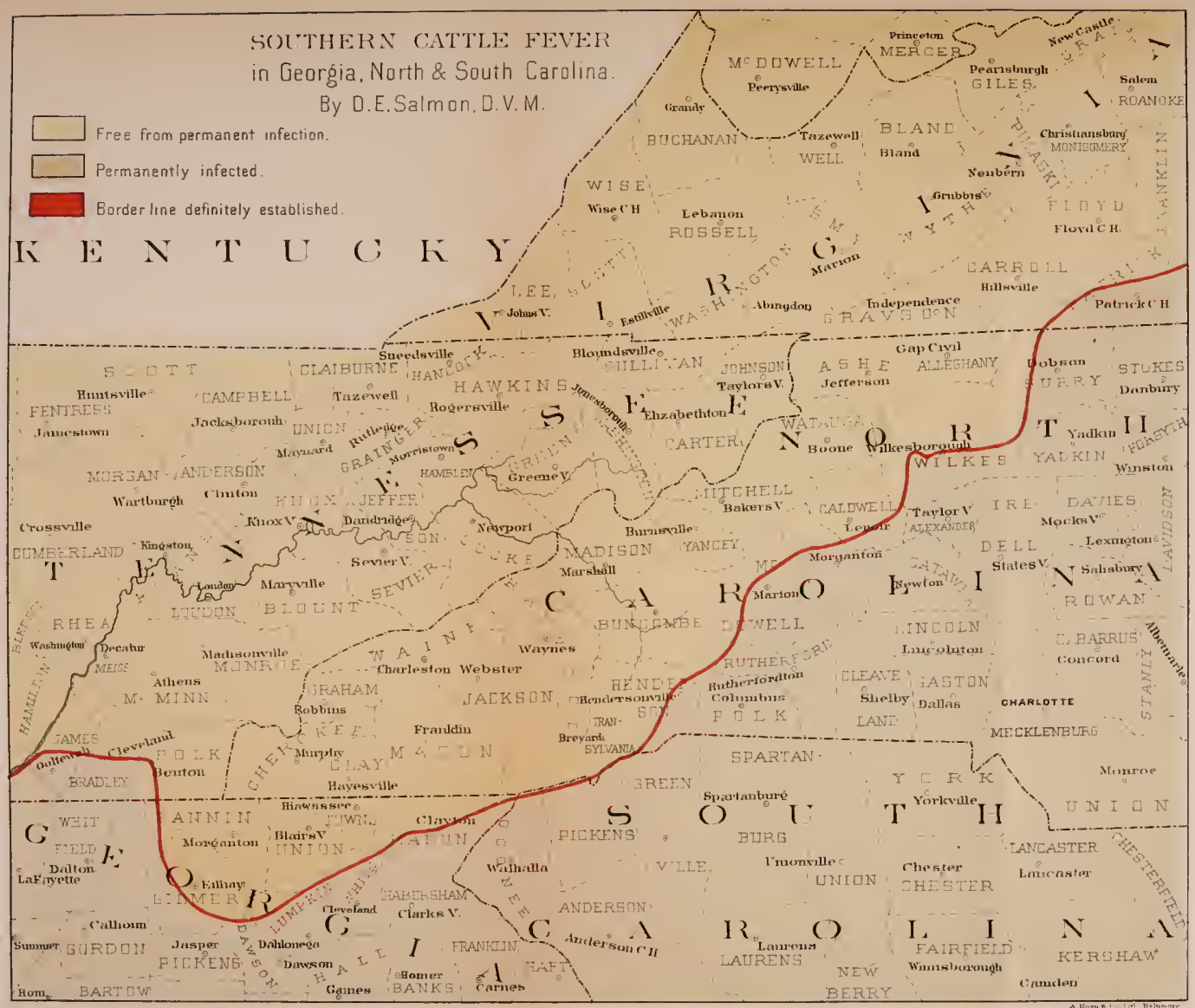




\section{1}

is

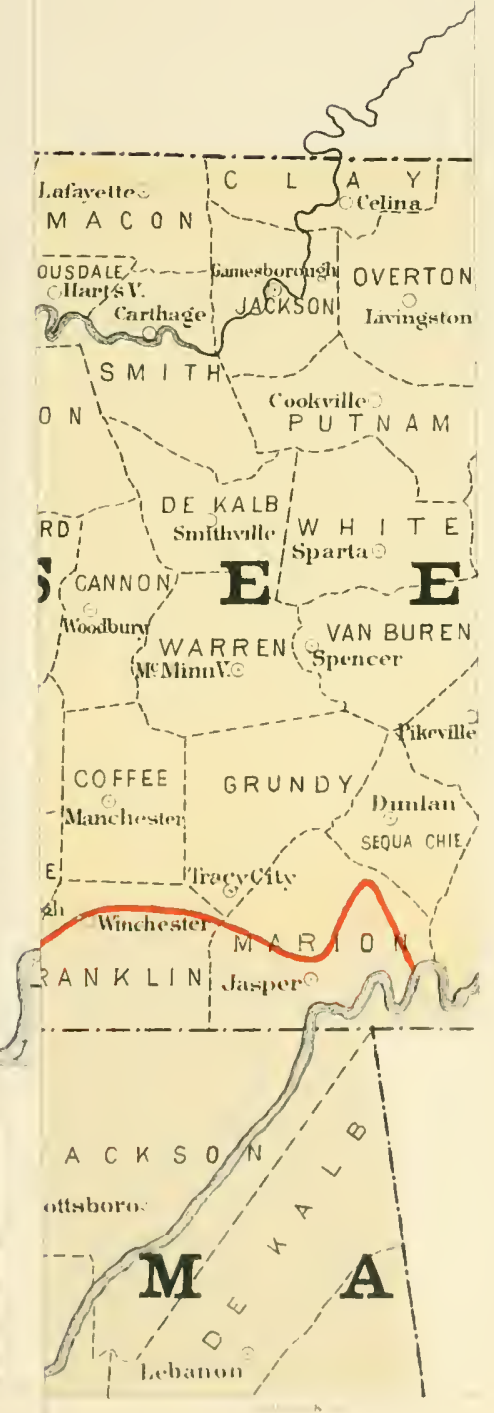





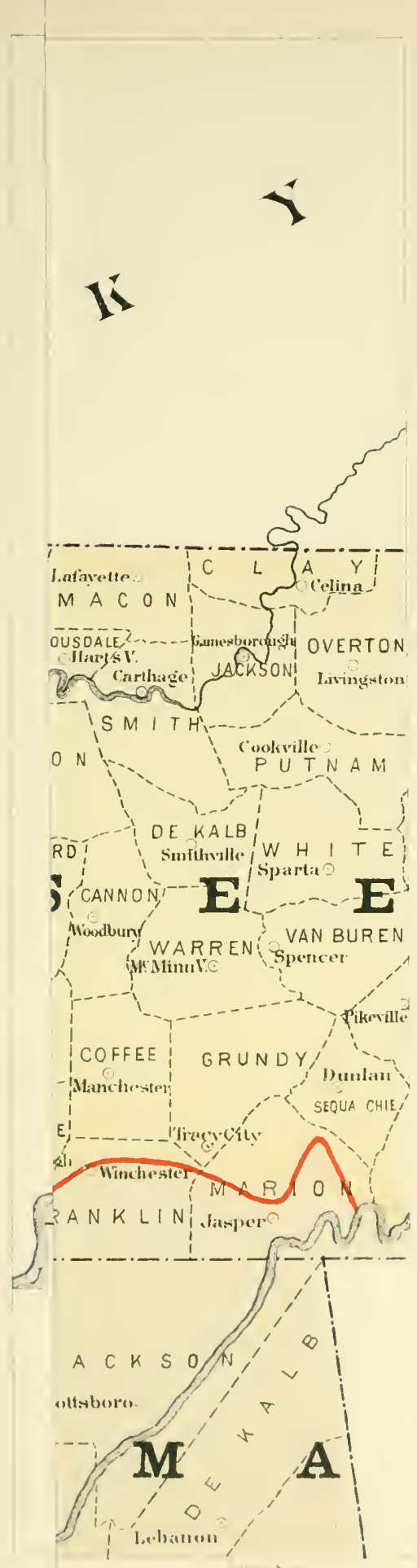




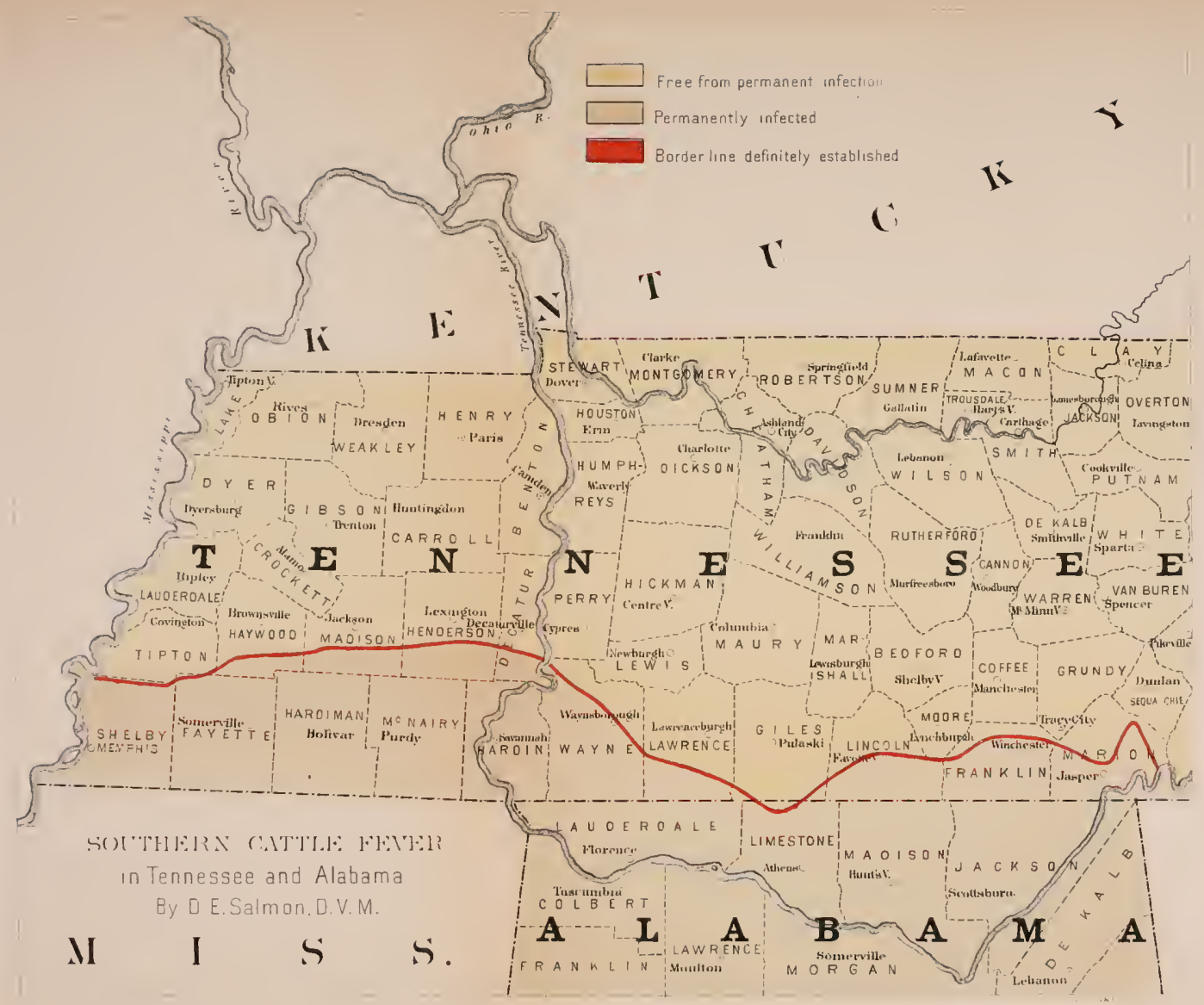


Decatur County and all of Harden. In Henderson County it reaches as far north as Shady Hill, then passes directly west to the viciuity of Mifflin, in the same comntr. From here the direction is slightly sonth of west to Denmark, the bonndary between Madison being crossed 2 miles north of Harleman Comnty; from here the direetion is westerly to Stanton Depot, in Harwood County, and onward toward the south. western corner of Haywood and along the northern boundary of Shelby to the Mississippi River. All of Shelby and Fayette Counties appear to he infected, while Tipton, as far as we have been able to learn, is free from ans infection.

This concludes our examination of the district permanently infeeted with sonthern cattle fever for the year. It will be seen that a considerable portion of Tennessee has alread $y$ become infected. Even the monntainous counties in the sontheastern part of the State have been invaded, while in the river valleys of the central part of the State the line has reached cousiderably farther toward the uorth. Along the whole line of the infecterl distriet in this State, as in the other States preriously examined, we have found the same history of the extension of of the permanently-infected district. At some points this extension has been insiguificant or is searcely noticeable within the last quar. ter of a century, but in the situations more farorable to the progress of the disease there has apparently been a regular advance of from one to four miles per year. This history coincides substantially with what wais learned of the progress of the disease in Virginia, North Carolina, and Georgia. As a consequeuce of these facts there can be no longer substantial reason to donbt the continued extension toward the north of the district permanently infected with this disease. Considering the extreme temperature which occurs in the mountains of sontheastern Tennessee and in the part of this State located in the Mississippi Valley, we can scarcely hope that the winters in any considerahle part of the stock-raising section of the country will be suffieiently severe to prove a permanent eheck to the extension of this contagion.

It is proposed to continue the examination of this district across Arkansas, Indian Territory, and Texas, to the Rio Grande River, and it is believed that a definite location of this line will be of great assistance to those engaged in the live-stock industry in the whole south western part of the country. The mortality among thoroughbred eattle taken south of the border line of the permanently infected district is so great that it has become a matter of importance to buy animals which have acquired a certain amounit of immunity from this disease. It is beliered by many breeders that by establishing breeding tiums just within the line of infection that there will be a smaller mortality from the clisease, and that the animals laised under these conditions will still be able to resist its effects in a very perfect mamer. Aleady such farms have been established in Southeast Kansas and Southern Missomi, under the belief that animals raised in this locality will prose insusceptible to the disease 

Decatn County and all of Harden. In Henderson County it reaches as far north as Shady Hill, then passes directly west to the rieinity of Mifflin, in the same eounty. From here the direction is slightly south of west to Denmark, the boundary between Madison being erossed 2 miles uorth of Hardeman County; from here the direction is westerly to Stanton Depot, in Haywood Comnty, and onward toward the south. western corner of Hayrood and along the northern boundary of Shelby to the Mississippi River. All of Shelby and Fayette Comnties appear to he infected, while Tipton, as far as we have been able to learn, is free from ans infection.

This concludes our examination of the distriet permanently infeeted with southern cattle fever for the year. It will be seen that a considerahle portion of Tennessee has already become infected. Even the mountainous connties in the sontheastern part of the State have been invaded, while in the river valleys of the central part of the State the line has reached eonsiderably farther toward the north. Along the whole line of the infecterl distriet in this State, as in the other States previously examined, we have found the same history of the extension of of the permanently-infected district. At some points this extension has been insignificant or is searcely noticeable within the last quar. ter of a century, but in the situations more favorable to the progress of the disease there has apparently been a regular advance of from one to four miles per year. This history eoineides substantially with what was learned of the progress of the disease in Virginia, North Carolina, and Georgia. As a consequence of these facts there can be no longer substantial reason to doubt the continued extension toward the north of the district permanently infected with this disease. Considering the extreme temperature which occurs in the mountains of sontheastern Tennessee and in the part of this State located in the Mississippi Valley, we can searcely hope that the winters in any considerahle part of the stock-raising section of the country will be sufficiently severe to prove a permanent cheek to the extension of this contagion.

It is proposed to continne the examination of this districtacross Arkansas, Indian Territory, and Texas, to the Rio Grande River, and it is believed that a definite location of this line will be of great assistance to those engaged in the live-stock industry in the whole sonth western part of the country. The mortality among thoroughbred eattle taken sonth of the border line of the permanently intected district is so great that it has become a matter of importance to buy animals which have acquired a certain amount of immunity from this disease. It is believed by many breeders that by establishing breeding farms just within the line of infection that there will be a smaller mortality from the disease, and that the animals raised under these conditions will still be alble to resist its effects in a verg perfect manner. Ahealy such firms have been estab. lished in Southeast Kansas and Southeru Missomi, under the belief that animals raised in this locality will prove insinsceptible to the disease 
when carried further sonth, but the great mneertainty which at present exists with regard to the exact location of this line makes it extremely douhtiul if these farms have been correctly located. A number of extensive breelers who have a rery intelligent idea of the nature and effeets of this disease hare recently expressed to me their high appre. ciation of the work now being done by the Department of Agrieulture towarl pstablishing the bonndary of this infecter district. It is believed that definite knowledge in regard to this will relieve them from many of the eauses of embarrassment connected with the shipment of thoroughbred eattle to the South.

\section{INVESTIGATIONS OF SWINE PLAGUE.}

In a communieation of M. Pastenl to the Paris Aeademy of Seienees (Comptes Rendus, 1383, l, 1163) it was asserted :

1. That the microbe of swine plagne is a dumb-bell mieroencens.

2. That pigeons are rery susceptible to the rirus, and passing this through a suceession of these birls inereases its activity.

3. That rabbits are also susceptible, and passing the virus through a suecession of these animals attennates it to such an extent that if pigs are inoenlated with it they only contrat a slight illness which grants them inmunity from subsequent attacks.

To these assertions Dr. Klein (Vet. Jr., 1884, July, p. 39) replies :

1. That M. Pasteur has orerlooked the true microbe, and that this is a liacillus and not a microeoceus.

2. That all of his (Klein's) inoculations of pigeons with rirus taken direetly from diseased swint-virus which invariably protuces the disease in swine and other suseeptible animals-and with his artificial enl. tures of the organism of swine fever, prouluced absolutely no effect, either general or local.

3. That it is impossible to say whether M. Pastem's labbits died of swine ferer or of septieamia, though he (Kleiu) had shown in 1577 that rabbits are susceptible to swine ferer when inoculater from material directly derived from the pig.

4. He adds in an addendum that he has recently satistied himselt that the artificial cultivation of the rirus in the organs of mice or rabbits by inoculating these from diseased swine will prodnee a mild form of swine plagne from which the animal quickly recovers, and is thereby protected from the disease.

It is very evirlent that before any safe method of protective inocnlation or vaceination can be adopted we must be satisfied as to the nature of the virus. Rabbits and mice are both subject to septiesmia, and it is quite certain, from the difference in the microscopical appearance of the germ iescriber by these two investigators, that either the one or the other had cultirated and inoeulated with a septic rirus. Dr. Klein 
does not hesitate to say that it seems probable to hin that, "as in the case of the microbe of fowl cholera, M. Pasteur dirl not work with pure cultivations of the microbe of swine ferer." M. Pastemr will doubtless suy, on the other hand, that Inr. Klein has evitently been eultivating and inoculating with the sejtic vibrio. Both eannot be right in their belief that they have been working with the true germ, ant, conseqnently, it is rery probable that both sets of hogs were not protected from the genuine swine plague. Each has made many inoculation experinents, each has enltivated his germ throngh a mumber of cultirations in purity as he supposes, and each believes that he has produced the true swine plague with such cultivations; but one of them is wrong: vaceination with the virus of one will fail in practice, and if the wrong virus is so easily obtained it becomes donbly important to know how to discrimiliate between them.

ln former reports I have given details of experiments which, if eorrectly stated, demonstrate berond question that the microbe of swine plagne is a micrococens. These experiments were made and the aceoms of them published in advance of those of M. Pastem, and the eridence furnished was all that conh reasonably be required to decide a scientific question of this kind. Dr. Kilein, homerer, has publisher evinlence which on its face is equally conelnsive in luis favor: and as it is not likely that two different diseases resembling each other so chosely in symptoms and lesions, but having snch dissinilar virus, have been investigated. the most reasonable conclusion is that one is mistaken in his conchnsio. It is necessary, therefore, to review certain points in the in restigations and to bring forward such new evidence as shall be required to remove these uncertainties.

1. The microbe of swine plague. - As I have show elsew here (Sicience, 1854, 1. 155) Dr. Kilein was first to demonstrate the presente of microcorei in the tissues of animals that had suffered fiom swine plague, bint he did not at that time (1566) attribute, nor has he at any time subsequently attributed, the cause of the disease to this organism. On the contrary, he published a long series of investigations in 185 (report of the medieal officer of the Local Govermment Board) from which he conchuled that the true germ of this disease is a bacillus, and in his last paper reiterates this conelusion and asserts that the micrococens is entirely an epiphesnomenon (Tet. Journal, July, 15st, p. 3!-17).

In my report for 1 sso (Department of Agrienlture, Special Riport No. 34, ple. 22-24), 1 publisherl experineents showing that the blond of sick, not ilead, hogs, which had been receives into varumm tubes that weres thrust inside the rein with poper precautions hefore heing opened. and were then immediately withliawn and hernetienlly sealed, contained mieroeote and no other organisms, and that loggs inoculated with this blood contrateded a severe form of swine plague. This organism was found to exist in the virulent liguids (blooml peritoneal eftusion, ide), in three distinct outbreals of the disease which were investigated at that 
time. This was the first discovery recorded, so far as I am aware, of the existence of micrococei in the blood of the affected swine before death; and it has a very important bearing on the etiology of the disease, since a post mortem development of the germs is ont of the question and they were found in situations to which there was no direct communication from the outside of the body.

In my next report (Department of Agriculture, Ammual Report, 1Ss 1 and 1852, pp. 267-269) I gave the details of experiments which demonstrated that these micrococci after they had been earried through six cultirations in considerable quantities of liquid were still capable of producing rery marked eases of the clisease. This was, I believe, the first satisfactory evidence of the pathogenic effect of the micrococei in the disease known as swine plague: and I desire to eall attention to the firet that these inoculations were made Jannary 17,1881 , or more than fourteen months before the discovery of the same organism by II. Pasteur and Thuillier.

To establish the connection of the bacilli with the canse of the dis. ease, Dr. Klein relies upon the following evidence:

1. The presence of bacilli in microscopic sections of the tissnes.

2 . The multiplication of bacilli in the artificial cultures of the rirus.

3. The production of disease by inoculations with the cultivated bacilli.

He has not forgotten that in his first report he deseribed microeocci and not bacilli as existing in the tissues, but there is an evident attempt to explain this by conreying the impression that these rere found exclusivels in situations where they might be derived from external sources. For instance, in his last paper (Vet. Jourual, Juls, 1884, p. 41) he says :

Preparing sections through the typically nlcerated mucons membrane of the large lutestine, staining these in aniline dyes, aud examining them under the microscope, I find this: In the superficial parts of the necrosed mewbrane are present large numhers of micrococci of varions kinds, chiety varying in the size of the elements and in the molle of aggregation. These micrococei stain well in Spiller's purple and in methyl blue, and are present only in the necrotic parts of the nleeration, in which they appear irregularly distributed. But in the depth of the tissue, and extendiug in many cases into the inflaned snb-mucons tissue, are seen streaks and elumps of minute rod-shinet bacteria, which coincide as regards size (length and thickness) with the bacilli which I deseriber in my former memoir, the single organisms being about 0.001 to 0004 wom. long, aud about a third or a fourth as thick.

In his first report he deseribed the situation of the micrococei in the intestine somewhat cifferently, as follows:

From. aurl even before the first sigus of neerosis of the mncosa, viz., when the epithelinu begins to break down and be sled from the surface, there are found manses of micrococei, which in some nlcers oecmpy great portion of débris. (Report of the medical officer of the privy comeil and local government boaril, 1856, p. 98.)

Again, in regard to the ulcerations of the nucons membrane of the tongue, he says in his last report:

1 have seen in the superficial parts of the nlecrs large clumps of microsocei, but in the deptlo of, and extending between the inflamed muscular tissue I bave foum the 
same rod-shaped organisms as mentioned above; they are chiefly in spaces letween the bundles of the inflamed connective tissue, forming here streaks of longer or shorter chains. (Page 42.)

\section{In his first report this was stated as follows:}

In the ulceration of the tongue just mentioned, and at a time when the superficial scab has not been renoved, I have seen masses of mierococei situate chiefly in the tissne of the papill:e, but at some places reaching as far deep as the intlammation extencls. (Page 99.)

In regard to the similar lesions of the epiglotis the following language was userl:

I have before me preparations through the epiglottis, the sulum ueosa of the posterior surface being in a state of necrosis, and near the edre so broken down as to eave there a deep uleer, while the mucous membrane of the anterior surface is only slightly inflaned in its snbmneons tissue; in this I tiud lymphatic vessels filled with miteroeocei, sce. (Palge 100.)

\section{As to the appearance of the lung his last report says :}

Sections throngh the diseased parts of the lnugreveal, in preparations stained as above, the presence of large numbers of micrococei in the eavity of the bronchi and nir vesicles, hut not in all lungs, since I have fonnd lnngs in which they wero altogether alosent. But there are always present in larger or smaller clnmps the same minnte rosl-shaperl organisms as mentionerl above. They are imbedled in at coangum tilling the air vesicles, or they block up a blemb-ressel in the wall of a loronchiole or air resicle. In the air vesicles I have seen exudation eells, white-blond eor puscles containing elumps of the rouls; they are well brought ont by spiller's purple. In the air vesicles of some luugs I have seen them grow to very long chains, leptothrix, ten, twenty, and more times the length of the single rods. These rods were present, not onl? in the air resicles, hnt also in the tissue itself, botlo of the walls of the air vesicles as well as of the smaller or larger bronchi. (Pages $41,42$. )

In his first report there is a most radical difference in the deseription of the situation where the micrococi were seen :

In the intiltrated, firm, more or less disintegrating parts I find great nasses of micrococe tilling up eapillaries aud veins, and also con ta ined in lymphaties aromel arteries. They may be founcl also in minor bronchi which have been eompletly hlocked up ly cheess inflammatory produets, but there the masses of microeocei, conspicnons by fleir blue coloration in hiruatoxylin preparations, are generally present in greater or smaller lumps between the outer surface of the plug and the wall of the bronchus.

The plena is much swollen, and contains great unubers, continuons layers, of lumps of unicrococei. The frese surfuce of the membrane is in many parts covered with them. The exulation fluil is also charged with them, as has been mentioned above. (Pages 100, 101.)

That is to say, in 1876,1$) 1$. Klein was able to find the micrococei not only in the necrotic parts of the nlerations, but he found them from and before the first signs of necrosis; he fomud them extending as aleep into the tissue of the tongue as the inflammation extended, and in the epighlottis at a point where the submucons tissue was only slightly inflamed he found the lymphatic esessels filled with microcorci. In the lungs, instead of the micrococei beinge confined to the cavity of the air resicles and broneh $\mathrm{j}$ as he desires us to muldristand from his last report, he really fomnd them in the infiltrated and firm parts, filling up capillaries, reins and lymphaties. They harl even penetrited to the plenta rhich contained great numbers

5751 1) $1-6$ 
and continuous layers of them: the free surface was covered with them, and the exuldation fluid wos charged with them. Their presence in the pleural effision is sufficient evidence that cross-section of bacilli had not been mistaken for micrococei in the tissues; and it may, consequently, be accepted as beyond question that this organism existed at the points named in the reprort of 1876 .

In the last report it is stated that the rods (bacilli) are found " in the bronchial exudation, in the juice of the lung tissue, in the peritoneal exudation, and oceasionally, but not generally, also in the blood already in the fresh state." Sections made through the fresh or hardened, swollen mesenteric and inguinai lymph glands are said to reveal the presence of chmps of the same minute rod-shaped organisms. Looking at a elump of these organisms, one imagines them at first to be a zoogleea of micrococei, but using oil-immersion lenses and Abbe's sub. stage eondenser it becomes eertain that they are undoul,ted rods-some smooth and uniform, others more or less "beaded."

In the results of the examination of the tissues it will be seen that, with the exception of the lymph glands mentioned, the baeilli of the last report have little if any ad vantage in sitnation orer the microcoeci of the first report. And if we consider that the organisms of these glands so closely resemble micrococi that it requires oil-immersion lenses and an Abbe condenser to make a distinction, and that eren muder such farorable conditions some of the rods are more or less "beaded," the reader will not feel so certain that they are nudoubted rods as is Dr. Klein.

The examination of the tissues of mice and rabbits which have died after inoculation with the more or less septic liquid of dead hogs cannot be aceppted as throwing any satisfactory light on so diffieult a problem; since others cannot finil to have the same doubts in regard to Dr. Klein's experimental animals that this gentleman is so free to express in regard to those of M. Pasteur. The question as to the organisms found in the tissues of animals so susceptible to various forms of septiciemia as mice and rabbits after they have been inoenlated with morbid products from hogs which have died of a disease in which loeal necrosis and gangrene is not mncommon, is one which ean only complicate the real issue without in any sense elucillating it. Indeed, when Dr. Klein tells us that he has "seen a good many pigs inoculated with eulture of the bacterium of swine fever, which beyond the swelling of the glands and beyond a transitory rise of the body temperature on the second and third day, by one or even two degiees C., showed no other signs," we have strong suspicions that the slight trouble produced was of a septic nature rather than a mild attack of the destruetive swine plagne. The period of incubation in swine plague is much longer than that of septiermia ; sometimes it is three weeks; generally it is from twelve days to two weeks, and it is only by the nse of enormons doses of virus that 1 have suceeded in redneing it to four or five days; and, therefore, when we are told that in these 
mild attacks the periol of incubation was but two or three lays, and that in at least oue case there was a lise of temperature within twentyfour hour's (Ibid., p. 43), the appearances are certainly very much more in faror of septiciemia than swine plagne. Certain it is that in none of my numerous inoculation experiments has there been a rise of temperature within so short a time. As I write this I hare just returned from making a post mortem examination of a pig killed in the last stages of the acute form of the disease; this was one of a lot of three inoculated with a virus so virulent that not one of a considerable number of swine that have been inoculated with it during the last three months has re. covered. With so virulent a virus one would expect the incubation to be at its shortest duration, anl yet neither of these three showed any appreciable signs of disease up to the twelfth day. All sickened at about the same time, and to day, the fifteenth day, all were so extremely ill that the most careful prognosis would be death of all within fortyeight hours.

In animals which hare died from the disease and on which a posts mortem exanination was not possible immediately after death, I have also found bacilli in the peritoncal and plural effusion, and even in the blook. A photograph of some of the peritoneal eftusion dried on a cover-giass at the time of the autopsy, and afterward stained and mounted, shows these very planly; this photograph has been repro. dueed by the heliocaustie process and accompanies this report as Plate XII. No doubt bacilli wombl also have been found in the solid tissnes of this animal; but these organisms were the lesult of changes which oceur either shortly before or after death, and have not been found in auy of the mumerous animals which I have destroyed for eximination when in the earlier stages of the lisease. In such cases the peritomeal, the pleural, and the pericardial effusions, and usmally the blood are fomnd to contain motionless micrococei of the figure of-eight form, but often uniterl in chains and varions-shaped clusters.

In the many cultivations which I have marle from material obtaind from slanghtered auimals I lave never found bacilli exeept in a very fer cases where the virus was not obtained mutil after contart with the ail, where the racum tubes had not been properly sabled, or where the animal was not slanghtered mutil the last stages of the disease. A photograph of a preparation made from one of these enltivations is re. produced in Plate Xl. It seens to be a perfectly pure enltivation of mierococei so far as eareful examination with the microsenpe is able to determine, and it was so virulent that there pigs inoculater with it all contracted the disea-e and all dien.

In my most recent investigations I find that the peritomeal efiusion is often impure in the last stages of the rlisease. In such eases a variety of organisms appear in the coltivations malle with this liquir, but jure enltures of miresoecei are still obtained from the plombal eflusion, or in those rare cases where this ton is impure the pericandial thuid and 
blood have yielded pure cultures of microeocei. A fact of great im. portance is that no pure cultures of bacili have been obtained, and that where but a single species of organism has multiplied this has invariably leen a micrococens.

Having obtained snch results from my investigations, and having repeated them orer and over again, and confirmed them with virus from various parts of the comntry, I eanuot but conclude that swine plague is due to a micrococens, and that the disease produced by Dr. Klein's cultivated bacilli was a form of septicamia. And this enchusion is confirmed by the short perion of incubation in his eases, and the fact that many of his animals showed no signs of lisease other than a slight rise of temperature and an enlargement and eongestion of the lymph glands.

The following record of experiments contains the most important of those which have heen made since my last report, and is a continuation of the evilence mpon which the above statements have been male:

Experiment No. 1.-Two pigs were inoulated June 2S, 18s3, with virns dried on quills and sent from Indiana. It was obtained by killing a sick pig and immediately dipping the quills in peritoneal and plenral effusion and the exudation liquid from the lungs, and drying this after the manner practiced for preservation of vaceine lymph. In this case the animal from which the virus was obtained ${ }^{\prime i}$ : not have a rery severe form of the disease. For inoculation the r rus on three or fonr quills was rubbed up with zec. of salt solution and injected under the skin of thigh. The tomrth day (July 2) there was elevated temperature (10240 and 10:310 F.) and slight redness at the point of iuoculation. The fiftl day there was diffised redness on the inner side of both thighs, an eruption of small papula on the thin parts of the skin and an inereaserl elevation of temperame (103:0 and $104 \frac{4}{5} \mathrm{~F}$ F.). July 5 to 9 the temperature remained at or above 1050 with one, and reached its highest point on the 7 th, being then $1055_{5}^{30}$, and the eruption was rely plain and extended over the greater part of the surfuce of the bong. From this time thoy began to improve, and in neither case was the disease fatal.

This was one of a 110 mber of inoenlation experiments male to obtain a reliable virus for experimental purposes, and is reeorded to illustrate the ahove remarks in regard to the period of inculation.

Experiment No. 2.-Fonr hogs were indeulated July 7 , with virus also from Indiana, and preservel in the same way as the other, but was obtained fiom an outbreak which was much more virulent and tatal. This was also suspended in salt solution and injected hypolermically in the dose 2ae to "cc. at the imner sicle of the thigh.

'To and inchubing July 17, or for the first ten days, there were small, hard swellings at the point of inoculation, but no positive signs of disease, and the appetite remained gool. There were considerable variations in the temperatmes, but it is cloubtful if this had any pathological sig- 
nificance. July 1s, three were evidently sick, with temperatures of $102_{5}^{3}$, $105 \frac{1}{5}$, and $106 \frac{3}{5} \circ \mathrm{F}$.

The one most severely affected was killed July 21 , at which time the temperature was $104 \frac{3}{5} \mathrm{~F}$., and there was complete loss of appetite. The point of inocnlation was much swollen, the enlargement extending. forward under the abdomen, and was abont 6 inches in length by 2 in breadth. When ent across it was found to be dense and fibrous and creaked under the knife. A clear lymph flowed from the eut surface. In the center of the swelling was an irregular carity, 1 to 2 inches across and partly filled with dry caseons material, reminding one of the seynestrum formed in fowl cholera when an inactive virus is injected in to the museles in large quantities. The right lung was nearly all of a deep-red color with extensive areas of infarction. There was a small quantity of effinsion in the cavity of the thorax. The intestinal tract was congested but there was no peritoneal effusion.

The plenral effusion was collected in racum tubes with all known precautions to prevent access of atmospheric germs, and hermetically sealed. Cultirations were made by infecting sterilized nutritive liquids in the eultiration apparatus with small quantities of this plenral eftusion. The cultivation liquids used were pork and beef broths which had not been uentralized and neutral veal broth. All the attempted cultivations were successful, and the organism which multiplied was of illentical appearance in each-it was a diplococens or figure eight in form, and had a tendener to adhere in short chains and small clusters.

This organism was carried throngh three cultirations, each aplaratus containing abont half an ounce (15ce) of liquid. Angust 2 experiment No. 3 was made by inoenlating 2 pigs with the third enltivation of this micrococens. One of these had a hypodemic injection of tec. and the other of $10 \mathrm{cr}$ of the cultivation liquid. This was marle on the inner side of both thighs and with the latter also between the fore leges.

There was sxelling at the point of inoculation within twenty fom hours: but no marked inerease of temperature nutil Angust 7 , when it reached $10.55^{\circ}$ with one, and $101 \frac{2}{5}$ with the other, with impared alpetite, thirst, and shivering. Two days later the skin orer the entire abdomen was wrinkled, flabby, and in places losing its epridermis. From this time they improved in general symptoms mutil Amgust 17, when the one that receeded the larger puntity of virus and which has been most sererely affected was killed for examination. At this time there was extrensive desquanation of the epithelium over the alodomen; the swelling at the point of inoculation had softened and contained pus. There was swelling of the lymplatic glands of the inguinal amb mesenteric reagions, petechiat of the serous membranes, and slight peritoneal efrusion.

Experiment No.4.-Three pigs, Nos. 26, 27, and 2s, were inoculated June 9 with a cultivation linnid seeded from the virulent effusion of a 
pig that had died from the result of inoenlation with a very tatal virus received from Inlinois. This cultiration liquid contained only microcoeci, the appearance of which are very well shown in Plate XI, which was reproduced fiom a photograph.

June 14 , all hal elevated temperatures varying from $104^{\circ}$ to $105^{2} \circ \mathrm{F}$., increased thirst, tueked up abdomens, swelling at the points of inoculation, rigors, and sechuled themselves in their bedding. The appetite was still fair.

June 20, there was complete loss of appetite, emaciation, and profuse diarrhea.

June 29, No. 27 died, and antopsy revealed congestion of intestines, hepatization of right long, with abundant effusion in the pleural, pericarlial, and peritoneal waties. Inocnlations with this effusion eatsed death of another pig July 8 , after showing the well-known symptoms of swine plagne.

July 3, No. 28 was found in a dying condition and was destroyed, in order to get fresh material for examination and for inoculation experiments.

July 6, No. 26 died in convulsions after having presented the cliaracteristic symptoms of the rarious stages of swine plagne.

The notable point in this experiment is the virulence of the cultirated virus. This virus was a pure eultivation of micrococei and produced fatal results in every case. The results of our inoculation experiments with enltivated micrococci have heretofore been more or less unsatisfactory, beeause, while the symptoms were those of swine plagne, the disease prodneed did not correspond in its malignaney to the swine plagne which so frequently decimates the herls of the West. In this case, howerer, the disease developing as a result of inoculation had all the malignancy of the most serere ontbreaks which I have ever witnessed, and in sub. seqnent experiments with virns obtained from these animals this fatal type has been retained and every animal inoculated has suecumbed.

On July 3 , pig No. 34 was inoculated with mixed plemal and peritoneal effinsion obtaned from No. 28, which was killed that day in the last stages of swine plague, prodnced by inoculation with enltivated virus as detailerl above. July 15, the temperature was $104^{\circ} \mathrm{F}$., and there were periods of shivering. From this time the progress of the attack was rapid; there was a red blush of the skin over the abdomen, diarrhea, loss of appetite, prostration, and tendency to hide in the litter. .July 18, it was very much debilitated, the breathing was rapid, and it was scarcely able to walk. It would nudonbtedly have died in a few hours. It was killed for examination and for pure virus.

Antopsy showed the lungs to be covered on pleural surface with pete. chive, but there was no hepatization. The inguinal ant mesenteric glands were greatly culargerl and congested; the small intestines intlamed; the earemum was the seat of three large ulcerons patches, 1 to 2 inches in diameter, and sereral of smaller size. These were black 
on the surface and on sections the tissue appeared dense, fibrous, and pale. The ileo-ceeal valve was completely eovered with such au ulcer, and the mucous membrane of the stomach was much congested.

Thoroughly sterilized vacum tubes were filled from the jugular vein, $f_{1}$ om the right rentriele, and with the pericardial and peritoneal effusion, each of which were abundant. At the time of the autopsy small quantities of each of these effusions and of the blood were dried on cover-glasses for examination in the laboratory.

The tubes of peritoneal finid when opened emitted a very disagreeable odor of putrefaction. Stained eover-glass preparations showed that it contained both microcoeci and rods. Cultures of the same containeci micrococei, a bacillus with pointed ends, probably the Bacillus butyricus, and a few rods of bacterinm termo. From this result it becomes an interesting question to learn if these rarions organisms really existerl in the peritoneal liquid at the time of the animal's slaughter, or if they were introduced from the atmosphere during the necessary manipulations for filling and sealing the vaeum tubes. In other words, is it possible for septic bacteria, in cliseases which produce lesions of the intestines, to penetrate the walls of these organs and multiply in the peritoneal effinsion before the death of the animal? In a former report (Annual Report Department of Agriculture, 1850, p. 432), I hare collected a number of observations which seem to answer this question in the affirmative. Fortunately in the case under consideration examinations were made which furnish satistactory evidence that there were various forms of bacterial orgauism in the fluid of the peritoneal earity before the death of the animal. Preparations were made by thoronghls drying this fluid on cover-glasses as soon as the abdominal earit? was opened, and in these, of course, there conld be no ehange before examination. Such preparations stained and monnted demonstrate conclusively that while the micrococei predominated, there were also present a considerable number of bacilli. These observations, which were made with the greatest precantions to aroid errors, go far to reconcile the discrepancies which have appeared to exist in the results of the various iurestigations of this disease.

Cover-glass preparations of blood from the jugular presented no definite bacterial forms even after staining. Cultures of this blood remained perfectly sterile.

The pericardial effusion contained large numbers of micrococei, easily seen both in unstained and stained prepatations. Cultivations gave pure growths of mierococci.

The blood from right ventricle showed angregations of microcoeci, and cultures of this blood produced a pure growth of the same organism.

Sections of the eiecal ulcer contaned enormous aggregations of mierocoeci in the depths of the eavity; the neerotic portion appeared to consist almost entirely of these bodies. In some sections small colonies 
of micrococei were found in the deeper parts of the tissue. No rods conld be found even in sections stained with fuchsine, a stain which Klein used in his investigations.

In sections of the spleen, stained in various ways, no organism could be detected.

Sections of the most congested mesenteric gland revealed no organisms within the gland tissue, but the peritoneal surface and its serous covering' were studded with micrococei, interspersed with which might be seen a considerable number of large and small rods.

Pig No. 39 was inoculated July 17, and was slanghtered August 11, being at that time rery severely affected, and presenting well-marked symptoms of swine plagne. The mesenteric ressels were congested, as - were those about the ileo-ciecal valve, but there were no ulcerations at this point. The lungs were pale, but contained a number of dark.colored eongested patches. There was no pleural effusion; the pericardial cavity contained a considerable amount of liquid, and there was also slight peritoneal effusion.

Cultures of the pericardial fluid gave a pure growth of micrococei. The racum tubes, filled with peritoneal fluid, were preserved until September 2, and were then found to contain large numbers of micrococci, but no other organisms.

A large number of observations similar to the above have been mate, and in all cases where a pure cultivation has been obtained the organism which multiplied was a microeoecus, and when the virulence of such enltivated micrococei has been tested by inocnlation experiments typical and fatal cases of swine plague have resulted.

Respectfully submitted,

D. E. SALMON, D. I. M. 



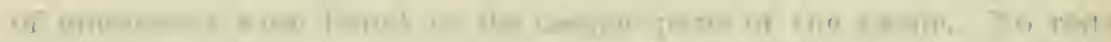

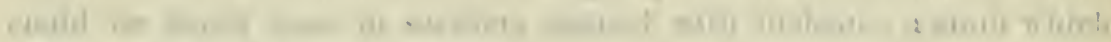

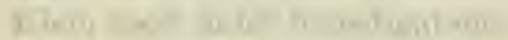

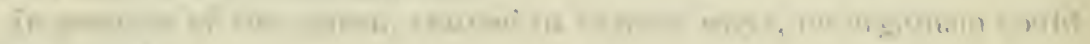
$\operatorname{lin}, \ldots+1,4$

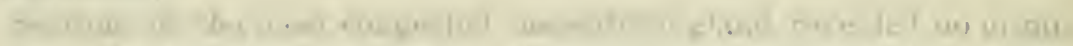

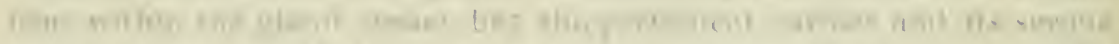
notwon

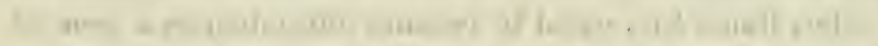

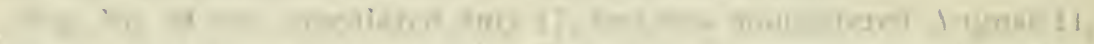

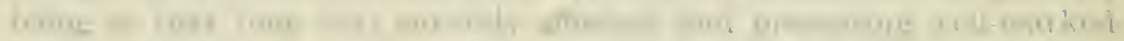

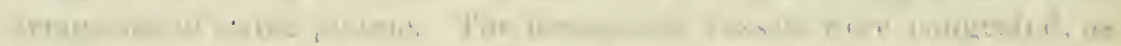

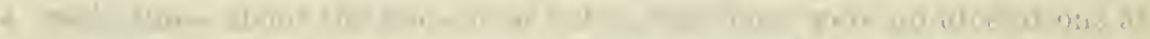

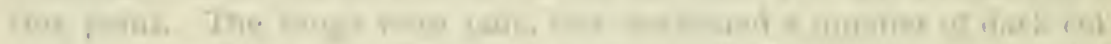

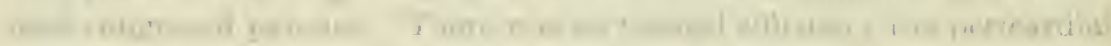

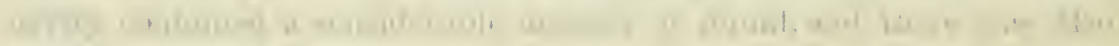

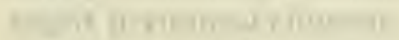

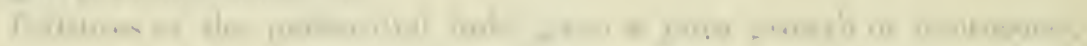

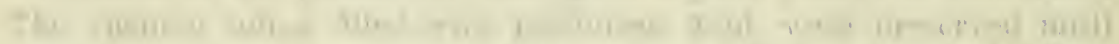

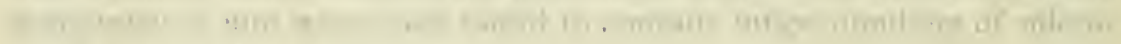

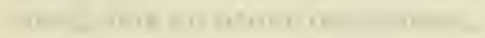

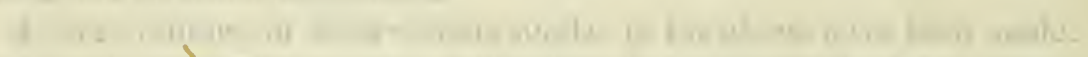

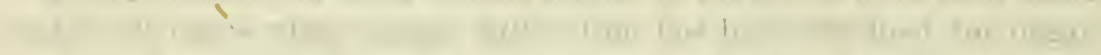

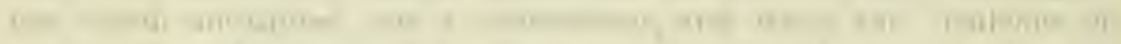

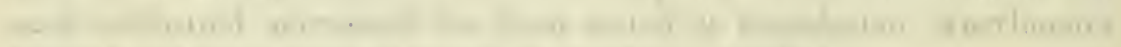

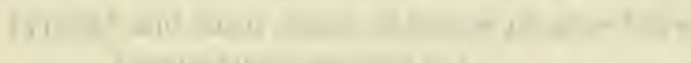

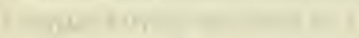




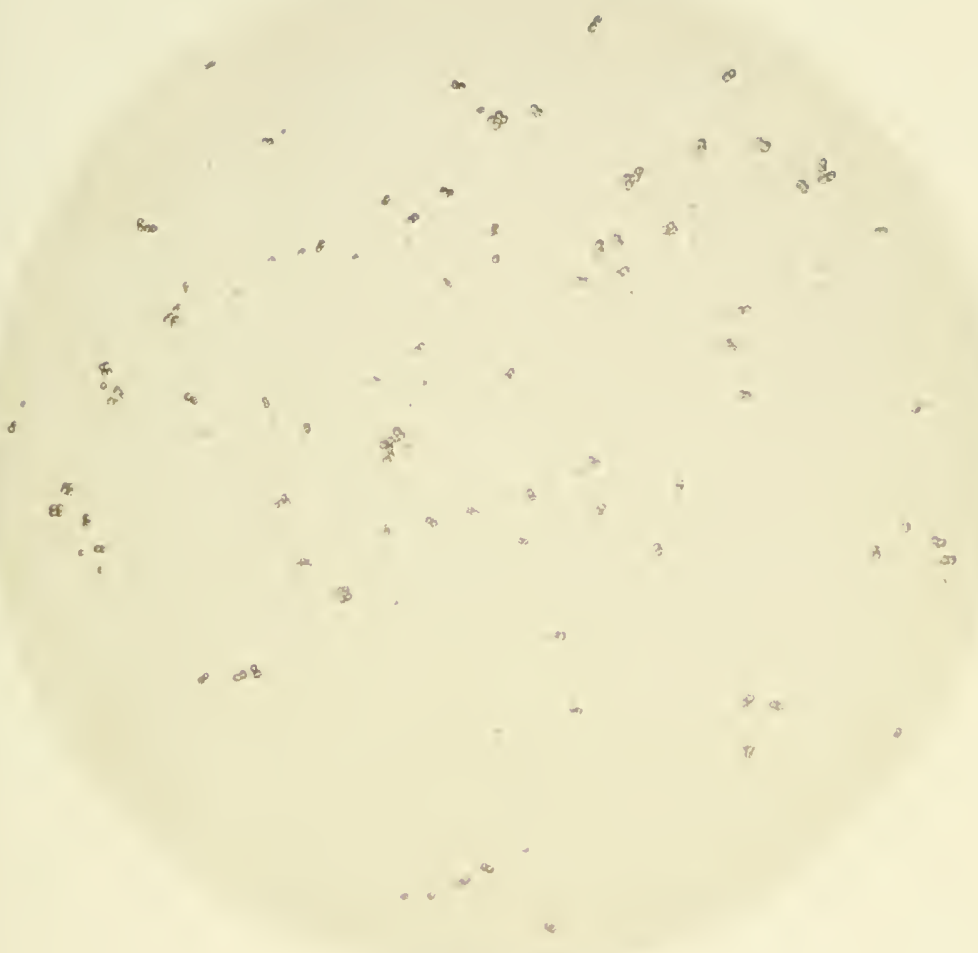

SWINL-PLAGITE MICIROCOC, US

Photo-micrograph of cultivation liquid $\times 430$. 



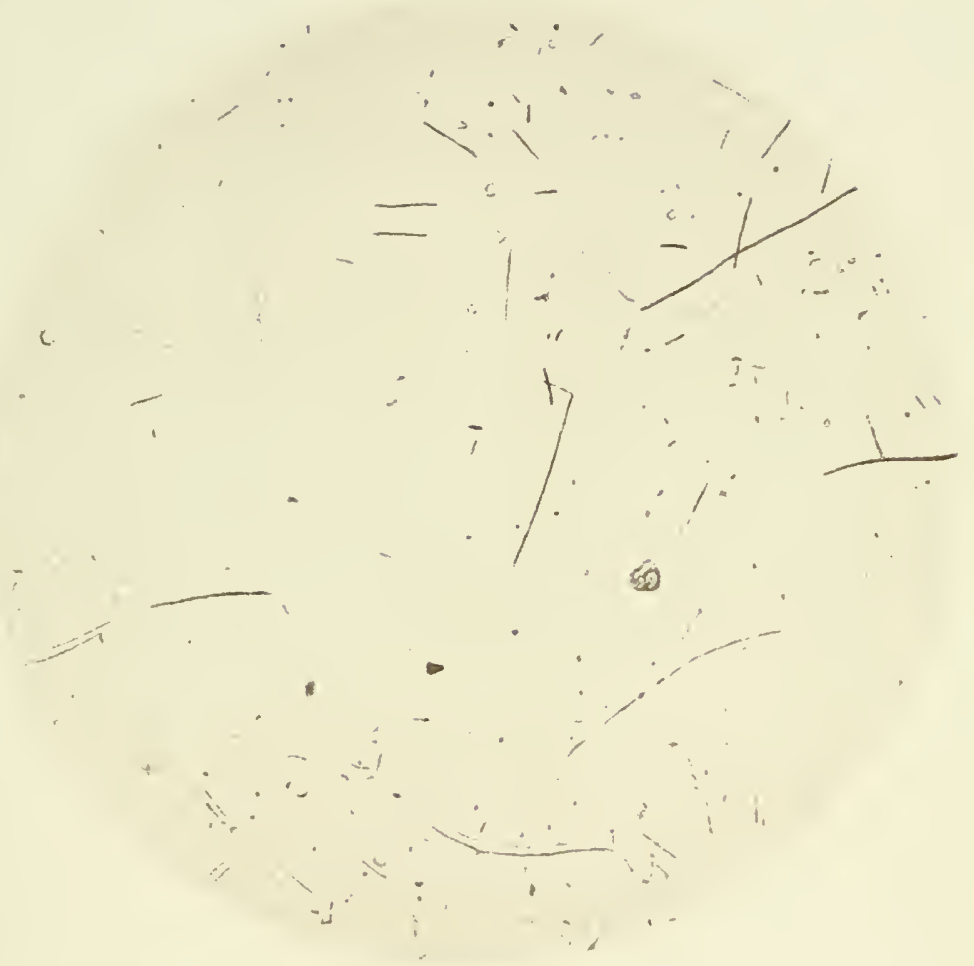

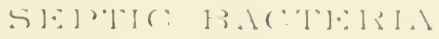

Photo-micrograph of Peritoneal Effusiun 



\section{ERGOTISII AMONG CATTLE IN K.INSAS.}

\section{Hon. George B. LoRIng,}

Commissioner of Africulture :

SIR : In obedience to your telegram of the 5th of March, requestnng me to go to Neosho Falls, Kans., and there to investigate a disease among cattle, I forthwith prepared myself and left on the 6th, arriving at Neosho Falls in the afternoon of the Sth. On my way to Neosho Falls I was delayed orernight at Burlington, Kans. On the same evening I lead a report in the Kansas City Journal of a meeting which had been held at Neosho Falls on the evening of the 6th attended by his excellency Governor G. Wr. Glick, Lient.-Gov. D. W. Fimner, who, in company with other State ofticials, Dr. A. A. Holcombe, 1). V. S., of Leavenworth, Dr. Wilhite, of Emporia, and a number of stockmen, had by special train proceeded to Neosho Falls, and investigated the disease among eattle in Woodson and Coffey Counties, and npon the anthority of Drs. Holcombe and Wilhite sail disease was pronouncerl to be the contagions foot-ani-month discase. At the meeting in the evening a quarantine committee was appointel, with Lientenant Governor Fimney as the chairman. This committee was instrncted to quarantine all infected cattle and premises, to guard aganst further diffinsion of the dread disease. Upon reading this article I was greatly surprised and alarmed. I had no reason to donbt the eorrectness of the diagnosis by Dr. Holcombe, whom I knew from personal knowledge to be a rery competent reterinarian.

()n my arrival at Neosho Fatls, Woolson Comnty, late in the afternoou of the sth. I was met by Lientenant-Guveruor Finney and Dr. Holcombe, who immeriately procmed a eonreyance and accompanied me to the resilence and farm of $\mathrm{Mr}$. I) aniel Keith, sitnated in the sonth east corrier of Coffey County, 5 miles north of Neosho Falls. Mere I wats conducterl to a smatl pen or indosure which containet 12 heal of yearlinge calves. This pen measured abont to by (i) feat, and was inclosed on two silles by a rail fence, by a hay ratek and cornerib on the west side, and horse stable and corn erib on the east. The pen was well bediled with hay and straw. On rotering the inclosure I walkerl along the hay lack and galve the hay a hasty oxamination, but foumd it clean, bright, and sweet, it being wild hay made on bottom lands. I also looker for ergot among the grasses which eomposed the aly, but discovered only two or three heals of wild rye which were ergotized; 
the amount being insignificant I gave it no further thought at the time. My expectation, after realing a description of the symptoms of the disease among the cattle, was to discorer ergotism, should the disease prove not to be the genuine foot-and-month affection. I inquired if any of the pregnant cows and heifers had aborted, and was told they had not; but ny attention was. called to one white cow, six years of age, which presented many ulcers on the ndder and teats. These ulcer's, according to the description of Mr. Keith, first appeared as vesicles or bisters abont three weeks previous, but at the time I saw her they were corpred with scabs, and were healing off. Mr. Keith stated that this cow was suckling a ten day's old calf when she first evinced symptoms of the disease, and that two days thereafter the calf died, having succumbed to a serere cliarrhea.

The yearlings in the pen presented the following conditions: Four of them liall lost both hind feet, the separation taking place at the fetlock joints; 5 hall each lost one hind foot; and 3 were abont to lose both hind feet. The latter cases presented a well-defined line of demarkation at or above the fetlock joint, extending and encireling the limb in a straiglit or slightly oblique line; the upper parts of said line presented a healthy surface, discharging a small anount of laudable pus, and were healing under a seab; the limbs below this line were perfectly derital. ized and shrunken in a dry gangrenons condition. In the elefts of ser. eral of the feet $I$ fonnd considerable evidence of previons nleeration, and loosening of the walls of the foot around the bull of the heel. Those animals which had lost their feet were apparently in a healthy condition, a slight elevation of temperature being the only appreciable evidence of functional derangement remaining, aside from the erippled limbs. They ate well; lickert themselves; the stmmps were scabbing over and healing; they occasionally got up and hobbled along for a few steps, then dropped down.

I next examinerl their months, which revealed denudation of the mucons membrane and discolored patehes on the nose, lips, tongue, and roof and elastie parl. In some of them only two or three of these discolorerl spots would be fouml on the lips, pad, or the roof of the month. The discolored or denuded patches dirl not extend deeper than the submueons connective tissue, and presented a brownish yellow or rusty color'; they were irregular in outline, and of varions dimensions, from the size of a pencil's point to half an inch in diameter, and were not cirenmseriber by any reddish or inflammatory borler.

No soreness or inconvenience was manifestel in the act of caring. Temperatures ranger from 1020 to $103.8^{\circ} \mathrm{F}$. I saw a number of other cattle in varions stages of lameness, also some which had recorered from lameness, yet no very recent cases were reported by Mr. Keith, from whom I receired the following brief history:

He first hecame aware of the trouble anong his cattle on or about the 234 or "sth of December last, when he noticed a peculiar jerking " "p of 
the hind legs among a number of the calves. They wond first jerk up one foot and then the other, or shalie the foot as if they wanted to shake off a foreign body, and acted as if they conld not place the affected foot to the gromml. They wonld then hobble along a few steps, and walk off moderately well or lie down. When ther stood quiet they arched the back and dropped the heat.

Some of them slobbered or frothed at the mouth, and would not eat hay vory well. In the conrse of two or three days they persisted in lying down nearly all the time; swelling abont the coronet then became apparent, extending as high 11 as the fetlock, or even higher in some vases, which was attended by great heat and tenlerness.

Soon after this swelling appeared-a very few days-a band around the leg would then appear, the skin becoming contracterl, drs, and hard; next the skin broke and a sore made its appearance. This sore encireled the leg and gradually deepened until complete separation of the limb at one of the joints oecurrel. The time eonsunerl from the first appearance of the disease until the final dropping off of the dearl portion of the limb wonld be from three to four reeks. In some eases he noticed soreness aud ulceration in the clefts between the claws. When he first noticed the jerking np of the feet and limbs he thought it was due to impaction of mud between the elaws; therefore he examined some of the feet, but found no impactions. On the 1st of Jannary abont 30 head of the calves manifested lameness. All of these calves were fed upon wild hay and shelled corn during the fall and winter. All the medical lreatment which these cattle receired was one application of muriatic acid arom the limb where the line of soreness existed. The described 12 hearl of yearling calves, and 51 more of the same age, he bonght from Mr. J. Davis on the 11 th of December, and took them home on the 12th. Mr. l)aris had bought these calres from different parties within a rarlius of 10 miles south and east of 'Teosho Falls.

Learing Mr. Keith's place, we went to the farm owned by Mr. A. C. Goodrich, which is ocempied by Mr. Edward Hindnan, who is the overseer of the stock on the farm. The Goodrich farm is ciivided from the Kéth farm by a public road lunning north and sonth. (On the Goodrich farm we saw 20 hrad of eattle, all of which were two years old and upwarls, fwhich had then lost or would eventmally lose one or more feet, or parts of them, and 2 of them wera abont to lose all their feet.

In one of these cases the line of demarkation was 6 inclies above the fetlock, and in the other $t$ inches, white some of them had lost only one claw or one foot at the secoud juint. All of these eattle presenterl greater or less discolorations, erosions, or ulcerations m the lips, tongme, or ronf of the month, and in several the month lesions were much more prominent than in any of the keith cattle. A two-yoar old real and white steer, which had lost both hind feet at the fetlock joints, prosented, "pon examination of the month, brownish yellow-patches on 
the roof, covering two-thirds of the space between the pad and soft palate. These patches coalesced and were elevated one-sixteenth of an incl, possessed a well-rlefined border and a flattened surface. On the pad were two large oval or oblong ulcers, one of which measured an inch aud a quarter in length. On the gums of the lower jaw, insids of the lateral and corner-incisor teeth of the right side, appeared one large uleer, which possessed a more reddish and inflammatory appearance than those on the pad. On the right side of the thick portion of the tongue existed an ulcer which had an excavated bottom and a greasy and dirty-looking appearance; this was $1 \frac{1}{2}$ inches in length and of an oval shape. Temperature $103.5^{\circ} \mathrm{F}$. A two-year-old red heifer, which had lost one hind foot at the fetlock joint, and the other was in process of separation at the same place, presented a month with lesions exactly similar to the first one, only that they were confined solely to the roof of the mouth.

A third case-a five-year-old cow which was losing both hind feet at the fetlocks-presented discolored patches and small erosions on the tongue, lips, and roof of the mouth, also ecchymosed spots appeared on the mncous lining of the rnlva, and mnens mixed with pus flowed from the vagina. An ulcer the size of a silver dime appeared inside of the sphineter ani. Temperature $104^{\circ} \mathrm{F}$. Mr. Goodrich, among his herd of 95 animals, had 21 cows and a number of heifers which were pregnant, but none of them aborted.

In an aljoining lot I saw a number of young calves; npon inquiry I received the response that these ealves were all well, and had not been with the diseased cattle. A number of hogs also were inclosed in another lot adjoining that of the diseased cattle, and I was told that they had not been in contact with the eattle. Night was now apploaching, and owing to the mumber of people which had gathered, and the excitement which prevailed, it was impossible to obtain any definite or extended history of the ontbreak, manner of feeding, surronnlings, Sc. Therefore 1 deened it best to return to town and comprare notes with Dr. Holcombe, and return on the next day to make a more thorongh investignation, and to obtain a full history. I was now told by some of the stockmen present that they desired to have my opinion on the nature of the disease; that they intended to hare the cattlealpraised, killed, and buried on the next day, if my diagnosis corresponded with that of Dr. Holcombe. 'Two of these parties came from Emporia for this expressed purpose.

This placed me in a very delicate and unpleasant position, as I haw not given the matter the thoromgh investigation that 1 desired to do before making my diagnosis. I hat to rely almost solely npon a history as given to me by partics mon whom 1 conld not plate absolnte reliance; nevertheless I felt compelled to make a diagnosis miter these jressing circumstances. Taking, therefore, into consideration, 1st. The history 
which was giren to me by Mr. Keith, which so elosely deseribed the first symptoms of the foot-and-month disease; the nlcers and previons resication on the udder of the Keith cow, and the dleath of her' calf' soon after the risease manifested itself in the mother; the absence of abortions or the supervention of nerrons affections which I expected to find in ergotism. 2d. Attributing the discolorations of the month to the remains of previous resications; the losing of the feet as a sequele to foot-and month disease aggrarated by neglect, and exposure to intense cold. 3d. Accepting the history of a case described to me by Dr. Holcombe, where he discovered an animal on the Keith place in the second or resicular stage of foot-and-month disease in which lie found several distinct characteristic vesicles in the mouth, accompanied by salisation, and another resicle in the eleft of the foot near the heel the size of a silver dime, and which he caused to rupture by a pressure with his finger, and registering a temperature of $104.4^{\circ} \mathrm{F}$. thl Ac. cepting as true the positive statement of $\mathrm{Mr}$. J. W. Beard, who lives 2 miles sonth of Mr. Keith. He stated that he had exchanged cows with Mr. Keith on the 1Sth of February, and that two days after he bronght the cow home from the keith place one of his cows contracterl the disease, and that several others followed in quick sincession; (this was strong evidence to prove the contagions character of the malarly); in the absence of recent cases, plaxing reliance npon the statement made by Dr. Holcombe, and upon his diaguosis, haring no valid objections to offier to it, I was led to conemr with him, and announced my belief that the clistase anong the cattle on the Keith and on the Goodrich farms wis epizootic aphthe. I went ont to the Keith farm again on Sunday, the !th, with the intention of obtaining a complete history of the ontbreak, to examine the quality of the feed, water, and soil, to make a more extended examination of all of the diseased animals, and to make post-mortem exaninations if opportunity afforder it. But when I arrired at the Keith place a strean of prople were passing in and out among the cattie. A delegation of stockmen were there with the avowed purpose of paring for and disposing of the diseased animals, and another number of persons were holding a eonsnltation in relation to petitioning Gorernor Glick, requesting him to convene the State legislature tor the purpose of enating laws and to make provision for the stamping ont of the distalse. These parties were monopolizing the time of the owners of the cattle, consernently I had to wait for a more tavolable day to aceomplish my work. This day, lowever, l made a more extented observation of the cattle on hoth farms, as I was exceedingly anxions to find a recent case. My seatreh was rewarded by finding a red yearling steer at keith's, which presenterl a blister at the anterior border of the soft pralate; it was about the size of a silver dime, and had a thin raised pellicle of mucons membrane which ruptured when I tonched it. Two small pointed resictes appeared on the upper surface of the tongue. No excessive salivation 
was present. A pinkish color was diffused orer the membrane of the montl atud tongne. Breathing accelerated; temperature 104.5०. In withluwing the instrument from the rectum an nleer was exposed to view, which bled slightly. (On the following day I saw this animal again and found the conditions unchanged, except that the blisters in the month had assumed the elaracteristic brownish-yellow color, similar to those found in the months of the worst cases. In the conrse of ten days this animal had about recorered.) On this ray I noticer ser. elal animals fiothing at the month, althongh they showed but slight in. dications of laneness, but for want of proper assistance was mable to catch them for closer inspection. On the Goorlich farm I found a 1 mm ber of cows and heifers to have discharges from the vagina, accom. panierl by thickening ecchymosis, or ulcerations of the inncons membrame of the vaginal walls. 1 noticed also small blood-elots and mucus or recently-chopped feces.

On Momday, the 10th, I looked again for recent cases, but did not succed in finding any.

Mr. Hindman gave me the following history: He has lived eight years on this place, and has been engaged in raising and feeding stock duriug tat time. He never before had any disease among his cattle. He took into a herd 5 miles cast, which was in charge of George Grant, 72 head of eattle last spring, and on the 10th of October bronght lome 7s head. During the summer 2 died and 5 were solel. Since the return of the 78 head $S$ calres have been born. These cattle, since the 10th of October, have been liept in a feed-lot, sheltered by timber, south and east of the house. They derived their drinking water from a pond (surface water) loeated in a field 20 rods north of the lrouse, and at abont the same distance from the residence and yards of Mr. Keith. On New Year's week he took all the cattle, exeept a few cows and a bull, ont of the feed-lots, driving then through a gate sontl of the house, and then drove them down the public roal a distance of 40 rods and turned them into a stalk-field and meadow, from whence they conld again retnrn throngh a gap in the hedge to the old feerl-lot and drinling place. He kejt 3 cows and a bull in a small field north of the honse, trom which they went to the same pond for water as did the other cattle. On or abont the 10th of Jantiary one of these milch cows became lane in one hind foot, and was yet lame when I saw her, bnt manifiesterl no indications of losing any part of her foot. The next cases of lameness appeared on the 14th of 15 th of Febluary, the dat after a leary rain and sleet storn. On that morning a number of cattle were lame, and new cases appeared daily for a mumber of rays there. after. The lameness attackerl cattle regardless of age, sex, or condition, old as well as yomng, and just as severely. As soon as they beeame too lame to get aromnd to feed and water they were driven into a small yald on the east side of the house, where they had a covered shed for sibelter, and feed and water was carried to them. In this shed 
the worst eases were kept, and in the west end of it a small stall was partitioned off' by a few fence boards, in which the bull was tied. This bull nerer manifested any symptoms of the disease. This is substantially the history which I obtained from Mr. Hindman on this das. With regard to the kind of feed which the eattle received, Mr. Hindman told me that all the eattle one rear old and upwards were fed mpon hay made on the bottom lands, that they depastured 30 acres of corn stalks, and lately received wheat straw in addition to the hay. The mileh cows, which were kept north of the honse, the bull, and the young calves received corn in addition to hag.

On a subsequent visit I was informed, either by Mr. Hindman or one of his hired men, that the hogs had been allowed to remain in the yard with the diseased cattle until they began to gnaw at their llearl feet, in consequence of which they were turned into the orchard. I also discorered that the roung calves hatd remained in this sard until they were crowded ont by the rapid increase of invalids.

History.-On the 11th of December Daniel Keith bought 63 head of rearling ealves from Mr. Joseph Davis, and brought them home on the 12th. Fom days previous to this time he had bought 5 yearlings from Nelson Stride, 2 miles sonth. He bought one from Wiiliam luge, 2 miles southeast, about a week later. Bought one from Balt. King, 22⿺ miles sonthwest of Neosho Falls, a day or two after the linge calf. Bonght one 4 miles south of Neosho Falls on or abont the 10th of Feb. rnary, and on the 20th bought 6 head from Alex. Linn, 1 mile down the river from Neosho Falls. On or abont the $23 d$ of December he first noticed the lameness to exist among the calves which he had bonght from Mr. Davis, aud lescribed their actions and symptoms as stated in the early part of this report, but he also stated now that in the commencement of the disease many of them slobbered profusely; numerons small blisters appeared in the month and on the tongue, and that they then refinsed to eat hay or rongh feed; that they manifested an inclination to lie in the snow, and on warm or sunshing days they sought cool and sheltered places. On the 1 st of January abont 30 of them were lane and new cases developed daily for a number of weeks thereafter, also that some were yet taking the disease while others hat recovered from it.

After the lapse of the first few days of sickness they regained their alpletite and ate as well as ever.

The best animal in the herd of yearlings, whieh was also one of the first ones taken siek, died on the 5th of Jammary ; he refised to a at corn, frothed at the mouth, and suftered intense pain. The seeond death oecurred on the 2Sth day of February; this was the ealf, which died two days after the mother of it was talien sick. One died on the Sth of Mareh; this one hat been suffering for ten weetis, and had lost hoth hind feet at the fetlock joints. Three were killed. The 8 heald which he bought sinee the disease broke out, all becane sick within two or 
three days after they arrived on the place. About a week after I obtained the above history Mr. Keith's hired man told me that only 4 or 5 of the 8 head bought subsequent to the ontbreak of the disease beeame affecterl. I also learned from Mr. Keith that in the early part of March he receired the report published by your Department for the year 1880 and 1881 , which contains a brief history and description of the foot-and-month disease; he read it earefully, and then made his first examinations of the mouths and states he foumd the conditions to accord exactly with the deseriptions there given.

Mr. Keith had another lot of eattle, numbering 40 head. These were two-year-old steers and heifers, and a few cows. They were kept in a timber lot, separated fiom the yearlings by an ordinary rail fence, and run into a stalk-field and received the same kind of wild hay as the yearlings. These cattle were bought on or about the 1st day of November. On the "sth of February the first case of siekness appeared in this herd, 15 or 20 of which manifested symptoms of the disease (March 10). Nearly all of these cattle were in excellent growing condition.

On the 13th I separated all of the well cattle from those showing any evidence of the disease on the Keith farm, and had the sonnd ones corraled by themselves. I recorted the temperature of a number of the yearlings which were diseaserl, which registered as follows: $103.8^{\circ}, 103 \circ$, $103.2^{\circ}, 104^{\circ}, 104.8^{\circ}, 105^{\circ}, 104.8^{\circ}$. A number of the milder cases registerell $100.3^{\circ}, 100.2 \circ, 101.8^{\circ}, 100 \circ, 101.5^{\circ}, 101^{\circ}, 100.4^{\circ}, 102 \circ, 101.5^{\circ}, 100.2 \circ$, $102 \circ, 101.6^{\circ}, 101.5^{\circ}, 101.2 \circ, 101 \circ, 101.2^{\circ}, 100.8^{\circ}, 100.2^{\circ}, 101.2^{\circ}, 102 \circ$, 102.20. (Here I broke my thermometer). This was quite a wam day, and I noticed an increase of temperature of nearly $1^{\circ}$ over the tests of the 9 th and 10th on the same animals. I found, ont of 118 animals then on the place, 74 affected ; of these 2 will lose all four of their feet; 4 have lost both hind feet; 9 hare each lost one hind foot; 1 four-yearold cow has lost both hind feet and one front toe: 2 lost each one toe; 3 are affected in one foot; 6 in two feet, and 1 in three feet, all of which will probably lose the parts affecterl. The rest were lame in various acgrees.

During my two weeks' observations among these cattle I fonn! only the one case (the yearling red steer) which I could eonsider in any manner a recent case.

On this day (the 13th) I also examined the pond of water from which the cattle were in the habit of drinking, but found nothing contained in it to which I eonld attribute the origin of the discase, and from the history which 1 was enabled to obtain I could not diseover any origin by contanination with foreign eattle. Yet it appeared to me that this ontbreak was very evidently not so contagious as the foot-and-month disease is known to be, and I began to lave very grave doubts alout its being contagions at all, or its being the gennine epizootie aphthe.

On the 11 th, in conpany with Mr. I. W. Beard, Judge Thateher, and Mon. Eli K. Titus, I drove out to the farm of Mr. Beard, and made a 
hurried examination of the eattle on his place, sitnateci 21 miles north of Yeosho Falls, in Woodson County.

I there found 5 animals, ont of a herd of 75 , affected similarly to those of Keith's and Goodrich's, althongh only one will lose both hind feet, and a.second one one foot. Mr. Beard attributed the origin of the disease among his cattle to the introduction of the cow from Keith's, as before mentionerl. As soon as he noticed any evidence of lameness he separated snch a one from the rest of his eattle, and thereto attributes the small number affeeted among his herd. Two recovered from Iameness after a few days. His eattle were fed on corn in the fodider and wild hay. The cattle drank from the Neosho River, which supplies good, clear water, and the approach to the drinking place is a grarelly bottom, free from mud. These cattle possess a timber shelter, with shed and hay-racks, and the feed-lot is sloping and well drained.

On the 1Sth I again risited Mr. Beard's place, aceompanied by Prot. M. Stalker, of the Iowa State University. No new catses had appeared since my previous visit. Mr. Beard was absent, but we saw Mr. A. W. Orrill, the hired man, who made the following positive statement: That he eame to Bearl's place to work on the 16 th of February; that on the following moming he noticed the old eow to be decidedly lame (this was the first one affected), and that on the 1 Sth he assisted in bringing the cow from Mr. Keith's for which Mr. Beard had traded.

The Keith cow was the second one to shor lameness, which was on the 22d. On the 1st of Mareh, the third one; a day or two later, the fourth one was slobbering profusely at 4 o'clock p. m., and died the next day at 10 a. m. The fifth one became lame on the 5th, and several others manifested slight lameness, but have recovered therefrom. At this risit to $\mathrm{Mr}$. Bearl's we examined the feed and hay rery elosely, endeavoring to find some cause for the appearance of this disease. We found mixed with the hay a large proportion of the wild rye, and found this wild rye to to be extensively ergotized. This diseovery at once accounted for the gaugrenous phase of the disease. We followed up this clue with avidity, and went directly to Keith's and to Goodrich's place, and found the same conditions present among the hay there, but not near so exten. sively as at Beard's. I had examined the hay at Goodrich's several times, but was unfortunate each time in seeing hay in the racks which contained lut very small amounts of the ergotiźed gralss.

On the 14th I separated the Goodrich cattle, placing the well cattle into a field by themselves. I fonnd 18 which had lost both hind feet; 5 had each lost one hind foot; 1 had lost both hind and one fore foot, and 1 was about to lose all four feet; 40 other's were lame in one or more feet. This left 31 well out of the 96 head. No new calses had appeared in this lierd during the time of my stay.

On this day I left for El Dorado, Butler Comnty, at the request of Gorernor Glick, to investigate a disease anong cattle said to be existing at or near that place.

$5751 \mathrm{I} \mathrm{A}-\mathrm{i}$ 
After my arrival I called upon Dr. A. Bassett, mayor of the eity. He told me that Mr. W. B. Collinsworth, residing 14 miles west, reported to him that he had a cow which appeared very stiff and lame, and that she had sores on the tongue. I drove ont early in the morning of the 15th and examined the cow belonging to Mr. Colliusworth, and found her to be recovering from a mild attack of puerperal apoplexy. I re. urned to Nrosho Falls on the same day. On the 17th I went to Hall's Summit, Coffey County, at the request of the county commissiouer of that district. I was directed to visit the residence of $M \mathrm{l}$. George R. Smith, who had a cow which had lost some of her feet. I found the cow presenting the following conditions: The left forefoot had come off at the joint within the hoof, the left hind leg har broken off half way between the fetlock and hock joint earrying the lower end of the metatarsal bone with it, and the right hind leg was coming off at the same place. The right horu had also broken off elose to the head. The cow was reduced to a mere skeleton, and was suckling a ealf. Mr. Smith gave the following history:

On New Year's night the cow became cast by being tangled up in the rope with which she was tied; she was found by him in the morning; was loosened, when she gotup and walked away. She ate and drank as usual. About a month afterwarls she began to show lameness in her hind limbs; frothed a little at the montl, and dicl not eat well. She gave birth to a calf on the last day of February. 'This cow was bought just before the holidays, and at about the same time he bought another cow. This second eow had a ealf one day later than the diseased one. Both cows and ealves have been kept in the same yard and on the same kind of feed, but only the one developed the disease. They were fed on chop, feed and wild liay.

I returned again to Neosho Falls on the 18th.? On the 19th, in company with Professor Stalker, I risited the Keith and Goodrich herds. On the 20th, in company with Dr. D. E. Salmon, of your Department, Dr. Stalker, Dr. G. C. Faville, of Colorado, and Dr. E. T. Haggard, of Lexington, Ky., I visited again the three affeeted herds, and also a fourth one owned by Christian Pribbernow, on Owl Creek, 12 miles south of Neosho Falls, Woodson County. Mr. Pribbernow owns 183 head of eattle, 54 of which are yearlings, 24 two-year-old steers, 15 three-year-old steers, 13 heifers with ealf, the remaincler cows and calves. At this place we found 16 affected, the symptoms and lesions being similar to those of the Keith and the Goodrich eattle. Seven of them will lose one or more feet, and the other 9 manifest lameness. 'Two or 3 which were slightly lame havo recovered.

Mr. Pribbernow stated that the disease male its first appearance on the 15th of Felusury, when several of the older eattle were noticed to be lame; soon thereafter swelling of the hind feet and extreme lameness appeared, rondering them unwilling to walk. He then placed 5 of the rorst cases into a small yarl by themselves. This yard was 
divided from the yard which held the yearling cattle by an ordinary rail fence. None of the yearlings becime affected. The large cattle had been fed on corn-fodder and wild hay, and the searlings in addition reeeived millet hay and oats. The wild hay on this place contained a great amount of wild rye which was extensively ergotized.

On the 20th we saw the cattle at Bearl's, Keith's, and Goodrich's, and found the conditions as lerein described. After making these inspections, it was decided by Drs. Salmon, Stalker, Faville, and myself that we believed the origin of the discase annong these four different herds of cattle to be due to the consumption of the ergotized grasses contained in the hay. But in order to more fully satisfy mrself, I requested Dr. Salmon to accompany me to a farm Iying adjoining that of Mr. Keith ; therefore, on the next day, we drove out to the farm of Mrs. Dipple, which is sitnated west of Keith's. We there examined the hay and found it to contain a very small amount of the ergot. We also examined several of the cattle and found slight discolorations of the mouth, yet the eattle had nerer shown any lameness or indisposition whaterer. We then looked over the well eattle on the Goodrich farm, which had been separated from the sick by me on the 14 th, but fonud no new cases.

During the course of my investigations I killed 3 animals for the purpose of examination into the condition of the internal organs. In one I found eulargement of the heart and softening of the muscular walls; in another I found an infiltration of a purplish-colored fluid into the mesenteric glands, and in the third one I found no abnormal condition of any organ to be present. In all of these 3 I examined the alimentary canal very closely, but failed to find any pathological changes in its membranes or glands; these animals had each lost both hind feet. In carefully considering the conditions presented by all of these diseased cattle, and well weighing the value of the histories as given by the owners, I firmly believe that the disease may be called the "chronic" or "g:ungrenous form of ergotism."

\section{Ziemssen says:}

It is not eertainly knowu why in the one case the ergotism assumes the spasmodic, in the other the gangrenous form. But it seems renarkable that the spasmodic form formerly prevailed chiefly in Germany. while the gangrenons form was found principally in Fance, and there partienlarly in the Sologne. But this differench does not hold universally, for epidemics of the gangrenous form have appleared also in Germany, Anstria, Rnssia, and Sweden. It is not known whether this variety depends upon the difference in the activity of the ergot in difiercut seasons, or whether sneh changes are the result ol some peculiar property of the ground in which the corn grows. In the Sologne it was generally the ergot of maize which produced the poisonons symptoms, whereas in Germany the ergot of rye was a most exelusively mentionerl as the eanse of the disease. It is, however, very improbahle that the diflerence between these illnesses is drpendent on the difierent parent plants, becanse at least therapentieally the same enfects "an be produced hy the ergot of maize als by that of rye, when the cumutities are equal. It is most probalile, then, that there is a simple quantitative difference in the alssolute and relative grantity of the poison taken into the system. 


\section{Of the action upon the human system the same writer says:}

The poison of this drug (ergot) lias a special and most powerful action upon the skin. Besides rery abundint perspiration, pustules often break out, or even larger furunenli. The exanthenata sometimes resemble seabious eczema. They apjear in the later stage of the malady; as, e. $g$., in Aschott's case, fonteen days after the first appearance of symptoms of poisoning. But other disturbauces of nutrition iu the peripheral organs are also reported, as, e.g., whitlows on the fingers, occurring as late as the fourth aud fifth reek, and diseases of the finger nails, which are encircled by a dark ring. Carliac contractions are generally slow aud feeble, the arteries are constricted and coutain little hlood. The respiration is very labored duriug the spasms, but tolerably regular in the free intervals. When death supervenes it is usually not until atter a fortuight or later; the courulsions may have ceased, ret loss of sight and hearing, with violeut headache, stupor, and delirum, may set in, attended with diarrhea; and thus the fatal stage may assume the form of typhus and general collapse. Death is geueraly ushered in by either convulsions or paralytic symptoms. The whole form of the illuess, therefore, is very variable, and its tourse lighly irregular. 'The illness may last four to eight weeks, and even longer.

The symptoms which characterize gangrenous ergotism as such, ofteu appear within from two to seven days, but are frequently delayed for two and three weeks. An erysipelatous redness shows itself on some spots in the periphery, most frequently ou the toes and feet, but also on the fingers aud hauds, more rarely on the ears and nose; soon after, the epidermis is raised like a bladder by serous exudation; the ichorous contents of this are soon discharged, and a gangrenous spot more or less large is left. Then dry gangiene develops very rapidly at the affected spot.

The part affected is very painful while the redness is invading it ; but later on it becones quite insensible. The gangrenons spot may exhibit either the dry or moist form, according to whether the discharge was ehecked or encouraged; npon this also depends the greater or less intenseness of the odor or putrefaction. In some cases the gangrene was limited to one or more toes, sometimes only to single phalauges; in other cases, howerer, the entire foot or hand was affected: not infrequently the gangrene extended to the trunk; it was possible for the patient to lose both feet or both arms. Indeed, a few cases are reported in which all four extremities were lost. The gangrenous parts become separated from the healthy tissne by a well-defined line of demarkation, and the affected part may fall off itself or must be remored by an operation. This process of demarkation is often attended with serious disturbances of the general condition of the patient; sometimes a modified form of continued fever is dereloped followed by phthisical chauges: in a few eases, from absorption of ichorous matter, pyxuia and septicemia set in, and are, of course, fatal. When the gan. grone was coufiued to parts of minor importance, the patients usually recovered; greater losses were naturally more frequeutly fatal. In some cases obstiuate diarrhea brought on usarasmus and death, even when the extent of the gangrene was not very considerable. We must mention, however, that in many cases the diseased process did not advance beyond the erysipelatons redness; marked cyanosis may be observed, and yet a separation may take place aud the circulation be restored. The duration of the entire illuess varies, aud mas be protracterl throngh sereral months. In favorable eases the conrse is ended in a few weeks.

This form of gangrene, like all other forms, depends on the fact that the part affected is deprised of its blood supply, aud its nutrition thereloy arrested ; consequently, it must pass into a state of decomposition. 'The only question which can he advancen here is whether it is inflammation which leads to gangrene, or whether the process is of a nou-inftammatory claracter, resembling that which oecurs when all the vessels going to a limb are ligatured. When we consider that the initial, so-ealled erysipelatons redness is simply dependent on the cranosis, and that these spots are not, as in a case of inilammation, hot aud swollen, but, on the contrary, they become very cold, and warmth cannot be restored in them, and that the affeeted limb is not at all swollen, 


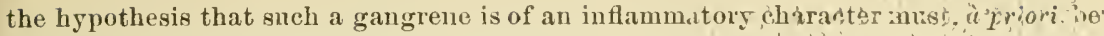
rejected. When we further reflect that there is no ferer at the ontset, the second hypothesis becomes still more probable. Exelusion of an extremity from its ordinary blood supply is quite conceivable from our enrrent views of the aetion of ergot on the vessels and the distribution of blood.

On the 10th of April I was requested to go 8 miles north of Sterling to the residence of Mr. John Kratz, who said that he had a number of cattle affected with lameness and sore feet. I proceeded to his place at once, and examined his herd of cattle, numbering 30 head. I found 11 cows and heifers more or less affected with excoriations in the elefts of their feet. In sereral cases I found these excoriations to extend around the bulb of the heels, cansing a separation of the horny walls at the coronet from the fibrous structure of the foot. In one cow, twelve Jears old, I found considerable ulceration at the bulb of the heels of both fore feet; the matter burrowing beneath the horny wall caused a destruction of the wall to the extent of 1 inch downwards, and the imperfect formation of an inch of the horn at the front part of the feet indicated that she had been affected for tro months or longer. These excoriations discharged a semi-liquid matter, which gave off an odor like to that of thrash in horses' feet. Mr. Kratz stated that two of the cows walked with difficulty for sereral weeks, and that for a week or more previous to their lameness he detected the peculiar odor arising from the feet while milking. On the 13th of March he bought a thor. onghbred short-horn heifer, and one week after he brought her home she also became lame. Then I saw her she was affected in all four of her feet, ant was exceedingly lame. All of his cattle, with the exception of two that were over two years old, were affected. In none of the feet was there any swelling, but they were extremely sensitive to handling. The disease appeared as frequent in the fore as in the hind feet, and in several cases three or all four of the feet were affected alike. The majority of them beeame lame while the ground was yet frozen up. Mr. Kratz has one of the finest bank barns in the county, and takes excellent care of his stock. He stables his cattle at night and on stormy days; they lave good bedding at night, and the stalle are cleaned daily. In pleasant weather the eattle were turned into the barn-yard. This yard is eovered almost daily with clean straw to be worked into mannre. The yard is sloping and well drained, and the cattle drink well water from a trongh laid in the yarl. During the winter the eat. the received ground feed, timothy, and clover hay, but about the 1 st of March he began to feed rye bran and second-erop meadow hay; the latter contained a large proportion of blue or June gratsi, and an exam ination of it revealed that it was ergotized; almost every seed capsule contained the fungus. If the ergot in the hay did not prorluce the disease I am unable to account for its origin. The cattle were not in a plethoric condition; the yarl was free from mul, and they were well loused, and the stables.kept serupulously clean. 
The disease was what would commonly be caller fonl in the foot. I treared them by eleatuing ont the clefts of their feet, applying carbolic acid solntion and tar secured to place by a wad of oakum and bandage. In ten days recovery was complete.

Mr. Thomas Comboy, of Hume Township, had 2, and Mr. Edward Tyne had 1, affected similar to those of Kratz.

Respectfully submitted.

Sterling, Ill., March 27, 1884.

M. R. TRUMBOWER, V. S. 



\section{SYNGAMUS TRACIIEALIS.}

\section{EXPLANATION OF PLATES.}

Plate I. Fig. 1.-The trachea of an adult pheasant, whose death was caused by the gapes, slit open longitudinally, and showing, in its interior aud attached to the mucons membrane, abont thirty pairs of syngames in various stages of ilevelopment (natural size).

FrG. 2. $-A$ pair of syngames, attached with the month of the male and that of the female (enlarged 4 diameters).

Frg. 3.-A pair of syngames enlarged 10 diameters; A, male; B, female; showing the intestinal canal, the osophagus, and the buccal capsnle. In the female $B$ may be seen, in addition, the uterus and its horns filled with ora and the ovarian tube coiled around the uterus and the intestine. In the male A the testicle is seen coiled about the digestive tube.

Fig. 4. Month of a female syngame; A, seen from its face; B, from the side (enlarged 40 diameters).

Frg. 5.-Portion of the neck of a female (enlarged 25 diameters), showing at $a \boldsymbol{a}$ the cuticle finely striated; at $b$ the subcutaneons, fusiform, muscular fibers; at $c$ the csophagus; at $d$ a salivary gland; and at $e$ the anterior extremity of the intestine into which the esophagns opens, and which is seen lined with hepatic cells.

Plate II, Fig. 6. -Reproductive organs of the female (enlarged 8 diameters); a, uterus; $b b$, uterine horus ; $c c$, oviducts or Fallopian tubes; $d d$, ovaries.

FrG. 7. Reprodnctive organs of male (enlarged 20 cliameters); $a$, spicules; $b$, spermatic canal; $c$, vesicula seminalis ; $d$, testes.

Fig. 8. - Ova in different stages of development (enlarged 260 dianeters). A, vitellus, segmented and muriform; B, ovum with granular vitellus, beconing constricted at its midlle, the embryo developing laterally; C, ovum with embryo fully developed, folded like the figure 8 ; D, ovum with the valves - at the extremities detached, and the embryo emerging.

Fig. 9.-Embryo directly after leaving the egg (enlarged 260 diameters).

Fig. 10.-Embryo somewhat older, undergoing the first molt (same enlargement).

Fig. 11. - Nymph (enlarged 100 diameters); $a$, rushment of the genital organ.

5751 D A 


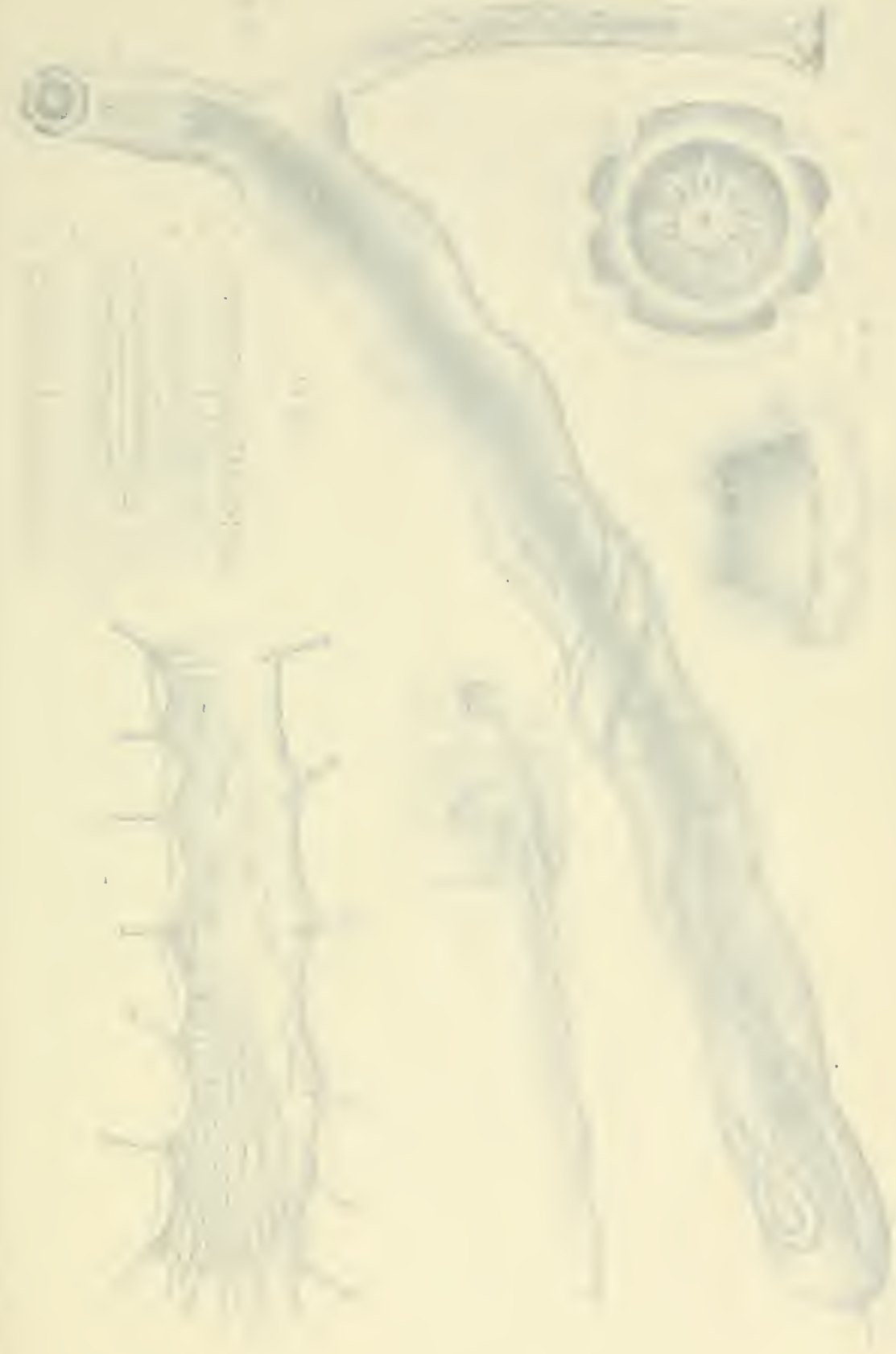




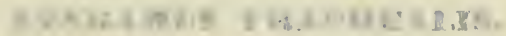

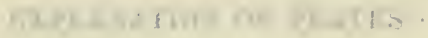

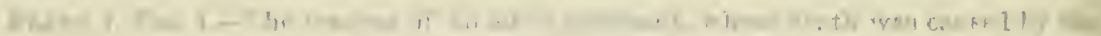

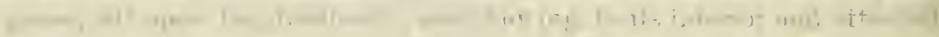

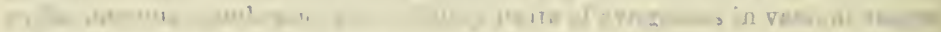

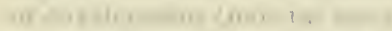

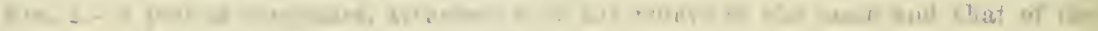

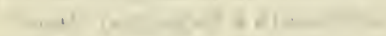

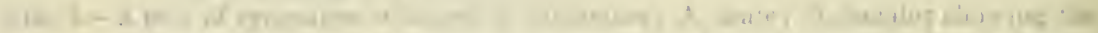

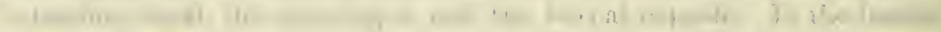

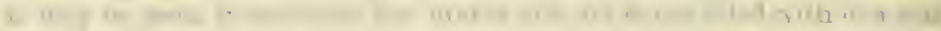

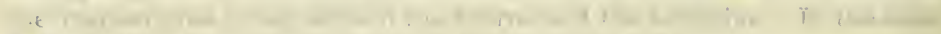

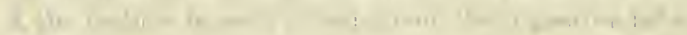

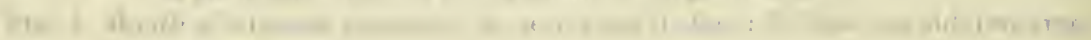

, :

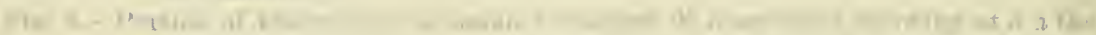

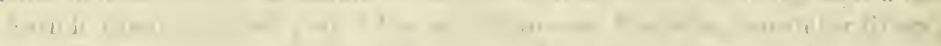

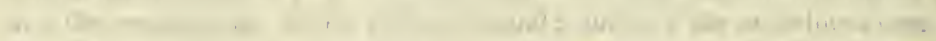

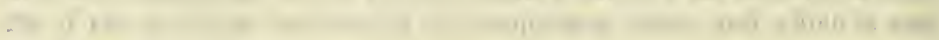

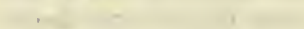

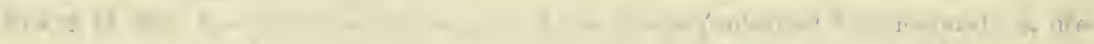

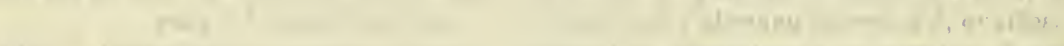

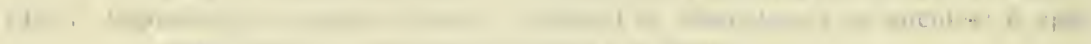

(1)

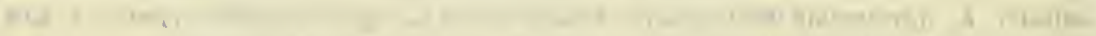

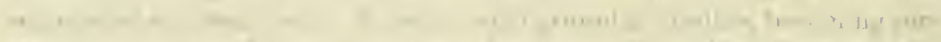

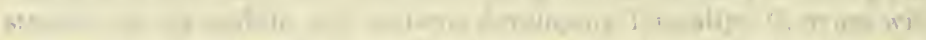

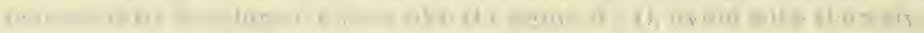

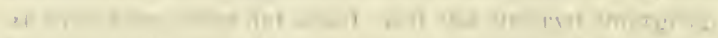

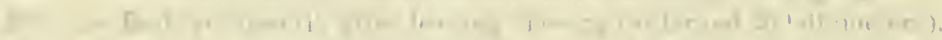

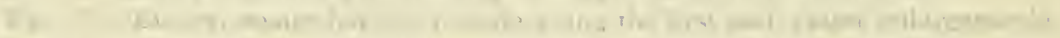

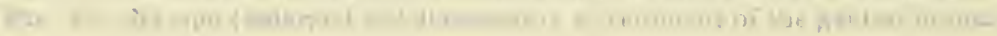

Wh $w$ 


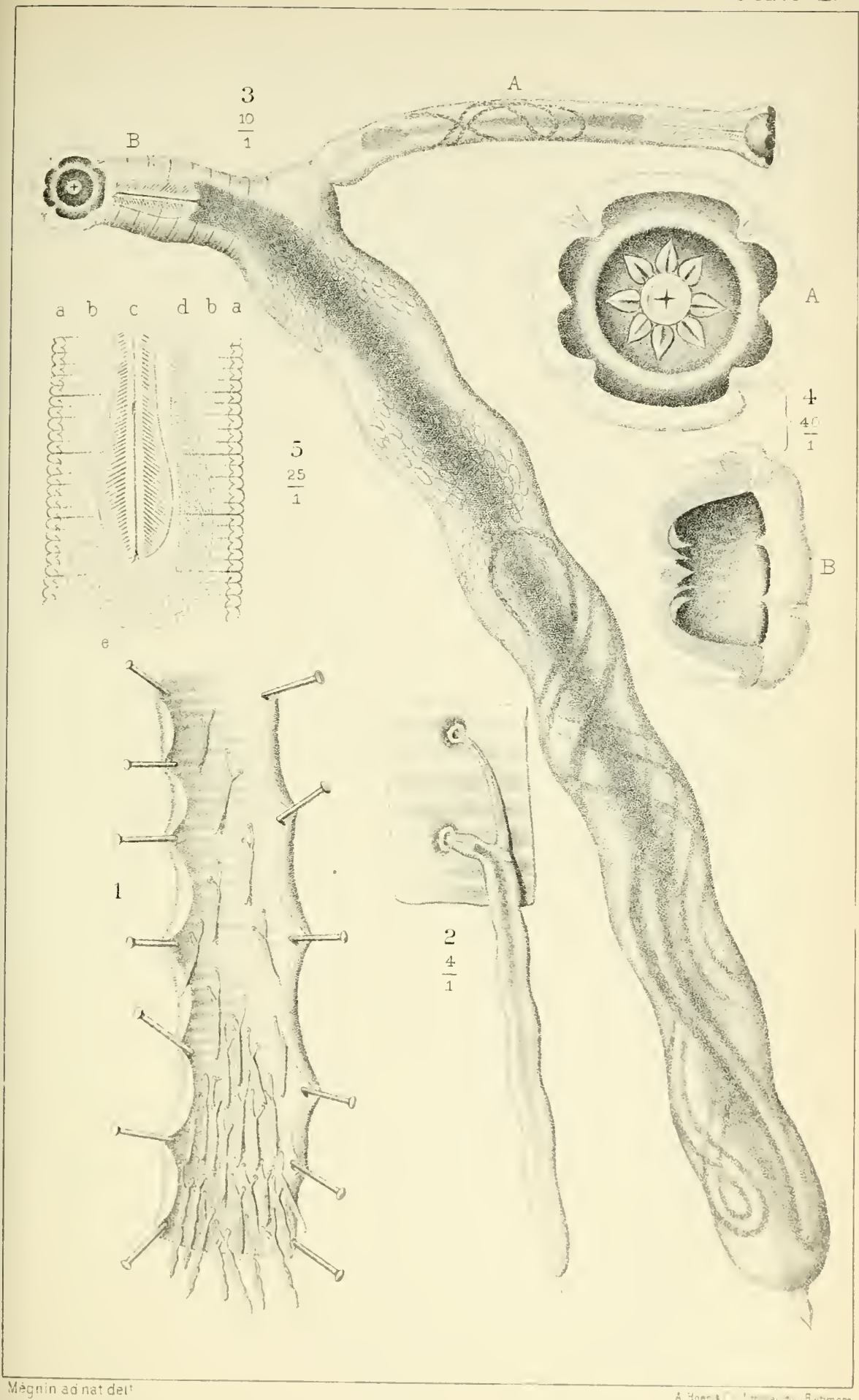

THE GAPE-WORM OF FOWIS,

Syngamus trachealis (v. Siebold.) - Sclerostoma syngamus (Diesing) 



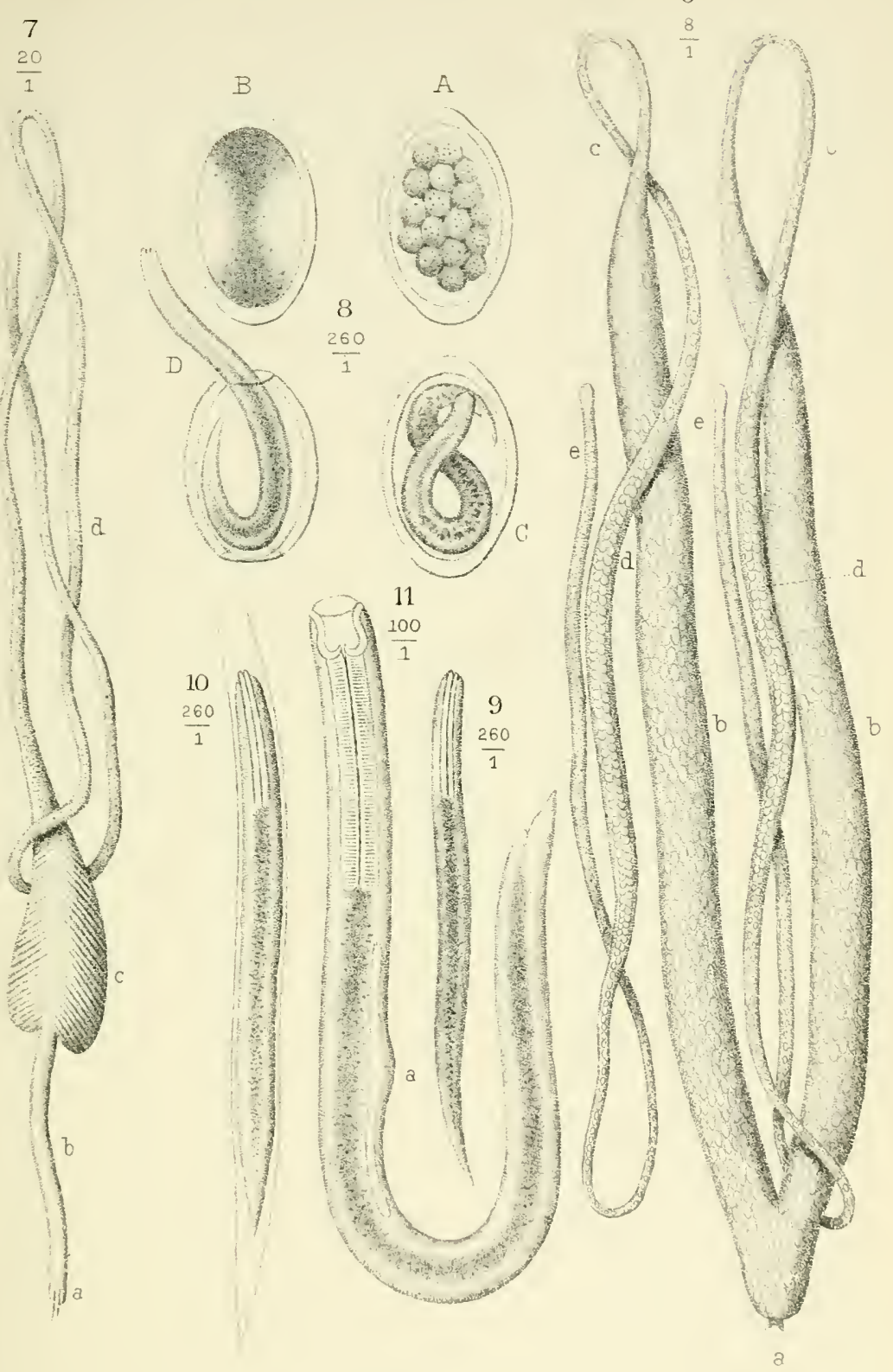





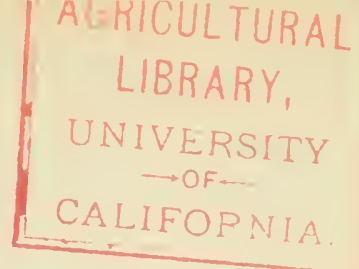

\section{THE GAPE DISEASE OF FOWLS, AND THE PARASITE BY WHICH I'T IS CALSEI).}

IEUOIR ON A TERMINOCS EPIZOOTIC DISEASE OF THE PHEASANTRIES* AND ON THE PARASITE WHICH CACSES IT, THE STYGAMUS TRACHEALIS (SIEB.), SCLER OSTOJIA STYGAJUS (DIES.), BY M. P. ILEVII, LAOREATE OF TIIE INSTITUTE (ACADEMIE DES SCIENCES), HEMBER OF THE SOCIETE DE BIOLOGIE. HONORARY ASSOCIATE OF THE ROYAL TETERIYARY COLLEGE OF LONDOX, ETC.

[Translated by Dr. Theobald Sirti.]

For several years past the pheasantries of the hunting forests of France have been ravaged br a most destructice malady, which has killed the fowls by the hundreds and eren thousands. The canse is a parasite, a so.called red worm, which develops in the trachea of birds and finally suffocates them. Particularly the young subjeets, from six weeks to three months of age, are apt to be the rictims, although adults by no means are always spared. The chief symptoms of this affection are a suppressed or aborted cough and a characteristic gaping, whence is derived the English name "gapes." It appears to have been observed long ago in England and Ameriea, whilst with us it has not jet been studied, a fact which seems to indicate that it has been introduced from England, and that we owe its introduction to commerce by which the hunting grounds have been restocked.

I inrestigated this disease on the site of its activity in the inclosures of the forest of Fontainebleau in 1875 and 1879. I received many carlavers killed by the red worm from different localities of central and northern France; from the poultry-yard of Baron Rothschild, at Rambonillet, where the daily losses amounted to 1,200 ; from II. de Janzé, of Gournay ; from the duchess de la Rochefoncanlt, at Montmirail ; from the inclosmes at C'hauteau-nenf, and from various localities of Loiret and de l'Indre. Finally a dispatch, in October, 1S50, informed me that the epidenic had appeared in the royal pheasantries at 'Turin, and was threatening to do much mischief.

This risease is not at present laging on the continent only. For ten years it has been the (anse of severe losses in England. Dr. Crisp) estimates that the red worm rlestroys ammally lalf a million ehickems, exclucling pheasants and partridges, so that he silys it would he of truly national importance to find the means of preventing the invasion

* This monograph, funisherl November, la-0, has reference to thr epirlouries in tho pheasantries of France. 
of this red worm or of destroying it.* Furthermore, the following statement is taken from the report of the meeting of the London Entomological Society, October 1, 1879 :

The president announced that Lord Walsingham, in conjunction with other gentlemen, had placed at the disposal of the conncil the sum of $£ 100$ to be awarded in two prizes of $£ 50$ each for the following sulyjects:

1. The best and most eomplete life history of Sclerostoma syngamus, supposed to prodnce the so-called gapes in poultry, game, and other birds.

2. The best and most complete Iife history of Strongylus pergracilis (Cob.), supposed to produce the grouse disease.

No life history would be considered satisfactory unless the different stages of derelopment were observerl and recorded; the competition was open to naturalists of all nationalities. Essays in English, German, or French were to be sent to the secretary of the society on or before October $15,1882$.

Althongh birds only are eoneerued in this matter, it is obvious that the economic interest involved in a solution of the questions con. cerning the gapes is sufficiently great. The scientific interest is no less so, beeause there is to be determined not only the zoologieal position of the worm under eonsideration, and its rôle in the terrible disease which destroys the gallinaceans, both domestic and wild, but also its mode of reproduction, a point hitherto entirely unknown.

This is the subject of the present memoir, a memoir in which I beliere I have eleared up all the pending questions npon the zoologieal position of the red worm, on its anatomy and physiology, on its rôle as a canse of the gapes, finally on its embryogeny and metamorphosis, and consequently upon its mode of propagation, and upon the best means of preventing its multiplication aud arresting its rarages.

\section{IIISTORICAL.}

The first mention of this disease was made by Dr. Wiesenthal, who observed it in 1799, at Baltimore, Md., among hens and turkeys.t In 1806,1807 , and 1809, Georges Montagnł saw this epizootic among chickens in England. He believed that of all the birds of the ponltry yard only the hen conld be its rictim, becanse he ouserved that the turkeys and ducks living with the infested hens were not attacked. He observed the same malady in young pheasants at a time when they as. sume the livery which distingnishes the two sexes, and in partridges whether the locality was elevated or low and humid.

Both Wiesenthal and Montagn recognized that this disease was caused by worms occupying the trachea and extending occasionally to the pharynx, but never an far as the lungs. They fomd as many as twenty at. tached to the mucons membrane, which, together with the lungs, was

* Path. Society of London, Oetober 15, 187?, ant Ifed. Times, 1-72, p. 4 7.4.

t.Merlical and I'hysieal Jourual (1799), II, p. 21).4.

$\$$ Account of a sprecies of fasciola which intests the trachea of poultry, with a mode of enre, Trans, of the Wornerirn Niet. Hist. Soriety, I (1811), 1) 195. 
in an inflamed condition. These entozoa, acting finally as an obstacle to the passage of air, produced death by asphyxia.

Wiesenthal did not ocenpy himself with the specifie determination of the worm, but Montagu regarded it as a distome, a fasciola (fluke) of a particnlar kind, having a round eylindrical body with two sneking disks, borne on two pednucles of mnequal length.

Rudolphi* and the authors of his time eontinned to regard the eanse of the gapes in the gallinaceans as a distome, and included it in the species Distoma lineare (Rnd).

Shortly after, helminthologists discovered, upon a variety of birds, a curions parasite likewise inhabiting the trachea, but this time belonging to the order of nematodes, and espeeially eharacterized by the singular habit of permanent mion of the sexes. Siebold $\dagger$ made it the type of a new genus-the genus Syngamus; later, however, yielding to the observations of Nathusins, he renounced his first idea and united this helminth with the strongyli in naming it Strongylus trachealis. $\ddagger$

After the creation of the genus Sclerostoma by Dujardin, in which this anthor nnites the old strongyli possessing a month which is armed with a tongh coriaceons eapsule, Diesing placed in it the Strongylus trachealis of Nathusius under the name of Sclerostoma syngamus. Finally Dnjardin § restored for this parasite the old genus Syngamus of Siebold, and gave it the old speeific name of syngamns trachealis of the same author.

Dujardin ascribes to the genus symgamus the following characters:

Worms ordinarily conpled in a permanent manuer or by mion of the integmments; the male, eylindrical, mueh smaller than the irregnlarly eylindrieal female, with constrieted neek and tail tapering to a point; head globnlar, large, snpported by an internal corneons eapsnle; mouth large, irregularly rounded, with six or seven broadened lobes; pharyux provided with fleshy papillie; integmment folded or wrinkled withont regnlar strie. The male has a truneated tail, the latter provided with a membraneons expansion whieh fastens itself to the integument of the female. The female has the tail eonieal, elongated; vulva sitnated anteriorly at the bise of the constrietion forming the neck; eggs large, elliptical.

The following, according to the same anthor, are the characters of the only species Syngamus trachealis, which this genus includes:

Borly soft, eolored bright red by a licynil interposed between the viseera. Male 4 to $4.5^{\mathrm{min}}(.157-.177 \mathrm{inch})$ long; $.4^{\mathrm{mm}}(.016 \mathrm{inch})$ wide ; eularged, obliquely truneated heal about $.7 \mathrm{~mm}(.028$ ineh) broarl. Tail terminated obliquely hy a convex, milateral, membraneons sae or bursa .25 to $.33^{\mathrm{mm}}$ (.009 to .012 ineh) loug, attached to the superior border of the valva of the female and supported by 12 to 15 equal rays. Female $13^{\mathrm{mm}}$ (.512 ineh) long; . 3 to $1^{\mathrm{mm}}$ (.01 to .04 ineh) broad, irregnlarly folded and wrinkled; head $1.3^{\mathrm{mm}}$ (.05 ineh) broarl tail resembling in elongated cone; ants $1.2^{\mathrm{mm}}$ (.047 inch) from extremity ; projecting vnlva at the base of a neck 1.5 to $2 \mathrm{~mm}$

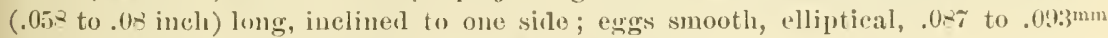
$(.0034$ to .0036 ineh) long, witl a short terminal neek.

*Synops. 1']. 414, 415.

$\dagger$ Archir $f$. Satmegeschichte, WViegmann (1-35), 1). 1.

†., e., 1833 .

fo Irstorei nat. des hetminlhes in snites a Bnflon. Roret, Paris, 1545, 1) 260. 
Dujardin found the Synyamus trachealis to the number of five pairs in the trachea of two magpies (Corvers pica) at Rennes. He was able to determine that even after maceration the male conld not be separated from the female without rupture of the integuments.

This parasite has been found by Nathusius either in Germany or in England within the trachea of the following species: The swift (Cypselus apus), the starling (Sturms vulgaris), the green woodpeeker (Picus rividis), the pheasant cock (Phasianus gallus), and the black stork (Ciconia nigra), granting that it was the same species.

What relation exists between the two parasites of the birl's trachea spoken of above-the fasciola of Montagu, the cause of the gapes, and the Syngamus of Siebold?

Dujardin aud Diesing regarded as entirely erroneous the classification among the distomes of the parasite found by Montagn in the trachea of birds affected with the gapes. This parasite was to them none other than the Syngamus, but as they did not enter into any details concerning the accidents which it is liable to produce, some doubts appear to have remained in the minds of French helminthologists concerning this assimilation. For we read in M. Davaine's treatise on Entozoa (2d ed. p. 37) the following statement concerning the parasites which canse the gapes among the Gallinae:

These entozoa, which for a long time have been referred to the distomes, are probably identical with the Selerostoma syngamus, a nematode worn, to which the permanent union of male and female has given a partienlar physiognomy which has deceived the earlier observers.

The word "probably," in the above extract well inclicates that for M. Davaine there was as yet no certainty that the gapes was cansed by the Syngamus trachealis; there was only a probability. Moreover, in the latest, fullest, and most noteworthy article which has appeared in France on the subject of helminthology as applied to domestic animals, * the author, M. Baillet, without saying a single word about the terrible disease, the gapes, with which in fact he does not seem to be acquainted, limits himself to noting the existence of Syngamus by the following sentence :

IBefore concluding the tribe of sclerostomes, we will mention the genus Syngamus (Siebold), a parasite of varions birts which has been oceasionally olserven in the trachea of the cock and the hen.

This is all he says of this parasite. Up to the present, then, there have been only vague conceptions or none at all, eoncerning the pathogenic action of syngamus.t Even its natural history is poorly known, since in a remarkable monograph on a new nematorle of the genus Hed. ruris $\ddagger$ Prof. E. Perrier, citing incidently the helninths which present the

Article Helminthe, Diet. Féterin. of Bonley and Regnal, vol. 11 I. P'aris, 1866.

+ Aceorling to Cobboli the Syrigamus is the sole eause of the gapes.

Nonvelles Arehires du Museum, vol. VIJ., Paris, 1871. 
peculiarity of a male united permanently to a female, says, concerning the parasite under discussion, page 6 :

Among the nematorles of the genus Syngamus the male lives attached to the female by means of a candal sncking disk and twines himself about her as does the male of Hedruis.

This last statement italicized cuntains an error which proves that M. Perrier had not jet seen the syngames in the position which they occupy in the trachea, for the male is never coiled about the female, as we will show further on, and as we have enabled $\mathrm{M}$. Perrier to demonstrate for himself.

We are now permitted to say, after having studied the gapes in the varions pheasantries of central France, and the enviromments of Paris, where this terrible epizootic has claimed thousands of rictims, that we know positively that the parasite which canses it, the so-called forkedworm, or red worm of the pheasant breeders, is none other than the Syngamus trachealis, and by no means a distome; we know that it corresponds entirely with the general characters traced by Dujardin and Cobbold, if we except a considerable number of anatomical and physiological details which we have to add or to rectify, and its migrations and habits which have thus far remained wholly undescribed. There was complete ignorance of its mode of development, reproduction, and its transinigrations. All these we have been able to follow experimentally or in the poultry-yards, and hence to deduce the most rational indieations to combat the gapes suceessfully and to arrest its spread. Experience has fully confirmed our deductions.

\section{ZOOLOGICAL AND ANATONICAL DESCRIPTION.}

We must, at first, rectify the diagnosis of the genus and species as given by the authors, because it appears to us faulty, especially in that which refers to the mouth-parts. We present the following diagnosis of the genns:

Mouth large, supported by a hollow, hemispherical, chitinous capsule, its background furnished with six or seren elitinous, entting papilla; border thick and turned back (retroussé), cut into six symmetrical lobes, uniterl to the integument by its entire external face, and furnished by it witlı four equal membranous lips, which form a prolongation to the lobed border of the capsule. To this they are mited by fonr bands, which attach the commissures of the lips to the four deeper notches between the lobes of the eapsinle. Female fixerl by its month to the tracheal mucons membrane of its host; the male likewise attached by its month to the same mueous membrane and mited immovably by its candal bursa to the rulva of the female, around which it is soldered, as it were. The two spicules exual, contignous, extremely fine, and very short. Ova provided with a valve at each end of the longer axis. The ecl-like embryos are developerl within the uterus of the female whence they 
emerge ouly at the death of the latter. Cuticle, with very delicate striæ, disappearing with age, but persisting in the cervical region.

Are there sereral species of Syngamus? Up to the present time helminthologists have agreed to admit but a single speeies, the Syngamus traehealis of Siebold; but the characters which they attribute to it differ in eertain points from those of the species which we have studied as infesting the pheasants in France. Thus the latter attains twice the dimensions giren by Dujardin. The head of the male, says this observer, is obliquely truneated, while in the species examined by ns it is squarely terminal. The tail of the female, Dujardin continues, is an elongated cone and the anus $1.2^{\mathrm{mm}}$ (.047 inch) from the extremity; while in the parasite of our pheasants the tail is either abruptly eonical or rounded like a stump and pointed; in other words, it has the form of a eylindro-eonical appendage, springing from the middle of the rounded posterior extremity (Plate I, Fig. 3); the anus opens at the base of this small tail, which is not more than 1 to $.2^{\mathrm{mm}}(.004$ to .008 inches) long.

Unless there was some error of obserration, or some typographical mistake in the figures, or mnless Dujarlin had not seen the highest degree of development which the syugames attain, the parasite of the pheasant wonld constitute a distinct speeies, or at least a rariety.

Withont wishing to decide this question, which is only possible by making a direct comparison of the individuals found on different species of birds, we shall give the diagnosis of syngamus trachealis after the species or variety which infests the pheasants before offering a detailed deseription.

Body cylindrieal, becoming with age, in the female only, more or less sinuous or torulose; colored bright red by the eoloring matter of the absorbed blood which tinges the nutritive fluid interposed between the organs.

Male $2^{\mathrm{mm}}\left(.079\right.$ ineh) long and.$^{\mathrm{mm}}(.007 \mathrm{~S}$ inch) broad at the beginning of mion with the female, and reaching a length of $6^{\mathrm{mm}}(.236$ inch) and a breadth of . $5^{\mathrm{mm}}(.02 \mathrm{ineh})$ at the end of ovulation. Body always eylindrical, surpassed in its diameter by that of the head by.$^{\mathrm{mm}}$ to $.3^{\mathrm{mm}}$ (.007S-.012inch); posterior extremity slightly club-shaped, inelined, oblique, terminated by a membranous bell-shaped sae or bursa, higher anteriorly than posteriorly, where it is eleft and notehed along its entire height, suplorted by twelve simpie rays, mited to the vulva.

Female about $5^{\mathrm{mm}}\left(.197\right.$ inch) long and $.35^{\mathrm{mm}}(.0137$ inch) broad at the beginning of copnlation, attaining a length of $20^{\mathrm{mm}}$ to $2.2 \mathrm{~mm}$ (.757-. 866 $\left.i_{\text {nch }}\right)$, and a breadth at the middle of the body of $1.1^{\text {mun }}(.043$ inch) at the end of ovulation; body at first eylindrieal with delieately striated integument, becoming later more or less sinnous, tormlose, and smooth, the stria persisting only in the eervieal region. Ilead $1^{\mathrm{mm}}$ (.039 inch), broal at the period of complete development, surpassing the diameter of the neck by .2mm (.007s inch), which is itself smaller by . $3^{\text {mm }}(.0118$ 
inch) than the diameter of the middle of the body. Vulva springing from the base of an inclined neck, which is $1.5^{\mathrm{mm}}$ to $3^{\mathrm{mm}}$ (.059--.118 inch) long. Ora innumerable, smooth, elliptical, $.085^{\mathrm{mm}}$ to .09 $0^{\mathrm{mm}}(.0033-.0035$ inch) long, and .05m (.002 inch) broad, each pole elosed by a hood-like, hemispherical ralve, which becomes entirely detached at the time of hatehing. Embryos eel-like, dereloped in the body of the female, which sets them at liberty only by its death and the destruction of its body; at birth they measure $.28^{\mathrm{mm}}$ (.011 inch).

Habitat of the arlults.-Trachea of plieasants.

We shall now study in detail the rarious parts of the body in the following order :

1. The general enrelope of the body, consisting of the cuticle and the muscular layer lining it; 2 , the digestive tube with its accessory parts; 3 , the nerrous system ; 4 , the system of excretory vessels; 5 , the male and female genital apparatus as it exists in the most highly developed adults.

Bodly envelope.-The cuticle (Plate I, Fig. $5, a, a$ ) is very thin, about $.05^{\mathrm{mm}}$ (.002 inch) thick, diaphanous, in appearance homogeneous, for we have been unable to distinguish sereral layers, as has been done with the larger nematodes. In young snbjects it bears fine transverse strix, but in old and mnited pairs of which the female is bearing eggs, and es. pecially when these eggs contain well-developed embryos, the stria of the trunk are completely eftaced, but persist on the neck, where they can be best seen in the female, in which they are $.087^{\mathrm{mm}}$ (.0034 inch) apart, each fourth or fifth being deeper than the rest. Around the month the cuticle expands like a collar or gamopetalous corolla, with four equal rounded divisions forming four lips. At the same time it furnishes a broad margin to the thick and scalloped border of the buccal armature. In the male the cuticle goes to form the caudal, bell-shaped bursa, which is cleft posteriorly and longer anteriorly, the latter aspect being probably the true dorsal aspect of the worm. This bursa is supported by six simple rays on each side. It caps the hemisplerically projecting vulva of the female and is united to it so intimately that eren after the death of the worms and their maceration in water it becomes torn before it can be separaterl from the vulva.

The muscular layer which lines the internal surface of the enticle forms four longitudinal bands, as among the other nematoid worms, two dorsal and two rentral, separated from each other by four linear intervals. 'These muscular tracts are very delicate and permit the internal organs to be seen through them. Only the superficial layer is distinguishable. It consists of longitudinal fusiform fibers (I'late I, Fig. $5, b$ ) and is lined with parenchymatous cells, which may be regarded as a deeper muscular layer.

Digestive apparatus.- ln the digestive tract three regions may be dis. tinguished-the mouth, the asophagus, and the intestine.

The moutl (Plate I, Fig. $4, A, b$ ) opens on the anterior extremity of 
the body. It is surrounded by four equal symmetrieal lips already deseribed. At the four commissures of these lips maty be seen four strong bands or nerrnes, which unite the membraneons labial circle to the coriaceous armature of the moutl. 'This armature, made up of brown chitine, has the form of a complete hemispherical capsule or enpule, the thick border of which is divided into symmetrical but mecqual lobes. These eonsist of two large lateral lobes, each corresponding to a lip, two small anterior ones (corresponding to the anterior lip and two small posterior corresponding to the posterior lip. At the opposite and symmetrical notches at the extrenities of the large lateral lobes are inserted the bands or ligaments which separate or which mite the membraneous lips. The bottom or background of the buceal cavity is a true pharyux, to which is attached the simperior end of the cesophagus. It is pierced by a round aperture opening into the asophageal eavity. On the periphery of this opening are disposed six, sometimes seven, radiating papilla, hard like the eapsule itself, with dorsal cutting edges. They are real fixed laneets, performing a function similar to those of the surgical instrument known nuder the name of bdellometer of Scarlandière.

The resophagus (Plate I, Fig. 5, $c$ ) is relatively short, extending from the pliarynx to the mildlie of the neek; it is elub-shaped and very thick. Its lumen appears to us tetraquetral rather than triqnetral, as among other nematoid worms. In finct, the pharyngeal insertion of the tube is conical, i. $c$, with four, not three, branches (Plate I, Fig. 4, A). The mucous membrane is surrounded by a longitudinal muscular layer, which, in turn, is enveloped by a layer of very stout radiating fibers, longer inferiorly. The whole is inclosed in a structureless membrane.

The upper extrenity of the intestine into which the csophagus opens is rery wide. It is contimed by a straight, wide, cylindrical tube, lined, in its entire extent, with brownish, distinctly nucleated cellules, and terminates in a short oblique rectum, having the form of an inverted cone. The anus is situated at the base of the very short tail which measures only 1. to .2mm (.004-.008inch) in length. It appears to open most commonly on the dorsal aspeet, that aspeet which is opposite to the inclination of the head and neck or to the vulva. This is due to the spiral twisting of the female borly when the uterus is larlen with eggs. The anus of the male opens near the notching of the eandal bursa posteriorly. This shows that in the male also the ventral aspect is uppermost, which in the female is indieated by the vulva. In both sexes the auns is very small; anc in fact an animal food, made ny of the blood of the host, ought to furnish a very small quantity of solid waste.

Nervous system.-The nervons system of syngamus trachcalis, like that of the larger mumber of the ligher nematodes, consists of a flattened ganglion forming a collar about the wsophagns, and giving ofl four quite symmetrieal cords anteriorly and four posteriorly. The former 
pass to the mouth parts, the latter to the digestive and reproductive orgalls.

Secretory apparatus.-The most eminent lielminthologists, among them Bastian, Schneider, and E. Perrier, have seen in certain nematodes secretory structures composed of utricles sometimes donhle, provided with a canal which opens on the skin in the middle of a prapilla. These structures have been observed near the posterior extremity of the body in the male, and in the region of the neck in both sexus. We have songht them without success in the syngamus of the pheasants. Once, howerer, we saw, quite distinctly, an oblique canal opening on the skin a little below the asophageal nervons ring and arising from a glandnlar mass situated in the region, where, in Plate I, Fig. $\tilde{5}$, we have shown the position of the lougitudinal fusiform muscular fiber's. Along the asophagus and under the same muscular layers there is sitnated an elongater club-shaped gland, which opens at the base of the pharyngeal capsule (Plate I, Fig. 5, d). This is a true salivary gland; its walls are lined with ovoid, doubly-nucleated cells.

Reproductive apparatus: Gonital organs of the male. (Plate II, Fig. 7.) - In the nematodes generally the testes consist of a long tube uniformly cylindrical in its whole extent from .1 to.$^{\mathrm{mm}}(.004-.008$ inch) in diameter. In the male Syngamus of the pheasants it presented quite characteristic differences from the known tspe. It is possible to see, through the translucent tissues of the body, and still better when the testicle has been foreed out of the body of the worm, a large, abrupt expansion of the tube $1^{\mathrm{mm}}(.0 \pm$ inch) from its inferior termination. This bag-pipe-like enlargement gradually contracts anteriorly and continnes as a cylindrical tube slightly narrower than at its commencement. At the middle of the worm's body it twines about the intestine, then redescends and termiuates in a cul-de-sac near the posterior extremity. The disposition of this seminiferous tube may be better seen when, by a fortmnate compression, or a patient dissection, it has been forced out of the body. The three portions of which it is composed may then be readily distinguished; the first as a vas deferens, the second as a resicula seminalis, and the third (which coils about the intestine) as the testicle proper. The latter is filled with an opaque, amorphons substance, the contents of the resienla seminalis and the vas deferens being likewiso opaque but segmented into gramnlar corpuseles of rery varying forms, having each a unclens of .01 to .03mn $(.0004-.0012$ inch) in dianeter. These are the spermatozoids. The vas deferens, aloont $.075^{\mathrm{mm}}$ (.003 inch) in diameter, opens at the posterior extremity of the borly in the center of the candal huma, between two very sultill, short, and nearly straight spicules, the extremities of which rest immovably in the vagina of the female. The resienla seminalis, entarged in the form of a pear, has its walls made up of muscular tibers which are all obliquely placed and inserted into a longitulinal lapphé like the barbs of a feat ther into the shaft. 'The object of this arrangement muloubterly is to eanso 
the expulsion of the spermatozoids aud their projection into the vagina of the female, the long duration of this function requiring a special and powerful apparatus.

Female genital "ppraratus, (Plate II, Fig. 6).-As in almost all nematodes, the female generative organs comprise a uterus with two long: branches narrowing abruptly into a tubular portion, the ovary proper. We have not been able to discover a bag-pipe-like swelling near the commencement of the ovary which E. Perrier has seen in the Hedruris armata, and which he calls the copulation pouch (vesicula copulatrix). Neither this ponch nor anything similar to it exists in the Syngamus.

The rulva, as lias been stated, is a small opening pierced throngh the summit of a hemispherical papilla which is permanently covered by the caudal bursa of the male. The vagina, the canal which penetrates the papilla, is very narrow. Lodging the spieules of the male it serves as a passage for the spermatozoils which the male pours into it during his entire adult existence. It will be readily understood that it never fulfills the function of oviduct, since the inseparable union of male and female renders the diseharge of ova through the vagina impossible.

The vagina is continued into a short, enlarged uterus, about . $6^{\mathrm{mm}}(.024$ inch) long and broad, which divides into two long cylindrical horns, having a diameter of $.3^{\mathrm{mm}}$ (.012 inch) at the base and $.25^{\mathrm{mm}}$ (.009 inch) at the apex. They are about three times as long as the intestine, about which they coil in the most eapricions windings. The uterus and its horns are filled with ova, the development of which proceeds with the age of the worm, as we shall see further on. Each horn at its apex contracts abruptly into a short eone, and is continued by a small tube about $.05^{\mathrm{mm}}(.002$ inch) in cliameter, which might be likened to a Fal. lopian tube. After a distance of $3^{\mathrm{mm}}(.118$ inch) these tubes gradually dilate into tubes of twice their cliameter, filled with spherical, gramular corpuscles, compressed and erowded together in one or two rows. These are the ovules, the tubes containing them, the ovaries. As long as the uterine horns, these tubes are wornd in a thousand different ways about the intestine, then contract each into a tube as narrow as the Fallopian tubes (or oviducts), containing only amorphous matter, and lastly ter. minate in a eul-de-sac deroid of dilatation or enlargement.

Amongst the ova filling the uterus and its horns, we have deternined the presence of spermatozoids closely resembling those contained in the vesienla seminalis and the vas deferens of the male, but we have not snceeded ilis seeing them elsewhere. We beliere that the fecundation is effected in the uterine horns near the ovarian extremity upon the orules brought there by the Fallopian tubes, since there is here no organ similar to the vesicula copulatrix, which E. Perrier has pointed out in the Hedruris armata. 


\section{EMBRYOGENY AND DEVELOPMENT.}

It has already been stated that the narrow terminal extremity of the ovary is filled with a finely granular, amorphous, opaque, ant homoge. neous substance. On approaling the coiled portion of the ovary this granular matter is seen to mite into spherules, which are the orules proper. They are ranged in a single row owing to the narrow tube, the internal diameter of which they almost fili up. In the wider portion of the orary they range themselves in two or three rows. Near the oriduct (Fallopian tube) they first become slightly ovoid, with a long diameter of $.05^{m m}(.003$ inch), and they possess a distinct germinal spot and resicle. Still withont shell or distinet envelope, thes are led, one by one, through the oriduct into the corresponding uterine horn, where they find themselves in contact with the spermatozoids, and whele they become inclosed in a shell. When this is completed, and the egg consequently perfect, it presents the form of an ellipsoid, with a long di. ameter of $.09^{\mathrm{mm}}(.0035 \text { inch) and a short one of } .05)^{\mathrm{mm}}(.002$ inch). The egg is not truncated nor provided with a neek at each extremity, as is the case with many nematoles. There is, on the contrary, al each pole a thickening, hemispherical externaly and almost tlat within (Plate II, Fig. 8, A, B, C). Tuis is an actual cover, lletaching itself eompletely when the embigo emerges. Only the empty ormm, therefore, is really truncated at its two extremities.

In the uterine horus the ova undergo eomplete segmentation. Their vitellus divides into 2, 4, 8, 16, Se., small spheres, which assume the mulbery form (Plate II, Fig. S, A). The development proceeds in the lateral regions of the egg (Plate $1 \mathrm{I}$, Fig. S, B), and at its close the embryo may be seen rolled up in the form of a circle or a figure of eight. The egg is now . $1^{\mathrm{mm}}$ (.004 inch) long and .06 $6^{\mathrm{mm}}(.0024 \mathrm{inch})$ broad.

But it is not to be supposed that all the developmental phases of the orum eall be followed ont in every syngame. Only in case of the largest specinens ean this be done by examining suecessively the genital organs of the female, from the extremity of the ovaries to the borly of the uterus after they have been taken from the borly and well spread out. It is also possible to trace the series of successive transformations which the ovule undergoes fiom the embryonic to the perfect state by examining a series of females from the moment of their sexulal union with the male to that of their greatest development. Thus in the syngames recently conjugated, at a time when the female is scareely 5 mm (.2 inch) long, only spheroidal ovules are found in the uterus and its appendages, which are rery short, but slightly rleveloped, and not distinct from the ovaries, their dianeters being the same. When the female has reached a length of $1^{m m}(. t$ inch), the utems and its loorus, now duite distiuct, contain egges fully formed and inclosed in a shell, but the vitellus is not yot segmented. When the body is $15^{\text {mm }}(.59$ inch) long the vitellus is alreary segmented, and lots even passed $5 \pi, 110 \mathrm{~A}$ 
beyond the morula stage, as many of the eggs, particularly in the body of the uterus, reveal the embryo in process of development. Finally, when a length of 20 to $22^{\mathrm{mm}}(.787-.566$ inch) has been reached, eggs containing fully formed embryos, rolled up and moviug within their narrow prison, are observed in the two divisions of the uterus. At this period they may be foreed ont of the shell by pressure between two glass slides; the covers at the extremities detach themselres completely and the embryo emerges through either opening. When it leaves the egge spontaneonsly, an aet we have frequently observed in the water, the cepbalic extremity al ways emerges first.

The embryo, on learing the egg, exactly resembles an agamous anguillula (Plate II, Fig. S, I)). It is about .2 $8^{\mathrm{mm}}(.011$ inch) long, and lias a diameter of $.013^{\mathrm{mm}}(.000 \mathrm{~s}$ inch) at the middle of the body. The oituse anterior extremity reveals a punctiform mouth, opening in the middle of a papilla and continned into an oesophagus which occupies the cephalie third of the body (Plate II, Fig. 9), and whose cavity is distingnished as a very fine median line. This portion of the body is clear; the remaining two-thirds is filled with granulations or fine globules. The tail is conical and elongated.

The embryos never leave the egg within the living body of the mother, however complete the development of both may be. Only by the death of the female and the destruction of its body are the ova placed at liberty. The embryo will then emerge if the medium offers farorable conditions. These are moisture and a temperature of at least $20 \subset \mathrm{C} \cdot\left(68^{\circ} \mathrm{F}.\right)$. These facts we hare frequently demonstrated by experiment and in other ways. We have even found still attacherl to the trachea of pheasants destroyed by the gapes couples of dead syngames, with the soft, flaccid body of the female, $24^{\mathrm{mm}}(.945 \mathrm{inch})$ long, opened in several places by the commencing process of maceration, throngh which a large number of eggs had already escaped. It still contained many of them, each inclosing a fully developed, very active embryo, but there was not a single empty egg or free embryo in the entire cadarer.

We have subjected the eggs to various conditions in order to deter. mine those most favorable to the hatehing of the young. 1 . When in a dry medium, as in sand, their contents dry up more rapidly in proportion to the elevation of temperature. 2. In a moist state they preserve their vitality for months, even for a year, without any perceptible modification of their contents, if the temperature is liept below $15^{\circ} \mathrm{C} .\left(59^{\circ} \mathrm{F}\right.$.). Under these conditions the contents finally undergo fatty degeneration and are dissolverl. 3. If, while in a humid state, the temperature be raised to $200^{\circ} \mathrm{C} .\left(68^{\circ} \mathrm{F}\right.$.) or better, to $25^{\circ} \mathrm{C} .\left(77^{\circ} \mathrm{F}\right.$.), the embryo within the egg moves and turns about and finally eseapes by pushing away one of the coverlets.

The combined conditions of moisture and warm th are powerful enough to bring about the development of the embryo and its escape from the $\mathrm{egg}$, in whieh at first no trace of it can be distinguished, and which eon- 
tains only the vitellns. In the water contained in crystallizing dishes, small enough to be placed on the stage of a microseope, we have studied day by day the formation of the embryo ilning the month of July of this year, when the temperature maintained an average of $2.50 \mathrm{C} .(770 \mathrm{~F}$.). We hare determined that in presence of these conditions twenty-eight to thirty days suftice for the development of the embryo and its eseape from the shell.

The embryos or larvag live in the water, where they swim about in a serpentine manner like the anguillule (rinegar ecls, \&c.). At a tem. perature of $20{ }^{\circ}$ or $25 \circ \mathrm{C}$. $\left(65^{\circ}-77^{\circ} \mathrm{F}\right.$.) we have been muble to keep them alive for more than eight or ten days, whilst at a lower temperature they lived for many months, almost a year. Doring this time they molt, the tail becoming less elongaterl, and assuming the form of a short cone (Plate II, lig. 10). When the lotehing has been delayed from insufieient warmth, and the embryo finally eseapes from the egg, it leaves within the shell an eurelope. This fact seems to prove that the molt, which takes place normally one or two days after birth, ocems in the egg itself when birth is retarded. In the experiment-glasses larve with short tails were often seen moving among those with long tails. The formes were simply older than the latter.

The following questions now arise: Does the larva molt a second time before assmming the adult form, and what are the ways and means. employed by it to reael the only place where athlt and paired sy'n games are tomnd-the trachea of birds?

Some species of Sclerostomatu presents a nymphal phase, during which the young parasite is provided with an almost complete buceal armature, and lives, rolled mp and encysted beneath the mueons membrane to which it attaches itself in its adnlt state. Repeated investigations have failed to reveal anything analogons in the syugame of the pheasants. IT a have every reason to believe that the nymphal stage, no donbt very short and active, is passed in the air-sacs and pulmonary bronchi, which, as is well known, intereommunicate very largely in biris, and which the larvir may readily reach by traversing the intes. tinal or osophageal tunies after escaping from the ingesterl eggs. We also believe that the parasites very soon after reach the trachea, to become adnlt, pair, and attach themselves. The following are the facts npon which this opinion is bassed:

1. The larrie of Syngamus, according to our observations, to not Atrelop well, nor will they leave the egg and become vigorons excepting in a moist and warm medinm, approatehing the eonditions offered hy the iuterior of a bird's body.

‥ In a yomng pheasant, lead from the gapes, we found in the mucus obtained by scraping the lining membrane of the esophagus, a large mumber of eggs of syruganes with the shell opened and abandoned by the embryo. We have preparations to demonstrate this fatet.

3. In the serous fluids which labricate the walls of the air-sates, more 
particularly those in relation with the dnodenum, we have found in the case of young pheasauts attacked with the gapes very actire larra, almost twice as large as those just emerging from the egg, seeking their way.

4. In the cellular peritracheal tissne, in the ueighborhond of the crop of one of the young pheasants referred to above, we found, stretched out parallel to the trachea, a roung female syngame, already colored red, $5^{\mathrm{mn}}$ (.2 inch) long, with the month formed like that of the adult, and even sexually matured. We think that it was a srngame which, having been delarerl in the migration, failed to reach the mucosa of the trachea in due time and now could no longer do so, because the adult structure of the month parts presented an impediment to its march across the tissues.

5. In the inclosures of M. de Janzé, at Gonrnas (Eure), which were desolated last year by the gapes, and which have presented this rear some cases of this disease, the following fact has often been observerl and rerified br M. de Janzé himself: The soung pheasants affer:ted with this malads frequently expel, in a fit of conghing, plump. fat syngames full of eggrs. The other forls near by consume with aridity the morms thus ejected, which they, no doubt, regard as earth-worms, or the red larre of the large tipulie which resemble them, and of which they are rery fond. Two or three weeks later these roung pheasants are sure to present srmptoms of the malads-the slight, aborterl hissing cough, which is so characteristic, and the gajping, which has gained for this disease its English name.

6. For the purpose of verifying experimentalls the accuracy of the facts related abore, the anthenticity of which, howerer, did not give rise to any doubt, we ferl to a female parrot, on the ith of August. four pairs of large syingames. We had just received from Mme. de la R-D de Montmirail some young pheasants. dead from the gapes, from which we obtained an ample number of syngames; the parrot being the only subject we had for experiment at the time. On August '2S this bird began to cough and to gape. On September 10 it died. suffocated by numerous syngames which we found. at the antopsy, crowded in the trachea.

Considering the large number of eggs-several thousand-which a cadaver of the female syngame contains, and the relatively small number of parasites-abont thirty or more pairs-which reach their destindtion, or, in other words, come to maturity, we may furm an pstimate of the prodigious number of larva which die on their way or never succeed in finding it. It is, moreorer, a law of nature. especially true of parasites, that the number of eggs laid is larger in proportion as the chances of destruction during the earlier period of existence are more numerous.

The great variation in the size, and hence in the age and the degree of development, noted among the syngames attached to the trachea of 
a bird shows that there are ordinarily sereral successive infections or ingestions of eggs at intervals more or less extensive. This fact may also be dne to the cireumstance that the eonditions favolable to the development of the parasite have not been the same for all.

The feeding of healthy pheasants upon syngames filled with eggs, which have been ejected by pheasants snffering from the gapes, is not the only means by which this disease may be propagated. The observatious which we have made concerning the vitality retained by the eggs of the parasite when in a moist medinn-a medinm in which the em. bryos are born and developed if the temperature reaches a suitable height $\left(200-25^{\circ} \mathrm{C}\right.$.) - prove that the ingestion of water and liquid or pasty aliments, containing these embryos or eggs, furnishes two other means of infection perhaps more active than the first. In every ease the only media necessary for the propagation of epidemics of the gapes are food and drink contaminated with the eggs or embryos, and the birds themselves when afferted with the disease, as they are then the source of an abundant emission of eggs of the parasite. No other animated medium, neither adult insect nor larva (the larve of ants, for example, which are a constant element of food for young pheasants, and which have been suspected with some appearance of truth), nor any molhusk, in short, ean be ineriminated.

\section{MEANS OF DENTROYING THE SYNGAME AND OF ARRESTING EPIDHMICS} OF 'THE GAPES.

The disasters caused by the parasite above deseribed in the parks devoted to the rearing of pheasants, point ont the extreme importance of finding rapid and effective means of arresting the spread of this destructive worm.

A remedy, common in England, consists in mixing the grains which are to be fed to the diseased birds with urine instend of water. Mon. tagu, who tried this remedy withont having any faith in its efficacy, was surprised at the sucress which he achieved, and which proved to him that it was not without utility. It is probable that the ammoniacal emanations arising thom the urine are poisonons to the red worm or its embryos.

Wiesenthal relates that in America a hen's feather is stripped of its barks to near the point, introduced into the trachea and rotated like a brush to detach the worms. We strongly question the efficiency of this practice; in the tirst place, beeanse we know from experience that the worms are too firmly attached to be removed by the friction of the barbs of a feather: Should they be detached, howerer, they would only be pushed to the root of the trachea, where, forming a ball, they would augment the obstruction in the tube and thus bring abont more promptly the death of the bird. On the other hand, the dianeter of the trachea of a young pheasant from five to six weeks old, being seareely equal to that of the shaft of a hen's feather, will not permit the introduction of 
the latter. Cobbold,* on the contrary, believes in the efficiency of this method, and adds that this effieiency may be-increased by impregnating the feather with a germicirle substance. Bartlett, who used salt for this end, or a weak infusion of tobacco, informed him that the essence of turpentine also had given excellent lesults. Cobbold adds with reason, that unless great eare be exereised with this method the birds may be seriously injured.†

These means, at once mechanical and medicinal, have been suggested several times and varied in different ways. One of our correspondents informed us that he had cured pheasants of the red worm by removing the parasites with a small rod and pouring into the montl of the birds a few drops of Fowler's solution. Another pretends to have removed the parasites with a piece of copper wire, which had one end enrved like a handie and dipped into oleum hypericum (red oil). We do not doubt that they conld have suceeded in thus removing red woms lodged in the pharynx, but we do not believe that they conld have extracted worms by this methor from the root of the trachea near the bifurcation of the bronchi, where they are most frequently lodgerl for it is actually impossible to employ a rod, and above all, a metallic wire enrved into a hook, as it would mudonbtedly tear the trachea. 'Ihe fact that young pheasants, and more frequently adnlts, sometimes recorer spontaneonsly from the gapes, may have given rise to their apparent success. This happens when ther are affected by only a small number of parasites, which may go throngh the phases of their development to thoir death withont producing sutfocation. This is the only mode of fatal termination, and it requires a certain number of parasites, from twenty to thirty comples for adnlt, and from five to ten for young pheas. ants. In these cases the disease is cured in spite of, and not becanse of, a certain morle of treatment.

One of the most rational methods of treatment has been pointed out by Montagu, who dial not stop with the common method ahove mentioner, but who obtained much snceess with the following means combined: Removal from the infected plaees, complete replacement of the

* Parasites : London, 1879; p. 445.

tCobbold's exact wolds conceming this method are as follows (loc cit):

"First. The simplest plan consists, as 10r. Wicsenthal long ago pointed mut, in stripping a foather from the tube to near the narrow end of the shaft, leaving only a few uninjurerl webs at the tip. The birl being secmed, the webbed extremity of the feather is introduced into the windpipe. It is then twisted romud a few times and withdrawn, when the worms are foume attached. In some instances this plan surecerols entirely.

"Secombly. Tho alowe inethod is renlered molo effrctual when the feather is previously steeper in some medicated solntion which will destros the worms. Mr. Bartlett employs salt for this purpose, or a weak infusson of tobacen; and he intorus mo that the simple applieation of tumentine extemally is sufficient to kill the worms. It should he borne 11 mind that the bird itself may bo injuriously aflected by these lrugs if thes are carelessly employed." Note that the tmrpentine is to be used extormally.-En. 
former aliments by new ones, in which hemp-seed and fresh grass figure prominently ; finally, for drink, an infusion of rue (ruta) and garlie, in. stead of ordinary water.

The efficacy of the garlic was demonstrated to us under the following circumstances: The pheasantry in the forest of Fontaineblean was laid waste by the gapes in 1877 and 1878. This malady, which we stndied on the site of its actirity, was arrested and completely driven out hy feeding the pheasants with a mixture consisting of hard-boiled eggs, boiled beef's heart, the orumbs of stale bread, and salad. These ingredients were chopped, pounded, and thoronghly mixed so as to make a paste. To this paste was added pounded garlie in the proportion of one clove or bulb to ten pheasants each day, the garlie being thoronghly distributer through the paste. This mixture was relished very much. Great care was bestowed upon the drinking vessels; the very pure water used was renewed twice a day. The same treatment was successful in the ser. eral inclosures belonging to the comtry-seats in the neighborhood of Fontainebleau and Melun. A large number of correspondents to whom we suggested it were fully satisfied in haring applied it. We also learned that the pheasants occasionally refused the garlic, and one of om correspondents informed us that he had sneeeded in making them take it by preparing a real garlic salad; for he had accidentally observed how the animals which had refused the garlie paste east themselves voracionsly upon a garlic salad which was not intended for them.

We ean readily explain the virtue of garlic, known from time immemorial as an excellent anthelmintie, as it is volatile and is eliminated by the respiratory passages, reaching, in this way, the trachea, where the syngames are iodgerl. The proof that the essential and volatile prin. ciples of garlic are eliminated by the lungs is daily furnished loy those persons who, like the inhabitants of the sonth of France, are foud of this condiment. The odor of their breath betrays them immediately.

Besides garlic, we have experimented with another substance, which, like the former, has the adrantage of being a strong-smelling rernifnge and more stmpefying than ether (which might also be employed), properties which enhance its parasiticide powers. We refer to assafoticla, which we have used as a powder with an equal part of yellow pnlverized gentian, mixed with the paste which is fed to the phrasants, in the proportion of .0 centigrams (abont 72 grains) per head each day. 1. a complement to this treatment we have added to and liter (or (quart) of drinking water the following solution: Saliẹlie aeid, 1 gram (ahont lis grains); distilled water, 100 glams (abont 3.1 fluid onnees).

The nse of the salicylic acid, the toxic power of which upon the embryos of syngames we have recognized experimeitally, had for its sole object the destrnction of those embryos which might be present in the drinking water of the yomng pheasants.

This treatment we have employed in the parks of Baron Rothschild, at Rambonillet, which were ravaged by the gatpes in a manner so dis- 
astrous that 1 , to 1,200 young pheasants were found dead each morning. A letter from the baron's steward, daterl September 7,1879 , testifies that the treatment has fully succeeded in arresting, in a few days eren, the epidemic.

We will conchule these suggestions by stating that it is alway benetieial and even indispensable to disinfect the soil of the inclosures after having transferred the roung pheasants to a virgin soil. One of the best means of destroying the eggs and embryos which may possibly exist ou the soil of the contaminated inclosures, consists in sprinking it with water containing in solution a sufficiently large quantity of salicylic or sulphnric acid, one gram (15) graius) to a liter (about 1 quart) for example.

ireat care shonld also be taken to isolate the sick birds on the first appearance of the symptoms of the disease, and to keep them closely confined till complete and well-confirmed recovery. The cadavers of dead birks must be buried deep, or it were eren better to burn then.

\section{SUPPLEMENT.}

In the investigatious which we have made concerning the development of syngamus trachealis, and which are reported in the preceding memoir, written about twenty months ago, we pointed ont that the eggs ejected during the coughing fits hatch in the water, and that the embryo, resembling an ang nillula, mary live in this medium for many months. becanse we have kept some alive almost a year in a low temperature. The birds are infected by drinking the water containing these embryos. But how are they developed in the borly of birds, and in what way do they reach the trachea, where they are fonnd, in the adult state, fixed to the mucons membrane like leeches, the two sexes united in a permanent manner and the females crowded with eggs?

In the preceding memoir we stated that we had every reason to be. liere that the uymphal phase, unknown to ns, was passed in the air-sact and brouchi, and that later on the worm reached the trachea where it became adult. We offered as a proof of this hypothesis the discovery of embryos of syngames, in every respect similar to those which we had obtained from the hatching of ova, in the air-saes of several young pheasints killed ly, the gapes.

There was, therefore, only a presumption, well founded, it is true, of the existence of the nymphs in the bronchi of the pheasants. At pres. ent it is no longer a presumption but a certainty. At the antopsies. lately made, of two red partridges, killed by syngames, we met the nymphal form in the pulmonary tissue itself, rolled up in the bronchial dilatations. (Plate II, Fig. 11.) It is eylindrical, very elongated, about 1.6 to $2 \mathrm{~mm}$. (.063 to .079 inch) long, and .04 $\mathrm{mm}$. (.0016 inch) in diameter. It is, consequently, ten times as large as the embryo when it leares the egg, and one-tenth as large as the alult worm at the period of its great est development. The armature of the month is already cupulate or 
cup-shaped, but still without color, border, and lobes. The musenlar esophagns is very long and eylindrical. The intestine, which extends in a straight line from the termination of the osophagus to the anus, fills almost the entire body, and is already colored red; near the anterior third of the body may be seen a fleshy thickening, which sends a prolongation forward beyond the posterior extremity of the cesophagus, and one, longer "than the first, backward toward the candal extremity. This is the rudiment of the sexual organ.

This discovery of the nymph enables us to say that all the developmental phases of syngamus trachealis are now knowu. The only two media which this parasite inhabits during its entire existence are the water or moist earth during its embryonal condition, and the respiratory organs of its victim during its nymphal and its adult phase. It is, therefore, developed withont the aid of any other medium than the water, corresponding in this respect to the immense majorits of verminous parasites. 


\title{
INTERNATIONAL, TETERINARY CONGRESS.
}

\author{
IREPORT OF DR. JAMES LAT.
}

SIR: I have the honor to submit the following report on the International Veterinary Congress at Brussels and the European Veterinary Sehools:

In aceordance with the call issued by the eommittee of arraugement, the Fourth Interuational Veterinary Congress met at Brussels on September 10,1883. There were present 311 veterinarians, of whom 218 were Belgians, and 93 from other eonntries of Europe and Ameriea. The eongress remained in session seven days, and engaged in the discussion of the following subjects :

1. Tire organization of VEterinary service.

2. Contaglous Pleuro-PNEUMONIA OF CATTLE.

3. EDUCATION IN VETERINARY MEDICINE.

4. THE RIGHT OF THE VETERINARIAN TO FURNISH MEDICINES.

j. Pulmonart phthisis.

\section{THE ORGANIZA'TON OF VETERINARY SERTICIE.}

This subject was ably presented by Zuudel, of Strassburg, the reporter of the committee appointed to introduce it.

The veterinary profession ean no longer be estimated only or mainly by its knowledge of therapentics and its sueeess in euring disease, otherwise it would be to the peeuniary interest of the veterizarian to keep the community in ignorance of the causes of diseases, epizootie, and sporadie, while he fattened on the proceeeds of an extended practice. But to-day it is the glory of the reterinary profession that it is pre-eminently a sanitary and preventive body. It ean point to day to the comparative absence from European flocks and herls of those plagues which but a century ago desolated the countries at frequent intervals : it can show pastures now'salubrious, which were formerly pregnant with the seeds of death; it can offer immmnity to the system from poisons whose tonch was heretofore deadly; and it ean show how to extingnish in animal hosts the causes of disease, which, when conreyed to man. would entail extended suffering and death.

By his knowledge of zootechny, the reteriuarian contributes to the improvement of the different races of domestic animals; by his knowl- 
edge of sanitary police he protects the purehaser of animals against imposition, and knowing how to exchule epizootics he protects international commerce, which the constantly increasing facilities for communication renter daily more important; by his special knowlerlge of animal diseases he can insure that maladies intercommunicable between animals and man shall not be conveyed to the latter throngh meat and other animal products.

The question of the organization of the veterinary service as a sanitary branch of every govermment had been extensively discussed at the Third International Veterinary Congress at Znrich in 1867, and at the following national veterinary conventions: For Germany, at Frankforton-the-1lain, in 1872; for France, at Paris, in 1878; for Italy, in Bolonge, in 18is; and for Belgimm, at Brussels, in 1880.

The Zurich Congress prononneed that:

1. The practice of reterinary medicine shonld be regulated by law.

¿. The veterinary art ought to be an integral branch, but independent, of the sanitary administration.

3. Veterinary medieine should be represented by competent persons closely related to the anthorities; inferior, medium, and superior.

4. No one should be allowed to practice veterinary medicine unlesis he has pursued the required studies in a public veterinary college, and has aequired after examination the diploma or the legal eharacter of veterinarian.

万. All veterinarians may be ealled as experts by private individuals, but the judicial anthorities onght only to eall as competent persons reterinarians who are officially recognized.

6. In cases of sanitary police the arlministrative anthorities ought not to have recourse, save exceptionally, to those who have not been officially recognized as competent.

7. The expression "competent person" should be mulerstoor in the sense that he is a diplomaed veterinarian.

8. All reterinarians onght to have the right to furnish the medicines required in their practice, but always under a suitalle control.

The four national conventions pronomeed in similar terms for a gnar. antee of education and competeney on the part of the reterinarian. and for the organization of a sunitary veterinary scrvice in each state, which shonkl deal with epizooties, advise how to render distriets salubrions. and how to improve the races of domestic animals, and inspeet abattoirs, slanghter-honses, and rendering works. The German convention pronounced in favor of a unitieation of the laws of the different German states in regald to veterinary sinitary police, and veterinary jurisprudence, and for the frequent publication of statisties of contagious diseases and mortality. The lirench convention pronounced in favor of including in the sanitary corps all the veterinarians pratising in a cie. partment, and for the election of a departmental veterinary direetor by their rotes. 
In the spirit of these antecerlent conventions the following resolutions were submitted:

1. To urganize in every country a veterinary sanitary service charged exclnsively with all that pertains to veterinary science, and the members of which shall be counsel of every department of the Govermment, but which shall be more especially represented directly in relation to the central power-that veterinary medicine shall there have her elief of serviee.

2 . The veterinary sanitary service should ntilize the greatest possible number of reterinarians. To do this efticiently and economically there should he recognized two degrees or classes of veterivarians. The one of a local nature connected less with the state than with the municipal and provineial anthorities and charged with the surveillance of fairs and markets of animals, the inspection of meats of the butchery and alnattoires, the control of rendering works, the inspection of breeding animals, the inspection or tirection of mntnal insurance companies against the mortality of animals, the revision of the census of donestic animals, Ne.; the second charged with a widler range of duties, comprising the service of the state, and capable of lecoming iuternational, embracing especially the suppression and prevention of contagious maladies and epizontics, and also the control of the different other veterinary corps.

3. Between the various states which by a regular repression and preventive serv ice against epizootics, can furnish the guarantees of a good reteriuary sanitary police there should be established a treaty having for its object: 1. To apprize the other states as speedily as possible of any eruption of Rinderpest, pleuro-pnemonia contagiosa, aphthons fever, sheep-pox, maladie du coit (lourine), glander's (or farey), and of scah in sheep. 2. To publish periodically a sanitary bulletin upon these diseases, their extent, progress, and extinction, which documents shonld also be published in the international bulletin if judged necessary. 3. To oppose these diseases by measures of sanitary police which have first been discussed ard adopted as the most ad. visalble. 4. To furnish with animals and herds that are moved into and out of a territory certificates of origin and health of al guanteed administrative value. 5 . To contribute to the publieation of an international veterinary sanitary bulletin.

\section{FIRST RESOLTTION.}

Among the arguments advanced in support of the first resolution wele the following:

In rarious countries of Europe and America these duties essentially veterinary are left too much in the hands of persons ignorant of veteri. nary science. In some they are largely dealt with by bodies mainly medical-sanitary boards. No one denies the great debt of veterinary medicine to that of man. The works of the physician in anatomy, physiology, patholog 5 , surgery, \&c., furnish the most valuable material for the medicine of auimals. The priuciples of both branches of medicine are the same. The observations and experiments on animals made to advance the one are of the highest value to the other. Many of the parasites and \%ymotic poisons of nan are eommon to the animal as well. But when we come to the application of these principles to the diagnosis and treatment of disease in animals the physician finds that the two medicines diverge at every step, and that without a special training he is helpless to deal with that of animals. At one time physicians comld be found who were more accomplished in microscopy, ive., 
than the reterinarian, but to-day in the reterinary schools of Europe the subjects receive as ample attention as in the medical.

In some cases the bureancratic element tends to the subversion of the veterinary, and men whose only knowledge of veterinary matters come rom eonsulting the writings of some one reterinarian will pass judgment upon the advice of the most skilled expert, and even deeline to employ it. It is for the jurist to formulate and promulgate the laws, but it is his duty to base these on the best comsels of reterinary medicine.

To maintain a satisfaetory system not only must the veterinary sanitary work in departments and cities be carried on by veterinarians, but there must be at the seat of power a veterinarian or commissioner of reterinarians as a centralizing point for all that relates to the veterinary service, and for the direction of that service. As comntries in which such centralization exelusively reterinary has been secured mar be named Holland, Denmark, Sweden, Russia, some of the southern Ger. man states, Saxony, Bavaria, Baden, and Alsace-Lorrain, Portugal, ant Belginm. In Austria there is a consulting committee on epizootics, but which ocenpies itself with prevailing maladies alone. In the depend. ent Austrian states the Landestlierarzt is a simple member, sometimes a simple agent of the sanitary council. In Prussia there is not even a chief reterinarian in relation to the minister, who only consults the technieal deputation in which reterinary seience is represented. In each provincial govermment of Prussia a departmental reterinarian or assessor is attached usually to the medical eouncil as councilor (referee) for veterinary service. In France the veterinary element now predominates in the superior committee of epizooties. In England the priry eouneil veterinary department has three veterinarians in a body of six members. In Switzerland, attached to the department of agrieulture, is a veterinary commissioner of epizooties as counsel on the whole sub. jeet of federal veterinary police, but he has no voice as to the eompetence of eantonal anthorities. In Italy there is no central reterinary officer, and the bulletin of epizootic statistics is compiled trom data furnished by municipalities.

After consiclerable discussion the following was passed with only four dissenting votes:

To organize in each rountry a veteriuary sanitary service, "haldger exclusively with all that pertains to this service, of which the members, all velerinarians, shall be conncilors of all branehes of the ahministration, hut which shall he especially represented near the eentral anthorities, where the "hief veteriuary oticial shall he stationed.

\section{SECONI RESOLITION.}

In regard to this the reporter pointed ont the impropriety of binding the Govermment to employ as its local expert the veterinarian who hap. pens to be in atteulanee mpon the infecterl herd, the danger of such a person carrying infection to other herls in the rumb of his practice, the suspicion, usually unmerited, that lo may hicle infection in the inter- 
ests of his employers rather than apply rigid measures of extinction for the good of the commonwealth, the fact that he may be an excellent general practitioner and yet not a specialist in epizooties, who may counsel treatment when the best sanitary science imperatively demands sac. rifice, who will make a dangerous distiuction between farey and glander's, or who will prefer preventive inoenlation in pleuro-pnenmonia to slanghter. What ean be expected of the reterinarian who has become hopeless and apathetic, whose calling is to him but a handieraft, or who has hecome morally debased?

The increasing numbers of live stock, the facility in transporting them long distances by steam, and the great demands of Western Europe for outside smplies demand for the inspector of to-day a very different ofticial from those of the past. The lack of a thoronghly efficient veterinary sanitary service was felt when the lung plagne attained such a wide extension in 1840, when the Rinderpest ravaged Holland and Englaud in 1865, and France in 1870 , when influenza spread over America in 1872, lung plague in 1878, or when hog cholera destroyed in a single state hogs to the value of $\$ 20,000,000$ in one year.

Already a good beginning has been made in different states. Holland has nine district veterinarians nuder state salary. France has in the department of the Seine five exclusively ocenpied in the state serv. ice: England las twenty-three salaried port inspectors; Portugal has twenty-one on state salaries, not large enough, however, to make them independent of practice, aud the same applies to the states of Ger. many and Austria where the Govermment veterinary officers have regular salaries, but insufficient for their entire maintenance.

The field with which a departmental reterinarian is charged should be large enough to insure that the office shall be no sinecure, and that he shall not by private practice interfere with that of the local veterinarians. He should be appointed atter a special examination, or exceptionally for signal services in sanitary police.

The department veterinarian should comsel the central authorities, advise legislation, take the direction in the prevention and extinetion of epizootics, and direct the work of the local veterinarians. To these last would be left the inspection of fairs and markets, meat markets, slanghter-houses, \&e.. of animals sent by railroad, and the general locil work of the serviee. They shonld make to the ehief veterinarian writ. ten leports of any extraordinary ocenrence in their district and periodic reports of the general work aceomplished. These will furnish data for the publieation of statisties of the animals kept, bred, purchased, sole, killed for food, dying of sporadic am epizootic disease, attacked by epizootics, sce. These in relation to geology, soil, drainage, meteorology; ('nlture, breeds, loreeding, alimentation, use, 太Ec., will supply data of the greatest value to stock holders, veterinarians, hygienists, physieians, dealers, and political economists.

As a rule the destruction of animals to arrest all epizootie should be 
orlered by the chief or departmental veteriuarian, thereby securiug at once the guarantee of a diagnosis by more than one expert and saring the local veterinarian from the unpleasant duty of ordering a work that may be unacceptable to his regular employer.

Not the least important duty of the local veterinarian is in connection with the mutual assnrance of animals against deaths from sporadic dis. eases. Losses from epizooties are indemnified by the state, but losses from diseases that are not communicable justly become a tax on the stock owners of the municipality or district. Sueh an arrangement engages the interest of the stock owner's not only to report the contagions diseases early, but the non-contagions as well, and to use all resources of seience for the eure of the latter, but much more for their prevention. The local veterinarian as a regular officer of such societies, directing, supervising, inspecting, finds his interest consulted in urging all that can conduce to health in breeding, mauagement, and treatment, and wherever such associations have been introduced there has been a notable improvement in all that pertains to the quality and numbers of the live stock.

The local reterinarian, being an essential part of the national veteri. uar5 sanitary service, it should not be in the power of the local authority to discontinue his services, nor to appoint to the position any oue but a competent reterinarian (a graduate).

After dischssiou mainly of the right of the sanitary veterinarian to engage in ordinary practice, and of the desirability of specifying two classes of reterinary ofticials, the following was adopted by a large majority :

2. That the veterinary sanitary service shonld ntilize the greatest possible unmber of veterinarians. It embraces the inspection of fairs and markets of animals, of meats of the butchery and abatton, the control of renlering works, the inspection of breeding animals, the supervision or direction of mutual assurance societies against the mortality of beasts, the revision of the census of domestic animals; * * * it compreheuds the service of the state and may become international, embraring especiall. the repression and prevention of contagions maladies and epizoofics, also the contro of all other veterinary service.

\section{THIRD RESOLUTIUX.}

In support of the thim resolution Zunclel advanced that contagious maladies are no longer recognized as of spontaneons origin ; that day by day the adrocates of spontaniety yield the point, and that well-ob. served fatets prove that it is by contagion that these maladies are at once propagaterl and perpetuated. To prevent the propagation of these malarlies it is necessary to have in all comntries enjoging an interna. tional commerce in live stock a common, permanent, and eficeient system of preventing or at least of arresting them in their inception. The value of an international arrangement for the control of Rinderpest has long been recognized and becomes yearly more important. Thedemands of Western Europe for a meat supply are constantly increasing, while 
the animal production in Western Europe remains stationary, or even diminishes. This imperious demand for beef, and the facility for its supply by cheap railway transport from the East, cannot fail to insure an increase of the Eastern traffic, and unless conducted under efficient international measures of protection this must deluge the West continually with this most fatal of all bovine plagnes. The improved culture on the Steppes and the introduction of better forage plants enable the stock owners to tide over the dry summer and the frozen winter more satisfactorily, and thus contribute still more to the numbers and excel. lence of the Eastern supply. Austria imported 20,000 Russian cattle in $1861,30,000$ in 1868 , and 55,000 in 1872 . The more stringent restrictions have later lessened the numbers, but the increasing demands of the West and supplies of the East must, ere long, turn the tide once more, and bring large installments of these Eastern beeves. Hitherto protection has been songht by the more or less perfect exchision of Steppe cattle, bnt the time must come when this shall bo superseded by an international arrangement founded on solid guarantees of the soundness of the cattle exported.

Already in regard to Rinderpest this has been attempted ; to-day all the different countries of Germany act on the same law, that of ith April, 1569, in repelling and repressing this plague, and in April, 1572, Anstria called in Vienna a conference to consult as to the requisite international guarantees, and delegates attended from Germany, England, Anstro-Hnngary, Belgium, France, Italy, Roumania, Russia, Servia, Switzerlaud, and 'Turkey. If each country would organize an efticient service to stamp out Rindörpest as far as possible and to prevent its radiating ontward from any existing center of infection, every state might by this perfect isolation of its limited infected area secure an untrameled eattle traffic for its entire territory besides.

The same can be done for contagions plenro-pnemmonia, and it is easily demonstrated how mueh evil has already resulted from the neglect of other Governments to respond to the Swiss morement in this di. rection in 1876. From this England loses searly about 5,000 eattle Belgium, „2,000 to 3,000; Prussia, ״̈,000; Wurtemberg, $500 ;$ Iustria, 2,000 to 3,000, and France and Italy corresponding numbers. Rinderpest is comparatively easily suppressed, because its prompt eruption and tat al issne strikes the population with terror and it eannot be hidden; but the lung plague strikes slyly, hicles its tracks, and, ereeping into the stahles unseen, it diffuses its poison, infects, benumbs, and paralyzes the lungs without the body appearing to suffer, and it only manifests itself by ontward symptoms when all is lost. More than this, the lung plague often assumes the benign and almost latent form, so that after montls of incubation it still rests unrecognized and unsuspected, assmming a chronic type, but still scattering the poison, and the subject eren appearing to recover, withont an abatement of its infecting power. Often, too, the laws, and even very recent ones, take but half 
measures against this plague, learing it to intrench itself more and more firmly and to maintain itself permanently in a contry where it is only an exotic, a foreign invacler, and where it eould easily be excluder throngh an efficient international system. For this, therefore, erem more than for rinderpest, an efficient system of mutual international protection is urgently demanded.

The aphthous ferer is largely combated by restrictions on the movement of eattle and the interdiction of fairs and markets, ret these rarely arrest its progress, but the bariers that put a stop to the rinderpest allow the aphthons ferer to pass, as happened in Saxony in 1867. With such a diffusible poison snceess must be songht in its declaration, suppression, and seclnsion in the home herds and by preventing it from passing at all into the channels of traflic, and this can only be secured through a common international system.

Formerly lung plague, aplithous ferer, and sheep-pox remained habitnally circumscribed in particular districts; to day, with the great movements of stock in mass, their concentration in vast markets, and their constant changes in the large feediug stables, it has become impossible to deal effectively with these plagnes except in native herds, and this imperatively demandsa uniform international system, with solid mutual guarantees.

Glanders and farey occurring in an ocenlt form with lesions interual and mususpected, and following a chronic comse, is another fruitful sonrce of trouble, and a comntry that pays for such animals when slaughtered especially suffers, as the diseased animals are smuggled across the frontier in order to secmre the indemnity. Fren the residence of several months required in order to the payment of indemnity is insufficient to guard against this sharp practice.

The mad dog does not always take the road to the custom-house, nor recognize the colors of the frontier posts. Here, therefore, it becomes necessary to maintain a common system of repression and the mutual notification of the existence of rabies.

Maladie du coit, though unlike the two last, in that it respeets tho human fanily, should yet as regards the equine races be mate the object of international gnarantees.

Anthrax and several parasitic maladies, inclnding even measles and trichinosis in swine, are more purely natters of loeal danger, and are to be controlled by local measures and by inspection in the great nueat markets.

Energetic sanitary measmes within the limits of a single state luave been often notably successful, as against lung plague in Switzerland, Holland, Portugal, Sweden, and Demmark against sleep-pox, apart from Northern Germany and Hungary, and against rabies in Barlen. How much better if there were a common international co-operation, which would at once more effectively repress animal plagues and release the commeree in live stock and all their fresh products (lides, hoofs, hair, $5751 \mathrm{D} \mathrm{A}-9$ 
bristles, fat, guts), as well as fodder and straw, from the present obnoxious and injurious restrictions.

Unfortunately in all modern legislation on the subject not only are the laws peculiar to the individual state, but they reflect the jealousies and lack of adjacent states. Thus in the absence of official trustworthy and tristerl reports a whole conntry has its trade restrieted, delayed, and serionsly injured for a slight outbreak which conld easily be sequestrated and a perfect guarantee of its non-extension furnished. It is to be feared, indeed, that in some instances what is practiced under the name of reterinary sanitary police is conceived more in the spirit of maintaining the high price of meat than of restricting and extirpating animal plagnes.

If the work conld be made international, and if the plagnes conld be effectively dealt with in the local areas of their prevalence, all the more obnoxions interference with commerce might be done away with, the present temptation to clandestine trade in infected animals obviated, and a better and more reliable protection afforded.

The inspection of animals at the frontiers has proved practically useless, becanse animals that have become infected but do not yet show signs of disease are necessarily allowed to pass, and with the modern immense railway traffic in fat animals a sufticient quarantine is practically mrohibitory of importation.

Another grare objection to this system is that animals found diseased are simply sent back orer the frontier, and as the service is national and not international, the neighboring state is not warned of the active focns of infection thus created within it.

Certificates of origin and health emanating from officials and based on expert knowledge of the sunitary condition of the district furnishing the stock should be really valuable documents, whereas certificates made ont by irresponsible indiridnals, and with which the smugglers are now most numerously supplied, are gronnds for suspicion rather than confidence.

The following sum mp the principles which onght to dominate in an international veterinary sanitary service:

a. Each state ought to notify the governments of adjacent states of those joining the international agreement, and of all that desire it, of every ontbreak of rinlerpest, lung plague, sheep-pox, muludie du coit, glamlers, and rabies, its exact locality and extension; and this should be llone as quickly as possible, even by telegraph.

Other grave maladies transmissible and importable, and especially the typhoid affections and sheep scab, shonld be made the object of extraordinary precuntions and mutual notification.

The anthorities onght to carefully investigate the channel by which contagion finds its entrance and is propagated ; and the officials of the conntry from which it was derived should be furnished with the information necessary to enable them to trace it to its earlier sources. 
Each Government ought to publish in its official organs a sanitary bulletin upon the sanitary states, the progress of epizootics, the meas. ures enforced, the interlietions of imports, the changes male in these prohibitions, and of the suppression of the plagne when that has been effected. This bulletin should be sent to enlitors of official journals of states that request it or that have signed the agreement.

b. The anthorities of froutier districts ought to notify directly the anthorities of neighboring districts whenever rinclerpest or aphthous fever has been detected within 100 kilometers ( 62 miles) of the frontier, or when luug plague, sheep-pox, glanders, or rabies has appeared within 50 kilometers (31 miles) of the frontier. In rinderpest, sheep-prox, and rabies the notification should be male by telegraph.

c. Every state shonld so organize its veterinary service as to be able to rapidly stamp out rinderpest or other contagions maladies.

d. Every state should provile that the laws of sanitary police shonld be rigoronsly enforcen.

e. By previous arrangement the laws of sanitary police in different states should be almost identical in measures of isolation, veterinary surreillance, sequestration, removal and burial of carcasses, and in disinfection of all persous and animals, of objects, elothing, and harness, stables, and of railway cars that have earried animals or animal prod. uets.

$f$. For all animals attacked or suspected of one of the contagions maladies abore mentioned, and killed by police order, an indemuity should be paid, which each government may fix by special law, but which should in no case be less than half the ralne of the animal if it had been sount.

g. A previons arrangement shonld preseribe the principles which onght to control the international relations, the roads and means of transport to be taken, the conditions of movement of stock, and, above all, that which refers to certifieates of health and origin, which onght as much as possible to be nuiform in the different comntries, and for the important assignments visid by the consuls of the respective eonntries. h. The laws of sanitary police should orter the transporting agent to make instant declaration of diseases that may supervene in transit, and shonld prescribe the measures of sanitary police applicable to them.

$i$. There should be published an international sanitary bulletin at intervals of fifteen days, and giving the sanitary condition of each country according to the special bulletin, which by international agreement each government shonld publish. The international guarantee should be based on government morality, on a spirit of justice, on practical reason: thus commeree will acquire that freedom and integrity which are essen. tial to it. It should prescribe the movement of all stock coming from a conntry, the sanitary condition of which is unknown. The great publicity given to the official reports, often sent by telegraph and difrused through the most rapid channels, would give a guarantee of their 
reracity; they ought to emanate from the authorities of the countries aul be (lrawu up by veterinarians.

With this bulletin they wonld know at each custom-house what comn. tries can supply stock to interuational markets, and from what the stock must be refused; this international bulletin should be a check on certificates of health and of origin, and shonld enable the officials to appreciate their value.

The bulletin would thus furnish the best mutual gnarantee for international commerce, and give mutual confidence between nations carrying on with each other a traffic in domestic animals.

The nations will better comprehend on the basis of epizootics what they generally fail to arrive at on that of politics. One step may perhaps lead to others.

The third resolntion, adopted unaumously, reads as follows :

Between the different states, which bs a regular service repressive and preventive of epizootics are able to furnish guarantees of a good reterinary sanitury police, there should be established an agreement having for its object: 1. To notify other states, with the least possible delay, of the eruption of lung plagne, aphthous fever, sheep-pox, maladie du coit, glauders (or farcy), and sheep-seab. 2. To publisin a periodic veterinary bulletin on these maladies-on their status, extension, and terminitions; which information should also be sent to the iuternational bnlletin, if julged necessary. 3. To combat these maladies by measures of sanitary police which have been previonsly discussed and adopted as the hest. 4. Not to permit the delivery of animals nor of herds which are being sent in or out of the territory, except on cer. tificate of origin and of health of a guaranteed administrative valne. 5. To contribute to the publication of an international veterinary bulletin.

\section{REIUARKS.}

The above has been reported at considerable length beeanse of its manifest bearing on the problems which now press on the Amerivan people for solution. In Anerica, as in Emrope, the medical and political anthurities have nudertaken too much of what properly pertains to the reterinary profession, and, as a consequence, wo hare had measures that aimed at repression rather than extinction of animal plagues, and the administration of these and eren of better measures has been made in such an irregular and badly sustained manner that what had been gained to-day by much effort and ontlay was lost on the morrow by a relaxation or entire suspension of the rules.

To have efficient legislation the best available reterinary adrice shonld be secured as to the measures to be framed in a bill, and a reterinary anthority should be intrusted to see the statute rigidly and impartially administered. Place it in the hands of a mere beanrocracy and this will too often, as in the past, lesult in its administration in what they consisler the spirit-not the letter-of the law, mutil all its valuable provisions are frittered away and lost. A knowlenge of the diseases is essential to a knowledge of the findanental principles on which suppressive measmes must be based, and, in ignolance of these 
principles, any attempt to carry out the law in its spirit rather than its letter is sure to end in blmulering and failure.

Then, again, as regards interstate administration, nothing ean be more instructive to Americans than the European difticulties in dealing with the animal plagnes under the motern conditions of great mann. facturing prosperity and the murecedented activity of the traffic br rail. Examinations of eattle in transit must be given up as absolutely inefficient, for herds that formerly develoned disease during the tardy and toilsome morement by highways can now be sent through in a few days hy rail and long before the deady germs within them can manifest their presence by overt symptoms. Fo better commentary can be furnished on the utterly futile provisions in a number of successive Congressional hills for the inspection of cattle in transit in our inland trade and of beeves abont to be shipped to Europe. Again, the enor mons proportions of the constantly increasing cattle trade toward mining, manufacturing, and commereial centers in Western Europe las been found to be utterly incompatible with the maintenance of such a quarantine as would protect against imported contagion, and they are for the first time brought face to face with the fact that the protection of any country in the line of this great cattle traffic must be secmred, if at all, by a perfect system of seclnsion and suppression in the country which furnishes the supplies of lire stock, and by an houorable exclusion by such conntry from the chammels of traftic of all live stock and their fresh products having their origin in an infected district. Americau lawmakers and administrator's must see that our minfected States and Territories can have no guarantee of continned safety in oul present system under which live stock fiom infected States and districts, withont even the pitiful and comparatively nseless form of inspeetion and certificate, are sent to the very source of our great live-stock traftic. Fortunately for us our westward traffic in live stock is so limitecl that it is quite possible to impose an effective cuarantine on all subjects moved in that direction. If nothing more can be done, this at least is within onr power. Each State can quarantine all cattle or other live stock from an infected State, or if the State fails in its duty to itself and neiginbors the United States can step in and regulate this item of intestate commerce.

Again, the experience of Enope with her great live-stock traftic by rail shows how utterly helpless we wonld be in any attempt to control these animal plagnes if they once reached the somrce of this trattie. As is now the case with Texas fever, our first resort would he to prohilhit all movement of susceptible stock from the infeeted areas, and the next to seek by every jossible means to stamp ont the infeetion on the native herels. If Europe with her extensive, not to say nuiversal, tields of infection, fincls lee profit in mantaning a uniform veterinary sanitary service, operating at every point over the hoad continent, and suppres. ing and sechuding animal plagnes wherever they may anpear, how much 
more profitable mnst it be for the United States in dealing with her one exotic and imported plague, that of the lungs of eattle, which is still confined to the merest strip of her territory, and when the proposed control is to prevent its extension over the whole continent, and the necessity for a similar service and control from the Atlantic to the Pacific? It would require but the ontlay of a sum equal to half our yearly losses on eattle exports by this canse alone to abolish this canse forerer; it wonld require but the expenditure of a trifling fraction to save us from the future loss of millions. Again, if the independent nations of Europe find it necessary to have an international șstem of repression and extinction to expel their prevailing animal plagnes, and if they have to sink national jealonsies and rivalries in the presence of these international enemies, will the United States of America, with a Federal Congress and one Federal Executire, sacrifice to a sentiment our birthight to the most extended live-stock interests in the world?

Shall we calmly see the Enropean states, with a legacy of ages of warfare and mutnal hate, and ground down by their immense standing armies, the root and frution of their common suspicions, mite cordially and loyally in a common international work to erush out the prevailing infections of centuries and to secure an untrammeled traftic in healthy lire stock and somd meat while onr mutually dependent States. bounil in one federation, an unit in war, an unit in commerce, and, an mit in all that relates to foreign nations-shall these states let a mutnal jealousy prevent an interstate sanitary work court the general diffinsion of onrexotic infections, load the continent with animal plagues moler which modern eonditions must he more ruinous eren than those of Enrope in the past, and shut themselves out from supplying the meat market of the world which it is now theirs to take and to hold?

\section{CONTAGIOUS PLEURO.PNEUMONIA OF CATTLE.}

This subject was introduced by an extended report by Professor Degive and two supplementary reports by Messrs. Leblane and Put\%. Degive arrived at the following conclusions :

\section{A.-Differential diagxosis.}

1. From an anatomieal point of view we may consicler as contagious and epizootic all interstitial puenmonias of a eertain extent of which the developmeut does not repend ou loeal conditions or eanses.

2. From a physiological stand-point, epizootic plenro-pneumonia is especialls charactrized in the living animal by its contagions character and the symptons of lobar puennonia.

3. In an infeeted stable every animal that shows fever with one or more spmptoms denoting irritation of the respiratory organs, eongh, lurried, plaintive breathing, de. should be suspected of plenro-pnenuonia.

4. The spontaneity of one ease of plenro-pmenmonin will not exclude the existence of the contagions affection. 


\section{B.-Propity LAXIS.}

1. The development of plenro-puemonia may sometimes be preveuted by a simple recourse to good hygienic conditions.

2. Animals affected with the malady, or suspected of it, slould he sacrificed as quickly as possible.

3. Animals susprected of infection, or very much exposed to contagion, should be isolated or sacriticel. The slaughter of animals suspected of infection is more especially indieated when the disease manifests itself very exceptionally, or for the first time, in a stable belonging to a commune rich in cattle.

4. Animals snspected of infection. or very much exposed to contagion, and not sacriticerl, wonld be profitably submitted to inoculatiou or to an appropriate preventive medication. Inoculation is especially applicable when the mimals make part of a large herd, subject to frequent changes, or where the malady has already appeared severil times.

5. Inoculation should not he preseribed as a general or obligatriry measure mutil a method is devised which can be practiced without danger to the bealth or life of the beasts operated ou.

6. Inombition should not be practicen withont the previous anthorization of the local authority. It should only be done by a veterinarian and under police surveillavee.

7. Every inoculated animal shoubl he considered as suspected of contamination and treated as such.

\&. The discased and suspected aninals should he reported to the anthority with the least possible delay. 'This report should be modeolyligatory on owners and at tendants, roterinarians, and inspecturs-the experts of the abatoir or butchery.

9. Quarantined (isoles) animals should he male the oloject of a special census and shonld receive a distinctive brand with a hot iron.

10. No animal stispected of infection slonld be moved without purious anthorization of the communal administration. The permit to move shonld only he granted for animals destined to the butehery ; it should only take place in special couclitions, under the nupervision of the police and in such a manner as to prevent all propagation of the malady.

11. Every bovine animal offered tor sale onght to bo accompanied hy a certilicate of health testifying that no epizootie las existed for at least six weelis in the contmume from which it ritule.

12. In cortain special cases to be detemined by the reterinary ofticial there may be prescribed the suspension of fairs and markets, the prohibition of the inportatuon of animals trom a suspected conntry, Inarantine, the posting of notices at the entrance of infected cireles or farms, and the writing of handbills and instructions warning the popmation of their oliligations and of the precantions to be taken to prevent the appearance or extension of the malaty.

13. An active supervisim shonld be exereised, not only over the cuarantined beasts, but alse : a. Of animals exposed for sale in makets, tields, and fairs. b. Orer animals locked temporarily in the stables of inns aljoining the markets. ¿. In stables containing many animals suljeet to frequent clanges, and whou the malaty has alrealy mate one or several outbreaks.

14. The duration of quarantine should be for 45 days at least after the disaplearance of the discase.

15. At the release from quarantine the cattle should receive a second mark to ammul the effect of the lirst.

16. 'The thesh of an aninal slanghtered shonld not be used for food nnless anthorized lyg the veterinarian making the antops.

17. The skin shouk not bo utilized until it has been steeped for at least twenty-tour lonts in an alproved disinfectant solution. 
18. Carcasses and callavric debris unfit for food should be buried or so treated as to become absolutely inofiensive.

19. Stables, fair-gromuds, markets, and vehicles which have been occupien by diseased or suspected animals, should be carefinly cleansed, üisinfecter, and purified. These different operations should be muder the direction of a veteriuarian.

20. A stable prerfectly disinfected aml prified by eight days' free ventilation mas be refilled withont danger.

21. Pasturages that have been occupied ly diseased cattle should be shut up for forty days at least.

:2:. The different materials, objects, and instruments that have been employed in the slanghter, transportation, and burial of diseased or suspeeted animals should be destroyed or thoronghly disinfected. Forage and litter should be ntilized for horses and other solipedes.

23. Persons who have becone soiled by infecting materials should wash their hauds, brush or wash their clothes, and wash their boots with a disinfectant solution.

24. All persons and animals capable of carrying the virus should be, as far as possible, kept from disea-ed animals, their carcasses, ant caravrie débris."

25. Indemnity should be accorded: 1. For animals slaughtered ofticially. 2. For those that have died from inoculation. 3. For different objects or instrments of which the destruction is judged necessary.

26. Very heavy penalties should he imposed on persons who violate the different sanitary regulations ordered by the anthorities.

2\%. A good organization of the veterinary service is the best guarantee of the application of the different measures prescribed.

28. A last and potent measure for secming the extinction of contagions plenro-pnenmonia cousists in adopting a provision for the contagious diseases of animals as has been done for the phyloxera of the vine; to formulate an international agreement, in which shall be.jndicated the essential elements which ought to form the basis of the legislation to be adopted by each comutry which shall join it.

Degive justly accorded to lung plague a principal place among the plagues which are most cletrimental to agriculture and the public wealth. In enumerating its anatomical lesions he lay's stress on the inflammatory action being especially provocative of exulation into the interstitial connective tissues of the lnng-interlobular, perivascular, interalveolar, and subplemal-mpon the prominent implication of the lymphatics, upon the great extent of lungs involved even when the general symptoms of illness have only just appeared, npon the presence of lesions of difterent ages, implying a long standing and a slow and oceult progress of the disease, and the existence in the exndate of the specific micrococcus of Willems, Bluylant, and Verriest. (Strangely enough, he fails to emphasize the infarctions and encysted sequestra which are socharacteristic of the affection.) Under the head of physiological characters, besirle the general symptoms of fever and intlammation of the lungs, he lays special stress on the two types of the disease, rapid and slow, the latter remaining insirlions, hirlelen, and apart from indications furnished by ansenltation and perenssion, harlly recognizable thronghout its entire conrse; on the nortality areraging 30 per cent.; on the infections property, very valiable in different cases, but always highly conchsive when well markel. He seeks to establish a theory of spontaneity from the facts that in many cases contagion eannot be traced, that Grawitz, Greenfeld, and buchner have cultirated patlogenic fungiand bacteria 
until they have become harmless, and harmless germs, until they have become pathogenic.

Under prophylaxis Degive adduces instances in which a thorongh attention to the laws of hygiene in ventilation, lighting, feeding, \&e., have seemed to arrest the propagation of the poison. In this as in the question of spontaneity the experience of Degive, limiterl to a country in which the disease constantly prevails, is misleading. He fails to take into account such sweeping evidence as the entire absence of the lung plague from America, Soutl Africa, and Australasia until the ocenrrence of a single importation of disease, and its deadly prevalence in all three from that moment onward, notwithstanding that in the two lastnamed places the victims enjoged an open-air life in mild and equable elimate, the most firrorable possible for the lnngs. He further ignores for the instant the irregular and ocenlt cases of the disease which confer immunity, and at once explains the sudden disappearance of the disease in particular herds eoincidently with a better hygiene or a worse one, and the introdnction of infection into a new locality where the best efforts of the reterinarians have failed to trace its source.

Degive strongly adrocates inoculation, snpporting his riew by the following facts :

1. Out of 6,706 inoculated eattle placed in the same pathogenic conditions as 2,453 non-inoculated ones, 182 only, or about 2.71 per cent. among the first, and 660 , or 26.90 per cent. annong the second have contracted lung plague.

2. Ont of 63 previously inoculated in the tail or by intrarenous injection, and in which a second inoculation was practiced in a region rich in comnective tissne (a deally region), 61 have shown no local reaction, and 5 presented a slight intlanmatory swelling, which in 6 beasts inoculated for the first time in the same dangerous regions, an test eases, all had an extensire inflammatory engorgement ending in death. ()at of 6 animals inoculated by intravenous injection in the jugnlar and afterward subjected to 17 inoculations in the space of 16 mouths, 4 provel unaffected, 13 had slight inflammatory reaction, and 1 only hat a considerable engorgement which did not prove fatal.

The immunity secured by inoculation has lasted four and fire years, as observed by Ziegenbein, in animals ronstantly exposed to in. feetion, and for one year in 16 test cases in the experiments of the Central Suciety of Veterinary Medicine of Paris.

The drawbacks to the operation are:

1. All the inoculated do not aequire al perfect immunity.

2. Inoculation preserves and spreads the poison.

3. A certain small proportion die from the extensive swellings and gangrene consequent on the inoculation.

That all the inoenlated are not protected is shown in the above sta. tistics; some lighly susceptible animals still contract the disease as some men contract small-pox after vaccination. To secure a better im- 
munity it is adrised to make more eareful selection of the virus from a lung engorger yellow and alrealy slightly fibrinons, or from the subcutuneous connective tissue in an inocnlated region rich in that tissue, to repeat the operation after a certaiu lapse of time, as arl rised by Willems, and with weakened virus to inoculate in a region rich in conneetire tissue. This, it is claimed, can be done safely with virus which has been kept six weeks in a hermetically sealed tube (Pasteur), or with what has been eultivated for a length of time in flasks in a speeial manner (Bruylants and Verriest). Virus diluted with 50, 100, and 500 times its amount of inert liquid still remained dangerous. (Vaudermies: Central Society of Veterinary Medicine, Paris.)

The danger of the propagation of the disease by inoculation is really very slight. Tet he acknowledges the presence of the rimlent micrococens in the inocnlation exudate, and advocates inoculation as a means of procuring pure virus for finther protective inocnlation.

To obviate the slight danger of lung infection throngh inoculation he advocates the use of attennated virus (ì la Pastenr, or ì les Bruylants et Verriest) and the intravenons injection of the virus pure or attennated. (It is to be noted that an absolute immunity is not elaimed for any method, nor an absolute protection against the propagation of the dis. carse by the inoculated; the claim is that these may be rednced to a very small fignre. It follows that the protective inoculation is a measure of repression, not extinction, and to a case like ours, where a prompt stamp. ing ont is imperative, it is quite inaphlicable.) This is the more evident from Degive's opinion that "all inocnlated animals are to be regarderl as suspected of infection, and treated as snch, and that after the completion of the operation all virulent products shonld be thoronghly destroyed or buried."

To obriate losses from inoculatiou he purticularly arlvises the use of attenuater rims or intravenoms injection, ann to aroid the operation during hot and rainy seasons.

For the destruction of the poison it is neeessary to attend to all fodder (which has remained infecting for 3,4 , and eren 9 months), all articles about the stables, or suspected eattle, all other animals (not bovine) that have cohahited with them, all places (buildings, Sc.) where they. have been, all rehicles used for their eonverance or that of their prodnets, and all persons that have come near them or the infected places. The infected herd, the eareasses, and fresh products must receire, of comse, the first attention. Thorough destruction or disiufection of all these is absolutely essential.

As the discovery of infection is the cormer-stone of success, it must be made obligatory on all owners and attendants on cattle, on all reterinarians and inspectors of abattoirs and meat markets, to promptly re. port all eases of the disease, under a heavy penalty for disoberlience and for the owner a liberal indemuity for cattle and objects destroyed.

At his risit the official veterinarian must note the animals sick and 
exposed, the somrce of the infection, what oljects hare become in. fected, what persons and animals may become rehicles of the rirus, and what measures (especially isolation and killing) are reguired.

Inspertion of fairs, murkets, and herds in an infeeted district, and risit, every fortnight, of large stables, then having frequent changes, and those those that have been infected, are requisite.

Slaughter should be resorted to for the sick and all suspected of disease, no treatment being permitted. Recorered animals should in all cases be nsed for meat only. All slanghter of subjects out of an infected herd shonld be in the presence of as few persons as possible and under the inspection of a reterinarian. The animals suspected of being infected should be inocnlated. (The provision against treatment should also preclude inoculation it extinction of the disease is desired.)

For iudemuity as a means of secming early reports he ald roeates, at least one-half the sonud value for heasts suspected, ret fit for human consumption, and at least three-fourths the somm ralue for those that are diseased and unfit for food. Better still to completely extirpate the infected herd and indemnify to the extent of the full value, as in Holland and England; the state to retain in such a case all proceets fiom flesh and hicle.

Under isolation come: (u) Sequestrution in a particnlar place near which no other cattle nor other animals are allowerl.

(b) C'antonnement or parkafie in a secluded place inclosed by walli, liedges, barriers, palisades or water, and sitfely apart from roads, parks, \&c., frequented hy other stock.

(c) Sanitury zomes or circles, including a part or whole of a rillage or commune or several communes, separated from all communication with ontside districts.

(d) Census and muring are essential to a perfect control of such secluded places.

(e) Prohibition of morement of all sick and suspected animals is abso lutely essential. Inder special precantions fat eattle may be moverl in closed wagons to slanghter, and work-oxen may be ntilized on exprain preseribed fields if there is no danger of commmication with other cattle, direct or indirect; no cattle shonld be exposed for sale anywhere withont an official certificate that no epizootic has existerl for six weeks or more in the commune from which they were drawn.

$\left(f^{\prime}\right)$ Suspension of fairs and marliets is only demanded when the lung plagne has attained to an extensive prevalence.

(g) Importution of entlle should be interdicted from any infected country unless they are accompanied by a certificate of health dated six days before and showing that no hnng-plagne has existed tor at least six weeks in the place from which they eame. (Such provisions show the aim at restrietion rather than extinetion of the malally, as they eonld not arrest the occult cases nor those having a long period of incubation._. I. L.) 
(h) Quarantine of newly-bought animals for fire or six weeks is an important precaution.

(i) P'osting notices of infection at the entrance of infected zones or fillills.

(j) Handbills and instructions for the people in or near the infected area.

(k) Sureillance with rery frequent visitation by insjectors and police.

Preventive mediention for animals exposed to infection may embrace setons medicated with hellebore, and antisepties, such as ferric sulphate, alkaline sulphites, carbolic aeid, borax, tar, ehlorine.

All restrictions may be removed forty days after the last case of disease lias been disposed of and the place and objects disinfected. (This is entirely inconsistent witl what he has already advanced as to ocenlt eases, chronic cases, and long periods of incubation which conld so easily ex. ceed twice the forty days required. It is another indication of an aim at restriction rather than extinction.)-J. L.

If carcasses have to be removed, this should be done in wagons with close joints, so that nothing shall escape, and drawn by horses under police supervision. The eareass and diseased products may be deeply buried, burned, rendered, or dissolved in sulphuric acid. It is often utilized for foor, but this should be prohibited when the lung lesions are rery extensive, adranced, and complieated by gangrene, when there is nleeration of the bowels, or when the flesh is flaccid, decolorized, ecehymosed, or the seat of serous infiltration. The slin may be sent to the tannery after steeping a length of time in milk of lime, or solntion of ehloride of lime, or zine. or carbolic acid.

Disinfection of stables demands washing, scraping, and the thorough application of liquid disinfectants. Mamure, fodder, and litter should be burned or disinfected, or the latter may be fed to horses. Horses and other animals that have been with-diseased cattle should have their surface cleaned and disinfected by an antiseptic solution.

\section{LEBLANC'S VIEWS.}

Leblane sought to throw doubt on the diaguosis of lung plague dur. ing life, on the specifie charaeter of the lesions seen in the carcass, and on the value of inoculation. Many inoculated animals have already liad the disease and are protected by that; eases alrealy infected before inoculation have the disease aggravated by the operation; the poison, and therefore the disease, is preserved and perpetuated in certain dis. tricts by the practice of inoculation; inoculation is no eertain prophylactic, for just as in the sime lumg we see chronic lesions side by side with the acute, implying a second attack, so may an attack follow a snccessful inoculation: and finally, the same measures of segregation and slanghter usually employed with inoculation would be successful withont that operation. 
PUTZ'S VIEWS.

P'utz does not hesitate to pronounce the physiological symptoms and pathologieal lesions as together reasonably pathognomic. He is a strong partisan of inocnlation, provided the operation is repeated after a lapse of time, and above all if repeated again and again. It is nseless or injurious for animals that are already infected, and the duration of the immunity acquired in successful cases raries with the individual susceptibility, as toes raccination for the prevention of small-pox. It is especially valuable in places where morements of great numbers of cattle are continually going on, aud where sequestration is in consequence impossible. Where, on the other hand, there are few morements of stock the isolation and slaughter of the diseased and strongly suspected beasts is speedily effective. In Holland with inoenlation the disease has been confined to the narrorest limits, while in most jarts of Germany it has been stationary or increasing, and in Saxony with little inoculation it has in recent years attacked three times the number of rictims seized in $1875-76$.

In addition to the measures of sequestration he advocates: 1 . That the quarantine mark shonld bear the year so that it may be afterward known when they were diseased or suspeeted. 2. That all diseased and strongly snspected animals should be killed, and that the entire herd should be slanghtered when judged necessary, indemuity being granted for the same. 3. When, owing to freqnent thanges in a large herd, or when, from economical considerations such herd may not be slaughtered, the same should be compulsorily inoenlated. Inoenlation may be anthorized in au infected country, if desired, by the proprietor, and cousequent losses should he paid for. 4. Every beast from a quarantined herd which dies or is killed ought to be the snbject of an antopsy ha a competent person. With this precantion such cattle shonld be devoted to slanghter for beef as much as possible, no neeessary precantion being forgotten.

\section{ACTION OF THE CONGRESS.}

$$
\text { A.-Diaginosis. }
$$

The question of diagnosis of lmug plague gave rise to a somewhat lengt ly, animated, and fruitlessdiscussion as to whether this disease can urisespon. taneously, or whether it is everyuhere and aluays the result of contagion. The arlvocates of a spontaneons origin of the disease acknowledgerl that the occurrence of a spontaneons ease was extremely rare, and that in spite of spontaneons cases a system of repression, baserl on a coustant assumption of contagion, was the best; yet they claimel, as alreaty stated of Degive, that the malady may originate by the transformation of harmless germs into virulent ones, or it may be by the transformation of normal histological clements of the body into diseased elements having a power of propagating themselves indefinitely. The opponeruts, 
on the other hand, held that the non-appearauce of this disease in historie time, in any conntry in which it had not previonsly existed, unless in cases where its introluction conld be elearly traced to the inportation of a diseased animal ol its products, and its eontinnel absence from all countries into which no such importation had been made im. plied, unequivocally, that the assumed cases of spontaneity were also cases of infection, though investigation had failed to show the precise channel bs which the germs had been introduced. A comparison of the mationalities of the adrocates of spontaneity and against it is rery instructive as showing that the belierers in spontaneity are those whose experience has been gained at the termini of the cattle traffic from Central and Eastern Europe, at points (Belgium, Frauce), iu short, where the infection of lung plague is being constantly imported, and from which it is never entirely absent, whereas the disbelievers in spontaneity are mainly from countries (England, Swerlen, Switzerland, Roumania, America, Sc.), in which lung plague has been stamped out, or into which it lias been first introduced in recent times by a well-attested importation of disease, and where its area of prevalence is sharply limited to places infected through such importations.

This well illustrates the prenlominating influence of the immediate surroundings. Hal the able alvocates of spontaneity lived in Spain or Portugal, where herds abound, but to which the lung plague has never penetrated, or in Scandinavia, where its occasional importations have been as persistently stamped out; or in Switzerland, the inme. worial home of the plague, but from which it has been expelled; or in England, which it respected until it was imported in 1839 and where it has prevailed ever since, but still spares the exclusively breeding listricts; or in the United States, where it was imported in 1848 and 195 !) and where it was effectually stamper out in the fenced farms of New Englaud but eontinues to prevail throngh the constant changes and successive infections in the eity dairies of the Middle Atlantic States, and finally where the whole IVest aul Sonth maintains a perfect immunity; or in South Africa or Australasia, where the disease, long nnknown, has spreal from single importations and from the constant mingling of herls maintains an universal prevalence; or, finally, in Canala, Newfonnd and, Mexico, or Sonth America, to which the plague has not ret been inported and where, as in the extusively breening districts of infected comntries, no spontuneous case has ever occurred to start it on its llesolating vareer, they would have realized that they were arlrocating a mere phantom dinger and that the plagne which has failed to appear in historic time in a comntry not already in. feeted from withont may safely be trusted not to appear in the future with such exotic contagion. They would no more argue from the first cise of the plague than the botanist would arene from the first oalk that oalis must now appear without seed or slips; they woull aecept the unvarying testimony from all parts of the inhabited earth which are 
not ret infected or which have been infected in historie time that erery extension of this plague has been by contagion and by contagion alone.

On motion of Wirz the followiug was adopted as the first resolution:

1. From an anatomical point of view, at least in its relation to veterinary police, every pnenmonia (of cattle) which is lobular and at the same time interlobnlar, and the development of which does not depend on tram tic local causes, should be considered as epizootic contagions plenro-pnemmonia.

The second resolution was modified by adding the word contugious, su tlast it might read :

2. From a physiological stand-point, epizootic eontagions pleuro-pnemmonia is specially eharaeterized, in the living animal, by the contagious character aud hy the syuptoms of lobar-pneumonia.

To the third resolution the following wording was given :

3. There onght to be considered an-

(a) suspectert of epizontic nontagious plenro-pnenmouia every animal which in an iufecterl place manifests symptoms of fever or of disease of the chest.

(b) suspected of contamination every animal fonu? in au infected stable, or which has been in one within three montlis, or which has been exposed to infection in any other war.

The fourth resolution was suppressed on motion of Lydtin and WVirz.

\section{B.-PropHYLAXLS.}

On motion of Zundel and Lydtin the congress decided to take up first the question of stamping out.

On motion of the same, Article 2 was modified and finally passed so as to read as follows:

2. Reeognizing that from the point of view of sanitary police epizootic plemropnemonia propagates itself only by eontagion, and is nsmally incmable aud fatal, this congress ifeclares that amimals affected by the malady or suspected of it should be sacrificed as quickls as possible.

The third article was alopted with the single change of substituting contaminated for suspected of contamination or very much exposed to contagion, the word retaining the idea ef exposed to contagion. It read this:

3. Contaniuated animals shonld he isolated or sacrificed. 'The slanghter of' contaminated animals is esprecially indieated when the disease manifests itself very exceptionally or for the first time in a stable belonging to a commme rich in castle.

On the question of the value of inoculation as a prerentive, much discussion ensued, the great majority, howerer, accolding to it the power of protection to a certain extent. A number, howerer, of these last, aud especially those who like Berdez (Swit\%ellaud), Law (Now York), and others had had a farorable experience of stamping ont, depr. reeated inoculation in any conntry where it was possible to promptly extirpate the plague by the radical measmes of slanghter and disinfecetion. Wir\% reprorted that of the 182,305 cattle inoculated in Holliurl, in the past four years (1S7S-185:) the losses from the operation had heen under 1 per cent., and the protection had been satisfaccory. Law le. peated the inoculation of 10 cattle with sterilized virus which obivated 
the rlanger of infection from the inoculated, and which, in a six-mouth's test, by inoculation with attested ripulent lymph, and by residence in infeeterl herds, had proved perteetly satisfactory. IVillem's proposition that "all scientific interpretations being reserverl no fact in practice has proved the contamination of a liealthy by an inoculated animal " was roted down, and the following of Potteral arlopted :

There is no proof that an inocnlated animal cannot transmit the disease to a healthy one.

The following, mored by Bonley, was adopted:

3. We have to-day experimental proof that it is possible to invest the organisin of animals of the boriue species with an immunity from contagions plenro-pueumonia by inoculation with the virns of this malady.

Two applications of inoculation were recognized-preventive inocula. tion (inoculation in the absenee of the lisease), and inoculation of necessity, (inoculation of animals (langerously exposed to infection). As an amendment to Article 4 the following was passed:

4. Porentive inocnlation, that is to say, that which is practicen where the malady does not prevail in a conntry, ongh t to be absolntely rejected ; inoculation, so called, of necessity, that is to say, that which is practiced when the malady exists in a herd, mas be permitter, but not male obligatory.

On the motion of Wirz, Article $\tilde{J}$ was stricken out; Article 6 was modified so as to read :

6. The inocnlation should always be done by a veterinarian.

Article 7 was dropped.

On Degive's motion Article $S$ was altered to-

8. Inocnlated animals should be reported to the anthorities.

Articles 9 to 13, inclusive, were not ealied in question. On motion of Miiller the following was adopted :

14. The duration of quarantine should be six months at least after the disapuearanco ot the disease.

Articles 15 to 1 ! , inclusire, were not objected to.

On motion of Lydtin, Miiller, aud Potteral, Article 20 was altered as follows :

20. A stahle shonli not be used again for animals mutil it has been completely eraenated and properly disinfecterl, and then puritied by eight days" exposire to free ren. tilition.

On motion of Bonley and Aune, Article 21 mas altered as follows:

21. I'astures that have been frequented by diseased animals ought to be quarantined for at least tifteen days.

Articles 22 to 24 , inclusive, were passed.

On motion of Quirogne, Potteral, and Lydtin, Article 25 was modified als follows:

25. It is proper to grant an inclemnity to owners for animals sacrifiecl by oticial order, and for the expense of disinfection. The indemnity should amount to four-fifths of the vilue of the inimals; and to the finll valne, deduction being matle of the value of portious of the carcass that can be ntilizerl if the animal should prove healthy.

Articles 26 to 25 were adopted without question. 
RFII ARK.

Without seeking to detraet from the importance of any one position taken by the congress, it may still be well to emphasize some that have a special ralue to the American statesman.

1. The extension of the incubation of lung-plagne for montlss, and the frequent occurrence of oceult and unreeognized cases of the disease, show how essential it is to stop all morement of animals in infecterl distriets, except under license, after an extended supervision, inchuling statistics constantly corrected; also to kill ont an entire infected herd, or to maintain the above-named strict supervision for a long perion (six months); also, to prohibit the contact of adjacent herds in neighboring parlss, \&ce, and their successive presence in the same pastures, on the same roals, or at the same drinking tronghs. These dangers are just those of which it has been most diffienlt to persuarle onr United States legislators and our non-veterinary arlministrators of State sanitary laws, and on the fundamental blunders made on these points depend our failure hitherto to extirpate lung-plagne.

2. The illea of the spontaneons origin of lung-plagne in the present day is effectually set aside. An abiding confidence in our perfect security from this disease apart from imported virus is essential to thorongh rork. Whenever the possibility of spontaneous eases is ad mitted this will be made a cloak for slovenly and inefiective work.

3. The voice of the representative veterinarians of Europe and America has been given against the assumption that inoculated animals cannot infect a somd animal. This is a decision of no small importance, as $f$ is operation of inoenlation is extensively praticed among us, and thon th it enables the individnal owner when left to his own resonrces to save the great borly of his herl, yet when the state mulertakes to stamp out the plagne, its practice becomes a serious bindrance by increasing and diffusing the virus.

4. In spite of the rliffienlty or impossibility of controlling the enor. mous eattle traffic which is constantly flowing westwarl through the center of Europe, and the consequent temptation to anlopt measmes of repression and restrietion rather than those of extinetion, the congress declares strongly in faror of the instant slanghter of all diseased ani. mals and of those suspected of disease. How much more should we who have to deal with but a mere patch of inspection relatively to onr territory promptly destroy every animal and every herd in which infeetion is found?

5. Even in Europe the veterinary sanitary anthorities feel that action by isolated states aiming at the suppression or extinction of lung-plagno is wofully ineffective, and they demand that the veterinary sanitary police administration shall orerstep the national boundaries and be made continental, to the extent that the different nations shall agree upon a uniform law, nuler which the disease shall be promptly stamped out

5751 D $1-10$ 
or honorably and effectually shut up in auy district where it may appear, so that an offeial certificate may give an absolute guarantee of somnness. How mnch more shonld the United States, bonnd into one nation and having one common Federal legislative body, and one Federal administration, arrange for a single law on th's subject for all the States and Territories and for its muiform alministration, whether though State or national officials? Hitherto the varying laws in different States have been a sonrce of constant uncertainty, tronble, and loss to dealers, and yet no certain guarantee against the extrusion of the plagne from State to State.

6. In dealing with an insiclions affection like lung-plague the reterinary profession in Europe radize the necessity of adopting erery means calculated to secure information of ontbreaks, and the restriction of surreptitions movements of animals; they accordingly leclare in favor of indemnity to four-fifths of the sombl value for suck cattle sacrificed and the full value for cattle exposed to infection but not yet cliseased, and also for heary penalties for all failmes to comply with the law. In our own State of Pennsylvania, infected herds lave been taken possession of by the state, and all that subsequently sicliened have been pain for at full alpraised value, with results incomparably better than where the law has been to give small indemnities and impose large penalties. Onr legislators should realize from this combined experience of Europe and Americal that niggardy mulemities mean concealnent, smuggling, and extension of the disease, while with liberal remuncration for the cattle taken the disease may be stamper out at a mere fraction of the outlay that would otherwise be necessary. In city dairies, where most of our lung-plague is to be found, the tiull value of the animals libled is far from compensating the owner for the interruption of his business mutil his herd and stables ean be prononnced somud. No economy is more false than that which saves on the payment for infected cattle sianghtered at the expense of concealment and sureptitions diffusion of the disease.

\section{EIUUATION IN TETERINARY MEDICINE.}

This subject was introduced by two separate reports-one by Hugues, of Brussels, the other by Professor Wirz, of Utrecht, and Miiller, of Iierlin.

\section{HYGUES' REPOLT.}

A.- Eduention in veterinary medicine and the social position of the retcrinarian demand a thorongh preliminary instruction corresponding to the classes in humanity or tho complete professional ones.

13.- Edneation in veterinary mediene shonld ho theoretical, scientifie, practical, experimental, and educational, in giving to ach of thesethe relative'impertance which the ral neorls of professional work clemands.

To this rad we ask-

1. That the stmblies st ould extent over five yoars. 
2. That the exterior of domestic animals he made the subject of au essentialls practical eonrse, of which the stndy of animal mechanies shall be the basis.

3. That there onght to he created in every school in conrse of equitation.

4. That exercises at the forge shonld he abolished.

5. That the conrse of special patlology should he abolished.

6. That there should lo theoretical and practical instruction in the inspection of alimentary matters of animal origin.

7. That there shonld he at least two professors of elinics in ench school.

8 . That a resilence ontside the walls (external) shond bo obligatory at least for the last two years of study.

9. That a period of probition (stage) lue imposed as complementary to the school studies.

10. That practitioners shonlu be made part of the examining boards.

11. That the appointment of professors should be mado on the donble basis of concours and of scientific reputation; that assistants or tutors shonhl he nominater on. the propasition of the professional college.

While we cannot follow Hugues through his elaborate report, yet we may enll a few of the points mate in favor of his propositions.

A liberal profession is marked by soliclarity ; it is cosmopolitan, knows no territorial frontier, no nationality ; it is the product of civilization, and protected by muiversal science. The liberal profession of medicine is one; its methorls only differ according to the species to which it is applied. The two professions of medicine-lmman and veterinayare sisters, equally liberal, and demand an equally extended preliminary training and give an equal right to consinleration. To secure this equality the edncation for the one must be as thorough as for the other, alike in its literary, seientific, and special features.

Co tinental Europe has thirty-three well-equippen veterinary sehools, each a Government institution, controlled and supported by the state. Great Britain has four veteriuary schools, none of which is muler state support nor control aside from the charters moler which they are maintained. In England and Austria the course of study extends over three years; in Germany and Switzerland, three, pears and a half; in France, Belgium, Holland, 1)enmark, Sweden, Russia, and Italy, fonl years: and in Rommania, Spain, and Portugal, five years.

As an example of the currieulum, that of the Brussels school will alone be givell.

\section{VE'TERINAR STHOOL OF BRUSSEIS.}

$$
\text { HILST YEAL-WINTER SLMESTER. }
$$

Descriptive anatomy, $1 \frac{1}{2}$ hour per week. Dissections, 9 hours.

Tnition in elemistry or plyyies, $1 \frac{1}{2}$ hom's. Lectures in chemistry or physies, $4 \frac{1}{2}$ hours.

\section{SUMMER SEMLSTER.}

Botany, $4 \frac{1}{2}$ lonirs. Botanieal exromion.

'Tuiton in lutany, $1 \frac{1}{2}$ homl. Chemistry or plysies, $4 \frac{1}{2}$ lomrs.

Tnition in chemistry or physics, $1 \frac{1}{2}$ hour.
Botiny, 3 hours.

lixamination in chemistry or physics, 18 lionr.

Zoologry, 3 lomis.

Tuition un deecriptive anatomy, $\frac{1}{2}$ lowx daily.

Examination in chemistry or physics, $1 \frac{2}{2}$ lioul: 
SECONI) YFAR-WINTER SEMESTER.

Tnition in ehemistry, $1 \frac{1}{2}$ hour.

Juition in physies, $1 \frac{1}{2}$ homr.

Examination in chemistry or pleysies, $1 \frac{1}{2}$ holli:.

Gemeral anatomy audiphy siologr, $4 \frac{1}{2}$ hours.

Tuition, general anatomy am physiology, $1 \frac{1}{2}$ hour.
Descriptive anatomy, 3 hours.

Dissections or exercises in histology, $4 \frac{1}{2}$ hours.

Dissections, 15 hours.

Physies or ehemistry, $4 \frac{1}{2}$ hours.

Comparative anatouy, 1 是 hour.

\section{STMMUR SEMESTER.}

Tuition in plysics or chemistry, $\frac{1}{2}$ homr. Tution in chenistry, $1 \frac{1}{2}$ hour.

Tuition in general anatomy or plysiology,

$1 \frac{1}{2}$ homr.

Work in histologry, $4 \frac{1}{2}$ honrs. l'hysies or chemistry, $4 \frac{1}{2}$ hours.

General ana tomy amd physiologr, $4 \frac{1}{2}$ homs.
Comparative anatomy, $1 \frac{8}{4}$ hour.

Tuition in eomparative anatomy, $1 \frac{1}{2}$ bour every 15 days.

Work at the forge (marechalerie) 3 bours.

Examination on chemistry or physics, $1 \frac{1}{2}$ hour.

\section{THIRD YEAL-WINTER SEMESTER.}

Clinies, 2 hours daily.

Pharmacologs, 3 hours weekls.

Tuition in general anatomy and physiologry, $1 \frac{1}{2}$ hour.

Theory of shoeing, $1 \frac{1}{2}$ homr.

Genemal patholong, and special and pathological anatomy, $4 \frac{1}{2}$ hours.

Tuition in general and special pathology, and pathological anatomy, $1 \frac{1}{2}$ hour.
Exercises in operative nenlicine (surgery), 3 honls.

Exterior (form), 3 hours.

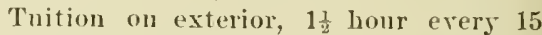
lays.

Special therapenties and pharmacodynamies, 3 homs.

Topoglaphical anatoms, $1 \frac{1}{2}$ homr.

Work at forge, $1 \frac{1}{2}$ hour.

\section{SLMMER SEMESTER.}

Clinies, 2 hours daily.

Operatious on the foot, $1 \frac{1}{2}$ hour pel week. Operative medicine, $4 \frac{1}{2}$ hours.

Denumstrations in pathological anatomy, $1 \frac{1}{2}$ hour.

Geneal pathology and special and pathological auatomy, $4 \frac{1}{2}$ hours.

Tuition in elinies, $1 \frac{1}{2}$ homr.
Pharmacology, $1 \frac{1}{2}$ hour.

General thelapentics and pharmaco-dynamies, 1t hour.

Pharmacentical manipulations, $1 \frac{1}{2}$ hour. Tuition un general pathulogs and special pathologieal anatomy, $1 \frac{1}{2}$ homr.

Zootechus, 1 hour.

\section{FOULTII YEAR-WINTEI SEMESTER.}

Clinies, 2 hours dailș.

Tnition, elinical, $1 \frac{1}{2}$ hom per week.

Surgieal pathology $4 \frac{1}{2}$ homrs.

Pharnacentioal mani]ulations, 3 hours.

Olistetries, $1 \frac{1}{2}$ hour.

Practical operative medicine, 3 hours.
Work at force, 3 hours.

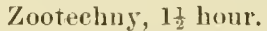

Tuition in surgical pathologr, $1 \frac{1}{2}$ hour.

Constitutional law, $1 \frac{1}{2}$ hour.

Equitation, 4 lonss.

\section{SUMMER SEMESTER,}

Clinics, 2 hours daily (2 hours weekly chinies in ehair).

Work at forge, $3 \frac{1}{2}$ hours.

Pharnacentical manipulatious, 3 hours.

Tuition, clinical, $1 \frac{1}{2}$ lourr.

Medical jurisprudenceand sanitary police, $1 \frac{1}{2}$ hollr.

Tuition in surgical pathology, $1 \frac{1}{2}$ loour.
Zootechny, 3 hours.

Examination of meats, $1 \frac{1}{2}$ loms.

Zootechnic conferenees, 1 hour.

Tuition in zootechny, $1 \frac{1}{2}$ homr.

Equitatiou, 4 hours.

Tuition in medical jurisprudence and sanitary police, $1 \frac{1}{2}$ hour.

Coustitutioual law, $1 \frac{1}{2}$ hour. 
Others of the sehools, and notably those of France. give instruetion in modern languages and literature, which Hugnes holds should he obtainer before entering the veterinary school. To further relieve the emrieulum and give more time to the exchsirely pofessional studies, he wonld abolish the class on constitutional law, that on shoeing, and even that on special pathologg as tanght fiom the chair, thus throwng the student back on books and elinical teaching for instruetion in the pratice of medicine. The need of some relinf is well illustrated in the fact that a large proportion of students to-day exceed the allotted period of sturly preliminary to taking a degree. Thus at Brussels in former times a tililure to pass in four years was altogether exceptional, while muler the modern crowding of studies but :33 out of 76 students have patssed in this prescribed period; of the remaning 44 students 20 took fire years, 20 six years, 1 seren years, and 3 eight yeu's.

The curriculum has greatly ontstripled the ability of the student to cope with it, and the two shonld be arjusted so that the majority may be able to graduate in the preseribed period. Though something may be done in eliminating subjects that are not purely professional, yet, with the rapid advancement of science, the exelusirely professional work incumbent on the student tends constantly to increase, and the strain must be met by securing a better preliminary training, and by extending the curriculum to five years. Thus, for admission to the school, a knowledge of one or more morlern languages should be demanded; those of the aljoining eomntries being always valuable as giving a rey to their literature and as being essential in the adminis. tration of sanitary police. The rudiments of Latin are very useful, but not indispensable. National and foreign literature have no oecasion to appear in the enrriculum, and shonld not be al condition of entrance. So of mathematics and the natmral sciences. If the same conld be applied to physies and ehemistry it would be well, but this wonld be asking too much of a boy of seventeen, and would endanger superficiality in all.

Then if the curriculnm were extended to five years, the present donble examination might be profitably extended to three; the first in seiences, the second as canclidate in veterinary medieine, on anatomy. pliysiology, histology, physies, chemistry, and perhaps the exterior, and the third one, pathological biology, therapentics, surgery, clinies, hygiene, zootechunies, sanitary police, \&e.

The examining boards should he composed of the faculty of the sehool aud a certain proportion of veterinary practitioners. This will tend to correct any tendeney in the sehools to a too exchusive attention to seientific minntia at the expense of the even more important matters of daily pratice, and give a sprecial valne and guarantee to the exanination and diploma. On the other hambl, the intimate knowledge of the eandidate on the part of the professor will euable the buard to qualify 
the results of a huried examination by the record of fire years of contimuons work.

In the appointment of teachers much is required. The professor should be a man of high morality, one inspiring respect and esteem, who knows his subject thoronghly, and who yet ean condense it to the demands of the case, and present it elearly, plainly, and concisely, ret in such a way as to engage the enthusiasm of his students. He may be a good professor withont being a sument, and ho may be a real sacant yet a very poor profiessor. To know and to teach are different things. A mind quick to write, subtle in the analysis of facts, facnle in the assimilation of all eontenporary progress, a ripe judgment, the power to present the analysis or synthesis in the for'm of a clear attractive résumé; these are the essential qualities, the rôle and mission of the professor. He mist besilles have such a knowledge of the entire curricalum as will enable him to direet his work parallel to that of his colleagnes withont exposing himself to contradiction, or nunecessary repetition by another chair. To successful teaching there must be a unity and harmony in the entire field of work. This necessitates that every professor in a chair bearing directly on specific reterinary instruction should be himself a veterinarian.

In the appointment. of professors regard should be had to the aptiande for scientific work alrearly shown by the candidate, and the aptiitude to teach, as shown experimentally before a concours. The concours alone in which the camdiclate is made to exhibit his teachiug nowers practically may often select the fluent but superficial man and reject the real seientist, as it has actually at different times rejecterl the illustrious Bichat, the creator of mieroscopical anatomy, Clande Bernard, the founder of general physiology, and Dupin, the learned procurator-general of the court of eansation. But, as corrected by repatation for work done outside the conconrs the latter becomes a means of the highest ralne in selecting a man who joins superior didactic power to a protonnd scientific knowledge and acumen.

Tutors should only be chosen from granluates, jn which case the excellence in examination shonld coincide with the julgment of the professor in charge of the department in making the selection. When professors are recruited from the ranks of the tutors they should have the experience of several years' practice.

\section{REPORT BY PROFESSORS MÜLLER AND WIRZ.}

Miiller and Wirz intorse in the main the principles ennneiated by the Intrinational Congress at Zurich in $186 i$, hut propose certain modifications. The Zurich resolutions were als follows:

1. The preparatory sturlies should be as extended for veterinary medicine as for humin melicine. It is desirable that wo shonld, as far as possible, denand for cutrance to the veterinary schools the same knowledge ats for the muiversity studies.

Since, for varions reasons, wo are not yet able to anforce such a rule, the congress is of opinion that the minimm knowledge preparatory to the special stmdies of voter- 
inary medicine shond correspond to those aequired in the second (class) of a school preparatory to university studies.

Those who have not pursued the course of snch an institution should not be admitted to the special veterinary studies nutil thes prove that they are possessed of an edncation corresponding to that of the class ahove named.

2. Three year's of special stuclies at least are necessary to secure the rank of reterinarian.

There is no call for the ereation of reterinarians of different elasses hased on differences in the rlegree of instruction.

3. Vaterinary schools mas he separate, independent establishments, or joined to ly miversities or other institutions of higher learning, hut their instruction should be special chairs. We cannot hut condemn the arrangement in which a single professor is charged with the duty of edncating veterinarians, this mode of teaching loing absolutely insufficient.

4. An organization of the instruction conformed to the ahore principles should be alopted above all when the practice of veterinary medicine is well established and regulated.

PROPOSITIONS OF MÜLLER AND WII\%.

I.

1. The preparatmy studies demanded for the study of veterinary medicine ought to be the same as those exalted of the stuclent of hmman medicine.

2. As for varions reasons this first principle cannot yet be eu forced, we ought at least to require that all who wish to enter on the study of veterinary merlicine should at least possess the acpnirements necussary to ardmit them to the highest classes of a superior school giving an orlinary grood edneation.

As an institution giving an ordinary gool edncation, we mean those schools which give a right to students that have conpleted their conrse to admission to the higher or university stmlies. (Grmuasiums, lycemms, atheneòs, Latin schools, colleges), (aud superior professional schools, Reelschulen, erster ordnung, of Germany), (Wirz and Miiller), in which Latin is olligatory (Miiller).

3. Candidates unprovided with a certificute of admission to the first class of one of these schools should show hy a special examination that they are possessed of an equivalent education.

II.

There is no call for the creation of veterinarians of ditlerentelasses having a differ ent amonnt of preparatory and reterinary edncation.

III.

1. Four years' study, at least, are remisite to make a full study of veterinary medieine, if that is made to emhrabe physical and natural sciences.

2. The instruction of the first two years (fond tirst semesters) should embrace the followingluancles: physics, ehemistry, natural history (geologs, mineralogy, botany, and zeologgy), anatomer, histology, physology, and sloeing, with the practical work attaching to them. A cunrse of pactice and demonstrations in micrography shomld always be inchuled.

3. In the same period may he tanght the zooterhine bramehes, comprehending the natural history of elomestic: animals, the exterior, and zootechuy propere.

4. Clinical teaching shonld anstinue thromerl the whole of the last two years of stuly. That the prationl instruction of thestudents maly he complete it is alsolutely necessary to have beside a stat ionary and comsulting olinie (hospital clinic and poly elinic), an ambulatory rluic (outside cliinc). 
5. L'ractical instruction in shoeing cannot be condenned as nseless, but it onght to be linited to the pul proposed; this instruction is on the whole very desirable.

6. "The in-pereti:n of mears of the butchery is an alsolutely essential branch of veterinary educations.

IV.

1. At the end of the serond year of stuly (fometh semester) the students onght to be examined on the brambles hey have studied during the two preceding vears. None should enter on the studies of the thind year mutil he has satisfactorily passed this examination (of 'andidate, or in physical and natural sciences).

2. None slumld be almitled to the examination for veterinarian until he has passed that of caudidate in veterinary medicine.

(The examination in veterinary medicine should embrace only those branches which have not formed part of the candidature examination._-Wirz.)

(The exanduation in veterinary medicine should emburce, hesicle anatomy and physiology, all branches of instruction not included in the examination of the candidate.Miiller.)

3. The regulations for veteriuary examinations shonld, as far as possible, be absolntely, or at least essentially, the sane lor all countrics.

V.

1. The system of residence in the school (interual) is not the best for the prusuit of veterinary studies and the social edncation of veterinarians.

2. If prenliar circunst ances, proprer to ans conntry, forbid the abolition of residence (interual), the students should at least be allowed entire liberty ontside the prescribed comse; the control of the internal onght to be as liberal as possible.

3. Obligatory "suterial" should be abolished.

\section{VI.}

Veterinary schools may be independent establishments, or they may be conuceted with nuversities or institntions for the higher etheation; but veterinary medicine should have its suecial chairs. One cannot hut disapprove of institutions iu which all brandeses of veterinary education are divided in a very limited number of university chairs; such a system is abselutely insuticient.

\section{VII.}

1. Prolessor's in veterinary schools should be possessor's of veterinary diplomas; an exception to this rnle may be adnitted in the ease of those teaching the preliminary courses of physics and natmal selences.

2. It is very desirable that veteriuarians before being called to a professorship should lave practiced veterinary medicine for some years.

3. The diplema of physician or M. D. shonld not in itself render the holder eligible to a veterinary protessiship.

4. The professors onght to be selected by freforence from anoug the assistants, and upon the proposition of the faculty of the scheol in inestion.

5. Finally, to be able always to complete the professional body, there onglit to be created unmerons places for assistauts.

\section{REASUNS.}

As the requirements for entering the miversity are more than eau at present be enforcerl, and more than is always reguireal for the study of medicine, for polytechnic schools, schools of mines, Sc., they shonld not 
be required at present. The same conditions of admission shomb he maintained in all reterinary schools, and for all students, national or foreign, for all, indeed, who do not attend as simple anditors. The entrance examination should be made before a commission of the faculty who best know the aroquirements requisite for the pursuit of the stmaly.

Since the Zurich congress the great additions to reterinary studies in practical chemistry, micography, \&e., necessitates the extension of the comse to fon years at least. Wirz thinks eren five yatrs desir. able.

Hugues' proposal to abolish the chair of special pathology is mitriable. So long as the chinie does not furnish abmelance of material to show and demonstrate to all the students cases of erery disease it is impossible to agree to his proposil.

While recognizing how much reterinary medicine is indebted to human medicine, they cannot admit that the knowledge of the one fits for the teaching of the other. Medical professors are far from comprehending all the requirements of reterinary education, or the exigencies of veterinary practice. Most of them continue ignorant of these from lack of inclination as much as lack of opportunity, and the edncation suffers proportionally. For professors ant assistants alike a veterinary diplona is a sine qua non.

\section{ACTION OF TIIE CONGRESS.}

After discussion the following was adopted as the first proposition:

1. For admission to veteriuary stulies one must be batchelor ès lettres or ès science's, that is to say, he must have finisherl the studies of the secondary edncation.

The second proposition of Miiller and Wirz was adopted, and rearls:

2. There is no eall for the creation of reterinarians of different classes, having a different amount of preparatory and reteriuary elucation.

The third proposition was arlopted with modifieations of the secoud paragraph, so as to krop all reference to practical work, and of the fomrth paragraph, so as to provide for two clinical professors in each school, and by the droplying of paragraphis 3 and 5 . As altered, it reads thins :

3. Four years of study at least are repuisite to make a full study of veterinary medicine, if that is male to enbrace physics and uatural sciences.

(a) The instruction of the two first pears (fomr first semesters) shonlel embrace the following branches : physies, chemistry, matural history (geology, mineralogy, hotany, and zoology), anatomy, histoloy, pliysiologs, and slocing. A conrse of practice and demonstrations in mierography shonld always bo inchuled.

(b) Clinical teaching should continue through the whole of the last two years of study. That the practical iustruetion of the students may he complete it is alosolutely necessary to have besides a stationary and consulting elinic (hospital clinic and polyclinic), an ambulatory clinic (outside clinic); there ought to be at least two furofissors of clinic.

(c) The inspection of meats of the butchery is an alsolutely essential branch of veterinary edueation.

The fourth proposition was modified by arloption of a motion by 
Quivogne and Larmet to have yearly examinations, by one by Wehenkel to make a two years' clinical course obligatory, and by one by Eraers and Leblane that examining boards shonld be composed of pro. fessors and practitioners. As adopted, it reads thus :

4. At the end of each year the veterinary students shond be examined on the studies which they have been tanght that year; no one shonlel he allowed to follow the eonrse of the alvanced year without having passed this examination.

No one shonld be almitted to examination for the degree of veterinarian who has not followed a conrse of clinical instruction for two years after having passed the eximination of the second year of sturly.

The board of exaniners for conferring grades shonld always be formed partly of professors and partly of practitioners.

On motion of Quivogne proposition third was altered to :

5. "Interual" and "external" are optional in veterinary sehools.

Proposition 6 was adopted nnchanged, and ou motion of Wirz, Fleming, and Laintard, an expression in favor of the maintenance of all reterimary sehools by the state. As adopted it reads:

6. Veterinary sehools mas be independent institntions, or they ma be connected with miversities or institntions for the higher edneation, bnt veterinary medicine shonld have its special chatirs. One eannot but disapprove of the creation of those institutions in which all branches of veterinary edneation are given in a verg limited number of nuiversity chairs. Such a system is absolntely insufticient.

It is very desirable that in every comtry the veterinary schools should be state instimtions.

Proprosition 7 was altered by a proposition of Quivogne to omit the second portion of paragraph 1, which effectnally suppressed paragraph 3 ; and one by Wirz to drop paragraphls 4 and 5 as affected by particu. lar local conditions and unsuited for a general decision. As adopted it realls:

7. The professors of veterinary schouls onght to possess diplomas of veterinary medicine.

It is very desirable that veterinarians before being called to the professorship shonld have practiced veterinary medicine for some years.

\section{REMARKS.}

The first thing that strikes one in connection with this subject is the contrast between the Old Workl and the New. Europe seeks to ploteet her animal wealth by the creation and maintenance of thirty-three state veterinary rolleges. The United States, with plactically the same area, and with a wealth in livestock which is fast making her the meat market of the world, has not a single institution of the kind supported and controllerl by State or Federal Government. Furope has learued, by a sad experience with animal plagues, that low only safety consists in the creation of exlucated veterinarians ly maintaining a sufficient ummber of thoronghly eficiont establishments, the diplomas of which shall be suffieient gualantee of the knowlerlge and ability lerpuisite to calry on an effective veterinary sanitary service to care for the eavalry and artillery lorses, and to provide everywhere the men wanted for the treatment of her flocks and 
herds. In the United States, in the absence of any Goverment college, the public demand for reterinarians has led to the establishment of sehools as private enterprises, some of which, like the eanlier sehools of Boston and Philadelphia, have prostituted their eharters by making it a mere expedient for the sale of diplomas to all who wonld piy the price, irrespective of education or fitness, while others have filled their chairs with men who were themselves destitute of a veterinary diploma, and made them veterinarians by bestowing the diploma of their own institntion. The result is that the connt? swarms with empirics, and that even the possession of a diploma is no guarantee of education or ability. If sur. denly called mon to stem at great wave of infection among animals it would be no easy matter for this conntry to speedily provide the necessary men who conld be relied upon for the work. If, again, it were neces. sary to secure the publie health by the suppression in animals of plagnes communicable to man, such as anthrax, tuberenlosis, glanders, and farer, milk-siekness, aph thous fever, diphtheria, trichinosis, \&e, we have no State accredited school from which we could draw the recquisite experts. Plysicians are not instrueted in the diagnosis and mandgement of these affections in animals, and what have we done to seenre reliable reterinarians? The number's of our horses and cattle are two-fifth those of Europe-the British Isles inchuled-and the number of our sheep and swine is over one-third of those of Europe, including the same islands.

Our latest eensus makes the value of our live stock in qualrupeds $\$ 1,700,000,000$, which is, doubtless, like all official valuations, considerably below the mark. 'This great moneyed interest, liable to injury by plagues, which tend to increase in geometrical progression, is left without that protection which should have its foundation in a national or State guarantee of veterinary edncation. Such a guarantee cannot be secured by granting charters. These have too often been made the mere oecasion of the prostitution of the science to mamnon-worship. To furnish it the institution must be placed above the temptation to acquire, and indeed beyond the possibility of acquiring, means by silerificing the profession. This may be serured by making the veterinary eollege part of a well-endowed nuiversity, and subject to the laws of the same, or it may be made an independent national or State veterinary school, like most of the sehools of Europe, under such laws as will prechite the entrance of the debasing influence referred to.

In view of the foregoing recommendations of the international congress, it would he superfluons to enter iuto the organization of reterinary selools and their enrienlum. It mily, however, be well to give some further data as to the fiveilities furnished in the European reterinary sehools. It may be permitted me also to hint that we in Ameriea camot abate one jot of the provisions male for this education in Europe, but rather increase the'n. In sixteen yeans since the congress at Zurieh it has been foumd necessary in Enrope to demand an increase of the period of study by one-third, because of the increasing extent of the 
fiells to be studied. In arldition to all this we are to-day confronted by the great question of the life-history of disease crems, which opens up) a new world in pathology, and which can be nowhere so appropriately investigated as in a retrinary college. This the forernment owes at once to the wreat livestock interests of the nation, and to the canse of sanitary seience as applied to the human population. The maladies transmissible between man and animals must be inrestigated through the latter, and from this man will protit directly by the restriction or extinction of these affections, and, indirectly, by analogies with the newly diseorered truths in the ease of other affections peculiar to the human race.

In five of the state reterinary colleges of the Continent which I luave visiteil the gromnds cover a large area, thongh situated in a city, as at Berlin, Utrecht, Brussels, and Lyons, and are provided with dwellings and offices for the faculty, library, boarding accommodations for students, musemms, dissecting-rooms, rooms for antopsies, laboratories for physics, chemistry, pathological anatomy, microscopy, and biology, pharmacy, lecture-rooms and instrument and retiring-rooms for the different lepartments, surgical operating theaters, funcee for buruing infecting products, horseshoeing forge, halls for clinics (averacing 350 by 30 feet each), proviled with forge, means of fastening for operations, \&c., and separate bnildings for the accommolation of the different kinds of hospital patients (soliperls, cattle, sleep, and swime and dogs), and with special stables for those of each kind suffering from contagious diseases. These last were paved with granite or hard-burned bricks, set in cement, and lined for 8 feet from the floor with enameled tile, set in cement, while all the fittings (stall, rack, manger, \&c.), were of iron to facilitate disinfection. Then each seloool had its botanical garden, and in some the different field erops were cultivated, and several specimens of each of the best breeds of romestic animals of the same or arljacent countries were kept for purposes of instruction.

These state veterinary schools turther have bursaries for poor but deserving students, the French Government providing no less than 240 of these muder conditions which demand excellence alike in deportment and stuly. The minister of war can further send a certain number of stulents (in France 60) to be educated tree for service in the eavalry and artillery.-J. L.

\section{THE RIGHT OF VETERINARIANS TO FURNISH MEDI- CINES FOR THEIR PATIENTS.}

This subject, introduced by Rossiguol, apropos of a recommendation of a commission of the French legislature to abolish this right, was shortly discussed, and after secming a statement from the attendant representation of each country in Europe and Anerica, as to the practice in that comtry, the congress decided as follows: 
1. Cousidering that veterinarians are initiated by the technical studies pursued in their schools into the posology which pertains to the arluninistration of medicines destimed to the different species of animals;

2. Considering further that from this point of view they possess better guarantres thau do drnggists against the dangers which result from erroueons preseriptions;

3. Considering that the right to prepare and sell medicines, especially destined to the treatment of diseased aniuals, is indispensable for veterinarians who have realy all the medicines necessary for the treatment of the animals to which they are called, and who can furnish the same to their employers at a low price;

4. Considering that a law prohibitive of this is not only nseless lunt opposed to sound ecouomy-

The international congress expresses its opinion that in all conntries veterinarians shonld have the right to prepare and sell medicines destined to the treatment of iiseased animals, at least within the limits'of their practice, and that it shonld be forlidden to empirics to kecp pharmaeeutical sulistances.

\section{TUBERCULOSIS IN ANIMALS.}

This subjeet was most extensively and ably treated by Lydtin, of Carlsruhe, reporter of the commission appointed to bring it before the congress. Unfortmotely so mueh time had already heen consumed on the preceling subjects that the congress could not give it the full and deliberate consideration which its overwhelming importance demands. Its full consideration may therefore be held to be deferred until the next reterinary congress shall meet in Paris, when the mcreased knowl. edge of the discase will doubtless strengthen views which may to-day be looked upon as in some respects premature. Meanwhile a smmmary of Lyaltin's excellent report, and the action of the congress on it, (:annot fail to have a high value. It concludes by proposing for the andop). tion of eongress the following resolutions:

1. Tulerculosis is transmissible hereditarily.

2. It is contarions.

3. It should be included among afiections which shonld be opposed by measmres of sanitary police.

4. The measures that ought to be ardopted for this pnrpose are the following:

(a.) Every owner of domestic animals must report promptly to the authority charged with this police service "very case of tuberenlosis, and any syuptom causing silspicion of the existence of this affection; he must keep every animal attacked or suspected out of any plaee where it way be able to transmit the malady.

The same obligation shonld he incmubent on the steward, or representative of the proprietor, on the person conducting a berd or flock in transit, also on the proprictor of a stable, fard, pasturage, or park where animals are temporarily received.

This report is equally obligatory on veterinarians, and on any person who practions by profession the art of veterinary medicine, on meat inspectors, and npm every person chugaged in the trade, of tho destruction, utilization, or manipulations of eadivers or their products, if before all intervention of the police he discovers the cxistence of tuberenlosis, or reeognizes symptoms which leal him to suspect the presence of this malady.

(b.) The appearance of the aflection and the particular herd infected onght to be publisherl.

(c.) The suspecter as well as the diseased animals shonld be sequestrated, ant their slanghter ordered by the police, animals snspected of being infected shonld be kept in fuarantine, unless there are comparatively low, in whieh case thoy should be 
slanghtered by official order. If a large number are suspected, they may be fattened aud sent to the abattoir as quiekly as possible.

(d.) Infected stables and other places shonla be nuder the special surveillance of the police tor an entire year, comnting from the last ease of the disease. The sale of beasts suspected of infection should be interlicted, unless it is for slanghter, and nnder the inspection of a veterinarian.

(e.) The place occupied by a tubereulons animal onght to be cleansed and disinfected, the animal having loen previonsly removed : it ought to be the same when the malarly has divappeared from stables and other elosed plices in whieh tuberenlons anmals have been kept; it is only after disinfection that the prescribed police measures should be removed. Dnring the whole course of the pituzootic the stables should be especially well ventilated.

$(f$.$) The flesh and viscera of a tuberenlons animal ean only be utilized for cousmup-$ tion when the disease is fonnd in the cadever in its incipient stage, when the lesions are confined to a very small portion of the body, when the lymphatic orlands are still liree from all morbid tuberculons lesion, when tle tuberculons formations have not yet mulergone softening, when the flesh presents the characters of meat of the first quality, and when the aninal is in a gool state of nutrition at the time of slanghter.

It should not he permitted to remove the thesh of tulerenlons animils, adinitted to consumption, ont of the locality where they havo been slan nhtered, and it should not be offered for sale in the ordinary buteher"s stall.

Every quarter of meat and all viscera showing lesious of tuberenlosis, as well as the llesh of any other animal iu which there is found at the neeropsy a tuberenlons. infection more pronomed thau that referred to above, should be watered with petrolemm oil, and afterward buried under police supervision. The extraetion of fat by cooking and the ntilization of the skin may br permitterl.

The in-pretion of every animal attacked by tuberenlosis should be male ly a roterinarian, who alone should decide if the llesh is lit for human consmption.

(g.) The milk of animals snffering from tuberenlosis, or suspected of it, shonld not be consmued by man nor certain animals. The sale of such milk should be severely interdicted. The milk of animals suspected of infection should only be ased after boiling.

(h.) Under proper safeguards against its abuse, it would be proper to furnish indemuities for cattle slanghtered hy official orler in consequence of tubereulosis, also for those that have died from this malady, and lor those foum to be tuberentons after they have been killed for human food. The indemnity may be paid out of the state treasury, or to create the reduisite funds resort may be had to an obligotary insurance.

(i.) Violations of orders relative to measures preventive and repressive of tuberenlosis should be punished.

(j.) As a safeguard of the public health agianst the dangers which threaten it through the consumption of flesh fumished from diseased animals, of stalo or putrid meat, and of falsitied samsane anl minee-meat there should be established in every commune a competent service for the inspection of meats.

(k.) Lstablishments which make a specialty of fiunishing milk for invalids, or for infants, ought, as regards these mileh animals, to be submitted to a constant control contided to veterina rims officially resignated for this purpose.

In recommenling these resolutions for the aloption of congress it has been felt that they are fully called for in view of the danger which has long threatened the interests of stock owners and the health of the community, and which constitutes a reritable calamity.

Lydtin hegins by tracing the history of tuberculosis, showing how like other discases, and notably glanders, it appears in forms that are 
not recognized as identical with the common types, and how, in consequence, its true characters, its prevalence, and, above all, its contagious property were ignored, until anatomo-pathological observations showed the identity of the lesions in different organs, and biological experiments established the true nature of the disease germ.

He thinks Moses refer's to phthisis in the word diirre-(leanness) Iev. xxii, 2-and Columella, as phthisis (De re linstica); the same idea is embrated in most of its common designations-as pining, consumptiondecline. sichuinden, sthrindsucht, phthisis, ulcerution pulmounire, Lungen verschuciorung, lungensucht, lungenfüule suffieiently illustrate.

Another form has been named and elassified, on account of sexual aberrations, mymplemuni, sntyrinsis, stiersueht, yeile'sucht, Honutsreiterei (German), minfomania, furore uterino (Italian), Brummel (Swiss), bulling (English).

Another form has been nimed, from the more or less firm excrescences which appear on the serons membranes and skin-l'erlsucht, Hirsesucht, Ileerlinsigkeit, Ziippiglitit, Krmuichtleit, Rindshammen, Trunbenlirunkeit, peall disease, knots, kernels, grapes, angleberies, clyers.

The smpposerl syphilitie character of the disease produced the fol.

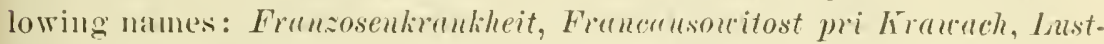
senche, Enreiniglieit, renerir et morbus gallians boum.

'The implication of the glands and the sareomatoms and fibrons elatrac. ter of the growth has given rise to still other names: Drïsenkrenliheit, malettia glendulure, satkomalyshrusie, enthexia boum sarromatosn, surcomatosis infertiosa, seren-tuberentosis, tuberculosis fibromatosn, rindstuberenlose, de. Again, as it appeans in the pig in the form of scrofula, it has been called scrofinlat tuberwe.

No wonder that the jalentity of all those forms of the disease wats slow to be reeognized, and that pathologieal anatomy and inoculative experiments had to be invoked to determine it. The nane to be preferred is the generic one tuberulesis (or tuberenlosis penzooticu coutugiosu), and yet this must not be helu to imply that the nolosity (tuberele) is a constant and pathognomonic feature of the distase.

The manifestations of the disease are entered on fully, showing that after the preliminary slight ferer (marked symptoms often subide and of the local lesions are enntined to certain mon-rital organs) there may be comparatively little sign of illness tur months or years. The flow of milk may be abundant, and thongh valiable yet of no fixel quality, and the animal may breen, work, or even fatten withont suspieion. Is the riseased processes extend orer the system fobrile symptoms reappear and tend to assume a remittent character, the temperatmre beroming abnormally low in the morning and high toward night, and at the same time wasting atrances more or less rapidly. Enlargment of the cervieal lymphatic glands, irregular appetite, tympanies, colies, constipations, and diardeas, and inclieations of lesions of the respinatory organs, are especially common. In certain cases there may be musen- 
lar or neprous disorder, cranps, paralysis, wryneck, epilepsy, turning in a circle, comil, blindness, in others disease of the testicles, or ndder, of the bones, joints, and skin.

The affection may prove fatal in less than three months, or it may last for an ordinary lifetime. It may induce other diseases of the organs in which it is located, and thus greatly complicate the symptoms or lasten a fatal result.

It follows that the disease is not alwatys easy to diagnose. Yet its symptomatology is quite as arlranced as that of many other diseases, and with the recent demonstration of its germ-bacillus tuberculosisit is sulfieient for the puposes of veterinary sanitary police.

The pathological anatomy of tuberenlosis is more perfect. The lesions most eonstantly met in the carlaver are the neoplasms on the plenre and peritonedm. These vary in size from a millet seed to a pea; they are single or united in bunches (grapes), pednnculated, polypoid, or walty, red, flesh-colored or brownish yellow, and of most varied consistency. Very often the center of the soft nodosity is rleep red, while that of the hard one is yellowish and caseated or of the consistency of mortar. Accorling to Virchow they appear first as little nodosities or pritrls in groups projecting slightly from the surface of the serons membranes ; later they become pedunculater, remaining connected by Vilscular bands of counective tissue; still later ear thy salts are deposited in them, and finally they soften, mulergoing fatty degeneration, and become like a thick mortar.

Whanges in the lymphatic glands of the head, neek, chest, abdomen, \&c., are also present in all but the most exceptional cases. These are swollen, and of a dull, yellowish eolor, impreguated with juice or pig. menterl. They show hrmorrhages as large as a pin's head, irregular enlargenents, and indurations. On seetion the surfice shows mumerous infiltraterl prints of the size of a inillet seed to a pea, of a grayish yel. low or whitish color, and the consisteucy of eheese or mortar. Larger eenters of irregular shape, but the same characters, are also met with.

The lungs in most eases present similar lesions in norlules and no. dosities in all stages from the simple hemorrhagic point to the easeous or calcalreons mass, also connective tissue neoplasm, which obliterate the pulmonary lobules and attain consilerable size, and finally caseous masses in the millst of lung tissue, otherwise mnaltered. Sometimes the nolosities of the plenra covering the ribs athere to those on the lungs, anl they m ty become continnons into the ling tissue for an indefinite distance.

The softened nodosities may open in to the plenral sac with fatal eflect, or into the bronchia, cansing a grumons discharge from the nose and mouth, and when empty they form eavities-vomice.

The nodules are common on the mucons membranes of the trachea, larynx, pharynx, and gnllet, and in the submeons tissue of these parts, and softening and discharming they form fummel-shaped ulcers, which 
hecome confluent and cause deep and extensive sores invading the sub. jacent cartilage and other tissues.

Sometimes the brain and spinal cord are invaded, but especially the pia mater and arachnoid, giving rise to the most varied nervous symptoms, and passing through the same changws with an especial tendency to puriform softening when in the brain substance.

Tubercular deposits in the coats of the bowels are fomnd in eattle in the form of nodules var?ing in size from a pin's head to a lempsesed on the inner surface of the peritoneum (Niklas), and in pigs in the forms torms known as serofula or caseons enterites.

The miliary nodnles and aggregations of them are also foum in the liver and spleen, less frequently in kidnegrs and bladiler, and in the crenerative organs (tunica vaginalis, cord, testicle, nterus, ovaries, Fallo. pian tubes, vagina), and in the mammary glands. The muscles are occasionally the seat of tuhercle, and the bones rather frequently so. The neoplasm takes place by preference in the cancellated tissue of the extremities of long bones, and in that of the bones of the cranim, and the spines of the dorsal vertobrae.

The relative frequetecy of the more common seats may be deduced from the following table of 1,596 cases observed in Barlen:

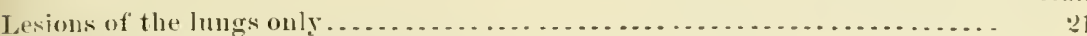

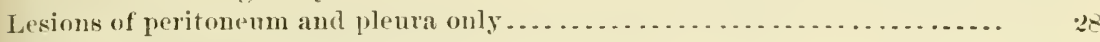

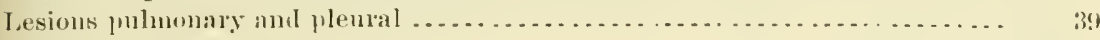

Lesions of generalized tuberenlesis..................................

Lesions of generative organs only ..............................

Microscopically the tubercular products are composed of--

(a.) Excessive growtl of new comnective tis-ne which, in the lumgs, may amount to .5.) to 100 pounds.

(b.) Connective tissue growths interspersed with centers of degmeration: first, hemorrhagic points; secom, small vitreous boling masses, and, third, soft caseons collections. Both these forms show a strung propensity to calcification, and in bones to gemnine ossification.

(c.) Sarcomatous neoplasms or tuberenlar nodosities. These have a rascular stroma of conbective tissue inclosing masses of romml lymphoil and fusiform cells. The peripheral cells have a clear ontline. and there are few tree nuclei, while in the center the cells become opanur and indistinct with little protoplasm and shriveles nuclei and frese nuclei and gramules abouml. These also are often calcareons.

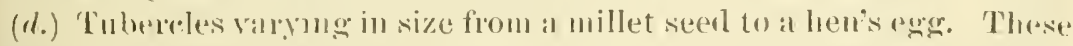
appear in the parenehymatoms tissue of the lung, de.e. while those for. merly desceribed affect ratlere the suface and the serons membranes. These are at first small and translncent, but increase by juxtaposition and conllucuce, and being exclusively cellular become cally ralcified, or more frepuently cascated. These are mnch more mumerous in an infected tissue than any product likely to be mistaken for them.

(e.) Vleers of varions forms and dimensions. In all these lesions 5751 1) $1-11$ 
there is the same initial change-proliferation of the connective tissue. The variations in the nature of the lesions depend on the different activity of the intercellular substance and the comnective tissue and endothelial cells, on the disaggregation of the elements and the occurrence of ulceration. Thus the fibrous growth is usually greatest where connective tissue is most abundant, as in bones, cartilages, and interlobular lung tissues, while the more cellular and rapidly disintegrating growth occurs in connection with epithelial structures, as in the air cells and on the inner coat of blood-vessels. This tendency to attack the connective tissue and lymphatics, and to show products varying according to the nature of the surrounding structures is common to other infectious diseases, and notably glanders, chronic lung plagne, actinomykosis, \&c. As in these cases, too, the morbid process is first localised and only becomes diffused when it has attained a certain local inteusity. Again, it agrees with other infectious diseases in being favored by certain unhygienic conditions, as damp pastures, close filthy buildings, overcrowding, poor food, excessive work or milking, \&c., yet is not absolutely dependent on any one or more of these, nor due to these alone. As in these other affections there is the disease germ-bacillus tuberculosis-the presence of which is essential to the development of the disease, and its recognition completes the diagnosis.

Again, there is a special constitutional predisposition in animals having an excess of connective tissue and of lymphatic development as in eattle and swine.

Climate seems to hare much effect, as the disease is virtually un. known in northern and arctic climates-Iceland, Northern Norway, and Sweden, Finland and Lapland-and rery common in the temperate and tropical regions.

(While frost doubtless chains up this germ when out of the body, as it does others, it must not be forgotten that the pancity of cattle in the extreme north will even more tend to retard the propagation of this disease. Other conntries formerly free from tuberculosis have now, by the influx of consumptive patients, and, in some instances, by the greater density of the population, become extensively affected with this disease, as witness the Hebrides, Anstralia, and our northwestern States and Territories.-J. L.)

To the same effect speaks the great prevalence of tuberculosis in dairies near cities where the stock is often clianged and new stock is being constantly purchased, and its almost complete absence from districts exelusively devoted to breeding and never importing strange stock. This is but a repetition of what is known of other contagious diseases. Wild races, too, living in the open air are largely exempt.

Heredity as a cause of tuberculosis. - In favor of the heredity of tuberculosis Lyiltin quotes from over a seore of veterinary anthors. The congenital presence of the disease is proved by quotations from König, Stiruimann, Adam, Butscher, Virehow, Semmer, Jessen, Fischer, Miil- 
er, Zipplius, \&c. The infrequent reeognition of the disease in real calves is noteworthy, being generally vnly a fraction of 1 per cent., but it must be added that tubereulosis in the dam, affecting the fetus, usually determines the death of the latter, followed by abortion, and that of those in which the discase stops short of this the tubereles often rest circumseribed and inaetive in an unimportant organ until the young animal is more fully developed, or even grown up.

(I have repeatedly seen abortions as the first indication of tuberculosis in a herd, and calves of lealthy breeds infected by milk grow to maturity and then fall victims, where the ancient calcified products were found side by side with the recent. It is further to be noted that the calves more severely affected perish of indigestions, diarrheas, \&c., and are buried by the owners withont any notifisation of the anthorities. These, therefore, cannot be fattened for veal.—J. L.)

Göring noticed that in bovine tuberculosis 123 were infected by the dam and $43 \mathrm{by}$ the sire. The hereditary cases constituted 12 per cent. of all eases of the clisease. All veterinary and agrieultural writers attribute a most disastrous influence to in-and-in breeding (in infected families).

The special predisposition of animals with much loose connective tissue has been already referred to. It is further noticeable that this is a prerequisite to aptitude to fatten, and it is notorions that many families of our best breeds of meat-prorlucing animals are affected with tuberculosis, while the disease is less preralent among unimproved races.

(In this connection we must not ignore the elose breeding of the latter, their residenee in a hot foreing atmosphere, and their preservation for breeding purposes, even when manifestly unhealthy, nor the free openair life and the prompt disposal of unthrifty beasts among the less val. uable breeds. The disease being clue to a speeific germ, it should be limited by the repression of that and not by abolishing in onr meatprodneing animals those qualities which constitute their value.-J. L.)

The eonchusions as regards heredity are thus:

1. Thit heredity is not without intluence npon the propagation of tuberentosis.

2. That this malady is transmitted alike by the sire and the dam.

3. That the transmission of the morbitie principle to the ovule or fetus in conrse of development, is a eamse of sterility in the parents, and frequently occisions abortions and premature parturitions.

4. That a fetus afiected with tuberculosis rarely attains complete maturity or comes into the world in conditions of nornal viability.

5. That notwithstanding these fatets, we cannot dony the possible birth (perlaps in great numbers) of tubereulous deserndants which can develop and multiply equap to animals, in porfect health and withont any predisposition.

Contagion as a cause of tuberculosis.-Lyaltin refers to the above proof of the transmission of the disease thromgh the ovmm, sperm, ntor. ine secretions, Er., and proceeds to ofter finther evilence of direct eon. tagion. He quotes Ruhliugr, Krunitz, Fromage, Huzard, Spinola, Crugel, 
Lafosse, Villemin, Dupont, and Zangger, in support of this, and arlvances the following proposition:

The morhific principle can enter the system either hy the respiratory or digentive apparatıs. The inspired air and the forages and drinks "an act as veluicles; it maly also be transplanterl by way of the genorative organs (coitus), or by wounds, accistental or experimental.

Instances of infection by cohabitation ale yuoted from Stahl (to 4 stud bulls by a newly-bonght tuberculons one of diflerent hloold); Renner (to cow and calf from tuberenlons cow of different blood); Fischer (heifer from tuberculous cow and 3 cows and ox from tubereulons cow of alien blood); and Janm (11 cows fiom a new tuberculous one); lioss ( $t$ cows from a new tuberenlons ons); and others by Yisen, Zundel, Grad, Hanshatter, Lentz, Huzart, Tessier, D'Arboval, Remy, and Hugnes. Cases of infection through foor are quoted from Jessen (calves sucking siek cows, died in six to twelve months); Volker's, Lehnerter pigs of healthy parents in one month after teeding unloiled milk of siek (ows); Bromley, Walley, kleming, Zippilins (calf sucking tubereulous dam died of diarthea with cirenlar, belt-like ulcers of small intestine); Gerlach (many calves and pigs infected by milk of sick cows), Se.

Transmission ly coition is less definite, but is inferred trom the occurrence of tuberculosis in the womb, Fallopian tubes, ant wary of the female (Adam), and the testicles of the male (Sehlotterer), also fiom the abortions in tuberculous herds.

Of transmission by raw surfuces, all the cases of experimental inoenlation are instances. Lydtin took $1 y m p h$ from lung affecterl with tubercle and lung plagne, but carefully avoiden any point where tubercle conld be detected, and avoided also the blood as far as possible. With this he inoculated 10 cattle, 5 of which, when killed twenty-three days later, showed numerons distinet miliary tubercles in the inoculative swelling, and one tuberele in the right lung; the remaining four showed tubercles of olier date in the lnugs.

Toussaint inoculated a tuberculous eow with cow-pox, furnished by a healthy heifer, and eight days later from the resulting cow-pox resicles inoculated four rabbits and a pig. 'All of the rablits became tuberenlous in two months.

In the field of the experimental transmission of tubercle, the work has now been extensire and the results most conrincing. Villemin, Gerlach, Chancean, Colin, Sonjon and Court Paul, Grinther and Harms, Rivolta and Peroneito, Bagge, Bollinger, Kohne, Semmer, Biffi and Verga, Bouley, Pench, Aufricht, Toussaint, aud others inave contributed in varying degrees to the solution of the question, and the grand result attests indubitably the communicability of the disease.

Giinther and Harms conveyed the disease to 5 rabbits by making them breathe the expired air from tuberenlous cows. Tappeiner eonveyed it to dog's by diftusing the tubereulons sputa of man in spray in the air they breatherl. 
Experiments in feeding the infecting matter are tabnlated as follows by Johne.

Animals experimented on

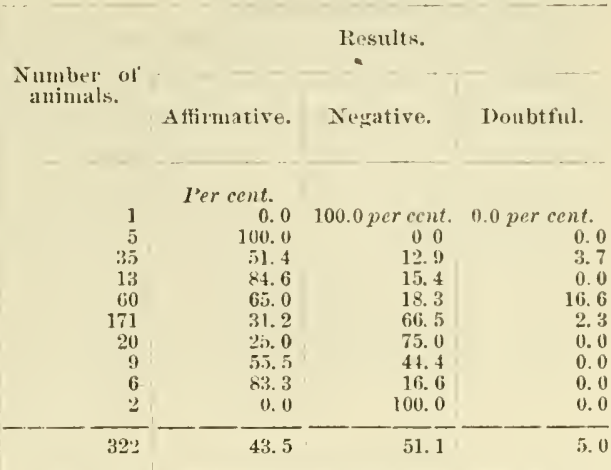

Table giring the resulls in the some animals accorling to the food eaten.

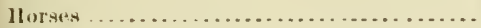

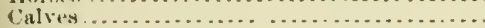

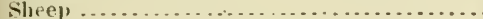

(jogts

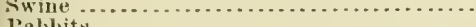

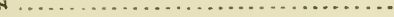

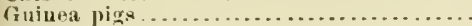

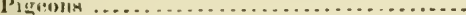

5.0

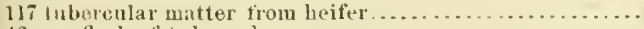

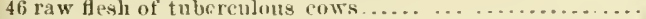

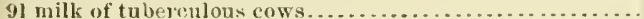

1 milk of tuberculous rabbit . . . . . . . . . . . . . . . . .

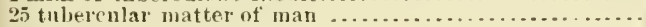

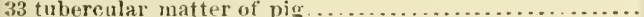

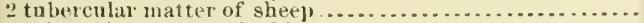

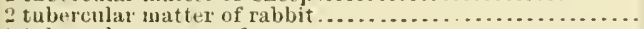

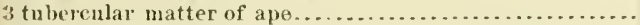

5 tubercular mat ter of birds.

\begin{tabular}{|c|c|c|}
\hline & Results. & \\
\hline Affismative. & Negatire. & Doubtfiul. \\
\hline I'er cent. & Per eent. & ler cent. \\
\hline 61.5 & 34. 2 & 4. 3 \\
\hline 13.1 & 86.9 & 0. 0 \\
\hline 30.7 & 59.3 & 1. 0 \\
\hline 100.0 & 0.0 & 0.0 \\
\hline 36.0 & 61.0 & 0.0 \\
\hline 53.0 & 47.0 & 0.0 \\
\hline 100.0 & 0.0 & 0.0 \\
\hline 50.0 & 50.0 & 0.0 \\
\hline 100.0 & 0.0 & 0.0 \\
\hline 100.0 & 0.0 & 0.0 \\
\hline
\end{tabular}

\section{Johne concludes-}

1. That tuberculosis ean be-transmitted from animal to animal and from man to animal by feeding on tuberenlous substanees, but this morle of transmission is much less certain than by inoculation.

‥ The materials which most certanly transmit tuberculosis by gastro. intestinal ingestion are tuberulous matter taken firm the lungs, pleura, and lymphatic glands; milk of tuberenlous animals, as regards its contagious properties, must be placed near to these. Infection by tubereulons matter taken from man is less certain than by that taken from animals.

3. Infection is less certain from the ingestion of muscle than by the substances indicated moler 2, and yet it ocenred in serenty-six cases in the abore-named experiments.

4. Calles, sheep, goats, and swine present the gratest susceptibility to tubereular coutagion; the pretemled immunity of carnivora is not so pronouncel as certain anthor's havo alleged.

Gerlach found that of 46 animals fed raw tuberenlons matter 35 bescane infected; that of is fied raw musele from tuberenlous subjects 8 because infectad, and that of 15 ferl cooked tuberemlar matter 10 were infected. 
Bollinger produced tuberculosis in pigs by prolonged feeding of the milk of tubereulous cows.

The subcutaneons inoculations of Villemin and his suceessors were hotly disputed on the gromd that they gave rise to lesions analogous to those prorlueed by inocenlation with non-tubercular matter. These were practically settled by the intraocular injection of white rabbits with tubercular matter by Cohnheim, Salomonsen, Hansell, Deutselımann, and Bammgarten. After an incubation of twenty to thirty days there appeared in the pigmentless eje distinet tubercular noclules, and this was followed by a generalized tubereulosis. Bammgarten developerl tubereulosis in the eye by injecting the blood of tuberenlous animal infected by inoculation. In test experiments with the blool of healthy animals the eyes remained soumd; when he used the bloor of septicemic patients intense infammation of the eyre ensuer, hut never tuberculosis.

Toussaint found the tubercular lung prodnets of cows coustantly infecting to rabbits and pigs atter they had been subjected to $55^{\circ}$ to $58^{\circ}$ C. in a water bath, and even after they lad been roasted like a beefsteak in the gas llame. He fonnd the nasal rischarges, the saliva, and the urine infecting, and as already noticen the lymph of a raceine resicie. Irydtin concludes :

That tuberculosis is contagious, like glanders or lung plague, and that coutaniou fills a more important röle than heredity in the propagation of the disease.

As slowing the iclentity of tuberculosis in man and animals, Koch's demonstration of the bacillus tuberculosis must oceupy a prominent place. The disease had alrealy been proved a liereditary and an infectious one, and this organism, found in the growing tuberele of man and animal alike, suggests itself at once as the morlific germ. It is found alone and unmixed with any micrococens, in deep seated tubereles, which have had no exposure to the air, while in sputa, romica, and other tabercular poducts exposed to the air a multiplicity of other organisms abouncl. In all cases of rapidle growing tubercles the bacillus is present in great numbers, while in those of slow formation they are seanty. These bacilli have a length of half the diameter of a red blood globule and a breadth of one-fifth of their length; they are motionless and form spores within the boty even during the life of the animal.

After many attempts Kocl succeeled in procuring a pure culture iu blood serum of cow or sheep in a prejaration of gelatine, on which the bacillus applears as finc seales at the ent of two weeks. They grow so slowly that it is only at the end of the third or fourth week that the mass attains the size of a poply seed. It does not develoj save at a temper. ature of 300 to $410 \mathrm{C}$. 'These peculiarities of enlture identify the parasite.

The bacillus, whether derived from the tuberele of man or that of animals, always shows the same form and the same habits during enlture, and on inoculation has prodneed the same pathological lesions, implying the essential identity of the two. 
By numerous earefully controlled experiments Koch has proved that it is impossible to produce the typical alterations of miliary tubereulosis by the inoculation of other matters than the baeilli; in these experiments he has taken all neessary precantions to avoid eonfusion with spontaneous tubereulosis, and to exclude all infeetion from any aceidental source of the subjects on which he operated. He coneludes that the presence of the bacilhus in the tubereulons masses is not a simple eoncomitant of the tuberenlons proeess, but the canse, and that we must recognize in the bacilli the canse of tuberenlosis, hitherto unsuspected, but now evilent in the form of a regetable parasite.

Koch has found this parasite in all forms of serofula and tubercle in man and animals, and in 109) inoeulated subjects (rabbits, guinea pigs, and cats) in the nodosities of the lings.

Add to this that Villemin and Klebs have demonstrated that the tubercle of man, on inoenlation, produces phthisis pulınonalis in animals, and that this inoeulated phithisis is transmissible by inoculation to other animals.

Johne mentions a case of successtul inoculation of tuberele from man to man, and Staug a case of the aceideutal infection of the son of healthy parents by habitual driuking of the warm milk of a tubereulous cow.

Another argument in faror of the identity of the disease in man and animals is the perfect analogy of the disease as regards heredity and contagion in the two.

The heredity in man is shown hy the presence of the clisease in the fetal oftspring of tuberenlons parents. Walshe reeords the frequency of abortion and sterility in tuberculous patients. The doctrine of the eontagion of tubereulosis in man las been sustained by Galen, Norton, Swieten, Home, Maret, and many later observers. Instances are quoted of infeetion throngh elothes and beds, and from husband to wife. Wichmann, in 1780 , said that one death in six in the popnlation of Zurich was from tuberculosis, aud details the different ehannels of direct and indireet eontagion, going so far as to adrocate a supervision of the sale of old bedling and clothing. Cullen, at the same date, speaks of its propagating itself most readily in the warm climates of Sonther'n Europe, where (Italy, Portugal) to the present day the clothing, bedling, and uther agents used about a person deceased of phthisis are invariably destroyed. Lyiltin concludes:

1. That tuberenlosis has bean observed in all warm-blouded animals subuitted to domestication or deprived of their liberty.

2. Tuberenlosis of animals mol of man present andogons manifestations in the living and in the cadtarer.

3. The conrse and termination of the two maladies are the same in man aml animals.

4. The tuberenlar masses, and, above all, the expeetoration of phthisical men dotermines tuberenlosis in animals when these masses are introlnced into the latter by the respiratory or digestive apparatus, or ly a derep wound. Tubereulosis inoculated from man to animals can be thenceforward transmitted from one animal to anotber, produciug in all eases tuberculosis. 
5. Tuberenlosis in man and in animals is transmitted ly heredity.

6. Tuberenlosis is contagions to man as it is to animals.

7. There are cinical observations proving the transmission of tuberculosis from animals to man thromglt the nse of the milk of phthisical animals.

8. Tuberulosis of man and that of animals are rare in the cold clinites, and eren appear not to be developer. They are more frernent in warm climates: the geograthical distribution of the two maladies is almost the same.

9. It is demonstrated that a pathogenie microbe having the same morphologieal and biolorical chanacters, exists in the tuberele of man and in that of animals. This organism, whether developur in man or animals, can produce tuberenlosis when, cultivated in a state of purity, it is transultted to a susceptible animal.

It is only necessary to add that tnberculosis in animals tends to concentration in the large dairies and feeding establishments which supply the great centers of population. The fumer, watehing elosely the animals he has owned since their birth, is led, by the instinet of self protection, to sell off' those that show symptons of failing, and these usually go to the large establishments near the cities, there to be erowded in close buildings with many others, to which they in turn convey the infection. If in a dairy, these smpply milk for the population at large, inchnding the suseeptible infints and invalids, and fina!ly all or nearly all of such animals find their way to the butcher's stall, when they ean no longer be utilizerl for other purposes.

(To show that America is no better than Enrope in this respect, it may be stated that 29 per cent, of the arlult males dying in New York City are tuberenlons, and that in eertain of the herds that supply that eits with milk, 20, 30, and even 50 per cent. are affeeted with the same disease. In some country districts of New York can be shown large liedels with !90 per cent. the subjects of mberculosis. Were all the known faets published concerning the ratio of tuberculosis in certain communities and in the herds supplying their meat and milk, there would be a testimong fal more telling than eren the striking example of New York City. One stands appalled at the immensity of this evil, eovering as it does the entire comntry, threatening at every step the health of the community, aud erying loudly for redress.) -J. L.

Nothing has as yet been said as to the propagation of tubereulosis frem man to animals. In the large stables adjoining cities the feeding of products fiom the kitehens, mixed with excretions of man, doubtless eontributes to this, and the contrast of the frequency of tuberenlosis among these and its absence among the wild oxen of Hungary suggests the importance of silch a firctor.

PREVENTIVE MFASLRES CALCULATEW TO CHECK THE EVIL RESITTING FROM 'IIE CONSTMPTION OF THE MILK AND FLESH OF TL. BLRCULOLS INIMALS.

lycltin refer's to the law of Moses, muler which the pining (diirre Schwinden) anual could not be eaten; to the Mlisehna, which expressly rondemns rarcasses the lungs of which cannot be intlaterl, or have attached growths; to the continuation of this law anong Ohristians mutii the third century; to the liomam masters of markets (apdiles), who silw 
that bad and corrupt meat was thrown into the Tiber; to the ehureh law published in the tenth century against the consumption of diseaser meat; to the ancient laws of Italy, France, Spain, and Germany against the sale of diseased meat, and to the more modern statutes on the same subject. He quotes from Ziickert (1775) the case of the death of twelre students from eating the flesh of cows of which the riscera were cor ered witl a great nmmber of vesicles, tubereular nodnles, and purnlent tumors. In furnisling such meat for the soldiers a French butcher was, in 1716 , condemmed to nine year's' exile, a tine of $f 5,000$, atud permanent prohibition from engaging again in the same trade.

A German law of 1732 imposed a penalty of 50 rix thalers, with the addition, in certain cases, of eorporal punishment for the sale of such meat or for evading itsinspection. About 1764 the doctrine of the identity of tuberculosis and syphilis was contested by Zink, Ruhling, Heim, Graumann, and Zwiellein, and the German law was abrogated while that of Lower Austria was modified so as to condemn only advanced eases. In Sonthern Germany, Anstria, and Switzerland the meat of tuberculous animals has always been more or less forbidien. In the main, however, it is only alvanced cases, those with protomm and extensiva lesions, that have been condemned. The same has been the case for France and Belgimm. France was the first, in 1810, to abolish frivate slaughter-houses in large and medium sized cities, and to introduce that essential coudition of all effective inspection-municipal abattoirs. Later this has becn adopted by nearly all the cities of lurope and a thorongh inspection rendered possible.

Cooking of diseased neat in general was held by Payen, lienantt, and others to render it innocnous. Its value as regurds tubereular products was filst investignted by Gerlach, who also led in the inquiry as to the danger from the different portions of a tubereular system. He fomd that the morbific matter resided mainly in the tuberele, from which it spread slowly along the lymphatics to the next lymphatic gland, and then still aloilg the sime vessels to more distant gilands and finally it became generally distributed. He further attached much importance to the multiplicity of eascons centers, espocially in the lungs, as the breaking down of the nodosities as well as the extension and increase in mumbers of the tubereles imply a greater danger of the contanination of the flesh. Emaciation is another indieation of the general aetion of the poison. A very advanced condition of any one of these morloil states shomld forbid the nso of the Hesh as lonod.

The Vetelinary Council of Germany (1575) and the Berlin Veterinary School (1575) respectively pronomaced on the subject with great reserve, virtually holding the matter still sub judice. Johne lield that the mere extension of tubereulosis from the lirst seat to the neighboring lynphatic glands did not imply mowolesomeness in the flesh, and lhat it was only requisite in such rases to cut out the tubercles, enlarger or diseased glands and adjacent commective tissme. He pronomeed the llesh 
as dangerous when the extended lesious implied an infection of the blool; whell, for example, from primary deposits elsewhere there are resulting tubereles in lungs or pleuræ. Zundel, basing his opinion on the failure of Koch to find the bacillus in any part save in the tuberen. lar centers, concludes that no meat shonld be condemned except that furnished by animals emaciated and thoroughly infected.

That measures protective of the public health should be taken is indisputable. The demands of those who demanded new experiments hare now been realized. The experiments demanded have been repented, and when practiced with all needful precautions have given positive results. The bacillus of tuberenlosis has been isolated, cultivated, and transmitted by inoculation, and whatever the soil from whieh it has been transplanted (man, animal.s, gelatine preparations, \&e.), it has always determined the development of true tuberenlosis in the inoculated animals, and this tubereulosis has proved transmissible from one inoculated aninal to another. Tuberenlous meat is certainly infecting. How, then, can we protect the community algainst its effects? One says: by thorough conking; another, by confisceting the diseased meat.

While the boiling temperature is destruetive of the tubereulous bacillus we eannot rely on meat being heater to this temperature. In North and Middle Germany people continue to eat raw meat, notwithstanding the frequent outbreaks of tubereulosis. Again, in ordinary cooking the center of the meat often remains below $212 \circ \mathrm{F}$, the color of the blood indeed frequently persists. The proposal to sell this meat only in separate stalls at a low price, so that the purchasers would be warned to cook it thoroughly, would be ineffectual, as it would not change the general habit of cooking, and above all it wonld furnish no safeguard against its careless preparation in public institations and elsewhere where it is used on a large scale.

Confiscation, applied to all cases, would be far more effectual, and with competent inspectors this eould be carried out; but in practice it is surronuded by numerous difficulties. Diagnosis is easy, and with a single umieipal abattoir all cases shonld be detecter, but it is fonnd that all the infecterl do not come to such abattoirs. In Barlen 20 per cent. of these are killed elsewhere. An attempt to apply the law stringently in Mannheim resulted in an organized effort to thwart the officers of justice. Stock owners refused to sell to the eity butehers unless relieved of all responsibility as to the soundness of the animals, and the butchers declined to nse the city abattoir and insisted on handling only dean meat which had been killed ontside. The opposition even extended to the consumers, on whom the price had been raised, and the vigorous measures were finally abandoned.

If the difficulty is met by inspection of herds a considerable expense will be incurred and other objections invoked. In short, a sound public: spirit is essential to the maintenance of any really effective work.

Another difficulty arises from the degree of infection. If all tubercu- 
lous carcasses are seizel the way is plain, but if a seiection must be made disputes will constantly arise over the interminable sharles of rifference in the varions subjects. The delicacy of the question to be pronounced upon in these cases would demand for each commune a veterinarian exclusively devoted to the work of inspection, but the would add considerably to the expense incurred.

Tuming to milk, it cannot be denied that boiling would give the required guarantee of safety; but in the milk-cure establishments and where this lignid is produced for infants, it is songht fiesh and used without boiling, and yet these places seek for the heaviest milkers, and often secure tuberculous cows. For these, and indeed for all daries, there should be a State control of the milch animals and their products.

In the present state of public opinion it may be impossible to afply measmres that will be really effective in preventing the sale and use of tuberculous meat and nilk, yet, where already applied, the preventive measures hive proved so beneficial that we must adrocate thejr maintenance and extension. It is enconraging to know that public opjuion is gaming on this matter, so that ere long more effective measures will be sustainerl.

The prescut dificulty resides in the inevitable imperfection of ans control of meat and milk by themselves, and that any permanent surreillance of the cattle withont the concurence of the owners will furnish no guarantee commensurate with the gravity of the langer.

The difficulties of the case will be largely met if the state will deal with tuberculosis in animals as with other contagious diseases. The owner, well accustomed to the effects of the disease and practicer in weeding out the consumption and sending them to marliet, can be ealled upon to report all cases to the anthority. The reterinarian can casily diag. nose the disease, or in the few uncertain cases can decile positively at the antopsy. He can further, as in the case of glanders, maintain a prolonged surveillanee over the jumates of that stable, and above all on those related by proximity or by blood to the animal slanghtered. Thorongh disinfection of stables, ntensils, elothing of attendants, \&c., can be carried ont. If the great majority of a herd are infecter, the apparently sommd may be taken to another building. The diseased and suspected may be slanghtered at once or after a few weeks' fattening. The sale of the milk and thesh of all tuberculous animals shomll be forbidrlen. Finally the owner can be indemmified for crery beast confiscated. This alone will secure the co-operation of the owner, withont which all efforts will be very partial and imperfect.

In view of the insidious progress of the disease it is drsirable eren to furnish an imlemnity for the carcass of an animal foumd to be diseased after slaughter. This will do more to check the clanclestine sale of tuberculous meat than the most rigid administrative control of the abattoir and butcher's stall.

This inclemnity will remove all injurious pressure from the veterinary 
inspector, and enable him to decide with a safe margin what meat and milk can be sent to market without injury to human health.

The indemnity may be a tax on the State, on the commune, or on the stork owners and butehers who will eventually profit most by the suppression of the disease.

\section{AUTION OF THE CONGRESS.}

On account of the short time available for the consideration of the question, Wehenkel opposed any aetion at the present eongress, but Quivogne, Larmet, Aune, Rossignol, and Bonley urged a decision of the question. "In uhat cases can the meat be userl for foorl?" This was igreed to.

Lydtin funisher a resume of his report and conchded by presenting paragraph $f$ of his resolution for the acceptance of congress.

Bonley held that one of the most difficult questions in practice was what an insprector should do with the carcass of a tuberculous beast. It is established that tubereulosis is a malady dangerous to the animals which are able to contract ir, not only by the respiratory passages, but also by ingestion into the stomach and by inoculation in any part of the system. He referred to Toussaint's experiments of which the results were frightful. The tuberculons element did not reside only in the tuherenlous lesions, but is diffused through all the tissues. The juice of the flesh of a tuberculons animal, even after it had been heated to $50^{\circ}$ or $60^{\circ}$ Cent., that is the temperature of roasting beef, has proved virulent for the ox, pig, eat, rabbit, se., eren when given only in a virulent dose, a small dose; large doses are not necessary. Considering the facts in this light we onght to establish no degrees in tuberenlosis; when it exists it renders the consumption of the flesh dangerous. He is convinced that tuberculosis, whatever may be its degree, shonld entail the condemnation of the meat; it ean only be ntilized if well cooked.

Tuberculosis of man is certainly eontagious, as is known to all the world, being principrally transmitted from husband to wife. The disease is rery widely spreal, affeeting one-fifth of onr population. We must look to butcher meat as one of the prineipal canses of this great prevalence of tuberenlosis; it is probable that the infection enters by the digestive passages as in the experiments of the laboratory. He conclumed by propusing the following amendment:

T'uberoulosis being experimentally demonstrated as a malady transmissible by the diegestive canal and by inoculation-

'The congress lecelares that meat provided by luberenlons animals shonil be exeluded from the fool ot man, whaterer mas be the stage of the tuberculosis, of the apparent ratilition of the meat.

In his julguent, stock ownels shonld be indemnifiel, aml lutehers urgerl to establish mutuil insurance societies.

Van Hertsen detailed the pratice in the Brussels abattoirs, long in 
nse, and which he had set forth in a paper lanreated by the Veterinary Society of Enre and Seine in 1S69. He seizes all lean tuberenlons animals, all having mumerons and generalized tnhercles, or with tubercles softened, casems on purulent, lesions which create the suspicion of general infection of the system. When their lesions are grate and multiple. whatever may be the pmality of the meat, seizmre is always ordered; when the tuberetes are localized and resent, and provided the earrass is sufficiently fitt to gnarantee good meat, it is allowerl to be used. As to the danger from moboled milk he had with Degive, in 1868, presented a paper to the lielgian A ademy of Medicine on the frepmency of tubercle in the mammie of eows, hut the acadeny discanded the subject withont diwensing the important nuestion of lygiene therein prenented to them.

Wir\% proposed an amendment of $f$ in Lydtin's report, that in place of "to a very small part of the horly, when the lymphatic glands are still free," de., rearl "to but a small part of the thoracic or aborlominal viscera. wh" $"$ the lymphatic glamls which do not belong to these are free," \&e.

Van Hertsen belieres that tuberenlosis can invale the lymphatic sastem when the disease is yet in its earliest stage. He has observed that the gland situated between the first and seeoml rib is tuberenlons eight times out of ten. This gland is of the greatest importance in determining the quality of the meat, as it establishes the finet of tuberenlosis withont the necessity of examining the viscera. It serves to distingnish tubereulosis fiom lung plagne in carcasses from which the plenrar has been removed, the rhest skinned, as the butehers say. (This gland has heen called the motive (motif') gland of the inspector.)

Lyaltin adrocated his proposition as more practicable under present circmustances than Bonley's; while Bonley anlled for the adrocu'y of thorongh measures, their administration was the eoncern of the anthorities.

After further ameminents of Rossigmol and Van Hertsen, paragraph $f^{\circ}$ of Lyytin was allopted, several members declining to vote.

Rossignol proposed to amend paragraph g by omitting the last sentence, permitting the nse of the milk after boiling, and as thus amended it was aropterl.

Bonley recprested a rote on paragraph $h$, offering the following modification :

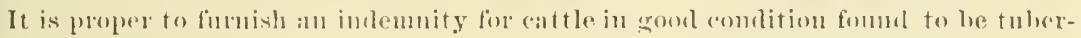
"ulous if ifer sliugliter.

Rossignol supported an indemnity for animals in good roulitum, lont only whon killed for hmman food.

Arts, Whenkel, and lydtin opposed on the gromul that this was muly a question of goods of bad quality, the nse of which for a purpose to which it is unfitted is forbidlen. An indemuty should only be given when an owner must give up his thance of the recorery of a sick animal in the interest of the pmblie groot.

As a prolonged disenssion was threatemed and time pressed, Miiller 
proposed the closure of the question which had already exceeded that proposed for the order of the day, namely, the utilization of the Hesh. The diseussion was aceordingly elosed.

A paper was handed in signed by eleven members explaining that they had declined to vote on tubereulosis on the ground of lack of time to snfficiently discuss such an important subject.

After providing for the next international veteriuary congress to be held in Paris, the meeting arljourned.

REMARKS.

(The importance of the question of the sale of meat and milk from tnberculons animals cannot well he overrated. But to control the former we need a complete reformation of our syste $"$ of slanghter in the large cities and villages. One municipal abattoir shonld be established in each great center of population where alone stock should be slaughtered for foot and where the carcass and viscera of every animal slanghtered would be examined by a competent veterinary inspector. All establishments for the killing of meat to be shipped fresh to the eities, to be salted or canned, should be placed under similar supervision. Meat from uncontrolled slanghter-honses should be excluded. So far as we know no American eity has adopted the system of municipal abattoir and complete veterinary inspection, and the great majority have neither. The expense would be considerable, though only a trifle as compared with that caused by the sicknesses, incapacity, and death now occurring from a disease which affects one-fifth and upwarl of the population in the great eities. We say nothing of the other contagious diseases from which this measure would protect the people. With regard to the milk supply there should be frequent visitation of the dairies supplying the large cities, the maintenance of a census of the animals, and an inspection by a competent veterinarian of all catlavers of animals killed or dying by natural cause. Not only would this protect the human population against infection through the milk, but it would overcome the present great difficulty in dealing with the lung plagne, which would thus be traced to every center of infection and conld easily be stamped out. The question of the suppression of this discase over the entire national domain is by no means sneh an easy one; the task is so gigantie and the outlay wonld be so vast. In many herds in the Eastern States the proportion of tuberenlous animals ranges from 10 to 30 per eent, and in the West with freer range it is doubtless far less frequent, yet if we were to estimate but one infected animal in thirty it would embrace over a million eatle and one and a halt million hogs. Indemnities alone for this number would amount to from $\$ 30,000,000$ to $\$ 40,000,000$, to say nothing of all eontingent expenses. That it would pay in the single item of the preservation of our live stock there can be no cloubt, while its effect on the health of the population would be beyond all estimate. for the professional man, fully acquainted with the enormity of the evil, 
it is hard to wait for the slow growth of public opinion while infancy and manbood are being eut down indiscriminately by a preventable coutagion, and while even he himself must continually run the gauntlet of the deally blow of the insatiate enemy. Erery instinct of sanitation, of justice, of humanity, of self-preservation, and of morality rebels against the indifference of the people, but more particularly of the statesuen. But it is with tuberculosis for animals in general as with lung plague for eattle in partienlar, or with glanders for solipeds and man, the retri. bution for neglect is not exeented with that promptitude which strikes terror to the mind ; the laity fail to connect the final desolation with the distant canse, and the most deadly of all contagia is permitted to hold on its darksome way unchecked.

A single case of cholera, rellow fever, or even of small-pox in a large eity is considered good cause for excited editorials in the newspapers and for extraordinary efforts on the part of boards of health, whice every day from January to December scores are perishing unnecessarily from the more insidions and far more deadly tuberculosis.

The control of this affection cannot be adrocated as either cheap or easy, or likely to be erowned by an early extinction of the disease as would be the case with lung plague. It will entail an immense organ. ization, large expenditure, and persistent application, not only until all our flocks and herds are purified, but until the present tuberenlons generation of men have given place to a healthier, and until by a slow improvement, generation by generation, the population shall have fiually risen above this baue of our civilization. It is, however, a work that may be profitably undertaken by installments, first in the abattoirs and dairies of our large eities and suburbs, then in our markets for live stock, and our great emporia for buteher meat, then in all our large pubiic institutions, and finally in our floeks and herds at large. It may safely be predicted for the eity that will take the first effectual step in this direction that the showing made by her vital statisties will soon attest the wisdom of the course. The results will be no less benefieial to the stock owner, for apart from the protection of his own health and the assurance furnished him that he is providing a wholesome fool for the people, his herds will be saved from a contagion which now causes incalenlable losses over the entire comitry.

Upon onr statesmen the burden of all this responsibility rests. They are intrusted with the expenditure of the nation's money, and with this trust the $y_{0}$ become severally responsible for every aril which it is in their power to ward off. To wait for the irresistible pressure of public opinion in a matter sueh as this, which appeals so strongly to their humanity, their religion, their patriotism, and self-preservation, is 1 worthy of the high place they hold and the charge which the people have confided to them. They have been ehosen to do the work of legislation for which the people at large have no time; it is tbeir duty to consider these matters when laid before them and to act on them, and on them must rest 
all the blame of the deaths and disasters that result from their ipath and neglect.)-.I. I.

RFEOLUTIONA ADOP'TED.

First question.-Trerinar!l serrive.

1. 'To on ganize in each eomutry a veterinary service, oxchnsively charged! with all that pertains to this service, of which the members, all veter. inarians, should be counselors of every department of the Government, but which should be more especially represented in close relation to the rentral power; that reterinary medicine shonlit there have her shicf of service.

2. The veterinay sanitary service shonld utilize the greatest possible number of reterinarians. It embraces the surveillance of fairs and markets of animals; the iuspection of butcher moat and abattoirs; the control of rendering works; the imspection of breeding animals; the surveillance or direction of mutnal assurance against the mortality of stock; the revision of the census lists of clomestic animals, dc. ; it comprehends the service of the state, and may be made international, embraciug especially the repression and suppression of contagious and epizootic affections, also the control of the varions other veterinary services.

3. Between the rarions states which, by a regular repressive and preventive service against epizootics, ean furuish gllaluntees of a good veterinary sanitary police, there should be established a treaty haring for its ohject-

(a) To apprise the other states as speedily as possible of any outbreak of rinderpest, pleno-pnenmonia, aphthous fever, sheep-pox, maladie du coit, glanders (or farey), or of seab in sheep.

(b) To publish periodically a sanitary bulletin upon these maladies, their extent, progress, and extinetion, which particnlars shonld also be published in the interuational bulletin if judged necessary.

(c) To oppose these maladies by measures of sanitary police, which have first been disenssed and arlopted as the most desirable.

(d) To furnish with animals and lerds, mored into or ont of ans territory, certitieates of origin and health of a value guananteed by the administration.

(e) To contribute to the fublieation of an international veterinars sanitary bulletiu.

second question.-Pleuro-pneumonia.-Lung plugne.

A.-DIFFERENTIAL, DIATINOSA,

1. From an anatomical point of view, at least in its relation to vererinary police, one may rousider as epizootic contagious pleme-pmenmonitu; every pnemmonia which is lobnlar and at the same time inter- 
lobular, and the derelopment of which does not depend on traumatic causes.

2. From a physiological standpoint in the living animal, epizootic contagious pleuro-pneumonia is specially eharacterized by its contagious character aud by the symptoms of lubular pnenmonia.

3. In an infected place every animal which shows febrile reaction or symptoms of disease of the chest should be considered als suspected of pleuro-pneumonia. Every animal found in an infected stable or which has been in one within three months antecerlent, or which has been able to be contaminated in any other was, should be considered as suspeeted of contamination.

\section{B.-PROPHILAXIS.}

1. Recognizing that from the point of view of sanitary police epizootic pleuro-pneumonia is at disease which propagates itself only by contagion, and is usually incurable and fatal, the congress declared that to prevent the development and propagation of this malady there should be applied the measures against contagious diseases that are at the same time fatal and ineurable.

2. Animals diseased or suspecter of the disease shonld be sacrificed as quickly as possible.

3. Contaminated animals or those rery much exposed to the contagion should be isolated or sacrificed. 'The slaughter of contaminated animals is especially indicated when the disease manifests itself rery exceptionally, or for the first time in a stable belonging to a commune or conutry rich in eattle.

4. We have to day experimental proof that it is possible to invest the organism of animals of the horned species with an immunity from eontagious pleuro-pneumonia by inoculation with the virus of this malady.

$\overline{5}$. Preventive inoculation, that is to say, that which is practiced when the malady does not prevail in a country, ought to be alsolutely rejected. Inoculation, so called, of necessity, that is to say, that which is praeticed when the disease exists in at herd, may be permitted but not made obligatory.

6. The inoculation should always be done by a veterinarian.

7. It is not prover that an inoculated animal cannot transmit the disease to a souml animal.

8. Inoculated animals should be reporter to the authorities.

9. Quarantined animals shoulu be made the object of a special eensus, and should receive a distinctive brand with a hot iron.

10. No animal suspeeted of infection should be mored withont prerious anthorization of the eommunal arministration. The permit to move should only be glanted for animals destined to the butelery; it shonld only take plate in special comlitions muler the supervision of the police, and in such a mannel ans to prevent all propanation of the malady.

5751 D $1-12$ 
11. Every borine animal offered for sale ought to be accompanied by a certificate of health testifying that no epizootic has existed for at least six weeks in the commmne from which it eame.

12. In certain special cases, to be determined by the official reterinarian, there may be prescribed the suspension of fairs and markets, the prohibition of the importation of animals from a suspected country, quarantine, the posting of notices at the entrance of infected circles or farms, and the issue of handbills and instructions warning the people of their obligations, aud of the precantions to be taken to prevent the a)pearance or extension of the malady.

13. An aetire supervision should be exereiser, not only orer the quarautined animals, but also, a, over animals exposed for sale in marliets, fields, and fairs; $b$, orer animals lodged temporarily in the stables of inns adjoining the markets; $c$, in stables containing many animals, subject to frequent changes, and when the malady has already made one or more outbreaks.

14. The duration of quarantine should be six months at least, apart from the last ease of the malady.

15. At the release from quarantine the animals should receive a second mark to anuul the effeet of the first.

16. The flesh of an animal slaughtered should not be used for foou, muless authorized by the reterinarian making the autopsy.

17. The skin should not be utilized until it has been steeped for twentyfour hours in an approved disinfectant solution.

18. Careasses and eadaveric débris, unfit for food, should be buried, or so treated as to be absolntely inoffensive.

19. Stables, fair grounds, marliets, and rehicles whieh hare been occupied by diseased or suspected animals, should be carefully cleansed, disinfeeted, and purified. These different operations should be under the direetion of a reterinariau.

20. A stable should not be refilled with animals until it has been entirely evaunated and thoronghly disinfected, and then purified by eight days of free ventilation.

21. Pastures that have been oceupied by diseased animals ought to be quarantined for at least fifteen days.

22. The different materials, objeets, and instruments that have been employed in the slanghter, transportation, or burial of thiseased or sus. pected animals, shonld be destroyed, or thoronghly disinfeeted. Forage and litter should be utilized for horses or other solipeds.

23. Persons who have become soiled by infecting materials, shonld wash their hands, wash or brush their elothes, and wash their boots with a disinfectant solution.

24. All persons and animals eapable of earrying the virus shonld as far as possible be kept from diseased animals, their calcasses and eadaveric débris.

25. It is proper to grant an indemnity to owners for animals slaugh. 
tered by official order and for the cost of disinfeetion. The indemnity should amount to four-fifths of the value of the animal, and to the full valne, derluction being made of the value of portions of the eareass that ean be ntilized if the animal should prove healthy.

26. Very heary penalties shonld be imposed on persons who violate the different sanitary regulations deereed by the anthorities.

27. A good organization of the veterinary service is the best guaran. tee of the application of the different measures preseribed.

2S. A last aud potent measure for seeuring the extinetion of coutagions plenro-pneumonia wonld be the adoption of means for the contagious diseases of animals similar to that in use for the phyloxera of the vine; to formulate an international agreement in which shall be indi. cated the essential elements that onght to form the basis of legislation to be adopted by each country whieh shall join to earry it ont.

\section{Third question-Veterinary erducation.}

1. To be admitted to veterinary studies one must be batchelor es-lettres or es-sciences; that is to say, he must have finished the studies of the secondary education.

2. There is no call to ereate veterinarians of different elasses having a different amount of preparatory or veterinary edueation.

3. Four years of study at least are requisite to make a full study of reterinary medicine, if that is made to include physies and natural seiences.

(a) The instruction of the two first years (four first semesters) should embrace the following branches: physics, chemistry, natural history (zoology, mineralogy, botany, and geology), anatomy, histology, physiologs, and shoeing. A course of praetice and demonstrations in micrography should always be ineluded.

(b) Clinieal teaching shonld continne througl the whole of the last two years of study. That the practical instruetion of the student may be eomplete it is absolutely necessary to have, beside a stationary and consulting elinic (hospital clinic and polyelinie), an anbulatory elinic (ontsicle clinic); there onght to be at least two professors of clinies.

(c) The inspection of butcher meat is an absolntely essential branch of veterinary education.

4. At the end of each year veterinary students should be examined on the studies which they have been tanght that year. No one shonld be allowed to follow the conrse of the alvanced year unless he has passed this examination.

No one should be admitted to examination for the degree of veterinarian who has not followed a course of elinical instruction for two years after having passerl the examination of the second year of stuly.

The board of examiners for granting dlegrees shonld always be formed partly of professors and partly of puatitioners. 
5. Internal (board under military rule) and external (resiclence outside) are optional in reterinary sehools.

6. Veterinary schools may be independent establishments, or they may be eomnected with miversities or institutions for the higher edneation, but veterinary medicine shonld have its special chairs. One camot but disapprove of institutions in which all branches of veterinary education are diviled in a very limited number of reterinary thairs; sueh a sys. tem is absolutely insufficient.

It is very desirable that in every country veterinary schools should be state institutions.

7. The professors of reterinary schools ought to possess diplomas of veterinary medieine. It is rery desirable that veterinarians before being called to the professorship should have practiced veterinary medieine for some years.

\section{Fourth question.}

(See body of report.)

\section{Fifth question-Tuberculosis.}

The flesh and viscera of a tuberculons animal ean only be utilized for luman foor when the disease is found in the eadaver in the ineipient stage, when the lesions are confined to a very small portion of the body, when the lymphatic glands are still free from all morbid tubereular lesions, when the tuberenlons formations have not yet nudergone softening, when the flesh presents the characters of meat of the first quality, and when the animal is in good state of mutrition at the time of slanghter.

It should not be permitted to remove the flesh of tuberenlous animals arlmitted to consumption ont of the locality where they have been slanghtered, and it should not be offered for sale in the butehers' stall.

Every quarter of meat and all viseera showing lesions of tuberenlosis, as well as the flesh of any other animal in which there is found at the necropsy a tuberenlous infeetion more pronounced than that referred to above, shonld be watered with petrolenm oil, and afterward buried under police supervision. The extraction of fat by eooking and the utilization of the skin may be permitted.

The inspection of erery animal attacked by tuberenlosis shonld he made by a veterinarian, who alone shond decide if the tlesh is fit for human consumption.

The milk of animals affected with tuberenlusis or suspected of it should not be taken by man nor by certain animals. The sale of this milk should be sererely interdicter.

Respectfully sulomitterl.

Hon, Geolige B. Loring, JANLS IAT.

Commissioner of Agriculture. 


\title{
HADIBURG INTERIATIONAL EXHIBITION.
}

\author{
REPORT OF J. H. SANDERS.
}

Hon. Geo. B. Loring,

Commissioner of Agriculture.

Sin: On the 19th day of May, 18s3, I had the honor to receive an al)pointment from sou with the following instructions:

Yon are hereby appointed and commissioned an agent of the United States Department of Agriculture to atteud the International Exhibition at Hamburg in 1-83, and you are instructed to examine and report upon the following special points:

The character of the Exhibition in all its departments of live stock as compared with our own.

The general eondition aud supply of live stock in Englaud and on the Contiuent.

The breeds most met with aud that seem to be most desirable and popmlar; also, their relative merits as compared with our own.

The probability of improvement to our own stock by further importatious, and the breeds most desirable for this jurpose, if any.

The dangers from contagions diseases that may be apprehended from eoutinued importations, if any.

The methods of live stock husbandry practised eompared with our own.

The probable future demand from European eountries for American live stock and meats.

The present hindrances and restrictions that affeet the exportation of live stock from the United States, and how they may be modified or removed, especially with reference to the exportation of onr live eattle to Great Britain, and our hog products to Germans.

In pursuance of the foregoing instructious, I started upon my mission May 26, landing at Liverpool. After a brief sojourn in that eity, deroted mainly to au examination of its cart-horses, I proceeded to Londou, where I spent several days familiarizing myself with the markets, the morles of travel, and other matters of importanee connected with the live-stoek industries of that eity. As one of the principal objective points of my visit was the Intermational Live Stock Show at Hamburg, I determined to go at once to the continent, leaving England and Scotland for my return trip. Aceordingly, Jnne 19, I left London purposing to make my journey to IImburg via Paris, stopping en roule to make a study of

\section{THE DRAFT HORSES OF FRANCE.}

The eonstantly increasing popularity of the French draft horses in this country, as evinced by the large mumbers anmully imported, and the 
interest I myself had taken in some of the diseussions growing out of the business, led me to attach a good ileal of inportance to what I might learu eoncerning them by a careful personal iuvestigation of some of the controverter points. Among the most important of these were the following:

1st. Are there any well-established distinet breeds of draft-horses in France? 2d. What guarantees, if any, can American importers obtain in France that the horses purehased by them belong to any particular race or breed, and that they are purely bred? And 3d. To what breed do the horses usually brought to Ameriea from France belong, and in what part of France are they bred ?

It may not be out of place for me to remark here that during the past six sears I have, myself, been compelled to participate in several controversies, through the agrienltural and live-stock papers of the eountry, touching the draft horses of France and the name by which they should be known in the United States. Throughont these eontroversies I relied mainly upon such of the printed history of these horses as had been translated into English, and upon what I conld gather from intelligent gentlemen who had personally given more or less attention to the subject in France. It was therefore with a good deal of pleasure and interest that I embraced the opportmity afforded me, by my present visit, to go into this question thoronghly for myself. And first let me say that many Ameriean importers, especially the earlier ones, and some eren at the present day, go to Paris, buy their horses of a dealer who has gathered them up from various quarters, and then return without the slightest knowledge of the breeding of their horses, or of the region where they are bred. It is not to be wondered at, therefore, that such men can tell nothing of the breeding of these horses when they get lome, because they know nothing, beyond the fact that they had bought them of a French dealer at Paris, Dieppe, or Havre. If they attempted to say anything beyond this, they simply drew on their imagination for their so-called facts. After awhile, however, those with some experience in the business, and with some knowledge of good horses, began to inquire into the subject, to try to find ont where the good horses eame from, so that they might get them, if possible, from first hands. I began my investigations in the same way. I went first to the sales stables of Paris, fortified with all the knowledge I had been able previously to obtain upon the subject. I went first to M. Vidal, who is a noterl horse dealer of Paris, and who has muloubtedly sold more stallions to American importers than all the other horse dealers of Paris combined. In reply to my question, he said: "Fully 90 per cent. of the horses that I buy to sell to Americans, for stallions, come from beyond Chartres, in the Perebe; the other's are picked up here and there, wherever' we can find one good enough for the market; bnt we sell them all as Percherons." The other dealers all told substantially the same story. 
After spending a few days in Paris, talking with horsemen and gathering what information I eould, I determined to see the Pereheron breeding district for myself. All anthorities agreed in pointing out Nogent le Rotron, sitnated about 100 miles sonthwest from Paris, in the ancient province of La Perehe, as the heart of the Percheron breeding comntry. It is at and near this place that Mr. Dunhan has bought humdreds of horses within the past three jears for the Ameriean trade, and where the Messrs. Dillon and several of the other importer's have male most of their purchases for some time past; and in this region is the only place where any attempt is made to maintain the Percheron race in its purity.

On the day of my arrival at Nogent le Rotron, a large number of Pereheron breeders had met to consult upon the propriety of establish. ing a Percheron stud-book, in order to preserve the purity of the race and to protect themselves from unsermpulons ilealers in Paris and elsewhere. I was much interested in the discussion which took place. The gentlemen present represented the principal breeders for some 20 or 30 miles aromd, and I was told that they owned at least 100 stallions that had been kept for service this senson. I questioner many of them. Among others, the stitement of Mr. Ernst Perriot, one of the most noterl of the breeder's present, is a fair sample of what all had to say. He is a very intelligent gentleman, and has sold many horses to Aneriean buyers. I should julge him to be about fifty years of age. His statement was in substance as follows:

I have been breeding horses right hero all ny life, and my father and grandfather were in the same bnsiness before me. We never lireed or sell any other than pure Pcreherons. We have usually liept 6 or a stallions each year for service. Thes travel around the country, serving mares owned by the farmers at about 95 fiancs each. We keep an ere un these mares, know where the best ones are, and when the foals are weaned we bny many of the best ones each year and keep them mintil we can sell them at a fair profit. I am sure there has been nothing but recognized pure Percheron stallions used in our stud since the time of my yrandfather, and nothing else has been nsed in this whole Percheron region within my knowledge. There is a tradition that abont the time my grantfather engaged in the business some Boullonais blood was introdnced into this comntry for the purpose of increasing the size of the Pereherons, bnt certainly there has been none since abont fifty years ago. The true Pereherons will now average as large or larger than the Bonllonais. Neither Mr. Dunham, Mr. Dillon, nor any other American importer has ever bonght any Norman horses here. We don't have any such horses. You can see plenty of Normans in Paris; they are all small horses, mostly bays, and are used in the cabs and carriages. They are generally half-bloods got by English thoroughbred sires, and some of them are out of Percheron dams, and are usually called Anglo-Normans.

The same statements, substantially, in regard to purity of race and the name, were obtained from all the breeders interviewed, motably Anguste Tacheau (provinee of Sarthe), Pierre Sagot (province of Eureet-Ioir), and Celestin Caget (province of Orne). In fatet, so far as I conld learn, it was almost an insult to ask one of the breeders present if they bred or sold any other than Percheron horses, and they spurned the term "Norman" with contempt. 
These are the men of whom all the leading American importers have been buying for several years past. They buy these horses as Percherons, from men who will eall them nothing else, and yet a few of them come home and abuse ererybody who lefuses to eall them Normans. There is not much in a name, but sometimes a name contains a deal of meaning within itself.

It was an agreeable surprise to me to learn that so much pains had bcen taken by these Percherous hreeders to preserve the purity of the race. It hat been asserted that nobody knew anything about it; that the Pereherons were mongrels, and that 110 man conld give the pedigree of his horse. I found, on the contrary, that, while they have not paid much attention to preserving the materual genealogy, many of the sires can easily be traced six or eight generations. One young horse, now owned by Mr. Erust Perriot, is a noteworthy example. This horse is a three-year old, and is so highly valued by his owner that he has ab. solntely refuserl to name a price on him. Fifteen thousand fiancs were offered for him by an American buyer in my hearing; but the owner shook his head and sain, "You might safely double it." This young horse was got by the hlack horse Brilliant (No. 1271 of the PereheronNoman stud Book), that now stands at the head of Mr. Dunham's stnd, at Wayne, Ill., and the line of sires back of him is known for seven generations. Mr. Perriot proposes to raise the service fee of this horse to 100 francs next season, a price that has hitherto been mheard of in the Percheron breeding district. As another instance of the eare which French breeders are taking to secure good breeding stock for themselves I may uention the fact that Mr. Anguste Tachean recently pair 3,000 franes for a snckling colt, which he designs to nse in the stutl.

Yon will donbtless remember that one of the things disenssed between us at our interview a few days prior to my departure upon this mission was the desirability of a Percheron stud-book in France in order to protect American breeders from imposition, and to afford some guarantee of the purity of the blood of the horses bronght to this conntry from France. And you will also no donbt remember that the desirability of such a publication was marle the subject of a sipecial communication from yon to the French minister of agrienlture, at that time. It is therefore with no small degree of satisfaction that I am able to report that the Pereheron breeders of France have fully resolved on a stud-book. The meeting to which I have heretofore alluded, as having occurred on the day of my arrival at Nogent le Rotrou, was simply informal aud preliminary, but on Saturday, June 23, a largely attended meeting was held at the same place, abont one humlred breeders, representing the provinces of Enre-et-Loir, Urne, Sarthe, and the whole of the aucient province of La Perehe, being present. At this meeting a permanent organization was effeeted unler the sanction of the Government, with M. Fardonet as president, and Messrs. Vinanlt, Perriot de Champean, Sagot Anatote Miard, Poullain, Lneas, Lamnay, A reline, Tacheat, and 
Caget as rice-presidents; M. Boullay-Chammard, secretary-treasurer. These, with the mayor of the city of Nogent le Rotron, the prefect of the department of Eure-et-Loir, and the prefect of Nogent le Rotrou, constitute the "board of directiou" of the Société Hippique Percherome. The rules for registration are very strict, and every application must he sworn to, giving the genealogy as far as it can be traced, and establishing beyond controversy that the animal is "born Percheronne." Penalties are proviled to prevent fuaudulent entries or disrejutable transactions generally. In short, it looks like a strong, resolute, agoressive organization from the start, and will mark an era in the Percheron breeding. business.

I conclude, from a considerable sojourn in France, that Americans who buy directly from the breeders and "stallioners" (stallion keepers) of the Percheron district have heretofore had a reasomably certain guarantee of purity of blood, and henceforth the assurance will be as complete as can be obtained with any breel of draft horses in the world. Those who buy of the dealers in Paris and in the cities on the coast can hare no such assurance, and their own eyes must judge of the breeding It is to be hoped that hereafter no imported horses will be admitted to registry in the Percheron-Norman stud-book of America that are not previously registered in the Percheron Stad-Book of France. It wonll have been infinitely better for the reputation of the breed, and for onr own horse stock, if such a regulation had been practicable and enforced years ago.

There are many most excellent horses working in the drays, trucks. and omnibuses of Paris. The omnibus horses will arerage much lar. ger than has been represented by most writers. They are usually thin in flesh, and the reights, when given at all, have been with reference to that condition. I stood on the street one lay for an honr in company with two experienced importers, watching these horses, especially with a view to estimating the arerage size. The rerdict was : arerage weight in good flesh-fat as stallions are usmally kept in America-between 1,400 and 1,500 pounds. These omnibuses are enormons, great doubledeckers, holding about sixty-five persons, and are drawn by thee horses harnesserl abreast. Fully serenty-five per cent. of these horses ale white, and ther nearly all have the usual Percheron characteristics. Mr. Vidal, the Parisian horse dealer previously alluderl to, told me that he sold abont 1,100 horses a year for use in the ommibuses; that nearly all of them came from beyoud Chartres ju the Perche, and that the averige weight was about 1,400 ponnds. The horses one sees in the dlays are larger; an average lot of imported Pereheron horses is but little if any better or larger than the average eart-horse as seen in the streets of Paris. They are massive, strong, patient fellows, and are nearly all Percherons.

In no eity that I have visited are the loorses driven so hard and treated so mmmereifully as in Paris. The drivers whip tleeir horses and rush 
abont like madmen, and although the streets are very wide and rarely crowded, yet the perlestrian who attempts to eross must keep a sharp lookont or he will be run over. The eab-horses of this eity are a sorry, lough looking lot, which I attribute mainly to their bad usage. The drivers of the eart-horses do not seem to be quite so unmereiful, but throughout all Paris the prevalent idea with a driver seems to be, that a horse was made to use and to abuse. Even in the Pereheron breeding districts I notieed traces of this same feeling, and here also I noticed the most striking lack of a knowledge of the value of eleanliness in the management of a horse. The French are miserable groomers; their horses are filthy and dirty, and are left mainly to take care of themselres, so far as cleanliness is concerned.

THE IIAMBURG INTERNATIONAL EXPOSITION.

From Paris I went direct to Hambarg to visit the exposition, or " 11 ternational Show," as it was called, which opened July 2. It was in many respects a disappointment. In some features it was equal to an ordinary Ohio, Illinois, or Iowa State Fair, but in many others it was far behind the usnal annual exhibit in those states. In the single featnre of dairy stock it was great; and I never had so high an appreciation of the quality of the Duteh. Friesian or Holstein cattle as since sceing them at this show. It is, however, so far as I can learn, the best exhibition of the kind ever held on the continent, the number of entries largely exceeding those of the Paris Exposition of 1878.

The "classes" were legion. There were 56 classes for horses and mules, with 424 entries; 141 classes for cattle, with 902 entries; 88 classes for sheep, with 728 entries; and 50 elasses for pigs, with 277 entries-certainly elasses enough and entries enongh to make a grand show. But, nufortunatels, many of the entry mumbers were blank, a condition of things which seems inseparable from the system of nmmbering and eataloguing an exhibition of this nature in advance of the opening.

The various breeds of live stoek of Germany and of Northern Enrope generally were well represented, with the exception of those of Russia, from which comntry I was not able to find anything. In this I was disappointed, as I had hoped to see a good representation of the famous Orloff trotting horses. The show of draft-horses was seareely worth mentioning. There were a few creditable specimens of the English carthorse, and some draft-horses from Belginm, but none worthy of especial notice. The government breeding studs, of Germany, were pretty well represented with horses of the thoronghbred type; rery fair specimens, but in no wise remarkable. In short, the horse-exhibit generally impressed me as a heterogeneous mass of no especial excellence in any partienlar. There were some dun ponies, from Norway, abont 14 1-2 hands high, very heavily built, and blocky-enormons draft horses in miniature, that were mnch admired. There were no French horses on 
exhibition. In fact no stock from Franee, so far as I eonld learn, except French merino sheep.

The feature of the eattle show was the dairy stock, and in this I nerer saw anything that conld approach it. Fundreds of the Friesian or Holstein cows were there, with their grand udders, and every indication of milk-producting capacity of the highest orler. I conld not help remarking to some American friends who were with me that I feared onr im. porters had not get taken across the waters any of the best of the race, for I certainly never saw such dairy eows in any show-yard in America as I saw at Hamburg. I am now more than ever convinced that, all things considered, the Dutch cow is the general dairy cow, par excellence, of the world.

I was also very much interested in the Oldenburg eattle, a race that in color elosely resembles the Holstein or Friesian breed; rather darker in color, not quite so good, I should say, for the dairy, but rery much better for beef. In fact, the very best beef eattle on exhibition, in my opinion, were these same Oldenburgers. Ther are smooth, rather fine in bone, handle fairly well, and bear every indication of good feediug quality. If it were possible to combine the beef-making quality of the Oldenburg cattle with the great miiking eapacity of the Dutch cows it would come very near making the model cow for the average farmer.

Another class of eattle that interested me much was the Angeler, a race that seems to be peculiar to Schleswig-Holstein; little fellows rather smaller than the average Jerses; very dark red, bordering ou brown in color, very fine in the bone, and eridently deep and very rich milkers. Mr. H. Chandos-Pole-Gell, one of the delegates from the Royal Agricultural Society of England, remarked to me that to him this class was the most interesting one in the show; but while I freely concede to them great milking and butter eapacity in proportion to size, I conld not help thinking of "Uncle Billy Smith's" bon mot, anent the Jerseys, at the Illinois State Fair two years ago: "They will do for a man who is too poor to keep a cow and who is ashamed to keep a goat." They are too little to be of much practical use, but they are evidently a very pure race, and good machines for making milk and cream, in proportion to their size.

There were some short-horus on exhibition, but they were, with the possible exception of one or two cows, miserable specimens of the bread. There were also a few Ayrshires, and one or two Polled-Angus, of rery ordinary merit. The Swiss eattle were ont in considerable force, and, from their uniform gray eolor and the immense bells that accompanied them, attracted a good deal of attention. They were of fair size, pretty good on the back, many of them, but coarse and bad handlers, evidently lacking in what cattle breeders usually denominate "quality."

As a matter of enriosity I was interested in the little cows from Norway. They are little things, much smaller than the Augeler cows above alluded to, with remarkably thin, flat bodies, on very short legs, 
white on back and belly, the sides a light yellow, streaked with black, marking them much like a tiger. About a dozen of them were in the show.

The show of sheep was not remarkable in any feature. The French merinos rather took the lead in numbers, closely tollowed by the English mutton breeds, the various classes of Downs, with a few Cotswolds and Lincolns. Of the French merinos, there were many most excellent specimens, better and larger than any I had heretofore seen. The peo. ple of Germany appear to be "taking to" the Sonthlowns, Shropshires, Hampshires, and Oxfords largely.

In the swine department of the show I was pleased to see our Ameriean-Poland Chinas holding a prominent place, and, in my judgment, the very best specimens of swine on exhibition were of this breed and imported from America. Mr. John C. Funch, of Uldenburg, was the enterprising gentleman who male this exbibit, and his swine are certainly most creditable representatives of the breed. In point of numbers, the white breeds, mostly of the rarious Yorkshire families, made up about 60 per cent. of the show, while the remainder were about equally divided between the Berkshires and Poland-Chinas, with a few Essex.

I may sum up my impressions of this show by saying that, while it was very creditable in most departments and great in display of dairy stock, I saw nothing worthy of especial remark in the management. The system of classification was very complete, and the several breerls were usually gromped together in their stalls or pens so that one desiring to examine any class of stock found but little diffieulty in doing so. The published catalogne of the exhibits was also a great conrenience to visitors, as in it full particulars as to name, age, pedicree, ownership, etc., were given. The custom of issuing a catalogne of this sort is general with European agricultural shows, and might be followed in our own country with profit.

I saw no breeds of live stock at this show the importation of which to the United States, in my judgment, should be enconraged or recommended other than the Holstein or Friesian-Dutch dairy cattle and the Oddenburgs, to which I have alluded in the foregoing. They are certainly most excellent breeds of eattle for the purposes indicated. The former have alrealy been extensirely introdnced in our country, and are certainly rapidly growing in public favor. To what extent the Oldenburgs might be profitably imported, if at all, I an not prepared to say. I can only reiterate my former statement, that they were certainly the best beef animals on exhibition, and that they also seem to possess an adaptation to the nses of the general dairy farmer, but little inferior to the Iolsteins or Friesians, which they closely resemble.

\section{OUR PORK IN GERMANY.}

While in Germany I made diligent inquiry in order to ascertain so far as possible the feeling of the Government and people concerning the 
admission of American pork to that country. Among the trades people in the cities, so far as I conld learn, the feeling is rery strong andinst the prohibitory policy of the Government, but among the best informed people, and those connected with the Government, the case is just about as follows:

The swine of both Germany and the United States are confessedly, to some extent, infeeted with triehina. The German authorities require that the flesh of all swine slaughtered in that country shall be subjected to a mieroscopic examination by a Government inspeetor, and pronounced free from trichiua, before it can be oftered for sale. No such examination is practicable with silted and packerl meats from America, and as no pretense of an inspection of our meats is male by us moler Government authority, or even under the supervision of the packing firms, the German Government says, "We cannot aceord to American packers and butchers a privilege which we refuse to accord to om own." So far as I conld gather, it is generally conceded that whenerer an inspeetion of our pork is made, under eareful goverumental supervision, similar to that now made by the German anthorities, there will be no objection to its sale in that comntry. Inrleed it strikes me that were such an inspeetion made there would be such a strong pressure bronght to bear upon the German Government by their own people that the embargo wonld be speedily removed. The presence or absence of this mieroseopic parasite in the pork of this country is a matter of but little interest to us, as Amerieans cook their pork before eating it, and thorough cooking obviates all danger, but in Germany, where mneh of it is eaten raw, it becomes a serious matter. Should further experiments confirm what has been alrealy partially showu, that thorongh emring in silt destroys the vitality of the trichina, if not entirely, at least, to so great a degree as to reduce the danger from meits that have been thoroughly cured by this process to almost nothing, it will doubtless be a strong point in our faror, and a proper presentation of the facts to the German Government, should this be clearly proven, ought at once to be made. Until this fact is elearly established, howerer, and in the absence of any pretence of inspection of American meats, either muler gorernmental or inlivilual supervision, the position of the German Gorernment is obviously sonml upon this question, and cannot be alssailed without first demonstuting that their own inspection is useless.

\section{OUR EXPORT CATTLE TRADE WITI GREAT BRITAIN.}

From all that I could learn while in England, the trale in dear meat between the Unitel States and Great Mritain is not at all satisfactory either to those engaged in the trate or to the consumer. The fianlities for securing the exact temperature necessing in order to maintain the propere eomlition of the meat dhring the ocean voyage are so inperfect that the meat not mifrequently reatehes the eonsumer in a more or less daniaged condition, and large losses hare resnlted. All well-informed 
persons agree that the most satisfactory results will be attained when we shall once more be able to show a clean bill of health, and send our live cattle, under such regulations as will insure their health and comfort, to the farms and pastures of England and Scotland, there to be slaughtered when their condition and the state of the market requires it.

It ought not to be considered strange that British farmers should make strenuous efforts to still further restrict or totally suppress the importation of live stock for slanghter in their country. They have suffered enormous losses in times past from imported disease, and during the last few years they have been contending with great obstacles, not the least of which has been the great supply of agrieultural prodnets that Ameriea has sent to that country. Under these cireumstances it is not to be expected that British farmers will be inelined to take a strietly judicial view of the ease. Naturally they would like to seeure a better market for their own stock, and equally naturally they magnify possible danger of importing disease from this comntry. On the other hand, it should be borne in mind that the English Government has steadily refused to yield to the demands for further restrietions, and has in the main done full justice to American interests, especially in the recent alarm over the reported existence of foot-and-mouth disease in this country.

It is doubtless true that British farmers do not regard the existing condition of the meat trade with this conntry farorably, and that whenever they are satisfied that it may be done with safety they would much prefer that the restriction should be remover altogether, rather than that the present arrangement of eompulsory slanghter be continued. As the trade is now conducted the supply received from the United States detracts just so much from the demand for home products, and the British farmer lias no opportmity for even an incidental share in the profits of the business. On the other hand, could our eattle be safely admitted without restrictions, immense numbers of store or partially fatted eattle wonld be shipped to that country, and wonld be taken inland to British pastures and finished up on British food, thus enabling British farmers to reap profits out of the better fitting of these eattle for the market, and also to utilize them in the converting of the provender of the farm into maune, a very important consideration with the farmers of that conntry. During my risit to that country I conrersed with many farmer's upon this subject, and I never met with a single man who expressed himself as otherwise than furorably disposed towards the free admission of Ameriean eattle whenever it conll be done with a reasouable guarantee of safety from contagions diseases; and in nearly every case the hope was expressed that the time would soon come when the present restrictions might safely be re. moved. Instead of being opposed firm motives of self-interest to the free introduction of onr cattle to that conntry, the feeling seems to be general among English farmers, so far as I heard any expression of 
opinion, that the profit derived from the "finishing up " process would more than compensate for the resulting competition.

Feeling certain that this is the view generally held by intelligent and progressive British farmers, and also strong in the belief that we shall at no very distant day be in such a condition as to enable ns to give our British consins assurances concerning the sanitary condition of on cattle that will be satisfactory, I confidently look to the entire removal of the present restrictions as a thing reasonably certain to oceur in the near future. Of eourse this belief and hope is based upon the contidence I feel in the course which our General Government, aitled by that of the infected States, will take in respect to the stamping ont of contagions diseases and in otherwise improving the sanitary condition of our cattle, and also in the surveillance which, in my opinion, will at no distant day be exercised over our exports.

The importation of cattle from foreign countries was a fruitful theme for discussion in Great Britain during the time I was in that country. The umusual extent to which foot-and-mouth disease has prevailed there during the past year and the losses resulting therefrom to British farmers have made them extremely restive, and while the Government has been active in its efforts to stamp ont the disease, it has been constantly importuned to adopt still more stringent regnlations to prevent the introduction of contagious diseases from abroad. All Americans interested in the subject are aware that for sereral years past a regulation has been enforced which requires that all eattle bronght to Great Britain from the United States must be slanghtered at the docks where landerl within ten days after their arrival, no matter what may be their condition or the state of the market. This edict of eompulsory slaughter is based upon the assumption that to almit the free transit of cattle from the United States to the farms and pastures of Great Britain would expose the cattle of British farmers to increased dangers of infection from pleuro-pnenmonia or Img plague, the presence of which discase along a portion of our Atlantic seaboard is admitted.

In the mean time Canadian cattle have been freely admitted withont compulsory slanghter or detention, no contagions diseases having been foumd among the eattle of that conntry, and the Canadian Govermment maintaining a rigid quarantine against the cattle of all foreign comntries, the United States included, and also making a eareful insprection of all exported eattle and exercising a rigid supervision over the ships in which they are earried. In conserpuence of these regulations a Carnadian bullock will bring $\$ 15$ to $\$ 25$ more at the Liverpool ox Lomdon landings than could be obtained for the same bullock if exported from the United States. To some European comntries where the sanitary condition of the cattle is not so satisfinetory as in the United States even the grace of eompulsory slanghter is not accorded, but the landing of live cattle therefrom is absolutely prohibited.

In Jannary last a shipment of eattle was received at Liverpool from 
Boston, which, upon inspection, was foumd to be suffering from footand-month disease. In March a shipment was received from Baltimore in the same condition. The publication of these facts led to a strong popular deniand upon the Government that absolnte prohibition shonld be applied to all eattle from the United States; and in July, while I was in London, Mr. Clapplin introduced a motion in the Honse of Commons which was, to all intents and purposes, a demand upon the Government that such action should be immediately taken. In spite of the opposition of the Government parts, $\mathrm{Mr}$. Chaplin's motion prevailed by a majority of eight.

I listend with a good deal of interest to the disenssion which this motion elicited, and, in eommon with all other Americans who took any interest whatever in the sulyject, I regarded the rote by which it was earried as a very threatening omen. Indeed, the agent of the Dominion Government of Canala said to me the day after this rote was taken that he wals certain that within a week an ordel would be issued absolutely prohibiting the landing of Ameriean cattle at British ports. I set at once actively to do what I conld to comnteract this. The pretext set up for this action was the presence of foot-and-mouth disease in the United States. My position as an accredited representative of our Department of Agricnlture, and my opportunities for ascertaining the facts as a nember of the Treasnry Cattle Commission, enabled me to make representations tonching the actual condition of our cattle that attracted attention, and which I helieve were quite generally aceepted as true. Throngh the London Times and by personal interviews with members of Parliament and with the chief reterinary adviser of the priry council, aided, I may say, by the efforts of others, I was able not only to connteract the effect of the vote on Mr. Chaplin's motion, but to bring abont a much more satisfactory state of feeling, so far as the security of the present condition of the trade is concerned, than had prerionsly existed.

I was able to explicitly deny the existence of foot-and-month disease in the United States, except in cases of direct importations from Great Britain, which eases had been promptly deteeted and closely quarantined, and to state positively that the cases of foot-and-month disease alleged to have been bronght from the United States were dne solely to the infected ships which liad bronght diseased eattle to our own ports, and withont proper disinfection had been loanded with fat cattle for Liverpool.

The effect produeed by this plain statement of facts was so considerable that Mr. Arnold eallenl attention in the House of Commons to the assurances contained in my letter in the Times of July 18th, and also to one of a subsequent date from Gencral Carman, of the Department of Agricultnre at Washington, and askerl the Govermment: "Whether, in view of these fauts, the present lestrictions might not safely be remover so far as cattle from the Western States were concerned." 
The answer from the Government Wis, as I smpposed it wonlil be, to the effect that, moler the existing act of Parliament, no concession conld be malle in taror of a portion of any comntry that combl not be accorelent to it as a whole, I suceeded in obtaining from l'rofissol Brown, the chief reterinars adviser of the privg eomeil, an alluision that in his opinion a plan might be derised ly which rattle fiom on Western States might now he arlmitted with peasomablesafety. This 1 regarded as a very important almission; but the nealluess of the end of the seasion of Parliament marle it mseless then to ask for such anditional legis. lation as would be necessary in orter to enable the priry council to cully ont this idea. I may add, in this commection, that Professone Brown, speaking for the miry comncil, expressed himselt as gleatly pleased with the steps which the Agricultumal and the Treasmy Departments of the Enited states had taken within the past year or two to improve the sanitary comblition of om live stock and to prevent the im. portation and sprean of contagions diseases; and that the implession is rapidly gaining gomud that we shall soon be in such a comblition that cattle from all parts of the United States may be arduitterl and taken inland without any danger fiom disease. This feeling is bised mainly upon the steps which our Govermment has already taken, and a fath that we shall continne to go forwarl in the same direction.

I camnot but regand it as extremely fortunate that some one who conld speak with some degree of assmance, and whose opportmities, from linowing the fincts, were acknowledged, should hate been on the spot 11 London in fuly last to correct the misapprehensions that existed tonching the prevalence of foot-and-mouth disease in this commtry; and I think it reasonably sate to prediet that, with the enforcement ot such regulations as are now contemplated by our Treasmre lepartuent, and with smeh alditional leyishation as may be reasomably expecten from om Congress at its next session, the time is not fal distant when American cattle will be placed upon an equal tooting with those from Canalia so far as almission to British ports is concerned.

\section{IMIRESSIONS OF BRITISH BREEDS OF CATTLE.}

Howerer much the substantial merits of short-horns in Great Britain, as well as in America, may have heen damaged within the past twenty gears by blind allegiance to what has been called "tashionable breeding," it is evident that the "color craze," which prevals to so great an extent in the United States, has not yet had any serions effect on tha of her side of" the ocean. In the stables, the pastures, and the show-yarls of lingland and Scotland I sam comparatirely fow red shopt-horms. Roan appears to be the farorite color there; the all white being quite as fiequently met with as the all-red. In the show-yads the rich red-roall-a color that is peculially characteristic of the short-horn lored-atplears to be in a deciderl majority orer all others.

ln point of leal merit, loworer, I think no andid man who has seen 
the eattle of both countries will dispute my assertion when I say that, judged by the gattle shown at the Royal this year, English short-horns are not equal to those shown at our leading fairs in America. 'There were no representatives of the breed at the show of the Royal Agricultural Society, at York, this year, worthy of being compared with the show herds that Potts, Pickrell, Sodowsky, Croft, and Palmer exhibited thronghout the Western States at our principal fairs last year. In this opinion I an sustained hy every American "cattle-man" that I met at Torls during the Royal show, and there were several of them-Hereford, Angus, and Devon, as well as short-horn lneeders. With the exception of the rearling and the two-year-old heifer classes, I thought the show wak throughout, so far as quality is concerned, although it was quite strong in number's. At this writing I have not real any of the com. ments upou this show by the English press, so I am not prepared to say whether it compares farorably with its predecessors or otherwise; but, judging by what I heard among the breeders, it was certainly up to, if not superior, to the average of the prast six years.

The show of breeds, other than short-horns, at the Royal was not large. The Herefords were reasonibly good, the cows very fat and very "patehy," as a rule. There was a fair show of Welsh cattlerigorous looking animals-uniformly black and possessing a good deal of "style"; they impressed me as being really much better beef eattle than I had been led to believe from what I had previously heard of them. There were a few yery good Aberdeen-Angus and Galloways, but these breds were not largly represented.

From my stand-point the very best beef animals I saw at York were of the Devon breed. Of course they were not so large as some of the other breeds, but they were as square and blocky almost as model Berkshire pigs, on rery short legs, with fine bone, neat heads, and snch handlers! As an old buteber remarked in my bearing, they were "all good beef from 'or'is to 'ocks."

F I also liked the red polled cattle of Norfolk and Suffolk quite well. They are much like the Derous in shape and color, but are hornless. While ther possess all the eharacteristics necessary to entitle them to rank as a distinct breed, yet it is coneeded that the eattle of Suffolk have been a trifle coarser than those of Norfolk-a difference, however, that is fast disappearing under the system of blood-mingling that is now praticed between the two counties. In addition to a high order of merit as bedf producers, the Norfolk and Sulfolk breeders elaim great superiority for the eows of the breed as milkers, and certainly their published recorls go far toward sustaining the claim. To those who have a decided preference for lormless eattle, yet with a dislike tor the black color, I can heartily recommend these beautiful red cat tle of Norfolk and Suffiolk.

The show of Jerseys at the "Royal" was much larger than that of any" other breed, except the short horns, and many of the cows carried 
with them evirlences of large milking capacity. The Ayrshires were not conspicnous, either in numbers or in quality, and the honors in the dairy chasses were carriel off hy the short-horn cows. I may jemark here that the prevailing type of short-horn cow, as exhibited at the "Royal," al)proaches much more nearly to that of the model dairy cow than does the type usually met with in onr American show-yarls. They are more after the "welge-shape" pattern-heary in the hind quarters and tapering toward the head-than is considered the highest model of form in a beef-producing animal.

Next to the "Royal," the most important agricultural show of Great Britain is that of the Highland Society, held this yall at Inveruess. The lealing feature was, of eomse, cattle, and of these the Galloways, Highlanders, and Aberleen-Angus took the leal. Many who had made entries here, however, as at Lork, were deterrel from bringing their cattle on account of danger from the wide-spread infection of font-andmonth discase. Among others there were many entries from Sir Coorge IcPlerson Grant's famous ballindalioch herd of Aberdeen-Angus eat. tle, but fear lest they might inenr the dreaded infection finally led sir George to keep) his favorites at home, although several of his choieest animals har been especially fitted for this show, and with every prospect of carrying a large share of the honors back with them to Castle Ballintalloch.

The short-horns were not numerons, hut there were a few goon ones: notably Goldfinder, a yearling bull breal by William Handley, Greenhead Milnthorpe, got by Sir Arthur Ingram (32490) ont of P'rincess Flora, by Alfred the Great (36121). This young fellow, a beatiful red roan, exhibiterl by James Bruce, who is reognized as one of the bust feeders in all Scothand, was shown in the very pink of condition, and is ratainly the best gomng bull I have seen this gear. He deserverly won the highrst honors in his elass aml also the gold molal as the hest short-horn bull of any age in the show. Among the other short horms there was nothing particularly noticeable; and certaiuly any of the American herds mentioned above would have had an easy victory over the hest of them in the show ling. I cannot help repeating here my strong conviction that on best American shorthorns are superior, as a general thing, to the hest I have seen here, either in the shows or at home on the farms of the breerlers. The hest specimens of the hreer I have seen (with the exception of the yonng bull above mentioned) were on the pastmes of the farmers of Aberleenshibe-beantiful. smooth, fine homerl cattle-sueh as womld delight the heart of a Smithield butches.

The West Highlanders were numerically stromger tham any other breed at Inverness, and with the seoteh people they appear to be prime liavorites. I fear, however, they are too slow in maturing, and tou small to be of value to American breaders. Hambiness they muloubterlly possess to an unusual deglee, but if hamliness alone is what our Wrestern 
ranchmen want they can get plenty of thit characteristic by taking a cross back to the Texan or to that still more harly and better "wrestler," the American buffalo. I take it that what is wanted by our West. ern randumen is a cross that will give earlier maturit, fineness of bone, lightness of oftal, and a greater tendency to take on flesh. The quality of hamliness is alrearly attained in the fom ration stock.

lor the same reason I am rather disposed to question the rlesirability of the Galloway as a eross for onr Western ranchmen. Ilardy they undoubtedly are, and of most admirable form in carcass, lnt I have a fear that this cross mpon the fonndation stock in use on our Western plains will be found coarse-boned and slow in reaching maturity. I renture this as an opinion, based entirely upon the prevailing type of these cattle as I have seen them in their native country. When mature I am inclined to think they are superior in shape of carcass, jurlged from a beef-producing standpoint, to their rivals, the finer-boned. finer haired, and earlier maturing Aberleen-Angus, but as a cross for the purposes abore indicated I certainly look for moch more satisfactory results from the latter breed, muless it be npon herils that have allearly been im. proved by several crosses with the earlier maturing breeds.

Among the herds visited by me in this comtry I have been especially pleased with the short-horms of Hugh Aỵmer and Amos Cruickshank, and the polled herds of Sir Genrge MePlierson Grant and Mr. George Wilken. Mr. Aylmer is an arlent admirer of the Booth sort, and as his breeding is contined to that line his herd nay be fairly taken as a representative one of that family. IIis cattle are distinguished for blocky, beefy form, on short legs, with well-sprung ribs, and straight top aud bottom lines. Not remarkable for fineness or smoothness, or style, or finish, but certainly most excellent beef-producing cattle.

Mr. Cruickshank is not a follower of either Booth or Bates. He has been breeding short-horns at Sittyton for abont fifty years; says it has always been his aim to breed good short-horns, regarlless of the uaprices of fashion; has tried bults of both Bates and Booth sorts, but thomght they did his herd harm rather than goor, and so discarled first one and then the other. The bull that, in his opinion, has been most productive of good results in his herl-the gleatest short-horn bull, in his judgment, that has existed within the past fifty years-was Champion of England, a bull bred by himself. He used this bull on his herd about ten years. Among the sons of the old bull he regards Roan Gamntlet as the best-but little, if any, inferior as a getter to his illustrious sire. He has now about 120 females in his herd, nearly half of the number being red, the balance red-and-white and roan, with a few all white. His cattle were not in high condition when I saw them; they were ruming ont on pasture. and had not been in stable, nor had they seren any other feed than garass since last spring. I was particularty inpressed with the evirlences of early maturity in this herrl; indeed I have nowhere else seen such perfectly developerl cons, anong 
yearlings and two-year-ohls, as at Sittrton; and it is here I think that the chief excellence of Mr. Cruickshank's breeding lies. This feature has given character to the short-horns of Aberdecushire, and so unisersally is it recognized, that even the hreeders of the Aberdeen-Angus eattle of that region all concerle, so far as I heard an expression of opinion, that up to two years old no breed will show such a gain as the short-horn. Mr. C. says his aim has been to probuce a first chass beef animal at the earliest possible age; and in sclecting is breeding bulls, he say's: "The only questions have been, is he a good short-horn? and, Will he uirk well with my herd?"

I have scen much of the Angus-A berdeen eattle on their native heathor: the pastures of the common firmers of A berdeenshire-and I certanis like them well. They are good-looking, smooth, fine-boned, early-matnring cattle wherever you see them. The Ericas (a fanily of this breed), as bred hy Sir Georme MePherson Grant, pleased me best, on account of their comparative lightness of hone and compact, level, beefy, carcasses. Sir George has either sncereded in fixing a strong family type in these Ericas, or else he has shrewdly retained those that approximate elosely to this type among those bred by him, and has sold the rest. The Prides (another popular A berleen-Angus family) are larger than the Ericas, and certainly have not quite the finish and style of the latter, but, judged by the show-yard trinmphs of this year, they are not a whit behind them in popmlar favor; indeed I am inclined to the opinjon that the show-yard hedgel of this year displays a decided halance to the credit of the Prides. But this may be, to a considerable legree, owing to the absence of the Ballindaloes herd from the Highland show.

I regret exceedingly that I was compelled to forego the pleasure of a visif to IIerefordshire. The "whitr-fices," as the Hereford cattle are oftell called, have gained so firm a footing and have beeome so widely popular in America that I very mueh desired to see them on their native pastures. I had arranged, while at the Royal show, to spend all of the last wees of my stay in England among the Hereford breeders, tim. ing my visit there, by special invitation, witl reference to an immortant gathering of Hereford breeders that was to take place at that time, but at the last moment I was compelled by urgent business demands to semd my regrets to Hereford and turn myse f homeward, without the coveted visit to llerefordshire, als well as to many other places that I had hoped to see before my return. What I have seen of this very populare hreed, howerer, has why contirmed my previons farorable impression of them as graring attle, But must I be prermitted to say of them, as I have alrearly sald of the slowt-horns, that judging by what 1 have

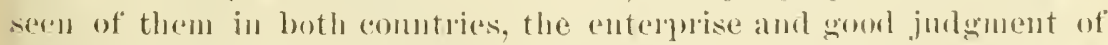
Ameriean buyers have ahearly transferred the crean of the breed to the United States 


\section{ENGLISII AND SCOTYII DRAFT HORSES.}

Another very prominent feature of the English and Scotch show-yards was the cart or claft hol-es, the Clylestales taking the lead in Seotland and the shire horses in England. So much crossing and mingling of bloorl has been practiced by the horse breeders of these two countries that it is rably very difficult to tell where the one leares off and the other begins. In fact, I have never yet been able to find a horseman whose eye was critical enongh to enable him to say positively whether a given animal belonged to the one or the other breal, mnless he kuew beforehand who the animal belongerl to, or where it came from. But as each breed now has its own sturbook it is not unlikely that a greater distinction than is now apparent may gow up in the near future. Judging by what appeared to be the prevaling type of the two breeds, as I saw them, I, should say, if there is any difference in them, that the shire horse was relatively better and stronger in the heart, back, and flank, than his Scotch rival; but, as before remarked, the most critical horse. man would be puzzled to give a good reason why they might not be classed as one and the same breed. They are certainly most excellent horses, and for heary draft it is loubtful if their superiors can be found in auy eountry. Large numbers of them are now ammally being taken to the United States, the honors being abont expally divided between them and the Percheron horses of France. The Clydesdale and the Shire lorses have each had a stud-book for some 5 or 6 years past, and the effect has doubtless been to canse greater attention to be pain to genealugy than was possible nurler the former orler of things; and Amencan importers now hare a mmel more reliable gnaranty of purity of blood than they could possibly have withont these published records. With the publication of the Percheron stud-book, to which I have before alluderl, it may now be said that our American importers have a stmal or herd book to rely mpon for every loreed of horses and cattle that is brought to our comtry, whether from Great Britain or the Continent.

DANGERS FROM INFECTIOUS DISEASES.-SUGGESTIONS AFFECTING OUR EXPORTS OF LIVE CATILE.

In conclusion permit me to say that I am aware of the fact that I have only imperfectly covered the suljects to which my attention was directed by you in my appointment. The time which I was able to give to each branch of the subjeet was neessarily brief; aml some of them I have been compelled to forego almost entirely. I cannot elose, howerer, without again calling attention to the very general prevalence of footand-mouth disease among the mattle of Great Britain, and the grat dauger which exists of the transportation of this pest to our own herels and flocks, through the frequent importations that ale now being marle from that eomnty. 'The system of quarantine now being mantained by our 
Govermment agaimst all imported cattle affurds very good security a gai st infection, throngh the bovine species; bnt sheep, swine, and goats, are eqnilly susceptible to this disease, and are quite as likely to bring it to our shores as are the cattle. Unfortunately there is no lat anthorizing a quarantine of any imported animals other than cattle, and herein lies our greatest present danger. It is to be hoperl that Congress may be indncer at a very early period in its next session, to confer the necessary anthority for enforcing quarantine a gainst sheep, soats, and swine, as well as eattle from all foreign countries, so that our flocks and herds may be effectually guarderl against this the most infections of all animal plagues.

I deem it important also to call attention to the fact that the estab. lishment of a rigid system of inspection of all live cattle cxported from this country and a strict supervision of the ships ased for the purpose of carrying the cattle from our ports, to the end that none but healthy cattle shall be placed on board and that the facilities for promoting the health and comfort of the animals dnring the voyage shall be ample, is of the highest possible importance in its bearing on the future of $\mathrm{om}^{2}$ export trate with Great Britain. In a conrersation between Professor Brown, the chief veterinary adriser of the British priry enneil, and uyself npon this point; he dwelt with especial emplatsis mpon the importance of attention to these matters on the part of onr Government. Americans as a class are very jealons of govermiental interference with trade and commerce, and cattle shippers especially are opposed to any regulations that shall interfere in the least with their present freedom of action. But the interests of the farmers of the United States, the men who raise the cattle for export, are laramonnt to those of the few who are engaged in the export trade. And no consideration of a rery slight reduction in the per cent. of profit which these dealers may realize should be allowed to stand in the way of the adoption of regulations whieh are absolutely essential to the permanence of the traflic.

Respectfully submitted.

Chicago, October :30, 18S:.

J. II. SANDERS.

IEPORT OF DR. RCSH SHIPIET HITIEKOPER.

SrR: Twenty years ago an International Cattle Slow was held at Hamburg, Germany. This exhibition attrated a great deal of interest; it proved a finducial suceess to the eitizens who guandered the cost; it bromght valuable agrienltual prodnets and animals fiom Eugland France, and other comntries, and it was encombaged by mumerous exhibits and an active eommittee fiom the Uniter States. The effects of this exhibition in North Germany were lasting. Faluable brealing animals were bought from the foreign exhibitors, and the muineroms German farmers who attended saw and appreciated the improved 
methods of tilling the soil, breeding, caring for and feeding their animals, and economizing the products. Some of the committee of the exhibjfion of 1863 were still taking an active interest in agricultural matters when the present Hamburg Cattle Show was proposed, and they found a prompt support in offering to the people another "concons" to show the arlvance which had been made in the two decarles. In the exhibition of $18 \mathrm{~s} 3$ but tiew of the foreign comntries lent the support whieh such an mulertaking deserved, and the exhibits were confined almost entirely to Germany, with her closely related neighbors of Holland, Denmark, and the Austro-Hungarian Empire.

The exhibition was opened on the 31 of July, 1883. The builnings were well arranged and every accommodation for the animals was prorided, the rletails of which will be fomd in the accompanying eatalogue.

Thr' exhibits were divided into nine sections, riz:

1. Horses.

2. Horned cattle.

3. Sheep.

4. Swine.

5. Bees and the apparatus connected with their eare.

i. Fish.

7. Fowl.

8. Stalls, buildings, agricultural implements, \&e.

9. Seientific apparatus and methods of teaching all matters pertaining to agrienlture.

\section{SECTION I.-HORSES.}

Division 4.-Classes 1 to 4 were componsed of thoroughbreds, which presented no partienlar interest. Among the stallions one of the best was an American, "Imagination," born 1874, by Longfellow ont of a Lexington mare.

Classes 5 to 6 contained several exeellent Arabs, which have been of great use in Germany, as in France and elsewhere, in improving the local breeds of horses before crossing them with the thoronghbreds.

Jivision Th.-Classes 7 to 12 called for riding, hnuting, and cavalry horses and manes, of three years and over, raised in Germany, AnstroHungary, Denmark. Swerlen, and Norway. These elasses were largely filled with good animals, especially from Austria, as the horses from this comntry showed much more blockl.

Dirision D.-Classes 1:3-15 were for the same class of animals fiom any endutry. England only of foreign comntries was represented with sereral wool animals from the Stamil Stud Compung, but the first prize Was a warled to the representative of the Royal P'mssian stur. In this division American horses conld have been shown with special profit. Equally good horses might have been sent from New York State and the whole Aleghang ridge, with an advantage of price on their side, even with the cost of transpontation and risk arlded. 
Division E.-Foals of the prerions classes.

Division F.-Heary carriage horses.-This dirision was complete in stallions, mares and colts, and presented, perhaps, one of the richest shows among the horses. From the many stmis representer the most nsuful for the United States womld mobably be the amimals of the Grand Duke of Oldenburg. These are magnificent beasts of full 16 hands, short compled, time, strong neck, legs well placed (d'uplomb), and gaod feet. The developing horses are of sufticient size for the farmer to mse economically while he is prepuring animals, which, if they are at fant as valuable carriage horses, ale still strong enongh to sell or keep for haril rork.

Division $G$ contained, in ardition to the preceding, a few good Englislı horses.

Jivision H.-Strong horses for agrienttural and industrial work. The Clyolestales wre entirely wanting. Sereral fine representatives of the Shire horse were shown, the largest weighing some 1,900 pommls, but all except a stylish mare were sleepy and had mufortmately flar fuet.

Classes 31 to 34 falled to obtain any representation from the snperb French, Belginm, and Norische or P'inzgauer races. 'The first two are so well known in the United States that it is useless to speak of them, but the Pinzganer should be better kuown. Originating (historically) in the Pinzganer and Styria these immense active horses have ever since been kept in all their jurity. Thes mere described and drawn from by the ancient Romans, and in the Middle Ages they furmished the mounts of most of the German and North Italian warriors. 'Their full blood has always exercised a strong influence npon the comtries directly surromding the South of Austria, but the limited territory in which they are produced in their purity has been a barrier to their wider dissemination, and of late years their export has becu almost entirely linited to Munich and Viemna. Fine examples of this race can be met with in these two eities, but they are best seen on the styrian Momitinis, where they usually work with a load on the back and go over the lieights, on a narrow foot wath, as surely as a mule, with the arlvantage of greater spees aud the strength for a greater load. As our agrienlturists are now bringing so many of the large European holses to Antericat, and the price of Euglish and French horses have advancerl so much in the last few gears, it womlel be well for them to pay attention to thesoanimals, which ran be procmed for less money. From Demuali were shown some fine horses with a goorl deal of blood and wejghing fiom 1,30 to to 1,500 pombls.

A few Aremeners were exhibitrel in hatress, but none of the pure type which was so renowned in the old posting service, and has

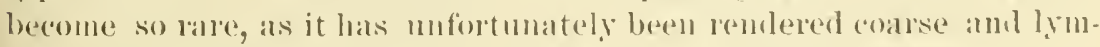
phatic by cossing with the lange Flomisle and English animals. 


\section{SECTION B.-PONIES.}

Among the ponies no type or race was expecially exemplifiel, except from Norway. The Scandinarian horses are magnificent heavy ponies of 13 to 14 hands, with short backs well morieled, short, strong set legs, good feet, and an intelligent head with a large open eye.

These animals keep in good comclition with a small quantity of poor food, and are adapted to momntain work. They walk very fast and trot woulerfully. They are good workers in haruess, though ther are usnally used under saddle, and carry the big Norwegian peasant as easily as they would a child. They could be profitubly raised in any of the mountainous districts of America, am would make an excellent mount for the cavaly in the West. Their price is rery low. and the cost of transporting then wonkl be less than for large horses. There Was no exhibit of mules and asses.

\section{Section II.-Cattele.}

The show of eattle was the great fature of the exhibition, although it was almost eonfined to the series of eoast cattle. The present divis. ion of these cattle descrves special attention, as the American nomen. clature has been decieledly arbitrary.

It is only within recent date that the proprietors and agriculturists have become comrinced of the necessity of establishing definite lines between the cattle of each locality, where the animals showed some particular merit; and in order to retain the purity of their herds, which was threatened by the increased ficilities of commerce, ther have found the solution of their problem in the establishment of "helrl books."

The catalogne "alled for a first division into the Marschschlage, or those families of animals coming from the lower comutry and into the Geestschlage, or those coming from the higher and more inland comntries. In the Marschschlage series are the East Frisians, Oldeniurgers, Hollanders, Wilstemarsch, and Breitenburgers: in the second series there are families from the first three of the preceding, the Angelers and the Jutlanders. Of these gronps the Wilstermarsch, Breitenburgers, Angelers, and Intlanders are in general terms "Holstein" cattle, and, except the last, have nothing whatever in common with the West Frisian, Ohlenburgers, and Hollanders, which are the socalled IIolstein cattle in America. The generic name of "Holstein" as applied to any race of cattle does not exist in North Gelmany or the Netherlands. 'The Wilstermarseh and Breitenhurgers present no special interest for the American, as they are simply two goorl breals of cattle which ale fair milkers, and owe their milk qualities to the crossing of short-horms on the large native latee, a bony anl coarser cattle. The Juthanders, Olilenburgers, and a part of the Frisians, especially that part of the latter to the east, have also felt the influence of the shorthorns to a very great extent, but the native breeds were generally 
strong enough to retain their color and their milking qualities. The continental preference, which formerly bonght only white short-horns, aided probably in the retention of the white and black color. While some of the families of those breeds are almost typical short-holns in form, a large number approach the Dutch and Frisian so closely that mistakes between them would be excusable. Ifowever, the lower thank, the larger hip, the finer development of the thorax, the shonlder-gutter, the fine heat, and the other milk characteristies distingnish the families from Holland and Friesland. At present the most of these cattle, if of any value, are registered in the bord books. While the name of a herd does not alfect its valne, it would be better that the proper name should be given in the establishment of foreigu herds in the United States. The two groups of these cattle, with their prerlominating qualities of milk or beef, should be better understood and separated at the ontset.

The Angeler cattle are a beantiful race of milkers, with most of the eharacteristics of the Channel Island cattle, including the riehness of the fatty parts of the milk, but they have their beef qualities better developerl. They are of a miform red color, with black muzales and legs.

The Swiss cattle were scarcely represented by a few Simmenthalers and Allganers, while the other celebrated breeds were absent. The few examples of the beautifnl Swiss cattle in the United States are too little known. Their special adaptation to high regions, their great milking qualities and economical transposition into beet, wonld make them a most profitable animal in the high eheese-prodncing comties of New York, Pennsylrania, and elsewhere.

The Anstrian and Russian eattle were wanting. A fer Rhenish (.Tnra) and Seandinavian cattle presented only a zoötechnical interest, and the great milk race of Flanders and the North of France, and the Salers and other great work and beef rattle, were entirely absent. The short-horus and Ayrshires were shown both from German and English lierds that wonld readily have yielded the prizes to American representatives had these been sent. A test of the quantitative and qualitative milk production of the varions races was carried on dluring the exhibition, of which an analysis is subjoined.

\section{SEC'THOX III,-SHEEI.}

This section was only notalle for the magnificent specimens of the Rambonillet merinos, which are owned in quantities in many parts of Germany.

\section{Section IV.-SWLT:}

The exposition of hogs contained many the Vo:kshires and berkshires, both from German and trom English proprietors; lont the tinest show was in Poland Chinas, which were almost all imported from the 
State of Ohio, and they attracted a great deal of attention and favorable comment.

\section{SECTION V.-BEES.}

In this division was a complete collection of the breeds of bees, with all the apparatus connected with their raising and the utilization of the honey and wax.

\section{Seution Vl.-Fish and Fisil Breeding.}

Besides a show of the implements comnected with fishing, a few models of fish-breeding and artiticially dereloped fish were shown, among which was the fine collection of earp from the farms of Adolph Gaschat Kaniow, in Galizia. 'This exhibit requires, however, no details after the larger ones which have recently been held.

\section{SECTION VII.-FOWLS.}

As no foreign exhibit was marle, the collection of fowls ean best be criticised as being eomposed of German birds. The representation of pigeons was wonderful, and the eatalogue will probably be of interest to breeder's of these semi luxurions but usefnl birds.

\section{Section VIII.-Staibling, Machines, and Inplements.}

The moderate exhibit of wagons, agrienltural implements, se., was almost entirely from the hands of German and English workmen, and certainly wonld have been much more valuable if it had had the addition of the standard American machines. The few machines which were modeled from American patents were of old patterns.

\section{SECTION IX:-SCIENTIFIC INVESTIGATION ANI PRODUCTS IN IREF. ERENCE TO ANHAL INDUSTRS.}

This section contained an exhibit which would possibly have been one of the least mnderstood at first sight by many Amerieans, bnt when once stndied would have been thoroughly alpreciated and wonld bave proved of great nsefulness in showing the extent to which Eiropean governments interest thenselves in aiding the agriculturist, by furnishing him with properly educated men to assist him in the selection and care of his land and animals; and to eare for his animals and protect them when they are sick or are threatened with the epizooties. The first collection was a well selected museum of the bookn, specimens, ap. faratus, and zootedhic prorlucts from the Royal Prussian a gricultural High School in Berlin.

The second was a similar collection from the Saxon Agrienltumal School. This inchuder a complete display of wool from all the ovine races and treerls, with an appendix giving a detailed report of the feeding and producing eost of the animal which furnished the samples. 
From the veterinary department the exhibits contained a collection of skulls of all the domestie animals, anatomical and pathological specimens, injected preparations, parasites aml wax molels of the same, apparatus eomnected with the use and care of the domestic animal. \&c. An interesting selection from the libuar showed the gratual derelop. ment of literatme pertaining to agriculture.

Tho veterinary selool and school for hacksmiths, of Saxony, were also represented by complete examples of their methuds of teaching and the means employed in their puatical demonstrations.

Instrument maker's showed microscopes, trichina microseopes, thermometers designed for stable and daip use, lactometers, alplabatus for qualitative milk analysis, ste.

Agricultural and reterinary literature was completely moresented, and contained many msefinl morlels of records for dairy and fiurm use, and an extensive eollection of all existing sturl and hord hooks. Silk and bee colture was show by a full series of the natmal iusects and their produets, and a duplicate spries of the same, enlanged in wax and papier mathe. There were also competitive prizes for essalys and desigus for stables and farm buildings, to be adapted to flat or hilly com tries; essays on the hygienic and other arrangements of farm buildings, manure, Se.; on the removal of animals from burning buildiugs; on animal prounction (breediug), Ec.

Thronghout the entire exhibition the most rigid measures were observerl in regarl to the sanitary police. A sufficient corps of reterinarians was constantly on duty, under the dinection of. Professor Johne. All animals before being admitted to the show-gromuls were patsserl through an inspection yan and earefully examined. A constant wateh was continned, and notwithstanding the inmense number of animals collected from all of Central Europe and transported thromgh the great centers of animal commeree on railway wagons and by other means of publie conveyance no cases of contagions disease were dotected, and none dereloped anring the ten days on the gromnds. This fortminate result is justly to be attributed to the present complete and thorough precautions talken by the German Govermment for the protection of its animals. Each district is provided with an ofheial reterinary smrgeon, to whom all cases of contagions disease must be reported, and this oflieial is empowered with the proper authority for enforeing the law. Each department has a superior veterinarian, to whom the district veterinarians report, and he is invested with greater powers. 11 the proprietors make an immediate report of any suspected ease of contagions discase on their farms, they are liborally indemmilicel in adse of loss, alter the oni. cial iurestigation, which is one of the official acts in (irmany, and executed promptly. If, howerer, al prompictor attempts to conceal any case of eontagions disatse in his animals, he not only forteits an! right to indemuity, but is punisherl. A retrimary surgeon who atfents such cases and does not report them is even more severely punished. This 
law of liberal indemnity and punishment combined has proven most satisfactory ; it leads to the prompt declaration of any outbreak of rlisease, and allows the Government to exert active measmes at the outset. In aldition to these rigid measures, the precantions taken on all means of transport for their proper disinfection are thorongh, not only in the law but in practice. Railway cars which have served for the transport of any of the domestic animals are immediately disinfected. The large railroad yarks are provicled with special tracks at the side of a building containing boiler's for an unlimited supply of hot water. After the car is swept it is washed from a hose with water as hot as can be handled; after another sweeping the interior of the car is washed with water heated to $70 \circ \mathrm{C}$., witl soda added. This most satisfictory means of disinfection is carried out at an expense of only two marlis (50 cents) a ear, and is paid by adrling that amount to the freight bill.

The slanghter of all contaminated animals, whether exeenter as a measure of sanitary police or for foorl, is done under the supervision of a responsible veterinary inspector, and so all attempts to sade the law for a little additional gain are aroided.

It is greatly to be regretted that Americans cond not have been enabled to exhibit their agricultural products, especially animals, at Hamburg, that they might have shown the great resonrees of the United States, and, what is more important, the ficeility with which these resomrees can be placed at the disposal of the European market, as this is as yet little appreciated ontside of England. The cavalry horse and the beef cattle are now the two articles which offer a favorable and profitable field for export, but it will be but a very few years before the heary draft holse can be arlded to the list. For the establishment of an active and paying commeree, however, the European Govermments will demand a greater security and guarutee of the liealth of the ani. mals shipped to them than now exists. The necessary enconragement for the edncation of a sufficient number of men to carry out the State laws and the work of the Crovermment in regard to the diseases of om animals will aicl very materially not ouly in onr own protection, but in the alvancement of onr cattle trade with Europe.

Very respectfully,

$$
\begin{aligned}
& \text { RUSH SHIPPEN HUIDEKOPER, M. D., } \\
& \text { Honorary Commissioner. }
\end{aligned}
$$

Hon. George B. Loring,

Commissioner of Ayriculture. 


\section{OUTBREAK OF SOLTHERI CATTLE FEV ER IN KANSAS.}

REPORT OF M. L. TITHBOHER, Г. S.

Holl. (iEORGE B. LORING,

Commissioner of Agriculture:

SIr: In obedience to your telegram, dated at Washington, October 9, 18S3, requesting me to proceed at once to Harper, Kans., there to inrestigate an outbreak of disease among cattle, I forthwith warle the necessary preparations and left on the + oclock train the same dar, arring at Harper on the morning of the 12th. My instructions not having yet anived, I remained in town and marke inquiries of different indivirnals in relation to the cattle disease. I soon became orerwhelmed with reports of the magnitnde of the ontbreak and extent of losses throughout Harper and Barbour Comities. I receired many reports from different individuals, stating that such and such persons hanl cat. tle dying daily at that date. After deliberating over the matter, I came to the conchision that I cond do no hetter than to remain in town orer Saturday and have some person mlo was well arquainted with the people to point ont to me the men who were then losing cattle, as many of them would probably be in town on a Satmrday. Here I met with disappointment. I met a number of men of whom it was sais that they were losing cattle daily, but on making a direst inquiry they alunost invariably saicl: "No; they were not losing any now," but manerl some other person who was. I seon fomd ont that the hetter plan woukl be to go directly into those sections where the greatest mortality had prevailed, and there emblearor to find suitable subjects for axamination. Therefore, on Sumbly morning, the 14th, I made alrangements with Martin Cochlan, of Harper, who is well alequanted with that conntry, to take me out into barlour Comby. We left Harper about s a. m. The first place we stopped was at D)r. Joseph Brockway's, on the Nine Cottomwoorls Creek, 19 miles sonthwest of Harper. ju Harper Comnty. He male the following statement: That he moverl lis cattle, numbering 75 hearl, from his place of resiclenere, taling them northwest 2 miles, on or about the 1st day of 11 aly ; that on or about the 10th day of .July his cattle began to die, and 10 head dient within eighteen day's time, neally all of them being two and these rasur

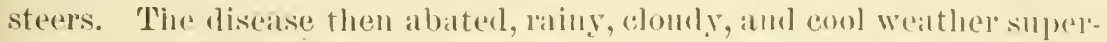
vening. On the 1st of Angust 4 or 5 were still sick, but making a slow lecovery. On the 12th of September the diseaso broke ont again. and 
13 heal more died in rapid snccession. He then fenced in a pasture for his cattle, placed them therrin, and has not lost any since.

The Boyl herl of cattle (suspecter-of which more hereafter) were driven on their way west from Harpor into Barbonr Comnty, along a freight road which crosses his lange, mpon which road also oxen attached to wagons and small herds of cattle were driven back and forth all stm. mer, and cattle passed in the care of herlers every moning.

Mr. Is. Walden, 2u miles north of Dr. Brockway's, lost all the cattle he had-7 heal. They died in the month of September. His cattlo have been near the Boyd trail, and also near the Anderson trail (auother suspected herd).

The nest place I visited was William A. Wool's, on the line of Halper and Barbon Counties. He male the following statement:

Mr. Boyrl, in the month of April, crosserl my range with his eattle: I drove my cattle back, 13 in number, to allow him to pass. A few days later a seeoud herd, umbering 900, were driven throngh on the same trail. I again turnesl my cattle back to allow this second heral to pass: they stopped on my range to graze for two hours; they then went west to the Little sandy, where they turned and went northwest. These cattle were loug-horns. I picketed 1 cow and 2 calves on the trail of these two lerdis. The cow was taken sick on the 1nt of October, and died on the 12th. All of my cattle crossed this trail daily; 5 of them were taken sick, but only the 1 diet.

I went ont on the range to see the one that died on the 12th (two days ago). I found her in a fair state of preservation, and leciled to make a post-mortem examination. I removed the wall of the chest and abdomen of the right side. Found the hungs in a nearly normal conclition; the perieardium contained four ounces of bloody colored serum; the heart was extensively eechymoserl on both the external and internal surfaces, the endorarlinm being somewhat softened and pal r than normal; no heart elots were present. The liver weighed 13 poumbs, the enlargement being due to hyperamia ; gall bladder contained 10 ounces of a dark olive colored bile, of a thicker consisteney than normal; splecen weighed $4 \frac{1}{2}$ pomuds; contents, a rlark pmrple semi-fluid julp; a general disintregration harl taken place; urine bladder empty ; kidneys normal in eolor and size. The fourth stomach presented extensive congestion of the mucous membrane, especially towards the cardiac end, and many small erosions exposing the vascular membrane were risible near the pyloric end; redness and congestion, accompanied more or less by thickening of the mucons membrane of the small intestines, was manifest npon close inspection; interstitial extravasations of blood between the membranes of the eacum and also of the rectum were fouml, and the feces conted with mucus mixerl with bloor. The nterus contained a male calf six and a half months old ; the liver of the fetus weighed $1 \frac{1}{2}$ pounds; sipleen ayparently normal; perienrlium contained 2 omnces of rery dark-colored bloody fluil, also an abmormal amount of bloody colored thid was discovered in the thoracic cavity.

f examined a white cow, six years of age, which was supposed to be recovering; she harl been sick for two weeks; pulse 112, temperature 
$106 \circ \mathrm{F}$. She was lying down. I matle her get up; her gait appleared rery stiff and painful, and as she slowly moved a way she roiled hoodycolored urine. She eats and ruminates. I examined another cow which hald bes'n sick for ten days; pulse 6 it, temperature $104^{\circ} \mathrm{F}$; rery thin in flesh; eats and ruminates. October 24 saw 241 . Wood in town; he stated that both the cows which I examined were alive and gaining in strength and health.

From Mr. Wood's place we proceeded to Mr. Jesse Boydls, in Jiarbour Conntr. Here we remained orer night. During the evening and the following inorning I received the following information from Mr. Bord and Mr. Cochran, viz: Mr. Martin Cochran, of Harper, spent nealy all wintel' at Judsonia, on Red River, White Comnty, Arliansals. Mr. Cochran hought 342 head of attle in this comnty, most of them being in a rery pon condition. attributed to cold weather and insuficient feed. One hundred of this number were bonght 12 miles north of searey. Mr. Cochran collected 242 hearl and drove them to Judsonia on or abont the 24 th day of Mareh. Mr. Jesse Boyd came to White Comitr, Arkansals, about the 1st day of February. He bonght edes head of eattle in this conntr, bronght them to Jndsonia, and there he and Mr. Cochran poold their attle, the combined herd then mumbering 470 heall. They drove them in miles to Conway, a railroad station, adding at Searey 100 head more (those which Mr. Cochran bonght 12 miles north of Searcy). They shipped at Conway, on the 1st day of A pril, the whole number of the combined herd $(500)$ and muloaded at Harper, Harper Connty, Kan. sas, on the 5 th. About 50 of them dien on the cars before they arrived at Harper; got down in the cars and were trampled torleatls. At Harper these cattle (520) were kept for three or four days, ranging north of the railroal track and traveling over a space of 2 miles, the range extenting northeasi to Sisson's Grove and to a small creek where they harl to go to water. At night they were yarded at the stock-yards.

Twenty of them being disabled were watered in the yards and fed on corn, eane, and millet-hay for a week or longer. On the 9th of April $11 \mathrm{r}$. Boyl drove 500 heal of them from the stock-yards, in a sonthwestern course, to the enge of town, passed I. J. Campbell's field, thence west 1 mile, then sonthwest 1 mile, west again 8 miles, crossing L. M. Pratt's range one-half mile north of $;$ is residence, then came on the road at the school-house on Bluff Creek, thence along the main roal as far as Richard Botkin's place, beyond whose place they encamperl one night. From there they left the roal to the south of the trail, but came back to the roat again at WT. E. Kline's. From Kline's they passed in a sonthwesteriy direction to the Nine Cottonwoods Creek, cist of Mr. Garduer's; here they stopped the second night. From this place they passed due west until they reached liogd's range, on the Little Sandy Creek, 4 miles across the Harper and Barbomr Comnty line. From Boyt's range 10: head of these cattle drifted away and were gathered in again in the romul-11, in Jume and July. They went south to the line of the 
Indian Territory, west 12 miles to Medicine liver, east 2 miles to the linits of the range. On the 10th day of July several of these cattle were noticed to be sick, and in a week 8 were dead. Mr. Boyd, at the same time that he held this herd of cattle, also had 140 head of Arkansas cattle which he bronght in last year, and were wintered by lim; he had 20 head of natives besides, which were also wintered by him. At the time that the recently imported Arkansas cattle began to die, two of the matives also became sick and died, both the latter being yearling heifer's. All of these three different lots of cattle were herded on the same range and drank out of the same creek mntil the latter pait of July, losing $s$ of the suspecterl cattle, two of the natives, and none of the wintered Arkansas cattle.

The 20 heal of erippled eattle which Mr. Boyd left at Harper were driven into I. J. Camphell's pasture field, located at the western edge of town, on or abont the 18 th day of A pril; there they intermingled with 150) head of native eattle belonging to Mr. Campbell. They remained in Camplecll's pasture for a week, then they were driven ont over the trail of the previons lot of eattle, as far as L. II. Pratt's, where they remained over night grazing with some of Pratt's cattle. From Pratt's they went in al direet course to Boydl's range.

On the E6th diy of July, Mr. Jesse Boyd was arrested and bronght to trial for bringing into the State of Kansas, contrary to law, wild and undomesticated cattle, which had spread a disease amoug the natives known as Texas fever. Four hundred and thirty head of the Boyd eattle were srized and prarantined by the sheriff of Barbour County, were placed into Mr. Cool's pasture field, 2 miles sonth of Mr. Boyd's honse, and there were kept nuder surveillance by the sheriff's assistants. The witnesses on part of the State were: Willian Garrison, Mr. Hufacker, David Clough, W. W. Cook, Albert Cook, M. B. Noore, George M. Gardner, J. H. Warren, A. B. Ramnals, W. E. Mattox, all men holding eatthe elose to Mr. Boyd. Mr. Boyd was fined by the court in the sum of $\$ 300$, and sentenced to imprisonment in the connty jail for a term of one month. Ile took an appeal to the higher cont. His second trial has not yet taken place.

On the 15th of October, I went to see Mr. Jackson, who has charge of the quarantiued cattle. He reported six deaths anong them since the egth of July. On the 1Sth I was again at Mr. Boyd's place. I then tested the temperature of 4 head of his wintered cattle which registered as follows, $101.8^{\circ}, 100 \circ, 101.4^{\circ}$, and $100.9 \circ$ Falurenheit. I proceeded to the priantined herd and tested the temperature of 20 heal among them. We hove them into a branding pen. They registered as follows: One four-year old cow, 102.10; two-year old heifere, 103.7०; three-year old steer, $101.6^{\circ}$; two-yeal old steer, $103.4^{\circ}$; yearling heifer, 102.60; theeyear old heifer, $103.7^{\circ}$; pulse, 66 ; two-year oh heifer, $101.5^{\circ}$; two-year old heifer, 102.90 ; yearling heifer, 1112.20 ; fonl' year old cow with ealt at her sirle, 102.90; three-i ean-old heifer (scomring), 10ะ.40; three-year 
old steer, 1020 ; six-year old eow, 102.8०; two-year old steer, $102.4^{\circ}$; twoyear old steer, $10^{2} . \mathrm{S}^{\circ}$; three-year old heiter, $102.6^{\circ}$; thee year old steer, 102.6०; ten-year old cow, $103.1^{\circ}$; six-year oll eow, 103.2॰ ; wo-months old ealf of the latter, $104.9^{\circ}$; one lame cow, a strily, ox yoke braur, which has becon lying around with these cattle since the July roumd-np, indicated a temperature of $103.7^{\circ} \mathrm{F}$.

These eattle did not appear wild and mulomesticated, and stood very kindly under my examination. Here I wish to mention a worl abont the July romnd-n]). In the latter part of Jume or the first of .July abont 2,000 heal of eattle were bronght to and centered npon Boyl's lange in the round-up; nearly all of the neighborsof Mr. Boyl, and many of hers, came to this place aud cut out their own cattle. Some of the strange cattle remained several days on the Boyll range. If any cattle were in this herd that carried the germs of the Sonthern antle ferer, it ficllows that all the eattle in this romnl-mp were expally exposed. or nearly so. In this herd of $ّ, 000$ were abont 10 head of stray cattle, for which no owners appeared, and it is not snown to-day where they belong, nor from where they originalls came. Again, Mr. R. B. McGee, secretary of the Cedar Hills and Sand Creek Pool, gave me the names of the membership of said pool, as follows: MeGee and Lorett, Jesse Boyd, M. B. Moore, Willian Garrison, Mr. Hufackel, Ml. Beals, I)avid Clongh, Perry Clough, John MeKeever, John Elmore, IInk, Moore, Muiger Brothers, J. H. Warren, E. C. Davis, Mr. Holmes, M. MeGuire, and Mr. Cross. All, or nearly all of these parties, had a greater or less number of eattle in this pool during the winter or spring, where they remained until about the 1 st of July. If any of the gromnd orer which these eattle passed was eapable of imparting the Southern enttle fever, or, if auy eattle were in this herd earying the germs of this disease and diseharging thesu, then all of the cattle in the herd were exponed to such gromuls or eattle. On Mouday, Octoher 15, Mr. Boyd and Mr. Cochran aceompanicel me to Mr. John Elmore's ranch, loeated on range 15 and 16, T. 33, R. $10 \mathrm{~W}$., Barbour Connty, or four miles southwest of Boyd's lange. Mr. Elmore stated that he held ou his range 210 leat of grown eattle abd 40 calves, all wintered cattle exeept 38 heall, which were bromght in from Atehison County, Mssomri, in thespring. Mr. Elmores cattle began to die on the 1st day of July; 13 head died in two weeles; the disease then checked up, but broke out again about the 1 st of September. Dming this month 143 died, including 3 or 4 spring andres. Out of the 38 head honght from Missond, 15 died. He states that he does not know of his attle being exposed to any thromgh cattle, or other

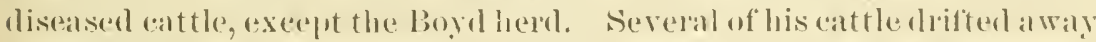
in the spring and were gathered in the romul-11p; one of them wats gathered in the Territory romul-n]) some tifty miles sonth of the line.

Last year Arliansas amd indian cattle wede helel on this range by Munger brothers. Late in the fall Mr. Elmole bromght 3ti2 isearl of cattle from Sortheastern Kansas and Sorthwestero Missomi and plated 
them on this range; in two weeks thereafter 6 of them dipd with Sonthern cattle ferrer. (See Dr. Detmer's repont of last year's investigation -Moore and Elmore.) Dmring the winter they lost 10S head, including the 6 just mentioned, ont of the number.

From Elmore's we drove to Cook's and Ramnal's, 4 miles sonthwest of the former, located on the restern side of the Cedar Hills. We found no sick mimals among this lield; only a small boy was with them, and he dirl not know how many they had lost.

I saw Wr. W. Gook at Medicine Lorlge on the 27th, when he gave me the history of his losses. He owns a 600 -acre pastmre 2 miles south of Boyd's resirlence, which was an open range mutil the 12 th of May, when he fencerl it in with barberl wire. He bonght fiom Mr. Perry Clongh 140 head of cattle on the 1st day of April. They were wintered on this range. In the month of May i bulls were added, and on the 10th of Jnne 217 head of cattle were bronght from Kingman Connty. These 217 head were bonglit from three different parties-IVilliams, Lowry, and Fowler. He llrove them in two lots. The first lot, composed of 11 hear, were driven south along sand Creek, comaled one night in Mr. Carlysle's corral, 12 miles northeast of Merlieine Lodge, and then brought on the range.

The secomd lot, 176 head, were bronght from the Chikaskia River, driven south throngh Mr. Wisner's range, and on sonth, crossing Mr. Boyd's range on their way to Cook's pasture, arriving at their point of destina. tion on the 12th of Jume. His cattle began to die on the 9 th of July; on the 14 th, 9 weredear and 7 slck. The cattle were then mored sonth of Ramnal's range, south and west of the Ceclar Hills; the 7 sick ones were allowed to remain in the pasture, 5 of which died and 2 recovered. On the 2!th of Angust his eattle began to die on the range, and he lost in all 75 out of 331 head; 10 or 15 that were sick recoveren. Change of pastme was not benefieial in this case. Mr. Albert Cook, who took care of W. W. Cook's eattle, testified at the Boyd trial that some of their cattle got ont of the pasture and others got into-it, by breaking dow the wires. This must have ocenred between the 12th of May and the 14th of Inly. Mr. Ramnal's, north of Cook's range, lost 30 ont of 150 heal during the month of September. These were close herled since the 1st of July. Mr. Ramnal's and a part of Mr. Cook's eattle were exposed to the Boyd cattle, and also to all other eattle in the comity romul-mp).

From Vlr. Cook's range we went to R. B. MeGee's, on the Little Salty, 'I. 34, R. 10 W. McGee and hovett hold 200 heal of cattle ranging on the east side of the Little Salty, 1 mile north of Mazleton. The first loss in their herd occurred on the 15 th of september; 21 died to date; 8 remain sick, butare recovering. One, a 5-year-old bull, died last night or this morning. I desired to make a post-mortem examination of the hull, to which Mckee realily gave his consent and assistance. We fonnd him lying on the left side; a few drops of bloody water were dis- 
tributed over the surface of his boly. I remored the right fore leg and shonlder, the wall of the chest and ablomen. The animal was not very fat, hut the fat was the color of yellow beeswax, with a slight greenish tint alded to it. I remoreal the spleen, but in doing so I had to use the utmost precaution in handling it so as not to rupture its covering memmane. The organ was of an enormons size, and apparently distended to its utmost capacity, weighing after lemoval is pomnds and moasuring 30 inches in length. I next removed the digestive organs. The contents of the third stomath were slightly hardened; the lining of the fourth stomarli presenter numerous and extensive patches of demuled surface of irregular forms, and many of them having an nker-like aplearance.

There was considerable capillary congestion of the mucous membrane throughout the intestinal canal; a few of the intestinal glands appeared to be enlareed and were changed in color to a grayish black. The liver weighed $24 \frac{1}{2}$ pomnds; its structure was somewhat softened by a fatty degeneration, and impressions of the fingers were left upon it as is common in aedenatous swellings. The gall-bladder contained 32 ounees of bile of normal color, but was reudered more or less riscid and glutinous by the armixture of mucus from the internal surface of the gallblatder; the walls of the gall-blather itself were thickened, caused by tumefaction of the mucous coat. The mine-bladder contained a gallon or more of a brownish red colored mine, specific: gravity 1.00s. The left kidney weighed 42 pounds; was darker in color than normal. The glandular structure of the right kidney was entirely absorberl the pelris and some of the larger lucts had become changed into cysts, containing a clear"amber colored fluid possessing the smell of healthy urine. It presinted eight of these rysts, each one distinet and separate from the other, and all taken togetler formed in bulk about the size of a normal kidney. After the letting ont of the fluid, l had nothing in my hand except a mass of fibrous tissur-there existel not the leust remains of glandulur tissue. The heart weighed s pounds; was enlarged and Habby ; the exterual surface was extensively exchymoser along the auterior and postrior ventricular furrows; internally, the fleshy eolumms were almost of a black color from acchymoses; no heart dots in the carities. The animal seemed almost bloodless, the veins and arteries beingempty and collapsed. $11 \mathrm{r}$. McGee stated that this animal had been lame for the past fifteen months in his light hind leg, and that at times he thought lac coull not well serve at cow on accomnt of weakness or pain in the back. In the latter part of Jume, Mc(Gee saw 250 hear of cattle rossing his range. They were satid to be going into Arizona; they looked like Arkallsas attle.

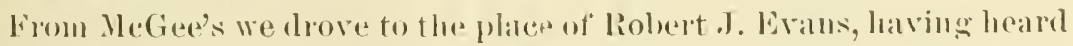
that he had serral sick eaftle. Ho lives about 6 miles east of Kiowa, Batbone Gomty. When we arrived at his place no one was at lome, but wr foumd a dead eow lying ant orer ten rods away from the homse;

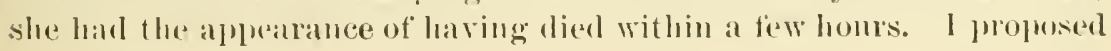


to make a post mortem examination, even if the owner was absent. We fomml her resting upon the stermm, the head thrown back to the right sirle. She was propped up in this way by the nose touching the gromud. Cadaveric rigidity had alrealy set in; drops of blood were dried on the laair along the silles of the neck aud flanks.

We turned her over on the side and I opened her in the msmal way. I found the lower parts of the posterior portion of the lumgs in a state of red hepatization, ann consinlerable serons effusion haul eollected in the thoracic cavity. The endocardinm was havily congested, thickened and liscolored; the fleshy pillars in the rentricles were of a dark purple (o)lor, and the amienlal appentages were extensively echymosed. Weight of liver, 20 pounds. Weight of spleen, 4 poumls. The gallbladdler contained one f'lart of very dark green bile, which was of a gramular appearance.

A serons aml bloody infiltration was discovered surronnding the kidneyss. The urine bladeler contained a rery dark blool-colorenl urine; specifie gravity 1.012; the organ was thickened by capillary congestion of the mucous cont, and a few ecchymosed spots presented themselies. The contents of the thirl stomach were very much drier than nomml, and the folds presentell a eongested and irritater appearance; fourth stomach congested, and numerous small erosions and granular elevations were to be seen on the mncors surface. This animal did not present mueh biliary discoloration of the fat, and the blool was not as thin and watery as is nsual in Sonthern cattle ferer. The nterns eomtained a fetus abont four or fire mouths old; it presented a liver enlarged to three times the normal size; the kidneys intensely congested, and partially disorganized by softening and disintegration; splenn nearly normal in color and size; the pericanlial, thoracic, and abdominal eavities contained considemble blooly colored effinsions of sermm. When I was nearly done with the dissection, Mrs. Evans retnmed, and she told me that the cow harl been sick three dilys. Another cow was sick in the heril; after some lively rmming we succederl in lassoing her; she hat bren sick fonr days; temperatme, $104.5 \circ$; pulse, ! 6 ; nose dry; roly saliva flowing from the month. October 20th met Mr. Evans, who reporter two arlditional deaths, and two more sick. ITe brought 116 head of goon gralle cattle from Allen Connty, Kansas, arriving on his present range with them on the 1Ith of May. Since that time the eattle hare not strayed in any direction 3 miles distant from a central point on the range. The first loss occurred on the :3ril of Oetober, and li have died to date, the 20 th.

IVe next risited Mr. Parsons. He lost some cattle last rear, attrib. nted to the bringing in on his range of Intian or Choetaw cattle by Morton and Tolliver. This year he lost 3 ont of 80 ; they lied in Angust. October 20 th he reports 22 more deaths October 23 al reports 2 heall of the oil-brand cattle, on the same range with his, as being sick. Hink Moore lost 5 out of 7 in hear. Boyl's entle rall with his for several weeks hefore the romud-up in July. 
We went north from Parson's to Thomas Brakey's ranch. He lives on the Medicine River, in Barbonr Connty. 32. miles sonthrest from Harper and:3 miles from Kiowa. We remained with him over night.

He eame from Chase Gomnty, Kansis, lats septenber. with 30') heal of fone high grade estth. In . Jannary they were in gooul condition and thriven well. After ab week's sleet and ribin in Februm they began to sicken and die. During the months of February and Ifarch he lost 110 hearl. Some of them dies in groml eomlition and most of them retanen a good appetite antil death. Tbe majority would tirst show lameness on the left foreleg, wonld then persist in lying down, and many of them lingered along from two to four weeks before they died. He fed all the corn, sorghnm, and millet-hay they could eat. Two of them died in the month of Jay while on grass. On opening them, after death, the fat presented a very yellow appearance. Mr. Rider also hat 400 head of eattleon this same range; he lost 75: they were alfiecter similar to Brakey's.

IIr. Brakey gathered 20 of of his cattle in the romm-nps in June and July. Abont the midlle of September one cow was taken siek; she dienl in a few days. Then other's sickened; some of them lived five or six day's, and others would be fomnd siek in the monning and dead at nom. He took them off the range and turned them into a eane field, but they still continued to die. I Ie lost 1.5 head.

Oetoher 16. risited Harry Matthews, aljoining Mr. Brakey on the north; he has held 36 heal of cattle in his fenced range tor two years. On the bth instant 110 head ownell by Charles Blackstone, of the Eagle Chief Pool, were turned into Mr. Mathews' field. A few days ago a threegear old steer of Blackstone's was fomd sick; he died last niwht.

Post mortem: weight of spleen, 8 pounds; liver, 182 pounds; heart, $5 \frac{1}{2}$ pounds; extensive extrarasations of blood into the walls of the right ventricle; bile thick and grmmons; urine bladder contained four pints of bloody colored urine; fat the color oi yellow bees-wax; third stomach slightly impacted witio dry food.

A three-year-old white steer was pointed out to me, which showed evidences of sickness, manifest by segregation, a weak, staggering gait, drooping head, and feces covered with mucns. One of the boys lassoed him. Temperature, $106^{\circ}$; pulse, 90. October 23,2 more reported sick and the white one dead. I saw MIr. Ewell, secretary of the bagle Chief Pool, in Harper on the 25th. He stated that no eattle died in their herd this season. MIr. N. Sherlock, of the same pool, eorrobolated the statement of Mr. Ewell.

From Mathews we drowe through a drizzling rain southeast to the line of the Indian Territory; stopped at W. E. Campbell's eow camp. Camplell's pasture is fenced in, located on the Indian Strip, 3 miles wide and $12 \frac{1}{2}$ long. The cow-boys told me they lost 6 or 7 ont of 3,500 head. They did not show any particular anxiety to be interviewed. Wo then proceded to Pryor and Miller's ranch. They own a fenced range in 
the territory along the line of Harper and Barbour Counties. The cowboys here reported a loss of 10 out of 500 heal of eattle bought from Hink Moore on the luth of September. Last year they lost on this range 50 or 60 out of 4,000 with Texas fever. Lost last winter 5 per cent. Hold this year 6,000 heal. Mr. Lathan, east of W. F. Camp. bell's, lost 16 out of 500 .

We next came to H. Hale's ranch, 28 miles sonthwest of Harper, in Barbour Connty. He holds 300 heal of eattle. The discase broke out among his herd abont the middle of September. He herds his cattle on all open lange. Lost 33 out of 300 ; 20 recovered.

The next place we stopped was at John Peters' eamp. He is located on an open range 6 miles sonth of Mr. Boyl's. He lost, ont of 1.55 lead of grown cattle and 100 calres, 84 grown and 12 calves. Three of the calves were only '2 months old; the other 10 were Mareh calves. One animal diod in July; the remainder of the deaths ocenred during the first fifteen days in September. After 94 had dierl, he left the herd and went home, stating, so I was told, that they might all go to - _ he was not guing to stay any longer to see them die. After a few clays he retminerl, and found 2 more dead; no deaths lave occurred since his return to the herd. Let us suppose for a moment that, had he commenced to exlibit medical freatment at the time he left them, and only 2 deaths occurred subsequently, would he not be justified in believing that his treatment had effected the change?

The Peters cattle were mixed n) with the Boyd cattle from the midrle of A pril mintil the 10th of July. A stage roal passes across the Peters range, and ox teams frequent this ronte. From the Peters ranch we drove to Mr. Boyd's and stopped for the night.

On the morning of the 17th Mr. Cochran and I left Mr. Boyd's and went west 3 miles to the residence of David Clongh. Te gave me the following history: His cattle began to die soon after the th of July. He lost 35 head ont of 300 during this montlı; the disease then disal\% peared. He sold 60 head of his cattle in Angust. In the early part of September the disease reappeared and he lost 30 hear more ont of 205. He wintered 150 heal; among these the mortality was the greatest. The wintered cattle intermixel, more or less, with the Boyd cattle from the middle of $A$ pril until they began to die. 'Two more deaths reported Oetoher 21 . Mr. Olomgh and several of his neighbors mall a mumber of post mortem examinations, and he described the appearances of the pathological lesions of southern cattle ferep rery accurately. Mr. E. C. Davis, 3 miles nortlawest of Mr. Clongh, on the Medicine Lodge stage road, and west of the lllinois rolony, states that one of his eows died on the lst day of July, and that the last deatl acemeded on the bith instant. The first animal that died had been running witli the Boyd herel ; the rest of them had heen exposed to oxen that .Mr. MeGuire boight

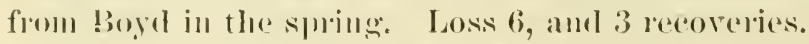

The next freson we sal was Mr. Willian Garrison. Garrison, Beals, 
and Hufacker hold 600 heal of cattle together. on an open lange north of the Medicine Lodge stage load, and sonth of Dr. Wismel's range. The three parties lice in the lllinois colony. All of their cattle except 80 head have been in the Sand Creek anc. Cedar Hill pool. They lost 30 in the month of July. On the 10 th of September the disease broke ont the second time; they then lost 55 hearl; 100 that were sick recovered. These same parties held cattle on this range for fonr snceessive year's, and this is the first year that they met with any loss by disease. Mr. Gampison stated to me that he hamght solleal of vaceinated eattle from the vacine farm at Webster Grore, Mo., all heifers, rearlings, and two-year-olds, with the exception of 12 head which were rearling steers.

He told me, in answer to my question whether or not the steers han also been raccinated, "Yes," said he, "they told me they could not always procure a sufticient number of heifers; consequently, had to use yomng sterers." He sayss he loader them on the ear's at the Old National stock-yards at Saint Lonis, and landed them at Harper on the 1Sth of Jnne. Mr: Garrison reports that the Anderson herd of eattle went as far trest as I'. B. Cole's range, which is directly north of their range. Mr. White, in the same colony, lost 2 cows and 1 ox out of 4 cows and 6 oxen. He kept them strietly under his care at home. He bonght one of the cows in Harper County, and she came over the same road where the Ireguire oxen had been traveling. These cattle died in the mouth of September. Mr. Pelton, in the colony, lost 2 out of 20 head, 1 in Juls and 1 in September. T. B. Stockstill, on the Medicine Lodge road, between E. C. Davis and M. B. Moore, holds 150 head of cattle.

Two died ont of 5 that were sick. The first one was sick on the 6 th instant and died on the 9th; the seeond one died a week later. These cattle were close-berded all summer, and were not in any way exposed to the Boyd cattle. He thinks his cattle took the disease through M. B. Moore's. We then risited M. B. Moore, directly west and arljoining Stockstill. He stated that his eattle began to die on the 11th or 12th of July, and 7 hearl died during the month. On the 1jth of september another ontbreak of the disease set in; they then died off rapidly for abont ten days, when the death rate began to diminish. Altogether he bost 40 ont of 1.23 heal ; is recovered and 3 are pet sick.

After death drops of blowd would he seen to onze ont of the skin between the legs and mulere the jaw and sirle of neek. I examined a sick two-year old heifer which he was bringing in from the herd as I drove up. Her temperature was raised to $107.80 \mathrm{~F}$.: she patsied feces corered with muens and blood. I also exannined a white cow with ealf at her sirle; had been sick for three weeks: temperatmo 103.20 Fo

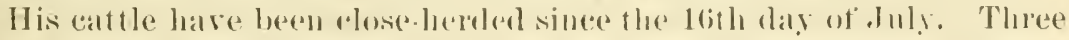
of them were cut out of the borrl herel at the loumd-11] in . Inne; none of the rest have I een a dexosed to boyot's or ang other linown diseased

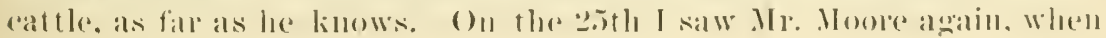


be stated that the sick cattle which I had seen at his place were grad. ually recovering. Mr. Mefuire, in the colony, lost 6 out of 60 hean of cattle. Mr. MeGnire bought two yoke of the Arkansas cattle from Mr. Boyd in the spring.

From Moone's we drove to B. F. Kemp's place, 4 miles south, and west of the Ceabur Hill. Hr made the following statoment: Ont of 108 head of cattle, 65 got away in Angust and ranged over the same gromul that Boyd's catthe had been grazing on; they remained from the evening until next morning; twenty days after this exposure they began to die; 10 were fombl sick in one day; they died in from six hours to ten days after they wero taken sick; 15 died amb 15 recorered. Ife knows of 4 that died which had heen on the infected gromm. One calf died, and 1 calf that was sick recovered. He brought his cattle from 10 miles east of Harjer, on the 27 th day of March ; close-berded them all summer. Some of the Boyrl cattle came over on his range in June and July. Every one foumd dead was lying tlat ou the side. When they got sick they quit eating.

From Kemp's we returned to Boyd's and remained overnight. Next morning, October 18, I tonk the temperatme of the quarmintined cat. the as recorled in the early part of this report. We then went south to the ranch of Mr. W. E. Mattox. We were there told that he lost 7 out of 125 head of cattle. He brought his cattle on the range in the spring, and they were frequently among the Bofl herd in the early part of the summer. All of the rleaths took place during the month of July.

From this place we turned and went north of Mr. Boyll's, 2 miles, to see Mr. James Roberts. He lost 1 cow on the bith, after a sickness of five day's; noothers were taken sick. His cattle have been on the Boyd range several times during the summer. Mr. Reeder, who lives 3 miles east of Boyl's, held 27 head of cattle; 3 of them died during the montl of July. Next we stopped at Mr. Crawford's, 2 miles west of Inyo post-oftice. They close-herded so hear of cattle near home; lost none. They are on a road leading west toward the colony and north to Dr. Wisner's. Crawtold, jr., reports having seen a herl of eattle passing between their house and that of Mr. Dougherty, half mile nortl. early in the season. 'They were going west.

We then drove to Dr. Henry Wisner's residence, n miles northwest of luyo post-office, in Barbour County. Dr. Wisner was not at home. so I applied to Mrs. Wisuer for information. I fomm Mrs. Wisner to be a regular M. I).; more than that, she took as much interest in the welfare of their stock as her husband did. She superintended a post. mortem examination of a bull that died abont a week previons, and described the pathological lesions as follows: She fouml considerable enlargentent and engorgenent of the radicles and blood-ressels of the liver; the gall-bladher was distenderl, with a greenish-black bile; spleen very hyperamie; eechymosis found thomghont the peritoneal sae; urine bladder filled with a highly bloody-colored mine-a deep wine 
color; kidners musually pale and somewhat enlargerl f feces in colon hardened. Dr. Wisner bonght in the month of July 120 head of the Mcinulten eattle on the Botkin range; a number of them died before they were taken home. He took them home in the early part of September, but dis not bring them into bis inclosed pasture-field among his other eattle mntil later; 29 of them died before they were plated in the field, and 1 after they were mored in. These cattle were closeherded and kept on poor and dry feed by Mr. Botkin after Dr. Wisner took them home he fed them on sorghum, millet, and had good pasturage. On an open range, north of the pastme-field where tine aloore men. tioned eattle were held, grazed 300 which were being elose-herded. Mr. Willian Garrison, on or about the 20th of July, drove his cattle on to Dr. Wisner's open range; Dr. Wisner drove them back abont the 1st of October. Several of the Garrison cattle died while they remained on this range, and were left to decompose near the pools and stream of water where the Wisuer eattle had to drink. Juring the month of lectober Dl. Wisner lost 1 thoroughlored bull and 2 highgrade calves ont of the 300 heal. In the month of February Dr. Wis. ner bronght from Waco, Tex., 7 car-loads of Texan cattle, moloted them at Harper, and then drove them out to his place. These cattle intermixed with his other cattle during the smmmer. An ox-team, bought from I)r. Wisner's herd of 'Texau eattle, was employed all summer in bauling hay from Inyo, or near Inyo post oftice, to Medi eine Lodge. They are owned by Mr. Downing. This hauling was over a distance of from 15 to 18 miles; wonld probably take three dass to make the roumd trip, and it is the custom of men driving ox-teams to stop any where along the roal to feed and to allow their cattle to graze. These cattle passed by Moore's, Stockstill's, Daris', MoGuire's, and other's living in the colony and along the roat to Medicine Lodge. I met the tean abont 1 mile east of Mr. Javis' house, and received from the driver (an Englishman) the faets as just staterl. J. H. Warren, 5 miles northwest of Boyd's, lost 4 out of 40 hearl of cattle'; they died in the month of September. His eattle strayed away and went on the Boyd range several times during the summer. On our way back to Ifaper we passed Mr. Gariner's plaee, near the Nine Cottonwoods Creek. Both the Boyd and the Anderson cattle erossed his range. He lost 1 out of 3 cows. Mr. Kepler, 1 mile west from L. M. Pratt, harl his cattle staked on and near the Boyd trail all smmuer; no loss.

We liext stopled at L. M. Pratt's, I' miles west of Ilapper. He lost 6 cows and 1 bull. The first one was taken sick on the th thay of July. All died within the spatee of ten days. He male post-mortem examinations of several that died; found the spleen enlarged to three times its normal size; gall-blatkler greatly distemded with bile; liver enlarged : boody water in the peritoneal cavity; tallow of a salfiron-yellow color; in one the mine bladder was filled with bloody mine, in atnother it was empty. Many of them passed bloody mine belore death. Mr. Boyd 
passerl one-half mile north of Pratt's house with lis wattle on the 9th of April ; a few days later bronght 20 head of his eattle to Mr. Pratt's house and left them there overnight. Mr. Pratt had 9 bulls and sereral mileh cows at home; these eattle grazed with the 20 head of the Boyd eattle, and also grazed over the trail of the Boyd herd. On the 15th of Jume Mr. Pratt took 8 of the bulls abont 8 miles southwest to his herd, and brought back with him one cow and her calf. This was the first cow to sicken and die. The $S$ bulls remained well. On the $23 d$ of June he took to the herd a dry eow and a bull; on or about the 6th of July both these died. No strange cattle, to his knowledge, passed along the range where the cows and bulls grazed except the boyd cattle. After I obtained the above history from Mr. Pratt I learned that a team of oxen coming from Fort Sill, near Rell River, Clickasaw Nation, were driven throngl by Mr. Pratt's honse and remained with him overnight; this was in the month of June. From Pratt's they went west, passed Otega post-office and crossed John Peters's range in Barbour Connty. It was now getting dark, so we retmined to Harper.

October 19, I met Mr. T. A. Barton, who lives in town. He staterl that he had his eattle on the range north of the railroad track, but did not lose any. This morning we drove west is miles to the residence of Mr. F. P. Melvin; he lost 2 ont of 4 hearl of cattle; one of these rlied on the Sth of October, and the other on the 17th. I went out into the field to ascertain the post mortem conditions of the latter, but found that the dogs had anticipated me; had mutilated the bods to such an extent as to render it unfit for further examination. Mrs. Melvin stated: "In the month of August I saw a herd of cattle going west, but I don't know where they eame from nor where they went."

We theu drove 1 mile further west to C. P. Bradford's. He stated that he lost 5 out of 6 head-2 bulls and 3 cows. Two died in October and 3 in September; 1 recovered. Hesaid: "In skinning them I found the flesh blubbering belind the shonlders ; urine bloody before death." This was all he eould tell of the symptoms during liteand the appearances after death. All of these eattlo had been picketed close to the house, and small herds of wattle were frequently driven past his house during the summer. He stated, also, that Mr. Bur's cattle eame over among his cattle while they were picketed, and that his eattle had not been within a mile of the Boyt trail at any time during the stason.

From Mr. Bradford's we went to Lonis Ilildebrant's. He stated that Charles Martin had bonght 60 or 70 head of cattle firom Mr. Potter and had driven them west and sonthwest of Harper, passing his (Hildelorant's) place on the (ith day of Angust. Two weeks thereafter Hildiebrant lost 3 milch cows ont of a herd of 12; they were all taken sick, and that theovered aborterl their ealves. The Martin cattle were taken to the Botkin herel.

Mr. Welker, s miles went of Harper, lives close to the Boyd trail; he settled on this range on the 1st of April. He picketed b head of oxen 
and 2 cows on the Boyd trail. No loss. We next saw Mr. S. H. Coyer, $1 \frac{1}{2}$ miles northeast of L. M. Pratt's. He took is cows into the Butkin herd soon after the Boyrl eattle passed his place. One of them died on the Botkin range, in July; he then took them home, but they continned to die mitil 14 ont of the 18 head were dead.

We then procerderl towarls Silas M. Shafer's place, north of Attica post-office. On the way we met his brother, who told us'that Silas lost 10 out of 18 head of cattle; ther died in July and September. These cattle crossed the Boyl trail in the spring. On the 1st day of July they were taken into the Botkin herd, and remainef there until the mildle of the month. In the latter part of April, or beginning of May, a small herd of strange cattle were driven over the same trail that Bord's cat tle passed over. 'This trail is located a mile south of Shafer's house. Mr'. Shafer has resided here for ¿̇ years, and has nerer before lost anc cattle. I saw Mr. Helbert, who lives:2 miles west of l'ratt's, at Anthony, on the 1st of November. He statrel that he harl two cows which followed the Boyd herd on the 9 th of A pril for a distance of 2 miles, and that dluxing the summer they grazed orer the Boyd trail. oft and on, withont aug barl results following. We then turued towarl Harper, and on the way stopped at Elijalı Vian's pla'e, 10 miles sonthwest of Harper. He lost 36 out of 100 heal of cattle doring the month of Septembel. Their lange was south of the Bovil trail. On the 20th we drose north of Harper to gather the history of an ontheak which has occurnerl in that loeality. We first saw Mr. A. S. Woodward, who resides 3 miles north of Harper. He reported a loss of 14 heal of eattle ont of '3:. These eattle, together with '29 heal helonging to D. W. Fye, were herden on the same range alt summer, said lange being $1 \frac{1}{2}$ miles syuare. One eow belonging to Mr. Carpenter, anotlier to Mr. Creighton, were also kept in this herrl; both of them dienl. and 20 ont of the 29 belonging to Mr. Fye died. The disease manifesterl itself about the lst of September, and in the space of three reeks' time all of these deaths occurred. Eight in the herd which presented evinlences of sickness recovered. They were all good grade native cattle. The history as given me by Mr. Woolwarl of the symptoms during life, and of the postmortem appearances, leads me to the conclusion that these cattle died with sonthern cattle ferer.

Proceedipg from Mr. Woodwarl's place castwarl, 1 mile, to the residence of John Challis, I was there informet by Mr. Challis, jr., that 12 out of 100 head of their cattle died and 6 recovered. Here, also, the disease appoared about the 1 st of September. Forty learl of these eattle were brought from Doniphan Comnty on the 12th of Mar, anel weret driven fiom the stuck-yarls at Harper, 4 miles northwest, to Mr. Challis' herrl. Two of the Doniphan Comnty cattle died ; the other 10) were of the domestic licrel. On the dith of .Jume, 200 hearl of eattle,

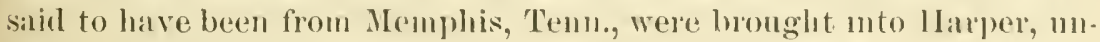
loarled at the stock-yards, and driven north 3 miles, where they were 
afterward close-hereded hy Mr. Seoby, the reputed owner. These wattha ranged somth and east of the Challis herd and south of Wroodward and Fye's herd, a public road being the dividing line between the three herds. I coulal get no lefinite history of these cattle. Mr. Cahlan, whose lange was sonthwest of the scoby cattle, states that $S$ or 10 of the Suoby cattle dief in the month of September; that the cattle were sold and driven north toward Kingman County; the owner then left Harper. I went to see one of the men who assisted Mr. Scoby in herling the cattle, but could get no satisfactory replies from him, otlier than that if I had money to pay for information he might tell me what; I lesired to know; that he was paid by Seoby for the services he rendered him. Some of these eattle were shipperl to Kansas City, the remainder were taken northwest by trusty men who would not disclose their destination.

I went to see Mr. William A. Creighton, of Harper. He made the following statement: That he wintered 27 hearl of cattle. They were in the stock yards at night with the Boyd cattle, and langed over the same gromel north of the lail road track with them several days. In the latter part of June they were iriven ont to I. M. Pratt's herd, passing along and over the trail of the Boyd cattle; one of them, a bull, was left at Pratt's for two weeks; he was then also taken to Pratt's herr ; he died five days after lie entered the herd. None of the rest of the 27 died, although all were equally exposed to the Boyd trail.

October 21, being Smbliy, I remained in Harper. At the hotel where I was stopping I met a gentleman from Linn Connty, who told me that a Mr. Goss, of that comty, lost 60 out of 70 head of cattle this summer with Texas fever. I met also Mr. Domahue, of Atchison, Kans, who holds cattle 4 miles east of Caldwell, Sumner County; he lost " ont of 14 heal in the month of September. These cattle he hought from Mr. Cox, who, it is said, lost a large number of cattle this season. Having heard that hog cholera existed at or near IVellington, Summer Comuty, and as fon desired to secure virus for the use of the Dublument, I therefore took the night train for Wellington. I there mate inclinies in regard to the truthfulness of the report, and was referred to the mayor of the city, Mr. Inamilton. He informed me that a fatal disease hat prevaled among the hogs on several farms sonth of town, notably so on that of Mr. John Botkin. I proceeded to Mr. Botlin's place, located one mile sonth of town, fommd him at home, and obtained the following history of the disease anong his hogs: Mr. Smith, a near neighbor, received some hogs last year from Missomi; soon after he wot them home a disease appeaned among them amb many died; soon thereatter, Mr. Botkin's hogs hegan to die, amb he lost nealy all he harl. Those that remaned well he sold in the fall, keeping no hogs over winter. 'The hog pesture of Botkin arljoins that of' Il r'. Smith. A larege pond of surfice water is inclosed in Mr. Botkin's pasture, and the surface water from Mr. Sulth's pasture flows into this pond. In 
the month of June, this year, Botkin bought a number of sows and pigs, took them home and placed them in the same pasti. pe that held his logs last gear. Within a month his hogis began to manifost evidences of disease. As there wele none in a dying condition when I saw them, I requested the privilege of killing one for eximination. Mr. Botkin willingly granted the request, and eunght a 2-montlssold boal pig. He presented the following symptoms: pulse, wealk and complessible; temperature, 106 $\mathrm{F}$; considerable swelling across the nasal bones, posterior to the wares; a large nleer, one inch in dianseter, opposite the first molar tooth in the superior maxilla, form. ing a deep eavity in the tissnes covering the alveola; this uleer was of an mhealthy, fonl, and sloughing character. Several small uleers were present on the tongue, possessing well defined borders, surromulerl by a rarliened, brownish-red areola; a rery oftensire orlor was emitted from the month. Several abscesses and nleers of variable sizes, from that of a pea to a silver quarter of a dollar were discovered on the abdomiual surface, and one large and deep ulcer immediately about the coronet of the right tore foot. (Several other hogs on the plate pre. sented similar symptoms to this one, but not so far adranced, the first and most pominent symptom being that of the swelling across the nose, accompanied by more or less sunfllug.) 'They continued to eat, and ro not lose flesh rery rapidly; a few of them sutfer by diarrlear, and colliquative diarrhea sets in betore death takes place. (Thero is no sprecial tendency to hide in the litter, nor is there any roseate blush present at any time rluring the progress of the risease, as there is in true hog cholera.) I severed the jugular vein and curotid artery on one sille of the neck and blen it to death, then remoral the wall of the chest and ablomen. I discovered a greenish yellow sermm in the ahdominal eavity; heart pale and flaceid ; lower lobes of lungs in a par. tial state of hepatization, abseesses and tubercles being distributed thromghout the afocted parts. The stomach presented two extensive, irregular-shaperl ulcers, appraenty in frocess of healing, one of them measuring two inches in length; they wele covered with a yellowish deposit of pus, mucus, and feed mixed, which was strongly alherent to the surfice of the ulcers. The intestines contained a great number of long worms, aseoris suille, and the intestimal glands presented at thickened, infiltriterl, tulerenlotic condition. 'The liver was enlawered to three times the normal size, was of a light olive yellow eolor, and 111 melons small absersses were fomd within thestructule of the organ ; the biliary duets were literally filled with worms of the sime species as were fomm in the intestimal camal. The worms in the liver obstrmeter the flow of bile. The gall blarbler was filled with bright geeen eolober bile, thinner and lighter in color than molmal. The mrime blarleler contained three onnces of light gereen eolored nrine; lishers were enlarged, softenerl, anrl partialy disintegrated, prosenting an olireanderen color. 'The fat, and also all of the intermal visceral, pesented an ieteric 
appearance. I recommenled a change of pasture and water; the hogpens to be removed and the boards usen for some other purpose; the old hog pastme to be plowed mp, and seeded with wheat or other grain for at least two years before it should again be used for a hog pasture. I also advised a destruction of all the hogs that. indicated plain șmplo. toms of the disease, and afterwarls an entire change in the breed or family of hogs. 1 inclosed in a tin ean a portion of the lung, liver, intestine, and stomaloh of the pig examined, and sent it to yom Inpartment by express, for microscopic examination.

After my return to Wellington I salw Mr. Hamilton again, when he tolil me that he and his partner, Mr. Flint, lost 16 or 17 head of their cattle ont of 900 head. Their pasture is fenced $\mathrm{in}$, and is locater in the cormer of Kingman, Pratt, and Barbour Counties, and comprises 30,000 acres. This pastme held Texan eattle last year. The cattle this rear in the field were not exposed to other eattle. The disease appeared in the month of september; 10 or 12 that were sick recovered. Changing pastme and water seemed to offer a check to the disease.

I returned to Harper in the night. On the 231 it rained harel all ray, and I remained in town. I saw I. J. Campbell, esq., who gave me the following history: He owns a fenced pasture on the western edge of town. On the 10th day of April Mr. Boyd placed 14 head of lame cattle in this fichl, which already contained 150 head of natives owned by Mr. Campbell ; the Boyd cattle remained for a week or more to recuperate, and were then driven by the way of Pratt's to the Boyd range. Some time dinring the month of July 2 steers that were bronght from the northern part of the county were turned into this field; soon thereafter both sickenced and one of them died. The steers in coming to Harper crossed a number of cattle trails. None of Mr. Campbell's cattle died. Mr. R. A. Jones, from Labette Comts, told me that while on a risit to his brother at Santiago, Cal., last year, his brother told him that eattle that were brought from Old Mexico and driven north into colder and freezing climates in California impart disease to native cattle.

October 24 we drove sonthwest 16 miles to see Mr. Richard Botkin. He held cattle belonging to Shafer, Coyer, Arnold, Collins, Me.Mnllen, and Martin, the total number being $56: 2$ heal. All of them were native cattle except the McIInlen eattle, which were brought from Webster Connty, Missonri, reaching Botkin's range in the month of May, and remained until the 1 st of September. Dr. Wisner took away 120 head of them, and the remainder were sold to and taken away by Mr. Petter. The Boyd cattle passed over his range in April, and all of these cattle have been grazing orer their trail. All the deaths in this herd which oecnmed while on the Botkin lange took place between the 2 d of July and the midllle of $\Delta$ ngust. Loss, 18t. Mr. Camploell, at Otega, lost one work ox ont of a yoke of oxen in the month of July.

Mrunger Brothers, of Harper, starter fiom Harper in the month of May 10 thoroughbred and high-grade bulls; by mistake the driver 
turned them in with the Boyd cattle, where they remained over night. Seven of these died, and 3 others in the herd of 500 , on the Hialk Moore range. They began to die sixteen days after exposure to the Boyd cattle.

October 25 , we drove 7 miles west from Harper, stopping first at Mr. Н. F. Burr's place. Mr. Burr stated that he shipped into Harper, then drove to his place, four lots of cattle ; the first one in the month of Mareh, one in April, one in May, and the last one in June; total number, 450 head. These eattle were bronght from Colony, Anderson Connty, and from Coffee and Allen Connties. Mr. Burr wintered 18 head of cattle. He has been on the same range for five snecessive years, and has never before lost any cittle. He lost 175 heal out of the 468 head this season, and Mr. Moier, his son-in-law, lost on the same range 4 out of 7 head. Mr. Burr thinks that all of his cattle except 25 head had been sick. He used tineture bellarlonna as a cmative agent. Sereral of his cattle died in the month of July, but the greater number of deaths occurred in the month of September. Mr. Boyd's cattle crossed his range in April. We went out to his herd and I tested the temperature of several, which registered as follows:

o $\mathrm{F}$.

Two-year-old heifer, has been sick ............................. 10.2.7

One-year-old heifer, has been sick ............................... 104.2

One-year-old heifer, has been sick ................................ 104.8

One-year-old heifer, has been sick ................................ 104.2

Four-year-old bull, has not been sick ............................. 102.9

One-year-old heifer, has not been sick ................................. 103.4

One-year-old heifer, has not been sick ............................. 103.1

Two-year-old heifer, has not been sick ............................. 102.9

We then drove 1 mile sonthwest to A. Hilliarl's farm. He lost 1 cow on the 20th of Juls, and another on the 10th of September. Mr. Boyd's cattle crossed his range half a mile sonth of the house. On the 1Sth of June Mr. Anderson's cattle went across the east end of his range, learing probably 80 rods between the two trails. Hilliard has owned a work ox for the past two years. This ox was pieketed on the Boyd trail a number of times during the summer, but remained well. While I was there I noticed a bull corraled near the barn; he appeared thin in flesh, and I inquired if he was sick. Mr. Hilliard replied, not that he was aware of. I tested the temperature of the animal; it registered $102^{\circ} \mathrm{I}$.

An eight-year-old eow was in a separate pen ; I tried her temperature; it wals $101.5^{\circ} \mathrm{F}$. On the 30 th, as I was going toward Harper in the evening, I met Mr. Hilliam. He stopred me and stated that the eightyear-old cow which I saw in the pen at the time of my visit to his place was sick. "She appeared stupid last night, and this morning yielded no milk." That this cow had positively not been exposed to the boyd trail, or any other infected place; that she had been kept closely yitded, and had been well fed on dry feed for the past three months. I fromised him to see her in the morning. The following morning I dhovo out

5751 D $\Lambda-15$ 
to his place, and found her manifesting the following train of symptons: Found her lying on the sterunm, head well poised ; horns warm; nose dry ; a dull and drowsy appearance of the eyes; sensible to the flies; pulse depressed ; respiration 22 ; temperature $104^{\circ} \mathrm{F}$. ; passage of manure slightly eovered with muens, and of a firmer consistency than it shond be. I learned that this cow had been turned ont to graze with the other cattle on the 29th, and as she had been kept up on dry feed for the past three months I conelnded that she had overcharged herself with food to which she was not aceustomed, and that this was the canse of her disability. On the 30th she would neither eat nor drink, but was disposed to lie down all the time. When I saw her on the morning of the 31st, she drank half a pail of water, and ate a few ears of corn; therefore I coneluded that she must be improving; that she was better the day I saw her than on the day previous. On the 3 d of November I again saw Hilliard, in Harper' he reported that the cow had recovered her health.

From Hilliard's we went to Matt. Miller's, 5 miles north west of Harper. He stated that in the month of July Hugh McClıug brought from north of Little Rock, Ark., 65 head of eattle; that he bought 35 head of these eattle from MeClung, and placed them with 40 head of his domes. tie eattle on the same range; he lost 9 head, while McClung, who held the remaining 30 head on a range of Mr. Matthews, lost none. His cattle died during the first and secoud week of September, after a sickness of from two to five days. Miller sold 30 head of his eattle on the 10th of September.

Messrs. Got and Weaver, of Springfield, Mo., brought into Harper on the 24 th of June, 200 head of cattle from Missouri. They drove them out 3 miles northwest, and had them herded on the Matthews range. Abont the 20th of July deaths amoug this herd began to oceur, and they lost 24 head of their cattle in rapid succession.

October 26, we left Harper for Medicine Lodge, Barbour Connty, a distance of 35 miles. We arrived toward evening. I saw several eattle-men in town; made the usual inquiries, and was told that many catthe died during this season all over the eounty; but, when I eudeavored to obtain a more definite aceount as to who the suffering parties were, and the extent of their losses, I eould get but little reliable information. I conchuded to remain in town over Saturday the 27 th, and endeavor to get a more definite history of the outbreak in this part of the counts. In the evening I was introdnced to Mr. Ebersole, who lives 7 miles west of Medicine Lodge. He told me that on a range next to him 10 had died ont of 700 head during the month of September, but that he, himself, had not lost any out of the 50 head which he owned. I also met Mr. Springer, Who lives 5 miles sontheast of Medicine Lodge. He lost 4 out of 420 hear this summer, and 125 out of a herd of 500 last winter. Mr. Springer also stated that his neighbor, Mr. Bullington, lost 12 out of 100 head this season. 
On October 27 I went to the oftice of Mr. T. L. OBryn, a live-stock broker. He told me that some emigrants passed through the town of Medicine Lodge, going north, on the $23 d$ or the 26 th of May. They were smplosed to come by way of Anthony, Harper County, and were going to Colorado. Thes had with them 4 or 5 ox-teams, with from one to three yoke in a team, and 50 hearl of loose cattle. They toh Mr. Riggs, the sheriff' of Barbour Conuty, that they came from Texas, but told Mr. OPBryan that they were from the Chickasaw Nation, near Red River. Their cattle were in good condition and had the appearance of gennine Texans.

In Mr. O'Bryan's office I entered into conversation with Hon. T. J. Shepler, who told me that in the rear 18i6, when the throngh trail for Southern cattle to Dodge City passed along the eastern banks of the Elm Rirer, near Medicine Lodge, 2 head of domestic cows which had been kept in close confinement all summer, were allowed to graze over the trail late in the fall after a fall of 3 inches of snow, and after so late an exposure both cows dich. He also told me that a prominent stockman from Montana assured him last spring that eattle coming from the State of Kausas would transmit to their eattle the Texas ferer in the most malignant and fatal form. Mr. Shepler thinks the only war to obriate the anmual losses among cattle in Kansas by the Southern ferer, is to establish a border line of infection and compel the Sontheru eattle to be slanghtered within the limits of snch boundary line.

I then went to see Mr. Frank H. Shellę, secretary of the Salt Forks and Eagle Chief pool. He said:

A number of throngh cattle, purchased at Caldwell, were located on the Eagle Chief Creek adjoining us on the sontheast; some of the salt lorks eattle drifted on the " $\mathrm{T}$ 5 " range, helonging to the Texas Land and Kansas City Company; several of our cattle clied, but not many ; two of them were high-grade bulls. I don't know how many of our cattle were exposed. The pool holds 20,000 head of cattle.

I next met Mr. I. A. MeCarty, in the office of the Barbour County Index. He is the captain of the Sand Creek and Hackberry pool. He stated that in the month of Augnst, Mr. Lockhart, a member of the pool, bronght from Kingman Connty sereral hundred head of cattle and placed them in the pool herd. Three weeks thereafter the pool cattle began to die; 15 out of 3,500 head exposed died It is supposed that several head of Arkansas attle were among the Lockhart lot. Ten per cent. of their cattle died last winter. I met Mr. Willian Kelley on the street; he lired $\$$ miles south of Medicine Lodge. IIe lost 10 out of 400 head this summer. He does not know in what manner they were a $\mathrm{x}$ posed. Last winter he lost 50 out of 500 head; they generally beeame lame in one fore leg; persisterl in lying down; would continne in this way ficm one week to a month before they died. Many of them were valuable cows. They were well sheltered and well fed after they beeame sick, but the majority of them ultimately died. Several clied after the grazing was good in the spring. In 12 or 15 cases that recovered one or both horns came off.' Mr. Vanghn, $2 \frac{1}{2}$ miles sonth of Medicine Lodge, brought 60 head of eattle from Kingmann County about the 1st 
of July. During the month of September he lost 3. Last winter he lost in Kingman Connty 42 head out of his herd of 300. The best eattle in the herd appeared to be the most susceptible. His cattle were fed on corn in the latter part of the winter. James Wilson, 8 miles sonth of Medicine Lodge, stated that he gathered one bull at the connty round-ı1) which died.

Two other animals died subsequently, and he does not know where these were exposed, except to the bull. Lost last winter 6 per cent. Mr. Hamlin, neighbor to Wilson, lost ont of 3 head gathered on the Boyd range, one bull. Mr. B. D. Keyes, on Elm River, 18 miles northwest of Merlicine Lodge, reported a loss of 40 head ont of 500 last winter. He fed millet, hay, and corn. They were sick from two days to two weeks. Some got lame, and wonld then lie dowin nearly all the time; most of them ate well until they clierl. One cow ate two quarts of soaked corn, then dropped over dear. He further stated that this tronble was almost nniversal in that part of the connty. After skinning the dearl eattle he found infiltrations of bloody water under the shonlder blade and foreleg. Mr. B. T. Shields, a neighbor to Keyes, lost this summer 16 ont of 225 head.

On Oetober :Sth we left Medicine Lodge and drove west toward Lake City ; the first place at which we stopled was Henry Morehead's, 3 miles west of Medicine Lodge. IIe told me that he had 144 head of cattle in a herd, uncler the care of P. B. Cole, on Antelope Flat, north. west and north of the Illinois colony. Also, that his neighbor, $\mathrm{Mr}$. Updegraf, hat 60 or 70 heal in the same herd; neither of them had suffered any losses. The next place on onr way to Lake City at which we stopped was Mr. Sanderson's, who lives on the north side of the Medicine River, 8 miles west of Medicine Lodge. He lost 3 head of cattle ont of 40 in this month. Canse of death, or manner of infection, not known. He told me that Mr. Robert Ingram, on Cedar Creek, 7 miles west of Medicine Lodge, lost 6 ont of 50 head during this month. Manner of exposure not known. We then proceederl to Lake City, which is 18 miles northwest of Medicine Lodge, and from there we drove 2 miles north, to Ml. W. F. Gordon's ranch. Mr. Gordon holds 400 head of cattle on a 7,000 -acre fenced range. This range is supplied with water from several clear-water springs, all of which head within the inclosed range. Mr. Gordon lost 35 head of cattle. The first one died on or abont the 25 th of September, and the last one on the 25th instant. Ten or 12 that were sick recovered. Mr. Gordon knows of no way in which his eattle were exposed, only that once or twice the gate at the north end of the field was left open by persons passing throngh, and a few of his eattle got ont, but were always returned within a few lours. One hundred and eighty-nine head of these cattle were bonght from Reuben Lake, of Lake City, on the 1st of July. They were Ar. kansas cattle, wintered by Mr. Lake in a fenced field adjoining that of Mr. Gordon. The balanee of Gordon's cattle, 212 head, were ilonble 
wintered in his field. As I was anxions to make a post-mortem examination in order to discoser the exact nature of the disease, I went out late in the evening to see the coudition of the heifer which died on the 25th, three days ago. She was badly bloated. I opened her in the usual manner, and found that the internal viscera were undergoing decomposition, and were searcely fit to handle. I removerl the spleen, which weighed $t$ pomnds. The liver was enlarged. A bloody-eolored thid was contained in the pericartial sac; also bloody-colored urine in the bladder. The fourth stomach presented the characteristic erosions and gastrie redness of sonthern cattle f'ever. Mr. Gordon stated that in $185 \mathrm{~s}$ he lived in the State of Missouri, on the throngh eattle trail. The trail led aromul a comer of his pasture field, the cormer not being quite square; late in the fall he built the fence out so as to form a square corner; by so doing he inelosed a part of the trail. The cattle which were in the field soon began to die after the moving of the fence, and continued to die nutil some time in the month of .lannary; 50 ont of 100 head diesl.

We remained over night with Mr. Gordon, aud next morning returnerl to Medieine Lodge. As we passed Mr. Morehead's place his wife came ont to the road and told me that her husband had fonnd the day before a sick heifer among his cattle on the Cole range; that he harl started her toward home, but she dropped down near Elm River, and was nnable to rise, and that he desired me to see the animal. I was direeted where to find it, and I eomplied with their wishes; I fonnd the heifer dear. I saw the animal at '2 o'clock on the 29)th, and Mr. Alorehear had found her sick at about the same time the day previons. She appeared to me as if leath had taken place in the night or early morniug; was barls bloated; a few suall balls of feces, eovered with dried blood, and mucus, were lying behind her. The mucons membrane of the rectum appeared inflamed, swollen, and protruded several inches from the anms. I opened her on the right side, following the nsual custom. Decomposition had taken place to a much greater extent than ans that I had ever eximined atter so short a period after death.

The blood-ressels contained more blool, and of a better quality than is nsmally fomd after death from sonthern eattle ferer. The animal was excedingly fat, and the fat was of a very high rellow eolor, very nearly a chrome yellow. All of the internal viscera were, more or less, distemled by gasses. The pericaldinm contanerl $10 \%$ 12 onnces of bloody-colored serum. In the arterial sirle of the heart I lound a rery extensive and strongly organized fibrinous elot, extending thromgh the valves, and into the aorta for at least 8 inches. The splecen weighed $3 \frac{1}{2}$ poumls, and blod extravasations were fomd nuder the peritoneal eovering. The liver was enlatred, and filled with blom, and runmously distended by gasses. Erosions and subatente eongestion of the lining membrane of the fourth stomach were present. The mine biatder contained a few onnees of bloody-colored urine. The kidners were almost completely disorganized by the ravages of aetive decomposition. 
At Medicine Lodge I saw Mr. Standiford, of the cattle firm of Standiford, Youmans \& Co. Their range is located 6 miles sontheast of Medicine Lodge, between the Medicine Rirer and Cedar Hills. He made the following statement:

Alont 150 head of eattle, eoming from near Wichita, Seclgwiek Connty, were drivell along sonth on the divide between Antelope Flat and Elm Creek, and wero bronght to and eamped ou the center of onr range one uight. As near as I remember the date it was about the middle of $J$ nne. I went out to see the cattle; they looked very suspieions. Mr. Shanstrom, who was with the eattle, told we that the eattle came from Arkansas; that he bonglit them in February, and shipped them into Wichita about the 1st of April; that they were kept on rough feed, and afterward herded on the Niuneseah River until they were started Sonth. Several well-bred bulls, which were bonght at Wichita, were among the herd, but a large proportion of the herd looked had. From my place they went southwest 100 miles to the Cimarron River, and were placed with some other eattle which were in a small pool formed by Blackstone, Tucker, Dills, Conner, and Sluanstrom.

Abont one week after Shanstrom's cattle left my place Mr. Theker (of the above. mentioned pool) eame to my place and told me that the Arkansas eattle which Shanstrom took dnwn were dying off rapidly; also, that some of the other eat tle in the pool were dying. On the range where these eattle eamped one night we have 700 hearl they have been elose ranged in the spring and sumner, lont several of them drifted away; afterward 3 were gathered on the Boyd range at the time of connty ronud-up. Two werks after the Shanstrom cattle were on our range one of ours died; soon another one; the seeond one was gathered on the Boyd rauge. Texan cows which had been donble wintererl, and harl also been exposed to the Boyd eattle, remained well. One bull died that I kept up and stall-fed all winter, which I know had no chance for exposure to the Boyd eattle, nor did be stray away from our herd. He died in the first week of October. Auother bull which had been kept exaetly like the first one died on the 25th. One eow that I kept in town until the last of June and then took her to the herd, where she was kept withiu sight every day, also died. Altogether we lost ten of the very ehoicest eattle in the herd. Last winter we lost 10 per cent. of our domestic eattle, and 6 per cent of the Texan cattle.

I met Mr. A. L. Duncan, of Medicine Lodge, who told me that three different herds of cattle passed through their place in the latter part of May and early elune. Une of the ontfits told him they were from Red River, Chickasaw Nation, and said they were going into Colorado. The second outfit were going to Montana, and the thind into Utah. The three herds numbered abont 500 head of cattle, and looked like Indian or Northern Texans. From Medicine Lodge they passed in a westerly direction toward Fort Dodge.

While at Merlicine Lorge I met Mr. P. B. Cole. He lives 2 miles west from Dr. Wisner and north of 'T. B. Stockstill. He owned 250 head of eattle, and held 150 belonging to other parties. These rattle were nearly all gathered in the comsty romul-mp on Antelope Flat, between the 1 st and 15 th of July, where they had been with sereral Imudred other cattle. In this romul-np 25 or 30 stray cattle were fomd tor which no owners appeared. The Anderson herd of eattle giazed on the Cole range for sereral days in the latter part of Jume. Mr. Cole Iost ont of his herd of 400 2.) head-2 in July and 23 in September. Willian Dark, north of Cole's, lost 16 out of 350 hearl of cattle dnring the mouth of September. 
The first place at which we stopped, after leaving Medieine Lodge, on Oetober 30, was the Hulitt, or open A range, on Camp Creek, Harper County. Hulitt Brothers brought 250 head of good high-grade cattle on the range from Iowa a year ago, which bave remained on the same range up to this time. Mr. Miller, of Washington County, Lowa, unloaded at Harper, on the 9 th of $A_{1}$ ril, 220 head of Iowa eattle, kept them on the range north of the stock-yards and in the yards at night for three successive days, then drove them out on the range occupied br Hulitt Brothers, and placed them under their care. Mr. Ament, of Anthony, Harper Comnty, shipped from Coffeyville, Mo., and nnloaded at Harper 300 head of wattle; they arrived at Harper on the 28th of June. He then drove them sontheast into the eastern part of the comnty on a sehool section, and herded them there until the 10th of July. They were then taken west and placed on the Hulitt Brothers range, arriving on the 12th. One of these eattle died on the same day that it arrived upon the range, and others of the Ament eattie died daily thereafter, until the number of deaths reaehed 47 . None of the Miller nor of the Hulitt Brothers eattle died.

The last death among the Ament cattle occurred on the 1st of October. This was a black bull, bought in Kansas for $\$ 540$. Forty head which had been sick recovered. The sick were treated by giring one quart of raw linseed oil at a dose, and by using the same by injeetion into the rectum. Sone recovered after passing bloody urine. The Boyd herd of cattle ranged over this ground in the early part of the smmmer, and 3 head of them were with the Hulitt Brothers cattle later in the season, 1 remaining six weeks.

The Miller eattle, which were muloaded at IIarper on the 9th of April, were with 20 head of the erippled Boyd cattle in the yards and on the range north of the yards, and ate corn, cane, and millet-hay from the same piles. The deseription of the post mortem appearances in the Ament cattle, as given me by Mr. Hulitt, eonvinces me that they died with the southeru cattle fever.

We next stopped at Attica post-office, Harper County. There I saw Mr. G. W. Markham, who stated :

One of my two-year-ohl steers got anong the Boyd herd as they were passing along north of my range on the 10 th of April. I followed him and bronght him hack home the sance evening. Two ditys thereafter I sold him to H. L). 1) rmum, of Kiow: who has siuce fold me that th" steer died.

Mr. Drumm had 2 head of the Boyd cattle amomg his herd from the latter part of A pril until the 1st of July, but did not lose auy of his cattle except the one bonght from Mr. Markham. At Attica I was told that a yoke of oxen had been staked on the Boyd trail, sonth of Garlner's; they were used for brealing sod, and remained there all summer. No sickness followed the exposure. In the evening I met Mr. J.C. Fox, of Seymour, Iowa, at the Glem House, Hanper. lle told me that he brought four ear loads of cattle into Harper on the leth of $A$ pril. He 
held his cattle in the yards at night and on the range north four or five days, 1 of the Boyd cattle being with them all this time. These cattle were taken northwest 18 miles, on a range, and lemained there nntil the 20th of August. No loss or sickness appeared in this herd. Mr. Harlwick, of the Gilem Honse, told me that he lad a sick cow, also that be lost one several days ago. I promised to go out in the moming to see her.

On the 31 st I drove out ¿2 miles west to Mr. Forrey's inclosed pasture field to see the Hardwick cow. I found the cow in the following condition at 9.30 a. m.: Temperature $106^{\circ}$; lying ou the left side with hear thrown somewhat to the right; was apparently suffering great pain, as was manitested by her deep and agonizing groans; eyes prominent; left horn much colder than the right; nose dry ; skin a deep yellow color; pulse 86 ; respiration 20 ; painful and prolongerl expinations ; conld feel through the abdominal walls posterior to the ribs decided enlargement of the liver; auscultation and percussion revealed no lung tronble; thick viscid saliva stringing from the month-not profuse. At 10.15 the temperature was 97.5०. At 10.30 I introduced the instrument into tire bladder, where it ragistered $97.4 \circ$. I cut a deep gash into the tail, 1 inch in length, abont 4 inches below the root, in order to observe the flow and the color of the blood, but only a few drops oozed from the incision; it was very thin and watery. I cut another gash into the fleshy part of the thigh, but only a slight trickling of blood followed. In making these in. eisions the animal evincerl no pain. At 11 o'clock she made an effort to get up, but failed. A sweat now broke ont on the nose; pulse very tense, jet weak. As I stool by her side I could liear distinetly each heart beat. It appeared as if nature was eoncentrating all the strength that was within the animal to maintain the heart's action. She is now rest. ing on the sternum, with head extended, the lower jaw resting on the gromul, and groans at exeh expiration of bleath, to which it is painful to listen. Tremors of the vasti muscles, and also of the muscles of the neck, now appeared. At 11.15 temperature 980. I then left her; returued again at '2 p. m., and found her dead. The surface of the body was yet warm, and ont of curiosity I inserted the thermometer into the rectum, when it registered $103.50 \mathrm{~F}$. An hour later I returued prepared to make a post mortem examination. There were present at the examination Messis. Ewell, Cochran, and lioss, of Harper.

The animal was lying on the left side, and a quart or more of a greenish watery fluid had eseaped from the month and nose. After exposing the interual organs to view I found the lungs slightly emplyy. sematous and a frothy suuta in the capillary tubes; perieardium containerl about fi or 8 ounces of dark, bloody-colored fluil; external surface of heart extensively ecchymosed; in fact, looked limp, brnised, and worn out by sheer exhanstion; the internal surface of the heart was almost black, cansed by capillary congestion and extravasation of blood into the endocardinn ; no blood elots in the heart. The heart weighed 5 pounds. The spleen weighed 4 ponnds, and presented a disintegration 
of the glandular structure: the external surface presented unmerons ecchymosed spots, and a purple and gray-mottled appearance. The liver weighed 15 pounds, and possessed a spongy feel to the tonch; was darker in color than uormal, and manifested fatty degeneration. The gall bladder contained 30 onnees of thick, gramnlar appearing bile, of a greenish-brown color. The third stomach presented nothing abnormal, but the fourth presented the eharacteristic redness and erosions, exposing the rasenlar membrame, indieative of sonthern cattle fever. Surrounding the kidneys was discorered a yellowish gelatinons intiltration. The kidueys were darker than normal, and contained bloodycolored mine in the ducts and tubnli. The uterus contained a sixweeks' old fetus; this organ presented no marked lesions. The nrine bladker was distentled with 2 gallons of a dark; almost brown, colored mine; speeifie gravity 1.012. The blood in the blood ressels was not so thin as is usual in such cases, but was deficient in quantity. Mr. Hardwiek bonght these two cows, together with 48 other eattle, on or about the 1ith instant, from Mr. Bailey, who lives 2 or 3 miles northwest of town. The 48 hearl were taken down into the Indian Territory on the 16th-the same day the two cows were placed into the Forrey fiell. All of these cattle crossed sereral cattle trails before they reached the Forrey pasture. This day I saw Mr. L. C. Bidwell, of Anthony. He owns 2,000 head of eattle, which are pastured in an inclosel field containing 1:,000 acres, located in the Indian Territory, along the sonth line of IIarper County.

He stated that eattle had been dying all aromd his pastnre, but that he did not lose a single one. Mr. J. W. Walcott, of Harper, kept 11 cows from which he supplied milk to the citizens of Harper. He herded them north of the railroal track. The first loss occurren on the th day of July, after six days' sickmess; 10 head died before the 1st of August. The remaining one was sick three or fonr days, then began to improre, and in a week was again apparently well. Mr. R. J. Jones picketed his cow north of the railload track for the space of a week in the early part of July; no sickuess followed. He has owned the cow for four years. John Elrok, of Harper, owned $S$ hearl of work oxen, all of them wintered eattle. One of them was a Texan, eight or ten year's old, and had been owned in the comty several rears. These cattle were pastured north of the railroad at IIarper for a month before any disease appeared among any of the eattle in or aromel Harper. In the month of October 4 out of the 8 oxen clied, the old Texim being the last one to snecumb to the disease.

Un Norember 1 we drove to Anthonr, 9 miles sonth of Harper, prineipally for the purpose of seeing Mr. Ament, who suffered such a heary loss on the Hulitt range; but we failed to find him at home. Here I made inyuiries relating to disease amomg cattle, and was told no eattle in that immerliate locality died this year. Mr. Northup, a prominent cattle man of Anthony, told me that nearly all the domestie cows along 
the trail of the Anderson cattle died. The Anderson cattle passed 6 miles west of Anthony on their way sonth to the Territory line. $\mathrm{He}$ also told me that Mr. Singer, 10 miles east of Anthony, lost a large percentage of his cattle last winter ; they are said to have been in good condition and were well fed. They had been brought from Iowa and Northern Missouri in the fall. After returning to Harper I traced up the town cows that died in Harper as follows:

$\begin{array}{ll} & \\ & \end{array}$

All of these cows grazed north of the railroad track. The town cows which were not allowed to graze north of the track escaped the disease.

\section{HISTORY OF THE ANDERSON CATTIE.}

Six car-loads of cattle shipped from Springfield, Mo., in the name of the Bank of Springfield, and consigned to Mr. Anderson, were unloaded at Harper on the 6 th day of June. These cattle remained at the stoek-yards about ten days, ranging northeast of the yards during the day. They were then taken ont west about 4 miles, sonthwest until they reached the Medicine Lodge roai, followed this road into Barbour County, through the Illinois colony, and rested upon the range of P. B. Cole a week or more. They then were driven back again by way of Inyo post-office, thence by Joppa post.oftice, passing over IV. E. Kline's range 5 miles west of Attica post-office, then in a southeasterly direction toward Anthony, but leaving Anthony 6 miles to the east, then south to the line of the Indian Territory, then east along the line to Gilmore's range, 6 miles west of Caldwell, in the Indian Territory. Seventy-right head of these cattle were sold before they left Harper to a Mr. Smalley, in the sonthwest corner of Kingman County; and were driven by him in a direet conrse northwest from Harper to Kingman County, Mr. Anderson stated that these were Arkansas eattle. Mr. Cochran stated that he bought eonditionally 100 hearl of cattle in White County, Arkansas, last winter, but that Mr. Anderson afterward saw the same lot of eattle, and by ofiering more for them elosed a bargain, and drove them to Springfield, Mo. 
On November 2, we drove ont to see Mr. Potter, but he not being at home his son gave me the following information: They held cattle 12 miles northwest of Harper; they bought 131 liead of cattle out of the McMullen herd on the Botkin range; afterward added 106 head of do. mestic cattle bronght from the line of Kingman Counts. Two native milch cows were also turned in with this herd. Ont of the first herd (131) 32 died; out of the 106 head 26 died. All of these, excepting 4 head, died previous to the 10th of Angust-the 4 died in September, and 10 that were taken sick in Sejtember recovered. The first lot of cattle were bought on the 1 st of July, and were taken on the range on the stlı; the second lot were bought a few days later. The McNullen cattle began to die on the sth of July. Mr. Potter knows of no other cattle dying near their range.

Clutfelter and Thomas have a fenced pastme, 6 miles square, in Kingman and Harper Counties. This field contained cattle belonging to Clotfelter and Thomas, 300 head; Aaron Canalt, 160 head ; Mr. Blake, 300 head; Harroldson and Sheldon, 700 head. All of these cattle, except 610 head of Harroldson and Sheldon's, were wintered in this field, and during the winter 150 head died, the loss being attributed to insufficient food and water, and want of shelter. Harroldson and Sheldon placed into this field, in the month of June, 700 head of cattle, said to have heen brought from Missouri; Munger Brothers put in 400 head after the disease broke ont, and allowed them to remain until the 1st of October. In the month of Jnly disease apjeared among cattle in this field, and Harroldson and Sheldon lost 30 head. They removed their cattle early in September. The loss among Blake's cattle I could not ascertain. Clotfeltel and Thomas lost 3 head; Munger Brotliers, 16. No other cattle adjoining this field died, except a few in Flint \& Hanilton's field, located in the corner of Kingman, Pratt, and Barbonr Counties.

William Nance, 15 miles northwest of Harper, bought 3 steers out of the Boyd herd in the spring, took them home, and picketed them near his honse. After the steers were removed a cow was picketed on the same ground; in about two weeks she became sick and died. Soon afterward Mr. Nance bought two cows, picketed them on the same place; both of them became sick, and one died. The steer's remained well. This completes my investigation of cattle disease in the comties of Harper and Barbour.

List of herds of cuttle suspected of conveying the disease.-No. 1, the Boyd cattle, arrived at Harper April 6; No. 2, the Anderson eattle, arrived at Harper June $\mathbf{6} ;$ No. 3 , the Scoby eattle, arrived at Harper June 6 ; No. 4, the McClumg eattle, arrived at Harper July; No. 5 , Arkansas cattle, which erossed MeGee's range in June; No. 6, three emigrant herds through Medicine Lodge June 1 ; No. 7, Shanstrom cattle, June 1; No. 8. Garrison cattle, arrived at llarper June 1S; No. 9, 
contyty round-11p, in Barbour, July 1 to 15; No. 10, Territory romd-11p, in Barbour Comnty, June and July; No. 11, enigrants which passed by Pratt's in June; No. 12, the Wisner oxen, inchuling the Downing yole, arrived at Hanper in Febrnary; No. 13, Martin cattle, from Mr. Potter, October 6.

It may be said that all of these herds rest under greater or less sus. picion; but, owing to the limiterl time allotted to me for my investigations, I have not been able to establish the fact that any of them were capable of communicating disease to other cattle, directly or indirectly.

The following summary may be readily understood :

\begin{tabular}{|c|c|c|c|c|c|c|c|c|}
\hline Owuer. & $\begin{array}{l}\text { Exposed to } \\
\text { herrls } \\
\text { number- }\end{array}$ & 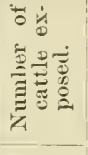 & 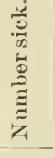 & 㟧 & 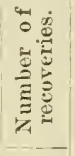 & $\begin{array}{l}\text { Date of out- } \\
\text { break. }\end{array}$ & Value. & County. \\
\hline Dr. Joseph Brockway. . & 1,11 & 75 & 28 & 23 & 5 & July 10 , Sipt. & $\$ 575$ & Harper. \\
\hline E. Wallen & 1,2 & 7 & 7 & 7 & & Sept $\ldots . . . .$. & 275 & Do. \\
\hline Wood. & 1,2 & 13 & 5 & 1 & 4 & & 30 & Do. \\
\hline B. Moyd ................ & $8,9,10,12$ & $\begin{array}{l}680 \\
200\end{array}$ & 16 & 16 & & Sept. & 320 & Barbour. \\
\hline Cook .............. & $1,5,7,9,11,12$ & $\begin{array}{l}200 \\
331\end{array}$ & $\begin{array}{l}29 \\
90\end{array}$ & $\frac{21}{75}$ & $\begin{array}{r}8 \\
15\end{array}$ & $\begin{array}{l}\text { Sept. } 15 \text {..... } \\
\text { July } 9, \text { Augr. }\end{array}$ & $\begin{array}{r}630 \\
2,000\end{array}$ & $\begin{array}{l}\text { Do. } \\
\text { Do. }\end{array}$ \\
\hline A. B. Ramalls... & $1,5,7,9,11,12$ & 150 & 30 & 30 & & Sep & 900 & Do. \\
\hline & $1,5,9,10,11$ & 250 & 156 & 156 & & July 1, Sept.1. & 4,680 & \\
\hline r. Pa & $\cdots$ & $\begin{array}{r}116 \\
80\end{array}$ & 10 & $\begin{array}{l}6 \\
5\end{array}$ & 4 & $\cdots$ & 300 & Do. \\
\hline (n... & $\begin{array}{l}5,6,9 \\
5,6,9\end{array}$ & $\begin{array}{r}80 \\
700\end{array}$ & 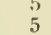 & $\begin{array}{l}5 \\
5\end{array}$ & $\because$ & dng., & 200 & \\
\hline$\cdots$ & $5,6,9,10$ & 200 & 15 & 15 & (n...... & Sept. $15 . . . .$. & $\begin{array}{l}150 \\
600\end{array}$ & $\begin{array}{l}\text { Do. } \\
\text { Do. }\end{array}$ \\
\hline & & 110 & 4 & 2 & & Oet. $12 \ldots$ & 80 & \\
\hline ... & Feneerl...... & 3,500 & 7 & 7 & & sen. & 210 & $\mathrm{D}$ \\
\hline & $\ldots .$. & 500 & 10 & 10 & & Sept, $10 \ldots$ & 300 & $\begin{array}{l}\text { Indian Ter- } \\
\text { ritory - }\end{array}$ \\
\hline$\cdots \cdots$ & 15 & 500 & 16 & 16 & & & 480 & Barbour. \\
\hline . & 1,5 & $\begin{array}{l}300 \\
255\end{array}$ & $\begin{array}{r}53 \\
136\end{array}$ & 33 & $\begin{array}{l}30 \\
40\end{array}$ & $\begin{array}{l}\text { Sept. } 1 \\
\text { Juls, S }\end{array}$ & 990 & $\begin{array}{l}\text { Do. } \\
\text { Do. }\end{array}$ \\
\hline $\mathrm{D}$ & $\begin{array}{l}1,3,10,11 \\
1,8,9,12\end{array}$ & 300 & 77 & 67 & 10 & $\begin{array}{l}\text { July 4, Sept. } \\
\text { l to } 10 \text {. }\end{array}$ & 2,450 & Do. \\
\hline E. C. Davis & 1 , & 60 & 9 & 6 & 3 & July $1 \ldots$ & 236 & Do. \\
\hline $2 \mathrm{t}$ & & 600 & 185 & 85 & 100 & Sept.10. & 2,250 & \\
\hline & & 10 & 3 & 3 & ... & & 120 & \\
\hline still. & $1,2,8$ & 20 & $\frac{2}{5}$ & 2 & & $1 y+8$ & 70 & \\
\hline AI. I. Moure.... & $1,2,8,9,12$ & $\begin{array}{l}100 \\
123\end{array}$ & 48 & 40 & $\begin{array}{l}3 \\
8\end{array}$ & July 11 , Sept. & 2,000 & $\begin{array}{l}\text { Do. } \\
\text { Do. }\end{array}$ \\
\hline C. Me & 1. 2 & 60 & 6 & 6 & & & 240 & D \\
\hline & $1,5,6$ & 108 & 30 & 15 & 15 & A & 480 & I \\
\hline II & 0 & 125 & 7 & 7 & & $\ldots$ & 245 & \\
\hline s. & 1,2 & 17 & 1 & 1 & 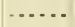 & .... & 20 & \\
\hline$\ldots \ldots$ & & & 3 & 3 & & $\cdots$ & 100 & Har \\
\hline W. H. Wisner ...... \{ & $1,2,11,12,13$ & $\begin{array}{l}120 \\
300\end{array}$ & $\begin{array}{r}30 \\
3\end{array}$ & $\begin{array}{r}30 \\
3\end{array}$ & & $\begin{array}{l}\text { Sept. ........ } \\
\text { Oet. }\end{array}$ & $\begin{array}{l}600 \\
500\end{array}$ & barbour. \\
\hline Ј. Н. Warreи........ & 12 & 40 & 4 & 4 & & Sept... & 160 & Do. \\
\hline . $\cdots \cdot$ & $1,2,11$ & 3 & 1 & 1 & & & 40 & Ifar \\
\hline$\cdots$ & & 15 & 7 & 7 & & July 4 & 340 & \\
\hline$\cdots$ & 11,13 & 4 & 2 & 2 & & ... & 84 & Har \\
\hline$\cdots$ & -5 & 6 & 6 & 5 & 1 & & 205 & \\
\hline rant. & 11 & 10 & 1 & 3 & 7 & & 120 & \\
\hline 政 & & 18 & 1 & 11 & & t.. & 56 & \\
\hline ... & & 18 & 1 & & & sept.. & 300 & \\
\hline & $1,11,13$ & 100 & 3 & & & & 1,260 & \\
\hline ard .. & & 5 & 4 & 36 & 8 & Si & 1,270 & \\
\hline & & 10 & 1 & . & 6 & $\mathrm{Se}^{\mathrm{s}}$ & 400 & \\
\hline & $1,2,4,8,12,13$ & 200 & 10 & 10 & & & 250 & \\
\hline ton & 1,11 & 27 & 1 & 1 & & $J_{11}$ & 200 & \\
\hline (1) & ........ & 70 & 60 & 60 & & & 1,800 & \\
\hline $\begin{array}{l}\text { Mr. Domalue ..... . } \\
\text { Flint \& Hatmilton..... }\end{array}$ & & $\begin{array}{r}14 \\
900\end{array}$ & $2 \frac{2}{29}$ & $\stackrel{2}{17}$ & i2 & Sept & $\begin{array}{r}70 \\
950\end{array}$ & Sumner. \\
\hline & & & & & & Selpt. & & $\begin{array}{l}\text { Rin } \\
\text { Pi's } \\
\text { Biar }\end{array}$ \\
\hline R. Botkin & 11 & 562 & 184 & 184 & & $J_{11}$ & 5,520 & IIarper. \\
\hline $\mathrm{Mr}$ & & 2 & & 1 & & & 50 & 1 \\
\hline 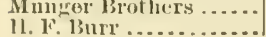 & 1073 & 510 & It & 10 & $\ldots .2>>$ & (1) June & 750 & 13arbour. \\
\hline & $1,2,13,12$ & 475 & 450 & 179 & 271 & Sept........ & 3,495 & Harper. \\
\hline
\end{tabular}




\begin{tabular}{|c|c|c|c|c|c|c|c|c|}
\hline Owner. & $\begin{array}{c}\text { Exposed to } \\
\text { herds } \\
\text { number- }\end{array}$ & 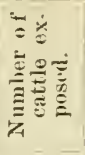 & 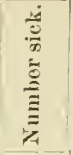 & 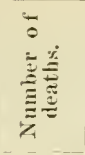 & 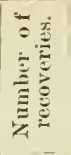 & $\begin{array}{l}\text { Date of out- } \\
\text { ureak. }\end{array}$ & Talue. & County. \\
\hline A. Hilliard & 1,2 & 5 & 2 & 2 & & .Inls, Sept... & $\$ 80$ & Harper. \\
\hline Matt Miller & 4 & 75 & 9 & 9 & & ..... & 200 & Do. \\
\hline Got \& Teaver ........ & $1,2,3,8,12$ & 200 & 24 & 24 & $\ldots \ldots$ & Juls $20 \ldots$. & 600 & Do. \\
\hline ort ..... & .............. & 700 & 10 & 10 & ....... & $\ldots$. & 300 & Barlour. \\
\hline ............ & $\ldots .$. & 420 & 4 & 4 & ..... & ... & 125 & Do. \\
\hline ( ......... & 6,7 & 60 & 3 & 3 & $\ldots$. & Sep & 75 & Do. \\
\hline$n n \ldots \ldots$ & $\ldots$ & 100 & 12 & 12 & $\ldots$. & ... & 400 & Do. \\
\hline $\begin{array}{l}\text { Salt Forkes and Eagle- } \\
\text { chief pool. }\end{array}$ & $(*)$ & 20,000 & $\cdots$ & sereral & & & ... & Do. \\
\hline $\begin{array}{l}\text { Land Creek and Hack- } \\
\text { berry pool. }\end{array}$ & & 3,500 & $\ldots$ & 15 & & $\ldots$ & 500 & Do. \\
\hline ley ....... & 6,7 & 400 & 10 & 10 & & Sept & 300 & Do. \\
\hline son ......... & $6,7,9$ & 550 & 3 & 3 & ... & ... & 150 & I ho. \\
\hline $1 \ldots \ldots \ldots$ & $1,6,9,12$ & 3 & I & 1 & $\ldots \ldots$ & $\ldots .$. & 160 & Do. \\
\hline ls $\ldots . . . .$. & ............ & 225 & 16 & 16 & ..... & ... & 500 & Do. \\
\hline ........ & $\ldots \ldots \ldots \ldots \ldots$ & 40 & 3 & 3 & ..... & ..... & 120 & Do. \\
\hline .......... & . . . . & 5 & 6 & 6 & ...... & ..... & 210 & Do. \\
\hline$\ldots \ldots \ldots$ & $\ldots \ldots$ & 400 & 47 & 35 & 12 & $25 \ldots \ldots$ & 1.555 & Do. \\
\hline$\ldots \ldots \ldots$ & $2,8,12,9$ & 144 & I & I & $\ldots .$. & ... & 30 & U. \\
\hline \& Co ....... & $1,5,6,7,9$ & 700 & 10 & 10 & ... & , Oct... & 520 & 1) \\
\hline . . . . . . . . & $1,2,7,8,9,12$ & 400 & 25 & 25 & . & July. Sept .. & 1,000 & I) \\
\hline Dark ........ & $1,2,7,8,9,12$ & 350 & 16 & 16 & & $\ldots \ldots$ & 480 & I) \\
\hline$\ldots, \ldots, \cdots \cdots$ & $1,2,3,8$ & 300 & 87 & 47 & 40 & July $12 \ldots$. & 2,081 & Harper. \\
\hline steer" & $(t)$ & $\begin{array}{r}1 \\
48\end{array}$ & $\begin{array}{l}1 \\
2\end{array}$ & $\begin{array}{l}1 \\
2\end{array}$ & . & 0 & $\begin{array}{l}30 \\
80\end{array}$ & Do. \\
\hline ott $\ldots . . . . .$. & $\left(\begin{array}{l}(1) \\
+\end{array}\right)$ & 11 & 11 & 10 & $i$ & $4^{20}$ & 500 & Do. \\
\hline . & & 8 & 4 & 4 & ... & $\ldots \ldots$ & 200 & () \\
\hline Harper ... & $\ldots \ldots \ldots \ldots$ & 18 & 18 & 18 & ....... & $4 \ldots \ldots$ & 695 & no. \\
\hline Potter \& Son ......... & $1,2,3,8,12$ & 239 & 68 & 58 & 10 & July $8 \ldots .$. & 1,160 & Do. \\
\hline Clotfelter \& Thomas.. & & 1,560 & 49 & 49 & $\cdots$ & July ......... & 1,470 & $\begin{array}{l}\text { Kingman } \\
\text { and Har. } \\
\text { per. } \\
\text { Harper. }\end{array}$ \\
\hline Total & & 19,229 & 272 & 1,168 & 60 & & 56 & \\
\hline
\end{tabular}

* Supposed Arkansas cattle.

t All of the trails at the west edge of Harper.

All noith of the railro:dl at IIarper.

It will be safe to sas that 2.000 liead of cattle died this year, in IIarper and Barbour Counties, with the soutliern cattle ferer, and that the direct and indirect loss will not fall sbort of $\$ 75,400$.

\section{GLANDERS AMONG HORSES.}

Before leaving Harper, I went northeast 11 miles to the residence of Mr. Alexander Cheesman, to investigate the nature of a disease among horses, supposed to be glanders. After arriving at the place, $\mathrm{Mr}$. Cheesman led the affected horses ont of the stable. The first one I examined was a ten-year-old horse belonging to Joseph Cheesman. This horse hail a discharge from both nostrils, of a greenish-yellow color; considerable tumefaction across the exteruai surface of the nasal bones; dulness upon perenssion was manifest orer the maxillary sinuses; numerous ulcers of rarious sizes were visible upon the nasal septum, chance-like, and of a dirty rellowish color, with elevated serrated borders; milliary tubercles appeared in clusters on the selneirlerian membrane, extending as far up in the nasal cavity as I conld see. Both the submaxillary lymphatic glands were enlarged, hard, and norhlar to the sense of tonch, but not strongly adherent to aljacent structures. An abscess was in process of formation on the lower surfice of the chest, one on the inside of the right hind leg, another one on the molar bone, and one on 
the left temporal bone-veritable farey burs. On pereussion, dulhess was manifest over the inferion lobe of the left lung; respiration was acceleiater. 'There was also a discharge of thick viscid matter from the left eye, and swelling and partial protrusion of the membrane nie. titans. I was told that this horse had been conghing, more or less, for a seal.

The next one which was len ont for examination was a six-year-old bay mare, also belonging to Joseph Cheesman. She had a discharge from the right nostril, which was of a very glney character, adhering around the maroin of the nares, numerous small characteristic glanders ulcers on the septum nasi, and enlargement of the submaxillary lymphatic glands on the colresponding side. Both hind legs were edematous and presented swelling and tumors along the lymphaties, extending from the hock upwards to the inguinal region; the inguinal glands also were enlarged, hard, and seusitive to touch.

The third animal examined was a gray horse, fifteen years of age, belonging to Alexander Cheesman. He had a discharge from the left nostril; a hard swelling-the size of a walnut-of the left submaxillary lymphatics; a few small circumscribed tumor's distributed orer the sur. face of the body-farey buds. This horse presented no visible nasal ulcerations. I examinerl two other horses, which have been in the same stable with the affected ones, but could discover no evidence of disease in either of them. Mr. A. Cheesman told me that a four-year-old mule died in the same stable in the month of March, and that she presented symptoms similar to the first horse that I examined. I pronounced the three horses to be affected with glanders and urgerl the owners to have them destroyed; but they did not promise to follow my advice, unless they could get some recompense from the county or State. On the 10th of November I addressed a letter to Hon. G. W. Glick, governor of the State of Kausas, stating to him how I found those horses affected, and requesting him (in the absence of a state boarl of health) to take the matter in hand if he had any anthority to order the destruction of such diseased animals. In reply I received from him the following auswer:

I have no anthority under the laws of this State to do auything in relation to the diseased horses of which you write, but I shall call the attention of the eonuty attorney to the matter and see whether he ean do anything by communicating with the parties to induce them to kill their discased stock.

\section{HOG CHOLERA, OR SWINE PLAGUE.}

Having hearr that hog eholera proved very fatal to hogs in the ricinity of Mulvane, Sumner Connty, Kansas, I left Harper on the moning of the is and anrived at Mulvane m the evening. There I saw Mr. E. F. Osbori. He informed me that Mr. Rucker, Mr. Kennedy, and Mr. Smith had suffered hravy losses this year by the death of their hogs. Next morning I saw Mr. A. A. Rucker, who resicles three-quarters of 
a mile sonth of Mulvane. He told me that a year ago a number of hogs were shipped into Mulvane, eoming from the State of Iowa. Several of them broke ont of the yards and had the run of the town for several days. Tiley got in with some hogs belonging to Mr. Hill, of Mulrane; soon afterward Mr. Hill's loges began to sicken and to die. Mr. Rncker's hogs eseaped from their pasturage and got in with Hill's logs, rooted around, and probably ate of some of the rleat : in seren or eight days Mr. Rncker's hogs beeame sick, and many of them died-he lost "25 per cent. Ten females recovererl, and were kept until this spring, but failed to breed. Last spring Mr. Rucker bought 110 head of hogs from his neighbors, and placed them on the same grounds where the hogs hat died the year previons. In the month of June they began to die; and this time he lost, ineluding small pigs aud shoats, 150 head. 'Ten of them were large, fat hogs. Estimate of loss, \$S00. I then saw Mr. E. A. Kennedy, who lives 3 miles sonth of Mulrane. He lost this year 150 out of 350 heal of $\operatorname{logs}$, 50 of them being large hearg animals. Estimate of value, $\$ 1,000$. Mr. Smith, a neighbor to Kennedr, also lost a large number of hogs this year. All the logs in these three different herds have been indirectly exposed to the imported hogs, or to each other. From the deseription of the symptoms of the discase, as given me by Messrs. Rueker and Kennedy, I eonclude that the disease luas been true hog eholera; but none were sick or recently died, therefore no opportmuity was afforded me to establish the nature of the disease positively.

\section{OUTBREAK OF SOL'PHERN CATTLE FEVER IN BUTLER COUNTY, KANSAS.}

In your instructions of the 9th of October, you referrer me to Senator P. B. Plumb, of Emporia, for information in relation to the locality of a disease among cattle in Butler County. I addressed a letter of inquiry to Senator Plumb, dated the 13 th of October, and reeeived the following reply:

Wasurgtox, D. C., October:20, 1--3.

Dear SIr: Yours of the 13 th has just reached me. I do not know exactly whom to suggest that you call upon in Butler Connty for information ahout cattle disease, but if you call on Hon. A. L. Redien at El Dorado, or Hon. Neil Wilkie, at Donglas, they can put yon on the track.

Respeetfully,

I. 13. PLIMIB.

M. R. Trumbower, V. S.,

$$
\text { Horper, hians. }
$$

After the receipt of Senator Plumb's letter, I acluesserl the parties referred to and received answers from both, stating that I should go to El Dorado to find what I desired. I reached El Dorado on the Th of November, and moceeded to Hon. Redden's oflice, hut found lim absent; his clerk took ne to the bink of El Dorado and introduced me 
to Mr. V. Brown, who, in turn, aceompanied me to the eity mayor's office and introduced me to him-Dr. A. Bassett.

Dr. Bassett assisted me very materially in my inrestigations and manifested the greatest legree of interest in my work while I remained at El Dorado. At his office I was introduced to the Rer. S. F. C. Garrison, who resides 3 miles west of El Dorado. He made to me the following statement: That he placed under the care of Mr. Matthew Robeson 18 head of cattle on the 17th day of April-17 of them being grown cattle, the remaining one a calt; that all of these cattle, excepting 2 head, were to be kept in the dry herd; that on the 1st of June 1 of these eattle was taken away from the herd, and on the 1st of July a seeond one was removed, leaving 16 head (ineluding the ealf) to remain. On the 24 th of September the 16 were also taken home; this took place owing to the report that eattle were dying in this herd under suspicions cireumstances. When Mr. Garrison took his eattle home he turned them into a fiell with 12 heal of other eattle. On the 30 th day of September 1 cow died after a sickness of two or three days; 11 of them died in rapid suecession, the last death ocemring on the 10th of October. All of the 11 that died had been removed from the Robeson lierd; none of the home cattle beeame affected. Mr. Garrison observed the symptoms manifested during the course of the disease to be-

A peculiar odor arising from the skin of the affected animal; then a dry, hard, husky cougl, especially when urged to move around; heal carried exteuded; ears droop; pnshing the head against straw-stack or fence ; loss of appetite; no desire for water; rumination suspended; segregation ; weak aud staggering gait ; saliva flowing from the month; whites of the eye assnme a yellow tinge; perspure excessively toward eveniug, which is of a very disagreeable odor; sliake the heal from sicle to side as if in pain; trembling of the muscles sets in upon the slightest exertion; pulse beats rapid aud hard; become nnable to rise; partial coma and death ends the scene. One of them liverl eight days; another five, and others from three to five dars before dissolution took place; several died in strong paroxysms of pain, mauifest by getting up aud lying dow very frequently, accompanied by violent efforts to uriuate and defacate. The manure was usually eovered with blood and uncus and the act of uriuation was very painfnl.

Mr. Garrison made three post-mortem examinations, and deseribes the following appearances :

Lungs filled with air and infiltrated with muens; the lining membrane of the airtubesseemed slightly congested and irritated ; the chest eavity contained some blowlycolored water; the contents of the pannch were hard, aurl the medicine which had been administered hat not been absorber; the contents of the manifolds in two of the animals was baked and dry as tobacco, and the folds softened and rotten; the intestines seemed swollen, and the lining menbrane coated with mucus; the kidneys were of a greenisl eolor, softened, and enlargerl; the urine bladder was ilistended with dark-colored mine, one of them eontaining fully one gallon of clotted black blood; the heart was pale and flacedi the blood in all three eases was darker and thicker than natural; jo secmed to be more like paint than blood; the splecen was greatly en]arede and the inside of it broken 11 iuto a pulp; the liver wats thickened and filled with blood, the ontside color boing a glossy green, some parts more highly colored than others; the gall-bladide containen in one case one pluat of thick, viscid, yellowish gramnlar bile; the large blood-vessels along the spine seemed diseased, 
presenting au unhealthy iuternal surface ; in one of the animals one of the horus became loose before death.

Loss, 11 ont of 18 ; value, $\$ 277$; 3 recoveries.

Joseph Sharp, living in El Dorado, said that he had 3 cows with their calves, and 2 weaned calves in Mr. Robeson's drș herd; they were put in on the 12th of May, and removed on the 25th of September. One of them manifesterl signs of sickness on the erening when she was taken lome, and in a week thereafter she died. This cow seemed to suffer more pain during the middle of the day than in the morning or evening. At the time the first one died, two other's were found to be sick; they both died; the last death took place on the 5 tin of October. Three of the calves were sick, but recovered. Loss, 3 ont of 6 ; value, 5125 . Post-mortem examinations of " 2 of the eows were made by Mr. Sharp' He found the bladder distended with a brownish-red urine, spleen twice or three times the normal size and rery dark colored on the surface. In one of them, which had been purged by feeding corn and millet, the contents of the third stomach were found soft, in the other, the contents were hart and dry, "could be shaved down into elipis," aud the folds black and rotten. The blood in all 3 of them that died was too thick. Only 1 of these eattle passed blood with the feces.

Mrs. Sunith lost one heifer in the Robesoli herd on the $22 d$ of September; another one, which she took home on the 25th, died on the 2sth. She hat only 2 head of eattle in the herd-value, $\$ 60$. On the 231 of September Mr. Robeson called upon S. P. Barnes, a butcher in El Dorado, to make examination of 2 head of eattle that died in the herd. Mr. Barnes gare the following statement:

I fomd one enw had been purging, and in this the contents of the third stomach were natmal; the secoml eow had been constipated, and in her I fomd the contents of the thirl stomach harder and drier than natural. The livers and kidneys in both animals appeared pale aul fuled in color, as if the coloring matter lial been removol.

In one I fonnd the urine bladler was empty ; in the other it was filled with bloodycolored urine; in the latter the inside of the bladler seemenl hart and tannerl, and alunst black in color. The spleens were three times as large as natural, but the livers were not enlarged. One of the auimals-a three-rear-old cow-was not quile ilead when I arrived at the place where she lay. I ent her throat, but harmy any blood escaped; the small amomnt which llowerl was too thin and watery. The cow that I found dead, also, was almost destitute of hool. The tallow in both these cows was much too yellow, and I fonnd this same yellow conlition of the lallow in sor 10 other eattle which died afterwarl on the same range with the same disease. The meat of these cattle was light colored, like veal, and a disagreeable odor was present in all of tho animals, deal and living. I never hefore saw any cattle sick with or die of Texas fever, but the moment I saw these I was sutisfied that they died with that diseaso.

E. B. Cook, residing 7 miles northwest of El Doralo, stated that he placed 6 head of eattle-all cows and heifers-in the drs herd of Mr. Robeson on the (ith day of May, and took them away on the ezal of September. One of them died on the 27 th, another on the $30 t h$, and a third one on the 4th day of Getober. Two of them passed bloody urine. "I'wo that were sick recoverel. When he took them home he placed 
them into a field with 14 head of other cattle. None died but those exposed on the Robeson range. Loss, 3 ont of 6 ; value, $\$ 100$; 2 reeoreries.

Mossman Bros. reside 8 miles northwest of El Dorado. History by Henry Mossman: On the 6th day of May 18 head of cows and ealves were taken into the Robeson herd, and remained until the 25th of July. They were then sold to Bearsley \& McAnaly. Twenty three head of steers were placed into this same herd on the 25th of July, and 17 eows on the 21st of September. On the 23d of September the steers and cows were taken home. One of the steers was sick on the day he was removed from the herd, and died on the day following; 6 more died in the conrse of three weeks, and 4 that were sick recovered. Of the 17 cows which remained in the herd only 2 days, 4 sickened, and 2 of them died-the first one on the 10th of October, the other one a few days later. The medication resorted to consisted in giving one gallon of melted lard at a single dose. In three cases this dose was repeated, and in a fourth one an addition of ten drops of croton oil was givell. Out of the 4 so treated 1 died. None that reeovered had been seen to pass bloody urine, but in a few the manure was covered with coatings of mueus and blood elots. Mossman Brothers made two post-mortem examinations, which revealed the following pathological conditions: Blood was contained in the bladder; in one blood extravasations were found in the region of the kidneys; also on the surface of the body, extending along the spine for a space of 18 inches. This one diei twenty-four hours after the first evidence of sickness was discovered. The spleens were greatly enlarged; livers appeared about natural. The contents of the third stomach were normal in one ease; in the other they were dry. Loss, 7 out of 23 steers, valued at $\$ 315$, and 2 cows out of 17 , valued at $\$ 60 ; 6$ recoveries.

I tested the temperature of 4 of the animals that had been sick, whict registered as follows: $103.2^{\circ}, 103 \circ, 102.6^{\circ}, 102^{\circ}$; of one which had not been sick, $102.2 \circ \mathrm{F}$. These cattle are all looking well, and are fattening rapidly. They are contined in a straw yard, and get all the corn they can eat. The hogs at Mossman's ate one of the dead cattle; ten days thereafter 4 of them were notieed to be sick; 3 recovered in about ten days; 1 died in fire or six days. The one that died had a fit of apoplexy two months previons, and had never entirely recovered from the effeets of it; was subject to involuntary diseharge of feces and urine, and had an imperfeet control over its morements. Matthew Robeson, a herder of eattle residing in El Dorado, made the following statement to me: That he has heli a range for four suecessive years, extending from the eorporate limits of the eity of El Dorado a miles northwest, by 2 or 3 iniles wille; that he has been herding eattle belonging to himself and to other parties on this range this season, beginning to take them in on the 17th day of April. 'The first death among his herd oceurred on the 10th day of September-a cow owned 
by Mr. Saxton; the second one which died was an animal belonging to Mrs. Smith; she died on the $22 d$; on the day following 2 head died belonging to Mr. King.

He then had an examination instituted, and as a result of that examination notified all the owners of eattle in his possession to remore them forthwith. Mr. Robeson also stated that he receired into his herd on the 20th day of July is head of eattle belonging to Daris \& Connelly, butchers, of El Dorado; that some of these eattle remained on the range until the 2Sth of September. They were half-breeds with the exception of 7 head, which were supposed to be thorough Texans. The Texans were in poor condition when they were brought on the range, and were marked ou the middle of the left side with an inverted $\mathrm{A}(\mathrm{F})$ brand. Again Mr. Robeson stated that he received from Isaae King 300 liead of eattle on the 9 th of June.

Mr. King bought, during the winter, along the north line of Arkansas and south line of Missouri 1,000 head of eattle, collected them at Fort Scott in Mareh, shipled them at the latter place, and unloaded at El Dorado on the 25th of April. He drove them on the range north and northwest of El Dorado, and there herded them until the 9th of June. He then drove 700 of them into Colorado on his eattle raneh, and placed the remaining 300 head nnder the care of $M 1$. Robeson, who already oceupied the range at that time with a number of the town and other cattle. On the 9th of Angust 120 head more of the King eattle were taken into Colorado. I next saw Mr. Comelly, of the firm of Daris \& Connelly, and got from him the following history:

I bought on the 18th of July 68 head of half-breed eattle from Mr. Page. These eattle harl been wintered on Deer Creek, 12 wiles southeast of Caldwell, Sumner County, Kausas. When I bonght them they were on a range, owned by Mr. Cox, 6 miles sontheast of Caldwell, on Bluff Creek. I bought 7 head more to fill out the car; these were brought to Caldwell early in the spring from Benton County, Arkansas. I unloaded at El Dorado on the 20th of July, and placed my cattle in the care of Mr. Robeson. When I bought the $\tau$ head of Arkansas cattle they were with a herd of 50 or 60 good grade native eattle, a $\$ 500$ bull and several polled Angus cattle. None of the latter died during this season.

Ir. Counelly also informed me that Mr. Carter, whose farm adjoins that of Mr. Cox, lost 38 out of 50 or 60 liead of eattle. Five of them were full blood polled Angus, and another a Hereford bull, for which Mr. Carter paid \$1,000 list spring. All of Carter's cattle were held seeurely in an inclosed field, and have not been exposed to any foreign eattle.

On the 10th I saw Mr. James Mossman, who had just returned from Caldwell, where he had been to ascertain where the Connelly eattle came from. As near as lie could discover the $6 s$ head were bought from Mr. Carter; had been wintered eattle, half-breeds; that Mr. Carter lost many cattle at abont the same time that the cattle began to die at El Dorado, and that Mr. Connelly hat bought the T head from a Mr. Sinythe (the agent for Mr. Donalason, of Arkansas City). These 7 heal were supposed to be through cattle from the Pan Handle, and 
were bought ont of a herd on the Johnson and Hosmer range, near Caldwell, in the Iudian Territory. Ou Sunday, November 11, aceom. panied by Dr. Bassett and Mr. Davis, I drove ont to ex-Brig. Gen. G. T. Wilde's, who, with his eopartner, Colonel Mason, are engaged in the breeding and feeding of cattle. Colonel Mason was absent from home, but General Wildes gave me the following history:

Mr. Mison visited Halsteal, Harvey County, Kansas, in the montl of August; here he found that a number of cattle had died-town cows-with the Texas fever, attributed to infection received through a herd of cattle bronght from the line of Arkansas and Missonri; that these were the only foreigi eattle bronght into Halstead this seison. These cattle unst come very nearly, if not quite, from the same section of country as that from which the King eattle are said to be derived.

On the 12th I went ont over the range where Robeson had herded his cattle during the summer. I found it to be an elevated ridge of limestoue soil, extending for miles northward along the west side of the Walunt Creek. The Walnut Creek supplied the cattle with water morning and evening. The water was perfectly sweet and pure. At noon the eattle drank from a spring ereek, which takes its origin from several springs located on the range. The grasses are the usual prairie grasses found throughont the middle section of the State, composed chiefly of bunch grass or blue top, blue grass, and here and there is to be seen small patches of buffalo grass, the latter oecurring where there is alkali soil or the remains of what are ealled buffinlo wallows.

I also went ont with Mr. Robeson to exanine and to see the condition of the King cattle. These are the only cattle which yet remain in the charge of Mr. Robeson and are located in a corral 2 miles west of town for winter feeding. I found them to be rery diminutive cattle (mullet heads) and also in a very poor eondition to withstand thr iuclemency of winter. Many of them were three-year-old steers, but none of them exeeeded 600 pounds weight. Many of them, however, have been siek, but have so far reeovered as to begin to lay on flesh again. I tested the temperature of 7 heal that had been sick, which registered as follows: $100^{\circ}, 100.2 \circ, 99 \circ, 101^{\circ}, 101.4^{\circ}, 102 \circ, 101^{\circ}$; of four that have not been sick, $97.7^{\circ}, 101.4^{\circ}, 101.3^{\circ}$, and $100.8^{\circ} \mathrm{F}$.

Through the kindness of Mr. Robeson I am enabled to make an acenrate tabulated statement of the number of cattle that were placed in his eare during the season, the dates at which he received them, and the time when they were removed from the infected range:

\begin{tabular}{|c|c|c|c|c|c|c|c|}
\hline \multicolumn{2}{|c|}{$\begin{array}{l}\text { Thate of } \\
\text { reception. }\end{array}$} & Orners. & $\begin{array}{l}\text { Number } \\
\text { received. }\end{array}$ & $\begin{array}{l}\text { Namber } \\
\text { died. }\end{array}$ & $\begin{array}{l}\text { Nimber } \\
\text { recoresed. }\end{array}$ & Value. & $\begin{array}{l}\text { When re- } \\
\text { moved. }\end{array}$ \\
\hline \multirow{6}{*}{ April } & 17 & litv. S. F. C. Garrison.............. & 18 & 11 & 3 & $\$ 277$ & Sipt. 24 \\
\hline & 17 & 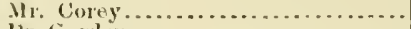 & ذ & 1 & - $\ldots .$. & 40 & St+pt. 2 \\
\hline & 17 & 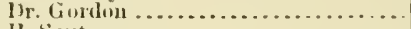 & 1 & & $\cdots$ & $\cdots$ & ....lo. \\
\hline & 17 & 11. Saxton $\ldots \ldots \ldots \ldots \ldots \ldots \ldots \ldots \ldots$ & 1 & 1 & ... & 40 & ... \\
\hline & 17 & 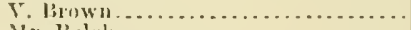 & l & 1 & & 40 & $\ldots \ldots$ \\
\hline & 27 & Alr. Baldeh $\ldots \ldots \ldots \ldots \ldots \ldots \ldots \ldots$ & 3 & $\because$ & $\because$ & & sept. 2 \\
\hline \multirow[t]{3}{*}{ May } & 2 & Mr. Cirpples....................... & 2 & 1 & 1 & 40 & . 10.. \\
\hline & 2 & 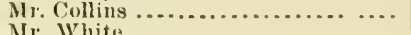 & 1 & I & & $\cdots$ & ....do . \\
\hline & 3 & Mr. Whito.......................... & 1 & & ........... & 40 & 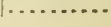 \\
\hline
\end{tabular}




\begin{tabular}{|c|c|c|c|c|c|c|c|}
\hline \multicolumn{2}{|c|}{$\begin{array}{l}\text { Date* of } \\
\text { reception. }\end{array}$} & Owners. & $\begin{array}{l}\text { Number } \\
\text { receired. }\end{array}$ & $\begin{array}{l}\text { Nimber } \\
\text { died. }\end{array}$ & $\begin{array}{l}\text { Number } \\
\text { recorered. }\end{array}$ & Talue. & $\begin{array}{l}\text { When re. } \\
\text { moved. }\end{array}$ \\
\hline \multirow[t]{9}{*}{ May } & 5 & Mr. Paseal . . . . . . . . . . . . . . & 1 & ; & & & Sept. 23 \\
\hline & 6 & Mr. Carpenter . . . . . . . . . . . . . . . . & 5 & & & $\$ 10$ & . do \\
\hline & $\begin{array}{l}6 \\
6\end{array}$ & 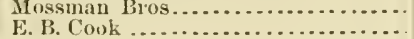 & $\begin{array}{r}18 \\
6\end{array}$ & 3 & & 100 & $\begin{array}{l}\text { July } 25 . \\
\text { Sept. } 23 .\end{array}$ \\
\hline & 6 & 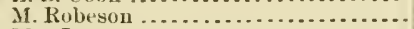 & 3 & & $\ldots$ & $\ldots .$. & ....do ... \\
\hline & 6 & 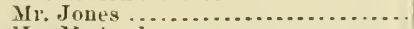 & 3 & & ............ & 40 & $\ldots$ do... \\
\hline & 6 & 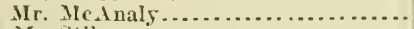 & 2 & 1 & …........ & 40 & ... 1lo ... \\
\hline & 6 & 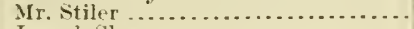 & 1 & ․ & ............. & & $\ldots 40 \ldots$ \\
\hline & 12 & 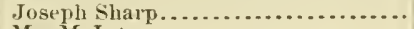 & 6 & 3 & 3 & 125 & Sept. 25. \\
\hline & 12 & 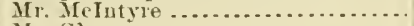 & 1 & $\ldots \ldots \ldots$ & $\ldots \ldots$ & ........ & Sept. 23. \\
\hline July & 29 & 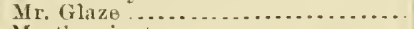 & 3 & .......... & 1............. & ...... & .... do ... \\
\hline Aug. & $\begin{array}{r}8 \\
23\end{array}$ & 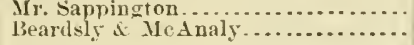 & $\begin{array}{r}1 \\
100\end{array}$ & $\ldots \ldots \ldots$ & (a...... & $\cdots$ & Airg. 27. \\
\hline \multirow[t]{2}{*}{ Jitne } & 9 & 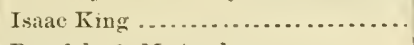 & 300 & 26 & 25 & 5011 & $\begin{array}{l}\text { Aug. and } \\
\text { Nos. } 10 .\end{array}$ \\
\hline & $\begin{array}{r}9 \\
20\end{array}$ & 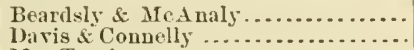 & 75 & $(*)$ & $\left({ }^{*}\right)$ & $(*)^{40}$ & Sept. 24. \\
\hline \multirow{2}{*}{$\begin{array}{l}\text { July } \\
\text { May }\end{array}$} & 6 & 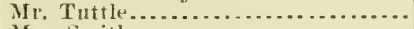 & 3 & 3 & & 115 & ........... \\
\hline & 6 & 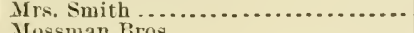 & $\stackrel{2}{2}$ & $\frac{2}{7}$ & ............. & $\begin{array}{r}60 \\
315\end{array}$ & Sent 23 \\
\hline \multirow{3}{*}{$\begin{array}{l}J u l y \\
\text { Sept. }\end{array}$} & 25 & 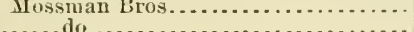 & $\frac{23}{17}$ & 2 & $\begin{array}{l}4 \\
2\end{array}$ & $\begin{array}{r}315 \\
60\end{array}$ & seje. 23. \\
\hline & 21 & 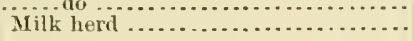 & 124 & 9 & & 325 & .... do .... \\
\hline & & Total. & 730 & 75 & 41 & 2,237 & \\
\hline
\end{tabular}

* Were remosed in small lots, September 28.

The milk herd contained exclusively milch cows from town, but were herded on the same range with the dry herd, although the two herds were liept separated for convenience. Mr. N. Rittenhouse herled 300 head of cattle nortl of the Robeson range, but he came no nearer than 1 mile to the range of the latter ; neither have the cattle in the eare of Mr. Rittenhouse crossed any of the trails of the Robeson cattle or been exposed to them or any other cattle in any manner whatsoever. They have been supplied with water from Walnut Creek, and have grazed over the same character of soil and grasses as have the eattle of Robeson's. Rittenhouse has not lost a single animal ont of his herd during the whole grazing season.

In view of all the facts and the circumstances, as they appear to me, I am compelled to attribute the appearance of Southern cattle fever at EI Dorado to the importation of Southern cattle by Mr. Conmelly.

\section{APPEARANCE OF DISEASE TIREE DAYS AFTER EXPOSURE.}

On my way to Harper, in October, I met Mr. E. F. Osborn, of Mulrane, Sedgwick County, Kansas, who related to me his experience with southern cattle fever, viz:

On or about the 1st of October, 1869, my partner and I started from Salina with 240 heald of high graté native cattle, bred ly ourselves. We drove south 80 miles to Selgwick City; then we crossed the through cattle trail, driving our cattle as fast as possible. We then drove 20 miles farther sonth and stopped tor winter feeding. On the third day after crossing wo found one high-grarle cow sick; on the sth slio died, and a humbed more were sick; in ten days after the diveane tirst appeared 200 of the 240 were deat. We then drove the remainiug 40 head into the Arkansas liver, and left them standing there in the water. Some of them were so siek that when they first went into the river they conld hardy keepon their feet. Many of then remained there from seven to ten or twelve dars; conld not be driven away from the water; but they all recovered. These 40 head were the poorest in the whole herd of 240 when we started with them. Before we left Sallina we had a hard frost, and dur- 
ing the drive sonth we had several frosts and continnons cool weather. We considered ourselves safe in starting after the frost; but to obviate all danger we endeavored to keep a safe distance away from the throngh trail ; therefore we kept 20 niles west of it until we had to cross it; we then tnrned a square corner and drove across the trail.

I asked Mr. Osborn if it might not be possible that they crossed trails of Southern cattle between Salina and Sergwick, but he said he was sure they had not. If their cattle were exposed only to the through trail then the stage of incubation in the first cow was probably less than three days, positively not more than four.

Respectfully submitted.

Sterling, Ill., December 20, 1383.

I. R. TRUMBOWER, V. S. 


\section{INVESTIGATION OF SOLTHERN CATTLE FEVER.}

REPORT OF DR. H. I. DETMERS.

\section{Holl. George B. Loring,}

Commisioner of Agriculture:

Sin: In the following I have the honor of subunitting my report on southern eattle ferer. In my last report I took the liberty of stating what has been accomplished, and what yet remains to be done; also what I considered as the chief object of $m y$ inrestigation, namely, to discorer the true cause of that apparently mysterious disease. My ob: servations and experience of last year more than ever convinced me that the (exciting) eause of southern eattle fever consists in something Intimately connected with or dependent upon the peculiarities of the Southern flora, and not-at least not directly-due to the elimate and higher temperature of the Sonthern States, which only indirectly exerts its influence or aids in its production and propagation. The cause of sonthern cattle fever consists in something that requires for its production certain conditions given in the Southern States, or in those parts of our extensive territory in which the fever has its origin or permanent source. Some, perlaps most, of the conditions farorable to its development, and some of those unfaromble to the same, ale knww. If one carefully studies the facts communicated in my last report, he will find that decaying regetable substances, a certain degree of waruth and noisture, and a low elevation above the ocean, are necessary requisites and important factors in the development of the infections principle; while a low temperature, a high altitude, and, without hardly any doubt, an absence of moist and decaying vegetable substances are detrimental to its propagation. In proof of this, allow ne to briefly restate some of the wore salient facts, apparently in part contradictory of alch other, but facts notwithstanding. As, however, my experience has only been with Texas and Western cattle I will limit my remarks to them, without intimating, thongh, that I regarl the disease in question as an exelusive product of 'Texas or of the Southwest, for it is a well-known fact that other Southeru States and the IVest Indies are just as well a somee of southern fever as 'l'exas.

1. Native 'lexas eattle never eontract southern cattle ferer, and possess immunity amainst infeetion as longas they remain on their native range or north of the same, provided they are not kept long enough north 
(in any of the Northern States) to become there acelimated, or, in other worls, have never passed a winter in the North. But the same eattle if taken from their native range and driven or shipped sonth will gradually lose their immunity in proportion to the distanee they go further south, and thus, if going far south, finally become liable to be infected and to contrat the fever. This shows the infectious principle must be the more intense the further sonth the locality.

2. If Texas or other Southern cattle, to all appearances themselves: perfectly healthy, are shipped or driven North, away from their native range, after new grass has appeared and become interwoven or intermixed with the old dead grass of last year's growth, which, owing to the warmer weather and the nsmally abundant rains of the early Sonthern spring, is in a decaying condition, and these eattle, thins eompelled to eat both the intermingled old and new grass, luve but once taken a good meal of this mixed herbage, they will as soon as they arrive at a eertain latitude further north infect every trail and pasture on which they graze, and every water-hole ont of which they drink, with the infections priuciple of southern cattle fever. And the native Northern eattle following them will, after some interval of time (period of incubation), contract the disease, as a rule, in its most fatal form.

3. If Texas ol other Southeru cattle are mored to the North before any new grass has made its appearance on their native range, or rather before the dead grass of last year's grow th has commenced to deeay, no. infection of Northern pasture, \&c., will take place, no matter how far north the Southern eattle may be shipped or driven. If, however, the eattle, thus leaving their native range in the Sonth early in the season, or in the winter, should travel slow enough to be set within a part of the South in which the sonthern cattle ferer has its permanent source, when warm weather and abundant spring rains cause a decay of the old grass and start a vigorous growth of the new, the effeet will be precisely the same as if the cattle had been kept that long on their native range; only the infectious principle imparted to the Northern pastures, \&c., may be a trifle less virulent, and taken up by Northern eattle may eause a somewhat milder, though in a majority of eases yet fatal, attack of the disease. I had repeated occasions to observe that the fever, as a lule, is the mere severe the further sonth the source of the infections prineiple.

4. Northern cattle shippled to Texas, or to otlier parts of the South, will contract the disease, and as a rule die of it, if ouly onee pastured soon after their arrival on land that contains both old and new grassparticularly if it is so-called hog-wallow land-or if only once allowed to drink out of a water-hole receiving the drainage of such land.

5. Grown Northern eattle imported into Texas usually contract the disease with more certainty, aud in a more fatal form, than imported, Northern calves and yearlings. Whether such is the ease because the latter have a smaller mouth, are more dainty eaters, and better able to. 
pick out the blades of grass they want, and to refuse what they do not like, or whether their young organism is better atapted to resist the influence of the pathogenie prineiple, I will not now decide, and will onls mention that some young animals, even calves, contract the disease in just as acute and severe a form as full-grown cattle.

6. In the North-say north of the southern boundary line of Kansasthe disease is only eommunicated through trails, pastures, and grazing gromels, or rather their grasses and other food-plants, and water holes previously infected by Sonthern cattle ; but it usually does not make its appearance until the latter part of July or in August, or until the Northern prairies, fields, and pastures, owing to the heat and often abmelant rains of the summer, contain a comparatively large amount of regeta ble débris or deeaying regetation, which, it seems, is an important factor in propagating the pathogenie principle if once depositer. That a propagation of the once deposited pathogenic principle actually takes place on the grass or herbage of the trails, pastures, or grounds, fe., and outside of the animal organism, is demonstrated by the fact that the period of incubation, as a rule, is a long one, if the native Northern eattle immediately, or within a few days, follow the Sontherners on the trails, pastures, \&c.; while it usually is considerably shortened if a few or several weeks intervene between the time at which the Sonthern eatthe left and the tine at which the Northem cattle entered the infected premises. As, however, the iufections principle is not volatile, and is not disseminated through the air or by winds, its propagation on the grass and herbage of the infested grounds may not be the sole canse of shortening the periol of incubation, and the difference just stated may also, to a certain extent, be accounted for br the following fact: In abont $\mathrm{t}$ wo, three, or four weeks after a herd of eattle has left its grazing grounds (trail, pasture, prairie, Se., as the ease may be) a fine crop of young and juicy grass will be found, if the season is not unfarorable to its growth, wherever the eattle lave grazed; while at all those places or spots where they have not been grazing the grass will be comparatively old ant tough. If a herd of native or Northern eattle immediately follows a herd of Texas or other Southern eattle, which have infected the premises with the prathogenic principle of sonthern eattle ferer, the former will principally graze where they tint grass, and not where the Southern eattle have cropped it, and where they, at the same time, have deposited, as I shall explain further on, the infeetions principle. But it the herd of Northern eattle enter's the pastures, Se, formerly ocenpied by the Southern eattle two, three, or four weeks after the latter left them, or after a new erop of young grass has made its appearance, the former, for obvious reasons, will juefer to graze at the very places where the Sonthern cattle have grazed, and deposited the pathogenie principle. As it is well known that the length of the period of incubation depends, to a certain extent at least, upon the quantity and intensity of the infections principle taken up by the animal organism, no further explanation will be necessary. 
7. In higher altitudes, such as in Colorado for instance, the sonthern eattle ferer, although sometimes appearing after an infection of the grounds by Southern eattle, is much less malignant than in the lower countries farther east, and comparatively seldom proves fatal, a fact which may find its explanation that in a higher altitude the atmosphere is thinuer and dryer, and less charged with organic substances; besides, the temperature, on an average, is lower. All this is less favorable to a decay of regetable substances and a propagation of bacteritic growth than the warmer climate and the more dense and moist atmosphere of a lower eountry. The dead or dried grasses of the Colorado plains, under the influence of the dry air, and often prevailing dry winds, are ground to dust, and thus disappear before any decay sets in.

8. The morbidly aftected tissues of animals affected with or killed by the southern cattle fever, even if examined at once, invariably contain bacteria* of the micrococcus and bacillus kind, and it applears to be very probable, particularly in the light of recent research in regard to infectious diseases and their causes, that at least one of these two kinds of bacteria bears some causal connection to the morbid process. Ms own observations, examinations, experiments, and a careful consideration of undeniable facts, point toward the bacilli, and not to the micrococciIy reasons $I$ shall take the liberty to state further on.

9. If all the facts known in regard to the communication of socithern eattle fever to Northern cattle by means of trails, grazing grounds, pastures, water-holes, dce., are duly considered as they present themselves, there can hardly remain any loubt that the infection of the trails, pastures, \&c., must be effected by means of the salira or slaver of the sonth. ern cattle. In proof of this assertion I may be allowed to state a few facts bearing on this point, and also to briefly dwell upon other theories now and then arlvanced. First, as to the latter: One theory charges the infection to a deposit of the urine of the Southern cattle. If it were the urine that causes the infection only those comparatively small and far apart spots in which the urine of the Sonthern cattle is deposited would be able to communicate the disease to Northern cattle, for it has been established beyoud a doubt that the infections principle is not carried through the air or disseminated by winds, and that even a wire fence separating a pasture ocenpied by Northern cattle from a trail or pasture of Texas cattle ( $f f$. my last report) is ample protection. Besides, cattle are not apt to graze where another animal has urinated; and as the urine is soon absorbed by the gromul or evaporated it conld nerer be explained how it can be possible that the infectionsness of a pasture or trail increases in intensity, at least for several weeks after the Sonthern cattles have left it. If the urine constituted the vehicle of the infections principle, the wholesale infection of every Northern herd of cattle that passes over and grazes on a trail of the Southerners, or feets on

* The word "bacteria," unless otherwise stated, is used as a generic term, hecanse better understood hy the arerage realer than Schizophytes or Schizomycetes. 
a pasture that has been occupied by the latter, would hardly be possible, and, at the utmost, only one or a few animals of a herd wonld contract the disease. Another theory charges the excrements of Sonthern cattle with constituting the rehicle of the pathogenic principle. The objections just made against the urine theory will also dispose of the dung theory; besides, all cattle, but particularly grown animals, carefully avoid to graze where other cattle have deposited their exerements. They are apt to sniff at places where horses have roided their dung, anoi when suffering from certain digestive disorders, attended with a vitiated appetite, may even eat some horse manure, but they will never graze if they can help it where the dung of their own kind has been deposited, a fact well known to every eattlemau. It may be possible that some pathogenie bacteria pass off' with the dung, or even with the urine; but if they do, they most assuredly do not furnish the principal source of infection. Another theory eharges the hoofs of the Sonthern cattle with being the communicators of the infections principle. This theors, too, can be easily disposed of, even if it were possible that the hoofs were able to take up the pathogenic principle (bacteria, for instance), at the native range, and eonvey it to some other place, that other place could only be in the immediate neighborhood, becanse at every step in the grass the hoofs are wiped, and in mud or water they are apt to lose whatever may cling to them; besides, neither the horn of the hoof nor the skin of the foot constitutes the soil or medium needed for the reproduction, preservation, and propagation of such a pathogenic privciple as that which eauses the sonthern eattle fever. Even if the skin of the foot, particularly in the eleft between the hoofs, constituted a suitable medium, aul aftoried all the conditions necessary to the existence and reproduction of the pathogenic principle, the constant wiping and friction which those parts are subjected to on the march would preclnde the possibility of conveying the principle (bacteria) in that way a thousand miles or even farther. Still another theory, which has ret a great mauy allherents even among practical cattle-men, charges the ticks often found on Texas eattle with being the bearers of the infectious principle, or even with constitnting themselves the pathogenic ageney. The prineipal objection that can be brought to bear against this theory is the fact that Sonthern eattle free from ticks will infeet Northern pastures, \&e., just as soon as those that have them, and that ticks of the same kind also occur in comntries in which the sonthern cattle ferer never originates or makes its appearance, muless it is introduced by Sonthern cattle infecting a trail, pasture, water-hole, \&c. The perspiration (through the skin) of Sonthern cattle, and even the expinations (from the lungs) have been aecnsed of constituting the pathogenic prineiple, or the vehicle of the same. But this theory, too, is fallacious, for, if true, the pathogenic agency would be of a volatile nature, and be communicated through the air, which it evidently is not, as alrealy stated. Hence, the only thing that remains as the probable veluicle 
and medium of the pathogenie principle is the salira or slarer of the Southern eattle deposited by them, not only whererer they graze and wherever they drink, but also often dropping in strings from their months when on their march. Any one familial with droves of Texas and Cherokee cattle will have observed that ther produce more salira and slaver more profusely than any other cattle not driven, or at rest; and cattle, when grazing, while grasping with their tongues a bunch of grass, and drawing it into their mouth to be ent off by their incisors, necessarily soil the stubbles which remain standing with their salira, particularly if slarering, as traveling Texas cattle always do. This salica or slaver is somewhat sticky, and the microscopic organisms (bacteria) it mas contain are thus temporarily glined to the grass that remains on the gromnd. The bacteria, thus deposited with the slaver (saliva and mucons secretions of the mouth), finc a new soil which offers them all the conditions necessary to their existence and propagation, particularly if old and deeaying grass or regetation, as is usually the case, is existing among or between the stubbles of the grass that has been torn off. Dew and rain afterwarl proride the neces. sary moisture and also the means of further distribution. If the Sonthern cattle, before being shipped or started on their journey toward the North, take up on their native range or at any place between their Southern home and their Northern destination, but sonth of a certain latitude, the pathogenic bacteria of southern cattle fever-and there can be hardly any doubt that bacteria which hare their source or origin in the South constitute the infectious principle or the cause of that dis. ease-either with their foud or their water for drinking, the bacteria, of conrse, will first pass into the paunch, where they find all the conditions (a suitable medinm, warmth, and moisture) necessary to their existence and propagation. Ascending to the carity of the mouth with the juices of the paunch when the animal is ruminating, they find a new and, at the same time, excellent medium in the saliva and mucons secretions, and thus it becomes possible not only that the bacteria retain their ritality, and that the same rastly increase in numbers, even if the journey of the cattle, as to time and distance, is a long one, but also that one herd of Sonthern cattle is able to infect a large territory (trails, pasture-grounds, \&c.), at a long distance, a thousand miles or more from their native range. I might advance several more arguments in proof of the assertion that grazing grounds, trails, pastures, yards, water-holes, \&c., are infected by means of the slaver, and that all other theories are untenable, but to do so will be in time, and ean be done with much more force, after it has been proved beyond a doubt that a certain kind of bacteria constitutes the true and the sole eause of the disease. To conchule, I may be allowed to remark that all the phenomena of an infection-the non-rolatile character of the infections principle, the varying period of incubation, the more freqnent occurrence of the disease in different seasous according to latitude, the kill- 
ing of the infections principle by continuons cold weather, or by a heary frost, and the wholesale infection of Northern herds of cattle-will find a full explanation, if the slaver constitutes the medium, in which the pathogenic principle lires and propagates in the Southern eattle when taken north, and in which it is leposited on the grass, in the water, Sc., while the sane cannot be explained, if not the saliva, or rather the salira and mucous secretion combined, but something else constitutes the medium.

As abore stated, I lave reasons to believe that of those bacteria found in the morbidly affeeted parts, particularly in the liver and in the spleen of cattle affected with the sonthern ferer, the bacilli and not the micrococei constitute the pathogenic principle, or bear a casual comection to the morbid process. Still, I will not deny that the micrococei, too, may possibly possess septic properties, particularly it obtained from a part in a slate of dissolution, for instance, from the spleen, an organ which I invariably, at every post-mortem examination, found to be in a disorganized condition, even if the affected animal las been killed by bleeding or by a pistol-ball. Such micrococci, if inocu. lated into the organism of a healthy animal, may have a septic effect, and may even cause disease and death, and still may not coustitute the infections principle of the sonthern fever. According to what is known of the behavior and the pathogenic action of the varions known pathogenie bacteria the morbid process and the morbid changes in southern eattle fever point towarl bacilli and not at all toward micrococci as the probable canse. Particularly the fact that the infections principle, whaterer it may be, is never conveyed through the air from one place to another, and requiles in orler to prolnee morbid changes in an animal a rery long period of incubation, and then rather suldenly develops its malignant action, it seems to me almost excludes the possibility of a micrococcus constituting the cause. It is true, in antlurax, a disease known to be caused by a bacillus, the period of incubation is a very short one, at least in those cases in which the disease is communicited from a diseased to a healthy animal, but the attack invariably is a sudden one, and Bacillus cuthracis not only shows a rery rapial proparantion, but is also otherwise entirely different from the bacilli found in sonthern cattle ferer. A microcoecus, as a rule, mopagates too rapidly to repuire a very long lime for the development of its yathogenic action, and would fill the whole organism, and very liliely be fomd in every drop of blood, long before the sometines very long periods of incubation of the sontlern fever has expined ; besides that, every infections principle known to consist of micrococei or diplncoeci is more or less folatile and ean be communicaterl through the air, while those consisting of bacili usually show a different beharior. But of course, if there were no other reasons, those just given, resting only upon analogs, might not eary much weight, or decicle anything: and might be met by saying that the micrococed or diplococei found in 
southern cattle fever may be entirely different in their behavior from any other known species of pathogenic micrococci. There are, however, some other faets which tend to show that the bacili and not the micrococei most likely constitute the pathogenic principle.

1. The bacilli are a constant occurrence in the liseased parts, but particularly in the liver and in the spleen of cattle that are affeeted with or have died of southern cattle fever.

2. The bacilli sufficiently differ in shape and size from all other wellknown speeies to be at one recognized when seen under a suftieiently high power, a faet which I intend to demonstrate, not by a description or by drawing, but by photo-micrographs, as soon as I shall be able to obtain fresh material in which the bacilli have not been subjected to any change whaterer by the action of hardening fluids or reagents.

3. In three sections of liver and spleen recently mounted in balsam. but cut last winter from pieces of liver and spleen which were hardened thirteen months ago, when perfeetly fresh, in alcohol and in a a solution of bichromate of potash, and have since been preserved in alcohol, the bacilli are yet intact, and under a high-power homogeneons immersion objective are easily recognized as the same kind of bacilli which I never failed to find in the diseased livers and spleens when examined fresh. Besides, the bacilli do not merely adhere to the surface of the sections, but appear to be imbedded in the tissue, because they are found at different depths, and require to be seen under a high power and different focusing, according to the plane in which thes lie. The seetions, when eut last winter, were stained in "Beale's carmine," and before being mounted were restained in an aqueous solution of methylviolet (1:500), but after they had been in alcohol and oil of clores, and been monnted, the aniline staining had almost entirely disappeared, been washerl ont by the aleohol and oil of elores, and thus the bacilli, which did not take the carmine stain, appear but indifferently stained with methyl violet, and are rather pale, but are plainly seen and easily recognized.

4. The micrococci or diplococci that may lave been present in the liver and spleen are now absent, at least cannot be found notwithstanding a most careful search, which proves to me that the same, if they have been present in those tisssues, must have been there by accident, or have existed only in the fluids, and lave never been imbedded in the solids like the bacilli. In my opinion the facts just related plainly show that the presence of the bacilli cannot be an aceident, but must have some connection with the morbia process.

Last year, when investigating the sonthern eattle ferer in the Southwest, and even before, wben I made my first observationson that disease and several post-mortem examinations of cattle that had died in Champaign, I became fully convinced that I lad to deal with a bacteritic lisease, or with a disease that owes its existence to some pathogenic; bacterium. As it is admitted that the southern cattle ferer has its 
origin or permanent source in the Sonth, I could not help arriving at the conclusion, after taking all the peculiarities presented into consideration, that the pathogenie principle (bacterimm) innst be connected with, or be dependent upon, the flora of the Southern States, and cannot be the direet product of the climate or the higher arerage temperature. Haring fomm the baeilli in the morbidly affected tissues several years ago at my first examination of the sonthern eattle ferer at Champaign, and considering them, eren at that time, as the probable, or at least possible, cause of disease, I naturally looked, when in Texas, for something corresponding to be found on, or to be connected with, the herbage and grasses which eonstitute the food of the cattle on the Texas cattle ranches. The well known experiments of Dr. Buehner directed my attention to infusions-natural and artificial-of the dear and decaying grasses of Texas hog-wallow land-to those of the latter in particular, as it was repeatedly stated by experienced Texas ranchmen that hog-wallow land is eonsidered as the most dangerous grazing ground for eattle recently imported from the North. The natural infusions I found in the spring prepared in the so-ealled hog-wallows themse]ves, and the artificial iufusions were made by putting some of the dead grass in a ressel and pouring rain-water over it. When examining my infusions, I found, as conld scarcely otherwise be expected, a variety of microseopie organisms (bacteria), but among them, in larger or smaller numbers, invarially a bacillus which, in every respect, closely resembled both in size and form those baeilli which I had found before and found afterwards in the liver and spleen of the diseased eattlecertainly something worthy of further investigation.

As I look upon it, the principal object in investigating an infectious disease, particularly if the same is very fatal, causes great losses, and is capalle of spreading a great distance, must be to aseertain the true canse, and to become aequainted with its nature and its mode of action, and the neans and eonditions necessary to its exis. tence, propagation, and communication. As long as we are in the dark in regard to the eause of a disease, partieularly if the latter is infections, our treatment and our prophylactic measures can only be of an empirical eharacter, and at best be very uncertain. But as soon as we know the cause, its mode of action, its means of existence, and its manner of propagation and communication, we have gained a great adrantage, for then, if the cause is aceessible and can at all be destroged its effects ran be nentralized or its propagation and communieation can be prevented. The possibility is then given to devise rational measures which will have the desired effect. Therefore, sincerely believing, naỵ. almost conyinced, that my endearors to discover the cause of the sonthern cattle ferer are in the riglit direction, it is and has been my desire to subjeet my conclusions, above stated, to a praetical test, and to decide by experiment whether the same are correct or erroneons. Latst rear 1 made some efforts in that direetion, but 
the experiments, for reasons stated in my last report, did not meet with satisfactory results, and some unaroidable mistakes were committed. So, for instance, I inocnlated a Texas cow, which undoubtedly possessed immunity, but was the only animal at my disposal, and as I had to remain in Texas I delegated that part of my experiments, of which snecess might have been expected, because to be carried ont in the North, where the cattle do not possess immunity, to a friend. It also miscarried for reasous stated in my last report. Another experiment, made by myself in the North, was made on rery roung animals, and too late in the season, and besides this, some other mistakes, partly unavoidable, and known to be mistakes when made, and partly due to a want of facilities and inexperience, were committed, which it will not be necessary to enmmerate, for they will be avoided in the future. All this combined, however, amply acconnts for the want of suecess, which, therefore, has not decided anything. Besides it is to me exceedingly donbtful whether a disease not known to have ever been directly or indirectly communicated by a diseased animal to a healthy one can at all be inoculated in the usual way. At any rate no well anthenticated case of any direct infection or communication of the disease from a diseased animal to a healthy one is on record, while many cases are known in which animals took sick with sonthern cattle fever and died of it in the midst of healthy herds and none of the heathy animals, unless previously infected, erer contracted the disease. Neither is it positively known that Northern cattle or cattle themselves susceptible to an infection ever infected northern pastnres, \&c. Still, whether under certain circumstances they are able to do so is anothor question. Northern or susceptible cattle, grazing on premises or drinking ont of waterholes infected by Southern eattle. almost invariably contract the disease and die of it before the system becomes accustomed to the action of the pathogenic principle (the bacteria), and charged with the same to such an extent that the latter will be present, and be constantly reprodnced in the mucous secretions of the month and in the juices of the palumch.

But it stauds to reason, if they (the Northem eattle) gradually ac. quired immmity like the Texans, and then continned for a certaiu length of time to ocupy infected premises and to take np the infeetions principle, or it it were possible to charge their system with the pathogenic principle, as just indicated, before they contract the disease and die of it, then these Northern cattle, if driven to uninfected pastures, would probably infect the latter just as effectirely and just as soon as Sonthern cattle, particularly if the Northern cattle were first driven like a herel of 'texams, and thus canned to slaver. That susceptible cattle, or such as will contract the disease, do not communicate it to others, strange as it maly seem, probably also almits an explanation, if all known facts are taken into due eonsideration.

In the list place, the pathogenic principle (the bacteria) of sonth- 
ern cattle fever does not seem to be indigenous to the animal system, but very likely belongs to the decaying grasses and herbage of the South, and only by what mas be ealled aceident euters the animal organism. In Southern eattle, or in such as possess immunity, that is, in such in which the pathogenic principle (the bacteria) produces no morbid changes important enongh to serionsly disturb the heaith of the animal, the organs, which constitute the principal seat of the morbid process in diseased eattle, the liver, spleen, \&e., it seems, have either become accustomed to the artion of the bacteria, or else have gradually become sterilized gromul, and thus cease to be a farorable medimn. That such is the ease will be mulerstood, if it is kept in mind-1, that the first introduction of the bacteria into the organism of Sontlern cattle takes place while the latter are young calres, which, as is well known, possess much less susceptihility than grown cattle; 22 , that the number of bacteria taken up the first time undonbtedly is a eomparatively suall one aud not sufficient to eanse serious mischief, but just large enough, particularly if smplemented hy successive small inrasions, to gradually eause an immunity, which, although but temporary, will last for some time after the inrasions have ceased. As long as Sontheru cattle ocenpy infected territory the bacteria will enter their organism with the food and water for drinking, and finding in the pannch all the elements nceessary for their development and propagation, many of them probably reach the cavity of the mouth by ascending with the food and the juices of the paunch during the process of rmmination, and then in the mucons secretions and saliva again find a farorable medium in which their existrnce and propagation are fully secured, and by which they become glued to the grass, \&e., as has been above explained. It is possible that a great many of the bacteria taken up with food or drink, or developed in the pannch, and, may be, the majority of them, pass on with the food through the digestive canal, and are discharged with the dung; but if they are they will be comparatively harmless, becanse they will be eonfined to those spots at which the dung is dropped, and at which other cattle, as a rule, do not like to graze.

If Norther'n cattle, not at all accustomed to the action of these baeteria, take them 11 with this food or drink for the first time, the bacteria likewise enter the panneh, and propagate in that organ, but passing on into the other stomachs and the intestines, they mobably canse inereased activity and increased absorption, or even lesions, by irritating the mucous membrane, and thus may find their way into those organsthe liver and the spleen-in which afterward the morbid process of the Southern fever has its prineipal seat, while in Sonthern cattle sueh an irritation of the digestive canal, which in them has become areens. tomed to the presence of the bateria, is either very limited or does not take place. That the bacteria, or whatever may eonstitute the infections prineiple, produce irritation and congestion in the digestive eanal

5751 D $A-17$ 
resulting in most eases in increased alsorption in the third stomach, and in lesions in the fomth stomach and a part of the intestines, is demonstrated by the morbid changes usually tound in those organs at post mortem examinations. It is, however, also possible that the baeteria, or a large number of them, reach the liver, the principal and, aceording to my observations, primary seat of the morbin process, in a more direct way-through the dhodenum. The bacteria, if once passed beyond the secoud stomach, or domiciled in interior organs, for instance, in the liver, spleen, se., cannot very well asend to the mouth, there mingle with the saliva and mncons secretions, and thus be deposited on the ground; conseqnently Northern eattle annot very well intect pastures, de., muless every day a new lot of bacteria is taken "l, and propagated in the paunch, as is the case with Sontheru cattle. Of course the explanation just given I wish to be considered only as a strong hint. Something more lefinite may be saisl after it has been conclusively demonstrated what bacterim constitutes the true canse of the sonthern ferer.

When retnruing to Texas last spring-I arrired in San Antonio about the 1st of May-it was my intention, as I explained on the 24th of April, when in Washington, to collect and to prepare what I believe to be infections material, and to returu to the North in about a month to complete my preparations (bacillus cultivations, \&s.), and then to put them to a practical test. I intended to return to the North for two reasons: First, no southern cattle ferer conld be found in Texas, nor could it be expected to occur hefore December, because the native Texas cattle possess immunity, and the Texas lanchmen, at least the more intelligent ones, aud all those who have had any experience with the Sonthern fever, take care not to import any Northern cattle except late in the fall and in the winter, for they have found that to be the least dangerous season of the fear. Secondly, my proposed experiments could only be expected to give satisfactory results if made on susceptible Northern cattle, and at a place where a natural infection is out of the question. But in the latter part of May, when my preparations were nearly completer, and I about realy to leave for the Torth, ciremistances beyond mị control compelled me to remain in Texas. Of contse my plans conld not be carried ont, my preparations conde not be used, and the question I was so anxions to deeide for the time being had to remain nusolved. I had order's to inrestigate, besides sonthern cattle ferer, also other infections diseases of more than local importance. But in Texas the infections and contagions diseases of domesticated animals, which are of general interest, or of an epizootic character, are rery few in number, and withont any fear of contradiction I may say there is hardly a eountry on the globe in which cattle and live stock in general are less subject to disease than in Texas. It is true Texas ranchmen sometimes snfier great losses, particularly in the latter part of winter, but these losses are not caused by disease, and almost with- 
out exception result from want of food, want of water, or want of shelter in inclement weather. Losses that occur during the summer months are far less severe, and are mostly cansed by insects and their larrie.

Besides the southeru eattle ferer, which does not, at least not visilily, affect the native Texas cattle, the only infeetions disease of any importance is so-called "lolack-leg" or "black quarter" (the ththrac symptomatique of the French), but even this disease occurs only at certain localities and during certain seasons of the year, particularly in the spring, and in my opinion will become a rare ocentrence in the grat. ing llistricts of 'Texas as soon as Texas stockmen will learn that dead animals must be buried or he cremated, and that it is bad policy to allow live stock to drink the water of stagnant pooks. The infections and epizootic diseases ocenring among sheep were investigated last year, and althongh I do not clain that eserything worth knowing abont them has been bronght to light, enongh is known to enable the Texas flock-master to apply such measmres of prevention as will protect his flocks. Besides, the spring is not the time in which those sheep diseases make their appearance, and, owing to a severe winter (severe for Texas at least), hardly any case occurred or eame to my knowledge. Last year an epizootic disease oceurred among the horses on the (inlf coast, but this year nothing of that kind hampened, at least not as far as I was able to learn. So not much conld be done, except examining some cases of so-ealled "black-leg," and in regarl to these I was not able to ascertain anything that is not alreads known, because being in a thinly settled comntry and far fiom home I lacked the necessary filcilities, such as a laboratory and experimental station. If it is desired to study and to thoronghly investigate the disease known as "blackleg," it can be done more easily and with better facilities in a more thickly settled comtry, where the distances are not so great as they are in Texas. Hence towarl the end of July, or about the first of August, I asked the Department, briefly stating my reasons, to be recalled from Texas, and in reply to my letter I received orders which assigned me to other work. So I left Texas in the forepart of August.

Very respectfully submitted.

DECEMBER 1, 1883.

H. J. DETMELS. 


\section{CONTAGIOLS ANIMAL DISEASES.}

\section{BY EZI.A M. HTNT, H. 1), SC. D., TRENTON, N. J.}

The relations of domestic animals to the public health-to food and milk supply - the comparative sturly of their diseases as throwing light on luman ailments, and the immense funancial and eommercial import of any serious diseases oceurring to them, cannot but impress any one who will give to the subject that consideration which its importance demanils.

In 1562 the medieal officer of the priry comeil of Great Britain made an important report on the diseases of live stock in their relations to the public smpplies of meat and milk. In that paper Prof. John Gam. gee states the number of horned cattle in the United Kingdom at $7,646,998$, and calculates the loss by deaths among these animals at

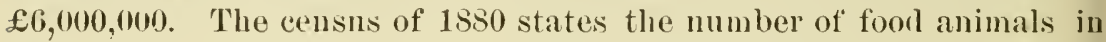
the United States at 91,505,232. The chief epizooties named in the report referred to are rinderpest, or typhoid or enteric ferer of cattle, which always spreals fiom the Russian steppes; contagions plenropneumonia of eattle, a disease always extending from Central Enrope, thongh probably traceable to Asia and Africa, in some parts of which it is a very common disease; the epizootic aplitha, murrain, or the footaud-mouth rlisease, and sheep-pox. Of the enzootic rliseases, which depend on local canses, and one parallel to endemies in man, anthrax or carbmnenlar ferer takes the lead. Of this there are so many varieties of elassification and lescription that we eamnot yet be sajd to hare a settled nomenclatnre. Thus, splenje apoplexs, braxy in sheep, the black-leg or quarter-ill of Britain, and other erysipelatous forms in the sherp and pig, boils and eabnucles, parturition fevers, hog cholera, Texis cattle ferer, and some other ailments have been inchrled in this class. Adrl to these the parasitic diseases of animals, and we have a score or more of diseases which are either deadly to the animals or injurious to meat and milk as food prodnets. Mamy of these are communicable, not only to different varieties of animals, but to human beings as well.

None of these diseases are clamed to have originated on American soil, exeept it be tho Sonthern eattle fever, which is regarded by many as only a variety of anthrax. When we consider, too, that rinderpest, plenro-puemmonia, and foot-and-mouth disease were brought to Groat Britain fom the Continent, and that the ravages of these diseases have 
cost and are costing the British Government millious of pounds sterling aumally, is it not wise for us to accept the signals of precantion and prevent them from becoming indigenons? As ret riuclerjest and footand-mouth disease have not obtained a foothold, and contagions plentopnenmonia las not passed the point of possible extinction. Plenropneumonia reached Eugland abont 1842; foot-and month diseatse in 1839 ; sheep-pox in 1847. Of rinlerpest there have been fon ontbreaks, riz., in $1745,1865-66$ (the most destructive one), 18ï, and 18i-. We have been singularly fortunate in that we have exalped two of these formidable diseases. Rinderpest is not rery likely to obtin a foothold here, but foot and-month discase, with its great contagionsuess and its inmense loss to milk-producing animals, is greatly to be feared. Fortunately, rumors of an outbreak in the Far ITest proved to be unfounded. But the faet is well known that more than once it las arrived at our ports from abroad, and has been prevented from sprearling here by rigid inspections on arrival and close quarantine after landing. During the past year the disease has been so prevalent in the United Kingdom as to cause widespreal alarm and great pecuniary losses.

We propose in this paper to state some facts, observations, and opinions as to contagious plenro-puemmonia, and also, in connection with the detail of some experiments as to foot-and-mouth disease, to offer a few comments upon it.

\section{CONTAGIOLS PLELRO-PNETMONIA.}

The general course and symptons of plenro-pueumouia are so well known, and have been so fully and acenrately described in the reports of the United States Department of Agriculture, that there is no need of repeating them here. The only points upon which perhaps there is need of more extended observation and a more concurrent testimony is whether climate or uther conditions have modified this disease as found on American soil, and whether different grarles of stock are equally subjeet to its ravages. No one can see much of the disease without being struck with the great rariations in its malignaney. We have seen ontbreaks in which every animal attieked secened early to become mortally sick, and where one or both lung's changed in a short time from a weight of three pounds to over twenty. In other cases the course of the clisease has seemed mild, and most of the animals were likely to recover. This has led to a distinction anong some reterinarians, so that they have come to speak of eertain eases an English or European, and of others as American cases. It would be a good service if this Department conld obtain the comparative statistics of English and American cases, and the accurate testimony of creditable veterinarians who have hat in charge many cases both in this conntry and aluroat.

It has been asserted that in certain exposed sections. as on Staten Island, common pneumonia is frequent and fital among cattle, and that some of these have been mistaken for contagions plenro-pnemonia. 
We last year offered to risit, on notice by telegraph, any such cases of common fuenmonia, which an extensive practitioner there asserterl he hat frecuntently seen, but as yet have receired no such notification.

The contagious character of pleno-pnenuonia in this country has certainly not diminished with the change of elimate. Still there is some reason to believe that onr severer winters tend to freeze ont the disease, and, where there has been a full exposure, give us a better hope of iuterrupting itscontagionsuess; yet the contagion itself seems very persistent muless there is suljection to freezing and to varions methorls of chisinfection. It is well establisherl that after an ontbreak lat ceased for a year or more, the removal of the old barns and the exposme of the mufrozen gromel beneath at onee revired the disease. A case not long since occmed on Long Island where the transfer to the new sheds and the destruetion of the old, near by, seemed to originate or reproduce the plague. Facts are accumulating to show that the aceidental protection from frost calused by shelter seems to continue some of the contagions both of meu and of animals. This is one of the contagions probably not wafted fin, but quite indestmctible unless largely exposed to air, to serere cold, and to disinfection.

But the most important (pnestion of all pressing upon our attention at the present time is whether we are to forsake the method of stamping out the disease by occision, and to substitute the system of inoculation as first practiced in Belgium and Holland, and as revived in Scotland under the anspices of Rutherford and Willimms, and as sanctioned also by Fleming and others. This is the more important because, moler the adrice and approval of the Drs. MeLean, the board of health of the city of Brooklyn has allowerl or anthorized this system in its stables, and at a point where the disense has long had a foothold. At one time Professor Law expressed the hope that the inocnlation method, under some modifications, would be revived. In New Jersey the State law permits inoenlation, uncler expert oversight, in a hed in which there has been an outbreak, if such inoculation is ordered or approved by the board of health. In the last instance the law was based on the views of Rutherford, Williams, sce, and on the fact that the State despaired of securing lindance of the disease, with reasonable expenditure, if it must be constantly subjected thereto by the transportation or driving of cattle from infected localities in other states.

The details of inoculation as followed out in New Jersey are of much interest. Through the inflience and prattice of Mh. Laner\%, a German reterinarian of Tewark, it has tor several years been a custom with dairymen in Essex Comnty, and especialiy abont Orange, to inoculate their herds, not only when there was an onthreak among their cattle, but as a customary precantion. It is worlhy of note that all who have pursued this plan express themselves fully satisfied therewith, and arer that they have never known any vase of the transmission of the contagion ly this means. While mnch of this is negative testimony, and 
may be partially set asirle by sayiug that most of them would have escaped contagion withont this, it is yet worthy of reeord that while there have been sporadie cases of the disease in Orange and adjacent localities, these hare been no more numerons than at some other points. For orel a fear it has been the babit of the reterinary servire of the State board of health of New Jerser to seck to erarlieate the disease by slaughter if only one or two cases had oremred. But if there had been nore extended scizures before notice, or if the disease threatened to spread, resort has been hat to inoenlation. Dr. J. W. Hawl, of Newark, and Dr. Leatherman, of ('linton, have had oceasion thus to inoenlate several herds. In abont two humdred cases of inoculation they report that the results have been altogether satisfictors. Iferds hare been protected and the disease limited. While a few of the anmals lave lost their tails, and some have been for a little time quite sick, no deaths have ocemred fiom this cause. Great cure has been taken in the selection of the inoculating juice, and it has heen gemerally intro. ducerl, by a seton of woolen yarn, into the muscle just beneath the skin of the tail.

While thus feeling our way on the basis of the anthorities before alluded to, and by a cantions use of the method in general accentance, the following series of cases orcurred:

A farmer and dairyman having about thirty head of animals in his herd, and not haviug and never hariug had any cases of contagious plemrophenmonia among his anttle. Was informed that two or three of his neighbor's had the disuase among theil herds. He was a mile and a half distan from the nearest one. The cattle lad not come near to each other by neighboring fields. Ile had no octasion to take auy of his cattle to other fards, or to have any bronght to his. He had not purchased an animal for three rears. Sot knowing the law of the State, he concluded to have his cattle inoculated hy a reterinarian of Newark. His entive herol was inoculated in the montls of Iecember. One or two of these animals lost their tails, several were some what sick and reeovered, and did not contract plenro-pmenmonia, though afterward exposed. On the tenth day after the juoculation tigo calves had convonlsions and died. Three of the healthiest tows wre taken severely sick with all the symptoms of contagions plemro-pmenmonia, ambl had to be slaughtered. P'ost-mortem examination left no doulot as to its being

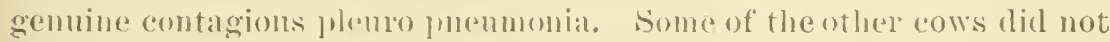

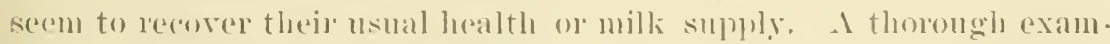

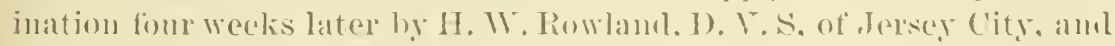
J. Gerth, jr., 1). T.S., of Tewark, showerl comditions of lung that would indieate nothing else than contagions plentophemmonia. As the cows were andining, the owner was permitted to lieepl them, on condition that they should not be sold mitil tit for slangliter, and then not for any other julpose.

Here we have a series of ("ases ju which eifler the veterinarian cansed 
the disease to the herd by person or fomites, or intrornced it by inoculation. If thu latter, it would seem to support the hypothesis of some, who, while almitting that the introdnction of the virus in o a muscle, insteal of by the breath or into the lumg, generally causes a milder olisease, which is protective, yet that occasionally, muler conditions not yet known, it will resume its malignant activity and light npon the organ wh ch seems to afford its chosen nidus. It seems somewhat analogous to the old facts as to the inoculation for sm H-pox, in which muloubtedly the introdnction of the virus into the skin or flesh insteal of into the lung did modify and mitigate the distase. But in this it was a known fact that now and then a strange exception wonlı ocenr, resulting in secondary tever and death. While single cases prove but little, and the mini must suspend its julgment mutil other cases occur, or until the ocenrrence is explained, it must be confessed that these cases were a restraint mon what harl $b$ fore scemed to us to be legitimate eonclusions. The great asserted facts mpon which the more recent hopes as to inoculation of cattle have been predicated are (a) that the virus thus introduced never causes any affertion of the lung, and $(b)$ that the animal that has been inoculated does not impart the disease to others.

In view of the immense interests involved, this Government should institute a series of experiments to settle this matter, and either arrive at the conclusion that systematic and rational extinction of the disease is to be secured by slanghter, or define how it can be aided or secured, if at all, by systems of regulated inoculation. Since the important experments and deductions of Pastemr, Chanvean, Touissant, Koch, and many others, it seems alınost imperative that. this Government should, by systematized methols of histology, pathology, and laboratory investigations, and by the experience of skilled observers, determine the means of checking those maranding epizootic's that imperil the health and life of so many millions of animals of various species, and with it imperil the industrial interests of all classes and the rery life and health of a race so dependent on good meat and good milk for food.

FOOT AND-MOUTH DISEASE.

We are fortunately dejendent on foreign anthorities for the most accurate descriptions of this disease. Unlike plenro-pneumonia, it is readily communicable "to sheep, goats, swine, and poultry; it is easily transmitted to the human smbject. It has been described as existing in the horse, $l o g$, wild fowl, deer, wild boar, eat, sc." The milk of animals in many cases seems to have conveyed the lisease to man, althongh some regarl this as having occurerl ouly when there were vesi. eles upon the udder or teats, the secretions from which had mingled with the milk. (Walley, Elimburgh, 1879.) The same author also spealis of it as "one of the most infections and contagions maladies which affect domestic animals, and the easiest of transmission," and as remarkable "in the effect which the milk of animals affeeted with it 
produces on their young and even the young of otherspecies." Because of its rapid and diffusire contagion, and of the fact that one attack roes not protect from another, that both the meat and milk supply are jeoparlized thereby, it is probable that its actual losses to food products are greater than that of any of these pervasive plagnes. Recently J. W. Stickler, M. D., of Onange, N. J.. a physician who had become interested in the disease only becanse of its comparative relations and its partial similarity to certain aphthous diseases of children, procured from Professor Williams, of Edimburegh, some of the virus of the disease, and inowlated somo ealves therewith. The saliva was talien from a cow affected with the foot-and-month disease, and put into glycerine tightly corked in a bottle, and inmediately forwarded to the doctor. In a recent note to the writer, I)r. Stickler says:

The history of this case is as follows: Alderney calf, two and one-half weeks old; hefore inoenlation seemed perfectly well; visible mneons membranes free from : eruption and discharge; skin and interdigital spaces normal in appearance. I inoculated the animal by subcutanens injection of the vims just posterior to the elbow joint and interior to the stille. Nothing at all positive developed till January 2 , when the temperature rose to $104^{\circ} .8 \mathrm{Fah}$. There was a discharge of quite tenacious mucns from the nostrils, and at varions points npon the mucous membrane of each there were snall papulie. The mouth was hot and red, although there were no distinct uleers or aphthe. The nearest approach to an nlcer was an apparent thiming of the mucous memlorane at one or two points. The saliva seemed to be increased somewhat in quautity. The bowels were loose. A mieroscopic examination of the blood showed the existence of small ronnd or oval hodies of a faint port-wine color. They had an activity which, I thiuk, was indepeudent of that caused by aug motion of the blood plasma. To determine this point, I was careful to place upon the glass slide only a drop of blood, arljusting the cover glass with sufficient firmness to canse an even dispersion of the fluid. I then noticed that these lit the bodies seemed to have the power to move in varions direetions. The saliva ant nasal discharge contained the mouals spoken of in the various works upon "cattle diseases." I au not aw wre, however, that atteution has been ealled to the existence of suall, active borlies in the blood of animals affected with "foot-aud-month" disease. The feet now becane slightly redilened, but showed no blebs or ulcerations. 'There was also a little swelling just above the hoofs. The condition of the ealf remained essentially as just given till January 10, when the feet became swollen to a marked degree and the redness more prononueel. In the interdigital spaces the skin was found to be loosened from its attachment, althongh there was no fluid to be seen. There was bnt little heat of coronets. The hack of the animal was arched. The redness of the feet became nore intense, the hair coming oft; leaving quite large areas of uncovered red integnment. The bowels again became loose, the animal fecling insufficiently, till, tinally, on .lannary 17 , it died.

As seen by us the disease was in its subacute stages. One calf had just died of it. When the resicles break, the red or scarlet surfice becones covered with a secretion, but shows little tendency to return to its normal condition. The emaciation of animals is rapid, both from the disease itself and the interference with feeding, which it canses.

We do not know of other experiments with the virus in this country. It is very certain that the most serupulous vigibnee should be exereised as to the disease, and that it shonld never be allowed to obtain a foothold here. There is 110 disease against which the vetermary inspector 
in England watches with greater care. Onr system of large herds and cattle ranches has no parallel in the cattle culture of the United Kingdom. Its spread here wonld, if it should get full headway, eompare with that abroad as does the sweeping fire of the praine with that of a city block, where the provisions for extingnishment are ready to the land. Well may all owners of eattle urge the National Government to exereise its preventive diseipline orer importation and all movements of cattie from the seaboard, all the more hecanse reeently a new demand has sprung np in the West for yomg stock from the East. The transportation which has beretofore been toward the seaboand is now likely to be met by a connter-current to be inland west, sinee the stock-breeding there does not supply the demands which the fields of space in the middle land between the oceans provides for the feeding and fintening of young cattle.

We scarcely need to emplasize the application of the same preeantions as to those diseases of swine and sheep which are equally de. structive to these smaller flocks, and which alike inperil interests in which large capital and great commercial enterprises are involved. The census of 1850 gives as for the United States 10,357,485 horses, $1,812,808$ mules and asses, $12,443,120$ milch cows, 903,841 work oxen, $22,485,550$ other eattle, $35,192,074$ sheep, and $47,681,700$ swine, or an aggregate of, or abont, $131,000,000 \mathrm{in}$ all. When we consider that the yenrly increase is constant, we ought not to need extended argument to show that the sums expended in competent investigation and in skilled orersight of these interests, if honestly and intelligently expended, is among the very best investments the General Government ean uake. Perlaips the lack at present is more in competency of observation and in tried and successful methods of protection than in a recognition of the desirability of such oversight. But as a demand creates a supply we are alreally seeing Harvad Unirersity and the University of Pennsylvania with reterinary departments, Toronto and New York with worthy reterinary colleges, and the Ameriean I'ublic Health Association giving it prominent consideration, the medical profession alive to its importance and co-operating here with something of the same spirit and aloility with which in England the foremost member of the Royal College of Physicins and Surgeons is found conducting and aiding in in restigations of a similar kind.

It is only by a combined aud entinned system of surveillance that we ean hope to prevent or arrest the wamlering epizootic pestilence or those enzooties which spring up in localities and are dependent npon canses which, althomgh diflicult of detection, are, in the light of the past few yars, likely soon to be mureled. I,y such a course, and by putting on record the fincts and experience obtained by skilled local obsersers, we shall sueceed in arresting or abating miny of the ragrant diseases, and thus greatly appreciate both the wralth, the comfort, and the health of our people, and be able to furnish the markets of the Old 
World with a surplus meat smpply excellent in quality amb almudant in quantity.

\section{GLANDERS AND FARCY.}

The discase known as glanders or farey is so insidions in its character as to need most eureful inquiry and inspection on the part of local, State, and national anthorities. Unless large powers are given, the latws will be evaled and the disease perpetmated. This has bren signally ilhstrated in a series of eases that have occured in the South Orange car stables, in Newark, llumg the last year. There is reason to beliove that over a year since at case of glanders occurred in those stables, which was claimed to have been cured. Abont August 1, 1853, the attention of the local boards of Sontl, Orange and Newark, and of the State, was called thereto through a legal process of inquiry. 'The liscase was fonnd so extensive that about sixty hearl of horses had to be killed. Not long after the veterinarian in clarge, Dr. J. IV. II wh, of Newark, condemmed three more. The owner consented at onee to their llestruction. 'Thure was delay as to one, which had the least external manifestation, and dming the delay the owner, mnder mufortmute rival advice, conchuled that the animal was sombl. Afterwarl the certificate of the veterinarian was given to that effect. The state board of health and its rot. erinarian were refused entrance to the stable. Owing to allegerl or possible rlefeets in the law a new one was passed. It was not, therefore, motil April that the hoard was again able to seenre nudisputed entry. On the first visit this horse was foum with symptoms of glanders, and a post-mortem examination fully attested the former diagnosis. There were other susplicions eases, and it was found necessary soon after to condemn two more. The disease is now in such a chronic, and in some eases proba $1 \mathrm{y}$ in such a concealed form. that it is claimed by some that nothing short of a destrnction of all the live-stoek and the bnildings will eraclicate it. Oerasional (' ses are now ocemring in other mats of the city. The whole history of these cases illnstrates the persistent infection of the malariy, and shows how delay by the interposition of lewal obstacles may result in entailiug mpon an entire city the continuance of a disease which conld have besn eladicated in the start.

As there is much difference of piritom as to the possibility of the spontaneons derelopment of glanders in stables where lorses are orerworked or illy kejut, it sexms rery desirable that the Gencal covernment should institute a serios of experiments and investientions for the purpose of determining this point. The disease is of a rery theatruing character to the great industries which so much depend on this class of amimals. As, too, it is athutterl that stables which have comtained affected holses, and all the halluess uscel come to ha fomites of foei of commumication, there is neref of the most precise directions as to the choice of disinfectants and their acenrate and suecessful nse. It is doubful whether this an be left to owners or even to the general ret- 
erinarian. It is better rather to commit it to those who understand all the details of fumgation, inhalation, and the washing aud saturation of all exposed surroumlings and material.

Our experienees in this State for the past year with pleuro pneumonia, glanclers, and hog cholera are sufficient to emphasize the immense importance of close investigation of all contagions animal diseases by the General (xorernment. There is need not merely of hurried inquiry into alleged outbreaks of contagions, and the rapid application of methods of isolation, destruction, or quarantine, but of scientific and laboratory investigations and such skilled observations and experiences as will prevent their occurrence. The notable results that have already ocenrred from the combined inquiry and insight of medical and reterinary experts into the general development and life-history of these marauling pestilences, is enongh to assure us that our neglect will be culpable, if we fail to protect our great commercial and industrial interests by saving as far as possible the live-stock of our country from invasions as disastrous as those of pestilence and famine. 


\section{TRICHINILSIS.}

[The following article on Trichina and Trichiniasis was contributed hy Dr. D. E. Salmon, Clitef of 1 lue Bureau of Animal Indnstry, to the report of the Commission, of which he was a mimber, ajpunted by the president to investigate the comlition of the swine inlustry, and the pork probuct of the: Enited states. It embraces the researches which have been made in regird to this subject up to this time.]

\section{EXTENT OF TRICHINIASIS IN AMERICA AND ELROPE.}

This subject being, in the present attitude of certain foreign Governments in regard to Ameriean jork products, the most important of all the questions that have received our attention, we have givan it a very calleful consideration. The alleged frequency of trichiniasis in American hogs has been the reason insisted upon by the various combtries which have prohibited the importation of such prodncts; for, while it is true that other objections have been advanced, particularly in France, none of these have sufficient foundation in fact to stand the test of even a superficial examination. It is, however, not a question of the mera. lence of trichiniasis here and its absence in other conntries, since this parasite has been found infeeting the hogs and other flesh-eating animals in the most widely separaterl portions of the earth. Dr. Minson examined '2's specimens of Chinese pork and fonml 2 or neally 1 per cent. infected.* Dr. Wartable has described epidenics near the sources of the Jordan resnlting from eating the flesh of the wild hoar, $\dagger$ aud in every European country in which inspections have been mate a very considerable proportion of trichinous animals have been discovered.

Certain writers have pretended that the animals of France have never been affected with trichiniasis, fout this conclusion seems to have been reached without any investigations. A large proportion of the rats of Paris were long since fount to be infected, $\$$ and in 1879 a serious enidemie of trichiniasis, knownas that of Crépy-en Valois, ocenred, in which sixteen persons sickened from eating the thesh of a native animal.|l

That trichince also exist in Ameriea and infest a small proportion of American hogs is a fact that must be admitted, but it is a more dinicult matter to compare the frequeney of American and Buropean infece-

\footnotetext{
* Iup. Customs. Medl. Report, Shanghai, XXI (1881), p. vti.

+ Yaneet, Aucrust 4, 1883.

$\ddagger$ J. Chatm : La trichine et la trichinose.

\$ Davaine: Trait6 des entozoaires, dEc., p. 755.

\|Gazette des Hopitaux, February $20,1879$.
} 
tion than las usually been supposed. American hogs lave usually been examined by microseopists who were competent to do the work and who wonld not orerlook a single ease, while in fiermany there has been an immense ummber of inspectors employerl (1S,581 in 1851), many of whom were utterly incompetent. An examination in 1876 showed that many of the microscopes were useless, that glasses used were too dirty to permit the examination, and that some of the iuspectors were ineapa. ble of detecting the parusite.* Even as lite as 1881 there were complaints in regard to the incompetency of inspectors, and the continued recurrence of trichiniasis among people from eating inspested meats demonstrates that these complaints were not male without reason.t Even the German inspections of American meats cannot be taken as a fair comparison with the arepage of their inspections of indigenous animals, 'for the reason that our meats are examined in their larger cities and by their most competent inspectors. It is absolutely necessary to bear these facts in mind, in considering the figmes which are given as representing the results of the microscopic examination of American and European pork.

\section{PROPORTION OF AMERICAN IIOGS INFECTED WITII TRICIINIASIS.}

'The hogs in Dearborn Comty, Indiana, seem to be infected in a larger' proportion than anywhere else in the conntry, or at least were in 1874. Drs. Halding and Robbins examined 245 animals slanghtered near Lawrencelurg, and found that $40, \mathrm{r}^{2} 16 \frac{1}{3}$ per cent., contained this parasite. This seems to be far beyond the arrage, however, even in this center of infection, for Drs. Gateh aml Miller examined 200 anima!s at the same place and omly fomm 13 infecterl, or 6.5 per cent. $\frac{\ddagger}{+}$

In 1866 Belfield and Atwood are reported to have found 2 per cent. of the hogs slanghtered in Chicago infected, and in 1975 an examination of 100 animals at the same place indicated that 8 per cent. container trichinat.

Fiom 1879 to $1 S S 1$ Dr. F. S. Billings, of Boston, examined S, 773 hogs, of which 347 , or 4 per cent., were reported as containing trichinde.

Dr. Deveron, of New Orleans, inspected 5,400 hogs in 1851 , of which only 2:, or 0.4 per cent., were trichinous. 0 of these animals $5: 29$ came from Saint Lonis, and among them were 18 infected ones, being 3.4 per cent.; „241 came from Lonisville, and 2 of these, or 0.83 per cent., contained trichina' 484 from mknown parts of the West, had but 2 infected, or 0.4 per cent., while the remaining 4,146 , mostly from the South, were free from this parasite.

Dr. C. A. Simpson examined 30 hogs at itlanta, which were mostly

* Vierteljalneschrift f. Ger., Med., de., N. F. XXx, p. 175-1s1.

† Lace cit. XXXviI, p. 345-351.

$\$$ A Report on Trichiniasis as observed in Dealuom Co., Indiani, in 18.4. By George Sutton, MI. J), Auroria, Ind.

Ș Report of American Health Assoc., vol. 7, p. 136. 
from Tennessee, withont finding any infected, and Dr. R. W. Steger ex. amined 180 at Sashville, Tenn., all of which were also free. Dr. William Mrers examined 330 hogs at San Antonio, Tex., finding trichina in but 2, or 0.6 per cent. *

Dr. H. J. Detmers has pamined from August to December, 1853, for the Department of Agriculture 3,331 at Chicago; of which S(), or 2.4 per cont., were fomml to he infected. Of this number 1,126 were trom nuknown distriets of the Wrest; 46, or 4.0S per cent., eontaining trichine; 50 were from Michigan, among whieh $t$ eontained the palasite; S31 were from lowa, of which 1!), or 2.27 per cent., were infected; 50 were from Dakota, of which 1 was infected; 5zll were from Illinois, anong which were 7 , or 1.35 per cent., eontaining trichinc; $30 t$ were from Wisconsin, with but 2 infected, or 0.60 per eent.; 350 cante fiom Neblaska, having but 1 infected, or $0.2 s$ per cent.; 100 were from Minnesota, and were free from infection.

Iu the laboratory of the Department of Agricultmre specimens from 300 hugs hare recently been examined, and of these 5 , or 1.66 per cent., were fomn to contain this palasite.

We have above the recolds of the examination of 18,859 hogs fiom varions parts of the United States, of which 517, or 2.7 per cent., contained trichinde. It is evident from these records that a eonsiderable proportion of the hoss from some sections of the comntry are trichinons, while those from other sections are practically free from infection. While it may be dilicult to ontline the trichinde districts and to trace the infected animals to the falms on which they were raised, it is believed that such a study would do much to elear up the origin of this infliction.

In addition to the insuections detailed above, Drs. Osler and Clement examined at Montreal 1,000 hog's firm Western Camala, finding 4 ufected.t 'The French inspectors report the examination of 103,525 piees of American meat, containing $2,0 \$ 0$, or about 2 per cent., infected. $\frac{\hbar}{q}$ The German inspectors, llnring the year 1880 , examined 78,850 pieces o American pork, of which we have record, and fomnd 1,265 , or $1 .(;$ per cent., to contain trichn: ; and in 1851 they examined 96, 455 pieces, finding trichina in 2,414, or 2.5 per cent.

Taling all the examinations of American pork thus far male, lootlo at home ams abroarl, and we have a total of 298,752 , during which trichina were fomd l,2s0 times, being 2.1 per cent., or 1 to 48 .

It would seem that this mumber of pieces. considering the close agree. ment between the results reached by American microscopists over this limited territory and those obtained hy the inspectors of American pork

* Report of American Ilealth Assoc., vol. \%, p. IB:-145.

† An Investigition into the l'arasite in tho l'ork supply of Montreal, 18-3, page 6.

¥ Chatin, ha Trichine et la Trichinose, Paris, 1083, page 217 .

11 II. Eulenberg. Ueber die in Jabre, 1831, anf Trichinen und Finnen nutersuchten sehweine. Vierteljahrschrifr, t: Ger. Med., dic., 18-2. 
in Europe, perhaps represents the condition of American pork so fur as examinetl.

In Europe there are some localities where the inspections have shown a greater proportion of infection than the arerage in the Uniterl States. At Stockholm 2,000 hogs contained 58 infected ones, or 2.9 per cent.; at Tannefors 300 hogs contained 10 infecterl ones, or 3.3 per cent.; and in 112 Bavinian hams 3 were trichinons, ${ }^{*}$ while Dr. Rine, of Linten, roported 4 infected animals in 45 , or nearly 9 per cent. $\dagger$ In Prussia, where the only really effective inspection is made, the proportion fonnd infected with trichine was, in 1876,1 to 2,000 ; in $157 \overline{7}, 1$ to 2,800 ; in 1 s.8, 1 to 2,000 ; in 1879,1 to 1,632 ; in 1880,1 to 1,460 ; in 1881,1 to 1,839 ; in 185:, 1 to 2,056 The number of inspector's in 1852 is placed at 20,140. Sereral inspectors at Erfurt were removed on account of incapacity, and complaints were made as to the condition of the microscopes. Indeed, it seems that the village barber is nsually trusted with the inspection of hogs in the smaller towns and rillages, and that he is required to make but three preparations from each animal.

Frequently, or generally, the specimens for examination are taken from the hams and hard muscles, where the trichinse are least abundant, instead of from the pillar's of the diaphragm aud tenderloin, where they are most easily found. Since the great epidemic of trichiniasis in Sax. ouy it seems to be admitted that these inspeetions are totally inadequate, and in order to make them more efficient the magistrates have awarded sums varying from 15 to 30 marks for each trichinous animal discovered. As a result of the rewards, and possibly of the fear exeited by the recent terrible ontbreaks of the disease in people, an in. creased number of infected hogs seem to hare been discovered. \$ These facts, as well as the extraordinary number of people reently infected from eating pork which had been inspected, are sufficient to demonstrate that large numbers of triehinous hogs pass the inspector's without being discovered, and that consequently the figures giren above are not a correct representation of the proportion of hogs which are infested with this parisite.

In nearly every country of Europe logs bave been examined and a certain number found to contain trichine, but the records do not seem to have been carefully kept; the clatil are not fully giren, and there is reason to doubt the acenracy of the work. It is difficult, therefore, to reach any satisfactory conclusion as to the proportion of infected hogs. We may safely assert, however, that no country ean with reason claim that its hogs are free from trichine, while the probability is that Eu-

\footnotetext{
"Warfwinge, Nord. Med. Ark., 1875, VII, 3, No. 18.
}

† Meissner, Sehmidt's Jahrbiicher, No. 130, page 118. Quoted by Glazier Rep., page 6 .

† II. Enlenber's, Vierteljahrsehrift f. Ger. Med., 1877 to 1883 .

(1)ispatehes of A. A. Sargent, American minister at Berlin, to State Department, dated Oetoluer 2 is and November 1:. 
ropean hogs generally are infected in a much larger proportion than is at present almitted.

In some parts of Europe rats seem to have been examined more carefnlly than pigs ; thus in Saxony one-half of the rats from flayers contain trichince, and 20 per cent. of all those canght are similarly infected; in Moraria sixteen ont of one lot of twenty lats were infected, nine of a second lot of twelre were infected, seven of a third lot of eight were infecterl. In Klederling, a suburb of Vienua, seren ont of forts-seren, and at Untermeidling two out of thirty-one were infected.* In France, where the anthorities now deny the existence of trichince jexcept as inported, and where one of the reasons for prohibiting American pork is the alleged fear of scattering this parasite over the comntry, the only outbreak of trichiniasis on record was cansed by the flesh of a native hog; and the rats from the ditehes and sewers of Paris, examined by Drs. Goujon and Legros, were infected in very large proportion; one lot of thinty-two contained three with trichine, and of serenty-two rats, five were full of these parasites.t

\section{EFFECT OF THE CURING PROCESS ON THE TRICIINA.}

If we admit that about 2 per cent. of Ameriean hogs contain trichi$\mathrm{n}$, it becomes a matter of the greatest importance for us to incquire into the eondition of the parasite after it has been subjected to the action of salt a sufficient time to enable the pork to be carried from the packing-houses in this country to the consumer's abroad. And here the effect on the consumers is entitled to more weight as a matter of eridence than those scientific experiments which are simply designed to prove the life of the parasite; for the triehina may sometimes still be living but not liave sufficient vitality to develop and reprodnce itself. Such trichina would be perfectly harmless even though the pork were eaten withont previous eooking.

In France it is said in the report of Academy of Medicine of Paris, that 9.5,000,000 kilograms or 200,000,000 pounds of American pork products had been consumed from 1876 to 1881 without eausing a single case of disease. And notwithstanding the fact that large quantities of such pork have been consumed for a number of years, the one ontbreak of trichiniasis at Créps, which was elearly traced to a French hog, is the only instance of the appearance of this disease among people that is recorded in that country.

In Germany, where it is the habit of the people to eat pork without cooking, trichiniasis among people is common, and it has been rery frequently asserted in some ruarters that many of these cases were due to American pork. During the recent terrible epidemic at Emersleben and neiglıboring towns, Dr. Brouarlol, of the Paris Academy of Medi-

* Dr. Glazier, Repont on Triehina and 'Trichiniasis, Washingron, 1e81.

$\dagger$ J. Chatin, 'Trichine et Trichinosen, 1. 15:3, foot-note.

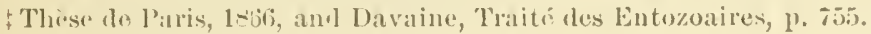

$5751 \mathrm{D} A-1 \mathrm{~S}$ 
cine, went to P'ussia to investigate the origin and nature of the disease and learn what he could in regard to the healthfulness of American pork. Not only did he find that these particular cases of trichiniasis were due to German hogs, but such eminent and well-known authorities as Professors Virehow and Hertwig, who have charge of the pork inspection at Berlin, asserted most positively that no case of trichiniasis in Germany had erer been clearly traced to American pork, although the people, as is their habit, persist in eating it raw.*

The so-callen outbreak of trichiniasis on board the English reformatory school-ship Cornwall has been much quoted as illustrating the diuger of American salted pork, but when closely inrestigated it proves to be an illustration of jumping at conelusions without eviclence, as always seems to have been the case where trichiniasis has been attributed to our meats. 'This outbreak of disease oceurred between September 23 and October 23,1879 , and forty-three boys were attacked ont of a' total of two hundred and sixty.two boys and fifteen officers on the ship. The idea that the disease was trichiniasis seems to hare been an afterthonght, for the ouly examination made was of the body of one of the boys two months after it had been buried. Doctors Powell and Cory thought they found trichinse in the muscles, and concluded the disease unst have originated from the American pork, which was used on board the ship; but no examination of this pork appears to have been made, and we are not at all certain that English pork was not used as well. Fortunately, specimens takeu from the corpse were submitted for examination to that well-known scientist, Dr. Charlton Bastian, and he prononnced the worms not trichinse at all, but a hitherto nnknown nematoid, which he classed with the genus Pelodera, calling the species Pelodera setigera. Dr. Cobbold, who is one of the very best authorities on this subject, asserts very positively that the worm was the Pelodera. teres, and had probably invaded the body after death.t As this worm has never been known to exist as a parasite in the hog, the assumption that the disease was produced by eating pork is an entirely gratuitous one, and the further assumption that it was dne to the American pork is evidently withont the least foundation.t

England has been one of the largest consumers of American bacou, hams, and pork, taking eren in $1 S 80$ and 1S81, when this tracle reached its largest proportions abroad, five times as much as either France or Germany. Belginm has also been a large consumer. The Comité consultatif dhygiene publique de France said in a recent oliticial report that in orles to determine the danger from the use of American pork they laal recently made new inquiries in England and Belgium. In England they were told that trichiniasis was so completely unknown that it was

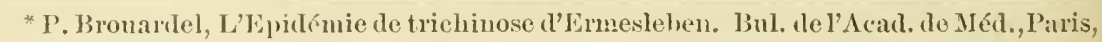
1383, p. 1501.

$\dagger$ Teterinariın, 183.4, p. 4.

$\ddagger$ Pow r, W. H. Ontlieak of lever proved to he Trichiniasis on board Reformatory School-ship, Cornwall. Rep. Med. Oft'. Local Gov. Bd., 1879. London, 1830. 
never mentioned, either in the newspapers, the hospitals, or in teaching medicine. Aud this was also the case in Belgium.*

We nay conclude, therefore, that notwithstanding the enormous quantity of American pork which has been consumed in Europe, there is no reliable evidence that any eases of trichiniasis have erer originated from its use.

We can now consider more intelligently the conflicting testimony in regard to the condition of the trichins in Ameriean salted meats when they reach Europe. In 1879 it was stated in the German reports that although a very considerable number of examinatious had been made at Minden, no living triehinge had been demonstrated in preparations of American pork. 'This statement was repeated in 1880 by the same authority.ț In France, Colin ant most others who have experimented with the trichine of American meats liave found them dead and incapable of producing any injurions effects when fed to other animals. It was also found that even slight salting killed all the triehina within two months. Colin concludes, therefore, that the dauger from eating American pork, considering the time that it must have been in salt before it can reach Europe, is slight or inappreciable.s Fourment || and Chatiu Thave eontested these results, but their opinions are so extremely ratical as to lose much of their force on this aceount. It is not impos. sible that in certain rery lare cases the capsules containing the triehinie may have become so dense or so impregnated with lime salts as to protect the parasites for a longer time than usual against the action of the brine; but the eomplete imnocuonsuess of our pork as demonstrated by its use on so large a scale in Englaur, France, Belgium, and Germany, with no eases of disease clearly traced to it, is the strongest possible evidence of the destruction of the triching during the process of curing:

Dr. Bromartel, of the Paris Aeademy of Medieine, who investigated the recent ontbreaks in Ermsleben, has furnished new and rery important evidence on this point.** He learned that the meat of the diseased hog was ehopped and mixed with suffieient salt to preserve it, and those who ate of this meat soonest after the kiling of the animal were not only more severely affected, but their symptoms appeared in a slorter time. The animal was lilled the 12th of September, and of those who partook of this meat on the 13th 33 per cent. died, while of those who did not eat of it until the 18th and 19th none dier. In fact, there was a rery regular graduation in the intensity and firtality of the cases when they were elassified according to the number of days which

\footnotetext{
* H. Bonley, 13ul. de l'Acarl. dlu mérl., l’àis, 1--1, 1. :3:3.

† linleuberg, Vitljhrscht, f. ger. mél., 1s79.

$\$$ Loc. eit., $1-80$.

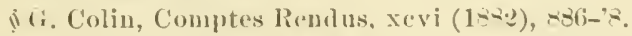

|| L. Fourment, Comptes liendus, xeiv (1-sio), 1:11-'13.

- J. Chatin, La 'Trichino ot la Trichinose, Paris, 1583, 16.4-190.

*+ Brouariel, Bul. de l'Acat. die míl., 1-83, 1501.
} 
had elapsed between the killing of the animal and the eating of the meat. It was very evident that the parasites were rapidly losing their vitality and their power to produce disease. M. Colin thought this was due to the effects of the slight salting, and M. Brouardel seemed willing to admit this.

If, then, so marked a result is produced in a single week by the slight salting which this ehopped meat reeeived, it is rery plain that the high degree of salting to which our packed meats are subjected must be sufficient in the rast majority of cases to eompletely destroy all trichinæ and to make the meats perfectly safe. The question eamnot be narrowed down for this reason to a comparison of the proportion of animals affected with triehine in Ameriea and Europe, eren if this were actuaily determined, which is not the ease, but it necessarily turns on the healthfulness of the meats of these comntries at the time when they are offered for consumption. And when the matter is viewed from this stand-point the very great superiority of American salted meats over even the inspected German hogs is too apparent to be questioned by unbiased scientific mell.

In the latest discussion on this subject in the Paris Acarlemy of Medieine M. Pronst saill :

The question is not a leternination if American meats contain trichine, but in what condition these trichine are found ; if they are alive or dead ; if they are injurious or not; in a word, if the consumption of American salted meats is dangerous or not to the public health.

In this comnection I ask permission of the academy to read a passage from a most interesting letter that I received this morning from Dr. Gibert, a health officer and distinguished sanitarian of Havre :

"In 1881," says MI. Gibert, "American salted meats entered largely into the food supply of the working elass of Havre; but in regard to this it is important to divide the consumers into two classes:

"1. The people buying Americau salted meat for family consumption always cooking it and never eating it raw. The inbabitants of the quarters of Eure and Saint François nomished themselves exclusively with it.

“2. The workmen employed in handling the packages of salted meat, who during fifteen years continned to eat this meatraw. MM. Bonley and Chatin conde easily have seen in their walks on the wharves of Harre workmen breakfasting on a piece of hread and a slice of raw bacon, eating not only the fat but all parts of the meat. Any one conld repeatedly see these workmen day after slay, even when at work, eating picces of raw salt pork withont fear.

"It is certain, then, that at Havre, for more than fitteen years, huudreds of workmen consumed salted meats trichinons as well as not trichinous, and never during this long period of years lias a single workman been incommoded by this food.

"No physician in Havre has seen a disease resembling in the least the Ermsleben disease described by MI. Bronardel aud Grancher. Such an assertion demands some proofs whichñ is easy for me to give.

"I would remark, in the first place, that if the meat consuned raw had affected the health of the workmen employed in such large numbers hambling salted meats the directors would lave soon discovered the vacancies in the ranks of the workers. After an investigation carrefully mate by me, and which it is easy to taake anew ofticially, it was found that never hat there been a knowledge of such a fact in any of the largo importing houses of Harre. 
"The worknen, after the arrival of the Paris savants, took pleasure in eating the pieces themselves that were pronounced trichinous, so certain were they of their perfect harmlessness. And neither during the stay of these gentlemen at Have nor afterwards was there a single case of disease, or even a simple indisposition.

"In the second place, I would remark that during this period of fifteen years we have had no serious epidemic of typhoil fever. That of 1880-1881, the ouly oue at all serious whieh has ocenrred in on' eity, affeeted the guarters occupied by the well-to-do or rich people, while the quarters where the American meat was consuned suffered very little. There was then no possibility of an error on the part of the physicians, even if sueh a gross error conld have been committed.

"It follows, from the facts that I have just related, that the salting of American pork is sufficient to kill the triching; and if, in addition to this canse of seenrity whieh has been experimented upon by the workmen of II avre for fifteen years, we add the cooking, as it is practiced everywhere in France, the conelusion is foreed npou every one not projuliced in advance that American salted meats are absolntely incaphle of prolucing trichiniasis in the consumers.'

\section{the same discussion M. Leblanc said :}

The aliseussion appears to me exhansteal; however, I ask peruission of the academy to communicate in support of the note of Dr. Gibert the following observation. It was fin ruished to ne by the prineipal meat inspector of Paris:

The reteriuarians nuder his direction examined dnring six mouths in 1, $-515,000$ kilograms (11,000 pounds) of Americau salterl meat per day. Sixty ihousaud kilograms were seized as trichinons, and a large part was shipped to England. Duriug these six months the employés and draymen of the dealers in salted meats who came to the station of Batignolles ate meat in presence of the inspectors which was notoriously infected with triclinie. Tot one of them beeame sick.

One of these, M. R., employed by Caluau, 11 Rue bergère, was atenstomed to this, and took pleasnre in eating the parts of the pork in which the microscope had demonstrated the presence of trichuac. To-day, after three years, he is well; more than this, having been receivel at Beanjon as a patieut of on colleague M. 'tillanx, for a fractured arm, aud having related his bravado, he was the subject of a special examination; his muscular tissue was recognized to be healthy, and no trichina couhl be fonud in it. *

\section{FFEECT OF COOKING ON TRICHINA.}

If the trichine of American pork are destroged by the curing process in a time much shorter than is necessary for such meats to be shipped from our packers to any of the consumers in Emrope, it may seem superfluous to go into a consideration of the effect of cooking, and yet it is not wholly so. Under certain couditions it would appear that the trichince do resist the eming process for a considerable time; and though these conditions ocemr so seldom that uninspected salterl meats are much safer than inspected fresh ones, it is still wortl our while to inquire if perfect safety against infection eannot be guaratech where a reasonable deglee of cooking is practiced.

There is some conflict of opinion as to the temperatme necessary to destroy trichine, and yet the results of experiments do not differ so widely. Vallint coneluded that a temuerature of $54^{\circ}$ to $56^{\circ} \mathrm{C}$. (129 to

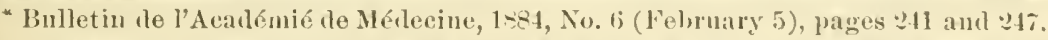

$\dagger$ E. Vallin. De la résistance destrichines a la clalenr et de la température cen-

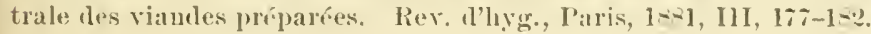


$133^{\circ}$ F.) kills most of them, and that $600^{\circ} \mathrm{C} .\left(140^{\circ} \mathrm{F}\right.$. $)$ is safe. Fiedler's experiments show that trichince are quickly killed at $62.50 \mathrm{C}$. (144.5 $5^{\circ}$ F.) Fjorl's investigations show that the interior of a ham weighing 8 ponnds reaches $65^{\circ} \mathrm{C}$. $\left(149^{\circ} \mathrm{F}\right.$.) after hoiling two hours and seventeen minntes; one weighing 10 ponnds, after three hours and six minntes; one weighing $14 \frac{3}{4}$ pounds, after four hours and eleven minutes; and one weighing 16 pounds after four hours and thirty-seven minutes. Vallin found that a lian weighing 12 pounds had an interior temperature of $65^{\circ} \mathrm{C}$. after three and a half hours' boiling. 'These results, therefore, correspond very closely. Hein* found that a 2.2 pound roast reached a temperature in its interior of $69^{\circ} \mathrm{C}$. after one and a half hours. Rupprecht observed that rapidly fried sausage only had an interior temperature of $53.5^{\circ} \mathrm{C}$., and was still capable of producing infection. Colin thad a steak weighing half a pound boiled for ten minutes, when its appearance on cutting was white, without any red points. It still contained living trichina, however, which, being fed to a bird, were afterwards found developed in the intestine.

The indications from these experments are that while fresh meats may not always be cooked sufficiently to kill trichinie, salted meats are almost invariably cooked for more than the necessary time. This conclusion seems also to be borne ont by the experience of people in all parts of the world. Trichiniasis from cooked meats is an exceedingly rare disease. In the United States, where pork in its various forms is consumed to as large an extent as in any part of the world, and where more than one-fourth of the hog product of the rorld is eaten, it is seldom, indeed, that we hear of any infection among our native population, becanse the habit of eating raw meats, particularly when fresh, does not prevail. The few cases which occur from time to time are nearly always among Germans and are traced to the ingestion of pork in some form, which has not been cooked at all.

In this connection Dr. Brouardel brought out a very interesting fact in his investigation of the epidemic at Ermsleben. No cases of disease occurred there except with those who ate the meat raw. The family of Herr Heine, the mayor of Ermsleben, consisting of five persons, consumerl some of this same meat in the form of sausage on the 15th of September. The sansage was cut in pieces about $1 \frac{1}{2}$ inches in diameter and was cooked by placing in boiling water for only five minutes. Not one of this family suffered in the least degree, but the cook who ate a small piece of the sansage before it was cooked contracted the disease. Boiling for so short a time has never heretofore been considered sufticient to clestroy this parasite, and yet in this instance it undoubtedly protected the consumer's from the infection.

At the session of the Paris Acalemy of Medicine, January 29, 1884, a report was presented by the special committee appointed to eonsider

C. Hein. Rep. of a case of trichiniasis, with remarkson diagnosis and prophylaxis. Mittl. d. Ver. 1. Aerzte in Nied Pest, 1883.

†r. Colin. Sur les trichines. linlletiu de l'deal. de méd., 1881, 243. 
(1) the report of M. Bronardel in regard to his mission to Ermsleben, (2) the communication of M. Grancher on the symptoms and pathological anatomy of the epidemic of Ermsleben, and (3) a letter from the minister of commerce asking the advice of the acadeny in regart to the question of trichiniasis. In this report appear the following points of interest:

A considerahle invasion of German rats has been noticet of late years after the freezing of the Rhine, aull MI. Brouardel no longer sees the same species of rats at the morgne that he formerly found there. M. Laboulbene and II. Colin had occasion to olserve quite a large number of trichinons rats that had been fonnd in the sewers of Paris. Finally, we are also invaded hy the trichine which penetrate France with the German hogs, which are infected in the proportion of 1 to 1,000 to 1 to 2,001 .

Without doubt we do not know precisely, scientifically, the clegree of activity of the trichin:e accorling to the time that thes have been ençssted in American meats, their vigor, the condlition of the meat and the stage of the curing-desiderata which future experiments can alowe supply.

The same ignorance exists in regard to onr own hogs-ale any of them trichinons? If so, what proportion? What is the condition of those in the suburban zone surrounding Paris which, nourished like the sewer rats, may be trichinons like them?

It remains for us to speak of the action of American salted meats in the production of the epidemics of trichiniasis in Germans which have been observed at Dusseldtorf, Rostock, and Bremen, but our information in this respect is entirely insufticient, aud according to the indications that MI. Bronarilel has alreadry presented to the academy the exotic origin of these epidemics is denied by sereral of the principal German savilus, aud particularly by M. Virchow. Out Gorernment might adelress the German Empire in regard to this in order to have official documents; but the results of such an incuiry have for ns, from the standpoint now under cliscussion, an almost secondary importance. It in fact we, like the English and the Belgians, have been free fron epiclemies of trichiniasis althongh we received salterl trichinons meats and eren tresh or slightly salted pork of German origin more daugerons than that which comes from Chicago or Cincinnati, since it harl only to cross the Rline and the Vosges, this is because our culinary labits are entirely different. Let ns remark also that in Ameriea it is above all the Geruans who are affected with trichiniasis-an arlitional proof of the effect of culinary habits.

But already we can conclude from the levelopments which precerle that no case of trichiniasis having been noticed either in France or in England fron the consumption of American salterl pork, the importation of these meats may be anthorized in lranee. This decision has been reached by the commission by a rote of 5 to 1 .

At the same session of the academy MI. Lunier presented the following table, showing the importation of salt-pork products for eiglit years, in lilograms:

\begin{tabular}{|c|c|c|c|c|c|}
\hline Year. & United States. & England. & Germany. & $\begin{array}{l}\text { Other comm. } \\
\text { tries. }\end{array}$ & Tutal. \\
\hline 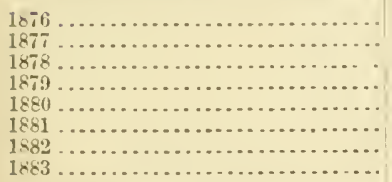 & $\begin{array}{r}3,269,960 \\
12,462,078 \\
28,102,290 \\
31,784,913 \\
34,246,195 \\
17,123,767 \\
4,611 \\
.2,396\end{array}$ & $\begin{array}{r}1,875,736 \\
1,889,905 \\
1,454,884 \\
1,107,6961 \\
1,233,228 \\
686,525 \\
1,109,870 \\
\ldots . . .6 . .\end{array}$ & $\begin{array}{r}702,530 \\
994,334 \\
921,167 \\
1,030,673 \\
846,174 \\
723,465 \\
1,055,783 \\
1,136,793\end{array}$ & $\begin{array}{l}1,047,920 \\
1,078,505 \\
1,314,437 \\
1,742,854 \\
2,387,671 \\
1,182,474 \\
1,074,259 \\
2,091,779\end{array}$ & $\begin{array}{r}7,896,146 \\
16,424,7222 \\
31,792,778 \\
35,675,131 \\
38,713,268 \\
19,716,281 \\
3,244,523 \\
3,274,966\end{array}$ \\
\hline
\end{tabular}

It follows from this table that the importation of American salted meats, which hat

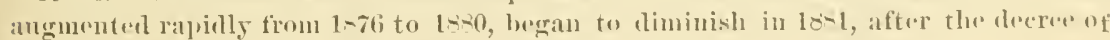
February 12, 10-1, which prohibited the inplortation of salted meits from the I'nited 
States into all the French territory. The 4,611 kilograms which appear in the sear 1882 came from a stock taken fiom the warehouses December 31, 1882. The 52,396 kilograms of 1883 were introduced atter the promulgation of the decree of November 27, 1883, which removed the interdiction.

The same gentleman presented the following table, which shows the number of live hogs importer into France in the years 1877 and 1882, and the comntries from which they came:

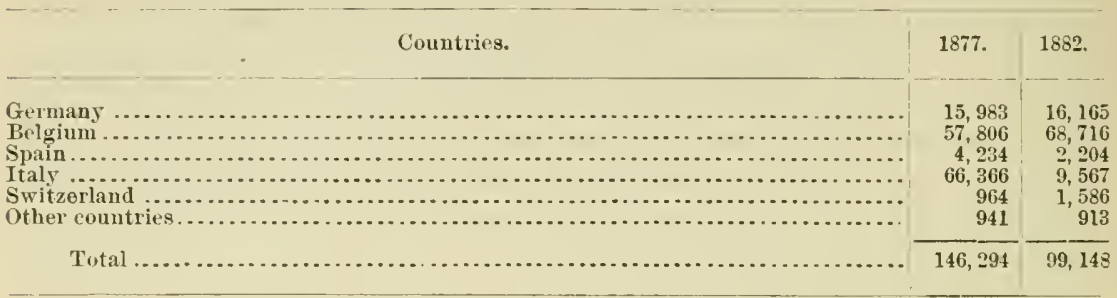

In this connection he remarked, "It is then, to-day, Belgium and Germany whieh furnish us the greatest number of living hogs. Is it not from this direction that there is reason to fear the invasion of trichince and trichiniasis ?" *

\section{TRICHINIASIS IN AMIERICA AND EUROPE.}

The number of cases of trichiniasis occurring among people in the United States is actually very small. The records of these have not been brought together in a thorough manner, but, as far as we liave been able to ascertain, the disease has never occurred in more than three or four localities in a single year, and during the last twenty years there does not appear to have been more than thirty different outhrealss. In none of these ontbreaks have a sufficient number of people been attacked to allow of the term epidemic being applied to them in any proper sense of the work. Usually but two to four people liave been affected at a time, and never, so far as we have been able to learn, more than ten. All have resulted from eating raw or very imperfectly cooker meat, and in very few of the instances had the pork undergone any preliminary euring. Some of the cases reported as trichiniasis were never demonstrated to be this disease, but seem to have been the result of poisoning by meat which had been preserved without sufficient salting until it had undergone partial decomposition. It has long been known that extremely virulent poisons are produced during putrefaction of Hesh, and the effects of these hare been observed so often in Germany when sausages were eaten that they have received the special name of wurstgift or sausage poison. 'This does not seem to be understoorl by many American plyssiciaus, and so nearly every case of sickness arising from the consmuption of the raw or imperfectly cooked tlesh of logs in the various forms in which it is preserver is reported as trichiniasis. So that while it may be true that some cases have not been reported or bronght 
to our notice it is equally true that not all the cases reported as trichiniasis were really due to trichinse.

In the debate which occurred in the French Senate June 20, 1552, II. Festelin referred to seren epidemics produced by American pork.* One of these so-called epidemies consisted of a single case of the disease which occurred in New York. Another was the disease on the English ship Coruwall, which was at first supposed to be typhoid fever, and was only decided to be trichiniasis when a body was exhmmed two months after burial, and worms, which the examining physician took to be trichinæ, were found in the muscles. But we have it on the very best authority that these worms were not trichina, and there is no evidence eren that they caused the disease. The most probable theory is that they gained access. to the body after burial. No trichinse or other parasites were found in the American meat consumed on this ressel.

Another epidemic ho referred to as having occured at Breneu, in which forty persons became diseased from eating an American ham. M. Chatin has mentioned this outbreak again and again, and iusists that it is a demonstration of the dangerous character of American meats. The charge was so serious that it has been inrestigated as carefulle as possible. M. Testelin does not give the authority who is responsible for this statement, nor does he so much as say in what jear the ontbreak occurred. M. Chatin is more definite, however, and says the disease was observed in 1575.t He refers to the Traite d'hygiéne publique et privée, by Pronst, published in $187 \pi$, as his authority for asserting that forty persons were affected at this place as the result of eating an American ham. By consulting the yearly health report of Bremen for 1875 we find that no cases of trichiniasis in man are recorded during that year. There is simply a statement that two trichinous hogs (native animals) were discovered near Bremen. The outbreak of trichiniasis referred to by-Testelin and Chatin seems to have been one that occurred at Hastedt, near Bremen in 1S7t, during which forty-two persons suffered, but all recorered. This epidemic was first announced August 15, and was cansed by eatiug the flesh of a hog that had been slaughtered July 31. The diagnosis was confirmed by microseopic examination of a piece of musele from one of the sufferers.t There had been a habit here, ats in most other parts of Gernany, of attributing all cases of this disease to American pork without inrestigation, and this may have been the origin of the story so industriousls circulated by M. Cliatiu. At all erents, this is the only extensire epidenic of trichiniasis which is rerorded as occurring at or in the vicinity of Bremen from 1573 to 1577 , inclusive, and there is no question but that this was cansed by a mative animal.

One of the other epidemics referred to ocenred in Madrid, and an-

* Chatin, Lil Trichine, Itc., p. 210.

tChatin, Lá Trichinc, Nc., p. 165.

‡Dritter Jahresherichl iber den ötr. Gesmulheitszustand, dr., in Bremen, in Jahre 1874 . 
other in Liege, in Belgimm. It is donbtful if in either case the trouble was traced to our pork; but no facts in regard to them have yet been obtainer.

II. Chatin, in his recent work on trichine and triehiniasis, states that "such is actually the frequency of trichiniasis in the United-States that the newspapers consider themselves happy if they have but a few deaths to reeord each week." Whether any one in France believes this remarkable exaggeration may be considered questionable, but still it is seriously advanced by a scientific man as a reason for prohibiting our pork. Those who see the American papers know very well that not only weeks but months elapse when no deaths are recorded from this eause. And if it were not for our foreign population, who have brought with them their dangerous habits of eating mneooked pork, America wonld be as free from trichiniasis among her people to-dlay as is France.

When we examine the records of Germany, however, we find that, in spite of the small proportion of infected hogs which they admit, in spite of the inspection, there ocenr a very large number of cases of this disease. In 1877 there were 16 in Königsberg, 1 in Potsdam, 6 in Berlin, 98 in Stettin, 1 in Oppeln, 61 in Merseberg, and 52 in Minden. In 1878 there were 27 in Köuigsberg, 8 in Marienwerder, 102 in Potsdam, 50 in Stettin, and 30 in Merseberg. In 1879 there were 55 cases in Königsberg, 93 in Frankfort-on-the-Oder, 82 in Berlin, 7 in Marienwerder, 3 in Schleswig, 60 in Erfurt, 7 in Merseberg, and several in at least three other places. In 1880 there were 149 in Merseberg, 83 in Erfurt, 49 in Frankfort-on-the-Oder, 3 in Marienterder, 29 in Königsberg, and 16 in Berlin. In 18s1 there were 3 in Marienwerder, 15 in Berlin, 10 in Frankfort-on-the-Oder, an indefinite number in Posen, 4 in Stettin, 148 in Merseberg, and 58 in Erfurt. In 1882 there were 3 cases in Berlin, 60 in Cologne, 4 in Merseberg, 4 in Heiligenstadt, and sereral in Posen.* In 1883 the remarkable epiclemic in Saxony oceurred from eating pork which hat been slaughtered and iuspected in the town of Ermsleben. In Ermsleben 257 persons contracted the disease, and 50 died. $\dagger$ In Deesdorf there were 40 cases and 9 or 10 deaths; in Nieuhagen 80 eases and 1 death. There were a number of other epidemies during the jear, the statistics of which have not yet been published, but we have already recounted sufficient to show that trichiniasis is incomparably more frequent in Germany thau in America.

Indeed, for the seven years from 1876 to 1S83, inclusive, the rery incomplete statistics given above show that 1,835 people contracted the disease, being an average of 262 cases per annm. When in addition to this we consiler that the United States is really the greatest porkeating nation in the world, that we consume more than four times as many hogs as are raised in Prussia, that a considerable portion of our population consists of Germans who retain their habit of eating raw pork,

*Enlenberg, Vrtljusiht. f. erer. Med., N. F., XXVIII-XXXvII.

† Dentsehe med. Worh., 1R2, No.1, p.7. 
the wonler is, not that we have a half dozen or a dozen cases of trichiniasis in a year, but that we do not have many times this number; and we see $n 0$ way of explaining the comparative immunity which onr people enjoy except by the conchision that our pork, eren when fresh, is not so much more dangerous than the German article as the results of microscopic examination thus far published would lead one to suppose.

\section{REPORTS OF BOARDS OF HEALTII.}

The commissioners prepared and forwarded copies of the following circular letter to the rarious State and city boards of health:

With a view to ascertaining the extent to which trichiniasis nrevails in the Uniterl States, the following questious have been formulaterl, to be addressed to the secretitries of the varions State and "ity boards of health.

As it is desirable that the report of the commission shonld be presented to Congress at once, the undersigned would beg as speety a response as possib]c:

1. How many cases of th ichiniasis have come to the knowledge of your hoard? Please give dates is far as practicable.

?. In how mauy cases was there a mieroseopic illeutitication of the trichine in the human subject and in the susperted meat?

3. How many of the cases were fatal?

Responses have been received from thirty-nine of these boards; of this number twenty-two give negative replies; they were as follows: Alabama, Arkansas, California, Delaware, District of Columbia, Kentucky, Lonisiana, Maryland, Minnesota, Missouri, Albany (N. Y.), Ohio, Pennsylrania, Rhode Island, Tennessee, and Virginia.

The secretary of the State board of Alabama says that no case has ever occurred in that State, though infected meat has been reported.

The secretary of the health department of Maryland says that after an examination of the recorts from January 1, 1834, to December 31 , 1883, corering a period of fifty years, he finds no cases of trichiniasis reporterl.

The heaIth officer of Cleveland. Ohio, says that in 187:-73 there were some cases of trichiniasis reported in that city, but no definite record of them can be fornd.

\section{CASES OF TRICHINIASIS REPORTED.}

Cases of trichiniasis are reported by the following boards, viz:

Connecticut.- Three in 185\%, all from the same pork and at the same time. The suspected meat was examined br Mr. C. IV. Chamberlain, of Hartforl, secretary of the board, and others. No deaths resulted.

Illinois. - The registrar of vital statisties for the city of Chicago says:

Three draths fron trichiniasis have ocenmel in this city within the last ten rears. Two of these oceured in December, 1820 , and the last one in Jammary, $1<-2$. . There was a microscopic identification in the two first "ases amd probably also in the last.

The secretary of the State board of health says:

Between 186 and 1<-1 there had been seven ontheaks of trichiniasis in Illinois. resulting in eleven deaths out of some serenty or cighty cases. Since li- I there haves 
been two deaths in Chicago; three ontbreaks, resulting in three deaths, and some twenty-fice or thirty cases in 1883, and one in Fulton County in 1854, details of which have not yet been received. In nine of the fatal cases the disease was identified by microscopic examination of the human subject, and of the suspected meat in all eases.

Iowa.-The Secretary of the State board of health reports as follows :

Since 1580 , in compiling deaths, I have found 3 recorded as from trichiniasis; in 1880, 2 in Aclams County, probably genuine cases; in 18s1, 1 in Butler Comnty, a very doubtful case. None of the cases were identified by microscopic examinations.

\section{Massachusetts.-The health officer for the State board of health for Massachusetts says:}

The number of cases of trichiniasis that have come to the knowledge of the board are as follows :

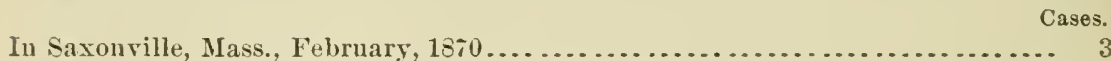

In Lowell, Mass., Mareh, $1870 \ldots \ldots \ldots \ldots \ldots \ldots \ldots \ldots \ldots \ldots \ldots \ldots \ldots \ldots \ldots . . . \ldots \ldots$

In Framingham, Mass., December, 1872............................. 3

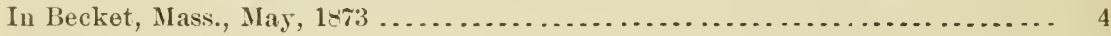

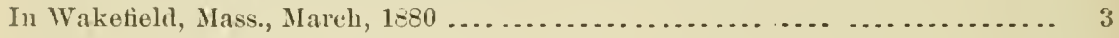

Total nnmber of cases................................... 19

One death oceurred in the ontbreak at Saxonville.

Ilentification of trichince was made in the fatal case at Saxonville by post mortem. In the Lowell cases trichinie were identified in the pork, as also in the Framingham cases. In the seren remaining cases at Becket and Wakefield the evidence was srmptomatic and by exclusion, i.e., members of families who had not partaken of uncooked pork were exempt from infection. The evidence, however, was satisfactory to the board.

Michigan.-The secretary of the State board of health of Michigan gires the following detailed report of ten ontbreaks of trichiniasis in that State sinee December, 1866:

1. A fatal case of trichiniasis ocenred in Detroit, Mich., in December, 1866 . Upon post mortem examination large numbers of trichine were fonnd in the abdomen and a lesser number in the mnscles of the leg. (Dr. Herman Kiefer.)

2. Five cases ocenred in Port Furon, Mich., in Jannary, 1874, with 2 deaths. The cases occnred in one family, and were raused by eating salted smoked ham. (Reported by Dr. M. Northup, Port Huron, Mich.)

3. Several cases of trichiniasis occurred near Flint, Mich., in the fall of the year 1875. Cases also occnrred there in June, 1876. In the last outbreak, at least, triehinie were found by microscopic examination in the meat, and also in a particle of muscle of the leg of one of the patients. (The cases were in the practice of Dr. A. B. Chapin, of Flint, Mich., now of Detroit.)

4. Five cases occurred in Otsego Township, Allegan County, Michigan, in February, 1377. All recovered. All were in one lamily, the members of which had eaten rat ham. Members of another fanily ate a suall quantity of the meat, and rere also sick, but recovered withont medical attendance. Trichince were found in the meat by microseopic inspection.

5. Three cases, with one death, occurred in the eity of Iona, Mich., in 1878, in the fanily of Mrs. Strunck. The meat was eaten raw. A microscopicexamination of the meat was male, ánd, I believe, trichine were also identified in the human subject.

f. $1 \mathrm{am}$ informed that eases, aud one or more deaths, occurred in the vicinity of Iona, Mich., in the summer of 1s80, in the practice of Dr. H. B. Barnes. Triclinie were fomm in the pork, and alsu, I believe, in the muscles of those who died.

¿. Five cases and two deaths oecmred in the family of a Geman named Rumsoek, in Lausiug, Mich., in the last of Jannary, 1881, and the first of February, 1831. 
The cases were in the practice of Dr. Dolan, of Lansing, who has since died. Great numbers of non-capsuled trichine were seen by Dr. George E. Ranney, myself, and others in the muscles of a boy who died. (I still have slides showing the trichina as taken from the muscles of a person in the family who died.) Part of the meat was eaten raw. It was not examined for trichina; but the hog was sick and was killed to aroid loss of the animal.

8. Five cases of trichiniasis occurred in Vickeryville, Miontcaln County, Michigan, in December, 1883. All resulted from eating the flesh of one hog. Onodeath occurred. The boy who died had at different times eaten small pieces of pork only partially cooked by holding them on a fork before the fire. He had also eaten raw, on several occasions, little bits of sausage made from the flesh of the hog. 'Two others lad eaten the meat cooked, but probably rare-done. The other person had eaten raw a little bit of siusage, perhaps half an ounce, but the rest of what he ate was well cookeri. Trichince in abundance were found in the pork, specimens of which are now in this office. (Reported by Dr. J. Tennant, Carson City, Mich.)

9. Fonr cases occurred in Jannary, 1884, in the eity of Niles, Mich. One death has occurred and three persons are now serionsly sick. The pork contains great numbers of trichine, as determined by observations made at Niles, Ann Arbor, and in this office.

Fnrther details as to the fire cases occurring at Port Huron, and also of the case at Detroit, are given in the published report of this board for the sear 1875 ; and of those ocenring in Otsego, in the report of this board for the year 18T.

Such answers as I am able to give to the four questions asked by your Commission have been summarized from the foregoing particulars, and are given with each question, as follows:

"Question I. How many cases of trichinasis have come to the knowlerlge of your board? Please give dates as far as practicable.

"Answer 1. I am able, at this time, to send you facts concerning ten outbreaks of trichiniasis occurring in Michigan. In three of these the number of cases was not stated. In seven outbreaks there was a total of twenty-eight eases. The dates are given in most instances in the report accompanying this.

"Question 2. In how many cases was there a microscopic identification of the trichin:e in the human subject and in the suspected neat?

"Answer 2. In two ontbreaks the observer did not state whether any microscopio eximination was made. It is believed that the human muscles were examined in five of the ontbreaks, and in each of them trichinie were found; in three of these it is positively known that trichince were found present. In seven ontbreaks the pork was examined, and in each of the seven trichin:e were found in the pork. In the other outbreak, microscopic examination was made only of the muscles of the human subject, in which trichince were found.

"Question 3. How many of the cases were fatal?

"Answer 3. In one outbreak it was stated that there were no fatal cases: in one ontbreak, where fatal cases occurred, the number was not stated; in one outbreak it was not stated whether any fatal cases occurred; in another outbreak, now in progress, one death has alrealy occurred; and in six other ontbreaks seren deaths were reported ; making in all, in which the number was reported, eight deaths."

New Jersey.-The records of the State board of New Jersey extend from January 1, 1875, to late, a period of about nine years. During this period but one death from trichiniasis has been reported. This was in May, 1S51, and was a female. The method by which the diag. nosis was determined is not known.

New Yorli-The following report is furnisherl by the secretary of the board of health of Tew York City :

A few cases of alleged trichiniasis have come to the knowledge of the board, but there is no record of the number or dates. 
In two families, luring the past eighteen years, there has been, within the knowledge of this boarl, microscopic identification of trichine in the human subject.

During the past ten years five deaths attributed by attending physicians to trichiniasis have been reprorted to this boarl: one in 1875 , one in 1878 , one in 1880 , and two in 1881 .

The secretary of the board of health of Brooklyn, $\mathrm{X}$. Y., sajs that five cases of trichiniasis have ocemred in that eity, of which a full histors may be found in the proceedings of the Merlical Soeiety of Kings Conntyfor 1579 .

North Carolina. - The secretary of the State board says that an equirocal ease of trichiniasis occurred in Wilmington, in that State, but no microscopical examination was male. It was in the person of a boy of German parentage, lubitnated to msing raw lıam.

Trest Virginia.-The health officer of the eity of Wheeling reports five cases-father, mother, and child of same, aged two and one-half years, and two females of other families. All ate of same meat-raw smoked ham-on Mareh 4, 1870. No microscopie identification was unde in the human subject.

Tisconsin.-The secretary of the Wisconsin State board of health says that some cases of trichiniasis have occures in Milwaukee, but does not give the number or dates.

\section{CALSE AND PREVENTION OF TRICHINA IN SWINE.}

The worm known as the Trichina spiralis has no stage of its existence outside of the animal boly, and eamnot multiply or even remain alive for any ennsiderable time, so far as has ever been ascertained, after it quits its host. Every infected animal must become infected either by eating the muscular tissue of another auimal which has previously obtained the parasite in the same way, or possibly by taking food which has been soiled by the exerement of an animal recently infected. It is generally admitted that eating flesh which contains the parasite is the most frequent, if not substantially the only, way in which trichina find their way in to the body. A few cases have been adranced to show that pastures and feeding places may be infected and be dangerous for a cousiderable time; but, according to our present knowlerge of the natural history of this parasite, it may be doubted if many instances of this kind occur.

When meat containing trichina is taken into the stomach the eapsule or eyst which surromnds the worm is dissolved by the digestive liquids, the parasite is set free, develops into its matme form, the females are impregnated, and each gives birth to one thousand or more young. The young trichimse penetrate the intestinal walls and find their way into the varions muscles of the body, while the mature worms, and doubtless nuny of the young as well, are voiden with the exerement. Now, it may be admitted that a lange number of the mature parasites will be passed from the bowels before they have bronght forth their young, and that if taken into the stomach of another animal the act of reproduction 
would continne; but it seems doubtful if enough of such mature worms wonld be consumed in this manner to canse any serious infections. We do not know, however, how long the worms are able to live ontside of the body in this dereloped condition; if they can exist but a few days the danger from them would be rery slight, but if this period ean be prolonged for weeks or months the danger would be more serions, and we might have at least a partial explanation of the many cases of infection occurring where the condition of life among the hogs seems to be all that could be desired.

The roung trichine or larra which are prodnced in such enormous numbers in the intestines within a few lays after infected meat has been eaten, and many of which are donbtless voided with the excrement, are practically incapable of dangerously infecting grom ds or feeding places. These cannot reproduce themselves nntil they have found their way into the muscular system, and have been encysted for a time, so that even a considerable number of such larve taken into the stomach would prodnce no appreciable effects.

In the present condition of kuowlenge the tendency is to conclude that by far the larger part of trichinous hogs are infected by eating the flesh of some animal which has previonsly been infected in the same way. Trichine cannot develop or live for any considerable time in the bodies of insects, cold-blooded animals, or birds, and, consequently, the infection must result from some of the warm-blooded animals, which either habitually or occasionally eat flesh. Among these cats, rats, and mice are the ones most frequently suspected; but an inquiry into the conditions under which hog's are raised in the West has led us to doubt if the infection conld occur in any considerable number of cases in this way. Hogs are usnally kept in grass fields, where rats and mice are not common, and where cats certainly do not abound, and in no part of the log-raising comtry is it a custom; so far as conld be ascertained, to run the hogs in corn-fields, where there wonld be an opportnnity of their finding rats and mice.

It has been charged that there was a custom of feeding the hogs which died from disease to the rell animals, and that this accomnted for the trichinous infection. After an extensive in restigation, however, we feel authorized to state that this assertion is not correct. Snch a practice seents to have been followed to some extent a half dozen or more gears ago, but as the contagions character of hog cholera became better mderstood, and as the demand increased for the cheal) grease rendered from such dead animals, they were more generally sold to rendering establishments at a price considerably beyond what they would be worth for animal food. The trichina of to-day must therefore be acquired from some other source than the hogs which die mpon the farms.

The French and German anthors have not hesitated to assume that our hogs were infected by feeding upon oftal from the slanghter-houses, but this assumption conld only have been made in complete ignorance 
of the actual condition of affairs in the hog-growing sections of the conntry. Practically all of the hogs which go to the packing-houses are raised upon farms miles, and generally hundreds of miles, from any large city where offal could be obtained, and they are nerer fed upon anything but regetable food. The blood and offal at the large packing.houses is dried at a high temperature and sold for fertilizers, and is never fed to the logs even in the stock-yards. The foreign microscopists have the proof of this in their own hands, if they would only give the matter a little consideration before accepting the absurd statements of ignorant and prejndiced parties.

During the killing season as many as 60,000 hogs are received at the Chicago stock-yards in a single day, and it is evident that it wonld be impossible to furnish accommodations for holding this enormons number for any considerable time before killing. Now, the trichina which are found in American pork are in the vast majority of cases encysted, and for this condition to be reached time is required, and much more time than it is possible to hold hogs in the cities where alone offal for feeding them can be obtained. It is four weeks after infection before cysts are formed, and it is six weeks to two months before they reach the condition in which they are generally found by the microscopic examination of our meats. While we know from our own observation in all the cities where hogs are packed that the animals are not fed upon offal previous to killing, we have here in the condition of the trichinæ themselves the best and the most incontrovertible eridence that the animals were not infected by offal fed while they were held at the packing-houses before slaughter.

It is evident from what has just been said that we are nuable at present to give a satisfactory explanation of the manner in which Western hogs become infected with trichinx, for the conditions of life, at least so far as we are able to see, appear in the rast majority of cases to be all that can be desired. The infected hogs must be tracerl to the coun. ties from which they come, and even to the farms on which they are raised, and the conditions studied as they exist on known infected premises, before it will be possible to give a solntion to this difficult question. And until this is doue no effectual rules for prevention can be formulated further than in a general way to recommend that the hogs have no access to any animal matter except what has been thoroughly cooked.

\section{SALT USED IN PACKING.}

The salts most generally used in packing in the Uniterl States are the Syracuse solar salt, of which $2,500,000$ bnshels were manufactured last year; Michigan solar salt, of which 50,000 bushels were mannfactured last year, and 'Turk's Islant salt. For rubbing hams either the ground solar salt or the Syracuse factory filled dairy salt is employed. 
Some years ago the War Department of the United States Government caused some practical tests to be made by having meats packed with Turk's Island and Syracuse solar salt. The meats were afterward sent to the different torts on the sea-coast, on the Gulf of Mexico, and in the interior.

The result of the experiment demonstrated the fact that the Syracuse solar salt is equal in every respect for packing purposes to the imported Turk's Island sea salt, and since that time the United States Government has required that beef and pork packed for the Army and Navy silall be packed with Turk's Island or Syracuse solar salt.

Amorican packers fully appreciate the importance of good salt, and are very eareful in securing the best brands.

The following analyses of American and European salts show that the salts used in this country compare very favorably with those of Enrope:

SART USED IN THE UNITED STATES.

\begin{tabular}{|c|c|c|c|c|c|c|c|c|}
\hline Description. & 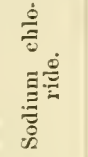 & 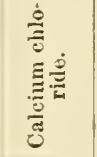 & 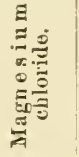 & 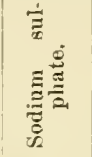 & 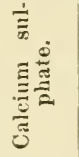 & 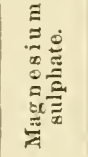 & 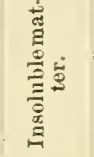 & Water. \\
\hline $\begin{array}{l}\text { 1. Turk's Island sea salt........... } \\
\text { 2. Syracuse, N. Y., solar salt ....... } \\
\text { 3. Saginaw, Mich., solar salt....... } \\
\text { 4. Lincoln, Nebr., solar salt......... } \\
\text { 5. Kansas, solar salt ............... } \\
\text { 6. Hocking Valley, Ohio, solar salt. } \\
\text { 7. Tetit Anse, La., rock salt ....... } \\
\text { 8. Syracuse, N. Y., "factors filled } \\
\text { dairy"...................... }\end{array}$ & $\begin{array}{l}96.760 \\
96.004 \\
95.831 \\
98.130 \\
93.060 \\
97.512 \\
98.882 \\
97.832\end{array}$ & $\begin{array}{c}0.092 \\
0.356 \\
\ldots \ldots . \\
\ldots \ldots . . \\
0.234 \\
0.004\end{array}$ & $\begin{array}{l}0.140 \\
0.089 \\
0.140 \\
0.080 \\
0.240 \\
0.089 \\
0.003 \\
0.037\end{array}$ & $\begin{array}{r}0.640 \\
\cdots \cdots \\
0.390 \\
0.350 \\
\cdots \cdots \\
\cdots \cdots \\
0.026\end{array}$ & $\begin{array}{l}1.560 \\
1.315 \\
0.316 \\
0.250 \\
1.220 \\
0.782 \\
1.263\end{array}$ & $\begin{array}{c}\cdots \\
\cdots \\
0.180\end{array}$ & 0.120 & $\begin{array}{l}0.900 \\
2.500 \\
3.344 \\
1.200 \\
4.950 \\
2.130 \\
0.330 \\
0.700\end{array}$ \\
\hline
\end{tabular}

ANALTSES OF EUROPEAN SALT.

\begin{tabular}{|c|c|c|c|c|c|c|c|c|}
\hline & 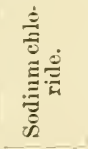 & 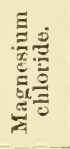 & 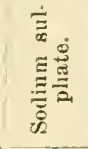 & 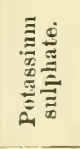 & 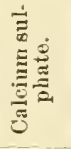 & 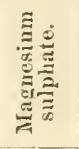 & 。 & Water. \\
\hline 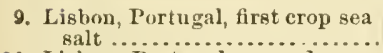 & 97.075 & 0.777 & & & 1. 538 & 0.565 & 0.045 & \\
\hline $\begin{array}{l}\text { 10. Lisbon, Portugal, second crop } \\
\text { sea salt } \ldots . . . \ldots \ldots \ldots \ldots\end{array}$ & 94.033 & a 151 & & & 141 & 6) 337 & 0008 & \\
\hline 11. A voiro, Portugal, first crop sea & 94. 050 & 0.101 & & & 1. 4.1 & 2. 301 & 0.008 & \\
\hline 12. Areiro, Portugal, second crop & 97.2 & 1.134 & & & 0.645 & 0.903 & 0.067 & \\
\hline 13. St. Felico sea salt & 98. 618 & 0.181 & & & 0.640 & 0.165 & 0.396 & \\
\hline $\begin{array}{l}\text { 13. St. Felico sea } \\
\text { 14. Velicka Gal }\end{array}$ & $\begin{array}{l}94.072 \\
90.230\end{array}$ & $\begin{array}{l}0.141 \\
0.450\end{array}$ & & & $\begin{array}{l}0.373 \\
0.720\end{array}$ & $\begin{array}{l}0.060 \\
0.610\end{array}$ & $\begin{array}{l}0.116 \\
5.880\end{array}$ & $\begin{array}{l}5.073 \\
0860\end{array}$ \\
\hline $\begin{array}{l}\text { alere, rock salt ...... } \\
1 \text {, rock salt.......... }\end{array}$ & 91.780 & 0.090 & & 1. & 1. 1 & 1. & 2.490 & 1.890 \\
\hline 16. Schönebeck, Prussia, Saxony.. & 95.400 & 0.080 & & 0.41 & 0.730 & 0.470 & & 2. 900 \\
\hline rg, Saxouy ........... & 92.642 & 0.719 & 0.307 & & 1. 632 & & & 4. 700 \\
\hline 18. Artern, Saxony ...... & 94.835 & 0.616 & 0.488 & & 1. 061 & & & 3. 000 \\
\hline 19. IIalle & 92.773 & 0.865 & & & 1. 296 & & 0.466 & 4.600 \\
\hline 20. Erfu & 96.941 & 0.017 & 0.049 & & 2.093 & & & 0.906 \\
\hline 21. Louisen & 96.866 & 0.060 & & & 0.964 & & 0.110 & 2.000 \\
\hline
\end{tabular}




\section{AUTHORITIES FOR ANALYSES.}

Analyses numbered 1 to 8 , of salts used in the United States, were made by C. A. Goessmann, Ph. D., professor of chemistry in the Massachusetts Agricultural College, and published in a lecture on salt and its uses in agriculture, delivered before the State department of agri. agriculture in Massachusetts.

Analyses 9, 10, 11, and 12, of Portugnese salt, is from the Mechanics. Magazine.

No. 13 is by Von Kripp, and is from Oesterr. Zeitschrift fiir Berg. u. Hïttenwesen, 1867.

Nos 14 and 15 are by Von Stoba, and are from Die chemische Mittheilungen, Prag, $18 s 0$.

No. 16 is by Heine, and is taken from Knapp's Lehrbuch der chemischen Technologie, 3 d ed.

Nos. 17, 18, 19, 20, and 21 are by L. Enders, and are from the Archiv. der Pharmacie, Vol. 143, p. 20. 


\title{
EXTRACTS FROI LETTERS OF CORRESPONDENTS.
}

\author{
DISEASES OF CATTLE.
}

BLACK-LEG.-Mr. S. Woodsum, jr., of Wilkin County; Minnesora, writes as follows concerning black-leg in cattle:

I desire to give jou my experience with the disease known as blaek-leg in cattle. Several years ago I lost quite a number of these animals, mostls calves, but 1 have had a number of cows attacked by the disease. It has invariably been those that were fat that were taken sick. The first indication of sickiess is loss of appetite. staring coat and lameness, very sensitive to pressure on the outside of shonlders. and very laborions breathing. A post-mortem examination revealed the hiud parts normal; the liver very black and tencler and breaking into pieces at slight touch; the air pas sages throngh the lungs, the heart, and the heart case cougested and filled with black bloorl.

The cause of this disease, I am conriuced by experience and ubservation, is orerfeeding. For instance, cows that were milked all winter, ausl were fed eight quarts per day of corn meal, linseed meal, oat meal, and wheat hran, went through the winter without getting siek; but eows that came to the barn fat and dry, and were not fed auything but hay until after dropping their ealf, when they were put on the same feed as those that had been milked all winter, were taken sick in every instanee. Again, cows that came to the barn dry and fat, and received a daily ration of feer of the same quality as the other cows, but a much less quantity than before dropping. and then increased in quantity to the same amonnt as the others, got throngh without being sick.

My experience has been about the same with calves as it has heen with cows. A calf that had been allowed to run with its dam all summer, being very fat, was turner into a field where grain had been harvested awd a very lusuriant growth of voluntees. grain harl spruug up, and it was soon taken sick.

As a preveutive we quite often read that salting $t$ wice a week will prove beneficial, but this never made any difference with the stoek in this vieinity, from the fact that I was about the only one that kept salt where the animals conld get it night and morning, and yet I lost as many, if not more, than any of my meirhbors. I have always fed more gratu than any one else in this neighborhood.

When Dr. Hurn, of the Signal Service, was here, some seren or eight years ago, I deseribed the post-mortem appearance of an animal that had died of hlaek-leg. He advised me to try drenehing with strong salt brine, and I an haply to say that 1 accepted his advice, and have not since lost either a eow "I' il calf. J'ut one-half pint of salt into a quart bottle, fill with water, shake well, and give abont half as ine first dose; in about an hour give the remainder, and one hom later repeat. The following day the operation should bo again repeated. I have nsed this resedy in the case of sick horses with sat isfactory results.

Mr. I. E. Rowe, of Anderson County, Kansas, lecently lost eight head of yearling steers by black-leg. Writing, under date of August 8 , he says:

I have lost eight head of yearling steers ont of a heret of one hundred and thirț-tive bronght from Shammon County, Missonri, to this conmy this season. The disense is 
called blaek-leg, and I can learn of no remedy from loeal sconrces. A steer, appar. ently well yesterday, at evening was olsserved staggering about, at daylight this moruing it was dorru, at $7 \mathrm{a} . \mathrm{m}$. it was unable to rise, and at $8 \mathrm{a} . \mathrm{m}$. it was dead. On eutting the animal open various clark, bloody spots were fomol under the skin and in volving the tissue. The heart was serionsly affeeterl.

An epidemic of black-leg prevailed among eattle in Trego County, Kausas, during the months of November and December last. In the early part of December Mr. Ben. C. Rich, of the above-named county, informed the Department that over one hundred head of cattle had died of the disease in Ogallah 'Township alone. He had lost eleven animals himself, a neighbor had lost seven, another seven, and still others three or four each. As to the post-mortem appearanees of the clisease, he says :

I was to-day called upon by a neighhor to make an examination of three animals which had just dierl, of which I send you the following imperfect report:

No. 1. A heifer calf four months old, still fed twice a day on milk and the run or wheat and rye. The first symptoms were weakness in hind limbs and sinall of back, aud a dragging motion of hiud logs when attempting to walk. When opened, the blood was fonnd discolored on inside of both hind legs and over the left kidney. The tissue which surrounds the panneh and intestines was also diseolored. The small intestines and manifold were very tender and easily torn. There was no bake. The melt was mneh inflamed and bloody and very tender. Other organs seemed normal. Yellowish froth issued from the mouth.

No. 2. A cow three jears old aurl giving milk. Appeared well yesterday morning when milked. Sickness discovered in afternoon, and died during last night. The first symptom wes lameness in righ hind leg, which was mueh inflamed at stifle joint and very sore to the touch. On opening, found the whole right horn very mueh inflamed; flesh very lark and blooty, and over right kidney the same; tissues surrounding the paunclı and small intestines much discolored; manifold baked ; liver inHamed, and so tender that I conld tear it easily with my finger. About a chart of bloody water was found in the cavity of the body. There was no discoloration on front part of body. All other organs seemed normal. The animal was five months goue with ealf.

No. 3. A fine, large-grade cow, three years ohl next spring, and six months gone with ealf: 'This cow did not seem stiff' in joints or weak behind previons to death. She ate heartily up to 4 o'cloek p. m. yesterday, at which time she was first noticerl to be sick. She died duriug the night. 'The lesions were confined to the breast and between the front legs. These parts were very much inflamed and the tlesh dark and bloody. No discoloration was found on hind parts, back, paunch, or intestines. No bloorly water in cavity. The liver seemed all right, but the manifold was baked. The heart was clotted, and the lungs discolored and congested.

Mr. A. E. Hall, of Fort Meade, Dak., writes as follows concerning the ravages of black-leg in that locality :

A disease is provailing among eattle in this county ealled black-leg. I examined two animals ibout twelve hours after death. Upon opening the body the blood seemed almost all gone. What little was loft seemed to have settled between the layers of flesh and tissues. The flesh was a little higher colored than beef. The first animal had a swollen shoulder, and when mbbed with the hand emitted a erackling sourid. It was full of air-bubbles immediately under the skin. The last stomach was very dry, almost baked. 'The small intestines leading to the last stomach were green or the distane of three or four inches. The animals show different symptoms. Some bocame swollen all over, some in one $\log$, and some not at all. We have lost about a dozen range ealves. Int yearlings are not exempt from the disease, and sometimes cows aro attacked. It does not nake any difference as to whether the animals are 
fat or thin, native or thoroughbred stock. Texas animals seem to be exempt. The disease is vers rapid in its work. An animal that is apparentls lealtly aud verr lively in the evening may be found dear the next morning. Occasionally one mar be stupid for three or four dars, but as a rule they die in a few hours.

There is also a disease here among eattle whieh affeets their feet. The foot swells between the toes, laming the animal. In the worst caste the leg swells as high as six inches above the arkle, nleerates, and exules a white matter. Sometimes the flesh protrudes from these ulcerated places. It generally disilpuears of itsown accord. but the worst cases either lame for life or kill the animal.

Cattle in Saline, Mitchell, Phillips, Lincoln, Ottawa, and otler connties in Kansas snffered sererely with this discase during the past season. Mr. Charles F. Fanlkner, of Salina. Kans., writing in December last to Hon. J. J. Ingalls, speaks of the disease as being wide sprean and disastrons in the comnties above named. The following extract is made from Mr. Finliner's letter, which was kindly formarled to this Department by Senator Ingalls :

Nany thanks for pour notice of my communication regardjug hlack-heg among eattle in Kansas. The Department seems to have male no special investigation of this disease. Loxses this season will be hearg in the state. Over one hundreal heal bave dierl in this comnty (Saline) luring the last three montho, and the end is mot ret. Losses from Mitehell, lhillips, Lincoln, and Ottawa are reported. I bope that Cougress will aid the Department in instituting a thomongh investigation of the sulject, in order that we mas hecome better informed of the nature of the disease, its cause, and preventive neasures.

CONTAGIOtS PLETRO-PNEUMONIA IN NEW JERSET.Dr. William B. E. Miller, of Camden, N.J., writing to the Defmement under date of November 10 last, says:

On the 31st ultimo I was summoned to visit a herl uf cuttle it White House, Readington Township, Hunterlon Comnty, in this State. On the lst instant I examined some cattle on the farm of Mr. George Clum. Among his bert o! abont fio cows I fouml several infeeted with plenro-puenmonia. During the pant fom months lie

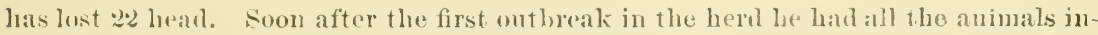
oculated. On another farm owned by Mr. T. W. Pirleock. and tenanted by Mr. Charles Snyder, near Three Brilges, IIunterdon Connty, is a herel of (io pows. Abont the first of Marclu last there was hrought from Brantord County, Penusclvania, to Farmington. N.J., a car-loal of cows. From this ar-load Messrs. Pilleock nut snyder pureliased 13 head. 'Ten of these aninals were put on their farm and thee weresint to another farm.

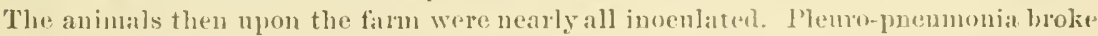
out among these ten new arrivals, and soon eight han died. One was killen for the purpose of securing virns for inoculation purposes. All the remaning animals were then inoculated a serond time. There have been several atses on the farm sinee. but I was mahle to get the exact mumber at the time of my visitatim. Every lot of fresh cattle hronght on the place since have immerliatroly heen inomlated, but out of every lot one or two animals womld either die of the disteist or be killoul. On an-

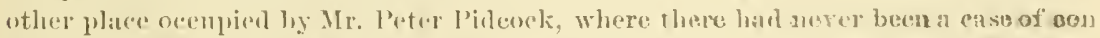

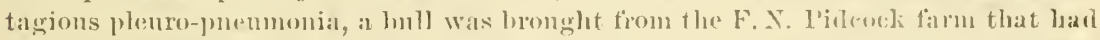

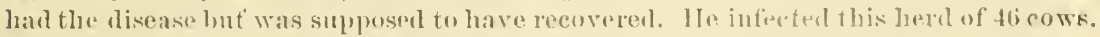
and 8 animals died before the contagion aloaterl. All the animals wers inoenlated as soon as the disease broke ont among them. On another tam. acenpied by Mr. W. 1).

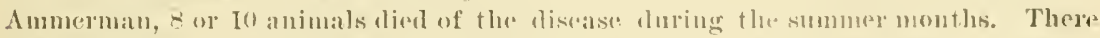
are 41 heal in one lot and 29 in another on this farm. All hasc been inomblaten. There is one acute cases now ou this firm. The animal has ben imonlated, hut stil l 
she is suffering fron alute plenro-pneumonia. On still another farm, owned by $\mathrm{Mr}$. Garret C. Gearluat, six animals have been attacked and four have died. All the other aumals havo been inoculated.

You will observe that erery fresh cow lirought on to these places, if not soon inoculated, suffered with phenro-pnemnenia, and that while inoculation prevented the aniwals on the farms firm death, the disease has been reproduced in every fresh lot in the geunine form, killing most of those attacked.

CAUSF OF ABORTION IN COWS.-Mr. Robert T. Burbank, proprietor of White Monntain Stock Farm, Shelburne, N. H., writes as follows, nuder date of Mareh 24 last:

In 1879 fourteen of my herd of thirty-five thoronghbred eows aborted. During the next year I kept strict watch over them, guarding them from storms in summer and keeping them dry and warm in winter, in order that I might discover the canse of the trouble. Notwithstanding uy care and watchfulness, five of the animals aborted the following year. I theu frecunently, with the greatest care, examined my bay tields. In two of these fields had sprung up, from seed I lad purchased for high-grade Western timothy, a rank growth of wild rye, and also weeds about two feet high, resembling what is sometimes called "wild strawberry." The seels of these weeds appeared runch like the reeds of timothy. I gathered some of the weeds and sent them to the seed merchant of whom I purchased my hay seed, stating that I was satistied that $I$ had discoverer in this wild rye and its seeds the canse of abortion in $\mathrm{my}$ cows, and requesting him to have the seels examined and report the result to me. He treated the matter with such iudifference that I have since ceased to purchase of lim.

The hay ent where the wild rye and those weeds grew in the following year (1881) I put in my young-cattle barn, and did not allow my cows to eat any of it. I have since raised nearly all $\mathrm{my}$ own hay seed, and last jear only one of my cows aborted. This year all have escaped. I already have serenteen beantiful, healthy calres. Their dams are also prefeetly healthy and in good condition. Several years since I expressed the opinion that there nust be something in the hay similar to ergot that cansed this mischief. I have from time to time reported these facts to breeders who is re called upon or nitten me in relation to abortion in their herds, and sereral have used eare in regard to hay seeds with good results.

I notice that the reterinarians employed by the Govermment to investigate the outbreak of alleged foot-and-mouth disease in the West state that the malaly is not the contagious disease it was supposed to be, but was cansed by ergot in the hay. Now, if ergot in the hay will "contract the blood-vessels and retarl cirenlation," as roported by these surgemus, have we not discovered the canse of abortion in cors that oat such hay? In wy case I feel quite sure that I have discovered a cure, viz., feed with hay free from ergot. I do not think hay seed from the West should be sold here until after it is thomughly inspected.

Tuberculosis.-19r. J. A. Rice, of Liberty Mills, Orange County, Virginia, in Jannary last reported the following cases to the Department :

Last smmmer a young steer in our herd that had been improving so rapidly as to be the sulyject of remark was one day found apparently suffering with rheunatism. He coutiuned to decline until sold. I afterwards learned that on being slanglitered his langs were found very much diseased. In October two of our dairy cows (one of them very fat) woro taken with symptoms very similar to those of the steer-separating themselves from the herd, stifl in the shonlers and neek, loss of appetite, costiveness, rapid shrinking in their wilk, no congh, and no symptoms by which we eould diagnose the disease. The decline has continued without any special symptoms except those mentioned, aside from a great shrinkage in flesh. 
Yesterday we slanghtered one of the cows to see if we conlil not find the canse of the disease. We found the heart and lungs very large and tilled with tulvercles. The omentum felt like a luard, round cord, and was filled with tubercles, in fact seemed to be one tuberenlons mass. We found the liver, spleen, stomach, aud intestines all healthy. Iu cutting into the tubercles they presented more of a sarcomatous appearance than of true tnberenlosis. Thinking the specinens might be of interest to sour veterinarian, I have boxed up the, lungs and onedtum ard forwarded to your Department, and would be glad to hear the result of the examination. These cattle were all hred upon the farm. I have bred their ancestors on dam side for more than thirty rears. They were superior lairy cattle, of fine constitutions and remarkably liealthy. I never knew one of them to be sick before. They were of different strains-the sire of the cows was a Mazurka bull by Royal Oxford, of the steer a Miss Kirby cow by the Rhenish bull Joe Johnston. If this is true tuberculosis, how did it origrinate?

\section{A rlay or two later (February 1) Dr. Rice writes as follows coneerning the second cow :}

We killed the other cow to-day, aud found such a growth of fungoid matter that I hasten to send speeimens, believing they will aid your veterinarian to form a more correct diagnosis of the cases. From all I can learn about the steer, he presented similar growths. They are remarkable, and owing to the previous Lealthfulness of the animals, and that of their ancestors on all sides, I am able to form no opinion in the premises. You will fiud myrials of small fungi growing from the larger onessome much resembling mushroom growths. The lung presented very much the condition of the one we forwarded yesterlas. We to-day send liver entire, its preternatural athesions to nidrift and pectoral eaat of stomach by fungous growth; a section of rib and brisket, showing growth of fungi to the inside nembrane of the ribs; sections of luug, peritoneal coveriug of bowels, omentum, \&c.; also a piece of stomach with growth growing from its ontside coat. All of the interior of the ribs were covered with growths such as specimens represent, and many with dark bodies hanging attached by long, narrow necks to the membrane between the ribs, resembling hydatids, but the bodies were hard and fleshy.

There has never been any eongh with either animal, only a gradual decline with the symptoms given in my first letter, exeept that the one we killed to-ilay was taken a day or two ago with a profuse, watery diarthea, which was weakening her down rapidly.

The speeimens arrived in good condition, and, after examination by the veterinarian, Dr. Rice was informed that the disease with which his cattle were snffering was undoubtedly tuberculosis. He was counseled to destroy all remaining animals showing signs of the malady, and advised to thoronghly disinfect his stables, which shonld not be again oceupien for a year.

Impaction of the MANifold.-Mr. P. H. Powers, of Wickliffe, Clarke County, Virginia, statistical correspondent, recently lost some cattle by a disease mnknown in that loeality. Under date of February 18 last, he wrote the Department as follows:

I have lost, within the past ten days, two three-year-old stecrs, atrected similarly and so acutely that I deem it proper to report the cases to the Department. When first observed, which was about 6 o'eloek a. m., each of theso steers secmed sufiering with violent itehing ahout the head, particularly along the jaw and aroumd the eyes. So violent was this that they would run to the fince or posts of the barn aud rub until the whole side of the head was made raw and blowly. Accomplnying this itching was a spasmodic twitehing or jerking of the head sideways and npward, oceurring constantly, and at intervals of about a minute. There was some foam about the 
month. So acute was the disease that each auimal was dead in less than ten hours. No otler symptoms were observerl. These steers were in good condition. One was raised on the farm, and the other bought in Chicago in November last.

Later, on February 25, Mr. Powers again wrote the Department giving additional information in regard to the progress of this disease. He says:

I have since lost another very fine animal with symptoms idlentical with the others. Death ensned within twenty-fonr homrs. These cattle were all in fine endition, have been well cared for and had access to water, and were ferl on corn-fodder and wheatstraw. In fact, the management lias been the same that I liave given my stock cattle in the winter months for thirty yeats. The difficulty seems to be that no evidence of disease or ailment appears which is noticeable unt il the animal is in extremis mortis, when all remedies woull seem unavaling. A farmer living some ten miles from mo in this comnty lias lost, I linderstand, some seventeen heal this winter. As soon as I can ascertain the facts I will report them.

On receipt of Mr. Powers' first letter, he was informed by the veterinarian of the Department that his eattle rere suffering with impaction or obstruction of the manifolds from eating too much dry food, and advised to give full doses of purgatives combined with stimulants.

The following deaths described by Mr. J. B. Warren, statistical correspondent of Rooks Ceunty, Kansas, no doubt oceurred from acute indigestion or impaction:

One of my neighhors has lost six head of cattle within the past ten days. They died within from one to three hours after the hirst symptoms were observed. I opened four of them, but fond nothing wrong with any of the organs except the stomach and bowels. The inside coatings of these seemerl as though bally eaten with lye or some other strong substance. There was very little blood, and around the stomach it was settled iu black clots. A foamy frothi, resembling thick, slimy soaj-suds, passect from the animal's month while sutfering from the disease. Before death they bloat badly. All the animals attacked were in apparent good health and excellent condition $n p$ to the time the first symptoms were observerl.

CAT'Tle poisonen BY Vegetation.-Mr. George WV. Carleton, Gayoso, Pemiscot County, Missomri, writes under recent date as follows :

Since the February overtlow of the Mississippi River, a great many cattle have died, especially cows. They are affected with weakness in the loins, break down, drag their hind legs, fall down and cannot rise, thrash their heads upon the ground, and die within two hours after being attacked. I assister in the dissection of a twoyear-old heifer that died within an hour after showiug symptoms of the malady. Tpon opening the stomaeh we found a quantity of an undigestrd root of a vine that grows in great abmudane here, known in the conntry as "cow iteh," trumpet-flower, or eow-vine-Bignonia radicans. Near the bank of the Mississippi River, where the current in the "back-water" runs very strong, the soil has been washed off and the ronts of this vine left exposerl, and, being very tender, eattle eat them ravenonsly. All the inner coating of the stomach was of a very diok purple color; on the spleen were found a few parasitie worms ; abont two inches square of the spleen was inlamed and appeared to have been perforated. In all pobah hility these parasites hat cansed the damage. Upon removing the skull we fonmd a great pressme of blood, sermu, and water on the hrain. This was no donbt cansed by the action of the poisomons roots fomml in the stonach, and was the immediate canse of the animals' death. Within the last ten days several farmers liave lost valuable cows, and all of them have eaten of the root of the Bignonia radicans." 
Mr. J. G. Knapp, Limona, Fla., who is the statistical agent of the Department for that State, forwards the following extract from a letter addressed to him by Mr. F.A. Hendsy, of Fort Myers (Caloosahatehee), Florida, in A pril last:

Some cattle have dropped dead in this locality, number not known. For several gears cattle have died lere from this mnkown camse. So far the canse is a mstery. A few sears ago one thousand or more animals died in fat condition. All agus and sexes wero alike affecterl. There is no lingering; apparently as sound as can he and in a minnte of time lifeless. It is not contagions-prevails only in certain localities. I have dissected the animals amb examinod carefully, but foumd no intermal evilence of disorginization.

Mr. Knalp adds that the indications are that some very actire vegtable poison is the eatise. Several very poisonous plants and trees, such as the Hippomane and other Euphorbiacere, with the Rihus meto. pium, grow there.

\section{HORISES.}

Horses PoIsoned BX VEGETATION.-A correspondent at San Antonio, Tex., informs the Department that these have been heary losses of horses throngh a strip of comntry where the live oak, red and post oak, and the hickory grow. This district rums thromgh Medina, Atascosa, Bexar, Medrullen, Live Oak, Wrilson, and Frio counties, and ends about the boundary line of De Witt. The land in this district is gemerally of a sandy nature, and does not produce a rigorons growth ot any valiets of grass, thongh it is for the greater part of the year, on an average, a fair range country. At this time of gear (April) there is little grass in this district, and stock have been subsisting partially, for some time, on acorns, to the eating of which the losses of horses are attributerl. MIr. Dnck, Mrs. O'Brien, and others, have lost quite a mmber of animals, and it is reported there have been some losses in W. W. Robuins' pastme, where stock has been placed for fattening. The horses, when first attackerl, seem to be drawn together as if in loin di-temper, and appear to suffere greatly, virtually walking on the tips of their hind hoofs. Then they grarlually yitch forwarl, fall to the gromul, and never get up again. The affliction does not seem to have any relation to the eondition of the animal, as some of the fattest horses in the conntry have fallen a prey to the malady. Mares seem to suffer most. Mr. Dnck attributes the losses to acous, which are not ouly worms, but were uot so well matured as in former years. Hogs, however, late grown rery fat on them.

TWRRIBLE DESTRUCTION OF FARM AXIMALS 13 Y BUFHAO GNATS.The losses of farm animals last sprime in some of the Southern states from the intation and poison of bufalo gnats were very heary. No deally contagions discase has erer eansed such destruction among the herls and flocks of the Sonthwest as have these poisomons pests during the past season. Mr. A. F. Osborn, Wimshorongh, Franklin l'arish, Lomisiana, writing to the Department moler date of May lin last, says:

Fully one-half of all the farm animalsof this parish have fallen vietims on the poison impregnatel by the bite of the buftalo gnats. Horses, mules, cattlo, sheep, and hogs 
have alike snceumbed to the scourge, aud there seems to be no abatement except in loealities where the material to act upou has disappeared or been exhansted. Some persons hiave lost all, other's two thirds, aud los is iudleed fortunate who has saved halt his stock. The dead carcasses lie bloating around ficlds and on highways, and nothing-not even a buzzard-will touch them. The stench arising from these putrid careasses is almost intoleralle, and fears are entertained that a pestileuce will follow.

On the 20 d of April we colleeted partial statisties from two of the uine wards into which the parish is divided. As far as we were able to aseertain the deaths in those two wards amounted, at that date, to 3,187. Many individnals, in bandling and skinning the animals, have been poisoned. Some have already diel, others will probably die, while still others will escape with the loss of a hand or an arm.

Mr. Thomas B. Gilbert writes from Oakley, La., under date of June 29 last, as follows :

Alont the middle of April last a fatal disease broke ont among eattle, horses, mules, hogs, and sheep in this parish (Franklin) and the aljoining parish of Richland. It attacked all of the above-named animals almost simultaneously, making its appearance first among the cattle a fow days after the dreaded buffalo gnats came in. The time for the buffalo gnats to make their appearance here varies with the heat or cold of winter. They came earlier in 1882 than I ever knew then to come before-say, about the 5th of Mareh; but the usnal time is from the 1st to the 10th of April. This year they came about the Ist of April, and in a few days multiplied into unillions, spreading over the entire country, and vo animal could survive their attacks many hours miless protected by smoke. They have a great aversion to smoke, and this is the only protection our animals have from their ravages. Work animals are greased as an additional protection. The gnats were more numerous this year than common, but not more so than they were in 1882. In this parish (a suall one) about 3,000 head of horned cattle died in a few days, and ahout 300 head of horses and mules, 5,000 or 6,100 head of hogs, and as many sheep. The horses and mules are still dying at intervals. In these the disease assumed the form of charbon; it did the same witi many cattle; and what is singular, the only cattle, horses, and mules that recovered were those that it attacked in that form. All those attacked in the other form of the disease (i.e., withont external swelling) died. Now, what conld have oceasioned this dreadful and fatal plagne amoug onr domestic animals? The disease appearer in a belt of conntry, say 25 miles in extent from uorth to sonth, and extended at least that distance east and west. North of that line there was no disease, and sonth of it there was none. How far west on that parallel the disease extended I do not know. But on the east the Bayou Macon was the line of demareation.

It is safe to say that the people of Frankliu and Richland parishes have lost more than $\$ 150,000$ worth of eattle, horses, mules, sheep, and hogs from this fatil disease. I thiuk that next year a competent man from yom Department ought to he seut into every county of Arkansis and Mississipui, and into every parish in Lonisiana infeuted with biffalo gnats to study their habits, origin, and the canse of the disastrons effect they are yearly having upon the inhabitants and the domestic animals of the infested district. This pest is assuming such alarming proportions as to threaten the depopulation and abandonment of all the high-land comtry adjacent to or bordering upon the overtlowed regions of the Mississippi Valley. It is not confined to the valley proper, but the highlands eontignous to, and for many miles inland, are worse cursed with the buftalo gnats than the lowlands themselves. I was born and raised here, am 46 years old, and never saw or heard of the pests mutil 1865. They have come with the annual overflows every year since, and their ravages are so far extended over this region of conntry, and so fatal to man and beast, that the continued oecupation of the conntry is problematieal. Some deat his and many eases of charbon have occured anong our people, both black and white. 
TARIOUs Reinedes AND PREventives.-Mr. Byron L. Sannders, Purdy, Tenn., writes as follows, under date of April 5, last:

The new disease which has recently made its appearance amongr cattle in Illinois and Iowa prevailed among my eattle list winter a year ago. If taken in time it is very easy to manage. Strong apple vinegar, or acetic acid, and blood-root-a strong decoction or tincture, applied three times a day will cure it.

For swine plagne and fowl cholera: Equal parts of soda, alum, and copperas, and one-tenth part of blue vitriol. To prevent the plague, feed mandrake to the animals in their slop.

For murain in cattle, Spanish fever, and inflammation of the liver: One-half cup of lobelia seed, $1 \frac{1}{4}$ cup of blood-root, 委 cup mandrake, 1 cup wild-cherry bark, 2 cups dor-fennel blossoms, a piece of garget, or poke-root, the size of a small hen's egg, to which add one gallon of water and hoil down to one pint and a half of solution. This is a dose for a grown animal, and if given in time will generally effect a cure in the aloove-llamed diseases.

Mr. L. A. Cook, Milledgeville, Ga., states that twenty-five drops of tincture of aconite given when symptoms are first observed is almost an infallible remedy in any form of colic. He has never known it to fail, and says that a second dose is rarely necessary. He regards it as the simplest and surest of all remedies.

\section{HOGS.}

Brefos AND sanitary Condition.-Mr. Henry C. Mosely, Law. rence, Kans., regards our present breed of hogs and their sanitary condition all that conld be desired. He writes to the Department as follows :

I have traveled for fifteen years in the great hog-producing regions of the Mississippi Valley, and have therefore no hesitaney in declaring that the sanitary condition of swine is now better than at any period in the past twenty years. And why? Because the swine producers are provided with acclimatized and better breeding animals, and are not now introducing new stock, which the farmers all admit lias been one of the most prolific canses of disease. The most extensive swine producers now allow their animals to range in pastures during the summer months; feed them less corn; provide more and better water; are watehing them more closely, and gradually reducing the reariug of this class of animals to a science. The American hog is now, in my humble opinion, all right, and the way to continue its prosperity is for the non-swine producers to adopt the non-intervention policy, or hauds off, and leave it where it now is, at the front.

EFFECTS OF FEEDING SWEET poTATOES.Mr. J. G. Kuapp, statistical correspondent for the State of Florida, writes as follows under date of April 10 last:

Allow me to call your attention to a remark made by I. M. Strickland, my correspondent from Putnan County, whreh is new to me. He says:

"It is thonght that feeding potatoes (to logss) during winter is the cause of cholera. Last year I lost all the hogs that I put on my potato gromd, and this winter they came off in poor condition, with a loss of 2.5 per cent."

Potatoes here mean tho sweet potato, Batuta cdulis. The hogs are placed in the grounds to root for those that are left after the crop is dug. These potatoes remain 
sound in the ground dnring the wintor, as there is not frost sufficient in many portions of the State to destroy them if disconnected with the vines. Can there be anything in these potatoes to produce cholera?

Cholera or swine plagne is a purely contagious disease, and can only be communicated to the animal by coming in contact with the virus. Possibly sweet potatoes might render hogs more suseeptible to the disease than some other kind of diet.

Swing Plague in Arkansas.-Mr. Felix G. Davis, of Grand Take, Chicot County, Ark., writes as follows muler date of March 5:

Throngh the kindness of Senator Garland and Hon. P. Dumn, of this State, I have receiver three eopies of the Report of the Department of Agrienlture fir 18s3, two of which I distribnted to my neighbor's. I think a eopy onght to be in the hands of every intelligent farmer. 'The reports on swine plagne, chicken cholera, and charbou are of great interest to us, especially the report on swine plague, or cholera, as it is vulgarly termed. On this Isle of the Swamps, or Mason Hills, as it is called, we are now being visited by this hog disease to an alarming extent. Fine stock hogs that in Jannary were fat and healthy are now dying on every farm, aud those left are generally poor in flesh. Being deprived of their usual range by an overflow of the swamps has no doubt had much to do with the spread of the disease.

\section{SIIEEP.}

New Disedse Aroxg LAMB.-Some montls ago Mr. G. W. Marshall, Eckley, Carroll County, Ohio, wrote as follows concerning a disease which at that time was destroying a great nany spring lambs in that locality :

We have a strange disease among our spring lambs here this spring that I think shonld be investigated by the Department. They ciie when they are from three to five weeks old. Apparently the very best lambs in the flocks will be well, as far as yon ean see, in the morning, and by night will be dear. They aet as though they had spasms or fits. We have lost six, and some farmers have lost as high as thirty or forty this year. It is not in all flocks, just here and there. Sometimes you will find five or six lying deal at a time. I hear of it in places all over the connty. We camot tell what the disease is, nor have heard of any remedy for it. Some clain they get too much milk; others say that is not the tronble. Some call it lamb cholera.

In answer to a letter of inquiry asking for further information as to the symptoms of the discase and the post mortem appearances of the animals that had died of it, Mr. Marshall writes:

No more lambs have died since receiving your note, hence I hare had no chance to make a post mortem examination. However, a neighloor says he examined several, and there appeared to be water about the heart, an unusual amount; the gall appeared dark and slender, as thongh rolled up ; stomach and other parts all right, as far as he knew. The lamb when first observed seems entirely helpless. It then las spells as though affected with a fit; phunges ahont, works its ear's and nonth, rolls its eyes and froths at the month. The animals generally attacked are from three to six weeks old, and are nsually those in the best eondition. Thry live from six to twelve hours after the first symptoms of the diseaso are observed. Wo took om ewes ofl' good blue-grass, white clover, and timothy pasture and put them in a woods pasture, after which we lost no more lambs. My observation has been that the lambs that have died have been those that have had the greatest amount of milk from their mothers. 
A FATAL LOCAL DISEase.-A fatal disease, which is no doubt local in its character, is described as follows by Mr. L. F. Dupron, living near Savamuah, Ga.:

A disease is prevailing here among sheep which seems to be peculiar to animals feeding on the seaboard. The principal symptom is a swelling on the under jaw. The swelling contains a hot, watery fluid; if opened and the fluid discharged it will soon fill again with increased heat over the affected part. Diarrhea sets in, which is soon followed by death." Shcep over three years old frequentls die before diarrhea occurs. The disease is most fatal to lambs, though I have known but two recoveries out of hundreds of animals attacked. Sheep grazed in woods pastures seem as liable to the disease as those grazed in the salt marshes. 


\section{GENERAL CONDI'TON OF FARM ANINALS, 1883.}

\section{ALABAMA.}

Barbour.-I have not heard of the prevalence of any diseases among hogs and sheep. during the year, and there has been no epidemic among either horses, mules, or cattle. I estimate the value of all animals lost by disease at $\$ 8,170$-except fowls-being my estimate of increase on the census of 1880. Onr State has established a department. of agriculture, and will hereafter require statistics gathered by the county assessors.

Bibb. - Some cholera has occurred among hogs and fowls, and not anong sheep, but the aggregate losses cannot be given. No stock-breeding here of any consequence. Notiing would pay better than the breeding of large draft horses, and heavy improved cattle for beef. The range for stock is good for nine months in the year.

Blount.-I estimate the value of losses among farm animals and fowls in this county during the year, by disease, as follows: Horses, $\$ 3,500$; cattle, $\$ 5,400$; hogs, $\$ 3,000$; shee1, $\$ 375$; fowls, $\$ 500$; being a total of $\$ 12,675$. This statement is derived from knowledge obtained from many citizens of the connty. Horses and mules have been afflicted with no special complaint. Hogs have died from cholera, neglect, and lice. A few sheep have died from rot, but a great many have been killed by logs. The loss caused by these animals is not included in the above.

Bullock.-Hogrs and fowls are almost always affected by so-called cholera. The only disease incident to cattle is hollow-horn. Mules frequently die of colic, and horses of bots and gravel. Not one horse in a hundred dies of epizooty when it comes around, but at least 10 per cent. of the mules succnmb to it. It has always been brought here by traveling showmen. We have no fatal disease among sheep. I have lived at this place since 18\%2, and have never lost a fowl of any kind by cholera or any other disease, and we have some hens that are known to be fifteen years old. My wife has lived here over thirty years, and says there has never been any disease anong ponltry since she can remember. We have no fowl-house; our chickens roost in trees, and we never allow then to roost in the same tree more than three months at a time. Year before last a niece of my wife lost all her chickens, and asked my wife to give her a start again. We did so, and furnished her with five hens and a rooster. Those fowls were carried a distance of 9 miles, and in less than a week's time they all died.

Choctax.- There have been some losses among farm animals, occasioned by disease, but it is impossible for me to give anything like accurate data. There have been, to my knowledge, several eases of glanders anong horses and mules. Those cases that came nuler my olsservation were not treated by veterinarians, but were neglected and the animals allowed to die.

Clarke. From my own personal knowledge and the best information I lave been able to obtain, I am able to state that no epidemic of any kind has visited the farm animals of this county during the present year.

Chilton. - It is very selelom that disease of any kind ever prevails to any extent among farm animals in this comty. Horses and cattle usually die of old age. Abont fifty sheep were killed by dogs lluing the past year.

Coffec. - Quite a destruetive disense prevailed anong chickens last spring. Seventyfive per cent. of the young chicks died of it. The disease was thonght to be cansed by mites. There has been no markerl disease of any kind among stock. Several valuable horses and mules have died, some from staggers and some from colic. Hogs lave done well and are still doing well where they have been properly fod. Our peo- 
ple are turning their attention to the finer breerls of hogs. Hog cholera has not prevailed to any consirlerable extent this year, though at least 50 per cent. of the hogs of the county died of it last year. It has been prevalent in several neighborhoods in arljoining counties the past season. Stock comes to fine perfection iu this county, and slicep-raising is very easy and of great profit. The largest mule in the State was bred and is still owned by Col. Thomas Patents, of this connty.

Coosu.-No disease of a destructive eharacter has prevailed during the year anong either horses, cattle, or sheep. Cholera has destroyed $33 \frac{1}{8}$ per cent. of the hogs of the comty. I cannot give the number of domestic animals in the eounty.

Crenshaw. - There has been no disease of any lind among our farm animals for the past two years.

Cullman.-Hogs are more subject to disease in this eonnty than any other class 0. farm animals. However, but slight losses luave oceurred from disease amoug any class of stock during the past sear.

Dallas. - The valne of horses lost by disease during the year I think will amonnt to abont $\$ 5,000$. I estimate the number of hogs in the county at 25,000 . Fifteen hundred of these have been affected by disease. Of the number thus attacked $\perp$ think 20 per cent. have died. The losses among other elasses have been very light.

Fayette. The only diseases that have prevailed to any consillerable extent among farm animals in this comnty the past year have been rot and scab among sheep. A grcat many fowls bave died of a fatal disease ealled cholera.

Franklin. - With the exception of a few cases of epizooty the health of horses has been good. No fatal eases have occurred. Sheep are also in good health. Cholera has prevailed among hogs and fowls, and abont all those attacked have died. I cannot give the number of farm animals in the county.

Genera.-Sheep valned at something like $\$ 700$ have been lost the past year from varions causes. No willespread disease of any kind has prevailed among our stoek during the year.

Hull. - The diseases that have presailed among our farm stock this year are common, and snch as are oftentimes oecasioned by neglect and ill treatment. Sheep die of a lingering disease called rot by some, which is regarded as incurable. Hogs die of cholera, a disease which is also regarded as incurable.

Henry.-No widespread disease of any kind has prevailed either among our farm animals or fowls during the current jear. Some few horses have diel, but I believe the loss was occasioned more from bad treatment than disease. A great many hogs have been raised in the connty within the last twelre months.

Landerdale. I can give yon no definite idea as to the number of farm animals in the county. A few cases of choleina among hogs have been reported.

Lawrence.-Hog cholera has been very destructive in this section this year, having destroyed five-sixths of this class of stock. Chicken cholera has also prevailed. Bliarl-staggers has been very fatal to horses and mules. I think the value of our losses for each elass has been abont as follows: Horses and mules, \$2,360; eattle, $\$ 1,000$; hogs, $\$ 37,500$; sheep, $\$ 150$; ehickens, \$1,500.

Limestone. I cannot procure the data you desire. There has been no unusual sickness among farm animals the past year. Last year many farmers ferl shelied corn to their stock withont hay, and the result was the loss of a good many animals.

Macon.-There has been no destructive disease among horses or other classes of domestic animals for the past year or so. What is known as cholera has been very destructive to fowls. It is a vers common disease, especially among elhickens.

Mobile.-No disease of a malignaut charicter has prevaled among any class of firm animals the past year. A few eases of eatarrlal fever liave oceurrel among horses aul mules bronght from the west and Tennessee and lientucky, wut they were at tended with no fatality.

Monroe. -The value of farm animats and fowls lost in this comty by disease the present year is between $\$ 0,000$ and $\$ 8,000$, distributed anong the ditherent elasses as

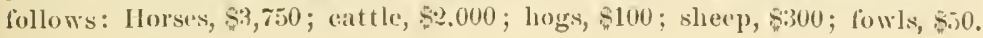


Pike.-Dómestic aniuals in this county have been remarkably healthy this year. No disease of an epitemic character has prevailed among either horses, nules, cattle, or sheep. Clrolera among hogs has prevailed to a considerable extent over an area of eight or ten square miles, but the loss would not probably exceed two per cent. of the hogs in the eounty. Cholera has also prevailed to a like extent amongr chickens.

Russell.-The only serions loss oceasioned anoug farm animals by disease in this county the present year has been occasioned by eholera among hogs. Carbolic acid, wheu given aceording to directions recommended by your Department, has proved a a vers efficient preventative, aud somewhat of a remedy.

Sumter.-13nt little disease of any kind has prevailed among farm stock the past year. More animals have died from poverty and bad treatment than from disease.

Talladega.-Farm stock has been unusually healthy the past year. Although hogs and ponltry are never entirely free from cholera, the disease has not prevailed as an epidemic this year. A disease more fatal than cholera his prevailed among poultry, having killed on two farms near us all the turkeys and ducks and about all the chickens. The symptoms are paralysis of the limbs and neck. None attacked recovered.

Wilcox.-There has been no prevailing disease among horses this year. Cattle have also remained healthy. Cholera among hogs and fowls has prevailed to a considerable extent, and has proved quite fatal.

\section{ARKANSAS.}

Arkansas.-Horses and cattle have been afficted to some extent with diseases incident to them during the year. The value of horses lost will not exceed $\$ 2,000$. Disease carried off cattle to the vahe of perhaps $\$ 1,600$, and hogs probably to the valne of $\$ 1,000$.

Baxter.-A disease generally known as blackleg has prevailed to some extent among cattle. It is generally very fatal. Perhaps 100 heat, valued at $\$ 1,000$, have been lost by the disease. About 50 head of horses have died during the year from disease and other causes.

Calhoun.-An unknown disease, causing blindness, prevailed among onr cattle. Sometimes it affects bnt one eye, at others both, cansing complete bliudness. Those that were affected last year are still blind and show no signs of improvement. Chicken cholera carries off about 30 per cent. of our fowls every vear.

Crawford.-The only epidemic disease that las prevailed in this connty has been among hogs and fowls. In one locality a number of hogs have died with what is s upposed to be cholera. They included all ages. The value of the losses will reach $\$ 1,000$. Upon inquiry I have found two farms on which chickens have been lost by cholera. One farmer tells me that his chickens commence dying as soon as his flock increases to 200 or more. Cattle aud horses are very healthy.

Craighead.-I hear of no complaint of the prevalence of disease anong farm animals exeept that of cholera among hogs. I think the loss will reach one-third of this class of animals in the county. But for this disease we wonld have had pork to export.

Dorsey.-Cattle, hogs, sheep, and fow is have been unnsmally lealthy this year, no destructive disease having appeared among them. A considerable nuuber of horses have been affected with blind-staggers. All those attacked have died.

Drew - There has been no disease of any kind affecting farm stoek in this county the past year. The number of hogs in the county has increased perhaps 50 per cent. Cholera has prevailed among chickens to some extent.

Franklin.-No contagions epidemic has occurred among either horses or cattle the past year. A horse has occisionally died of bots, blind-staggers, and colic. Cholera has prevailed among hogs, but not to any great extent. Cholera has also appeared in a limited degree among fowls.

Garland.-There has been no epidemic of any kind amoug our stock this year, hence the losses have been light. 
Grant.-The only losses that have occurred from disease among onr farm animals during the past year have been confined to hogs, and the aggregate has been so small that it is barlly worth recording.

Hempstead.- No serious disease has prevailed amoug horses, mules, cattle, and sheep in this comnty during the sear. Quite a number of hogs have died from the usual diseases.

Marion. -No contagrous or epilemic disease has visited anț class of our farm stock the past year. This is a the comty for farm animals, aud they are nsnally healthy.

Mississippi.- We have been very fortunate with our farm animals the past year. Wo have hat no disease of any kind among them.

Montgomery.-Horses have not been aftlictel with any discase of eonsectnence the past yair. Cattle and sheep are always healthy. A fer hogs have died, and a few chickins have been lost by the usual diseases.

Newton.-So far as I have been able to learn, I can state that stock of all kinds in this comty is in a healthy contition. There has heen no nnusual sickness among any class of firm animals for the past two years.

Phillips.-Horses aud mnles ralned at perhaps $\$ 6,000$ bave died during the vear, but in most cases the losses were occasioned by abuse and bad treatment on the part. of laborers. The value of the losses am'mg cattle will reach about $\$ 2,000$, and that among hogs between $\$ 600$ aud $\$ r 00$. A great many more sheep are anmially killed by dogs than die of diseise. The average quality of all furm animals in this county is low.

Pope. The greatest loss we have sustained from disease has been from eholera among hogs and fowls. Perhaps $\$ 5,000$ will cover the losses among hogs, and $\$ 500$ the losses oreasioned among fowls.

Poinsett.-Neither horses, eattle, sheep, hogs, nor fowls bave bren visited bs any epidrmie disease for the past twelve montlis. Wesuftered heary losses from hog ehol. era in the year 1882. It was estimated that filly 85,000 died that year in this comty.

Proirie. - We have had to contend against no disease anong our farm animals the past fear. Fowls have been afflicted to some extent, but I presmme $\$ 000$ would corer the losses.

Puluski.-All kinde of farm animals, inchding fiwls, have been very bealthy the past year.

Saline.-Animals of all kiuds in this county maiutained munsually good health in 188:, and I bave no epidemic to record as having prevailed anong any class the present year.

Sharp.-Wo discase worthy of being reported lats oecurred among hogs, shecp, or fowls in this county for several years. Some tive or six attlo have died in ono section of the eonuty within the past fortnight, with a disease resembling dry murrain. The clisease, whatever it is, is not spreading.

CALIFURNIA.

Amador.-For three months past an epidemic has raged amoug cattle in this eomnty. The distase is black-leg. It attacks those of the young stock in the best eondition, particularly thuse pastmred in the Sierras duriug the smmmer. All attacker die. The exact number that have been lost eanot be ascertained. Two of my neighlors have lost 12 or 15 heal each. No dlonbt not less than 100 have died. Their average value would be about $\$ 15$.

Calaveras.- I estimate the value of farm animals lost by disease in this connty the

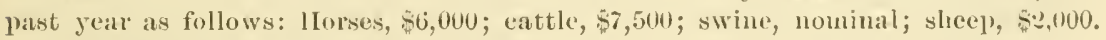
The principal disease anoug sheep is scab.

Contra Costa.- Horses have sufleres to some extent from puenmonia and epizooty, and eattle from big-head or rotten-jaw. A good many fowls are lost from a cliseaso supposed to bo enlargement of the liver. Stoek geuerally seem to bo in good health.

P'lacer.- 'rhe only disease that has aflected any elass of fam animals the past year has been scab amongr sheep. The losses from this canse have been light.

$$
5751 \text { D } \Lambda-20
$$


Plumas.-As rugards diseases of cattle, the only thing we have suffered from has been black-leg. Only yomng cattle-calves and yearlings-liave been attacked by this disease. The mortality has been greatest among thoroughbred stoek.

San Diego.- The.1nost fatal disease among horses ean harlly be explained. When they run ont they eat what is known as the "crazy-weed," from the effects of which many of them die. Black-leg hils prevailed to a consirlerable extent among cattle. The losses have been heavier this year than ever hefore. Hogs have snffered some, but not to the extent of other clisses of animals. It has been rather an unfavorable year for sheep. lowls have suffered with all the diseases incideut to them.

Solano.-There are no prevailing or contagions diseases among any of the domestic animals in this connty, and there are no lossess to record other than those that might be expected where such animals are ordinarily healthy.

Tentura.-Farm animals have been very healthy in this comnty the past year. Sheep are the only animals that have been affected, and the value of the losses in this class will reach $\$ 5,000$ or $\$ 6,000$.

Tuba.-Perhaps $\$ 3,000$ will cover the valne of losses amoug all kinds of farm animals in this connty during the past yoar from the varions diseases whieh affect them.

\section{COLORADO.}

Center.-There is not now, nor has there been for the past two years, any disease of a general character among the farm stock or fowls of this connty.

Mesa.-All farm stock has been remarkably healthy the just pear; no disease whatever. Can hear of no losses, except by acciclent.

Larimer.-No disease of any kind prevails among farm stock in this county. I cannot learn of the loss of any animal by disease during the year.

\section{CONNECTICUT.}

Fairfisld. - I give the value of the losses of farm anmals in this connty for the year as follows: Horses, $\$ 5,000$; eattle $\$ 2,500$; hogrs, $\$ 300 ;$ sheep, $\$ 750$; and fow $1 \mathrm{~s}, \$ 1,000$.

Litchfield. - I suppose 20 per cent. of the horses in this county were atflicted the past year with colie, distemper, or more serions diseases, and that one-third of those so afflieted died. Ten per cent. of our cattle have snffered with murrain, milk fover, tuberenlosis, and lung worm in ealves. About one-half of those attacked died. Hogs die of surfeit, cholera, \&c. Alout all die that are attacked by disease. Sheep have been afflicterl with lung worm, tuberculosis, \&c., and fowls with eholera, ronpe, and gapes. I give the following estimate of the value of our losses for the past year, viz: Horsen, $\$ 25,000$; cattle, $\$ 81,000$; hogs, $\$ 10,000$; sheep, $\$ 975$; fowls, $\$ 4,500$.

New London.-There has heen no epidemic of any kind among our domestie animals that has proved generally fatal; simply pink-ege among lorses, and distemper to some extent among fowls. The losses have been comparatively light.

Tolland.-But few losses have oceurrel in this connty by sickness among farm animals. The eases that vecur are of the usual maladies.

Windham.-Farm animals in this eomnty have been unusually free from all kinds of diseases during the past year.

\section{DELAWARE.}

New Castle.-Horses, eattle, sleep, and hogs now enjoy an entire cxemption from epidemies, and the returus show a gradnal inerease in numbers. One deplorable fact exists, and that is the large shipment of ealves to market. An anbition to possess thorongli-bred eattle has seized some of our best farmer's in Kent County, and imported eattle seem to have hecome a necessity to a large number. Tho Alderney and Gurernsey breeds are favored. With the investinent of large sums of money in "Blooded" eattle comes a greater amount of eare in their keeping, such as the foeding of ehopper feed, meal, oil eake, kc., when but a few years ago straw and eoarso 
fodder were abont the only food given. Better care in every way is now taken with the animals, and they are furnished with comfortable sheds for inclement weather. Pumps in the inclosure with clean tronghs and pure water insteat of that which formerly stool in the mudly, stagnant water-hole, and good clover fields for pasture insteal of the turned-out and exhausterl lands or wood-range. Our cows often go to the pail at eighteen months of age insteal of three years, as formerly.

FLOIIIDA.

Aluchua. - No destructive disease has prevailed amoug auy elass of farm animals in this connty in the past year, though a great many fowls has been lost by cholesa.

Bradford.-Horses have been afticted with staggers, cattle with black-tongue, hogs with cholera, sheep with seah, and fowls with eholera. These are the most fatal diseases, and have destroyed horses to the valne of $\$ 15,000$; eattle, $\$ 2,500$, and hogs pretliaps to the value of $\$ 1,000$. The liealth of farm animals and fowls has been good considering the care given them.

Bretard and Orange.-Horses, cattle, and hong have been attlicted with the usual diseases the past year. I estimate the valne of the losses abont as follows: IIorses, $\$ 3,000$ : cattle, $\$ 5,400$; ant hogs, $\$ 300$. Sheep and fowls have remained he:althy.

Clay.-A gieat mauy cattle have died of hollow-horn, hogs of eholera, and fowls of swell-heal. Hogs to the valne of 200,000 have been lost. Perhaps the valne of towls lost woukd reach $\$ 3,000$.

Columbit. - A good many horses have died of staggers, bronght on no doubt by summer pasturing iu shadeless ranges. Cattle lave been lost by thx, hogs trom eholera and thmmps, sheep from what is known here as rot, and fowls from cholera and sorehead. I think the valne of onr losses have been abont as follows: IIorses, $\$ 2,000$; eattle, $\$-40$; hogs, $\$ 3,750$ : and towls, $\$ 200$.

Inde.-Teither farm animals nor towls have been attacked by ang epidemie or contagious disease during the past year. We bave but little farm stock in this connty.

Heruando.--Some epizootic diseases have prevailed amoug horses recently bronght to this county from Kentucky and Tennessee. The malady is the result of a chauge of climate.

Hillsborough.-I have not heard of the prevalence of diseases anong any class of farm animals the past year, except distemper, which affected a drove of horses brought in from Kentucky. But one animal died.

Jachom.-It is only at certain seasons of the year, and in certain localities of the county, that farmanimals suffer with disease. Our losses have been light the past year.

Yadison.-The principal disease among horses and mules are colic and staggers. These diseases canse quite a heary amnual loss. Hogs valued at $\$ \cdot, 500$ have died during the year of eholera and thumps. Bnrned corn is a preventive of cholera, it is saill.

Marion.-Horses, cattle, ant hogs are subject to such diseases as colic, blind staggers, and cholera, the latter being eonfinerl to logs. Cattle in soure loralities are troubled with a disease known as salt-liek. It is manifested by a slow debility, and is sometimes accompranied hy diarrhea. No remedy has been fonn tor the disease.

Sunta Rosu.-A few horses died during the year in this connty. A large number of cattlo dien in the spring of 1882, mostly from starvation. Very fow hogs have bren lost ly discase this year, hut more sheep than usual have died. Cholera has been very destructive to fowls.

Surannce.-Horses and unles die of hlind staggers, sand, and eolic. No glanders or farey, but almost every horse that sickens of either staggers or sand disease clies. $\Lambda$ great may cattle have been lost, and a great many hogs have died, I suppose of cholera. The same can be said of fowls. I estimate the valne of our losses as follows: Horses, $\$ 15,000$; eattle, $\$ 2,000 ; \log s, \quad 32,300$ sheed, $\$ 200 ;$ fowls $\$ 600$. 
Taylor.-All I have been able to learn is that a few horses have died of blind stag. gers, and some hogs have died of cholera. There is but little farm stock in this county.

\section{GEORGIA.}

Balduin.-We have more nules than horses in this connty. The only deaths among either class have been cansed by colic. No epiclemic has occurred. 'There have been but very few cases of cholera amoug hogs. No disease amoug cattle to cause serions loss; a few deaths here and there.

Broolis. - Horses, cattle, and sheep have heen generally liealthy. For the past eight or ten years our hogs and elickens have died at a rapid rate from cholera.

Burkir-Only one epidemic of glanders among horses has been reported during tho past eighteen months. The disease was hrought from 20 miles west of here, and was contiver to one public stable. Cattle and sheep have been healthy. About one-half of the hogs and two-thirds of all the fowls in the connty have been lost during the sear by the cholera.

Camden.-Neither horses, cattle, sheep, nor hogs have been affected by contagions diseases the past year. Cholera has destroyed a great many fowls.

Campell. - No destructive disease has visited any class of our domestic animals or fowls during the current sear.

Carroll.-I am muble to hear of the prevalence of any epicleuic disease amoug farm animals in this county the past year. Cholera has prevailed among fowls, but to no great extent.

Catoosa.-Hog cholera has been simply awful in this connty this year. No remedy was efticient, but preventive measures mere somewhat serriceable. Our hogs have been singularly exempt from disease heretofore, but we have been scourged at last.

Charlon.-A few horses have been lost the past year by the usual diseases. The greatest and only loss from contagions or epidemic diseases lias been anong hogs, caused bs the disease known as eholera.

Chathem.-No disease of an epidemic character has existed among any class of farm animals in this county during the year just closing.

Chattooga.-Horses and eattle have beeu unnsually healthy the past jear. I few hogs have died from what was thought to be a mild type of cholera, but the disease was not marked with its usual maliguaney and fatality.

Cobb. - The total loss of farm animals and fowls from disease in this comty the past jear will aggregate about $\$ 5,000$. There has been no extensive onthreak of clisease except amoug hogs and fowls, and among these the destruetion lias not been sogreat as in many former rears.

Coffee.-A few horses have died the past season of staggers. Cat the have been healthy, thongh some have died from poverty and neglect. Hogs have been aftlicted with cholera, but the losses have not been heary.

Colquitt.-There have been no losses among farm animals this jear except from common casualties, old age, $\mathbb{f}$ c.

Dade. - I thiuk $\$ 1,000$ will cover all the losses of farm animals in this comby the past fenr from the various diseases to which they are subject.

Dauson.-There have been a less number of deaths amoug horses and unles the past jear than usual. The same can he said of cattle. Hog cholera has heen very tintal in some portions of the conuty, but the disease has not prevailed generally. But little attention is paid to the raising of sheep.

Dooly. - Not a case of contagious disease lias occnrred among farm animals in this county the past year so far as I am able to learn. Sheep have suffered to some extent from dogs.

Early. - I estimate the value of the losses among the principal classes of farm animals as follows for the current year: Horses, $\$ 2,500$; cattle, $\$ 500$; hogs, $\$ 1,000$. 
Effingham.-With the exception of hogs and fowls, all kinds of farm animals in this connty are in a healthy condition.

Emamuel.-The only epiclemic we have had to contend with for some years past is cholera amoug hogs. These animals are more or less affeeted with this or some other disease every sear. A few horses have died of staggers, amb a good many for lack of proper eare and attention. They are kept on the rauge throngl the winter, and often die from hunger and exposure. I estimate the vahe of horses lost at $\$ \pi, 500$; hogs. \$2,500; sheep, $\$ 3,500$.

Fimnin.-With the exception of a few eattle that have died of milk-siekness, firm animals in this connty have enjoyed exceptionally good health the past rear.

Franklin.-There have been no contagions diseases prevalent auong farm animals since 185. During that year about 50 per eent. of all the hogs in the connty died of cholera. A few horses have died the present year from neglect and had treatuent.

Fulton.-There are but a liniterl number of farm animals raised in this connty for market, and I have but few losses to record. Onr bogs were formerly affected with cholera, but since the adoption of the stock law we have had no tronble from it.

Gilmer:-I estimate the value of farm animals and fowls lost in the connty the past year as follows: Horses, $\$ 4,000$; eattle, $\$ 1,000$; hogs, $\$ 1,000$; sheep, $\$ 2: 5$; fow ls, \$1:20.

Gordon.-This bas been an exeeptionally healthy year for farm stock. A few cattle have died of "murrain," or Texas fever, but so very few that they are not worth recording. A good many fowls have died from so-ealled eholera, but i: is impossible to give auything like a correct estimate of the number lost.

frecme.-I have no heavy losses to record as occurring amoug auy class of farm animals in this connty. The year has been an a verage one as regards the health of farm stock.

Habersham.-No special epiclemic tlisease has prevailed among our stock the past season. The number of each elass of animals has gradnally increased. We have more hogs in the county than at any previons time during the piast five years.

Haralson.- I think abont 10 per cent. of the sheep of this comnty dio ammalls of the discilse known as rot. Ahont the same proportion of fowls die of so-called cholera.

Huris. - This bas been a remarkably healthy year for all kinds of stock. Omr people are giving much more attention than formerly to the care of stock, and I think the business will ultimately provo profitable. We have a elimate capable of a variets of prolnetions-corn, cotton, wheat, wats, barles, rye, potatoes, vegetables, and all kinds of stock.

Hancock.-No dliseases have prevailed amoug farm animals as epridemies; only sporadie cases now and then, contined to linited localities. Cirubs liave proved fatal to sheel', and cholera and "soreheal" to fowls.

Jackson.- - Horses and cattle bave not been serionsly affected with disease during the rear. IIogs and sheep have sutfired to a considerable exteut with contagions diseases. 'Thonsands of fowls die annmally of disease.

Tasper. - I know of no disease existing among either horses or cattle. Oceasionally a horse dies of colic and a cow from mogleet. Cholera has prevaled to some extent among bogs. It is said it may he avoided by letting them lave free aceess to salt and wood aslies.

Johnson.-The only farm animals aftecterl by clisease here are hogs. The eholerat never dies ont among these animals. IIogs aro lying now in almost every seetion of the connty. Om losses $n$, to this time will reach from $\$ 5,0100$ to $\$ 10,000$.

Lumbin.-Horses, eattle, and sheepare healthy. Hog elobera is not so prevalent as usmal. One-fifth of all the logs in the comty died of this discase in 1802.

Mclune.-With the exerption of an oceasional case of colic, we wrely have any distase anong onr horses. Cattle are selfom atheted. Hogrs die of choleria more or lessevery rear. Inereased interest is leeing patd to stock, and tho amonnt now raised is donble that of a fiew years agn.

Morgun.-Nearly all labor is performed by mules, which, I suppose, ontmunher the 
Lorses fonr to one. No special discase prevails among them. We frequently lose many hogs by cholera, bnt the disease seems not to have visited the county dinring the past two years. Sheep are healthy. Fowls in some localities have suffered from roupe and eholerit.

Muscogee.-This is not a stock-raising conuty, and I have no report to make relative to discases.

(conce.-Cattle are frequently attacked with bloody murrain and sheep with footrot. Hogs and fowls suffer to a greater or less extent every year with cholera.

Picksus. - The greatest losses among eattle in this county are cansed by murrain aud distemper. Cholera and quinsy prevail amoug hogs, aud cholera anong chickeus. I estimate the value of onr losses in fowls alone at $\$ 100,000$.

Quilman.-No contagions diseases are prevalent among either horses, eattle, or sheep. Recently the hogs in many localities have been attacked with cholera, which seems te be unusually fatal. The chickens are being decimated in entire neighborboorls by the same disease.

Rockdale.-Horses, mules, and cattle have been affecterl with no musnal diseases the past year. Hogs and fowls, however, annually die in great numbers of the disease known as cholera. On stock has wonderfully improved nnder the no-fence law, which has been in operation in the county two years.

Talbol.-Domestic animals of all classes have been mnnsually exempt from disease the current year. Some cholera bas prevailed among ehickens, which is generally checked by putting them np, a few together, and destroying the dead. Inch attention is being paid to improvement in the breeds of cattle. We have the Jerser fever.

Terrell.-Horses are geuerally lost by poverty, or some disease indnced hy ill-treatment. But little small grain is raised, and the animals are fed on chaff, weevil-enteu corn, and poor fodiler, which the horses camnot assimilate. The most of the work is performed by mules, and of course the losses are greater among this class. Perhaps the value of these losses will reach $\$ 2,500$ annualy. No contagions diseases among cattle. What we term cholera canses heary losses in ponltry. Abont once in five Jears it almost annihilates the chickens.

Thomas.-Black-tongue or murrain occasionally carries off' a tew head of eattle. Blind staggers is about tho only destructive disease to horses and mules. Cholera and sorehead are the diseases which aftliet fowls.

Tronp.-No disease has prevailed among our stock during the past year-at least the losses have been so light as not to be worthy of recorl.

Uniou.-Distemper is the ouly disease existing among horses, but I lave hearl of no deaths resulting. Milk-sick has prevailed to some extent among cattle. This is cansed by a mineral poison, and is confined to particular localities.

Tashinglon.-Not much discase among lomestic animals in this conuty. Have no menus of securing correct data.

Webster.-An epidemie prevailed among cattle in the northern portion of this comnty in March last. It proved fatal in almost every case. The disease was not identified. There was inflammation of the intestines, black, watery discharges, loss of appetite, and deatl withiu a fer days.

White.-The only contagions disease that has prevailed among our farm stock is hog cholera. I suppose hogs to the valne of $\$ 2,000$ or $\$ 3,000$ have bern lost by this discase.

Ililkes.-IIorses and unles suffer nore from short rations than any thing else. IIogs are healthy, and on the increase. Sheep sufier only tiom dogs.

Horth. - Stageres is about the only diseaso affecting borses. Those attaeked scarcely evere recover. The "attle are of the serubliml. They are generally brought from Texas to graze on our mesifut grass. A great many of them die from exposure in severe weather. We have had mo rain since June. The grass is dead, and the cattle look very weak. No disease anong logs. The hreed is the bottle.nose, piney woorls, rooter or razor loack. 
ILLINOIS.

Adams. - With the exception of a few cases of pink-eye in horses, no disease of a serious character has prevailed amoug any elass of domestic animils in this connty the past year.

Boone.-During the past year all kinds of farm animals have remained very healthy. The only disease worthy of uote is chicken cholera. This has been very fatal iu many cases. No remedy is kuown.

Carroll.-The largest stock-shipuer in the connty informs me that he has never known a time when all kinds of farm animals were su free trom disease as at present. I give the losses for the year as follows: Horses, $\$ 12,847$; cattle, $\$ 11,131$; hogs, 84,463 ; sheep, \$604.

Christian.-About 5 per cent. of the horses and cattle of this connty are anunally lost by sickness, accidents, \&c. Twenty-five per cent. of the logs aud 25 per cent. of the fowls of the county generally die of some disease incident to tinem.

clarli. -The assessor's returns for this comty give the value of the losses of farm animals for the past year as follows: Horses, $\$ 15,718$; eattle, $\$ 4,291$; Logs, $\$ 5,205$; sliee $1, \$ 1,3 \pi \%$.

Clinton.-The following is the most accurate estimate $I$ cau give of the value of the losses among farm animals in this conaty for the past year, viz: Horses, $\$ 15,669$; cattle, $\$ 4,969$; hogs, $\$ 7,095$; sheep, $\$ 1,392$; fowls, $\$ 384$.

Crawford.-Mauy hogs have died of so-called eholera. Losses of all classes of domestic animals for the year: Horse's, $\$ 1,325$; cattle, $\$ 5,000$; hogs, $\$ 18,900$; sheep, $\$: 3,600$.

Cumberland.-Farm aumals have been in better health the past year than usual. I think the following estimate will cover the value of losses among all classes as weil as fowls: Horses, $\$ 3,000$; cattle, $\$ 450$; $\operatorname{logs}, \$ 5,000$; sheep, $\$ 2,000$; fowls, $\$ 400$. There hats been some distemper among horses.

De Kalb.-Farm animals have enjoyed remarkably good health this year. I think the aggregate value of the losses will not exceed $\$ 4,000$.

Edgar.-Colic, bots, distemper, de, occasionally canse the death of a horse. There is no general disease among cattle aud but little among hogs. The following is an estimate of the value of the losses among the varions classes: IIorses, $\$ 12,000$; eattle, $\$ 5,000$; hogs, $\$ 3,000$; sleeep, $\$ 300$; fowls, $\$ 1,000$.

Edwards.-Hogs to the valne of $\$ 3,000$ or $\$ 9,000$ have beeu lost the past year by farmers of this connty. A few horses and cattle have also died of diseases inciclent to theni.

Franklin.-Aside from the ravages cansed by hog eholera, I lave uo losses to record among other firm animals. The value of the losses cansed by the ahove disease will reach $\$ 3,000$.

Fullon.-IIog cholera prevails in the connty, and many cases havo terminated fatally. No other cliss of animals seems to bo serionsly affecterl.

Gallatin.-Perhaps 100 head of horses have died in this comty of tistula. Cattlo have been extremely healthy. Murtain aud mal-iteh have probably caused the death of 50 hearl. Some cholcra has prevaled among hogs, from which alout 500 hear have died.

Cimudy.-All classes of firm animals and poultry have heen exeedingly healthy the past year. The losses hy infections and contagious diseases will not exced one per cont. in either cliss.

Ifenry.-Some horses aud "attle have been lost by alecident and disease. Hogns are healthier than last year, thom the vahe of omr losses for the enrevt year will reach $\$ 15,000$. Cholera has swept ofl fow $k$ to the value of $\$ 1,500$.

Jefferson. - The only loss of eonserunes among our farm stock has occurred amoug

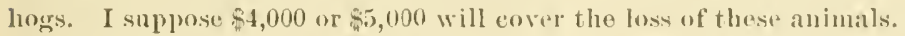

Jersey. - The assessors for this comnty make the following returus of the value of 
farm animals lost in 1833 : Horses, $\$ 10,275$; cattle, $\$ 16,705$; hogs, $\$ 5,000$; sheep $\$ 1,148$.

Johusou. - Some eattle bronght into this comnty from the sonth were affected with disease and a few of thein died. No losses worthy of unention amoug other animals.

Jo Lariess. - The value of the losses of farm aninals in the county for the year 1883, with slight moditieations is given by the assessor's as follows: Horses, $\$ 21,990$; cattle, $\$ 16,705 ; \operatorname{hogs}, \$ 4: 2,789 ;$ shee $1, \$ 1,114$.

Lunkuke. - But little disease of any kind seems to have prevailed among any elass of onl farm animals the past year. From the best information $I$ can get $I$ am led to believe that the losses among all elasses will not exeed $\$ 1,200$ in value.

Fendall.-Hogs to the value of $\$ 15,540$ have been lost by disease in this county iluring the past year. A few flocks of sheep have been aflicted, but the losses have been light.

La Salle.-A few horses ded in this connty last spring of hysteria. During the summer a disease attacked the cows near Mendota. It was very fatal, aud killed the animals in a few hours. A good many hogs died in the conrse of the farrowing season. I hear of but one flock of sheep attected with scal.

Lawrence.-Horses and eattle are healthy. Hogs have suffered with cholera as usual. A great many sheep have died of a disease of the bowels. Large numbers of fowls have been destroyed by cholera.

Lee.-As a general thing farm animals have been quite healthy the past year. A few hogs have been lost from various causes; but the value of the losses will not exceed $\$ 1,600$ or $\$ 1,800$. Some foot-rot prevails among sheep, but the disease is not destructive.

Mason.-Some pink-eye has prevailed among horses, and a mild type of cholera among hogs, but the losses have been very light. Other classes of stock have remained healthy.

Morgan.-No new disease has previterl among auy elass of farm auimals the past year. Cholera among hogs and fowls is abont the only disense that has cansed losses worthy of mention.

McHemry. - The following are the nnmber and value of farm animals lost in this conuts the past year, as shown by the returns of the assessors: Horses, $\$ 15,702$; eattle, $\$ 12, \sim 79$; logs, \$5,230.64; sheep, $\$ 2.269$; and fowls, $\$ 900$. The heaviest losses among all kinds of stock ocenred during the months of Mareh and April. Noconta. gions diseases seem to be prevailing at this time.

Oyle.- While no epidemic seems to have prevailed during the year among our farm animals, the losses have been quite heary. The value of the losses is given as follows: Horses, $\$ 16,000$; cattle, $\$ 19,800$; logs, $\$ 3,900$; sheel, $\$ 432$.

Peoria.-The losses among domestie animals in thiscounty were quitc heary duriug the year. Ther are given as follows: Horses, $\$ 29,186$; cattle, $\$ 10,014$; hogs, $\$ 20.580$; sheep, 52,330 . Of the hogs lost 2,895 died of elolera aud 1,203 of other diseases.

Perry. -Perhaps $\$ 8,000$ or $\$ 10,000$ will cover the ralne of the losses of farm stock in this comnty during the year from all canses.

Pnlasli. - After the high waters of last spring subsided a lisease appeared among hogs which scemed to have its origin and to more serionsly atteet those that had been kept in erowded pens and ill provided places dming the continuance of the flood, and were returned to the ground before it had sufficiently dried. In some instances thoso that recovered ehanged their color from black to gray.

uturm.- Inring the year we lost 91 heal of horses, 106 head of cattle, 5960 hogks, and 79 sluee], valned as follows: Horses, $\$ 9,359$; eattle, $\$ 2,931$; $\log$ s, $\$ 3,576$; sheop" $\$ 4011$.

I'ope.-All classes of farm stock seem to be healthy-no disoase of consernence the past year. In $188^{\circ} 663$ hogs dien of eholora in this connty, and 893 sheop were destroyed liy dogs. 
Rock Island.--Quite a large number of hogs have been lost by the nsual diseases the past year. The losses among other classes of animals are hardly worth recording.

Saline.-The loss of domestie animals by disease has not been very great in this county the past year. I give the valne of the losses among the various classes, as follows: Horses, $\$ 1,995$; cattle, $\$ 693:$ hogs, $\$ 2,407.50$; sheep, $\$ 4=0$. Fowls are healthy.

Schnyler.-Seven horses affected with glanders have been condemned and destroyed by order of the State veterinarian, and five others are supposed to liave the disease. These will be finally examined by the veterinarian on his return to the county. Other classes of farm animals are liealthy.

Shelby, -Farm animals in this county lave been musually healthy the past year. No epidentic of ans kind has prevailed. The value of the hogs lost is estinated at but \$2,0;4.

Stark.-Only the ordinary diseases have prevaliled among our horses aud eattle the past year. Sheep have also been healthș, and hog eholera has been less destructive than for many years past.

stcphenson. - Notwithstanding there has been no specual epirlemic among horses, I estimate the value of those lost in the county the past year by ordinary maladies at $\$ 35,000$. The ralne of the other classes of animals that have died of clisease or by accident I give as follows: Cattle, $\$ 3,600$; hogs, $\$ 1,500$; sheep. $\$ 1,000$.

suint Clair.-But few farm animals are kept in this counts, and what we have are kept in the hest possible condition, hence they are scarcely ever visited by epidemics.

Tazercell.-No severe epillemie has prevailed among aug class of farm animals in this connty the past year. Even swine plague has prevailed to a less extent than formerly.

Termillion. - The bealth of all classes of domestic animals has heen musnally good the past year. What losses have occurred have been small and were the result of natural causes. A few logg died in one township of the cholera : the loss was insignificant.

Woyne.-Farm animals ralued as follows have been lost by the farmers of this comnty the past year, viz: Horses. $\$ 1,000$; cattle, 8975 ; hogs, $\$ 1,680$; sheep, ses0 and fowls, 50,250 .

Trabash.-Pink-eye prevailed among horses not long since in one locality in our connty. but I heard of but one death from the disease. Cattle and sheep have been healthy. A few hogs were reported as having died late in the fall.

Traren.-One hundred and twelve horses are reported as having died in this connty the past rear. They were valued at $\$ 6,720$. One lundred cattle, ralued at $\$ 20$ per heat. were also lost.

Will. -The value of the losses among farm animals in this county for the eurent year are griven as follows: IIorses, $\$ 1,360$; eattle, $\$ 8,000$ : hogs, $\$ 2,400$ : shecp, $\$ 310.50$.

Irilliamson,-Cars that had been used for transporting cattle to Saint Lonis were bronglit to this eonnty to be loaled with coill. The manure was thrown ont alongsicle the railroad track, and all the cows that visitnd the locality were infected with Texas ferer and dient.

IInucbug. -The connty assessors return the following as the value of losses among farm stuck for the year: llorses, 811,512 : cattle, so, 196; hows, sil112: sheep, siv0; and tiwls, s1.5.5.

INI) IANA.

Altums.-No disease has prevailed during the year anong pither horses or cattle in this connty, but some logs have died of cholera. This disease has been neitler so widesprearl nor destructive as in 1 202.

Benton,- Some fiw cattle died during the year with piuk eye. We can't depend on the health of onr longs from one week to another. They are now sutfering with the old-fashioned cholera. Sheep have died of foot-rot and scah, aubl a great many fowls have been lost by cholera. 


\section{CON'TAGIOUS DISEASES OF DOMESTICATED ANIMALS.}

Clinton.-The value of the losses among domestic animals in this county for the year, from the various canses and diseases inciclent to them, is abont as follows: Horses, $\$ 12,650$; eattle, $\$ 10,000 ; \log s, \$ 6,000 ;$ shee $1, \$ 1,000$; and fowls, $\$ 450$.

Crawford.-Farm animals in this comty have remained in good health during the year. No epidemic of any kiul has prevailed among them.

Decatur. - The loss of animals in this combty has been very heary, though no general epirlemic is reported as haviug prevailed among any partieular elass. Fowl cholera has been particularly destructive, so much so as to diseourage poultry raisers. The value of the losses for the rarions elasses are estimated as follows: Horses, $\$ 17,570$; cattle, $\$ 4,200$; hogs, $\$ 16,107$ : sheep, $\$ 2,205 ;$ mules, $\$ 2,400$; and forls, $\$ 2,500$.

Dubois. - Hogs are the only domestic animals that seeu to have been seriously affeeted by disease during the past year. The value of those that have died amount to $\$ 9,462$. Chicken eholera lias carried of fowls valued at $\$ 2, \$ 56$.

Fryette.-No disease of a destructive character has previnled during the year among either horses, cattle or sheep. Hogs valued at from $\$ 6,000$ to $\$ 7,000$ lave died of the usual diseases.

Franklin.-I know of no particular disease to which horses have beeu subject. About 75 per cent. of the hogs lost during the year died of swine plague, and about 40 per cent. of the losses among sheep were cansed by dogs. Abont 20 per cent. of our fowls bave died of cholera. The total value of the losses among hogs aggregates $\$ 20,056$. The results of the experiments made by the Department through its agencies in the treatment of swine plague have been thoronghly tested here duriug the past year, and noadrautage seemerl gained either in cure or prevention. Hog cholera, when malignant, fields to no known remedies with us. It is wholly unmanageable aud fatal.

Iulton.-The county assessors give the following as the value of the losses amoug farm animals in this county for the past year: Horses, $\$ 1 \%, 400$; cattle, $\$ 4,400$; hogs, $\$ 7,500 ;$ sleeep, $\$ 600$.

Gibson. -The records in the connty auditor's office give the following losses of farm auimals for the sear: Horses, $\$ 17,800$; mules, $\$ 6,975$; cattle, $\$ 6,740$; hogs, $\$ 33,710$; sheep, s.5.

Harrison.-No destruetive epidemic of any hind has visited the domestic animals of this loeality during the year. I have no means of securing the statisties of losses of those that have dier.

Hamilton.-A great many cows have died of milk fever. The disease is very fatal, aucl about all clie that are attacked. Quite a number of hogs have died in the county of late. If one of these aninals die the disease is always called cholera. I estimate the value of those lost, whether by cholera or some other lisease, at $\$ 12,800$. Cholera and gapes frequently prove very destructive to fowls.

Hancock, - No disease of consequence has prevailed among horses, cattle, or sheep' the past year. With a few exceptions hogs have been healthy, and the aygregate loss will not much exceed $\$ \$, 000$. Whenever any disease prevails among this class of aninals it is called cholera. A clisease also called cholera and roupe have prevailed to some extent among ehickens.

Ifudricks. - Losses of animals in this connty for the gear 1883 are given as follows: Horses, $\$ 8,750$; cattle, $\$ 4,820$; logs, $\$ 1: 50,56$; sheep, 80,290 .

Hemy.-It is diffieult to answer the desired questions. In some localities there have been lieavy losses from hog eholera, hut as to the value of the losses $I$ am at a loss to know. 'Two men near liere have lost about $\$ 1,000$ worth each and of hers quite largely. No disease has ocenred among loorses or eattle.

Howard.-No epidemie disease prevailed among horses during the years 1-8-?-83. Anthrax prevaled to some extent among eattle, destroying animals valued at upwarls of $\$ 5,000$. I estimate our losses by so-ealled hog cholera at $\$ 30,000$. This disease prevails anong hogs throughont the year.

Jay.-Oeeasionally pink-eje appears anong onl horses and distemper rages to 
some extent, but the losses are generally hght. Our eounty has again been visited by hog cholera in its worst form. Some famers have lost nearly all their animals. Nothing seems to have any effect on the disease when it gets a fair loold; the animals die anyhow. Chickens also die in large numbers of eholera. Sheep are fearfully slanghtered by dogs.

Jemings. - The only divease worth mentioning among farm animals is hog cholera. 'This discase, however, is not so widespread and destrnetive as in some former years. Last year I lost 70 heal myself by the disease.

Johnson.- The records in the anditor's oftice give the following as the valne of farm animals lost during the year, riz: Horses, $\$ 1,250$; eattle, $\$ 300$; hogs, $\$ 5,000$; sheel. $\$ 1,200$; and fowls, $\$ 250$.

Knox,- The most careful estimates give the value of farm animals lost in this conuty dnring the year as follows: Horses, $\$ 1,000$; eattle, $\$ 5,000 ;$ hogs. 825,000 ; sheep, $\$ 1, \geq 62$.

Lagrange.-No special disease has prevailed anong onr horses or eattle. Cholera had destroged hogs perhaps to the valie of $\$ 5,000$. The actual loss by death and hindrance in reprodnetion is no donbt greater than this; in all probability it wonlel reach $\$ 10,000$. As a preventive of this terrible disease carbolic acid and turpentine in swill or feed has been fonnd the most efficacions.

Madison.-Cholera has prevailed among hogs in some portions of this comty, and has destroyed animals during the year worth in the neighborhood of \$10,000. Other classes of animals have been measurably healthy.

Marshall.-The following figures represent the losses of farm stock in this comnty for the past year: Horses, $\$ 7,000$; (attle, $\$ 3,200$; hogs, $\$ 3,200$; sheep, $\$ 350$; aud fow 1 , $\$ 2,777.50$.

Miumi-No epidemic disease Las visited either horses, cattle, or sheep. The number of sheep killed by dogs was 390 , valued at $\$ 1,462$. The valne of hogs lost by the diseases incident to them was $\$ 31,400$.

Morgan.-None other than ordinary diseases have affected onr stock during the past year. There has lreen a slight spriukling of cholera amoug hoth hogs and fowls, but it is hard to determine the actual loss as regards either numbers or valnes. Perhaps one-third of the chickens hatehed have died of the disease.

Monroe.-No epidenic disease has prevailed among horses. A few animals have died of pink-ege and distemper, and others of old age, colic, bots, bad treatment, fe. No disease among cattle or sheep, except foot-rot among the latter, cansed by keeping too many animals together. In some neighlorhoods the hogs liave suffered from swine-plague.

Parke.-Hogs have dien with the nsual diseases the past year. The muber that died is given at 4,2-5, valued at npwards of $\$ 20,000$. The loss among sheep has also been quite heave.

lipley. - The following figures represent pretty acenrately the vilue of lomestic animals lost in this connty the past Jear: Horses, $\$ 11,075$; cattle, $8.3,104$; logis, 54,165 : sheep, 51,550 .

Scott.-Perlaps 85,500 would curer the value of the losses of loogs during the past year. Chicken rholera hiss been very destructive. Quite at number of fowls have also died of fatty degeneration of the heart. The heart seemed to be transformed unto a lump of fit. This ruptures, and the fowl dies almost instantly.

Shelby. - 'The mortality among domestic animals in this county has been quite heary the past year. Cholera among lowgs and fowls has proved more destructive than any other disease.

spencer.-Some young lomses have died of distemper. A great many hogs liave died of eholera. Ahout all that are attacked by this diseaso die. Cloberat and gatpes bave destroyed a good many fowls.

Switzerland.-Sixtr-six horses died in this connty during the year. Of these abont 5 per eent. died of pink-eye. Mr. Perry colton lost 18 lead of cat the by an muknown 
disease. Freruent deaths have ocenrred among hogs from cholera and among sheep from rot.

Tippecanoe.-With the exeption of cholera among hogs our farm animals have been very liealtly the past year. No disease of any kind is prevailing at present.

Cnion.-About 1,200 hear of hogs have died in this eounty during the year, valued at $57,-00$. Diseases have also been very lestructive to fowls.

Jigo. - No epidemie bas prevailed amoug farm stock in this county the past year. The following balues of the losses are the result of deaths from orlinary diseases aud aceidents, viz: Itorses, $\$ 16,350$; cattle, $\$ 7,590$; hogs, $\$ 5,360$; sheep, $\$ 816$; and fowls, $\$ 320$.

Walrash.-A great many animals died of the varions diseases to which eaeh class is subject during the year. The valne of the losses are about as follows: Horses, $\$ 12,960$; mules, $\$ 1,700$; cattle, $\$ 12,810$; hogs, $\$ 19,456$; sheep, $\$ 1,424$.

Hayne.-Cholera proved very disastrous to hogs in this county during the sear. The number reported as having died of the clisease was 9,253 , valued at $\$ 92,530$. Some cattle died of murrain aud sheep of liver-fluke. Fowls suffered from cholera.

IOWA.

Adair- No destruetive disease has prevailed among any class of farm animals in this county for the last two years.

Allamake.-Farm animals have geverally continned in good health the past season. In some loealities diseases have prevailed among hogs, but not to the sweeping extent of the years 1880 -'s1. The same might be said as regards fowls. Some 2,800 loogs have died, valued at $\$ 14,000$.

Bremer.-As to diveases aftecting different kinds of farm animals, I frequently hear it remarked that cattle. horses, and hogs were never more free from disease than they have heen the past rear. One assistant says: Now and then a calf dies with what is known as black-leg, but these deaths do not amonut to one in fifty.

Buchanan.-The following figures represent the valne of the losses among farm stock in this comty for the year 1883 : Horses, $\$ 15,000$; eattle, $\$ 3,750$; hogs, $\$ 8,500$; sheep, 8180 . The mortality amoug horses was mainly cansed log influenza. Abortion has prevailed to a consiclerable extent among cows, and has caused some deaths. No emcir or prevention is known. Hogs have died of the disease kuown as cholera.

Iinler.-The only epidenic disease that has prevailed among any class of animals has leeen that among hogs. I think the valne of the animals lost will not exceed $\$ 4,000$.

Calhom.-A clisease recently broke ont among cattle in one of the townships of this county, which resulted in the death of a number of animals. The disease was blackleg, or something similar. Cholera has prevailed among fowls, but to no great extent.

Cedar.-Our horses have been afllieted with pink-eye and distemper. Cattle, as a rule, have been quite healthy. A few cases of black-leg have oceurret. Cholera, or some kind of lung complaint, eaused by worms and neglect, have caused the loss of a great many hogs. Some rot has prevailed among sheep.

Chichasaw. - The disease most prevalent among hogs seems to be hard to name and equally as difficult to prevent. In some places it is called quinsy, and in other loealities cholera. But it does not prevail anong our hogs to so great an extent as in other years. In a limited area of onr county during the fall months horses were atilicted with an influenza which it was feared at the time would prove very disastrous, but I beline it has rntirely abated.

Clinton.-As a general thing all kinds of farm animals in this eounty are in good health. Hogrs valued at $\$ 1,000$ have heen lost during the year by the usmal diseases.

Cruuford.-1 estimate the value of the losses of farm stock in this eonnty the past year as follows: Horses, $\$ 3,100$; cattle, $\$ 1,560$; hogs, $\$ 3,600$; sheep, $\$ 200$. 
Davis. - We have been very lucky with onr stock this year, no disease of any kind worthy of mention. About 800 sheep have been killed by dogs.

Deeatur.-Never in the history of the eounty have farm animals been so generally healthy. Every assistant makes the same report. I believe this result is attribntable to the shortmess of grain to feed with.

Delurure.-Horses and cattle have been healthy, lut logs have suffered to some extent with the nsual diseases. Animals perhaps to the value of s5,000 have heen list.

Dubuque.-The ouly diseáse that has prevailed among any class of domestic animals in this county the past year has been the disease known as cholera anoug hours. I canast give the number or value of those lost.

Emmet.-The losses among farmanimals in this eounty have been so iusiguificant for the past year that they are not worth recoldiug.

Fayetle.-A few herds of hogs have been affeeted by disease, but the losses have been comparatively light. No disease has prevailed in an epidemic form.

Floyd.-Epizootic influenza has prevailed to some extent among lorses, aud a lew cases of glanders have been reported. Cattle have suffered with lung disease's and hogs with eholera. The losses, as to value, have heen about as follows: Horses,

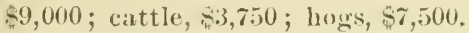

Greene.-Horses, cattle, and sheep ine in goon health. The prevailing disease anong hogs and fowls is that kuowu as cholera. The valno of the loggs lost by this disease is about $\$ 4,000$, and chickens abont $\$ 900$.

Indiu. - Some cloblera has prevailed among hogs aud fowls. Sometimes this disease will earry ofi almost every hog oue farmer will have, while those of a neighbor will not be affected. I think $\$ 6,000$ a fair estimate of the value of those lost by the malady.

Henry.-No disease among fam animals, and no losses except from old age, accident, de. ; cholera prevailed anong fowls during the months of July, August, ant september.

Ida.-One thousand dollars will, perhaps, cover the losses among hogs by disease. No other class of animals have been aftlicted in this comnty the past year.

Iowa.-Farm stock has been unusually healthy the past year. No cpidemie has prevailed. Common diseases, neglect, and accident have cansed ahout the usual losses.

Jasper. - The only disease worthy of notice is that prevaling among swine and lowls. The per cent. of disease among the former will not exceed 2 per cent., and among the latter abont 5 per cent.

sefferson.-Chicken eholera prevails to a greater or less extent every year, and the losses from this canse are often very serious. Farm aumals generally are in good heal

Lee.-Among horses there has been no epidemic of note for several years. We hear occasionally of a case of pink-egr, colie, hots, and meningitis. Cattle have also been affecterl to some extent this season with pink-eve. Calves frequently die of black-leg. Sheep are unore frequently trouhled with scal than any of prerhaps all otlere diseases. Grub in the heal kills its proportion. Some sheep died of loven during the two past wet seasons. Fowls have leen subject to but oue disease-that known as cholera-and this frequently depopulates whole inru-yards of ehickens and turkeys. Almost all ppidemies among domestie animals are eonfined to sualler areas thim formerly ; sometimes to hit one farm, section or township. A few rears ago, hog and ehieken eholera generally extendel over one or more states. Blaek-leg in cattle was never so general or wide-spread as now.

Limu. - No epidenic has visited horses, but the vast ummber of unsomnd ones is alppalling. The mumber of halt, hlint, ring-bonel, spavined, fee, is astomeling to a close observer. A fow eattle lave died of ordinary diseases. Somo little cholera amoug chickens.

Marion.-Dnring the past three monthis inlluenza lats ben destructive to miny 
young hogs. Swine plagne has also prevailed in certain localities. Scab and foot-rot have eansed losses among several different flocks of sheep.

Mitchell.-Domestic animals generally are healthy, and havo been so throughout the rear. The diseases that have prevailed from time to time have been the usmal well-kuown maladies. The value of the losses are estimated as follows: Horses, $\$ 8,350$; cattle, 55,000 ; hogs, $\$ 2,500$; shecp, $\$ 250$.

Monomu,-Some eattle have died of black-leg during the year. Soune little disease has frevailed anong hogs, but the losses lave been light.

Monroe.-Wo contagions diseases bave prevaled among any elass of domestic animals in this connty during the year except black-leg among ealves. These cases have been few. Clolera has killed a great many fowls.

O'Brien.-For two seasons our horses have suffered from an epizooty. It left many with a running at the uose. In eareless hands the discharge has run aloug until maus horses here are suffering from an offensive nasal disease called every name between luad cold and glanders.

Palo Allo.-Farm animals generally are healthy. I have not heard of a case of contagions disease amovg hogs for the past year.

Plymouth.-Horses in some localities in this connty are said to have chronie glanders, which is eansing some exeitement. A disease called measles has prevailed among hogs, cansing some losses.

Potturattamie.-Last spring, in one neighborhood in the connty, a new aud quite strange disease appeared among both horses and cattle. It was prononnced "buttoufares " in horses. The symptous were similar in cattle.

Shelby.-There las been some disease followed by fatal results among horses and cattle the past year, but swine have heen healthy. A great many fowls have also died.

Tuma.-Horses, cattle, sheep, and towls are in grood lealth and condition. Hogs are dying to an alarning extent thronghont the county with both quinsy and cholera. These diseases broke out about six weeks ago.

Thahington.-There is no disease prevailing among farm animals in this connty. Even the hog cholerit has disappeared. Perhaps this is owing to a very poor erop of coru.

Toodbury.-Horses are healthy. A few cattle die aunually of black-leg. Hogs are comparatively healthy. Now and then a farmer loses his pigs, and a fow grown hogs die of cholera. Chicken cholera is quite prevalent.

KANSAS.

Allen.-Stoek has generally been healthy in this county. I know of some 5 head of fine steers, worth $\$ 300$, that died of Texas fever. A few eattle were also reported to have died after being tmrned unto stock fields. I think they died for want of sufficient water.

Barbour. - The horses in this eomty are Texas animals, and die principally from eating Loco, a poisonons weed. They also die of iteh and other skin liseases. A great many cattle have died; perhaps the vahe of those lost in the connty will aggregate 520,000. They lave to get their living on the range, and during a severe winter many die from exposure. The same may be said of shcep, of which there is a large number in this eomity.

Burton. - Stock is in good health and condition in this connty. Oceasionally an animal is lost hy accident, but one seldom dies of disease.

Broun.-The comty assessors make the following retmrns as to the value of animals lost in this conuty the past year from all eanses, viz: Horses, $\$ 9,900$; cattle, $\$ 8, \$ 80 ; \operatorname{logss,~} \$ 10,995$; sheep, $\$ 345 ;$ mules, $\$ 1,125$.

fiutler.-This county contains a large number of cattle, hogs, aud sheep, bnt they bave been measurably free from disease during the year. Porhaps 50 head of eattle would cover all the loss worthy of recording. 
Choroke.-Texas fever prevailed to a limited extent among some lierds of cattle in this comty, but the valne of the animals lost by the disease would not exceed \$2,000. All classes of animals are in good health, ant the losses hate been romparatively small.

Colfey.-With the exception of an ontbreak of 'Texas fever' anong cattle in the sontheastern portion of this comty, all classes of tomestic animals liave been free from contagious diseases during the past year. The mortality among cattle reached letween 3,000 and 4,000 head.

Crauford.-So far as I an alle to learn, all kinds of farm animals are healthy amb doing well. Crain and grass are loth abumlant. Some fowls have died with roupe and eholera.

Decatur.-Pink-eye is the prevailing disease among horses, ant black-leg anomg cattle. A great many sheep have died from disease and other canses.

Dickinson.-The value of the losses of domest ic animals the past year in this comnty from all canses aggregate as follows: Iorses, 815,675 ; cattle, $\$ 9,-60$; $1008,85,170$; slieep, s547.

Honiphan.-In the early part of the season quite a number of cattle diecl. The

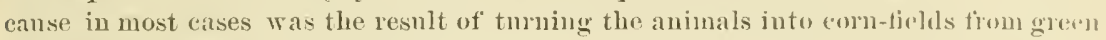
pastures, or into yards where they were fed on husks. So far as I lave been able tu learm, alont 100 head died, mostly feeding steers.

Ellis.-A great mans of omr horses and mules have been attacker with gleet or farcy, so called by many, aud by other's pronounced glanders. They have invalriahly dicd where not killed. A great wany deaths have oceurred among calves and yearlings from hlack-leg. As a preventive we give salt, sulphur, saltpeter, and eoplperas in the proportion of 1 bushel salt, 4 pounds smlphur, $\frac{1}{2}$ ponmil saltpeter, and 1 ponnd copperas; mix thoronghly, and place in tronghs where the animals can have free access to it. Some scab exists among sheep.

Elk:- The aggregate value of farm animals lost in this eombtelnring the past year is given as follows: Horses, $\$ 8,440$; cattle, $\$ 9,360$; hogs, $\$ 14,1>3$; sheel, $81,37-$. Seventy-eight sheep were killed by ilogs.

Greentrood. - I estimate the value of the losses among domestic animals in this comits for the past year from all causes as follows: Horses, \$10,000; eattle, \$10, 100 ; hogr, 58,000 ; sheep, s1,250.

Harper:-Onr losses among rattle trom Texas fever alone has been at least $\$ 15,000$. Myown opinion is that the estimate is too low. Partiesnaturally hesitafo toadmit their full losses. Black-leg among young stock has caused eonsiderable loss. Over onehalf of the sheep of the county are affected with seah. The muner in the connty is perhaps over 30,000 . Nearly every flock owner dips his sheep thoronghly after shearing, yet many flocks are again infected by introdneing diseased bneks among them. Have not heard of a sick hog in the eomry the past season.

Harrey.-Stock of all kinds doing well at present. Cattle have died from exprosme and accidents, and some calves of black-leg. A tew hogs have died of the manal disrases, and some pigs from exposure. A few lambs have also diend fom exposme, and a gleat many sheep of seal.

Johnson.-The varions diseases affecting fam animals are hard to determine, but the value of the losses in this rounty may he stated as tollows: Horses, si, - for: eat-

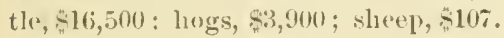

Labette.-I fiul it diffienlt to determine the value of animals lest ly disease during tho year, but 1 think the following a very fair estimate, viz: Itorses, sl6, 200 ; cattle,

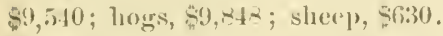

Lane.-The puncipal disease that prevailed among our cattle the past spason was

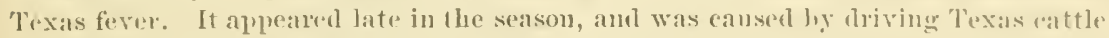
throngh the eomty. Scal, is prevailing to a considerable extent among sherele, of which a gool many die. Sheep and eattle raising is the funcipal industry of this eounty. 
Lincolu. - Some horses have died of distemper or pink-rye, and a good many young cattle of black-les. Some older animils have died of dry murrain. A report recently recrived from the morthwestern section of the connty states that a great mans eattlo have died there within the past few days of an mknown disease. A disease confined to young pigs in the entral prat of the eonnty has been quite fatal. I lost 27 in two hays, and another man 15 in the same length of time. Some called the clisease quinsy, but I don't think it was.

Meade.-Ahn' 500 horses and mules died in this conuty the past year of pink-eye, and perhaps 900 head of eattle hy disease, old age, accident, \&c. There are about 100,000 sheep in the comnty, of which 25 per cent. generally die of scab.

Montgomery.-Xo rpilemie has prevaled among any class of aniuals iu this comuty, and the following losses lave been caused by the ordinary maladies to which domestic animals are subjece, viz: Horses, $\$ 15,500$; cattle, $\$ 15,000$; hogs, $\$ 12,000$; sheep, $\$ 6,500$. Chicken cholera lias prevailed to an alaming extent in some localities.

Neosho.-No epiclemic clisease has prevailed among onr borses. Calves and yearlings have been afilieted to some extent with anthrax, or black-leg. There seems to be no remedy for this disease. About all those that are attacked die, and are generaly dead hefore they are known to he sick. A great many pigs muler six months old have died. Olel aud fat bogrs are seldom attacked by disease. Fowl cholera prevails to a considerable extent.

Osborne.-Horses have been exempt fiom any special epiclemic. Black-log has prevailed and proved ruite fatal to cattle in some localities. There has been no epidemic amoug hogs. Scals among sheep prevails, but not to as great an extent as fornerly. Black-leg among cattle is the chief treat among stockmen and farmers.

Ottana.--I hear of a flock of Mexican or grade Merino sheep, composed of abont 900 hearl, all of which are afflicted with scah. No other class of animals in this comnty seems to be afflicted with contagions diseases.

Punnee.--The only contagions disease I have to record occurred during the past season among a herd of cattle in this comnty. The disease was Texas or Sonthern ferer. The animals were placed in charge of a veterinary surgeon. who promptly quarantined the herd aud prevented the spread of the disease.

I'hillips.-Pnenmonia or lung fever has cansed the death of a few horses in this connt?. The disease known as black-leg has proved very fatal to cattle. Animals one year old and younger suffer most. At least one-half of those attacked die. The only disease affecting sleep is scah. Great complaint prevails as to the disease known as cholera among chickens.

Rawlins. - There have been a few cases of Texas itch among horses, a disease which is very effectively treated with merenrial ointment. There have been a few cases of black-leg among cattle, and one case of murrain. The opinion prevails among the owners of cattle that the Texas trail hrings ferer with it, as the losses generally oceur within the near vicinity of this trail. Cattle along the trail are infested with lice, or ticks, as they are termud iy some. But they look like common lice, with the exception of being larger and having gras lieads. Shere are afticted with the scab, and are treaterl by dipping in tohacen wash.

lieno. - Glanders is andting pretty well distrihuted over this county, and many borses dio evers year of it. Some cholera prevals among hogs More eare is being taken of stock than formerle. Farmers are bewinning to liam that more feed and better shelter, with less loss, is the luetter may.

Rooks. - No disease of a contagions character among horses. Black-leg is about tho only fatal disease among cattle. Ilogs snifer more in hot weather fhan during the

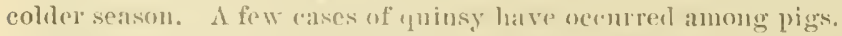

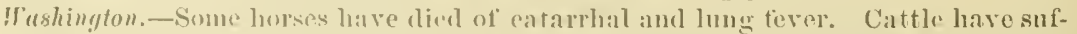
fered in a consideral)le extent with blalek-legg, and hogs with guinsy and eatarhal troubles. The great loss anong pigs was cansed ly flus sows having suffired with these diseases. The young anhuals had not vitality enough to live. 
Wyandotte.-The only disease of a contagions character prevailing among any class of farm animals is seab anoug sheep. The disease known as cholera still prevails among fowls.

\section{KENTUCKY.}

Allen.-There have been a few cases of cholera among hogs in some localities, and some chicken cholera, but the losses have been light.

Breckinridge.-With the exception of cholera among hogs, there has been no disease of consequence prevalent among any class of animals in the county. The cholera has been very fatal to hogs, but as yet the discase is confined to one locality.

Boyle.-Pink-eye has been quite prevalent, and several fine horses and mares havo died from the effects of the disease. Hog cholera aud Texas fever of cattle destroyed a good many of onr animals in 1882, but the rliseases have not made their appearance this year.

Calloway. - No disease among horses or cattle. Hogs are dying at a rapid rate in one locality in this county. The disease does not seem to be like the cholera in all respects. The animals droop, refuse to eat, have very sore nose, the bclly is tncked up, and the excrement harl. They die in from 3 to 10 days. About 70 per cent. die. The value of the loss up to this time is $\$ 17,860$.

Carter.-Horses and cattle are healthy. A considerable number of hogs died in 1882, and also in this year, bnt I am unable to give the number or value of the losses. Cholera is quite prevalent among fowls.

Clinton.-With the exception of a severe type of epizootic distemper among horses all classes of farm animals are free from disease. I have heard of no deaths from the disease.

Crittenden.-Cattle have died of hollow-horn, bogs of cholera, sheep of rot, and chickens of cholera. The losses have not been very heavy in either class.

Cumberland.-Hogs valned at $\$ 3,000$ have died of thumps in this county the past year. The greatest fatality has been among young hogs. Chicken cholera has prevailed all over the county, and has been quite serious in some localities.

Fayette.-Some horses, cattle, and sheep have died from accidental causes, but there has been no epidemic among either class of these animals. Hogs and fowls have died to some extent from cholera, but the disease is certainly less prevalent than a few years ago.

Grayson.-No fatal diseases have prevailed among horses, eattle, or sheep. Great fatality has been caused among pigs in some localities by a disease known as measles.

Green.-Cattle and shecp suffer from the various diseases to which snch animals are incident. Hogs and poultry suffer principally from the disease knowu as cholera. Hogs valned at $\$ 10,920$ have becn lost during the year, and chickens valued at perhaps $\$ 1,152$.

Greenup.-Comparatively little disease among farm stock in this county.

Hancock.-No disease anong farm animals at present, though at this season of the year such disorders generally appear.

Harlan.-All kinds of farm animals have been comparatively healthy for the past sear.

Hopkins.-All kinds of animals and fowls have bcen exceedingly healthy the past jear. I think this is due in a great measure to the observance of the advice given by the veterinary surgeons appointed by the Government to investigato the diseases of animals. I have largely distribnted these reports, and have been greatly benefited myself by the information they contain. I have not lost a hog by cholera sinco reading these reports.

Jessaminc.-Some hog cholera has prevailed in this county, but there las beeu no disease among otlıer classes of animals the past year.

Johnson. - In the spring cattie in this seetion aro sulject to murrain, which generally proves fatal. Hog tholera is very tronblesome to farmers and log-raisers at all seasons of the year. Sheep are affected with rot to some extent.

5751 1) $\mathrm{A}-21$ 
Tienton.-A great many cattle die every season of dry murrain. There have been some losses by hog cholera.

Finox.-IIogs died thronghout this county the past year of cholera. Other farm animals have generally been liealthy.

Laurence.-Farm animals have been unusually healthy the past year. Cholera has prevailed to some extent among fowls, but it is impossible to give the number that have died.

Letcher.-No disease of cousequence has prevailed among farm animals in this comuty. A few hogrs and fowls have died of the so-called eholera.

Levis.-In some localities whole herels of hogs have been swept away by cholera. There have been some losses among other classes of animals, but they have not been hears.

Lincoln.-I presume that 10 per cent. of all our hogs annually die of cholera. Great numbers of fowls also die annually of a like disease.

Madison.-An oceasional case of pink-eye among horses is reported. Cholera prevails among swine and poultry. When cholera attacks hogs (and it has been more prevalent than usual), it affeets most of the herds, and 50 per cent. or more die.

Martin.-Hog eholera is the most lestructive stock disease known here. Other classes of animals are liealthy.

McLean.-The loss of hogs in this county has not been so great the past year as usual. Just now I hear of no eomplaint. The disease did its work during the months of July and Angust. A few eases of pink-eye have oceurred among horses.

Menifee.-The disease prevailing among hogs here seems to be unknown. Some call it cholera and others prononnee it sore throat, eansed by the fanlty mast.

Mercer.-A large number of all classes of farm animals have been lost by the varions diseases to which they are subject during the past jear. I will state that more sheep were killed by dogs than wero lost by disease.

Monroe.-No epidemic among either horses, eattle, or sheep. Ilog cholera prevails in some localities in the county, as does also chicken cholera.

Montgomcry. - No disease of an the past year or in $188 \%$.

Muhlenburg.-After consnltation with farmers in different parts of the connty, I find that all classes of farm animals are in a healthy condition. No disease in 1882.

Nicholas. - Horses and eattle are healthy. Some little eholera among hogs, but not much, say 2 per cent. of disease, of which 1 per cent. die. Cholera prevails to some extent among fowls.

Owen.- We have no disease among our farpi stock worthy of note.

Owsley.-No disease among stock. Something like cholera or roupe prevails among fowls. About all that are attacked by the disease die. No remedy appears to do any good. The fowls frequently drop off the roost dead.

Pike-Horses are aftlieted with distemper, bots, and eolie, eattle with murrain, quinsy, and sore throat, logs with quinsy and oceasionally cholera, and fowls with cholera.

Robertson. - I have no general or fatal disease to report as affecting farm animals in this county.

Liock Castle.-No prevailing disease among horses, eattle, or sheep. Some log eholera prevails: perhaps 2 per eent. of the animals in the connty have been attacked.

fiussell.-Hogs have been afrected in a few localities by swine-plagne. A like disease has been more general among fowls.

Scott.-We have no prevailing disease among our farm animals except eholera among hogs. Fowls are also aflicted with a similar disease.

Shclby. - Hogs valued at between $\$ 7,000$ and $\$ 8,000$ have been lust by eholera during the year. A number of fowls have died of the same disease.

Taylor. - Wo liave no losses to report among our farmı stock by disease of a contagious cliaracter. 
Trimble.-Our county is unusually healthy for farm animals. Never any disease among ans class except an occasional case of hog cholera.

Inion.--Horse's and eattle hare beeu unusually healthy. A great loss has beeu oceasioned by hog cholera. More animals have been affected with the disease, and it is thought that more died, this snmmer than during the six years preeeding. The value of the losses may be set down at $\$ 50,000$ or $\$ 60,000$. No remedy has been tound for the disease. A few sheep liave died of rot.

Tashington.-Horses and wules have suffered from piuk-cye. Cattle have been visited by an unknown epidewic. Cholera las been more fatal to hogs than usual. Sheep have suffered from various calses and ailments.

Thitley.-The only loss anoug farm animals in this county has been anong hogs. I think $\$ 10,000$ would cover the valne of these losses. The disease affecting both hogs and fowls is known here as cholera.

\section{LOUISIANA.}

Bienrille.-None bnt ordinary and common diseases have affected farm stock in this county the past year.

Bossicr.-Horses, mules, eattle, sheep, and hogs lave been extremely healthy this fall, aud all are doing well.

Catahouln.-Value of horses lost the past year, \$2,334.50; value of cattle lost, $\$ 3,727.50$. Hogs have continned very healthy. A few sheep have died of pleurisy and puemonia.

Franklin.-Horses have been aftlicted with glanders, staggers, charbon, and bighead ; cattle with eliarbon, big-head, and hoilow-horn; hogs with staggers, and sheep witb rot.

Ibcrille.-All kiuds of farm animals have been healthy during the year. There has been some fowl cholera.

Juchson.-Less disease among horses this year than for twenty-five years past. Cholera and mange bave been fatal to a great many hogs. Cholera has also been destructive to fowls.

La Fourche.-No epidemic disease has prevailed among any class of our animals the past year.

Livingston.-The following are perhaps correct estimates of the ralne of farm auimals lost in this county the past year, viz: Horses, $\$ 170$; eattle, $\$ 1,500$; hogs, $\$ 2,000$; sheep, 4750.

Matison.-We have hut few hogs, and no malarly among them. He have a great many fowls and plenty of chicken eholera.

Morehonse.-All kinds of animals are healthy. Our soil is destitnte of gravel, and we have to grind up old crockery, \&c., for our fowls. When this is neglecterl eloolera appears among tlem and kills from 10 to 20 per cent. of the whole number.

Richlund.-Much stock was lost hy the overflow in this comnty, and many cattle were afterward forwarded to Texas, so that we have hut fow of this class of animals left. No disease of conseruence.

Saint Helenu.-During October and Novenber a disease prevaled anong our hog which was said to he cholera. In the higher piney woods portion of the parish the disease killed many hogs-as near as I have been able to learn, full 50 per cent.

suiut Marys.-We have but little stock in this county, and what we have is in a remarkably healtly condition.

Saint Tammany.- - None but common diseases lave visited any elass of farm animals the last year, and tho losses liave been very light.

I"ernon.-With the exception of sheep, all elasses of donestic animals liave remained liealthy.

IIest Carroll. - Wo have lost quite a mumber of all chasses of farm animals during the year ly disease. The diseases, however, have not heen of a contagions character. 
MAINE.

Androscoggin.--Horses, eattle, hogs, and sheep are in about the same condition as to liealth as last year.

Cumberland.-Domestic animals have been very free from epidemic diseases. Pinkeye has prevailed to some extent anong horses, bnt no eases have proved fatal. An nnknown disease prevailed among horses to some extent last fall, of which several died. Some attributed it to poison, and others thought it a congestive fever. The horse wonld bo sudhenly attacked, lose the use of his hind legs, as well as all power to swallow. If on the road, in haruess, would fall without warning, never to rise again.

Franlin.--An oceasional case of pink-eye has been reported among our horses, but no deaths havo occurred from it. No other diseases among farm aninals.

Kenucbec.-pink-eye and epizooty in a mild form have prevailed among horses. Cattle, hogs, and sheep are healthy.

Oxford. $-\Lambda$ ll kinds of domestie animals are reported healthy in this connty.

Penobscot.-All kinds of farm animals are healthy. There has been no special disease among our eattle during the past twenty jears.

Somcrset.-Horses are reported to have had lnng troubles. Some eows coming in hare been sick. Sheep have bad the foot-rot, but the percentage of loss to the whole number has been exeedingly small. There have been no epidemie or contagions discases.

Washiugton.-With the exception of pink-eye among horses, with no fatal results, I can hear of the prevalence of no disease among the farm stock of this connty.

Fork.-The domestic animals of this connty have been free from all kinds of epidemic diseases during the past year.

\section{MARYLAND.}

Anne Arundel.-There has been no epidemic among farm stock in any part of the connty, and losses have only been snch as usually occur from aecident or to such acute attacks as animals are sometimes subject.

Baltimore.-My district lias been aftlicted by a disease among fattening hogs, which spread to others in this and adjoining districts. I myself lost all but one sow, some 20 head, and my neighbors on each side of me for a mile lost all they harl. The disease was so rapid in its results (death) that we were not able to make much use of remedies, or tahe steps to prevent its spread. The symptoms were so different, or were deseriberl so differently, that I am nnable to give an acconnt that wonld cover any but my own cases, althongh I am sure that what cansed my loss was the same as that which cansed the loss of my neighbors. My pigs commenced to mope; refused food; jaws seemed to lock; some had eough, and were dead in a day or two, except in one or two instances in which they limper and broke ont into sores all over the borly. The first one attacked recovered, which she did withont having been given anything in the shape of medicine. The neighbors doctored and gave medicine, but lost their animals just as I did. I could not bring myself to use all the remedies recommended, because I conld not tell just what ailed the hogs, and preferred to trust to nature and good food and nursing, rather than be donbtful after whether I or the disease killed them. I know the loss must have been nuch leavier than I have represented $(\$ 2,500)$, as I have just learned from one coming in of additional cases in varions localities, enough to raise my estimate $\$ 500$.

Calvert.-This has been an unusnally healthy year for all kinds of farm animals in this connty. There have been no deaths that I can hear of except such as are incident to aecident and old age.

Frederick.-There has been no epirlemic disease among either horses, eattle, hogs, sheep, or fowls; hence the losses have been occasioned by accident or old age. 
Garrett.-I do not hear of the prevalence of ayy disease among horses, cattle, or sheep. Hog eholera prevails to some extent, but not so generally as last year.

Howard. - We take good eare of our stock by stabling and sheltering, as a rule; hence we rarely have destructive diseases amoug our farm animals.

Prince George's. - l have heard of no epidemic among farm animals of any kind in onr connty. A neighbor of mine bought a yoke of youmg oxen, large, fuc animals, which cost him \$100; a month or so ago they were taken with weakness across the loins, aud conld not raise npon their hind legs or feet. They lingered for three weeks and both died. The State veterinarian pronounced the disease Texas fever.

Somerset.-In some parts of the comty the swine plagne is now prevailing quite seriously, but the area orer which the disease extends is not large. I have hearl of no disease among fowls this year.

Talbot. - We have, no disease among stock or ponltry. Occasionally a few hogs die, but the cause can generally he traced to drinking impure water or eating poisonous matter. All animals are in remarkably good health at this time.

Irashington.-The value of the losses anong farm aninuls in this county the past year mas be estimated as follows: Horses, $\$ 4,000$; cattle, $\$ 2,500 ;$ hogs, $\$ 1,200$; sheep, $\$ 600 ;$ and fowls, $\$ 150$.

Torcester.-During the eurrent year there have been no prevailing diseases among any elass of farm animals, and the sporadic cases of siekness and death have beeu so rare and seattered as to render it impossible to give reliable data.

\section{MASSACHUSETTS.}

Berhshive.-Few horkes have died from the disease known as pink-eye. Hogs have suffered to a considerable extent from eholera. I shonld think $\$ 2,000$ worth have been lost by the discase. Cattle, sheep, and fowls are in comparative good health.

Dukcs. - No epidemic disease has prevailed among domestic animals in this county the current year.

Franklin,-Among lorses, eattle, and hogs in this connty the losses have not been over 1 per cent. by disease the past sear. There has, perhaps, been a loss of 3 per cent. anoug sheep.

Plymouth.-An animal very rarely dies of disease in this county. Much of this is dne to the kint provision made for all kinds of domestic animals.

\section{MICIHGAN.}

Allegan.-Our firm animals are rarely attacked by fatal diseases. Occasionally a horse contracts cold which settles on his lungs aud he dies. Cattle, hogs, and slueep are healthr.

Bicnzic.-To diseases of an epidemic or eontagions character secm to have visited the farm stock of this county the past sear.

Calhoun.-Horses bave suffered from a mild type of pink-eye, which has seldom proved fatal. Several deaths have oceured from colic, intlanmation of the lungs, and other diseases conmon to horses. There bas heen no epielenic anong houg, eattle, or sheep during the year.

C'uss.-There hive been several fatal cases of pink-eye among tho horses in this connty. It seens to have prevailed throughont the connty. Mlilk fever has been tho most destrnetive disease that has prevailed anong eattle. There lave been some lmug troulules, but no cholera, among hogs. Some loss of slicep from diseases in the heal, bnt more from lung aflections cansed by colds.

Charleroix.-I have heard of the prevalence of no disease of any kind among the stock in this county the current year.

Clare.-So far as I can learn, there seems to have been no disease of consequence. among farm animals in this connty during tho yart.

Crawford.-Eieght horses hatre dierl during the year with what was supposed to be pink-eye. No other clomestic animals have suflered to any extent. 
Delta.-I can liear of no disease of a contagions nature prevailing among any class of farm animals in this county.

Gcnesee.-No epidemic diseases have prevailed among stock in this connty. The following is perhaps a fair estimate of the losses among all classes of animals for the year, the result of discase, old age, accilent, de., viz: Horses, $\$ 3,500$; cattle, $\$ 1,250$; hogs, $\$ 1,125$; sheep), $\$ 1,875$; fowls, $\$ 1,000$.

Glaclwin.-No destructive disease of any character has visited any class of domestic animals in this connty the past year.

Huron.-No epidemic has visited either our horses, cattle, sheep, or hogs during the past year. I have not even heart of a casc of glanders.

Ingham.-The following is probably a fair estimate of the value of the losses among farm animals in this county for the current year: Horses, $\$ 14,700$; cattle, $\$ 7,000$; hogs, $\$ 2,250$; slieep, $\$ 1,660$; and fowls, $\$ 1,000$.

Ionia.- We have har no disease of consequence that I can hear of amoug either horses, cattle, hogs, or sheep lluring the year.

Jackson.-There has been no disease of any kind among animals in this connty, and the deaths have only been those arising from natural causes, aud have been rather under than over the usual annual average.

Lialamazo0--No contagious or epidemic disease among animals in this county.

Lapeer:-Farm animals go into winter quarters in first-rate condition. No diseaso of a gencral character prevalent.

Lcelenaw.-All kinds of farm animals are very healthy. Horses have suffered to some extent from epizooty, and a few cattle have died of dry murrain. A few sheep have clied of pueumonia.

Liringston.-It seems impossible to get the information you desire. However, there has been no destructive disease of any kind among our domestic animals during the past year.

Hacomb. - A good many young horses annually die in this connty. There has been no disease among eattlo and hogs. Sheep seldom recover when attacked by disease. Many fowls die of cholera. Some farmers have lost their entire flocks by the disease.

llanitou.-No disease worthy of mention among farm stock. A great many fowls have been lost by disease.

Marruette.-The only disease among horses is a swelling of the hind legs. They do not die of it, bnt when they get very bad they are shot, as the swelling gets so large they become useless. I have no other discases to report.

Mecosta.-I can safely say that there has been no epidemic among any class of farm animals in this comby during the present year.

Occana.-There has been no epidemic disease among the farm animals of this county during the past season.

Osceola. - No diseases among farm stock in this county.

Oscoda.- Very few animals in this county, ant, of course, but little disease. I do not know of a sheep in the county.

Ottura.-Bnt few farm animals are ever affected with disease in ihis county, and only those that are improperly treated or exposed to inclement weatler.

Presune Iste. - I have no case of lisease or death from contagions diseases among farm stock to report for this county.

Seginaw.-All kinds of domestic animals-horses, eattle, logs, and sheep-in this connty are in a very lealthy comdition.

Saint Joseph.-I am unable to get accurate information in regard to losses of farm animals in this connty, but I am satistied thoy are very small.

Tuscolt.-The only losses that have occurred anong our farm animals lave been caused by old age, aceirlent, dec.

Tan liuren.-No prevailing risease among animals in this county that I know of, except among breeding sows. Camot say how many animals have tlied; perhaps thirty heal in the comnty. 
Washtenaw.-Horses, eattle, sheep, and hogs are all free from contagious and infections diseases. Stock of every kind in this county is in good condition.

Trayne.-I do not know of the loss of any stock in this county the past year, except from natural causes.

\section{MINNESOTA.}

Becker.-As far as I ean learn, the farm animals of this connty have been quite free from disease the past year. In cases where distemper, lung fever, and influenza have occurred they have generally been eaused either by the carelessuess of exposing animals to sudden changes of temperature from a heated state to a coll or ehilled one, or from being confined in darn stables.

Big Stone.-There are no diseases prevailing among farm stock here. A fow horses have been killed by overwork.

Blue Earth.-Animals of all kinds are free from disease.

Brown.-A few farm animals have been lost in this connty by disease, more cattle perhaps than animals of any other class.

Carer. - There has been no mortality from disease anong farm animals in this county for the past ten years. Fowls are aflicted with cholera.

Chisago.-No disease of any kind is afflicting our stock, for which we are duly thankful.

Chippeua.-There has been no disease amoug horses, hogs, or sheep. Some few cattle have died of black-leg, but not so many as in former years.

Dakota.-No disease among our domestic animals.

Lodge.-There have been a few deaths among horses from pink-eye, and from blackleg anong cattle. A few hogs have died. During the past twenty-eight years the farm animals of this connty have not suffered from any fatal epidemic disease.

Fillmore.-There have been some losses of young eattle from the disease kuown as black-leg. A few hogs have died of a disease pronouneed cholera, but I have not seen a case of real hog eholera in the county. There have been losses among fowls, but no more than usual.

Honston.-Pink-eye has prevailed to some extent among horses, but it has not often been fatal. No disease this year among cattle or hogs. Fowl cholera has prevailed to a limited extent. This disease seems to be disappearing.

Jackson.-No contagious or infections disease is prevailing among any class of domestic animals or fowls. A few young eattle dred during the season from black-leg.

Kanabec.-I liave no losses worth recording among the farm animals of this county for the past year.

Lac-Qui-Parle.-Stock of all kinds perfectly healthy. Few animals die except from old age or mismanarement in feeding and watering.

Lake. -There are but few domestic animals of any kind in this county. The only losses that occur are among drauglit horses, eaused by overwork, carelessness, \&c.

Lc Sueur.-A few cases of epizooty have occurred among horses. Cattle, hogs, and sheep aro in good health and condition.

Lowndes.-The losses cansed by disease anong the farm animals of this county the past year are very small. No epirlemic disease has provailed.

McLeod.-A few eases of pink-eye have oceurred among horses, and black-log bas prevailed to some extent among eattle. Young animals of the are of one and two years have suffered most. It would be a great alvantago to stoek-raisers if the eanse and a remedy for this disease could be discovered. Duriug someseasons a great many young eattle dio of it.

Martin.-Thore has been no disease among stoek in this eonnty this year-that is, not suflicient to bu worthy of note. Some cattle have died of black-leg.

Meeker.-As far as I can learn-and I have had good facilities for obtaining information-thero has been no loss of stock from disease worthy of mention during tho year. 
Morrison - But very few farm animals have died of disease during the past year. No epidemic of any kind has proviled among stock.

Nicollet.-No destructive disease to reeord among any class of farm animals in this eominty.

Nobles.-Farm animals of every class have always been very liealthy. The value of the losses for the past year are therefore not worth recording.

Norman.-No epiclemic disease has prevailed among any elass of our farm stoek the past year. The only losses that have oceurred were cansed by want of proper eare in feeding and watering animals.

OTmsted.-Diseases among firm animals are so rare, and the fatality so small, that the losses are not consillered worthy of recording.

Pine.-After careful inquiry I cannot learn that there has been any particular disease prevalent among the domestie animals of this connty during the enrrent jear. This is not a stoek-raising connty in any sense.

Pope-Pink-eye has prevailed more or less among horses. One man lost six animals. Cattle have been affected with black-leg, and hogs with cholera. Some eases of rot have ocenred among sheep.

Redwood. - The past year has been a very favorable one for farm animals. I eannot learn of a sufficient number of losses to make a basis for any sort of a report.

Rice.-No epidemic diseases have been noted among farm animals the past year. Fowls have been cliseased, and the losse s have been quite heavy. Considerable interest is being manifested in the raising of improved breeds, especially horses of larger types. An interest is also being awakened in the dairy industry, for whieh this county seems well adapter.

Scott.-The only losses that have ocenred among farm animals in this eomnty the past year have been the result of natnral causes, aeeidents, \&e.

Sherburne.-Oecasionally a horse dies from old age, a eow from milk fover, and a calf from scouring. The loss will not amonnt to 1 per eent. per annum to any elass of animals.

Sibley.-Pink-eye has prevailed among horses and black-leg among cattle. I presume cattle worth $\$ 1,000$ have died dnring the year of the latter disease.

Stcarns. - Nothing but the usual horse ristemper has appeared amoug any class of our farm stock during the past year.

Steele.-No opidemie among farm animals the past year. Losses among all elasses have been eonfined to very young or very old animals, thus greatly reducing the average value of those lost.

Stevens.-I have no losses among farm animals from disease of sufficient maguitnde to report.

Traverse.-There has been no disease anong onr stoek which has assumed an epidemie form. A few animals have died of disease, but the percentage has been small.

Watonuan.-No disease amoug horses. Oeeasionally one dies from abuse, old age, or natural canse. The only disease among cattle has been an oecasional ease of blackleg. Young calves suffer most. One per eent. will cover the losses from this disease. There has been no disease among hogs or sheep.

Tinona.-All classes of farm animals have remained free from eontagions or epidemie diseases during the past year.

Wright.-There has been no speeial disease among onr farm animals during the year. A great many sheep have been killed by dogs and wolves. Many farmers have been compelled to give up trying to rear this elass of stock.

\section{MISSISSII'PI.}

Alcorn.-Very fow deatls have occurred among farm animals in this eounty from discase. The losses among eaeh elass huve been small, and generally from natural causes. 
Amite.-Among horses, mules, and eattle we have had no prerailing disease this year nor the year previous worth mentioning. Hogs, sheep, and fowls suffered to some extent early in the spring, during the wet season.

Benton.-There has been vers little disease of an epidemic eharacter amoug onr farm auimals the past year; hence onr losses have been small.

Calhoun.-Wo disease amoug furm stock the past year.

Carroll.-No epidemic has prevailed among the furu stock of this county, and the losses for the past year have been nominal.

Choctaw.-The farm animals of this conty have been measurably free from disease the past year. There have been a few cases of charbon among eattle and cholera anous hogs.

Copiah.-There has been no disease among our farm animals. Chicken cholera has bzen widespread and destructive. Many persons liave lost almost their entire flocks.

Covington.-The only disease of consequence that has visited onr farm animals is that of cholera, which has prevailed to some extent among hogs. The losses have been light.

Greene.-The only loss of farm animals in this connty has been among sheep. A great many of these animals have been destroyed by dogs, in addition to those which have died of disease.

Harrison.-No losses from disease among onr farn stock for the past year.

Hinds.-No serious disease has oecurred among any class of our farm animals. A number of eattle died during the winter from exposure to inclement weather. Some winters our losses are very heavs for lack of adequate protection to stoek.

Jasper.-There has been some distemper among horses. Hogs have suffered with cholera, and sheep with a disease called sore-hearl.

Marshall. - Horses have died of blind-staggers, piuk-eye, and eolie, but the majority of poverty. Cattle have died of murrain, and a great many also of poverty. Hogs worth, perhaps, $\$ \tau, 000$ or $\$ 5,000$ have died of a disease denominated swine fever or hog cholera. Sheep are afflicted with rot. Large numbers of fowls have died of cholera, as described by veteriuary reports.

Newton.-There has been no epidemic of any kind among our farm animals during the year. Even fowl eholera has not been so tronblesome as formerly.

Oktibbeha. - Some little cholera has prevailed among hogs, and oceasionally there has been a case of blind-staggers among horses, but nothing like an epidemic has oceurred among any elass.

Simpson.-Cholera has swept ofi about one-half the hogs in this county; ralne, over $\$ 12,000$. A new disease prevailed amoug cattle, which destroyed a great many head. They lived only about twenty-four hours after being attacked.

Tippah.-There have been no losses from disease among the farm animals of this eounty worthy of reporting.

Tishomingo. - The past year has been a very favorable one for farm animals in this county. No disease of eonsequenee has visited any elass.

Union.-Hog cholera has prevailed in the northeast corner of the county, but it has not been very destruetive.

Warren.-Texas fever has prevailed among our eattle. All those attacked died. Nine of wy own cattle died within three days. Native cattlo were not affected-only the imported animals seemed to be susceptible. Sheep are allieted witl flukes. Thoso afticted with this disease will all die if not physicked.

Waync.-1)istemper has occurred among both horses and sheep, murrain among cattle, and eholera among logs and fowls.

Minston.- Some fifteen or sixteen horses have died this year from distemper. No other disease of a destructive character has prevaled among stock. 


\section{MISSOURI.}

Adair. - No disease of a destruetive nature has occurred among farm animals or fowls in this county during the year.

Barry.-Distemper has prevailed to some extent among horses, and a few cases have proved fatal. About 20 per eent. of onr hogs have been affected with cholera and about 10 per cent, of those affeeted have died. Cholera also prevails among fowls.

Bollinger. - No destruetive diseases havo visited any elass of our farm animals during the past year. They are healthy withont exception.

Calduell.-During the past year the losses cansed by disease among farm animals in this county have been eomparatively small. No disease of a very maliguant character has prevailed.

Carter.-All four classes of furm aninals have been exceedingly healthy throughout this county the past rear.

Cedur. - A few cases of distemper and glanders have occurred among horses. Cholera prevails among hogs, and about half the number attacked die. Dogs destroy a great many sheep. Cholera prevails to a wide extent among fowls, and about all that are attacked die.

Crawford.-We have had no fital diseases among our stoek the present year.

Dallas. - The deaths from disease among our farm animals have been so few that I am unable to even approximate the value of the losses.

Daviess. - There has been no destructive disease among our domestic auimals. Cholera has prevailed to sowe extent among fowls.

Dent.-I have heard of no losses among farm animals during the present year.

Douglas.-Our horses are healthy. Blaek-leg has oecurred among cattle, and hogs have beeu aftlicted with cholera.

Franklin.-The principal eanse of disease among our horses is over-feeding with corn or oats, and then too much water and over-driving. In winter cattle are lost from neglect, both as to feed, water, and shelter. Hogs are lost by improper shelter and too much eorn-in other worls, a lack of a sufficient variety of food and clear water to drink.

Gaseonade.-No diseases of a fatal character have prevailed among any class of farm anim

Greene.-So far as I can learn, there is no prevailing disease among domestic animals. We occasionally have an epidemie among logs and poultry, but just now not any.

Harrison.-Farm animals in this county the past year have been unusually healthy. To epidemic disease has appeared among them.

Hickory. - We have had no hog cholera in this connty since 1875-'76.

Holt.-No epidemies exist among domestic animals in this county. The diseases that usnally affect horses and mules are the result of hard usage. The losses from rarious causes may be stated thus: 150 horses, $\$ \tau, 500 ; 50$ cattle, $\$ 1,500 ; 500$ hogs, $\$ 1,000 ; 30$ mules and asses, $\$ 2,250$.

Jcfferson.-But few diseases of a fatal character have visited onr farm animals the past year. The value of the losses may be thus given: Horses, $\$ 2,000$; cattle, $\$ 10,200$; hogs, $\$ 300$; sheep, $\$ 200$.

Iohnson. - In the northeastern part of the county consilerable cholera prevails among pigs and small shoates. Fully three-fourtlis of those attacked die. As a rule, farm aninals are healthy in this eounty.

Laelede.-We have no disease to amount to anything among either horses, eattle, hogrs, sheep, or fowls. A very limited number of cases of hog eholera have oceurred. Lawrence.-Several cases of Texas fever oecurred anong cattle in this eounty last summer. Ilog eholera previlils to a considerahle extent, but $I$ eannot give the value of tlie losses.

Lincoln.- We have had no contagious disease aung horses or cattle. Cholera has 
prevailed among both hogs and ehickens, and rot and scal, among sheep. The value of the losses among swine has been about $\$ 24,000$; anong sheep, $\$ 6,950$; and fowls, $\$ 2,000$ or $\$ 3,000$.

Limn.-We have had no disease among farm stock in this county the past year to amomint to anything.

Livingston.-No disease except among hogs and fowls. IIogs are more healthy than they have been in the past eight years. The losses this year will perhaps foot up $\$ 15,000$. The losses anong fowls have been quite heary; the value will perbaps reach $\$ 7,500$.

Macon.-There have been but fow fatal eases of disease among our farm animals the past year.

Madison.-About 3 per eent. of the logs of this connty have died during the year of disease. Two per eent. of the horses and one per cent. of the eattle have also died.

Miller.-A large number of hogs have died of eholera during the year. Other classes of animals have remained in good health.

Moniteut.-This is not only a remarkably healthy eounty for all kinds of live stock, but this has been an exceptionally healthy year, so much so that we consicler it proper to report no diseases or losses at all.

Monroe.-No fatal disease has prevailed to any considerable extent among the domes* tie animals and fowls in this comnty during the past year. A few eases of black-leg among ealves and eholera among hogs have ocenrred. Fowl cholera has also prevailed to a limited extent. This fatal disease among fowls can be controlled or prevented by the use of hyposulphite. Wo have fully tested it during the past two years. It is a valuable medieine.

New Madrid.-The total valuo of animals and fowls lost in this county by diseaso the past year is $\$ 18,641.87$. Ahout $\$ 16,000$ of this amount is attributable to diseases among hogs. Several cattle died of an unknown disease. The livers of those I cxamined were rotton.

Newton.-There liave been no losses of cousequence aunong our fam animals by disease the past year.

Nodacely.-Distemper of an epizootic eharacter has been quite fatal to horses in this county. Pink-eye and black-leg have visited our eattle, and eholera has been quite prevalent among hogs and fowls. The following estimates of om losses are given: Horses, $\$ 30,000$; eattle, $\$ 4,000 ;$ hogs, $\$ 20,000$; sheep, $\$ 1,500$; fowls, $\$ 2,000$.

Osage.-No disease of an epidemic elaracter has appeared among any class of farm stock exeept cholera or swine plague. I suppose hogs to the valne of $\$ 5,000$ have died of this disease tho past year.

Ozark:-There has been no epiclemic or fatal disease of any kind among our domestic animals during the year

Platte.-For the last year or two all kinds of animals in this county have been remarkably healthy. This is no donbt owing to the faet that farmers are taking better eare of their stock than in former years.

Pulusli.-Cattle are about the only farm animals that have been aftieted anring the past year. The disease known as black-leg has prevailed anong them, and a great many calves and yearlings have died.

I'utnum.-The following estimates of the valne of losses anong farm animals from all eauses are given for the enrrent year: IIorses, $\$ 25,000$; cattle, $\$ 62,500$; hougs, $\$ 10,000$; sheep, $\$ 2,500$; and fowls, $\$ 1,000$.

Randolph.-The value of animals lost in this county the past year from disease and natural causes is given as follows: Horses, 43,200 ; cattle, 10,$000 ;$ hogs, 85,700 ; sheep, $\$ 4,600$, and fowls, \$1,2:0. When a horse or cow is aflected with disease the owners endeavor to eure them, but with loggs, sheep, and fowls nothing is done.

Srint Charles. - IJogr holera has prevailed to some oxtent, and has poved very fital to the animals attacked. The value of the losses will reach $\$ 7,000$.

Saint Lonis.-IIave heard of six horses diseased with glanders, of whieh three died. 
IIave heard of lut one lot of hogs afilicted with disease. They have something like diarrhea or flux. Some fiftem or twenty of them died. Other animals are healthy.

Schuyler-Cattle have suffered with black-leg and hogs with cholera. Sheep are becoming badly affected with seal. Fowls have been afilicted with the nsual diseasecholer:.

Shelby. -Farm animals of all kinds are healthy. Fowls die every year of cholera and ronpe.

Stoddard.-The only loss I have to record among farm animals in this connty has been anong logs. The valne of the losses have been small. Will not exceed so, 000 .

Taney.-I can hear of no disease except black-leg among cattle. This has been quite provalent, and is generally fatal. The value of the losses from this disease will perhaps reach $\$ 1,000$.

Trmon.-No fatal epidemic disease has visited any elass of our farm animals during the year.

Waren,-The health of all classes of farm animals here was never better than now.

Wayne.-The value of the losses from disease among our farm animals during the past year is estimated as follows: 1 Iorses, $\$ 7,500$; cattle, $\$ 2,750$; hogs, $\$ 2,500 ;$ sheep, $\$ 1,300$; and fow'ls, \$2?5.

\section{NEBRASKA.}

Adams. - So far as $I$ have been able to sseertain, no disease of any consequence has prevailed among our farm animals during the past year.

Antelope.-So iusignificant have been the losses ly disease among domestic animals that I do not deem them worthy of report.

Boone.-Horses, cattle, hogs, and slieep are remarkably healthy-no disease of any kind. A horse dies necasionally of old age or accident.

Cass.-Cattle and hogs are the only classes of animals that have suffered with disease in this connty. Cattle have been aftlieted with black-leg and hogs with cholera and limg diseases.

Cedar.-The losses anong farm auimals in this comnty by discase the present year have been very light.

Dawson.-But few farm animals have been lost by disease in this conuty during the year.

Donglas.-Five or six horses died dnring the year of pink-eye. In the fall some cattle died of indigestion, cansed by eating corn hnsks. We have lost some hoge and fowls by cholera, aud some sheep have died of scall.

Furnas.-Animals of all kinds have generally been healthy the past year. A few horses have died from change of elimate, overwork, \&ce. In some localities cattle have died of the disease known as black-leg. I havo no losses to report among hogs, sheep, or fowls.

Hall.-Black-leg has lately made its appearance among some herds of eattle which lave been allowed to feed withont restraint upon newly hnsked corn fields. I believe this to be the principal canse of the disease. No other disease has appeared among farm stock. Chicken cholera prevails in some localities.

Hamilton. - I have heard of but very few eases of clisease among farm animals in this county. There has been considerable loss by ehicken eholera. Some farmers have lost all-others fow.

Johnson.-All farm animals are in good health and condition. No epidemie las oceurred during the year.

hearney.-I have no losses to report from discases among domestic animals for the past year.

Lancaster.-I ean obtain no reliable data as to losses among farm animals in this county for the curvent year.

Merricli.-Some horses have been lost during the year by diseases incident to them. 
Cattle, hogs, and sheep are healthy. Cholera lias prevailed to some extent among fowls.

Nemaha.-There is so little disease or loss among farm animals the current year as to harlly be worth meutioning. Some distemper and pink-eye among horses, but no loss. A few cases of "kidney worm" among hog*, which readily yields to treatment, and scab among sheep.

Phelps. - The only loss among farm animals worthy of record has been among sheep. I suppose $\$ 1,000$ wonld cover the value of these losses.

Platte.-No epidemic has appeared among the domestic animals of this conuty for the current year.

Polk.-No fatal diseases among farm animals. Chicken cholera has been quite prevalent and fatal.

Richardson.-Searcely any disease amoug the farm animals of this connty. I do not know personally of the death of a horse, cow, or hog during the seasou, and my location is a central one.

Saunders. - I have been unable to hear of the prevalence of auy fatal disease among live stock in this county.

Tebster. - With the exception of hog cholera, no other contagious disease seems to have visited any class of our farm animals during this year.

\section{NEVADA.}

Esmeralda.-Horses have been aftlicted with distemper and lung fever. The latter has proved very fatal to stallions. Black-leg has been quite fital to calves and yearling eattle. It has been fatal iu almost every instance. The symptoms are the swelling of one or more of the legs. Sometimes the swelling is confinerl to the hip or side of the neck and head. After death the part affected becomes badly bloodshotten. No remedy lias been found for the malady.

Lyon.-Lung fever has proved fatal to some horses, and black-leg has been very fatal to cattle. Hogs and sheep are healthy.

Nye.-The annual losses of farm animals in this connty from disease are trivial.

\section{NEW HAMPSHIRE.}

Belknap.-There has been no prevailing disease amoug animals in this comty the current year. Some few animals have died, but I am unable to form any iclea of the number or value. It nust be, however, a very suall percentage of the whole number.

Cheshire. -No epidemic disease among horses, cattle, or hogs. Some foot-rot among sheep aud diseases among fowls. .

Coos.-No epidemic disease of any nature has prevailed among our farm animals during the year. The losses have been comparatively small.

Millsborough. - I hear of but few losses of cattle, sheep, or hogs during the past year. No epidemic has occurred anong either class of domestic animals.

Sullivan.-The value of the farm animals lost in this comty by disease the enrrent year will probably aggregate in the neighborhood of $\$ 5,000$, as lollows: Horses, $\$ 2,400$; cattle, $\$ 1,500 ; \operatorname{hog} \$, \$ 250$; sheep, $\$ 700$.

\section{NEW JERSEY.}

Allantic.-I have leard of no contagious or epilemic diseases existing anong our farm animals. The increase of live stock in this connty since 1820 bas been at least 15 per cent.

Camden.-All classes of farm animals have been umusually exempt from disease the past year. I canot hear of a case of contagions disease that has proved fatal. Fowls have suffered with cholera, but this clisease yields realily to treatment with suiphur and sulplurie acid.

Cape May. - No diseases exist among farm animals or fowls in this connty. Oceasion- 
ally there is a case of pink-eye among horses, but the disease rarely proves fatal. Some loss among fowls by disease.

Essex. - With one exception there has been no contagion among horses or cattle in this county. The exception was in Sonth Orange, where forty-six horses in the Sonth Orange and Newark horse-car stables suffering with glanders were killed by order of the health officers of the State.

Gloucester.-No disease prevails among any class of domestic animals in this county. Chieken cholera prevails to a more or less extent thronghont the connty.

Middlescx. - I have no losses from disease to report among the farm animals of this connty. There has been a heavy loss among fowls.

Morris.-I have heard of the prevalence of no disease among famn stock for the past rear.

Oceau.-I am glad to state that the live stock of our county is remarkably (I might almost say absolutely) free from all contagions diseases.

Salem.-The losses of farm animals by diseases during the past year were very few in this connty.

Waren,-I do not think any disease of a contagions cliaracter has provailed amoug any class of our farm animals during the year.

\section{NEW YORK.}

Allegany.-No serious epilemic has occurred among any class of domestic animals in this connty during the year. The value of the losses, from all eanses, may be stated thus: Hot ses, $\$ 3,500$; cattle, $\$ 1,600$; $\operatorname{logs}, \$ 150$; sheep, $\$ 250$; aul fowls, $\$ 1,262.50$.

Iroome. - I have not been able to hear of the prevalence of any contagions or fatal malady among any class of our farm animals.

Cayaga.-The usual diseases have prevailed among farm stoek in this connty the past year, thongli they have been of rather a mild form. Pink-eye and influenza have been the prineipal discases. There were 72 eases of pink-eye, of which 13 proved fatal. Ont of 32 cases of influenza there, were 7 deaths. Cattle and swine are healthy. There were 73 cases of seab among sheep, but no deaths. Of foot-rot there were 160 cases and 32 deaths. 'There has been a great deal of' cholera among fowls. About all that have been attacked have died. The same might be said of ronpe. These diseases trouble us a good deal.

Chatcuquu.-There bas been no epiclemic disease among farm stock in this part of the State during the past three sears. The following estimates of losses for this county are for diseases of all kinds liable to affect farm stock. The largest share of suel casualties may no doubt be eharged to improper feed and eare or to neglect. The estimates are: Horses, $\$ 1,275$; eattle, $\$ 1,100$; hogs, $\$ 325$; sheep, $\$ 150$.

Columbia.- While no epidemic seems to have prevailerl among any class of farm stock in this county during the year, the aggregate loss foots np quite a large sum. The losses in detail are given as follows: Horses, $\$ 12,500$; cattle, $\$ 8,000$; logs, $\$ 3,750$; sleep, $\$ 2,500$; and fowls, $\$ 1,125$.

Corlloud.-No losses from disease ase reported as having occurred among the farm animals of this connty.

Jutchess. - I am pleased to say that no contagions or infections diseases have prevailed among onr farm animals the past year.

Essex.-There has been some little tronble with pink-eye among horses. Generally, lowever, farm animals have been very healthy.

Frenlilin.-None but the common ordinary diseases incident to farm stock have prevailed the past year. This is a good climate for both man and beast.

F'ullou.-Horses, eattle, sheep, and hogs have remained healthy during the year. Some disease has prevailed among fowls.

Cienesee. - We have very little disease among onr farm animals, and what we bave are isolated eases. Farmers know that good feeding and proper treatment are better than doctors' nostrums. 
Greene.--The ralne of the losses among farm animals in this county for the sear are given as follows: Horses, $\$ 3,125$; cattle, $\$ 1,260$; hogs, $\$ 700$; sheep, $\$ 665$; and fowls, $\$ 1,000$.

Hamilton.-There have been no epidemics during the past year among our domestic animals or fowls. Last winter was a very severe one on work horses, and sereral died, probably more from orerwork and exposure than from clisease.

Herkimer. - We have had no epidemic disease among our domestic animals during the past year, except abortion among dairy cows, and this to a less extent than is former years.

Levis. - I have no losses to report among farm animals in this county. No epidemic has prevailed among any elass.

Livingston.-The value of farm animals lost in this county the past year from disease and other causes may be estimated as follows: Horses, $\$ 3,750$; cattle, $\$ 1,250$; hogs, $\$ 400$; sleep, s105, and fowls, sio.

Madison.-All kinds of farm animals and fowls have remained free from disease during the year.

Monve.-This is not a stock-growing county, but among the limited number of animals kept there has been no prevailing disease, and only the nsual deaths from common maladies, accidents, \&c.

Montgomery. - No epidemic is reported as having prevailed among farm animals in this county, ret a heavy mortality is reported among some classes. The value of the losses is given as follows: Horses, $\$ 3,000$; cattle, $\$ 30,000$; hogs, $\$ 1,200$; sheep, $\$ 240$, and fowls, $\$ .562$.

Niagara.-There has been no epidemic among any kind of farm animals in this connty during the past year, so the comparative loss has been very small, and the result principally of some acute disease or accident.

Oneida.-There has been no disease of a marked nature amoug any class of our farm stock. This is pre-eminently a dairy county, and the number of eattle raries but little from year to year.

Onondaga.-I have no losses of consequence to report among the farm animals of this connty for the year.

Ontario. - No epidemic occurred among any class of farm animals during the year 188:. Fowls were affected in 1882 to about the same extent as during the present year and with the same disease, called chicken cholera.

Osicegn.-A great many horses were affecterl with pink-eje in 1822 ; perhaps 1,500 were attaeked, causing a loss of 150 head. No disease of a contagions character has prevailed among any class of animals this year.

Otsego.-From all the information I have been able to obtain I an led to believe there have been no appreciable losses from epidemic diseases among any branch of farm animals during the sear.

Schoharie. - There has been no unusual discase of any kind among our firm stock this year.

Seneca.-There has been no prevailing disease among either eattle, hous, or sheep. A few horses have died of distemper. Hen cholera has prevailed, cansing a loss, perhaps, of $\$ 1,000$ in the connty.

Suffolk. -The most fatal diseases among horses in this county are lock-jaw and spinal meningitis. Scab has proved very fatal to sheep.

Tioga.-There has been no disease of an epidenic or fatal character among onr farm stock this year.

Harren.-The losses anong the varions elasses of domestic animals and fowls in this county for the prast year have been so small, that I am satisfied no disease of an epidemic eliaracter has occurret.

Washington.-There has been some pink-eye among lorses and puemonia anong cattle. Hogs have suffered with staggers, sheep with colds, and fowls with the usual 
diseases. The value of the losses for the year are abont as follows: Horses, $\$ 4,500$; cattle, $\$ 5,000$; hogs, $\$ 3,300$; sheep, $\$ 2,400$; fowls, $\$ 4,000$.

Wayme.-No destructive disease seems to have prevailed among any eiass of farm animals in this connty the past year.

Hyoming.-No fatal disease has prevailed among any of our farm animals this year.

Yates.-Pink-eye has prevailed to some extent among our horses, but in rather a mild form. Chicken cholera prevails in this locality, and seems to be very contagions. Turkeys are occasionally attacked and die. It is plainly a disease of the bowels. Some seasons the valne of the losses in this county will reach $\$ 1,000$.

\section{NORTII CAROLINA.}

Alexander.-There has been no prevalent disease among farm stock in this county the past year, and no lata upon which to base au opinion as to the number of animals that have been attacked and died within the year.

Alamance.-I have no diseases to report as prevailing anong our farm animals at present. There has been no log cholera this season. About 75 per cent. of the animals die when it prevails.

Ashe.-Nove other than the common well-known diseases have prevailed during the year among the live-stock of this connty.

Carteret.-The losses from diseases among domestic animals have been comparatively small in this county the current year.

Caswell.-A few hogs and fowls have died during the year of diseases incident to them.

Clay.-Cholera has prevailed among the hogs and fowls of this county to a limited extent during the year. Horses, cattle, and sheep have remained healthy.

Columbus.-Farm animals are generally healthy, at least no contagions disease prevails among any class, except among hogs. They are afflicted with cholera, as are also our fowls. We have found no remedy for this disease.

Cumberland.- With the exception of hogs, all our domestic animals seem to have been very healthy the past year. Some years the loss is very heavy among these animals.

Dane.-A number of horses along the beach have died of blind-staggers. Cattle, hogs, and sheep have been very healthy. A great many sheep have been killed by dogs.

Davidson.-Several of our farmers havelost their hogs-almost their entire stockby a disease which earried them off very rapidly. They broke ont in boils which had a very offensive odor. The animals only lived abont 36 hours after the attack was noticed. So offensive were the tumors that the buzzards were attracted while the animals were yet living. The boils conld be penetrated to a depth of an ineh or more.

Forsyth.-There have been no fatal diseases among our farm animals during the year. A great many fowls have died of cholera.

Franklin.-The only loss of any importance among any class of onr farm animals during the year has been among hogs by the usual diseases incident to these animals.

Gaston.-A few horses and cattle have died of disease during the past year, but not many. Hogs are the most uuhealthy of all classes of farm stock. They die mostly of cholera. A great many fowls are also lost by eholera.

Gates.-I an unable to furnish the information desired in your eirenlar.

Greene. - Since the enactment of the stock law diseases among farm animals are not so prevalent. We have had a few cases of cholera amoug hogs, but the disease has not been widespread as in former years.

IIalifax.-AII kinds of farm animals have been free from disease, and tho losses during the year amount to but little. Oceasionally cholera appears among our fowls.

Harnett.-Cholera has been quite fatal among our hogs. At least one-half of those attacked have died. 
Henderson.-I find it impossible to procnie the statistics relating to losses among farm animals.

Iredell.-Our farm animals have been musually exempt from disease, espeejally of a fatal character. The losses will not exceed, in valne, over $\$ 3,000$ or $\$ 4,000$ for the entire connty.

Iones. - There is not much attention paid to stock in this connty. The animals are allowed to roam at large and tilke care of themselves. But tew losses have occured from diseases.

Monfgomery. - We have no reliahle basis from which to report, and do not propose to guess. The returus of assistauts are uot reliable, and I clo not propose to make a statement unless based on some facts measurably reliable.

Ouslow.-Cholera has prevailerl among hogs and fowls in this comnty. No other disease of a contagions character has appeaved among steck. The valne of the losses among the varions classes for the year may be stated thus: Horses, $=16,250$; eattle, $\$ 2,475$; logs, $\$ 1,800$; slreep, \$312.50.

Pumlico.-Abont 40 horses have died in this connty this year of blind-staggers. The losses have not been heavy, but more or less disease has prevailed among the other classes.

I'asquotank, No special disease has prevailed among any elass of our farm animals this year, except eholera, which has eatused the death of a limited unmber of hogr.

I'ender.-Blind-staggers has been quite fatal to a number of horses in this comnty, and cholera has prevailed quite exteusively among hogs and fowls. The valne of the horses lost may be stated at alont $\$ 3,000$, and hogs a like amount.

I'olk.-Farm stock his generally been healthy. There have been some cases of cholera among hogs, hit I am of the opiniou that 15 per cent. wonld fully cover the loss for the year. Among horses and eattle the losses will not excred 5 jor cent.

Randolph.-Losses aurong horses and mules, \$3,175; cattle, $\$ 500$; hogs, $\$ 1,446$; sheep, $\$ 520$ : fowls, $\$ 219$.

Robeson.-Horses have bren exceptionally healthy this sear. Cattle have been aftlicted with murain. Warm wiuters seem to be more mhealthy for eattle tlan cold weather. Hors are afflicted with cholera, and aloont all that are attacked with the discase die. We have noremedy for chicken cholera, although the disease is wiclespread and fatal.

Rutherford.-Forses have suffered with distemper, glauders, and hlind-staggers, and cattle with distemper and murrain. A large number of hogs have died of cholera, aud a tew sheep have been lost by scab. Fowl cholera prevails.

Sury. -No fatal diseases have visited the farm animals of this connty during the eurrent rear.

Trunsylintuit.-The losses from disease among all elasses of farm animals in this conuty for the past year will aggregate abont $\$ 5,000$.

Inion.-The horses and cattle in this connty have been remarkably free from disease" the past year. Dogs have killed abont 225 sheep. A considerable munber of fowls havedied from eholora and sore-head.

Hayne.-No special thiseas has prevailed among the live-stock of this comnty. Cholera has been quite destrinctive to fowls.

Willkes.-The aggregate loss among all "lasse's of tarm stock and fowls in this commty for the year may he staterl at about $\$ 8,000$.

Wilsou. - Llog cholera prevailed to a wide extent in this county in 1s-2. I lost hogs myselt valued at 3500 . I smprose the loss in the eomity that year reached 86,000 or \$7.000. On experience is that it does no good to doctor animals sullering with the disease. Fencrally ahout is per eent. of the fowls attacked with cholera clie.

Ladlin.-No dentruetive disease has prevaled anong farm andmals in this comnty. All clatsis's are in a healthy condition.

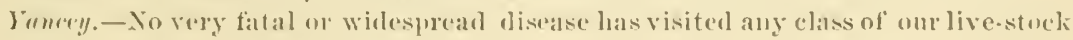
this year.

$$
5751 \text { 1) } 1-20
$$


())III).

Allen.-Tho losses from diseases among firm animals were quite heavy for the past year in this comty. The values are given as follows: Horses, $\$ 10,832$; eat1le, $\$ 6,202$; logg's, $\$ 18,350$; sleep, $\$ 2,4: 25$.

Ashtabula. - No destructive diseases have visited the live-stoek of this connty during the sear, and hence the losses have only been nominal:

duglaize. - While no special epidemic soems to have prevailed among any class of farm animals in this county, the losses for the year are quite heavy. They are given as follows: Horses, $\$ 9,746$; cattle, $\$ 4,717$; loggs, $\$ 13,100$; sheep, $\$ 1,085$.

Brown. - I find it impossible to make a eorrect statement in regard to losses of farm stock in this county, and therefore think it best not to make any.

Carroll.-No diseases lıave prevailed among either horses, eattle, or hogs. Some flocks of sheep are affected with foot-rot, bnt not many die of the disease. Occasionally they die of grub in the head. Fowl cholera is often quite destruetive, but the disease does not seem to prevail at this time.

Champaigu.-Ouly sporadic eases of disease have occurred among our farm animals during this year. Fowls die by the dozens on many farms, but there are no records showing the number lost.

Crawford:-No disease among horses. Cattle and hogs are healthy and in good condition. There is some foot-rot among sheep, and a great deal of cholera among fowls.

Clinton.-The following are the estimates of the losses of farm animals in this eounty for the past year: Horses, $\$ 16,800$; cattle, $\$ 5,190$; hogs, $\$ 14,416$; sheep, $\$ 2,428$.

Coshocton.-No epidemic disease has ocenrred among our farm stock this year.

Darke.-Horses and eattle are healthy. Cholera or splenie fever has, and still is raging among hogs in some sections of the connty. I have no data as to the valne of the losses, but the aggregate will be large. There are isolated cases of cholera among fowls.

Defiance.-No disease of any kind among stock. Nothing but uatural causes occasion losses.

Delaware.-There were killed by dogs in this eomty during the sear 335 sheep, valued at $\$ 1,26 \%$. A number of eattle and hogs have died of the diseases incident to such stock. The value of the eattle lost was $\$ 6,27 \%$, and of hogs $\$ 7,234$.

Fairfield.-All kinds of farm animals have been free from disease. No signs of an epidemic, and no losses worth mentioning.

Fayette.-No losses of consequence have been occasioned by disease among the farm animals in this county.

Franklin.-No epidemic has oceurred among our horses and eattle. Hogs have suffered from eholera, which has lessened the production more than one-half. It is very fatal; 90 per cont. of those attacked die. The value of our losses among these aninals will reach $\$ 37,000$ or $\$ 38,000$.

Geanga.-No destructive disease has appeared among any class of our domestic animals this year.

Harrison.-The losses of farm animals in this connty by disease during the current vear have been only nominal.

Hemry.-Distemper prevailed to some extent among horses the past winter and summer, but was of rather a mild form. The value of the hogs lost by disease will amount to $\$ 16,000$. Cholera has been quite fital to some flocks of fowls, while others have romained exempt from the disease.

Hocking.-1 estimate the value of losses amomg farm animals in this eomnty for the year as follows: Horses, $\$ 1,780$; cattle, $\$ 2,736$; loogs, $\$ 1,913$; sheep, $\$ 3,778$.

Holmes.-Milk fever has leeen very fital to dairy eows in this county. Animals of this elass valued at $\$ 10,000$ have died, mostly of the above-named disease. Hogs, by bunching and sleeping together in straw and manure beds, have become diseased. 
While sleeping together in this way they get warm and sweat, and being ealled ont to eat in the cold air they become chilled and thus contract disease. A large number of fowls have died of cholera.

Huron.-No epidemic is now prevailiug among our farm animals, nor has anything of the kind prevailed among them during the year. Cholera prevails among chickens and turkeys.

Jackson.-Onr farm animals have been reasonably healthy the past year, and consequently our losses have been enly nominal.

knox.-No special malady has visited any class of live stock in this county during the year, and the losses which hare occurred have been from natural eauses.

Licking.-There has been no epidemic among horses, yet some liave died of disease. Cattle generally are healthy, yet there have been a number of deaths from milk fever. Sheep have suffered from a disease known here as "white skin," which seems to be attribntable to the past wet season. Cholera and thumps have causud the loss of some logs, yet neither disease can be said to prevail at present. Cholera prevails quite extensively among fowls, and few that are attacked recover. The valne of the losses are estimated as follows: Horses, $\$ 11,040$; eattle, $\$ 1,290$; hogs, $\$ 1,556$; sheep, $\$ 19,797$ : and fowls, $\$ 10,619$.

Logan.-There has been very little disease among horses except pink-eye, and that seldom proves fatal. Hog cholera has not heen as thad as it was a year or two ago, yet the value of the losses in this county will reach over $\$ 30,000$. Foot-rot and paper skiu have destroyed sheep ralned at $\$ 9,435$. Chicken cholera has caused considerable danıge.

Lorain.-A few cows have been lost by milk fever, and quite a number of sleep by paper skin and grub in the head. The valne of sheep thus lost in the comby will acrgregate about $\$ 7,00 \mathrm{~J}$.

Lucus. - It is dificult to determine with any degree of accuracy the number or value of farm animals lost in this connty by disease during the year. The following is thonght to be a fuir estimate of the value of those that have died: Horses, $\$ 6,981$;

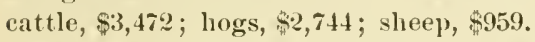

Hahoning. - There is no epidemic disease pre vailing among farm stock in the eonnty. Some pink-eye oecurred dnring the year among horses, but there were no losses.

Meigs.- The heaviest loss that has oecurred among any class of farm stock has been among sheep. The losses bave been principally among lambs just coming in, and yearlings. Some farmers have lost a largo per eent. of such animals. The vature of the disease is not known. The total amount of the loss will reach about $\$ 8,000$.

Miami.-I cannot learn of the prevalence of any fatal diseases among live stock. They all seem fat and healthy.

Montgomery.-The following is as near an approximation of the losses of farm animals in this county for the year as it is possible to obtain, viz: Horses, \$17,780; cattle, $\$ 2,000$; hogs, $\$ 12,600$; shee $]$, $\$ 4,000 ;$ and fowls, $\$ 250$.

Morgan.-The statisties desired cannot be obtained.

Morrow.-Neither our horses, eattle, nor hoggs lave been visited hy any epidemic: or rontagious disease for some years past; therelore the loswes have not heen great. This is a sheep county. The lattor part of last winter was very hard on this storek. particnlarly those that were not sheltered. There was a heavy loss anoug lambs. The total loss is estimated at $\$ 18,350$.

Mnskingum. - The largest loss in this connty has been among slecp. Fanmers know but little abont the symptoms and nature of diseases: lience it is difticult to tell what they dio of. The losses among the varions chasses are estimated as follows: Jlorses,

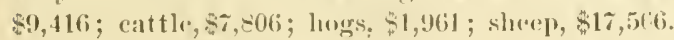

Oltawa.-The entire animal kingdom is tree from all diseases as far as I can bearn.

l'aulding.-A few cases of pink-eye have ocenred among loorses, but nothing like an cpiclenic has prevaled. There have been sume eases of murain and red-wates 
among cattle. Jogs seem to have been healthier than usual. Some fowl cholera prevails, but to what extent I am unalole to say.

rroble. -The loss of hogrs in this county has been quite heary, and will amount in valne to $\$ 32,524$. There does not seem to have been any unsual epidenie among this or any other elass of farm stock, and the aggregate loss for the year is about an average. Fowl holera has prevaled quite extensively.

seneca. - The loss among hogs in this eomty is estimated at $\$ 10,000$. The diseases affecting these animals are eholera, thmmps, staggers, and rhenmatism. Fowl cholera visits us with unwelcome regnlarity. The value of the losses for the year will reach $\$ 5,000$.

Stark. - We have had no special or very fatal diseases among our farm animals for the past year. 'The losses are therefore only nominal.

Trumbull.-No epidenics have provaled among our farm animals during the year.

Tuscuracus. - AII classes of domestic animals are free from contagions and infections diseases.

Inion.-A great mauy animals of all classes have died during the past year of disenses incident to them. Among the horses lost were several very valuable imported ones. The losses among the varions classes are given thus: Horses, $\$ 12,760$; eattle, $\$ 4,100$; hogs, $\$ 2:, 709$; sheep, $\$ 9,994$.

Finton.-There seems to be no complaint as regards the health of lomestic animals in this eounty. Isolated eases of fowl cholera are reported.

Farren.-I hear of the prevalence of no epidemic except that known as cholera among hogs and fowls. The value of the hogs lost in the county will reach $\$ 18,000$ and upwards, and of chickeus abont \$250.

Wryne.-The present year has been remarkable for the good health of all elasses of firm stoek.

Wood.--I hear of noepidemic disease except cholera among fowls. Onr losses have been quite heary from this disease; will amonnt in value to $\$ 1,500$.

Hyaudot.-The total value of the loss of farm animals in this comty for the year will reach $\$ 7,000$, divided among the varions classes and fowls as follows: Horses, $\$ 2,000$; eattle, $\$ 500 ;$ hogs, $\$ 2,500$ : sheep, $\$ 1,000$; and fowls, $\$ 1,000$.

\section{OREGON.}

Bulier.-Pink-eye has prevailed to some extent among horses, hut it bas not prover fiatal in any case that I have hearl of. A few cases of black-leg in calves have occurred.

Ientom.-Int few animals have died from the effects of disease in this comty the emrent year, and those that have been lost have died of the usual well-known diseases.

' 'lackamas. - The only disease worthy of note among any class of firm animals has heen anong horses. They are aftlicted with enlargement of the kidness, which seens to canse the bots to leave the stoma'l and go to the throat. Some cases have proved fatal. There have also heen some cases of blind-staggers among horses.

Clatrop.-Five per eent. of the sheep of this comnty are nsually lost by discase. Alont one-thiml of this number clie from the eftects of the water-leech.

Columbia.-No epidenic disease has prevaled among any class of live stock in this comity during the past six years. Our hogs are mostly of the old long-nosed breed, and hunt their living until they are wanted for fattening purposes.

Cury. - Some flocks of sheep are aftected with scab, but the disease rarely proves liatal. All other classes of farm animals are in a renarkably lealthy eondition.

foseghine-Tlere are but a small number of donestie animals in this conuty, and the few we have are in a halthy condition.

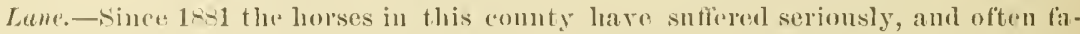
tally, from an cpiclesic not mulerstoml hy our prepple. The disease, I prestume, is slanders. 'The symptoms are a swelling muder the jaw and a free discharge at the nontrils of a grayislu sticky matter. Sometimes one nostril or the other diseharges 
blood, and small bluod-blisters appear npon the hind legs of some, which breati, disrharge, and heal. The hair sticks ont from the bodies of the animals, their appetites fail, and soou they rum down and die. The distase is contagious in a lighly degree. Mang tine animals, worth thousands of dollars. have died of the malidy. 'The loss, I think, will aggregate $\$ 10,000$ almually. Sheep are oceasionally atfected with seab; aud ronpe, which is contagions, fremently sweeps off large numbers of fowls.

Limn.-In some sections of our county horses are occasionally aftected with luner fever and staggers. A few die of nasal gleet, or some disease resembling catarrh. Sheep are sulject to leech and scab, and chickeus to elolera.

Bultnomah. - No contagious disease has prevailed among any class of our domestic. animals.

Polk.-The only loss we have sustainel among our farm animals has been anong horses and sheep. No contagions disease seems to have affected any class.

Washington. - We have here every winter a disease among horses, ealled staggers by some, aud by others spinal meningitis. I hear of some suffering thus early in the winter season. I estimate the average anmul loss by that disease alone at 8 per cent. There has been no fatal disease among other classes of stock. C'Lolera among fowls has prevailed to a limited extent.

\section{PENTSYLANIA.}

Allegheny. - There has been no disease of ans kind among our fam animals. Cholera among fowls has been quite prevalent.

Bedford.-A number of horses lave suffered with pink-eye, distemper, ancl lumg fever. Hog eholera has prevailed, and fowls have also suffered with cholera and gapes. The losses are estimated as follows: IIorses, $\$ 35,000$; eattle, $\$ 1,600$; logs, $\$ 10,000$; sheep, $\$ 6,000 ;$ fowls, $\$ 2,500$.

Bradford.-No contaurions disease has prevailed among live stock in this county the piast year.

Butlr.-I cannot hear of the prevalence among either horses, cattle, bogs, or sheep of any disease whatever. The deatlis have been the result of accident, natural defrets, or for liack of proper care.

Cumbriu.-No disease of a fatal character has prevailed among any clans of onr domestic animals.

Camcron.-But few losses have been occasioned by disease among the fam animals of this connty during the past year.

Clinton.-I find it impossible to furnish the information you desire as to losses from disease among fanm animals.

Crunford.-No contagions or epridemic disease has prevailed among auy class of our farm stock the pist year. Animals oceasionally die, lunt generally of some common diseise, old age, sc.

Elk. - The losses anoug domestic aninals in this county are oceasioned by bad treatment, old age, or accident.

Erie.- We have had no prevailing disease within the past year among any class of our farm animals, lut we have had the average anual losses from old age, accilent, want of proper attention, se.

Grecne.-There never has been an epidenic among the farm animals of this conntythat amomnted to augthing. Chicken cholera has cansed greater losses than any disease among live stoek.

Lutrence.-There has heen some chicken cholera among fowls, but the disease has rot been so general as heretofore. No epidemic has visited our farm animals during the year.

Lyeoming. - No contagions or infertions disease has prevailed among onr domestie: animals the past year. The losses havo been oceasionel by natural eauses.

Montour.-Some hogs latve died in this county dnring tho year. It is supposed that 
the disease of which they died was oceasioned by feeding them with moldy corn. Abont one-third of our ehickens have died of cholera.

Torthampton. - No epidemie disease has prevailed among any class of farm animals in this connty. The ehicken disease has eansed considerable loss. It has also attacked turkey's with fatal results.

Schuylkill.-No serions or destructive disease has visited onr live stock the past yeat.

Somerset.-I am of the opinion that there has been no epidemic disease among our stock for two or three years past, but of eonrse there have been some deaths from natural eanses and common ailments.

Sullixan.-This is a high, rolling connty, with fine nntritions grasses, and is very healthy for all kinds of farm animals. The losses the past year were only nominal

Susquehunna.-Scareely any losses have ocenrred anong onr farm stock from disease the past ycar. There has been quite a heavy loss among sheep, cansed by dogs.

Cnion.-No contagions diseases have made their appearance among our farm animals the past year.

Venango.-There is not, nor has there been during the year, any eontagions or infectious diseases among our domestie animals. The losses are such as are incident to $\mathrm{al}_{1}$ stock.

Thrren.-Of conrse an animal occasionally sickens and dies, but $I$ can hear of the prevalence of no epidemic among our stock during the current year. One butcheran isolaterl case-lost some hogs by eholera.

Thashington.-A few horses, eattle, hogs, and sheep have died from the efteets of the various diseases incilent to them luring the past year. I eannot give the valne of such losses. The cholera or rompe has been destructive to fowls. The loss will aggregate several thousand dollars for the year.

Nayne.-No eontagions or epidemic diseases among farm stock in this county. A great many calves and yearlings have died of malignant authrax or black-leg. From 200 to 300 sheep are annnally killed by dogs.

Westmoreland.-Farm animals usually do well in this eounty. I ean proenre no reliable data as to annual losses by disease. The aggregate would amonnt to but little.

Hyoming. - I have no diseases to report as prevailing among farm animals. I estimate the value of the loss of fowls at $\$ 2,375$.

Fork.-I estimate the valne of the losses among the varions elasses of farm animals and fowls in this eounty for the year as follows: Horses, $\$ 8,500$; eattle, $\$ 2,000$; hogs, $\$ \cdot, 000$; sheep, $\$ 65$; and fowls, $\$ 500$.

RIIODE ISLAND.

Bristol.-The prevailing horse disease has been pink-eye, of which few animals, however, tlie, and those ehiefty from ignorance. A small, eheap pamphlet, in large type, leseribing the more frequent diseases incident to horses and cows, and indicating proper treatment, wonld save much loss and untold suffering to the animals.

Kent.-The most prevalent disease among horses is pink-eye. Hogs have fevers from exposure, and fowls are afllicted with ronpe, eansed by their damp quarters.

Nenport.-The loss among farm animals in this county during the past jear has not been very Iarge. Nothing like an epidemie disease has prevailed. A large trafie in the production of eggs has within the past few years grown np in the sonthern part of the connty.

\section{SOUTII CAROLINA.}

liarmell.-IIorses, cattle, and sheep in this connty are remarkalbly free from all contagions diseases. 'They die from such sporadie attacks as are common everywhere, and in some cases from poverty and bad treatment. Ilogs and fowls are suffering from a disease called cholera, of which numbers are being carried off. We have no remedy. 
Chesterfield. - I have not heard of the prevalence of any fatal disease among the farm animals of this county during the past year.

Clarendon.-The ouly loss of any consequence that has ocenrred among any class of stock in this connty during the year has been among liogs. The value of the animals lost will aggregate $\$ 10,900$. Fowl eholera has been widespread and destructive, and has destroyed fowls valued at $\$ 2,350$.

Hampton.-I am unable to turnisl the information desired for this connty.

Newberry.-Horses occasionally die of common ailments. Cattle die of "hollowhoru" and exposure. No eare is given these animals. Cholera is very fatal to hoth hogs and fowls. No unusual epidemic has prevailed among our animals during tue year.

Richland.-Cholera has prevailed to a considerable extent amoug hogs in this county. Other farm animals have remained healthy.

Sumter.-All classes of farm animals in this connty are free from disease.

Hilliamsburg. - No statistics aecessible, and cannot give the in formation clesirerl.

TENNESSEE.

Anderson.-This has been a rear quite free from stock epidemics. In the early spring quite a number of milch cows died of a disease popularly known as murrain. aud a few logs of cholera.

Bedforl.-The ouly disease from which our horses suffer is distemper, with occasionally a chronic ailment. A disease has prevailed the past summer among our cattle called mmrain by some and by others Alabama or Texas fever. It ouly affects native eattle which are grazed ou pastures after Alabama or Texas cattle. Strange to say, the Sonthern cattle are never affected, bnt fitten well, while native cattle that follow in the same pastures sometimes die by the berd. Hogsand fowls are affected by cholera.

Benton.-Some horses were killed in this eounty during the sear that were supposed to be suffering with glanders. But little disease has prevailed among cattle. Hogs valued at about $\$ 2,000$ have died of disease. Fowl cholera has been quite destructive.

Blount.-There has been no disease of an alarming character among our farm animals the past jear. Swine plagne was very destrnetive in 1882.

Bradley.-The only ilisease of conserquence that has visited any class of stock in this connty the present year is what is generally known as murrain among cattle. Cholera among fowls prevails to a wide extent.

Claiborne.-No diseases prevail among onr horses, cattle, or sheep. Swine have suffered with swine plagne, and fowls with cholera. These diseases have not heen so lestructive, however, as in some former years.

Coffee.-For several years past but few diseases have prevailed among any elass of onr farm animals except hogs.

Cumberland.-Our hor'ses, cattle, sheep, and fowls have been unusually healthy the past year. In one neighlorhood hogs were aftlicted with elolera, which resulted in a loss of abont 200 head of all ages. The disease is not now prevailing.

Iaridson.-I find it impossible to procure the information you desire.

Decatur.-There has been but little clisease among farm animuls in this eonnty the past year. Several cattle died, but of what disease I am not informed.

De Kalb. - There has been a great deal of choleral among hogs in some parts of this comnty this year, and very littlo disease of any kind among other classes of farm stock. Cholera has also been very destructive to chickens, turkeys, \&e., in certain localities.

I) ickson.-No diseases among lorses or eattle in this eounty. Some cloolera among hogs and fowls, and oceasionally rot anong sheep.

Fayette. -No diseases prevalent among lorses, cattle, sheep, or fowls, but hog cholera has prevailed to some extent in cliflerent localities in the connty. 
Gibson.- No disease cxeept ordinary distemper among horses. Bloody murrain and Traas fever reported in two or three nerghborhoods; very fatal. In three or tour districts cholera is reported as being very fatal to hogs, especially to fattening hogs. (ialpes quite often prove fital to young forls and cholera to oleler ones.

Giles.-Horses are ynite healthy. The loss of cattle is the result of contagious disease's produced by the importation of eat tle from the mountainous distriets of Alabama. Ther shonld be a law enacted by the present Congress to prevent the importation of stock from one State to another in such eases. The disease has proved fatal in every instance to native stock. Our county has lost many hundreds of dollars by the importation of sneh stock. Our losses for the year are estimated as follows: Horses, $\$ 12,750$ : cattle, $\$ 18,750 ; \log \mathrm{s}, \$ 20,000 ;$ sheep,$\$ 850$, and fowls, $\$ 1,200$.

Grainger.-There has been some hog and fowl eholera in this connty the past year, but as to the extent and value of the losses no one knows. Cattle, horses, and sheep seem to have been free from disease.

Greene.-Cholera has prevailed among hogs and chiekens in some loealities in this county. A few horses bave suffered with blind staggers. Ilog raising is still decliniug in favor of cattle growing.

Huncoch.-One-fonrth of the hogs of this connty have been affected with eholera luring the fall season, and the disease is still raging with great destruction. Some cattle have died of murrain ; fowls have died of cholera, and chickens of gapes. I estimate the value of cattle and hogs lost as follows: Cattle, $\$ 1,080 ; \log \mathrm{s}, \$ 17,500$.

Hardeman.-No epidemic disease has prevailed during the jear among any elass of onr domestic animals exeept among hogs. Fowls have suffered also to some extent. The disease prevalent among both logs and fowls is known as cholera.

Haynood. - No disease of a general eharacter has prevailed among any class of farm animals in this county the past year. All that have been lost is the resnlt of old age or neglect. Onr comnty is in a prosperous eondition as regards stock of all kinds.

Henderson. - Cattle have been affected in some localities with what is here called blooly mmrain. 'The true natwe of the disease is little known. It usually proves fatal. Hog cholera has prevailed to some extent in certain localities, but the disease is not general througliont the connty.

Hichman.-Hog cholera prevailed in this county to an alarming extent during the year 188\%. Nore than 75 per cent. of the hogs died that year. It has not prevailed in a destrnctive form sinee. A few eases of pink-eye oecurrel among cattle the past spring and summer, but there were no deatlis.

Humphreys. - I estimate the value of hogs lost by cholera in this comuty the past year at $\$ 10,000$. Cholera has also prevailed among forls, and has been quite destmetive.

Icmes. - The most fatal epidemic we have to contend against is that ealled murain among eattle. It is called both bloody and dry murain, and kills almost every animal it attacks. Unless some remedy is found for this malady, it will destroy the eat tle interest in this section.

Johnson.-In the early spring horses were affected to some extent with pink-eje. Cattle have suffered with black-leg, hogs with cholera, sheep with pneunonia, and fowls with cholera.

linox.-Only a small number of our farm animals have been affected by disease, and lint fer of those affecterl have diecl. No epidemic worthy of mention has occurred. There have heen a few cases of cholera among hogs and fowls, but the losses have not been so great as in former years. A few deaths have occurred among cattle, cansed by the introduction of animals from more sonthern States. For instance, one farmer bouglit a car-loarl of cattle in Alabama, some hundred miles south of this loeality, and bronglit them to his farm to pastnre throngh the smmmer. These cattle did very well, but ahnost all the native eattle on the farm died. The eanse and nature of this disease is not muderstnorl here.

Luke.-The value of the farm animals and fowls lost in this eounty the past year 
by the various diseases incident to them is estimaterl as follows: Horses, 56,000 ; cattle, $\$ 1,620$; hogs, \$42,750; sheer, \$64; fowls, \$279.

Lawrence. - A few horses bave died cluring the rear of blind staggers. Dry unrrain has been very tatal to cattle in some loealities. Hog cholera has prevailed, abd has been very fatal along the large water-courses. Animals on the mplamis have remained healthy.

Loudon.-No disease of fatal character has prevalud among any class of our dourestic animals the past year. Oceasionally an animal dies, but not of a contagious disease.

Mudison.-The losses among some classes of farm animals have been quite heavy in this county during the past year. I estimate the value of the losses among all classes as follows: Horses, $\$ \tau, 500$; eattle, $\$ 10,000 ; \operatorname{hogs,} \$ 20,000$; sheep, $\$ 900$; and fowls,, 3600 .

Meigs. - All kinds of farm animals have heen in good health th" past year. There has beeu some eholera anoug chickens, bnt $I$ have no means of aseertaining the value of the losses.

Morgan.-Horses, cattle, and sheep have remained free from disease during the year. Cholera has prevailed to a considerable extent amoug hogs and fowls. Valne of hog: lost, $\$ 6,000$; fowls, $\$ 800$.

Montgomery. - I fiud it utterly impossible to furnish the information you desire.

Moore.-An estimate of the value of the animals lost in this county during the pear is given as follows: Horses, $\$ 6,000$; eattle, $\$ 4,000$; hogs, $\$ 2,500$; shecp, $\$ 400$; and fowls, \$8:0.

Pery. - No disease of an epilemic character has prevailed among any class of farm animals in this conuty the past year. Cholera has prevailed among fowls, but $I$ cannot give an accurate estimate of the value of the losses.

Jickett.-No epndemic among either horses or cattle. Some hog eholera, but not of an epidemic eharater. Not a great amonnt of disease amoug fowls.

I'olk.-Horses have been liealthy, and the same may be said of hogs and sleep. Onr eattle have suffered with an epidemic of murrain. Fowls bave been afflicted with cholera.

I'utnum.- No disease of a very fatal nature seems to have visited any class of farm animals in this county during the enrent year. There has been some clisease among shecp and also amoug fowls.

Robertson.-There has leeu no epidemic auong farm stock in our eomnty dnring the past year. A few hogs in sone loealities have had cholera and in others fowls have lied of the same disease, but nothing like an epidemic has prevailed.

Shelby.-Some little cholera among hogs and fowls is now and then reported, but the losses have been small.

Sequatehie.-A considerable number of hogs have died of elolera during the rear. A few horses have suffered with what is known here as piuk-ere, but no deaths have resulted.

Serier.-The disease known as hog cholera has prevailed to a linited extent during the year, hut the losses have been comparatively small. Chicken eholera is less prevalent than usiual.

Hashington.-Heary losses havo occurred among swine and poultry in this connty, caused by the ravages of eholera. Farm animals generally have remained free from fatal diseases.

Wayme.-There have been some cases of unrain anong cattle aud cholera among logs. The disease was fital to cattle, and three-fourths of tho logss at tacked died.

Hhite.-Hogss have suflered from eholera in some neighborhoods Although the disease has not heen general, I estimate the value of the losses at about $\$ 8,000$. Other elasses of farm animals have remained free from contagions diseases.

Wilson.-Cholera has been very fatal to hogs, but I lave no means of ascertaining the value of the losses. No special disease among other classes of stock.

V̈illiamson._All classes of domestie ammals have been remarkably free from con- 
fagious diseases except hogs. There have been a few canses of eholera among these animals. Cholera is now prevailing and proving quite fatal to fowls.

Unicoi.-No diseases of a contagions or epidemie charaeter have prevailed among our farm stock the past year.

TEXAS.

Aransas.-No contagions disease has prevailed among any class of farm animals in this county the past year. Cholera is the prevalent disease among fowls, and anmully kills large numbers of them.

Austin.-No disease among any class of farm stock, except the usual sickness among logs. The losses have not been very heavy.

Bandera.-The only loss $I$ have to report among our farm animals was among eattle, cansed by the disease known as hlack-leg.

Bustrop.-I cannot give the statistics desired, but I an prepared to say that there lias been no fatal diseases prevalent among our farm animals the past year.

Bee.-Horses, cattle, and hogs have been remarkahly healthy the past year. Shcep have died of lombriz and scab, but owing to the dry weather they have been healthier than in former years.

Bexar.-No destructive disease has visited onr horses, eattle, or logs the past year. Scab prevails to some extent among sheep and cholera among fowls.

Borie. - I have no diseases of a contagious eharacter to report as prevailing among the farm animals of this connty.

Brazos. - Sheep are the only class of animals that have heen serionsly affected by disease in this county. They have suffered with seab and foot-rot. Cholera among fowls prevails in some neighborhoods almost continuously.

Brown.-Horses, cattle, and hogs have escaped all epidemie diseases the past year. Sheep had a hard time of it last winter-no shelter and bad feed. Abont one-half or two-thirds of the number in the connty died.

Caldwell.-Horses and eattle are healthy. Hogs are suffering with eholera, which is now prevalent in this county. Sheep are affected with scab. Cholera is prevalent and quite destructive to fowls. This disease annually destroys about half the hogs and fowls in the eounty.

Callahan.-A few horses have been attacked by blind-staggers during the past year, and abont all attacked with the disease died. Cattle are plentifnl here. I know of one man who owns 4,000 head, another 3,400 , and several others who own from 800 to 1,200 each. They have been free from discase the past year. I have hearl of some fow deaths among young cattle just brought in. I think fine stock should be bronght here in the late fall, say from October to Deeenber, in preference to the spring montlis. Ings do well, and are healthy. Sheep have largely increased within the last year. There are probably more than 100,000 head in the county. Some few eases of scab prevail, but this usmally only rednces the elip of wool and rarely kills the animal. Under the laws of Texas we now have a sheep inspector in each county, who examines diseased herds and preseribes proper treatment.

Cass.-Our losses among horses and mules the past year from blind-staggers were unusually large. This disease is supposed to be cansed by eating smutty corn. Cattle are healthy, but a great many die amnully from poverty and lack of proper shelter. Hogs are aftlicted with cholera.

Chambers.-We lave had so fow deaths amoug farm aninals the past year that the number is hardly worth recorling. Abont 10 per cent. of our fowls are annally attacked by eholera, and 90 per cont. of those attacked die.

Cherokee. $-\mathrm{No}$ infectious or contagious diseases have attacked the farm stock of this county the past year.

Clay.-No epidemic of any kind has visited our farm animals this year.

Coleman.-Some little disease has recently appeared among horses in this county. loung cattle on the range are reported as snffering seriously with black-leg. Animals 
valued at from $\$ 10,000$ to $\$ 12,000$ have becn lost by the disease. A great many sheep died from the effects of cold and starvation last winter. Flock-nasters were unprepared for the unprecedented cold weather, and were canght withont either shelter or food. The loss is estimated at $\$ 30,000$.

Collier.-The ouly epidemic that has prevailed among any class of domestic animals is that known as cholera among hogs. A similar disease has prevailed anong fowls.

Dallas. - I think, upon the whole, that our stock has been pretty free from epidemics of any kind. Hogs have suffered some what from cholera, and the same can be saicl in regard to fowls. We have hut few sheep, and they are healthy and well cared for.

De Witt.-Our heaviest losses have been in sheep and cattle. 'This may partially be accounted for in the fact that weither class are properly sheltered and cared for duriug cold and inclement weather. A great many fowls have died of cholera.

Donley.-Horses in this comnty are frequently poisoned by the loco ween. We have no autidote for the poison, and it generally proves fatal. A great mauy cattle are auนnally killed by being erowded upon wire fences.

Euslland. - A very fatal disease known as black-leg has been quite prevalent among young cattle in this county. We have no remedy for the malady. The animal when attacked becomes indifferent, lame in forelegs, with slight swelling, feverish, consillerable thirst, and finally drops down and soon dies. The disease terminates in deat in about forty-eight hours after the first symptoms are shown. Calves and yearlings are the classes usually attacked. All other rlasses of animals have renained healthy.

Earth.-Blind-staggers, a very fatal disease to horses, has prevailed to some extent in this connty the past year. A few cattle die annually of black-leg, and a large proportion of the fowls die of cholera.

Fannin.-The farm animals of this connty have been exempt from all epidemic dis. eases during the jast year.

Grayson. - Native cattle are very healthy, but imported animals almost invariably die. No fatal diseases among domestic animals this year.

Gregg. - A disease has prevailed among horses in this county for the past two years having all the symptoms of glanders, but it does not seem to be very contagions. I have seen some five cases. None have recovered. Sheep aud cattle are free from disease. Hogs and fowls occasionally suffer from cholera.

Guadulupe.-No diseases of a contagious nature have visited our farm stock the past year.

Hardeman.-Both horses and cattle are often killed by eating the loco weed. It is more injurious to horses than cattle, and if the former should recover they are nevir of any use as work animals. Sheep are suffering to some extent with scab, and chickens are dying in considerable numbers of eholera.

Hardin.-All classes of farm animals are yery healthy. At least 25 per cent. of the entire number of fowls in the connty have suffered with cholera, and fully 90 per cent, of those attacked have died.

Henderson.-I have hearl of the prevalence of no disease among horses and cattle this year. Hogs aud ehickens both seem to be snflering with eholera or some other fatal disease.

Johnson.-Farm animals of all kinds do well in this connty and are moderately healthy. I have no means of ascertainiug the value of the losses.

Jones. - There have been a few eases of pink-eye among horses. Five or six per cent. of the total number of sheep of this county died last winter of seab and poverty.

farnes.-No epiclemic has appeared anong horses. Short and dry pastures in the early spring cansed the loss of a great many cattle. Theso animals are now fat and healthy.

Kanfman.-The losses among our farm animals from diseaso during the past year have been comparatively small.

Kiuney. - Sheep are affected with seah, hut the discase now seens to be under control. The greatest loss has been felt in a reduction of wool. 
Lampasis.- Sheep in this connty have sutreret severely with scab. Fully fifty per cent. of these animals have died from the ravages of this disease and of starvation. Horses aml cattle seem to have suffered from scal, also, which was commmicated to them by grazing on the sane pastures with the diseased sheep.

I/ $1 /$ ullen.-Xo epidemic has previliled here, either anoug animals or fowls. During the winter of 158:-'8:3 ahout 20 per cent. of the sheep died from exposure to inclement weather, which was musually severe for this latitule. Horses and cattlo are now healthy and in good condition for the coming wiuter.

Madison. - Some eattle have dien of the disease known as murrain. Hore hogs have died from eating eotton seeds than from actual disease. The greatest loss both to sheep and eattle has been the lack of proper shelter.

Muriou.-No wide-spread or epuldemic disease has prevailed among any elass of domestic auimals in this county the past year.

Matugorda.-No contagious disease has appeared among our farm animals this year. Flies and the screw-worm have canserl the death of a great many sheep.

Menard.-lIorses have been affected with a disease knowu here as loin distemper. Scal is prevalent among sheep, and has caused some losses. Cattle aud hogs are health $y$.

Morris.-The only fatal disease to which onr horses are subject is blind or sleepy staggers. But few animals recover from this disease. A few cases of cholera have been reported among logs. A similar disease is often very destructive to fowls.

Parker.-Stock of all kinds was never in better condition than at present. 'The loss on all range stock last winter was estimated at 2 per cent.

Polk.-No losses of any consequence among auy class of domestic animals in this connty.

Runnels. - There is no prevailing disease among om farm animals, and the losses are principally caused by starvation. The losses for all classes will not exceed 10 per cent.

Rusk:-Hog cholera is now prevailing on many farms, and some farmers have lost a large per cent. of their fattening logs. They die very suddenly, ouly refusing to eat a day or so before death occurs. No remedies seem to have any effect. A change of range has been fond beneticial. Other tarm animals have continned healthy. Oue of my neighbors, having good Bermuda grass pastures, imported from Ohio in the mouth of October thirty head of high grade Jersey eattle. The first half of October was hotter weather than we harl in Angust. The thermometer ranged from ninety to uinety-five degrees daily on the north side of the honse. In about a week after the arrival of the cattle some of them began to froop and refuse to eat. They were costive, and it was diffienlt to get an operation from the bowels with salts anil other drenches. One very sick one was drenched with a quart of melted hog's lard, which operated, and the cow recovered and is now doing quite well. Of the thirty head, eleven died within about a period of twelve days. The remainder are now doing well. We attribnte the canse of the sickness to the extreme lot weather and the sudden change of elimate. Cholera is prevailing among fow Is on many farms.

San Augustine.-No fatal disease has prevailed among any class of our domestic animals during the year.

Shelby. - We have had no cpirlemic among our farm animals this year. Some cholera has prevailed among hogs, and a few deaths have occurred, lut the agregregate loss has been light. Chicken cholera has also prevailed.

Stephens. - No lisease exists anong farm stock in this connty except scab in sheep, and as that disease rarely kills, the loss has not been very heary. The "norther" struck our sheep just after leing "dipped," and eansed the death of a great many.

Throckmorion.-lleavy losses occurred among sleep in this county in 1882, eaused ly the animals eating a weed which grows on the ranges. Sheep feeding upon it would dis in a few lours. I myself lost 400 head of higll-grade Merinos, worth $\$ 5$ per head. Three hundred of this number died in two days. Similar losses extended over 
the entire connty. I telegraphed Dr. II. J. Detmers, who was then at San Autonio, requesting him to come and investigate the cause of the tronble, lut he made no reply. I afterward wrote him and inclosed a specimen of the weed, but failed to elicit a reply. The only disease now prevalent is scab, which has resi.jted our eftorts for many sears, hut wo are now getting it somewhat nnder control.

Titus.-Horses have not suffered with any epidenic disease the past vear. Cattle are generally bealthy, though a good nans die of poverty during the winter, Fowls die here with a disease known as cholera, and when it strikes a flock it solum leaves one alive. We haveno preventive or cure.

Tom Green.-Horses, cattle, and hows seem to be in a healthy condition. Sleep ase suffering with seab, hnt the losses on the gromul are very suall.

Trinity.-All kinds of domestic animals are free from contagions discases. A disease of some kind prevails among fowls in certain localities.

Tyler.-No diseases of a destructive charactor have prevailed among any class of farm animals in this county the past year.

IFashington. - No epidemic worthy of notice has appeared among any elass of our firm animals the past year, though animals die occasionally from varions canses. Somo disease prevails amoug fowls.

Hebb.-No epidemic lus appeared among the domestic animals of this connty during the rears 1820-33. Sheep raising is our largest interest. The losses among these animals are not large.

Williamson.- Poverts and neglect canses more losses among filrm animals than disease. Distemper is the principal disease among horses and cattle. I lave also to report a few rases of black-leg among young cattle, and some scab among sheel?. C'lolera prevails to some extent among forls.

rietoria.-On furm animals have never been visited by an epidemic of any kind.

\section{YERMONT.}

Benuington.-From all the information I can gather I am led to believe that the general condition of all farm animals in this eomuty, as regards health. has been good. To disease of an epidemic nature has prevailed among neat cattle, and only the ordinary distemper of a mild charaeter among horses. The only serions tromble we ever have among cattle is ahortion in cows. The direct eanse of this tronble has wever been satisfactorily given.

Culedonia.-Several lorses have died during the year with the following symptous: Finst. dumpish, mable to swallow, low pulse, cold extremities, dificulty in walking, aud in two or three days down and unable to rise; lungry and thirsty, but muthle to swallow, convulsions, and death iu most cases in three or fonr dass. On one farm three lorses died in this way. The second and third were exposed to the first. What was the disease? Many pomng hogs have died sudrlenly. While apparently well they would give a piereing seream and drop dead, and the carcass womld mortify in a few minntes. What was the dismase?

Chittenden.-I find it inpossible to grive the statistics desired.

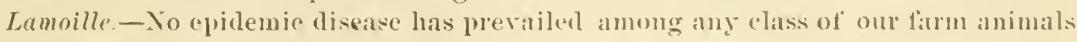
the past year, henee the losses have heen viry small.

Orlenns. - All classes of farm animals in this connty are very lualthr.

Rntland.-There has hern no prevailing disease among our fam animals. Horses occasionally have an epizootic cold, but these are not as severe of frepuent as whon the disease first appeared, and but few losines oceur.

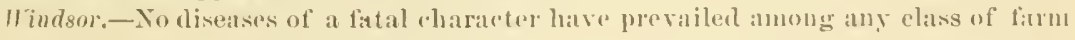
animals in this eonnty during the enrrent year.

\section{VIlicisIs.}

Albemarle.-There las been some eholera among hogs, but the fatality las uot been great. Some cattle fever was bromght here ly the importation of some cattle from 
the sonth side of the James River. This disease was more extended this year than last.

Amelia. - I give the value of the losses among farm animals as follows for the past year, viz: Horses, $\$ 2,000$; hogs, $\$ 8,000$; sheep, $\$ 4,000$; and fowls, $\$ 2,000$.

Bath.-I have no losses to report among the farm animals of this county as the result of contagions or epidemic diseases.

Bland.-No contagions diseases have prevailed among any class of our farm stock during the past twelve months.

Buchanan.-All farm animals have been entirely free from diseases the past year except horses. An occisional case of distemper has occurred among these animals, lint I liave heard of no deaths resultiug.

Caroline.-Distemper among horses has been the most prevalent disease that we liave harl to contend with among farm stock. Considerable disease has existed among rhiekens.

Clarke.-So far as I have been able to learn, no epidemic diseases have appeared among any elass of onr farm animals the past year. In $188: 2$ hog eholera prevailed extensively, and entailed a loss of, say, 500 animals, valued at $\$ 1,500$.

Essex.-All elasses of farm mimals have enjoyed remarkably good health dnring the past year.

Frirfax.-There seems to be no disease of a fatal character prevailing amoug any elass of farm stock in this eonnty.

Frederiek.-From the best information I have been able to obtain I am satisfied there lias been but little disease prevalent among onr farm animals the past year. A fow hogrs and fowls have died of a disease generally designated as cholera.

Greene.-No losses of eonsequence have oecurred fiom disease among farm animals in this comnty the current year.

Hunover:-Bnt few losses have ocenrred from disease among the farm aninals of this connty the past year. I estimate them as follows: Horses, $\$ 2,500$; cattle, $\$ 1,000$; hogs, $\$ 400$; sheep, \$360; and fowls, $\$ 250$.

Heny. - No diseases have prevailed among horses and less than the usual number among cattle. Hogs and fowls have suffered to some extent with the usual maladies.

Highland.-No epidemic disease has visited any class of farm animals in this county the past year.

Isle of Wight.-Sheep have died of some kind of head or brain disease. Hogs for many years, and especially the past, have suffered greatly from the ravages of cholera. They rarely ever recover from an attack, and if they do, are rarely of any valne thereafter. Great numbers of fowls also annually die of a disease called cholera.

James City.-Horses, cattle, and sheep are healthy. Hogs are affected with cholern and mange. Fowls, especially hens and turkeys, suffer severely with cholera. If you conld banish this disease from this county the raising of fowls would be most profitable.

King and Queen.-From the best information I can get I am satisfied that our losses among farm animals bave not been very heavy the past year. The following is regarded as a fair estimate of the value of the animals that have died of disense: Horses, $\$ 2,000$; cattle, $\$ 1,500$; hogs, $\$ 2,000$; shee $1, \$ 250$; aud fowls, $\$ 625$.

Laneaster.-I find it impossible to furnish the information called for by your cirrnlar.

Lonisa.-We have had no epidemie among horses, cattle, or sheep. In some neighhorhoods we have had what was supposed to be cholera among hogs, a disease which proved quite fatal to the animals attacked. The same might be said of fowls. Of the mmber of the latter attacked more than 50 per cent. disd.

Lunenbury. - No infections or contagions disease lias prevailed among onr farm animals the past year. There have been some losses among fowlo by the usnal disease.

Mutthers. - No special disease to report as prevailing anong farm animals. A great many fowls die of choleri. 
Mecklenburg.-Distemper has prevailed quite extensively among horses, and while it has rarely proved fatal, it has been very inconvenient. There has also been some distemper among cattle aud cholera among hogs. A great mauy hogs have also died from eating poisonons mushrooms.

Montgomery.-The loss during the past sear among hogs and fowls has been heary. It is difticult to get reliable figures, but I think at least 70 per cent. of the hogs of the connty have died during the jear, and perhaps 20 per cent. of the towls. Garden rne is used successfully as a preventive of chicken cholera. It is nsed as a tea, which the fowls drink instead of water.

Northampton.-For the past twelve months the domestic animals in this county have been extremely healthy.

Orange.-I find it impossible to give anything like an accurate estimate of the value of losses among farm animals in this connty for the past year. No epidemic disease has prevailed among any class.

Princess Anne.-The only animals that have suffered from disease this year have been hogs. The disease is not so wide-spread as in former years, and seems to be of a differeut character. It is called "thmmps." Fatal diseases have prevailed anong fowls.

Prince Edward.-The following is regarded as a fair estimate of the value of the losses anong farm animals in this county for the past year: Horses, $\$ 4,600$; cattle, $\$ 950$; hogs, $\$ 600$; sheep, $\$ 138$; aud fowls, $\$ 500$.

Richmond.-I have heard of no diseases worthy of reporting among our domestic animals and but very little among fowls. Fowls suffer most from the disease known as cholera.

Spottsylrauia.-Horses have suffered to some extent with pink-eye and distemper. A great many hogs have died of cholera and black-tooth. Cattle and sheep have been free from risease. Fowls have been afticted with cholera.

Tazewell.-The principal loss among eattle is cansed by a disease known among us as black-leg. The disease attacks the fattest animals only, and those that are attacked live bnt a few hours.

IFise.-Hogs are the only farm animals in this county that havesutiered during the past year with anything like a contagions disease.

\section{WEST VIRGINIA.}

Barbour.-No diseases prevalent among horses. Diseases among cattle are confined mostly to young stock. The loss among these animals has been quite heary, and will amount in value to over $\$ 7,000$. Cholera has prevailed extensively among fowls and has been quite fatal.

Berkley.-No destructive disease has visited any class of our domestic animals the past year.

Boone.-Losses caused among onr farm animals by disease dnring the past year have lieen very small.

Cabell.-Hogy cholera is about the only disease that has proved destructive tu ourfarm animals the past year. It is now prevailing and generally proves fatal.

Doddridge.-The following I regard as a correct estimate of the value of the losses among farm animals in this connty the past year: Horses, $\$ 100$; cattle, $\$ 3,375$; $\log 8$, $\$ 3,000$; shee $1, \$ 1,250$; and fow]s, $\$ 2,500$.

Fayette, - The only losses of conserueneosustained among any r.lass of farm animals by disease the past year have been among hogs.

filmer. - No contagious or epidenic diseaso has prevailed among any elass of dumestic animals in this comby the past your.

Gront. - A majority of the furm animals of this counts have maintained good health the past gear. There has been some eholera among both hoge and towls.

Greenbrier.-There have been some rases of prink-oye anomb horses and black-led among yearling calves. Hogs have suthered with a liscase supposed to be cholera. 
They have a congh and soon quit eating. Nearly all the young animals affected die. The disease seems to be coutined to localities where the logs feed on acorns. Cholera also prevails among fowls, and the losses have been quite heary.

Hardy.-Yery little disease among horses. Cattle have suffered with black-leg, bollow-horn, murrain, and foot-evil. Last spriug onr young hogs died of cholera in certain localities like flies. Sheep lrave died of rot, and a great many fowls of cholera. The following is regarded as a fair estimate of the value of the losses for the year: Horses, $\$ 800$ : cattle, $\$ 7,500$; hogs, $\$ 7,500$; sleep, $\$ 2,250$; aud fowls, $\$ 500$.

Ilarrison.-But few losses have occurred from disease among the farm animals of this county the current year.

Jackson.-Farm animals of all kinds are looking well. No contagious or infections disease has existed among them the past year.

McDoxell.-Our farm animals have escaped all fatal diseases during the past two years. Hog cholera appeared in some localities in the adjoining eonnty of Buchanan in the early part of the fall, but the area of infection has not enlarged.

Marshall. - There have been no losses from disease among any class of farm stock in this county which could be reliably estimated. Some eases of distemper have been reported among horses, but there have been few deaths.

Mason.-No contagious or epidemic disease has visited auy class of our domestic animals this sear.

Mercer.-No disease of a virulent type has prevailed among our horses, though an animal occasionally dies of distemper. Cattle have been affected with muraiu, hogs with cholera, and sheep with rot.

Mineral.-All classes of our farm animals are exceptionally free from disease of every kind. A few eases of cholera have occurred among hogs and forls during the sear.

Monroe.-The loss of hogs in a portion of this county has been considerable. The disease is similar to scarlet ferer, with more or less throat trouble. Some prarties have lost all, while others have saved a few auinals. Those that recover continue poor and worthless. The disease is varionsly pronounced scarlet fever, diphtheria, and a new kiud of cholera.

Morgan.-The only disease that has prevailed among any class of farm animals has been among hogs. Fowls have suffered to some extent with the usual maladies.

Monongalia.-Horses are frequently attacked with distemper, but animals rarely die of the disease. Cattle are subject to black-leg, which usually proves fatal. Sheep rlie of rot, and fowls of gapes and cholera.

Nicholas.-1lorses are oceasionally afflicted with a mild type of distemper. Cholera has destroged a great many hogs, bnt I have no means of ascertaining the number or value. Sheep have the rot, but that disease don't amount to mueh.

Plensants. - There have been no contagious or epidemic diseases among our farm animals. Some losses have occurred amoug sheep and fowls, bnt it is very diffienlt to value the loss.

Preston.-Dixty-three horses died in this county during the year of pnenmonia, and 27 of other diseases. A few eattle died of murrain, and some hogs of the msnal diseases. Grub in the head is the only thing that his aftlicted sheep.

lialeigh.-Hog cholera is the only disease of a contagions eharacter prevalent among farm stock in this county. It has heen quite destnuctive.

liandolph. - We have had no widespread disease among any class of onr domestie animals churing the year. A few cases of black-leg have oecured among cattle.

Pitchie.-Sitock is in nnusnally good condition and entirely free from disease.

lioane. -1 few hogs and quite a large number of sheep have died during the year of diseases incident to these animals.

Summers.-The only losses of conserpence anoner farm animals have ocenred arnong loges. I think I cam salfely estimate that 40 per ecut. of the total ummloce in the connty have died during the year. The disease is similar to swine plague as de- 
scribed in your Department report. 'The lungs were much discolored; there was swelling unler the jaws; weakness in the hinder parts, so that when they attempted to get up they wonld fall baekwarl. Mans persons lost overy hog they had.

Tyler.-Ocensionally our best and most pownising yearling ealves are attackerl and rlie of the disease known as black-leg. At least 90 per cent. of those attacked by this discase die.

Upshur.-Pink-eye has proverl fatal to some horses $j$ th this connty rinring the sear. Black-leg has been very destructive to young eattle.

Tebster.-No epirlemic diseases have prevailed among any rass of our lomestic animals this year.

Hetzel. -I find it impossible to promre the statistics yon desire.

IVyoming.-Hogs have sulfered with cholera during the sumurs and fall months. 'Fho disease has proved quite fatal. No treatment seemed to be of any serviec.

\section{WISCONSIN}

- Adams. - I have but a limited knowledge of the nmmber of tarm animals in this comby, and havenot the statistics at hand to answer your eireular letter intelligently. There are but few diseases ammug auy class, and I do bot think that over 1 per cent. of the whole number rlie of rlisease.

Burrom.-There ate no speeial disatises prevajling at this time among our farm animals, nor have there hen during the past year.

Browu.-All classes of lomestic animals in this comb yave remained exempt from infections and contagions rliseases this year.

Buffalo.-The losses among faru animals in this comnty eansed by discase have been exceelingly light the past year. Nothing like an epilemie has prevaled annong any elass.

Calumet.-No fatal disease has visited any of our farm animals during the past ten years; hence I have no report to make of losses.

Chippewa.-Some lung diseases bave prevailed among horses, but the losses have been very light. Farm animals generally are in good health.

Dane.- No diseases of any kind prevail among the domestie auimals of this comnty.

Dodge.-Pink-eye las prevailed anong lorses, lut it has rarely proved fatal. A cisse of supposed glanders ocemper ealy in the gear. Two valuable lorses were attacked, one of whieh was killed Before the other one was killed anotlier veterinarian deeided that the disease was not glauders, and took the horse in hand and soon enred lim. Ther has been no distase among other elasses of animals.

Dorr.-No diseases of a fatal cluateter have recently visited any class of omr domestic animals. A few forls died with the cholera during the smmmer months.

louglas. - There is no disease brevaling anong onr farm animals, nor has there luen the past year. Our fowls, when powerly eared for, are remarliably lualthy.

Duun.-All our farm animals are exceptionally liealthy. With the "xception of horeses which dic from neglect, old acre, acc, the losses are so faw that they are hardly wortlı mentioning.

Ean rlaire.-No infeetions or coutagions diseases bave prevailed among our furm stork or fowls during the jear.

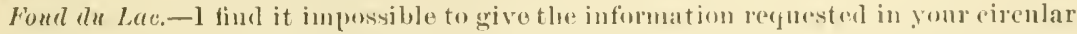
litter.

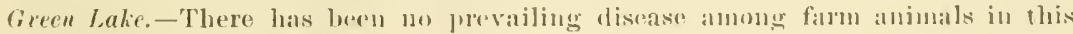
comuty during the past year-not that all animals are in perfiet lualth, but there

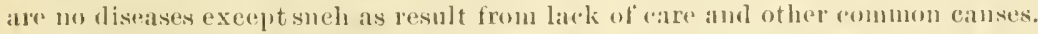

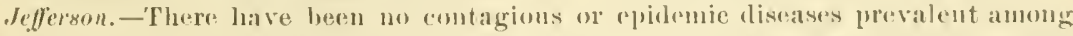
farm stuck in this county during the past year. Jhe mortality has, therefore, hren no greater than eould be looked for among lowithy stock.

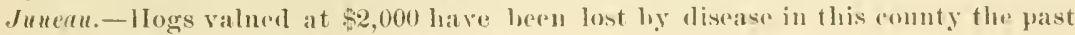
year. A great many fowla have also diod of the rarions diseases incident to them.

$$
5751 \text { D } A-23
$$


Fenosha.-No futal diseases have been reported as prevailing among farm animals in this county the past yrar.

Kewaunce.-No losses worthy of reeord have occurred among any class of our farm stoek fluring the pist year.

La Fayette.-No evidemic disease has prevailed during the year among horwes, cattle, hogs, or sheep. Fowls are suffering with cholera to some extent; perhaps 2 per eent. have heen afficeted.

Marquetc.-Some few horses aud eattle have died during the year, but hogs and sheep have remained hoalthy.

Pierce.-A great many horses have been attacked by distemper, and several eases have proved fatal. Pink-rye prevailed quite extensively among these animals last rear.

ir Polk-The past gear has been one of more than usnal health among all elasses of farm,animals in this county.

Racine.-Farm animals generally have done well the past year. I have uo means of ascertaining the vahe of the losses.

Richland.-I hear of the prevalenee of no diseases among stock except pink-eye in horses. A great many of these animals are blind or nearly so. The disease is not often firtal.

Sauk.-The diseases of borses are mostly caused by overwork. Hogs in one locality have been aflicted to some extent, bnt the losses have not been very great.

Sheboygan.-No epidenic of any kind has appeared anong onr domestie animals the past year. That our comty is so exceptionally free from all animal plagnes is in a great measure owing to the stringent regulations of our connty dairy assoeiation.

Trempeateau.-The only contagious disease that has prevailed among any class of live stock the past year has been horse distemper. There have been some losses from this disease.

Ternon.--Horses have heen afflieted with distemper, and cattle with beart disease, or dry murain, and black-leg. Swine plagne has prevailed ynite extensively, grul, in the hearl has cansed the death of a great many sheep, and ehol ra bas prevailed to some extent anong fowls.

Waukesha.-All kinds of farm animals are in exeellent health. No unusual or epidemie disease has visiterl them during the year.

\section{THE TERRITORIES.}

ARIZONA.

Apache.-Aside trom eattle and sheep there are but few farm animals in this eounty There are 12,000 of the former and 300,000 of the latter. The comty is better alapted. to sheep raising than angthing else. Both eattle aud sheep are in good health.

Yavapai.--No eontagions diseases have visited any class of farm animals in this comty the past year.

\section{DAKOTA.}

Auroik.--This connty has been organized but thirty months, and the fow farm animals we have were bronght in from the States. All elasses have been very healthy. It is reported that in the extreme sonthwesteru part of the county a peculiar ciisease has attacked the horses, cansing the death of two or three animals. The symptoms ares similar to an attack of hiceongh.

bun Homme.-I have no losses of eonsequence to report as having oceurred from clisease among our farm animals for the past jear.

Brulé--A good many horses died in this comnty during the year, hut none with infections or contagions rliseases. Hard work, no stables, long rrives, poor eare, and in some eases poor water, all eombined make the fitality serions. Black-leg or an- 
thrax prevailed to some extent among cattle in the sonthwestern portion of the county. The disease was quite fatal.

Cass.-The furm animals of this comby have remained exempt from all infections and contagions diseases during the year.

Clay.-No epidemie diseases have previled anong onr farm animals during the luast year. An oceasional death has occurred, but always from natural or aceidental causes.

Codington.-All classes of domestie animals, with the exception of horses, have remained healthy throughout the sear. A correspondent at Watertown reports granlers as prevalent in his part of the county. He says there are probably 50 horses affected with the disease at this time. It proves fiat in almost every calse.

Charles Mix.--Horses have been healthy. A disease has prevaled among mules which has proved fatal iu almost every instance. The disease is callen meningitis, but nobody really seems to kinow anything about it. Some spring ealves and a few yearlings have been lost by a disease kuown as black-leg.

Dencl.-Horses, sheep, cattle, and hogs, where well taken care of, have been exceptionally healthy. Onr feeding phees are high and dry, and eondueive to health.

Faulh:-This connty was only organizerl abont one month ago, therefore we have no statistics as to numbers of animals or value of losses. I have heard of no fatal diseases among auy class.

Grant.-It may seem like a strange report, to say that there have beeu no losses among farm stock in this county during the year, but such is literaliy the fact. The county is new, and the stock young, vigorous, and healthy.

Hamlin.-The only losses that have oeeurred during the year among onr farm animals have heen among horses and sheep. These losses have been quite light, and were not eaused by any epidemie disuase.

Hand.-We have but a small number of domestic auimals in this eomty. No musual lisease has prevailed among either class or amoug fowls the enrent year.

Hutchinson.-There has been no general disease among domestie animals during the your. Casi s of sickness are generally brought on by exposme or neglect. Three or fomr eases of so called black-leg that I investigated appeared to be intlammation of the lungs. Farmers are abandoning sheep raising.

McCook,-A great many horses have been affected with a dropsical disease, which seems to have proverl fatal in some cases. Black quarter has affected the eattle to a consilerable extent. It has been mostly eonfined to ealves, yearlings, and two-yearolils.

Minnchuha.-A rew eattle have been affected witl the big jaw, or swelling of the jaw and throat. Our heaviest losses among eattle have ocenred from black-log.

Morton.-The only disease of a contagious character among anf class of faru animals is that known as seal, among sheep. It prevails only in one thoek-a drove of 2,000 head, bronght from Minnesota in Oetober.

Samborn.-No losses are reported as having ocemred among the domestic animals of this eomnty during the year.

Spink.-I have uo facilities for p'roeming the information asked for by your eircular lettir.

Stutsman.-This comnty has heen but recently organized, and we have but a limited number of farm animals as yet. There aro no contagious diseases prevalent. Exposme to inclement weather 'ansed the death of alout 5 per eent. of the sheep of the conuty, liast wintrr.

Turner,-Some pink-rye bas pevailed anong horses, hut no deaths lave resulted. Other classes of animals are healthy.

IIalkh.-No diseases worth mentioning are previlunt anoug any kinds of live stock.

Funktom,-1 estimate the value of the farm animals and fowls lost in this comty the past year as follows: Horses, $\$ 12,000$; cattle, $\$ 2,400$; hogs, 83,000 ; sheep, $\$ 150$ and fowls, sili. 


\section{MONTANA.}

Gullatin.-Theres have been some deaths amoug horses eansed by tistemper and purumonia. There has been some scab among sheep, but the losses have been light. Hog rlikeases are not known liere.

Letris and Clurke.-All classess of domestic animals are healthy and free from destructive clise:ases.

\section{NEW MEXICO.}

Grunt.-In May last a discase supposed to be black-leg broke ónt among calves in this connty, and carried off all attacked. In September 'Texas fever was brought into the comnty by a herd of Texan cattle. Fully 500 head of cattle were destroved by the disease. Inring the summer months cholera destroyed a large number of furls.

Suntu Fé-I find it impossible to furnish the information desirerl by the Department.

Son Miguel. - A number of horses have been poisoned and died from eating the loco weed. We have 100,000 hearl of eattle and 500,000 head of sheep in the connty. I do not think the annul losses among these animals from all eanses will exeeed 2 per eent. A grrat many of these animals havedied from eating the poisonons loen weerl. In some localitiess litis weed does not seem to affect stock.

['TA11.

Bor Elder.-No destructive diseases among omr farm animals this year. Last year 50 horses died of the discase known as pink-eye, and 150 heal of yearlings of horned "ilttle died of hlack-leg.

Ineris. - I latie no means of ascertaining the number of farm animals in this connty. I have heard of no cliseases proviliug among them.

sult Lahe.-A few horses have died during the year of clisease. This is a very healthfinl emuty for stock, and if the animals were properly proteeterl and eared for the losses wonld be nominal. Scal is the only disease that tronbles sheep. Putrid fever has prevailed to some extent amoug eattle on the ranges.

Millard.-This is a very good climate for stock, and the mortality is never very great among any elass from epidemic diseases.

Morfan.-Horses and horned eattle do rmmarkably well in this county, aurl are ravely visited by epiclenie diseases. Cholera and black teeth are the prevailing diseases anong hogs. There is some scab anong sheep and the usual diseases among fowls.

Toerele-The value of the losses anong all classes of tarm animals in this comnty from disease the past year will not exceed $\$ 2,000$.

\section{WASHINGTON.}

Asotin - We have the disease known as pink-eye among horses. It reems to be (puite variable in its fatality-to repend, to a eousiderable extent, npon the range. some cases of black-leg have occured among roung cattle, with invariably fatal results. 'This is a new county, formed fiom a portion of Garfield and Columbia conuties.

Cullohan.-Onr farm animals are in good health, and I have no losses to report form disease for the curmut year.

(iarfeld.-Pink-eye prevails among horses, but generally in a mild forus. Rest and turning ont to grass has been fouml the most sucerssful treatment. Black-leg prevals anomg cattle, but is generally confiued to yomng stock. Hogs are never diveased in this locality.

Islend.-There las been no epidemic among farm animals here. liowls, however, are fregnently troublecl with a disease that causes the cleath of numbers of them, 
both at maturity aud while young. Early spring turkers have a stiffening of the joints of the legs that soon eanses death. It is apparently a kind of rheminatism. Those hatched late eseape the tronble. I have been latehing by artiticial means the past season. As a result, I fiud a chicken's future is determined by its first three weeks of care.

San Iutn.-There have been twelve fatal eases of black-leg anong calves in this locality. Bleeding in the early stages of the disease has been found heneticial. A few fowls have been lost, hut with no marked disease.

spokiane.-Horses in this comnty are frequently afteeted with glanders, distemper, and other nasal diseases. Black-toot is the only disease that ever attacks our cattle. Diseases among swine are not known.

Therston.-I have no losses to report among farm animals or fowls for the past sear. All seem to be healthy and in fine order.

Wahkialum.--I an glad to be able to say that no diseases of any kind prevail anong our farm auimals, consequently I have no losses to report.

Whatcom.-No diseases of a tatal character have prevailed amoug any class of our domestic animals for some gears past.

Whitman.-Some few eases of anemia and pink-ege have oecmred among horses, but not more than 5 per eent. of those attacked have died. No other class of stock bas suffered with discase.

WX'MIITG.

Albany. - No disease of consecfuence has prevailed among horses or eat the this year. Sheep have been afflicted with scib. Animals valued at $\$ 1,1: 25$ have been lost by this disease.

Johnson.-The prevaleut disease among our horses is called pink-rye, which occasionally proves fatal. This is a grazing county, and contains some 200,000 head of cattle of all ages. A few of these animals have been affected with swollen jaw. As a general thing they have been healthy, and the value of the losses will not exceed $\$ 5,000$ for the year. Scah has prevailed in sheep, but the losses have been light.

Cintah.-There has been 110 epidemic or fatal disease among farm animals in this comnty for some years past. Scab in sheel oceasionally eauses a small loss. 



\section{N D E X .}

Abortion in eows.

Page

Agriculture, statement prepared for Honse Committee on ..............

Alabama, general eomlition of farm animals, $1883 \ldots \ldots \ldots \ldots \ldots \ldots \ldots \ldots$.

American hogs, proportion triehinosed . . . . . . . . . . . . . . . . . . . . .

in Germany - . . . . . . . . . . . . . . . . . . . . . . . .

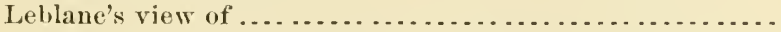

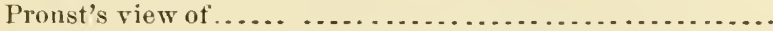

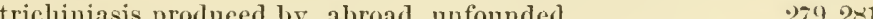

Analises of American and Enropean salts . . . . . . . . . . . . . . . . . . .

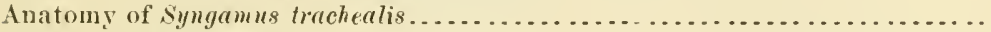

Animail diseases that are contagious . . . . . . . . . . . . . . . . . . . . . .

their relation to human health .....................

industry at the Hamburg International Exhibition ..............

Animals of the farm. (See Farm animals.)

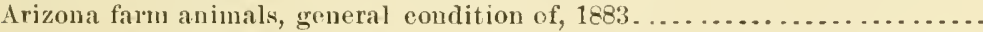

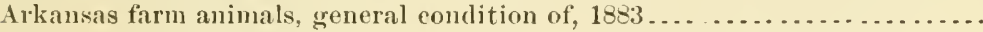

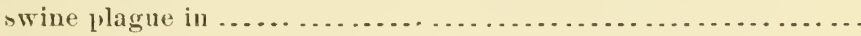

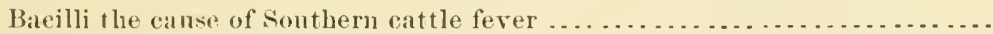

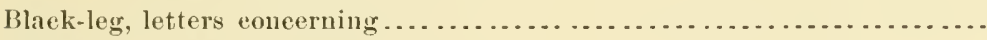

Breeding horses in La Perehe, France...........................

Brevels of eattle in England ... . . . . . . . . . . . . . . . . . . . . . . . . .

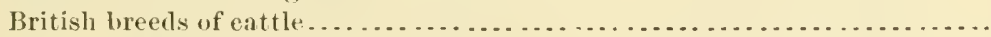

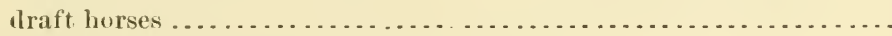

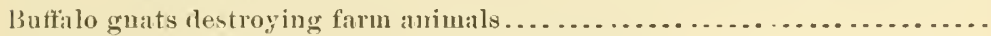

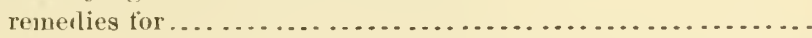

253

291

18.3

193

193

198

2.17

299

305

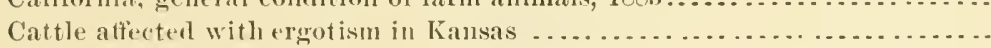
at the Hamburg International Exhibition $\ldots . . . . . . . . . . . .$. British breeds of . . . . . . . . . . . . . . . . . . . . . . . . . .

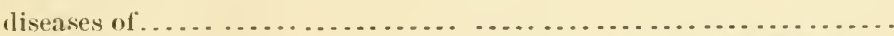
exposed to pelnro-pmemunia ausl slaughtered in l'enusylvania, table of: fever. (See Sontheru eattle fever.)

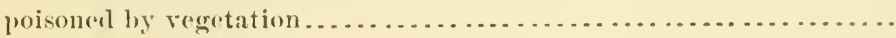

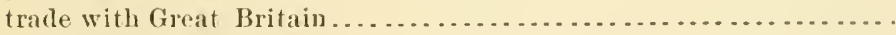

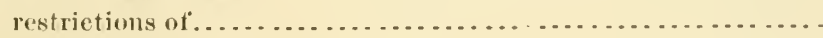

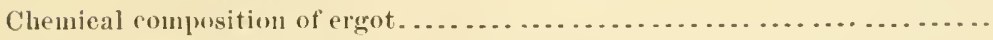

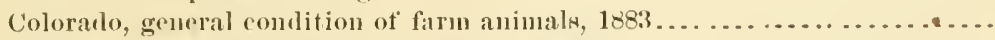

Connecticut, gromemal eomlition of farm animals, $18.33 \ldots \ldots \ldots \ldots \ldots \ldots \ldots . .$.

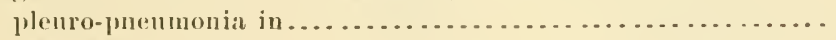

Corstitutional symptoms of foot-and-month disease ...................

Consumption. (See Tulureulosis.) 
Contacious animal eliseases, by Dr. E. Ml. IInut

laboratery for the invertigation

Contagions plenro-puenuouia. (See Plemo-pmeumonia.)

Contagiousuess of foot-and-mouth disease ... . . . . . . . . . . . . . . . . . . 37

Cooking, efficet of, on trichine ................................

Corresponelents, letters firom ................................. 291

on abortion in rows. ........................... 294

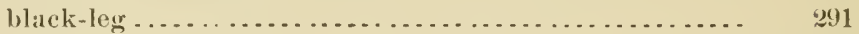

impaction of manifoli......................... 295

pleuro-pnenmonia ... . . . . . . . . . . . . . . . . . .

poisonous vegetation ......................... 296, 29. 297

tubereulosis . ................................ 294

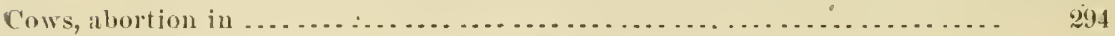

Cultures of the micrococeus of swine plague . . . . . . . . . . . . . . . . . . 85

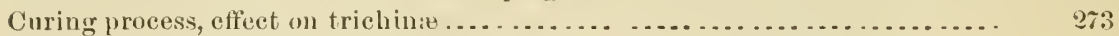

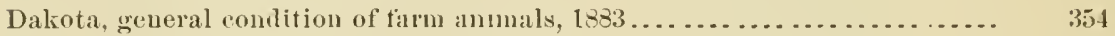

Danger from contagrous plenro-pnemuonia........................ 18

Deaths from contagious pleuro-pnemmonia in New Jersey . . . . . . . . . . . . 15

Peunsylvania.............. 14

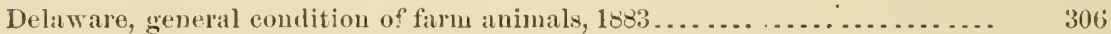

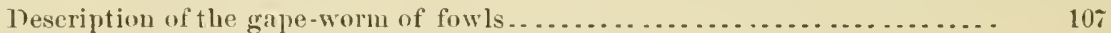

Detmers, Dr. H. J., report on Sonthern cattle fever . . . . . . . . . . . . . . . 247

Difierential diagnosis of contigious plenro-pneumonia . . . . . . . . . . . 134, 140, 141

Disease of fowls cansed by the gape-worn . . . . . . . . . . . . . . . . . . . . . . $10 ; 3$

Diseases of animals that are contagions. . . . . . . . . . . . . . . . . . . . . . 260

Distribution of Sonthern cattle fever ... . . . . . . . . . . . . . . . . . . . . $\quad 70$

District of Columbia, contagious pleuro pneumouia in . . . . . . . . . . . . . 6

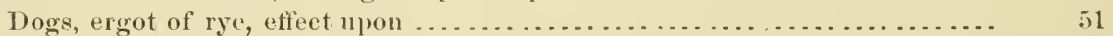

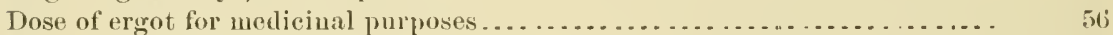

Draft horses, freuch ....................................... 1<1

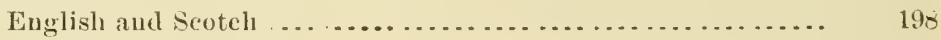

Euluation in veterinary medicine ............................. 146

resolutions of the International Veterinary

C'ongress . . . . . . . . . . . . . . . . . . 153, 179

24,28

275

Emersleben epidemic of trichiniasis . . . . . . . . . . . . . . . . . . . .

Euzootics of ergotisu . . . . . . . . . . . . . . . . . . . . . . . . . . . . .

Epizootic aphtha. (See Foot-anc-mouth disease.)

Ergot, action on animal hoty

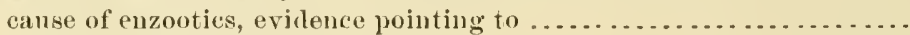

chemical composition . . . . . . . . . . . ....................

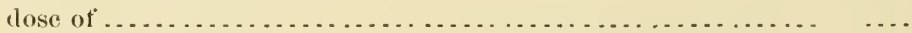

fool, pereentage in ..................................

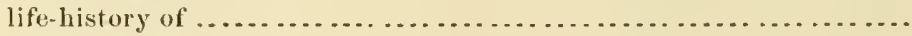

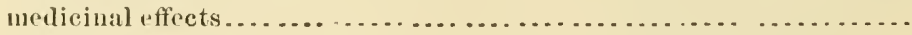

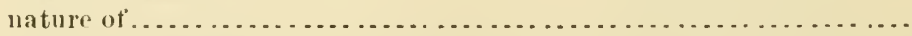

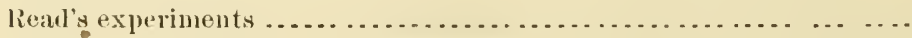

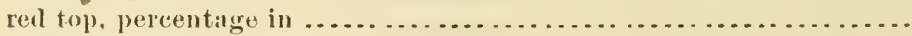

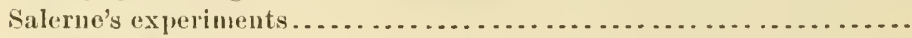

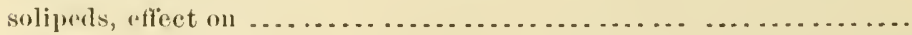

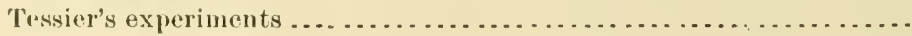


Ergot, toxic effects of.

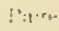

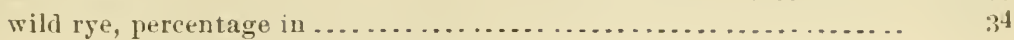

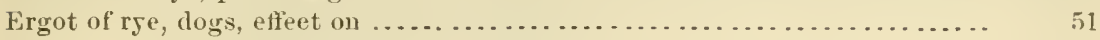

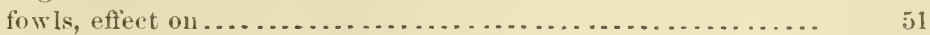

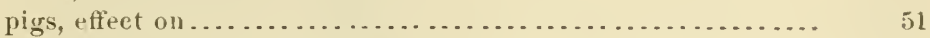

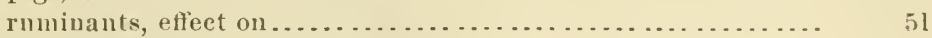

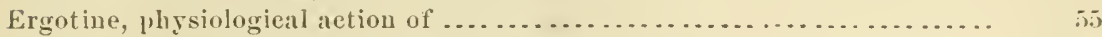

Ergotism anong eattle in Kansas.............................

condition of eattle attackerl ........... 30

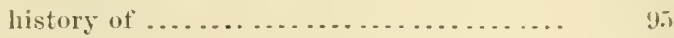

Ergotisn, enzooties in the West ............................... 21 as distingnished from foot-and-month disease. $\quad 36$ fonl-in-the-foot ...... 41 conditions fal vorable to ............... $4:$ ? gangrene in ........................ 32,33 mouth symptoms in ................ 32,40 objections to theory of $\ldots . . . . . . . . . . .4$ oeenring at the same time on widely sepal-

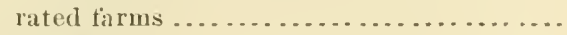
pereentage of ergot in food .............. udider, eruption on the..................

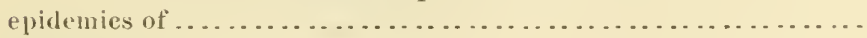

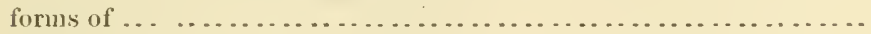

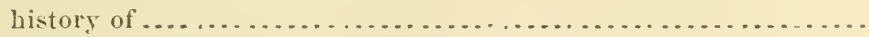

in New York ... . . . . . . . . . . . . . . . . . . . . . . . . .

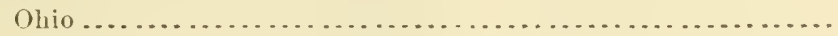

Penusylvania.......... .........................

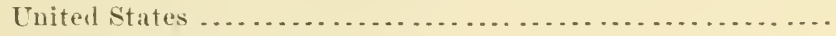

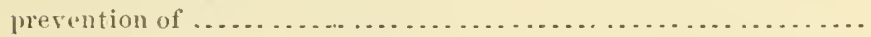

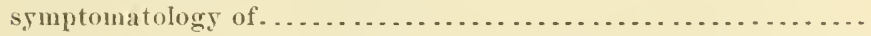

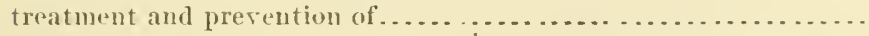

Europe, history of ergotism in . . . . . . . . . . . . . . . . . . . . . .

European hogs, preentage trichinosed . . . . . . . . . . . . . . . . . . . .

Experiments with virus of swine plague $\ldots \ldots \ldots \ldots \ldots \ldots \ldots \ldots \ldots \ldots \ldots$.

Expori cattle tralle with Great Britain . . . . . . . . . . . . . . . . . . . . . .

Extermination of plenro-pnemmonia by the Government of the United States, arlvantages of

Farm animals destroyed by butfalo-gnats. general condition, 1803

in Alabinlla .....................

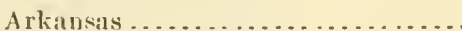

Arizona1 ....................

California ...................

Colorado .....................

Conneetient .................

Daliota... . . . . . . . . . . . . . .

Delaware...................

Florirla . ......................

Georgial ......................

Illinois . . . . . . . . . . . . . . . .

Indiana ..................

Iowa ....................

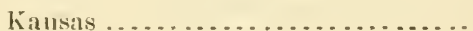

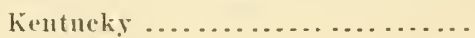


Farm animals, general condition. 1883, in Lonisiana $\ldots . . .20$.

Maine ........................ 324

Maryland ...................... 324

Massachusetts .................. $\quad 325$

Michigan ..................... 325

Minnesota .................... $32 \tau$

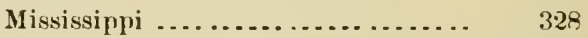

Missonri..................... $\quad 330$

Montana .................... $\quad 356$

Nebraska................... $\quad 332$

Nevarla...................... 333

New Hampshire ................ $\quad 333$

New Jersey .................. 3333

New Mexico ................... $\quad 356$

New York .................... 334

North Carolina ................. 336

Ohio ....................... $\quad 338$

Oregon ...................... $\quad 340$

Pennsylvania................. $\quad 341$

Rhode Island ................. $\quad 342$

Sonth Carolina .................. $\quad 342$

Tennessee .................... 343

Texas ....................... $\quad 346$

Utah ....................... 356

Vermont ..................... $\quad 349$

Virginia..................... $\quad 349$

Washington Territory ............ $\quad 356$

West Virginia ................. 351

Wisconstn .................... 353

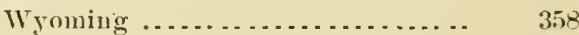

Feeding animals with tuberenlar matter ........................... 165

Feet symptoms in foot-and-mouth disease ........................ 40

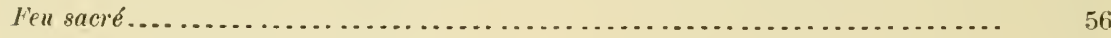

Fever. (See Southern cattle fever.)

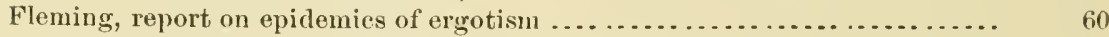

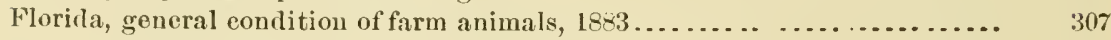

Food, condition of, in the Western enzootics of ergotism ................ 34

Foot-and-mouth disease ........................................ 264

contagionsness of.......................... $\quad 37$

distiuguished from ergotism.................. $\quad 36$

in Great Britain ............................ 198

nature of ................................. 36

supposed ontbreak of, in Kansas................ 21, 89

symptoms of .............................. $\quad 39$

Foot-rot, symptoms of .............................................. 41

Fonl-in-the-foot distingnished from ergotism ........................ 41

Fowls, ergot, effect on .......................................... 51

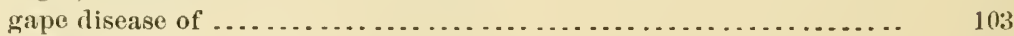

French draft horses ........................................... 181

pleuro-pneumonia commission, results of experiments........... 19

Gangreno in the Western enzootics of ergotism .................... 32,41

Gape disease of forls, history of . ............................... 104

means of arresting........................ 117, 119 
Gape-worm of fowls, description of .

Page

development of .

destruction of .

embryo of

larva of.

Geographical distribution of Sonthern cattle fever ...................

Georgia, districts infected with Sontheru cattle fever ................

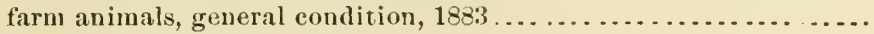

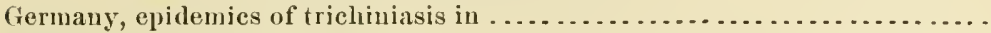

Glanters and farcy in Now Jersey . . . . . . . . . . . . . . . . . . . . . . . . . .

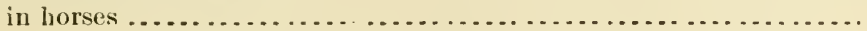

Hamburg International Exhibition

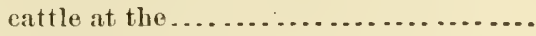

horses at the ...................

sheep at the.....................

198

swiue at the ...................... 188

Heredity as a canse of tuberculosis

History of ergotism anong eattle in Kinsas ......................

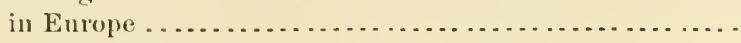

the United States...........................

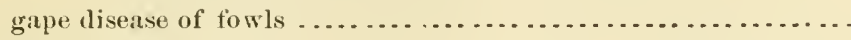

21,95

Hog cholera. (See Swine plagne.)

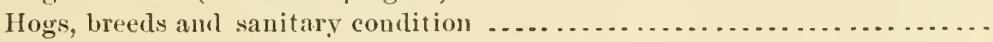

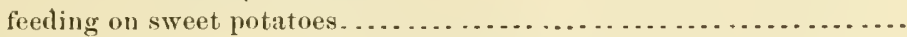

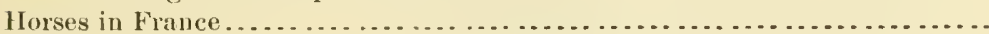
at the Hamburg International Exhibition .................. 186, 200 poisonerl by vegetation .................................. 297

Hngues' report on education in veterinary medicine .................. 146

Huilekoper, Dr. R. S., report on the Hamburg International Exhibition .... 199

Hunt, Dr. E. M., contagrions animal diseases . . . . . . . . . . . . . . . . . . . 260

Illinois, enzootic of ergotism, condition of food ................... 35

syujptouns.......................... 40

general condition of farm animals, $1883 \ldots \ldots \ldots \ldots \ldots \ldots \ldots \ldots \ldots \ldots . . \ldots \ldots$

Impaction of the manifold .................................... 295

Indemnity for diseased cattle.................................. 146

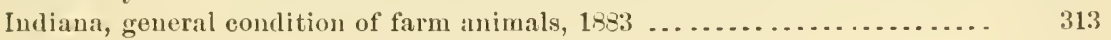

Ineficiency of State action in regard to plenro-pnennonia . . . . . . . . . . . . 19

Infection of pastures with virus of Sonthern eattle fever . . . . . . . . . . . . 250

lnoculation with virus of foot-and-1110ntl disease ... . . . . . . . . . . . . 265

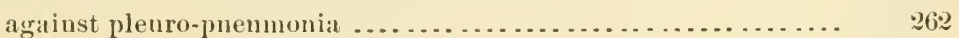

results of ....................... 18

with virus of swine plague.......................... 84

Inspection of exported cattle, necessity of . . . . . . . . . . . . . . . . . . . . 199

International Veterinary Congress of $138: 3$, report by Dr. Law . . . . . . . . . 12:2

plinro-putenmonia of cattle..... $1: 34$

tuberenlosis .................. 157

veterinary service ............ 122

International veterinary service, prineiples of an .................. 130

Investigation of contagions diseases, importance of . . . . . . . . . . . . . . 20

Iowa, general eondition of firm animals, $1883 \ldots \ldots \ldots \ldots \ldots \ldots \ldots \ldots \ldots \ldots . . . \ldots \ldots$

Kansas, ergotism among cattle in ........................... 21,89

brief history of ................... 25 

ergot as a cause .....................

fool, condition of ................... (See also Ergotism.)

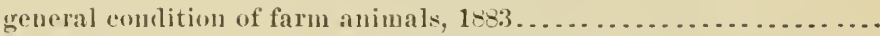

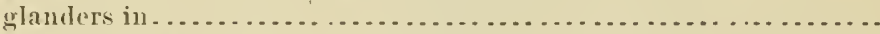

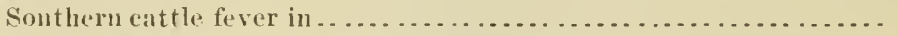

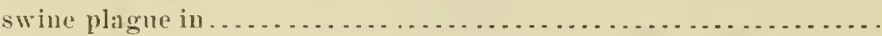

Kentucky, general condition of farm animals, $188.3 \ldots \ldots \ldots \ldots \ldots \ldots \ldots \ldots$.

Kirksville, outbreak of disuase in ............................

Klein, Dr, investigations of swine plague.....................

s.tge.

Laboratory for the investigation of contagions cliseases ................ Law, Dr. J., report on the Interuational Veterinary Cougress of 1833..... Leblane's views of plonro-pnenmonia . . . . . . . . . . . . . . . . . . . .

Letters from correspondents concerning animal diseases . . . . . . . . . . . .

Losses from plenro-pneumonia in the United States anmally ...........

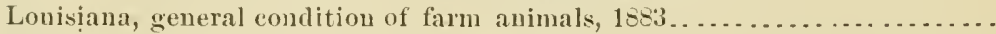

Lung plague. (See Plenro-pneunouia.)

Lydtiu's resolutions coneerning tuberculosis in animals . . . . . . . . . . . . .

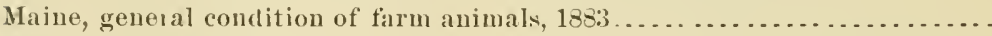

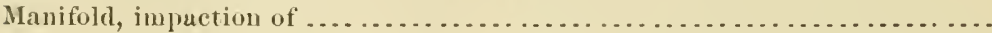

Maryland, general comlition of farm animals, $1-8,3 \ldots \ldots \ldots \ldots . . . . . .$. plenro-pnemmmia in . . . . . . . . . . . . . . . . . . . . . .

Massachusetts, general contlition of farm animals, 1883..............

Meat of tubereulons animals, laws against nse of . . . . . . . . . . . . 168, 17:, 174

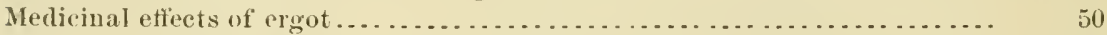

Megnin, P., galpe disease of fow ls . . . . . . . . . . . . . . . . . . . . . . . .

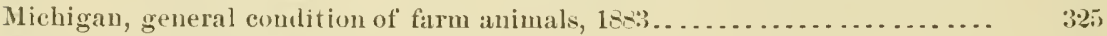

Microbe of swine plagne .................................... 79,85

Milk of tuberculons animals, danger from ........... . . . . . . . . . 171, 174

Mimesota, general condition of farm animals, $1883 \ldots \ldots \ldots \ldots \ldots \ldots \ldots \ldots \ldots . .327$

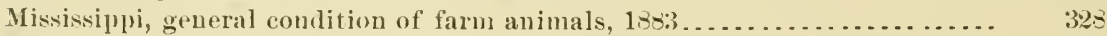

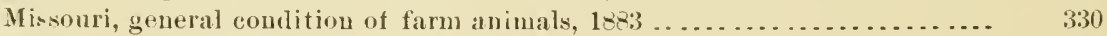

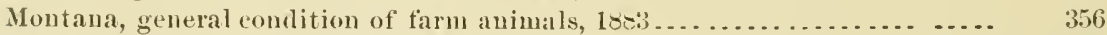

Month symptoms in the Western enzooties of ergotism . . . . . . . . . . . . .

foot-and-month disiase.................... 39

Nebraska, general condition of farm animals, $1803 . \ldots \ldots \ldots \ldots \ldots \ldots \ldots \ldots . . . \quad 332$

Nroslia Falls, ontbreak of supposed foot-aud-month disease ..........21, 25, 37,89

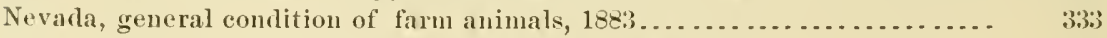

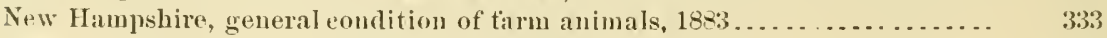

New Jersey, general condition of farm animals, $1383 \ldots \ldots \ldots \ldots \ldots \ldots \ldots . \ldots . . \quad 333$

contagious plenro-pnenmonia in .................... 14,293

glauders and farcy in . . . . . . . . . . . . . . . . . . . . . . . 267

Now Mexico, farm animals, general conlition, $1883 \ldots \ldots \ldots \ldots \ldots \ldots \ldots \ldots \ldots . .556$

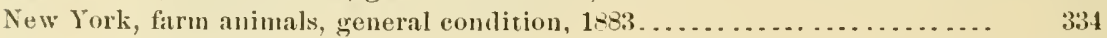

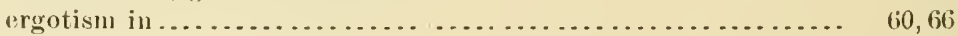

North Carolina, districts infected with Sonthern cattle fever............ 75 farm animals, general condition, $18-3 \ldots \ldots \ldots \ldots \ldots \ldots \ldots . . . . . . .336$

Objections to the theory of ergotiom in liansas answered . . . . . . . . . . 42

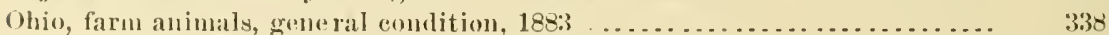

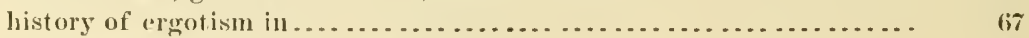

Oregon, general condition of farm animals, $1 \times 33 \ldots . . . \ldots . . . . . . . . . . \quad 340$ 
Packing, salt 11 sed in

Parasitic disease of fowl

Pasteur's investigations of swint ylague . . . . . . . . . . . . . . . . . . . .

Pastures, theories as to the infeetion of, with Sonthern cattle fever........ 250

Pathologieal anatomy of tuberenlosis........................... 160

Penusylvania, cases of plenro-puenmonia in ....................... 12

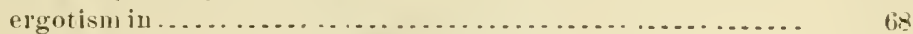

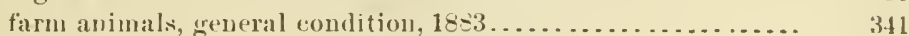

Perriot, E., on breeding hor'ses................................ 1 . . . .

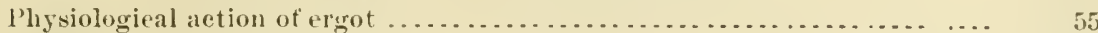

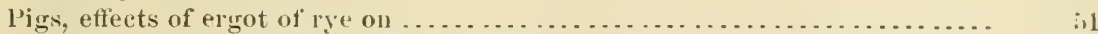

Plemo-pneunonia (contagions), annmal losses in the United States fiom .... 20

in the Atlantie States, reasons for believing in the existence

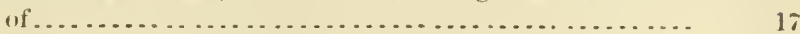

Connecticut .............................. 10

contalgiousness of ............................. 141

langer from, greater than the extent of infected territory

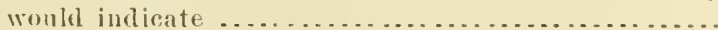

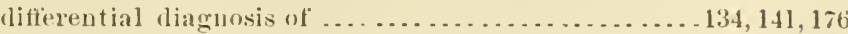

liscussed by the Interuational Veterinary Congress... . . 13.1, $176^{\circ}$

iu the Distriet of Columbia .................... 6 , $;$

extermination by the Govermment of the Cnited States, adrantages of .............................. 20

indemnity for diseased eattle .................... $146^{\circ}$

inoculation against ........................ 135, 141, 143, 26: advautages and disadvantages ...... 137 in Tew Jersey .................... 14

insidious nature of ......................... 125

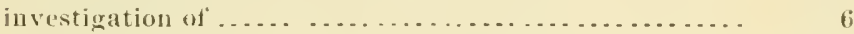

Jusstes firmu ..................................... 128

in Maryland ................................... 15

New Jisey ................................ 14, 293

pathologrs ut, acoldiug to Degive.................. 136

in L'ennsylrania, number of eattleexposed and slanghtered . 12, 13, 14 prevention of, rules for the ....................... 1:35, 143 preventive inoeulation to he absolutely rejected ........ 144 staupiug ont, means ot........................ 143

statement prepared for the Honse Coumittere on Agrienlt-

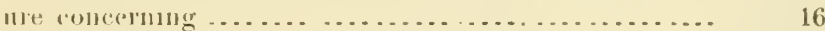

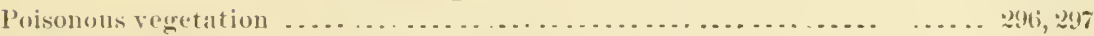

Pork, examination of, tor trichinat : . . . . . . . . . . . . . . . . . . .

fro.ll the Unite I States in Germany ........................ 10

Prevention and treatment of regotism .......................... t9

of trichiniasis in swint . . . . . . . . . . . . . . . . . . . . . . .

Preventive measmes in the consmuption of milk and meat of tuberenlous

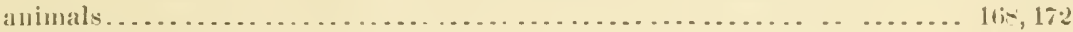

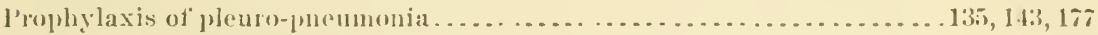

Proust's statement concrining Amejican pork . . . . . . . . . . . . . . . . . 27t

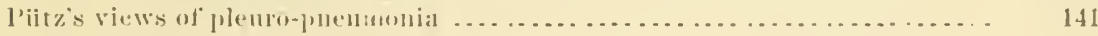

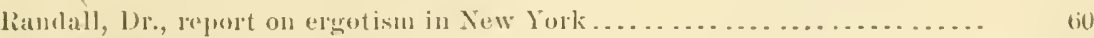

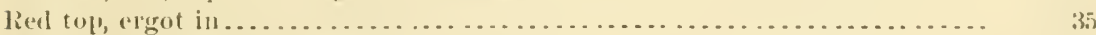

lied worm. (sec Gaje-worm.)

Resuedies. (sec Treatunent.) 
Remedies for buffalo gruats

Resolutions proposed and adopted at the Interuatioual Veterinars Courress. 1.24, 176

Rhode Island, general eondition of furm animals, $1883 \ldots \ldots \ldots \ldots \ldots \ldots \ldots \ldots \ldots . . . \ldots$. . . .

Ruminants, effect of ergot of rye on .......................... 51

Salmon, Dr. D. E., investigation of swine plague.................. 78

report on enzooties of ergotism.................. 21

plenro-pnenmunia .......................

Southern eattle fever ....................

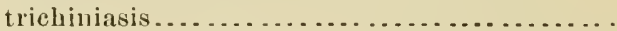

Saliva as the infeetive agent in Sonthern eattle fever .................

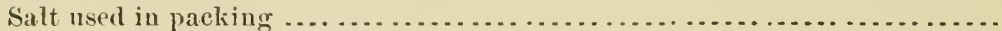

Salts, analyses of . . . . . . . . . . . . . . . . . . . . . . . . . . . . .

Sinders, J. H., report on the Hamburg International Exhibition ...........

Sheep at the Hambnrg International Exhibition ... . . . . . . . . . . . . .

a new disease among...................................

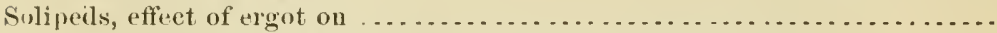

South Carolina, districts infected with Southern eattle fever............

farm animals, general condition of, $1883 \ldots \ldots \ldots . . . . . .$.

Southern cattle fever, report of Dr. H. J. Detmers . . . . . . . . . . . . . . . .

bacilli as the cause of . . . . . . . . . . . . . . . . . . . .

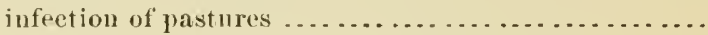

iufeetions principle, relation to food ..............

saliva the intective agent of ...................

report of Dr. D. E. Saluon ....................

its advanee................................

in Georgia, line of infeeted distriet ..............

North Carolina, line of infected district ..........

South Carolina, line of infected district...........

Tennessee, line of infeeted district.............

Virginia, line of infected district ..............

Kansas .............................

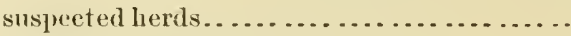

table of eattle exposed ................. 2:36, 244

State action, inefficieney in controlling plenro-pnemmonia..............

Statement concerning pleuro-pnenmonia prepared for the Honse Committee

on Agrienlture..........................................

Steel on foul-in-the-foot ....................................

Stickler, Dr. J. W., experiments with virus of foot-and-mouth disease.....

Stud-book of Pereheron breeders . . . . . . . . . . . . . . . . . . . . . . .

Swine at the Hambur.y International Exhibition . . . . . . . . . . . . . . .

perceutage of Ameriean and European trichinosed . . . . . . . . . . . .

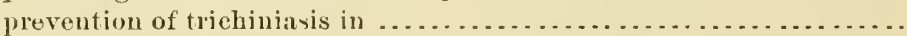
(See also Hogs ; lork.)

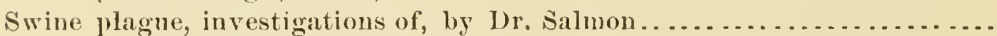

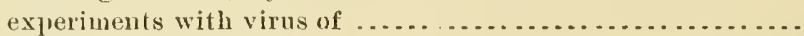

Klein's investigations of . . . . . . . . . . . . . . . . . . . .

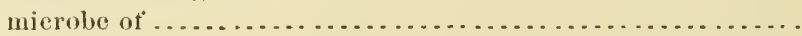

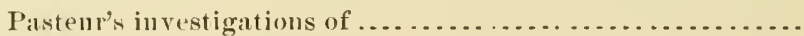

pure eultures of virus of . . . . . . . . . . . . . . . . . . . . .

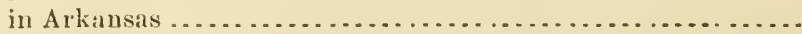

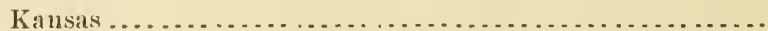

Symptoms of the diseased animals in the hansas enzootic ............. 
auong eattle in Kansas ..................... 90

foot-and-month disease and of Western enzooties compared....

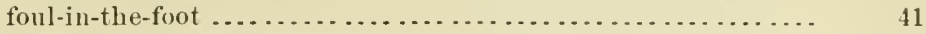

syngamus trachealis. (See Gape-wornı.)

Table of the number of cattle exposed to plenro-pnemmonia and slaughtered in

P'musylvania.................

Sonthern cattle fever in Kansas.... 2:36,:241

stables exposed to pleuro-pneumonia in Maryland ........... 15

Tabourin on the action of ergot ............................... 50

'lennessee, distriet infeeted with Southeru cattle fever . . . . . . . . . . . . 76

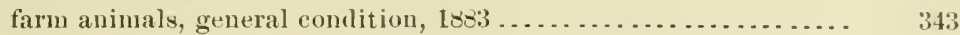

Tessier's experiments with ergot ........ . . . . . . . . . . . . . . . . . . . 49

Texas cattle fever. (See Sontheru cattle lever.)

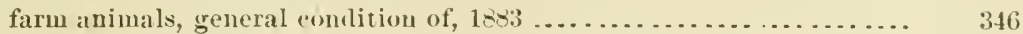

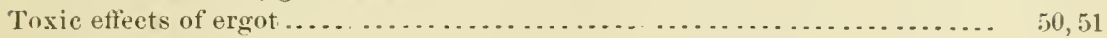

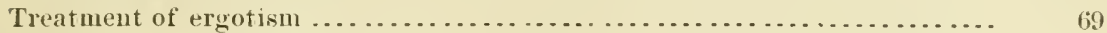

gape disease in fowls ................................ 117

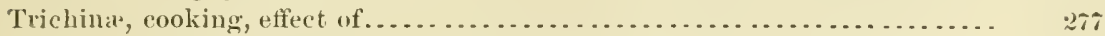

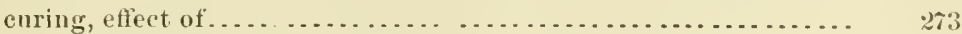

in Ameriean and European hogs..................... 270,27\%

life history of....................................

Trichiniasis, report hy Dr. Salmon . . . . . . . . . . . . . . . . . . . . . .

iu man, reports of boards of health on ................ 28.3

cases of, in foreign countries ................... 280

the United States ................... 283

epidemies of, in Europe..................... 28.

swine, cause and prevention of .................... 286

Trumbower, Dr. M. R., report on ergotism among cattle in liansas........ 89

Sonthern eattle fever in Kansas ......... $20 \%$

Tubereulosis in animals, bacillus of .......................... 166

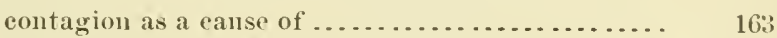

feeding experinents ..................... 165

forms of .............................. 159

heredity as a cause of ..................... 16.

idlentieal with tnbereulosis in man ............. 167

laws against the use of meat................ 169, 174

lesions of .................................... 160

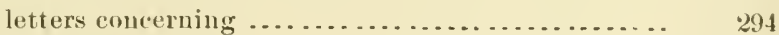

milk, danger from ......................... 171, 174

in New York City ....................... 16.

resolutions proposed and adopted at the Interuational Veterinary Congress................ 15i, 180

Udaler, erujution on, in the enzooties of ergotism .................. 41

United States, ergotism in the history of .......................

Government veterinary selnools, necessity of, in the........ 154

triehiniasis in the ............................ 283

veterinary service in the, necessity of a ............. 13.

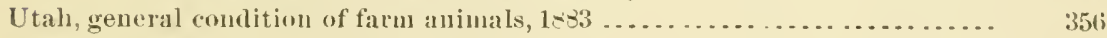

Vegetation poisonous to eattle....................................

liorses ................................

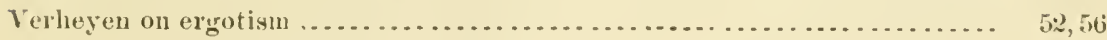


Vermont, general condition of farm animals, 1883

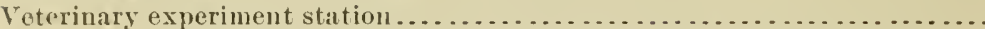

medicine, reports at the International Veterinary Congress on education in .....................................

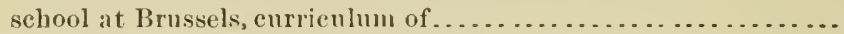

service, necessity in the Inited States of a ................. 1332

organization of a ............................ 122

principles of a............................... 130, 176

Virginia, district infected with Sonthern eattle fever.................. i1

general condition of farm animals, $1883 \ldots \ldots \ldots \ldots \ldots \ldots \ldots \ldots . \quad 349$

Washington Territory, general condition of farm animals, $1883 \ldots \ldots \ldots \ldots . .356$

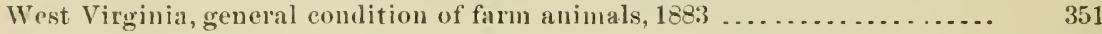

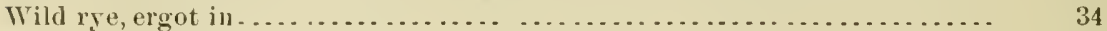

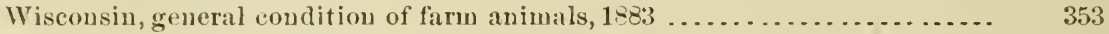

Wyoming Territory, general condition of fam animals, $1883 \ldots \ldots \ldots \ldots \ldots . .358$

Ziemssen on ergotism........................................... $\quad 99$

Zoological description of syngamus tracheulis ...................... 107

Zundel on the organization of a veterinary service ................. 





RETURN TO the circulation desk of any

University of California Library

or to the

NORTHERN REGIONAL LIBRARY FACILITY

Bldg. 400, Richmond Field Station

University of California

Richmond, CA 94804-4698

ALL BOOKS MAY BE RECALLED AFTER 7 DAYS

- 2-month loans may be renewed by calling (510) 642-6753

- 1-year loans may be recharged by bringing books to NRLF

- Renewals and recharges may be made 4 days prior to due date.

DUE AS STAMPED BELOW

FEB 32000

$12,000(11 / 95)$

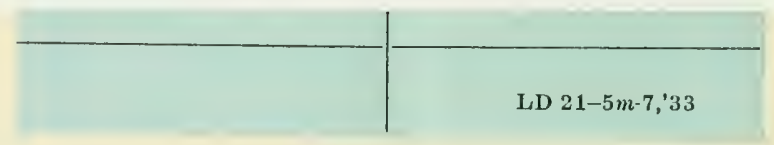


$S F 6 z^{-2}$

$73 \quad 270475$

$1+5{ }^{2} 4$

B1OLOSY

LIBRA

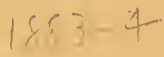

UNIVERSITY OF CALIFORNIA LIBRARY 
